DANIELLE SOUZA DE ANDRADE E SILVA

\title{
A INVESTIGAÇÃO PRELIMINAR NOS DELITOS DE COMPETÊNCIA ORIGINÁRIA DE TRIBUNAIS
}

\author{
Tese de Doutorado
}

Orientadora: Professora Doutora Maria Thereza Rocha de Assis Moura

Faculdade de Direito da Universidade de São Paulo São Paulo 
DANIELLE SOUZA DE ANDRADE E SILVA

\section{A INVESTIGAÇÃO PRELIMINAR NOS DELITOS DE COMPETÊNCIA ORIGINÁRIA DE TRIBUNAIS}

Tese apresentada ao Programa de Pósgraduação em Direito da Faculdade de Direito da Universidade de São Paulo como exigência para obtenção do título de Doutor Área de Concentração: Garantias constitucionais

Orientadora: Professora Doutora Maria Thereza Rocha de Assis Moura 


\section{AGRADECIMENTOS}

Um trabalho de pós-graduação pode parecer uma atividade solitária, e muitas vezes o é, reclamando o silêncio, o afastamento, o estudo, a concentração, a abdicação, o tempo. Mas nessa atividade ninguém está sozinho. A muitos tenho que agradecer pelo só fato de concluir essa etapa e, sem a pretensão de ser exaustiva, ousarei cometer a injustiça de nominar alguns daqueles a quem tributo a mais incontida gratidão.

À Professora Maria Thereza Rocha de Assis Moura, que com coragem aceitou orientar-me e, com paciência e esmero, dirigiu valiosas críticas e sugestões que me iluminaram a mente para o tema estudado.

Aos Professores Rogério Lauria Tucci, Antonio Magalhães Gomes Filho e Antonio Scarance Fernandes, pelas preciosas lições hauridas em sala de aula, e aos Professores Maurício Zanoide de Moraes e David Teixeira de Azevedo, pelas importantes sugestões feitas no exame de qualificação e incorporadas ao trabalho.

Ao Professor Francisco de Queiroz Cavalcanti, pelo essencial apoio que dedicou, com a rara sensibilidade de docente e pesquisador, ao meu pedido de afastamento da função judicante, quando Presidente do Tribunal Regional Federal da 5. ${ }^{a}$ Região.

Aos colegas Arthur Napoleão Teixeira e Paulo Parca de Pinho, que diligentemente me substituíram na titularidade da $8 .^{a}$ Vara Federal/PE, enquanto dela estive afastada, transmitindo-me a tranqüilidade e a confiança necessárias aos estudos.

Aos amigos Francisco de Barros e Silva, Érika Pires Ramos e Paulo Sérgio da Rocha Júnior, por me terem sempre encorajado, cada qual a seu modo e com seu exemplo, desde antes do ingresso na Pós-Graduação da Universidade de São Paulo.

A Vilma e a Lourdes, dedicadas bibliotecárias da Justiça Federal em Petrolina e em Recife, que prestaram auxílio constante e eficaz na pesquisa bibliográfica.

Aos profissionais que, tão generosamente, receberam-me em seus ambientes de trabalho para trocar idéias sobre o assunto, os quais deixo de citar nominalmente por questão de ética da pesquisa.

Aos meus pais, José Bonifácio e Antonia, há muito privados, por razões profissionais, do meu convívio constante, privação esta acentuada com os desafios acadêmicos, mas que na distância incrementaram o incentivo o e o amor que me movem.

A Cláudio, pela paciência e estímulo constantes, mesmo quando o cansaço quase se aproximou - pois ele não permitiu. E a Luciana, amiga-irmã, colaboradora em tantos aspectos de minha vida e que não mediu esforços em ajudar na revisão do trabalho.

A todos os colegas da Pós-graduação, pelos elevados debates travados ao longo do curso, e a todos os diletos amigos que tonaram essa trajetória mais amena, meu agradecimento. 


\section{RESUMO}

SILVA, Danielle Souza de Andrade e. A investigação preliminar nos delitos de competência originária de tribunais. 2009. 321 f. Tese (Doutorado) - Faculdade de Direito, Universidade de São Paulo, São Paulo, 2009.

A investigação preliminar é tarefa das mais importantes na persecução criminal. Nos delitos atribuídos a agentes com foro por prerrogativa de função, cujo processo e julgamento é destinado à competência originária de Tribunais, a Lei 8.038/1990 trata do processamento das causas, mas não regula o trâmite da respectiva fase investigatória. Apesar de a prerrogativa de foro criminal ser instituto antigo em nosso ordenamento, não existem normas legais disciplinando o procedimento da investigação preliminar nesses casos, sendo necessário tratamento específico e adequado aos preceitos constitucionais, que confira segurança jurídica à sociedade e siga o devido processo legal. A Constituição da República de 1988, ao efetuar clara separação entre as funções de acusar, defender e julgar, e gravar, pela primeira vez, expressamente em seu texto as garantias do devido processo legal e da presunção de inocência, instalou o sistema acusatório de processo penal. Nele, o Poder Judiciário encarrega-se de processar e julgar causas, não lhe cabendo ingerir na investigação de delitos, tarefa administrativa que recai sobre outras esferas estatais. $\mathrm{O}$ trabalho é um estudo sobre a investigação preliminar no direito brasileiro; as garantias a ela aplicadas; a sua natureza jurídica, suas funções, seus sujeitos e os atos nela praticados; as diversas modalidades existentes, situando-se a investigação envolvendo titulares de foro especial, diferenciando-se as investigações interna corporis das demais; o relacionamento entre os agentes estatais nela envolvidos; o papel do juiz na investigação preliminar e a reserva de jurisdição; o regime constitucional da publicidade, as hipóteses de sigilo investigativo e as peculiaridades na sua fase de encerramento. Mediante pesquisa bibliográfica, de jurisprudência e visitas a órgãos atuantes nas investigações em análise, conclui-se que o procedimento adotado na prática, com o exercício de amplo controle ou supervisão da investigação pelo Relator, não se afeiçoa ao modelo constitucional, trazendo conseqüências também sob o ponto de vista da eficiência da etapa investigativa, porquanto torna o procedimento mais lento e burocratizado. Apresentam-se, enfim, algumas diretrizes procedimentais para a investigação preliminar dos delitos submetidos a julgamento de órgãos colegiados, com o objetivo de depuração do modelo acusatório brasileiro. Entre elas, a definição da natureza administrativo-policial da investigação; a constituição de equipes específicas em cada setor da Polícia Judiciária, com conhecimento desses inquéritos penais especiais; a definição legal do juiz de garantias da investigação nos Tribunais com competência penal, cuja participação será restrita aos incidentes que envolvam ameaça a direitos fundamentais; a separação entre juiz da investigação e juiz do processo, abolindo-se a atual regra de prevenção, para preservação da imparcialidade do julgador; a tramitação direta dos inquéritos entre a Polícia Judiciária e o Ministério Público; a regra da publicidade do inquérito, e o sigilo como exceção.

PALAVRAS-CHAVE: investigação preliminar - sistema acusatório - competência penal originária - prerrogativa de foro - inquérito policial. 


\begin{abstract}
SILVA, Danielle Souza de Andrade e. The preliminary inquiry in delicts under original jurisdiction in higher Courts. 2009. 321 f. Thesis (Doctorate) - Faculdade de Direito, Universidade de São Paulo, São Paulo, 2009.
\end{abstract}

The preliminary inquiry is one of the most important tasks in criminal prosecution. In delicts charged to agents with the prerogative of having original jurisdiction - process and judgment - in higher Courts, Law \# 8,038/1990 deals with the processing of the cases, but does not regulate the proceeding of their respective investigatory phase. Although such prerogative in Criminal Law is an old institute in our legal system, there are no legal rules disciplining the procedure of the preliminary inquiry in these cases. Therefore, it is necessary to give the institute an specific treatment and adequate it to the constitutional rules, one that will assure legal security to the society and will follow the due process of law. The Brazilian Constitution of 1988 has installed the accusatory system in the criminal procedure, making clear distinction between accusation, defense and judgment functions, and expressly highlighting, for the first time, the guarantees of the due process of law and the presumption of innocence. In such system, the Judiciary is responsible for processing and judging cases, and may not intervene in the investigation of delicts, an administrative task designed for other state branches. This essay is about the preliminary inquiry in Brazilian Law; the guarantees applied; its juridical nature, functions, subjects and acts; its various existing modalities, situating the investigation involving the holders of the prerogative of being originally judged in higher Courts, differing interna corporis investigation from the others; the relations between the involved state agents; the role of the judge in the preliminary inquiry and the reserve of jurisdiction; the constitutional regime of publicity, the hypothesis of investigative secrecy and the peculiarities in its closure phase. By means of bibliographical and jurisprudence research, and also visitation of operating organisms in the investigation under analysis, the essay comes to the conclusion that the procedure adopted for criminal offenses under original jurisdiction in higher Courts is not sympathetic to the constitutional model, also bringing consequences from the point of view of the efficiency of the administrative phase, for it makes the procedure slower and bureaucratic. Finally, there are some procedural guidelines for the preliminary inquiry of criminal offenses subject to prosecution in collegiate bodies, with the objective of depuration of the Brazilian accusatory model. Among them are the definition of the administrative-police nature of the investigation; the constitution of special teams with knowledge regarding these special criminal inquiries in each sector of the police, the legal definition of judge of guarantees in the investigation, in courts with criminal jurisdiction, whose participation will be restricted to the incidents involving threats to fundamental rights; the separation of the judge of investigation from the judge of the process, abolishing the current rule of prevention, in order to preserve de impartiality of the judge; the course of the inquiry to be held directly between the judiciary police and the prosecutor; the rule being the publicity of the inquiry and the secrecy, the exception.

KEYWORDS: preliminary inquiry - accusatory system - original jurisdiction in higher Courts - police inquiry. 


\section{RIASSUNTO}

SILVA, Danielle Souza de Andrade e. L'indagine preliminare nei delitti di competenza originaria dei tribunali. 2009. 321 f. Tesi (Dottorato) - Faculdade de Direito, Universidade de São Paulo, São Paulo, 2009.

La ricerca preliminare è un compito tra i più importanti nella persecuzione criminale. Nei delitti attribuiti ad agenti con diritti per prerogativa di funzione, il cui processo e giudizio sono destinati alla competenza originaria di Tribunali, la Legge 8.038/1990 tratta del processo di cause, ma non regola il tramite della rispettiva fase investigativa. Nonostante la prerogativa del foro criminale sia un istituto antico nel nostro ordinamento, non esistono norme legali che disciplinino il procedimento di indagine preliminare in questi casi, essendo necessario un trattamento specifico ed adeguato ai precetti costituzionali, che trasmetta sicurezza giuridica alla società e continui il dovuto processo legale. La Costituzione della Repubblica del 1988, al momento di effettuare una netta separazione tra le funzioni dell'accusare, difendere e giudicare, e registrare, per la prima volta, espressamente nel proprio testo le garanzie del dovuto processo legale e della presunzione dell'innocenza, ha inserito il sistema accusatorio del processo penale, nel quale il Potere Giudiziario si incarica di processare e giudicare le cause, non spettandogli l'ingerenza nell'investigazione dei delitti, quale compito amministrativo che ricade sua altre sfere statali. La tesi è uno studio sull'indagine preliminare nel diritto brasiliano; sulle garanzie ad essa applicate; sulla natura giuridica, le sue funzioni, i suoi soggetti e gli atti in essa praticati; sulle diverse modalità esistenti, situandosi, l'indagine, ad abbracciare titolari di carica speciale, differenziando le indagini interna corporis dalle altre; la relazione tra gli enti statali in essa coinvolti; il ruolo del giudice nell'indagine preliminare e la riserva di giurisdizione; il regime costituzionale della pubblicità, le ipotesi di segreto investigativo e le peculiarità nella sua fase di chiusura. Mediante una ricerca bibliografica, di giurisprudenza e visite agli organi attuanti nelle investigazioni in analisi, si desume che il procedimento adottato nella pratica, con l'esercizio di ampio controllo o supervisione di investigazione fatta dal Relatore non si rifà al modello costituzionale, portando con sé le dovute conseguenze anche sotto il punto di vista dell'efficienza dalla tappa investigativa, visto che rende il procedimento più lento e burocratizzato. Si presentano, infine, alcune direttrici procedimentali per l'indagine preliminare dei delitti sottoposti a giudizio dagli organi collegiali, con l'obiettivo di depurazione del modello accusatorio brasiliano. Tra queste, la definizione di natura amministrativo-poliziesca di indagine; la costituzione di gruppi specifici in ogni settore della Polizia Giudiziaria, con conoscenza delle indagini penali speciali; la definizione legale di giudice di garanzia delle indagini nei Tribunali con competenza penale, la cui partecipazione sarà ristretta alla conoscenza di incidenti che riguardino minacce ai diritti fondamentali; la separazione tra giudice di indagine e giudice di processo, abolendo l'attuale regola di prevenzione, per la preservazione dell'imparzialità del giudicante; la trasmissione diretta delle deposizione tra la Polizia Giudiziaria ed il Ministero Pubblico, la regola della pubblicità delle indagini, ed il segreto come eccezione.

PAROLE CHIAVE: indagine preliminare - sistema accusatorio - competenza penale originaria - prerogativa di foro - l'indagine poliziesca. 


\section{SUMÁRIO}

INTRODUÇÃO 1

CAPÍTULO 1: O sistema constitucional acusatório e a investigação preliminar. 12

1.1 Breves notas sobre os sistemas informadores do processo penal 12

$1.2 \mathrm{O}$ princípio acusatório e o reparto de papéis no processo penal: a investigação preliminar. 19

1.3 A afirmação do modelo acusatório pela Constituição de 1988.....................................23

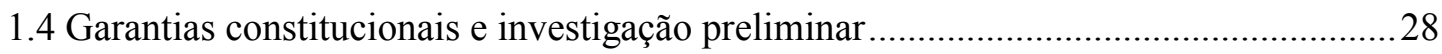

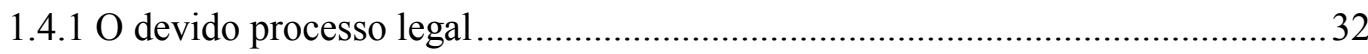

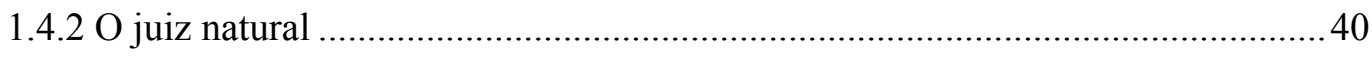

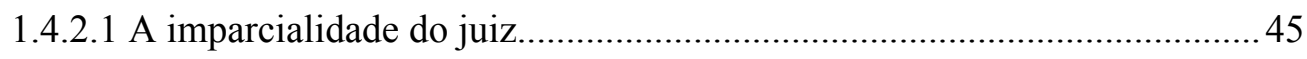

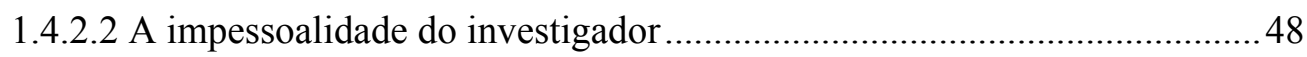

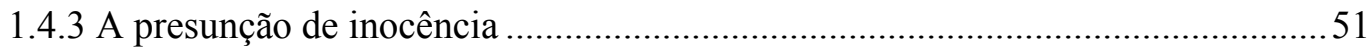

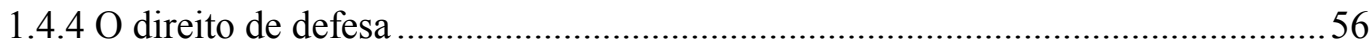

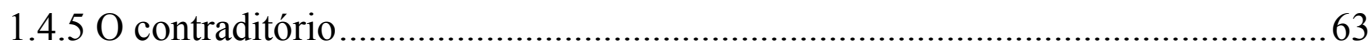

1.4.6 A publicidade e a motivação das decisões....................................................... 71

CAPÍTULO 2: A investigação preliminar no direito brasileiro ..................................... 80

2.1 Caracteres e funções da investigação preliminar ......................................................... 80

2.2 Natureza jurídica da investigação preliminar............................................................. 85

2.3 Modalidades de investigação preliminar segundo o condutor ...................................... 89

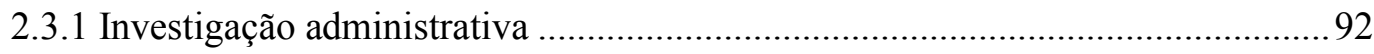

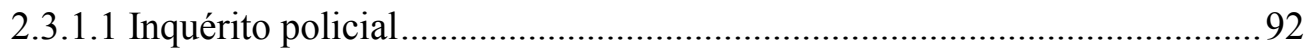

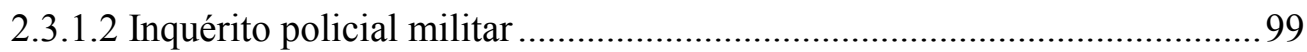

2.3.1.3 Investigação administrativa em sentido estrito ...................................... 101

2.3.1.4 Investigação ministerial ................................................................... 105

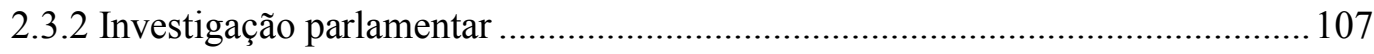

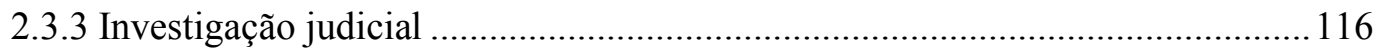

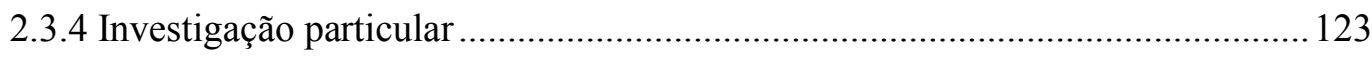

2.4 Modalidades de investigação preliminar de foro especial segundo o investigado....... 127 
2.4.1 Investigações interna corporis. 130

2.4.1.1 Investigações envolvendo membros da Magistratura 132

2.4.1.2 Investigações envolvendo membros do Ministério Público 139

2.4.2 Investigações envolvendo agentes políticos 142 $2.5 \mathrm{O}$ sujeito passivo da investigação preliminar: a posição do investigado e o problema do indiciamento. 148

2.6 Os atos praticados na investigação preliminar e seu valor probatório 163

\section{CAPÍTULO 3: A investigação preliminar nos delitos de competência originária de} tribunais 178

3.1 A prerrogativa de função como critério definidor de competência jurisdicional 179

3.2 A ausência de parâmetros procedimentais e de terminologia legal para a investigação: a uniformização necessária

3.3 Visão crítica da praxe judicial e propostas de diretrizes para a investigação preliminar 197

3.3.1 Instauração do procedimento investigatório e seu aforamento no tribunal 198

3.3.2 Aquisição ou perda superveniente da prerrogativa de foro: o art. 567 do CPP.213 3.3.3 A competência por conexão ou continência e a separação de autos na investigação .223

3.3.4 A condução da investigação e controle externo da atividade policial pelo Ministério Público .234

3.3.5 A definição do juiz de garantias na investigação preliminar .249

3.3.6 Separação entre juiz da investigação e juiz do processo...................................225

3.3.7 Publicidade ou sigilo na investigação preliminar ..............................................263

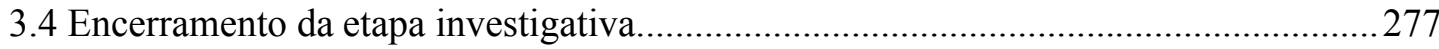

3.4.1 O arquivamento dos autos da investigação.....................................................279

3.4.2 O juízo de admissibilidade da peça inicial acusatória ......................................286

CONCLUSÕES .295

BIBLIOGRAFIA 301 


\section{INTRODUÇÃO}

Ao lado da preocupação mundial crescente com a positivação e concretização de instrumentos que propiciem ao acusado de um crime a garantia de que será processado e julgado sem ranhuras a seus direitos fundamentais, também a eficiência da atividade jurisdicional do Estado, desenvolvida mediante o processo, tem atraído atenção e reclamos sociais. Ilustrativamente, no final do ano de 2004, o Congresso Nacional aprovou reforma constitucional do Poder Judiciário e, no ano de 2005, os chefes dos Três Poderes da República firmaram o "Pacto de Estado em favor de um Judiciário mais rápido e republicano"1.

Tramitam no Congresso Nacional diversos projetos de lei visando à reforma do Código de Processo Penal brasileiro (Decreto-lei 3.689, de 3 de outubro de 1941), com destaque aos Projetos de Lei oriundos do Poder Executivo 4.206, 4.208 e 4.209, e aos recém-aprovados Projetos de Lei 4.203, 4.205 e 4.207, todos de $2001^{2}$, que modificam amplos aspectos da lei processual penal, sobretudo pela simplificação de ritos e formas, com vistas quer à compatibilização de normas procedimentais ao arcabouço acusatório da vigente Constituição, quer à ainda pouco sentida efetividade do processo $^{3}$, impedindo que o tempo faça transmudar o instrumento (o processo) em verdadeira sanção autônoma ao acusado e aumente o descrédito da sociedade na atuação das normas penais.

1 O documento integral pode ser obtido na página eletrônica do Ministério da Justiça. Em seu preâmbulo destaca-se: "Poucos problemas nacionais possuem tanto consenso no tocante aos diagnósticos quanto à questão judiciária. A morosidade dos processos judiciais e a baixa eficácia de suas decisões retardam o desenvolvimento nacional, desestimulam investimentos, propiciam a inadimplência, geram impunidade e solapam a crença dos cidadãos no regime democrático". Disponível em: <http://www.mj.gov.br/reforma/pacto.htm>. Acesso em 13 dez. 2006.

2 Dentre os projetos de reforma pontual do Código de Processo Penal apresentados pelo Executivo, os PLs 4.210, 4.204, 4.203, 4.205 e 4.207, de 2001, foram já objeto de deliberação parlamentar, resultando nas Leis 10.258/2001, 10.792/2003, 11.689/2008, $11.690 / 2008$ e 11.719/2008, que alteraram, respectivamente, disposições referentes à prisão especial, ao interrogatório do acusado, à prova, ao Tribunal do Júri e aos procedimentos.

3 As noções de eficiência, eficácia e efetividade, não privativas do direito, são utilizadas no texto como sinônimas, muito embora encontrem distinção etimológica. Em estudo sobre os termos, Antonio Scarance Fernandes (Reflexões sobre as noções de eficiência e de garantismo no processo penal. In: FERNANDES, Antonio Scarance; MORAES, Maurício Zanoide de; ALMEIDA, José Raul Gavião de (Coord.). Sigilo no processo penal: eficiência e garantismo. São Paulo: Revista dos Tribunais, 2008, p. 17-18 e 24-25) define eficiência como a capacidade de algo produzir um efeito (qualidade do meio); eficácia como a virtude de produzir um bom resultado (qualidade do resultado) e efetividade, como a expressão positiva do resultado produzido, sua correspondência às finalidades esperadas. $\mathrm{O}$ autor conclui que a eficiência do processo penal deve ser vista sob a ótica dos seus componentes (relação jurídica e procedimento) e a partir da sua finalidade, entendida esta conforme seja a linha de pensamento seguida: assegurar a defesa do acusado, punir os autores de infrações penais ou obter um resultado justo que se legitime pelo procedimento 
Não poderia passar ao largo dessas meditações uma questão crucial e anterior mesmo ao processo, mas a ele de tal forma imbricada que insuscetível de tratamento disjuntivo ou secundário: a investigação preliminar ${ }^{4}$, peça fundamental para o processo penal, atividade pela qual se reunirão elementos aptos a justificar a instauração ou não da fase judicial da persecutio in criminis, etapa esta, em si mesma, sobremodo danosa à pessoa do acusado.

Investigar sobre a existência de um delito é tarefa das mais relevantes dentro do sistema processual penal. Porque, no dizer de Aury Lopes Jr., “o processo penal sem a investigação preliminar é um processo irracional, uma figura inconcebível segundo a razão e os postulados da instrumentalidade garantista" ${ }^{2}$. Deveras, para não se incorrer no grave vício de primeiro acusar e só depois investigar, para se coibirem acusações apressadas, despidas de fundamento mínimo probatório, cumpre resgatar e salientar a dignidade científica da etapa investigativa, a merecer regramento específico e adequado aos preceitos constitucionais.

É com esse pensamento que direcionaremos o foco da pesquisa à investigação preliminar dos delitos atribuídos a sujeitos com foro por prerrogativa de função, cujo processo e julgamento a Constituição da República e as Constituições dos Estados destinaram à competência dos Tribunais, em caráter originário.

A ausência de norma legal prevendo o modo de realização dessas investigações não impediu que elas ocorressem - e ocorrem em grande número -, fazendose todavia premente o estabelecimento de paradigmas para esse subsistema investigatório, no que não se poderão adotar, por pura e simples transposição, os regramentos do inquérito policial trazidos no Código de Processo Penal, senão que tal instituto há muito demanda releitura em ordem a conformá-lo aos preceitos garantísticos do processo penal moderno e democrático. Urge que se o faça tomando-se como parâmetros os mandamentos extraídos

adequado. Também em face dessas três correntes seria medido o grau de eficácia e a efetividade, quer do processo, como entidade unitária do direito processual, quer dos atos que compõem o procedimento.

4 A terminologia investigação preliminar, importa logo esclarecer, será utilizada neste trabalho como significativa da investigação criminal prévia ao processo, ou seja, designando um gênero a contemplar todas as espécies de instrução preliminar ou etapas pré-processuais da persecução penal, que se apresentam, no Brasil, sob formas as mais variegadas, com preponderância o inquérito policial, como será oportunamente explanado. A tônica do trabalho será o estudo da espécie de investigação preliminar praticada nos delitos processados e julgados, originariamente, por tribunais.

5 LOPES JR., Aury. Sistemas de investigação preliminar no processo penal. 3. ed. rev., ampl. e atual. Rio de Janeiro, Lumen Juris, 2005, p. xxi. 
da Constituição de 1988, diploma que, verdadeiramente, inaugurou uma nova ordem normativa ${ }^{6}$.

De fato, embora ainda vigore em nosso sistema - conquanto, em muito, já alterado - o Código de Processo Penal editado por meio do Decreto-lei 3.689/1941, de inspiração nada liberal ${ }^{7}$, certo é que o advento da Carta de 1988, ao tempo em que efetuou clara separação entre as funções de acusar, defender e julgar, gravou, pela primeira vez, expressamente em seu texto as garantias do devido processo legal e da presunção de inocência, além de conferir maior robustez a outras, como as da ampla defesa e do contraditório, fortalecendo a conclusão, abraçada por copiosa doutrina, de estar-se diante de um sistema acusatório de processo penal ${ }^{8}$.

Em relação à investigação preliminar, embora não configure um processo propriamente dito (mercê da ausência de elementos essenciais à estrutura do processo, como a existência de partes contrapostas que atuam sob o controle de um órgão supraordenado), também nela há de se estudar os reflexos do sistema acusatório, para a efetiva implementação das garantias individuais talhadas na Lei Maior e a conformação das atividades dos sujeitos que a protagonizam (investigador, investigado, Juiz e Ministério Público) às exigências democráticas da ordem constitucional vigente. Afinal, "o processo penal, notadamente na sua fase preparatória, é de fato um excelente espelho das liberdades que um Estado concede ou nega aos seus cidadãos"9.

6 Essa visão interpretativa diz com a idéia de um processo constitucional, um instrumento não puramente técnico, mas sobretudo ético e político, de atuação da justiça e garantia de liberdade, cumprindo, assim, sua vocação primeira, a de efetivação dos direitos materiais. A Constituição, resultante do equilíbrio das forças políticas existentes em um dado momento histórico, constitui-se "no instrumento jurídico de que deve utilizar-se o processualista para o completo entendimento do fenômeno processo e de seus princípios" (CINTRA, Antônio Carlos de Araújo; GRINOVER, Ada Pellegrini; DINAMARCO, Cândido Rangel. Teoria geral do processo. 17. ed. rev. e atual. São Paulo: Malheiros, 2001, p. 79).

7 Fortemente influenciado pelo Código Rocco, de matiz fascista, visava o CPP, conforme se lê no item II de sua Exposição de Motivos, "ao objetivo de maior eficiência e energia da ação repressiva do Estado contra os que delinqüem".

8 Nesse sentido, vide, por exemplo: BAPTISTA, Francisco das Neves. $O$ mito da verdade real na dogmática do processo penal. Rio de Janeiro: Renovar, 2001; BARROS, Antonio Milton de. Processo penal segundo o sistema acusatório: os limites da atividade instrutória judicial. Leme: LED, 2002; CHOUKR, Fauzi Hassan. Garantias constitucionais na investigação criminal. 3. ed. rev., atual. e ampl. Rio de Janeiro, Lumen Juris, 2006; JARDIM, Afrânio Silva. Direito processual penal. 10. ed. rev. e atual. Rio de Janeiro: Forense, 2001; LIMA, Marcellus Polastri. Ministério Público e persecução criminal. 3. ed. rev. e atual. Rio de Janeiro: Lumen Juris, 2002; PRADO, Geraldo. Sistema acusatório: a conformidade constitucional das leis processuais penais. 4. ed. Rio de Janeiro: Lumen Juris, 2006; ZILLI, Marcos Alexandre Coelho. A iniciativa instrutória do juiz no processo penal. São Paulo: Revista dos Tribunais, 2003. Contra: LOPES JR., Aury. Introdução crítica ao processo penal: fundamentos da instrumentalidade constitucional. 4. ed. rev., atual. e ampl. Rio de Janeiro: Lumen Juris, 2006.

9 PRADEL, Jean. La phase préparatoire du procès pénal en droit comparé. Revue de Science Criminelle et de Droit Pénal Comparé, Paris, n. 4, oct./déc. 1983, p. 624, tradução livre. 
O trabalho se debruçará sobre a investigação preliminar dos crimes de competência de tribunais em sua estrutura (os sujeitos que dela participam, o seu objeto e os atos nela praticados) e em sua função (ou finalidade institucional), visando a uma síntese inerente ao próprio conceito de procedimento ${ }^{10}$.

Pode-se creditar a escolha do objeto da pesquisa, em primeiro lugar, ao fato de não se encontrarem, no direito positivo brasileiro, regras procedimentais dedicadas, precisamente, à investigação preliminar dos crimes processados e julgados, em sede originária, pelos tribunais. Vigora peremptório silêncio legal quer sobre o procedimento a adotar-se, quer sobre as garantias a respeitar-se, quer mesmo sobre os órgãos incumbidos de sua realização. A só existência de leis ordinárias federais que estabelecem normas de procedimento para as ações penais de competência dos tribunais - Leis 8.038/1990 e $8.658 / 1993^{11}$ - não altera esse quadro, eis que tais diplomas não versam, a rigor, sobre a etapa pré-processual, mas sobre o processo propriamente dito.

A lacuna normativa sequer é preenchida pelos regimentos internos das Cortes, que tampouco regulam o trâmite da investigação, preocupando-se apenas com a autuação do feito, a partir do momento em que se supõe encerrada a etapa preliminar ${ }^{12}$, e com o estabelecimento da competência para a futura ação penal porventura instaurada ${ }^{13}$, nisso repetindo, inclusive, a opção do legislador do Código de Processo Penal brasileiro em atribuir ao magistrado que de alguma forma atuou na fase pré-processual a competência, por prevenção (art. 83 do CPP), para a futura ação penal, com conseqüências a serem igualmente estudadas neste trabalho.

10 Antonio Scarance Fernandes, com base na obra de Giuseppe Gianzi, define o procedimento como uma entidade jurídica de formação sucessiva, caracterizada pelo vínculo especial entre os seus diversos atos, segundo o qual cada um é conseqüência do precedente e pressuposto e condição necessária do sucessivo, seguindo uma ordem preestabelecida (Teoria geral do procedimento e o procedimento no processo penal. São Paulo: Revista dos Tribunais, 2005, p. 32). Assim, o procedimento é composto de vários atos, sintetizados em uma unidade, podendo-se construir a idéia de um modelo de procedimento, embora se trate de uma entidade reconhecidamente complexa.

11 A Lei 8.6581993 estendeu a aplicação das normas da Lei 8.038/1990 às ações penais de competência originária dos Tribunais de Justiça dos Estados e do Distrito Federal, e dos Tribunais Regionais Federais. Antes de sua vigência, a Lei 8.038 regia apenas os processos de competência do STF e do STJ, de modo que os processos decorrentes de prerrogativa de função nos demais tribunais eram regulados pelo CPP (arts. 556 a 562) e pelos regimentos internos, aplicando-se a Lei 8.038 apenas em caráter subsidiário.

12 Vide, a propósito, o art. 231 do Regimento Interno do Supremo Tribunal Federal (RISTF), que versa: "Distribuído inquérito sobre crime de ação pública, da competência originária do Tribunal, o Relator encaminhará os autos ao Procurador-Geral, que terá quinze dias para oferecer a denúncia ou requerer o arquivamento. Se o indiciado estiver preso, o prazo será de cinco dias.".

13 Art. 74 do RISTF: “A ação penal será distribuída ao mesmo Relator do Inquérito”. 
Tais constatações, longe de diminuir a importância do tema, realçam-na, ao tempo em que indicam a necessidade de depuração do modelo acusatório brasileiro na persecução preliminar dos delitos sujeitos ao julgamento de órgãos colegiados.

O segundo fator digno de ressalte prende-se à verificação de que, na praxe judiciária brasileira, são recorrentes os inquéritos e outros tipos de expedientes investigatórios autuados nos tribunais, sobretudo pela grande quantidade de agentes submetidos ao foro criminal por prerrogativa de função ${ }^{14}$. Ou seja, o tema revela significativa aplicabilidade prática e, ante os diuturnos episódios em que se vêem envolvidos parlamentares, membros do Poder Executivo e mesmo do Judiciário, desperta crescente atenção.

Em terceiro lugar, impressiona o quão escassa é a literatura específica sobre a matéria, de forma a aparentar certo desinteresse pelo tema, dificuldade teórica que acaba por refletir-se na prática, já que o assunto permanece obscurecido ou ainda confuso para os operadores do direito em geral. O que se vê, no presente, são os próprios tribunais (em especial, o Supremo Tribunal Federal) serem compelidos, por exigência do cotidiano forense, a posicionar-se em questões não dantes reguladas, assentando-se sobre terreno ainda bastante polêmico, que envolve desde a reunião ou cisão da investigação sobre diferentes sujeitos passivos (com e sem prerrogativa de foro penal), aos direitos e garantias a serem observados nessa fase e, principalmente, ao modus operandi da investigação.

Confere destaque ao tema um quarto fator, que diz com a eficiência da persecução penal de crimes processados originariamente por tribunais.

14 Em apanhado comparativo histórico das cartas constitucionais brasileiras, Luciano Rolim (Limitações constitucionais intangíveis ao foro privilegiado. Boletim Científico da Escola Superior do Ministério Público da União. Brasília, v. 4, n. 14, jan./mar. 2005, p. 112) demonstra que a Constituição de 1988 foi a mais generosa na atribuição desse tipo de competência originária, referindo a existência de dezenove hipóteses da prerrogativa em seu texto, extraídas dos arts. 29, X; 96, III, 102, I, $b$ e $c$; 105, I, $a$, e 108, I, $a$. Além disso, há constante ampliação daquilo que deveria ser exceção no sistema constitucional, como ocorreu com a equiparação, entre outros, do Chefe da Casa Civil e do Presidente do Banco Central ao status de ministro de Estado, pela Medida Provisória 207/2004, depois ratificada pelo Legislativo (convertida na Lei 11.036/2004) e pelo Judiciário (ADI 3.289/SP, rel. Min. Gilmar Mendes, Plenário, por maioria, DJ de 3.2.2006); com a Lei 10.628/2002, considerada formalmente inconstitucional em controle concentrado no Supremo Tribunal Federal, e com nova investida mediante a Proposta de Emenda à Constituição 358/2005 (Reforma do Judiciário), que caminha para a constitucionalização de foros por prerrogativa de função em ações cíveis e sua extensão a ex-mandatários de cargos eletivos. Frisa-se a preocupação de Antônio Carlos Biscaia: “É lamentável que isso aconteça a todo momento, não só pelas dificuldades que traz aos tribunais superiores, como, de resto, pela mensagem que transmite, no caso, de que lá a impunidade é mais acentuada.” (BELLOCCHI, Roberto Antônio Vallim; BISCAIA, Antônio Carlos; CAZERTA, Therezinha. Investigações preliminares: ação penal de competência dos tribunais. In: Propostas para um novo modelo de persecução criminal: combate à impunidade. Brasília: CJF, Centro de Estudos Judiciários, 2005, p. 160). 
Verifica-se que o atual mecanismo praticado na investigação preliminar nos delitos sujeitos ao foro por prerrogativa de função (autuada no Tribunal, recebe um Relator a cujo crivo se remete todo e qualquer passo da investigação, como o simples pedido de prorrogação de prazo para diligências) provoca desnecessária sobrecarga aos já assoberbados gabinetes das Cortes, além de refletir em maior demora na conclusão da etapa investigativa, justamente em casos que envolvem, em sua maioria, gestores da coisa pública e atingem um universo plúrimo de sujeitos passivos, inseridos no gênero dos chamados "crimes do colarinho branco"15.

Pesquisa divulgada pela Associação dos Magistrados do Brasil, no ano de 2007, revelou um diagnóstico da situação dos processos relativos aos detentores de foro por prerrogativa de função no Supremo Tribunal Federal e no Superior Tribunal de Justiça, tribunais estes submetidos a volumoso trabalho decorrente dos milhares de feitos que, anualmente, são distribuídos a cada um de seus integrantes ${ }^{16}$. Observou-se que, de 15 de dezembro de 1988 a 15 de junho de 2007, foram distribuídas 130 (cento e trinta) ações penais no STF, das quais apenas 6 (seis) obtiveram julgamento do seu mérito por aquele tribunal, redundando em absolvição dos acusados/querelados. Os demais processos ainda estavam em tramitação, ou haviam sido arquivados por causas diversas (entre elas, a extinção da punibilidade decorrente de prescrição, o decurso da suspensão condicional do processo ou a perempção), ou remetidos a tribunal ou instância inferior ${ }^{17}$.

No STJ, foram distribuídas 483 (quatrocentas e oitenta e três) ações penais entre 23 de maio de 1989 e 6 de junho de 2007, sendo que apenas 16 (dezesseis) haviam sido objeto de julgamento por aquela Corte, redundando em 11 (onze) absolvições e 5 (cinco) condenações. Os demais processos ainda estavam em tramitação, ou se

15 Derivativo da expressão inglesa white collar crimes, cunhada por Edwin H. Sutherland, em 1939, cuja teoria define tais crimes sob uma perspectiva subjetivo-profissional, identificando-os como "os delitos cometidos por pessoas dotadas de respeitabilidade e elevado status social, no âmbito de seu trabalho" (cf. FELDENS, Luciano. Tutela penal dos interesses difusos e crimes do colarinho branco: por uma relegitimação da atuação do Ministério Público: uma investigação à luz dos valores constitucionais. Porto Alegre: Livraria do Advogado, 2002, p. 115-116).

16 A íntegra da pesquisa pode ser conferida na página eletrônica da Associação dos Magistrados Brasileiros. Disponível em: < http://www.amb.com.br/portal/docs/noticias/estudo_corrupcao.pdf $>$. Acesso em: 14 jun. 2008.

17 Uma pesquisa mais recente, realizada pela Assessoria de Gestão Estratégica do Supremo Tribunal Federal, revela que, de fevereiro de 2002 a dezembro de 2008, 172 inquéritos foram reautuados como ação penal naquele pretório. Conforme o levantamento, 165 pessoas estão sendo processadas criminalmente no Supremo e 339, investigadas. Das 102 ações penais e 265 inquéritos que tramitam atualmente na Corte, 79 inquéritos e 13 ações penais correm em segredo de justiça. Desde 2002, 9 ações penais foram julgadas improcedentes. O Supremo registrou 43 inquéritos com denúncia recebida, 
encontravam arquivados por causas diversas (entre elas, a extinção da punibilidade decorrente de prescrição, o cumprimento da suspensão condicional do processo ou a morte do acusado), ou foram remetidos a outro tribunal ou instância, ou estavam aguardando autorização legislativa para processamento.

$\mathrm{O}$ baixo índice de julgamento das causas criminais remetidas ao foro originário tribunalício fortalece o interesse na pesquisa eleita neste projeto porque, embora os números aqui trazidos retratem os feitos já autuados como "ação penal”, é irrefutável que o retardo das investigações preliminares contribui para que as essas ações encontrem o destino da prescrição, da morte do agente, do término do mandato que determinou a prerrogativa, enfim, de tantos eventos impulsionados pelo fator tempo e que contribuem à não-solução do relevante conflito de interesses que subjaz à deflagração da persecução processual penal. Como resultado, há o descrédito não só do Poder Judiciário perante a população, mas do sistema persecutório estatal como um todo.

Necessário, por fim, destacar a originalidade do tema eleito para pesquisa em nível de doutorado. É parca a bibliografia aprofundada sobre a investigação preliminar em crimes da competência originária de tribunais, quiçá pela falta de percepção de sua importância para a maior eficiência e credibilidade do processo penal brasileiro ou, enfim, pela dificuldade mesma de coleta de material bibliográfico: as obras consultadas sobre o tema da investigação preliminar, que não são poucas, ou silenciam ou pouco se referem ao procedimento prévio de apuração dos crimes submetidos ao julgamento de tribunais.

Não há negar que a ciência jurídica brasileira muito evoluiu, nas últimas décadas, rumo à democratização do processo penal e à consagração (e proteção) de valores hoje componentes de quase todo o capítulo dos direitos e garantias individuais na Constituição de 1988. Nada obstante, alguns problemas jurídicos - como o ora enfrentado - ainda carecem de adequado e específico tratamento.

Por essas razões, a conferir certa nota de originalidade ao tema, é preciso reconhecer o caráter desafiador do seu enfrentamento, o que funciona, antes de tudo, como incentivo na busca de meios que propiciem uma investigação criminal mais célere, ao tempo em que mais justa e igualitária, albergando mecanismos aptos à manutenção do equilíbrio entre o direito do investigado a atuar defensivamente contra todo tipo de imputação e o direito da sociedade a um processo penal eficaz.

inclusive em parte, e 46 inquéritos com denúncia rejeitada. Disponível em: < http://www.stf.jus.br/portal/cms/verNoticiaDetalhe.asp?idConteudo=101385>. Acesso em: 11 jan. 2009. 
Os pontos de partida da pesquisa radicam (i) na verificação da completa ausência de norma que regule as investigações preliminares dos crimes de competência originária de tribunais, de molde a se garantirem direitos essenciais ao investigado e também às vítimas desses fatos ${ }^{18}$, e (ii) na constatação de que os tribunais brasileiros, à falta quiçá de uma base teórica sobre o tema e embora de maneira não-uniforme, interpretam a Constituição como se lhes conferisse não apenas a competência, em caráter originário, para o processo e julgamento de determinados delitos, mas, por extensão, também a atribuição para a respectiva investigação preliminar, a qual não raro vem-se praticando quer diretamente, pela própria autoridade judicial (na prática de atos como interrogatórios e oitivas, por exemplo), quer por delegação, aí exercida a direção formal pelo magistrado relator.

Não se olvida que, em algumas espécies de investigação dos crimes sujeitos ao foro tribunalício (a saber, naquelas realizadas interna corporis, conforme as Leis Orgânicas da Magistratura e do Ministério Público ${ }^{19}$ ), há preceptivo legal indicando quem conduzirá a investigação, mas, em nenhuma delas, existe qualquer tratamento sobre o modo de condução da apuração prévia.

O vácuo normativo aqui referido é peculiar e contrapõe-se a tantos outros campos do Direito nos quais vigora a profusão legislativa, editando o Estado, por meio dos Poderes Legislativo ou Executivo, um sem-número de normas (decretos, regulamentos, leis em sentido formal, etc.), muitas das quais terminam sem coerência intra-sistemática ${ }^{20}$. E preocupa, porque pode estar ele mesmo, o silêncio, dissimulando algum objetivo distanciado dos parâmetros garantísticos constitucionais.

Logo, a principal questão que se propõe enfrentar refere-se a como será feita a investigação preliminar à míngua de disposições legais sobre a matéria; qual a opção

18 Lembra Aury Lopes Jr. ser uma ilusão pensar que o sistema não possui conflitos e que nele nada há a acrescentar ou retirar. Segundo o autor, "o dogma da completude cai por terra quando verificamos que o sistema está eivado de lacunas e de conflitos internos" (Introdução crítica..., cit., p. 292).

19 Respectivamente, art. 33, parágrafo único, da Lei Complementar 35/1979 e art. 41, parágrafo único, da Lei 8.625/1993.

20 Eduardo Novoa Monreal refere-se a tal fenômeno como um emaranhado legislativo, cada vez mais complicado e profuso, verificável na generalidade dos países ocidentais com sistema de legislação escrita e experimentado a partir da segunda metade do século XX, depois das grandes guerras. Sobre as conseqüências que tal situação acarreta, observa que "[o] cidadão encontra-se ante um Direito que está obrigado a obedecer, mas que lhe resulta quase impossível chegar a conhecer" $(O$ direito como obstáculo à transformação social. Trad. Gérson Pereira dos Santos. Porto Alegre: Sergio Antonio Fabris, 1988, p. 39-42). 
procedimental mais apta a prevenir máculas a preceitos constitucionais; quais os atos passíveis de se praticar em seu bojo e que dinâmica devem apresentar.

A adequada solução desse problema por certo supõe o esquadrinhamento de outros, como a natureza jurídica da investigação preliminar originária e a sua conciliação ao sistema acusatório de processo, em que o juiz é alijado de qualquer atividade administrativa pré-processual, intervindo na investigação apenas nos episódios que demandem jurisdicionalização.

Além disso, surge necessário responder às seguintes inquietações: Qual a situação jurídica do sujeito passivo da investigação e que garantias devem ser observadas em seu favor? Que meios teria ele de participar defensivamente no procedimento investigativo? Seria legítimo instituir o sigilo para a investigação preliminar pelo só fato de envolver autoridades sujeitas ao foro por prerrogativa de função? Como preservar a garantia do juiz natural e a imparcialidade do julgador nesses procedimentos?

Qual a posição do Magistrado, da Polícia Judiciária e do membro do Ministério Público nessas investigações? Haveria nelas tolhimento do controle externo da investigação cometido ao Ministério Público pela Constituição (art. 129, VII)? Teria o Relator a função de intermediar todos os petitórios oriundos das autoridades policial e ministerial? A quem caberia a prática dos atos de investigação e o controle de sua legalidade? Poderia o magistrado negar o pedido de arquivamento de inquérito feito pelo órgão ministerial? Confundir-se-iam as pessoas do relator do inquérito e do "juiz de garantias" que tanto se busca delinear na persecução extrajudicial moderna?

O Supremo Tribunal Federal, ao defrontar-se com o problema em algumas oportunidades, chegou a anunciar que "1. A competência penal originária por prerrogativa não desloca por si só para o tribunal respectivo as funções de polícia judiciária. 2. A remessa do inquérito policial em curso ao tribunal competente para a eventual ação penal e sua imediata distribuição a um relator não faz deste 'autoridade investigadora', mas apenas lhe comete as funções, jurisdicionais ou não, ordinariamente conferidas ao juiz de primeiro grau, na fase pré-processual das investigações" ${ }^{\text {21 }}$.

No entanto, a palavra "supervisão" é utilizada em alguns acórdãos do STF prolatados em inquéritos autuados naquela $\mathrm{Corte}^{22}$, para designar a atividade exercida pelo

21 STF, HC 82.507/SE, rel. Min. Sepúlveda Pertence, 1. Turma, v.u., DJ de 19.12.2002.

22 Nesse sentido: "Compete ao Supremo Tribunal Federal supervisionar inquérito policial em que Senador tenha sido intimado para esclarecer imputação de crime que lhe fez indiciado.” (Rcl 2.349/TO, rel. p/ 
tribunal em casos tais, entretanto sem definir-se o seu conteúdo, donde aflorarem outras indagações. Em que consistiria essa supervisão e qual a sua viabilidade dentro do sistema processual penal brasileiro? Teria ela força de conferir à investigação natureza judicial? Abrangeria também a prática de atos próprios de investigação, como é o caso da oitiva dos investigados e de testemunhas? Assemelhar-se-ia ao controle externo ministerial, tal qual previsto no art. 129, VII, da CF/1988?

O objeto da pesquisa será didaticamente fracionado em três capítulos. No primeiro, tratar-se-á de definir as principais características do modelo acusatório de processo penal e suas implicações sobre a investigação preliminar, além de demonstrar a sua acolhida pela Constituição brasileira de 1988 e a imperiosidade da aplicação das garantias inerentes ao devido processo legal já à fase pré-processual.

No segundo, far-se-á um estudo da investigação preliminar adotada no direito brasileiro, identificando-se a natureza jurídica dessa etapa pré-processual em nosso sistema e as modalidades então existentes, inclusive aquelas relacionadas aos agentes com foro por prerrogativa de função, distinguindo-se as investigações interna corporis das demais e traçando-se necessários pontos de aproximação entre elas. Meditar-se-á ainda sobre a posição do sujeito passivo na investigação, a problemática do indiciamento, os tipos de atos praticados na investigação preliminar e o seu valor probatório.

O terceiro capítulo versará sobre o procedimento de investigação preliminar nos delitos de competência originária de tribunais, especificamente os inquéritos envolvendo agentes políticos (ou seja, como regra procedimental, não se focalizarão as investigações que se praticam interna corporis, servindo estas apenas de contraponto para com as demais), porquanto constituem o procedimento-padrão no subsistema da prerrogativa de foro. Reunir-se-ão propostas de sistematização das investigações dessa natureza, no sentido de conferir ao modelo hoje encontrado aptidão para responder à sua função com maior eficiência e compatibilidade ao sistema acusatório garantista de processo $^{23}$, para que a aplicação dos valores consagrados na Carta de Direitos não fique sujeita à mera conveniência e liberalidade da autoridade condutora da investigação.

acórdão Min. Cezar Peluso, 2. ${ }^{\text {a }}$ Turma, por maioria, DJ de 5.8.2005). Vide ainda, dentre outros: PET-QO 3.825/MT, rel. p/ acórdão Min. Gilmar Mendes, Plenário, por maioria, DJ de 4.4.2008; Inq-QO 2.411/MT, rel. Min. Gilmar Mendes, Plenário, por maioria, DJ de 25.4.2008; Rcl 1.258/DF, rel. p/ acórdão Min. Marco Aurélio, Plenário, por maioria, DJ de 6.2.2004.

23 Afinal, como ressalta Denise Neves Abade, "a noção maior de eficiência processual, antes de excluir o conceito de garantias do devido processo penal, as pressupõe" (Garantias do processo penal acusatório: o novo papel do Ministério Público no processo penal de partes. Rio de Janeiro: Renovar, 2005, p. 119). 
Fixado o substrato do estudo ora proposto, cabe referir os métodos adotados. Utilizar-se-á basicamente o método de pesquisa bibliográfica, mas não de forma exclusiva. As fontes bibliográficas fornecerão o arsenal histórico e principiológico necessário ao esboço teórico do instituto, até então pouco explorado nos manuais de Processo Penal e mesmo em monografias específicas sobre a investigação criminal preliminar. O manejo, ainda que tópico, de obras de outras disciplinas, como Direito Constitucional, Direito Administrativo e Sociologia do Direito, será importante para retratar a complexidade do tema. Far-se-á ainda a pesquisa de dados publicados na mídia eletrônica, com vistas a referências ocasionais acerca dos reflexos práticos do estudo.

A análise da jurisprudência brasileira, por sua vez, poderá trazer a compreensão de como a investigação preliminar nesses delitos de competência colegiada foi-se delineando na praxe judiciária, assumindo feição ímpar em nosso direito, e qual o seu perfil atual na visão dos tribunais. Não se descurará da pesquisa legislativa e jurisprudencial estrangeiras porventura existentes, estabelecendo-se traços comparativos entre os sistemas de investigação dos delitos imputados a autoridades públicas.

Por fim, para complementação da pesquisa e reforço da perspectiva crítica ${ }^{24}$, realizaram-se visitas in situ a alguns tribunais, entrevistando-se magistrados, membros do Ministério Público e funcionários atuantes no dia-a-dia dessas investigações preliminares e manuseando-se alguns autos de seus procedimentos. Foram visitados órgãos judiciários - o Supremo Tribunal Federal, o Superior Tribunal de Justiça, o Tribunal Regional Federal da 3. ${ }^{a}$ Região (compreendendo os Estados de São Paulo e Mato Grosso do Sul), o Tribunal Regional Federal da 5. ${ }^{a}$ Região (abrangente dos Estados do Ceará, Rio Grande do Norte, Paraíba, Pernambuco, Alagoas e Sergipe) e o Tribunal de Justiça do Estado de São Paulo e órgãos do Ministério Público - a Procuradoria-Geral da República, a Procuradoria Regional da República da 3. ${ }^{a}$ Região, a Procuradoria Regional da República da 5. ${ }^{a}$ Região e a Procuradoria-Geral de Justiça do Estado de São Paulo.

24 Reputamos o método crítico como o mais consentâneo ao estudo da Ciência do Direito, tão complexa e problemática como a realidade que pretende regular. Somente uma postura crítica serve ao jurista, não se satisfazendo o pensamento crítico em, simplesmente, descrever ou narrar um instituto jurídico ou um acontecimento social como ele se oferece à observação. Como anota Michel Miaille, a teoria crítica torna transparentes os institutos jurídicos e permite a descoberta de diferentes aspectos dinâmicos que a realidade aparentemente estática estaria a ocultar. A crítica, assim, desbloqueia o direito do seu isolamento, aproxima-o à vida, identificando-o com ela, dentro da sociedade organizada. A teoria que reflete sobre as condições e os efeitos de sua existência na vida social reencontra a sua ligação com a prática, com o mundo social existente (Uma introdução crítica ao direito. Trad. Ana Prata. 3. ed. Lisboa: Estampa, 2005, p. 23). 


\section{CAPÍTULO 1: O sistema constitucional acusatório e a investigação}

\section{preliminar}

\subsection{Breves notas sobre os sistemas informadores do processo penal}

A atividade de aplicação da lei penal não se fez de maneira uniforme no tempo e no espaço, sofrendo mutações metodológicas que refletem a maior ou menor intensidade participativa do juiz e das partes na investigação da verdade processual $^{25}$, conforme o influxo das transformações políticas, sociais e culturais dos povos. O estudo do processo penal, sob uma perspectiva histórica, revela a sua evolução desde um sistema inquisitorial primitivo, em que se concediam poderes ilimitados ao rei e aos magistrados, passando pelo sistema acusatório liberal-individualista romano ${ }^{26}$, depois pelo arcabouço inquisitório medieval, em que o juiz formulava a acusação e perquiria a prova, até a adoção dos institutos do sistema acusatório público moderno.

25 Como verdade processual quer-se expressar aquela verdade que se pode atingir no processo, não uma verdade material obtida a qualquer custo, mediante verificação unilateral dos fatos e não raro com atropelo a garantias constitucionais. Não aquela verdade freqüentemente contraposta à verdade formal do processo civil, como se se tratasse de uma dicotomia intangível. Uma verdade, sim, extraída do confronto dialético entre as partes, mediante provas e contraprovas, revelada ao julgador por mecanismos que previnam ao máximo a ocorrência de erros e sem ranhuras à integridade humana. Sobre nossa crítica à expressão "verdade real" no processo penal, cf. SILVA, Danielle Souza de Andrade e. A atuação do juiz no processo penal acusatório: incongruências no sistema brasileiro em decorrência do modelo constitucional de 1988. Porto Alegre: Sergio Antonio Fabris, 2005, p. 144-147.

26 Como indica Rogério Lauria Tucci (Lineamentos do processo penal romano. São Paulo: Bushatsky, 1976, p. 109-146), na arcaica Roma, o mais antigo dos procedimentos penais, remontando à época dos Reis, foi a cognição (cognitio), um procedimento fundado na inquisitio, carente de quaisquer formalidades legais, em que o rei e seus magistrados agiam arbitrariamente, com poderes ilimitados, baseados em atos de império e revelados pela coercitio (meio de constranger os que não lhes observassem as ordens). Pouco a pouco, essa atuação arbitrária sofreu limitações, sobretudo com o surgimento da provocatio ad populum, no início do período republicano. Pela provocatio, o cidadão romano poderia opor-se ao arbítrio do magistrado, reclamando à Assembléia do Povo contra decisão condenatória impositiva de pena capital ou de multa grave. Surgia o processo comicial, caracterizado por um procedimento de cunho preparatório, denominado anquisitio, no qual o órgão julgador passava a funcionar como verdadeiro acusador, justificando a sua decisão punitiva perante a assembléia popular, a quem cabia, afinal, o julgamento. Com a anquisitio lançaram-se as bases de um procedimento penal disciplinado por lei, composto de cinco fases: citação do acusado, instrução sumária, pronunciação de sentença pelo magistrado, reclamação para o povo e decisão final, por votação dos comitia. Mas foi apenas no último século da República, com o surgimento da accusatio (prerrogativa de qualquer cidadão - então representante do interesse da coletividade - de deduzir a acusação perante o povo), que se estabeleceu o procedimento penal público, de natureza acusatória e juridicamente regulado por leis especiais, com o julgamento perante tribunais denominados quaestiones. O Estado continuava conhecendo e julgando ações criminosas, mas agora seu representante exercia meramente a função de deliberar e pronunciar a sentença; a iniciativa de persecução ficava a cargo de um representante voluntário da comunidade, não integrante da magistratura romana. 
Num retrospecto dos grandes sistemas de aplicação da lei penal que a história experimentou, segundo a predominância de uns princípios norteadores sobre outros, merecem ênfase o acusatório e o inquisitório, convindo observar serem essas as formas puras, freqüentemente, porém, intercalando a legislação atributos de ambos os sistemas, embora prevalecendo, sempre, a feição de um deles.

O sistema dito acusatório, é, essencialmente, um processo de partes, sendo o mais aplicado nos países que privilegiam a liberdade do cidadão, entre os quais Alemanha, Áustria, Bélgica, Itália e Portugal. Caracteriza-se pela atuação de partes contrapostas acusador e acusado -, que duelam em igualdade de posições e de direitos, apresentando-se entre elas um julgador, desvinculado dos seus interesses ${ }^{27}$.

Historicamente, acompanham o sistema acusatório as notas da oralidade, da publicidade, da presunção de inocência e do contraditório ${ }^{28}$, o que faz realçar a imparcialidade do julgador, despido, agora, das funções de acusador e defensor. Nele, o acusado é verdadeiro sujeito do processo, assumindo postura ativa na marcha processual, mercê da exigência do contraditório. Com essas características, vigorou em quase toda a Antigüidade grega (e, na romana, apenas na fase republicana, considerada a mais democrática ${ }^{29}$ ), assim também na Idade Média, sob domínio do direito germano. Importante notar que, nas suas origens, o acusatório correspondia a uma concepção privada

27 O enfoque do processo penal como um processo de partes, representa, no dizer de Ada Pellegrini Grinover (Liberdades públicas e processo penal: as interceptações telefônicas. 2. ed. atual. São Paulo: Revista dos Tribunais, 1982, p. 53-55), a síntese dos princípios políticos que informam o sistema acusatório, eis que o processo penal "não pode ser concebido senão como um diálogo de três pessoas. O acusado não é mais, como em tempos idos, objeto do processo, mas é sujeito da relação jurídicoprocessual, ao lado do juiz e do ministério público".

28 Nilzardo Carneiro Leão (Princípios do processo penal. Recife: Imprensa Universitária, 1960, p. 83-84) destaca o acusatório como o primeiro sistema a aparecer na história, dele se encontrando vestígios nos antigos povos orientais, na Idade Média, na Grécia, em Roma e em Portugal - e, ainda hoje, na Inglaterra e nos Estados Unidos, com algumas modificações. Alinha o autor, entre seus princípios preponderantes, o de disponibilidade do particular, o de legalidade, o da verdade material, o do contraditório, o de publicidade, o de oralidade, o de imediatidade, o da identidade física do juiz, o do livre convencimento, o da instância única e o do ne procedat judex ex-officio.

29 Entre os romanos, a estrutura do processo oscilou consoante os sistemas de governo, que podem ser separados em cinco fases históricas: os períodos da Realeza (754 a.C. a 510 a.C), da República (510 a.C. a 27 a.C.), do Principado ou do Alto Império (27 a.C. a 284 d.C.), da Monarquia Absoluta ou do Baixo Império (284 d.C. a 565 d.C.), e Bizantino (565 d.C. a 1453 d.C.). O processo penal romano, como se viu, nem sempre foi acusatório. No período monárquico, o processo, ainda embrionário, caracterizava-se por uma atuação sumária, com estrutura inquisitorial (a inquisitio, seguida pela anquisitio). Somente com a República romana e as quaestiones surge o processo de feição acusatória, sendo que, ao depois, com o Império e o sistema da cognitio extra ordinem, ressurgem as linhas inquisitoriais. 
de direito penal e se autotutelava - nisso, praticamente, não se diferenciando do direito civil, como no original sistema germânico ${ }^{30}$.

Ao final da República romana, afloravam já alguns inconvenientes do sistema: o risco de o acusador popular, caso agisse temerariamente e não lograsse provar a sua acusação, ser processado por calúnia, prevaricação ou tergiversação; o alto grau de impunidade (por depender o processo da provocação de algum interessado em assumir a acusação); a freqüência em utilizar-se o expediente como meio de vingança ou extorsão, porquanto destituído de prévia investigação ${ }^{31}$, e a não-contemplação da parcela menos favorecida do povo, pois dificilmente o mais fraco cobrava a imposição de penas ao seu senhorio.

Com a queda do Império romano e a invasão germânica, o processo penal passa a seguir as regras do Código Visigótico (652 d.C.) - um sistema misto formado pelos direitos germânico (acusatório) e romano (inquisitório), com complexo regime de distribuição de competência - e do direito consuetudinário visigodo, pautado pela proteção da divindade, cabendo ao acusado o ônus exclusivo de demonstrar a impropriedade da acusação e aplicando-se provas indiretas e costumes bárbaros que refletiam o estágio de crendice dos povos à época e que foram suportados durante séculos ${ }^{32}$. O processo de

30 Cf. DEU, Teresa Armenta. Principio acusatorio y derecho penal. Saragoza: Bosch, 1995, p. 21.

31 Interessante anotar que o primeiro ato do processo romano acusatório era a acusação. Somente após admitida a acusação, o pretor fixava dia para comparecimento de acusador e acusado perante juízes. Até o dia do julgamento, o acusador deveria proceder às investigações, dirigindo-se a lugares, apreendendo documentos, notificando e inquirindo testemunhas. $\mathrm{O}$ acusado tinha direito de seguir o acusador, fiscalizar seus atos, assistir à oitiva de testemunhas, interrogá-las e contraditá-las. Era a fase de colheita dos elementos de prova, posterior à accusatio e precedente à sessão de julgamento. Cf. ALMEIDA JUNIOR, João Mendes de. O processo criminal brasileiro. 4. ed. Rio de Janeiro: Freitas Bastos, 1959, v. 1, p. 3233.

32 Segundo relata Maria Thereza Rocha de Assis Moura, desde a queda do Império Romano, no século VI, até a Idade Média, as provas penais assumiram natureza peculiar, já que o processo, "fundado em bases religiosas, passou a repousar na suposição da intervenção da divindade, considerada infalível. Quase inexistia pesquisa da verdade, mas tão-só um convencimento puramente formal, derivado do resultado da prova" (A prova por indícios no processo penal. São Paulo: Saraiva, 1994, p. 9). Essas provas eram os denominados "juízos de Deus" e "ordálias", verdadeiros testes de sacrifícios, provações físicas por vezes mortais às quais se submetiam os acusados, sendo que, se saíssem vivos, por intervenção divina, eram considerados inocentes. Sua prática foi generalizada, sendo utilizadas durante séculos em toda a Europa. Exemplos dessas lutas contra o próprio corpo eram a "prova das bebidas amargas", a "do veneno", a "da água", a "da cruz", a "das serpentes", a "do cadáver" e a "prova pelo fogo", em que o acusado deveria caminhar com os pés nus sobre várias barras de ferro incandescentes, sem se queimar, sob pena de ser considerado culpado (cf. MENDES DE ALMEIDA, Joaquim Canuto. Princípios fundamentais do processo penal. São Paulo: Revista dos Tribunais, 1973, p. 82; TOURINHO FILHO, Fernando da Costa. Processo penal. 19. ed. rev. e atual. São Paulo: Saraiva, 1997, v. 1, p. 82). Criou-se também o "duelo judiciário", em que combatiam acusador e acusado na crença de que Deus, infinitamente justo, não permitiria que o acusado fosse vencido, se inocente. Tal mecanismo suprimiu a prova por testemunho e outras provações; com ele, não se identificava quem tinha dito a verdade, mas quem era o mais forte e, ao mesmo tempo, teria razão. 
eliminação desses métodos cruéis de investigação criminal foi lento, iniciando-se, sobretudo, com o Cristianismo, já que a Igreja os proibiu após a adoção do catolicismo, o qual redundou também na limitação da discricionariedade dos poderes monárquicos pelo respeito aos dogmas da fé e da moral cristã (fundamento espiritual da monarquia) ${ }^{33}$.

O sistema acusatório entra em declínio no século XIII, a partir do predomínio do direito canônico. Cede lugar, paulatinamente, ao sistema inquisitório (também chamado inquisitivo ou inquisitorial), caracterizado pela concentração dos poderes processuais de investigar, acusar e julgar nas mãos de uma só pessoa, o inquisidor (semelhantemente à reunião dos poderes da soberania - administrar, legislar e julgar - na mesma pessoa, nos regimes absolutistas), que inicia, de ofício, o procedimento e colhe provas ao seu alvedrio, independente de proposta da acusação ou da defesa.

Vigora o inquisitório nos países que preconizam a punição do culpado mero objeto do processo -, ainda que mediante a supressão de garantias individuais, razão pela qual se diz que ele não é, conceitualmente, um verdadeiro processo ${ }^{34}$. Sobre ele, com percuciência, manifesta-se Gustavo Badaró $^{35}$ :

Por essas características, o processo inquisitório é incompatível com os direitos e garantias individuais, violador dos mais elementares princípios processuais modernos. Sem um julgador eqüidistante das partes não há imparcialidade. O juiz que formula a acusação liga-se psicologicamente à causa, perdendo a objetividade no julgamento. Há uma nítida incompatibilidade entre as funções de julgar e acusar.

Esse sistema é marcado, grosso modo, pela persecução escrita e secreta (embora a escritura e o sigilo não lhes sejam essenciais e também se encontrem em alguns

33 Cf. BARROS, Marco Antonio de. A busca da verdade no processo penal. São Paulo: Revista dos Tribunais, 2002, p. 61. De fato, foi grande a influência do direito canônico na transição do período místico para a fase do sistema legal de provas. Como observa Maria Thereza Rocha de Assis Moura ( $A$ prova por indícios..., cit., p. 11), "[e]m contraposição à magia, até então existente, os canonistas proibiram os ordálios e os juízos de Deus, o mesmo acontecendo mais tarde com o duelo. As provações foram substituídas pela introdução de inúmeras regras para a indagação da verdade, que conduziram a uma verdadeira apreciação jurídica da prova. O sistema da certeza moral foi combinado com algumas normas lógicas, de modo que a sentença passou a corresponder ao resultado da prova, sem ignorar o princípio da livre convicção". A solução dos conflitos humanos deixou de ser confiada a Deus para constituir-se em tarefa dos próprios homens.

34 Por isso Hélio Tornaghi (Compêndio de processo penal. Rio de Janeiro: José Konfino, 1967, t. II, p. 576), calcado nas lições de Alcalá-Zamora, conclui que o sistema inquisitório "é, afinal, a afirmação de um procedimento administrativo em que o Estado se auto-defende. Não se trata de atividade jurisdicional a não ser formalmente", indo de encontro à assertiva de que o Estado não pode auto-executar o seu direito de punir.

35 BADARÓ, Gustavo Henrique Righi Ivahy. Correlação entre acusação e sentença. São Paulo: Revista dos Tribunais, 2000, p. 24. 
modelos acusatórios, desde o direito romano), sem contraditório (não há o contraste de forças, a luta entre acusador e acusado), tendo por regra o encarceramento preventivo do acusado e a sua incomunicabilidade. Aperfeiçoou-se com o direito eclesiástico, a pretexto de evitar escândalos sobre os fatos que se pretendia punir, coibir a propagação de condutas heréticas ou contestadoras do poder real e desestimular a vingança privada ${ }^{36}$.

Nele, ganha importância o papel do juiz na instauração, de ofício, do procedimento e na colheita do material probatório, em nome do "interesse público", visto que o Estado, tendo a função de defesa da sociedade contra os delinqüentes, não mais poderia admitir o poder dispositivo das partes sobre as provas.

No século XV foi criado o Tribunal do Santo Ofício, ou Tribunal da Inquisição ${ }^{37}$, seguindo-se o definitivo abandono do sistema acusatório, substituído pelas regras do inquisitório, situação que perdura até o século XIX. A denúncia anônima passa a aceitar-se como forma de instauração do processo penal, a acusação é tida por despicienda, a prova oral é colhida secretamente e de ofício pelo juiz eclesiástico, o juramento de dizer a verdade quando interrogado torna-se obrigatório. Desaparece o debate oral, substituído pelas formas escritas; legitima-se a tortura como meio de forçar a auto-acusação. E mais: veda-se a defesa, sob o pálio de poder ser prejudicial à obtenção da verdade.

Essa metodologia, perversa em termos de garantias do indivíduo, propagouse às justiças laicas da Itália, Espanha, Alemanha e França ${ }^{38}$, causando repulsa pelo sofrimento impingido aos acusados em geral. Com efeito, os argumentos de que era preciso

36 Consoante esclarece Antonio Magalhães Gomes Filho, o método inquisitivo aprimorou-se sobretudo no seio das jurisdições eclesiásticas, fundado no poder de vigilância papal e na necessidade de repressão da heresia e das condutas irregulares do clero, a exigir permanente investigação das autoridades religiosas. Com isso, instituiu-se o segredo, a pesquisa praticamente ilimitada da verdade, dirigida por uma busca desenfreada pela confissão, tida como a melhor forma de se alcançar a verdade real, inclusive com recurso à tortura. Em avaliação dos novos métodos adotados pela jurisdição eclesiástica, diz o autor: "A rigor, bem analisadas as coisas, a técnica do inquérito não chegava a superar o irracionalismo dos duelos e ordálias, em que a revelação do verdadeiro é confiada à divindade; afinal, a tortura também não passava de um jogo (desigual) entre o juiz-inquisidor e o acusado, em que este ganha, resistindo, ou perde, confessando" (Direito à prova no processo penal. São Paulo: Revista dos Tribunais, 1997, p. 21-22).

37 Referido Tribunal, de triste fama pela crueldade de seus procedimentos, foi criado em 1480, na Espanha, com a nomeação dos quatro clérigos que o integrariam no início, e começou a funcionar no ano seguinte, estendendo-se por quase toda a América hispânica. Sua organização compreendia um Conselho Supremo de Apelação, presidido pelo Inquisdor Geral e integrado por três monges, e tribunais inferiores. Tinha competência restrita aos delitos de fé (heresias e delitos conexos). Conduziu ao extremo as características do sistema inquisitivo (entre elas, o segredo absoluto das atuações, a obrigatoriedade da denúncia ou delações, inclusive entre parentes, e o interrogatório do imputado sob juramento e tortura) e foi abolido definitivamente em 1820 (MAIER, Julio B. J. Derecho procesal penal argentino. Buenos Aires: Hammurabi, 1989, t. 1, v. b, p. 67-68).

38 Ressalte-se que a onda inquisitorial não encontrou eco na Inglaterra, onde mantidas as garantias criminais inerentes ao sistema acusatório (publicidade dos processos, direito de defesa, vedação da tortura). 
tornar mais firme a repressão estatal aos delitos e de que tais meios facilitavam a apuração da verdade no processo penal não encontraram suporte moral. Faltou ao direito canônico instrumentalizar adequada proteção ao homem acusado de um fato delituoso ou herético.

Foi o modelo prestigiado durante séculos por vários países do continente europeu como meio de corrigir os defeitos do acusatório e apenas sofrendo sensível alteração, mais tarde, com a codificação napoleônica.

No final do século XVIII, cresce a reprovação ao sistema inquisitivo canônico e toma a França um movimento libertário de rechaço a institutos fundamentais do sistema processual penal do Antigo Regime, como as denúncias secretas e as torturas, e de formulação dos novos paradigmas do direito liberal.

A Revolução Francesa, em 1789, seria o princípio do abandono do sistema inquisitório. Algumas leis que se lhe seguiram procuraram imprimir maiores garantias em favor do acusado, mas o rompimento definitivo com o procedimento inquisitório ou com o puro acusatório introduzido pela legislação revolucionária dá-se com o Code d'Instruction Criminelle de 1808 (Código de Napoleão), que entrou em vigor em 1811, inaugurando um terceiro gênero, denominado sistema misto ou francês.

Pretendendo ser um elo entre a necessidade de repressão e as garantias individuais e apagar as imperfeições de cada um dos outros, o sistema misto dividiu o processo em duas fases: uma inquisitória e uma amplamente acusatória. Na primeira, faziase a instrução preparatória, escrita e secreta, dirigida pelo juiz de instrução, para apurar o fato em sua materialidade e autoria, sem acusação e sem defesa ${ }^{39}$. Na segunda, totalmente pública, oral e contraditória, fazia-se o julgamento pelo júri, instituição baseada no direito inglês. Um acusador público - o Ministério Público - passou a deter o monopólio da acusação em nome do Estado, além de exercer o controle dos atos das autoridades incumbidas da investigação preliminar e do próprio juiz, na fase de julgamento.

O sistema francês construiu dogmas que se propagaram por muitos países, especialmente quanto à separação das funções que caracterizam a instrução (investigação),

39 Tratava-se da etapa de investigação criminal, que no sistema misto integrava o processo penal propriamente dito, não constituindo uma fase pré-processual, como no sistema acusatório. O Código Napoleônico definia sua natureza jurídica como sendo processual, tanto que a denominava de fase dos "processos verbais". Mauro Fonseca Andrade sustenta que "a natureza processual da investigação criminal do sistema misto é o que o diferencia do sistema acusatório. Isto porque estes dois sistemas processuais penais exigem a presença do princípio acusatório (necessidade de um acusador distinto do juiz), mas o sistema acusatório exige que sua investigação criminal tenha natureza administrativa, ao passo que o sistema misto exige que sua investigação tenha natureza processual" (Ministério Público e sua investigação criminal. 2. ed. rev. e atual. Curitiba: Juruá, 2008, p. 43, nota 46). 
a acusação e o julgamento, constituindo a base dos ordenamentos afetos à tradição continental $^{40}$. Marcou o início da fase dita moderna do processo penal, caracterizada pelo sistema da certeza moral, em que se busca a formação da livre convicção do julgador e dos jurados. Abandona-se a fórmula da certeza legal, afastando-se qualquer valor prédeterminado das provas, que passam a valer segundo entenda o julgador, guiado pelo livre convencimento formado segundo provas produzidas sob o crivo do contraditório ${ }^{41}$.

Entre os sistemas processuais adotados hodiernamente, destacam-se os juizados de instrução, típicos do sistema inquisitório e de inspiração francesa, e o modelo anglo-saxônico, no qual se vislumbram mais nitidamente os componentes do sistema acusatório. No primeiro caso, a fase investigativa fica a cargo do magistrado, como ocorre na França ${ }^{42}$, na Argentina e no México. No segundo, próprio do common law, deixa-se ao Ministério Público e ao imputado a titularidade da instrução, sendo defeso ao juiz interferir na etapa das investigações preliminares (fase pré-processual) e na iniciativa instrutória.

40 Mesmo nos países que adotam o sistema misto, não são ausentes as críticas. Na Itália, a realidade processual vigente desde o Código de 1989 não se desvincula da experiência vivida sob o Código Rocco, com fortes marcas inquisitórias: liberdade do juiz na investigação e na formação da prova, em regime de segredo, relegando-se o imputado e seu defensor a posição de inferioridade, excluídos da atividade probatória. Segundo Siracusano, Galati, Tranchina e Zappalà (Diritto processuale penale. 3. ed. Milano: Giuffrè, 2001, v. 1, p. 39-40), um sistema tal, certamente pouco idôneo a satisfazer a real expectativa de justiça, suscitou a exigência de uma profunda reforma da "infeliz combinação do sistema misto" para adequá-lo a um ordenamento democrático, com ampla consideração pela pessoa, acentuação dos poderes da parte na formação da prova, valorização dos debates e da oralidade. Concluem, entretanto, os autores que a miragem do rito acusatório dura muito pouco, tanto quanto a ilusão de um Código seguro e duradouro, mantendo-se um aglomerado de normas sem harmonia, resultante das modificações legislativas e de não poucos pronunciamentos da Corte constitucional.

41 Como afirma Antonio Magalhães Gomes Filho (Direito à prova..., cit., p. 161-162), a cada um dos sistemas probatórios contemporâneos corresponde uma metodologia própria de acertamento dos fatos, assim como determinado critério de valoração das provas. Ao método inquisitório, ligam-se as provas legais, em que a função do julgador é de mera constatação da existência da prova e dedução do seu valor (pré-estabelecido em regras gerais e abstratas). No sistema anglo-americano, de natureza acusatória, a apreciação se faz pela íntima convicção, que pressupõe uma tomada de posição pessoal para solução das questões de fato, desvinculando os juízes e jurados de regras probatórias e da indicação dos motivos da convicção. Por fim, no sistema misto, a avaliação das provas obedece, regra geral, ao critério do livre convencimento ou da persuasão racional, o qual também investe o agente de amplos poderes de crítica e seleção do material probatório, sendo que tal liberdade é racionalizada, delimitando-se o caminho legal a ser percorrido pelo julgador mediante a fundamentação, a justificação perante as partes e a sociedade. Cf., ainda, Julio B. J. Maier (Derecho procesal..., cit., p. 592 e ss.).

42 Mesmo na França, criticam-se os juizados de instrução, que vão aos poucos cedendo vez à polícia judiciária. Como noticia Gonzalo Jar Couselo (Modelos comparados de policía. Madrid: Dykinson, 2000, p. 50-52), na intenção de promover uma reforma da justiça, o Presidente Chirac deu a conhecer, em julho de 1997, o Informe Truche, no qual, entre outras questões, pretendia retirar as atribuições dos juízes instrutores, incorporando a figura do "juiz de liberdade" (que decidiria objetivamente os casos de detenção policial), bem assim as faculdades policiais de manter os detidos, durante as primeiras vinte horas, sem assistência de advogado, o que provocou protestos dos sindicatos de polícias. Nessa permanente tensão entre os Poderes Executivo e Judiciário (os juízes franceses exercem uma direção funcional da polícia judiciária, ao passo que a orgânica permanece com o Executivo), houve mesmo um 
A adoção de um ou outro sistema não resulta de mera opção legislativa, mas lança raízes na própria natureza do Estado que o perfilha. É interessante, todavia, atentar para uma gradual substituição, no direito comparado, do modelo inquisitivo pelo acusatório, este que seria, no dizer de Geraldo Prado, o sistema vocacionado a cumprir a função garantística do processo penal ${ }^{43}$.

\subsection{O princípio acusatório e o reparto de papéis no processo penal: a investigação preliminar}

Ao se delimitarem os grandes sistemas informadores do processo penal, empregamos a palavra sistemas como indicativa de categorias compostas de normas e princípios fundamentais que lhes dão contornos. Corriqueiro é identificar-se o sistema com o princípio $^{44}$ que lhe é determinante, o que não deve, contudo, induzir à coincidência entre ambas as categorias (sistema e princípio), malgrado a aproximação tipológica. Assim, por exemplo, o princípio acusatório constitui o núcleo básico, essencial do sistema acusatório, embora não o esgote, dado que este último é composto também de outros princípios e normas, algumas já dantes mencionadas ${ }^{45}$.

caso, em 1996, no qual os membros da polícia de Paris negaram o requerimento de um juiz, para que o acompanhassem em busca no domicílio do prefeito da capital.

43 PRADO, Geraldo. Sistema acusatório..., cit., p. xiii-xiv. No mesmo sentido, Juan Luís Gómez Colomer (La investigación criminal: problemas actuales y perspectivas de unificación internacional. Revista del Poder Judicial, Madrid, n. 64, 2001, p. 210) afirma ser o princípio acusatório o que melhor serve à justiça da decisão e mais garante o "juízo limpo", o que significa por sua vez uma "investigação limpa”, ou, como melhor se compreende na Europa continental, um juízo imparcial para o acusado, o que implica também uma investigação imparcial ou objetiva.

44 Como princípios, entendem-se as idéias que estão no princípio de algo; as orientações de caráter geral que servem de pontos de partida e de chegada num sistema, alçadas, com o pós-positivismo, a normas fundantes dos ordenamentos. Como assinala Paulo Bonavides, "[a]s novas Constituições promulgadas acentuam a hegemonia axiológica dos princípios, convertidos em pedestal normativo sobre o qual se assenta todo o edifício jurídico dos novos sistemas constitucionais" (Curso de direito constitucional. 21. ed. atual. São Paulo: Malheiros, 2007, p. 264). Os princípios atuam normativamente, integram o direito positivo como normas primárias e distinguem-se de outras normas, quais as regras jurídicas, por vários critérios. Robert Alexy aponta entre as regras e os princípios uma diferença qualitativa e de grau: os princípios são mandados de otimização e por isso podem ser cumpridos em maior ou menor grau a depender das possibilidades do caso concreto. A sua vez, as regras são normas que só podem ser cumpridas ou não, numa lógica binária (Teoría de los derechos fundamentales. Trad. Ernesto Garzón Valdés. Madrid: Centro de estudios políticos y constitucionales, 2001, p. 86-87).

45 Conferimos ressalva, embora dela não partilhemos, à posição de Rogério Lauria Tucci (Teoria do direito processual penal: jurisdição, ação e processo penal (estudo sistemático). São Paulo: Revista dos Tribunais, 2002, p. 226-230), para quem o processo penal conteria apenas um princípio, um ponto de partida sobreposto ao direito positivo. O sistema processual penal seria orientado, conforme leciona o autor, pelo princípio publicístico, sob o qual se posicionariam todas as demais regras, algumas mais genéricas (oficialidade, judiciariedade e verdade material ou atingível) e outras, mais específicas 
Ponto fundamental desse sistema é, portanto, o princípio acusatório, que, no dizer de Roberto Falcone, tem caráter eminentemente formal, na medida em que se perfaz com a exigência de abertura do processo mediante uma acusação, formulada por órgão diferente daquele que tem a obrigação de decidir o conflito ${ }^{46}$.

Semelhante noção é a esboçada por Teresa Armenta Deu, que localiza a essência inescusável do sistema acusatório na "prévia existência de uma acusação, exercitada e sustentada por sujeito diferente do órgão julgador" ${ }^{\circ 7}$.

Geraldo Prado vai além, enxergando-o sob uma tríplice divisão, ao enunciar que tal princípio, avaliado estaticamente, alicerça-se no reparto, entre três diferentes sujeitos, das tarefas de acusar, defender e julgar. Consiste na distribuição do direito de ação, do direito de defesa e do poder jurisdicional entre acusador, acusado (e seu defensor) e juiz, e só se desenvolve regularmente em um processo de partes, centrado nas relações recíprocas estabelecidas entre elas ${ }^{48}$.

A evolução publicista do processo rumo à oficialidade da ação penal, retratada no tópico anterior, direciona-o, de fato, a um processo de partes, com separação das principais atividades processuais (acusar, defender e julgar), sem, no entanto, descurar o Estado da persecutio criminis: entrega a acusação a uma instituição independente (o que se torna possível com a criação do Ministério Público), seja em caráter exclusivo (como na Itália, Alemanha e Brasil) ou compartilhado (como na Espanha), desvinculando o juiz dessa atividade. Daí a sua identificação com um verdadeiro actum trium personarum ${ }^{49}$.

Intermédio entre o processo acusatório extremamente individualista e o repudiado inquisitório, o processo penal moderno criou mecanismos para que a atividade jurisdicional se faça de forma justa, independente de interesses privados, retirando-se o magistrado das funções persecutórias e, em conseqüência, resguardando-lhe a imparcialidade, que constitui nota fundamental do processo. Previnem-se, ademais,

(inevitabilidade do processo, procedimento de ofício, jurisidicionariedade, administratividade, inquisitividade, contraditório real e livre convencimento do juiz).

46 FALCONE, Roberto Atilio. El principio acusatorio: el procedimiento oral en la Província de Buenos Aires y en la Nación. Buenos Aires: Ad-Hoc, 2005, p. 17-18.

47 DEU, Teresa Armenta. Principio acusatorio..., cit., p. 26, tradução livre.

48 PRADO, Geraldo. Sistema acusatório..., cit., p. 104-107.

49 A expressão é de Búlgaro, que a cunhou no século XII, e reflete a verdadeira afirmação do juízo penal, em que a acusação será sempre formulada por órgão diverso do juiz, não podendo existir jurisdição sem ação, em virtude do princípio da inércia (HAMILTON, Sergio Demoro. A ortodoxia do sistema acusatório no processo penal brasileiro: uma falácia. Revista de Direito da Defensoria Pública, Rio de Janeiro, v. 13, n. 17, 2001, p. 193). 
possíveis resquícios do chamado processo inquisitivo, que conferia ao julgador poderes instrutórios amplos, sob o pálio da tão propalada "busca da verdade real ou material",

Reconhece-se, portanto, no acusatório o perfil do processo mais condizente com a realização da Justiça criminal, porquanto se liberta o juiz de qualquer vinculação psicológica com a pretensão em causa, vez que não teve a iniciativa de instaurar a ação ou de buscar a prova. Deveras, por suas notas essenciais históricas (separação entre juiz e acusador, paridade de armas entre acusação e defesa, publicidade e oralidade dos atos processuais, etc.), evidente é a tendência garantista do processo acusatório ${ }^{51}$.

Posta essa premissa, resta saber de que maneira há de ser modulada a fase de investigação preliminar, para manter-se harmonizada ao perfil garantista e à separação de funções entre os sujeitos envolvidos na persecução penal, preconizada pelo modelo acusatório, sejam elas jurisdição, acusação e defesa. Afinal, a estrutura da investigação criminal é um elemento crucial para distinguir entre sistemas de índole acusatória ou inquisitória.

No estágio atual do pensamento instrumental penal, avulta o debate, no confrontar dos sistemas, sobre a legitimidade para instaurar e conduzir a investigação preliminar. Nesse ponto, o juizado de instrução, típico do sistema francês, cede espaço a uma etapa investigativa livre de ingerências do julgador que não sejam para garantir a legalidade das medidas investigatórias tomadas, contra e a favor do investigado.

As maiores aspirações reformistas retiram dessa cena o julgador e a diluem entre os agentes de segurança pública e o Ministério Público, conferindo-se ao juiz o posto de garantidor, atuando em incidentes jurisdicionalizados dentro da investigação criminal $^{52}$. No transcurso dessa etapa, o modelo acusatório ideal repudia a introdução de outro órgão

50 Essa adjetivação da verdade que se pretende alcançar com o processo, conquanto ainda recorrente no meio jurídico, parece-nos, como já afirmado, infeliz, seja pela natural impossibilidade de reconstituição perfeita dos fatos trazidos a juízo em todos os casos, seja porque, em qualquer situação, a verdade da decisão será mesmo ditada mediante o processo, o encontro das partes, com oportunidades equânimes de apresentação de provas e de contra-argumentação. Cf., a respeito, ZAGREBELSKY, Vladimiro. Modello accusatorio e deontologia dei comportamenti processuali nella prospettiva comparatistica. Rivista Italiana di Diritto e Procedura Penale, Milano, n. 36, p. 435-492, apr./giugno 1993.

51 Sobre o inevitável nexo estabelecido entre sistema acusatório e modelo garantista, cf. FERRAJOLI, Luigi. Diritto e ragione: teoria del garantismo penale. 8. ed. Roma: Laterza, 2004, p. 575.

52 Quanto a essa tendência, Fauzi Hassan Choukr (Garantias..., cit., 2006, p. 26-28) destaca que, nas propostas de alteração legislativa na França, o juizado foi abrindo espaço à polícia judiciária, sobretudo com o recrudescimento da importância das enquêtes préliminaires, realizadas pela polícia, agindo autonomamente ou por delegação da magistratura. Nada obstante, ainda é mantido o juiz de instrução, embora intervindo em uma minoria de casos. Há uma ligação inclusive hierárquica entre a polícia judiciária e o Ministério Público, a quem cabe a fiscalização do trabalho policial. Aponta o autor também 
estatal que não o legitimado ativo para sua condução e valoração. Consolida-se o Ministério Público como titular da ação penal e orientador de sua preparação, contando com o apoio da polícia judiciária ${ }^{53}$.

Assim, não se tem por válida a inserção, na fase pré-processual, do julgador (sujeito a quem cabe, na tripartição de poderes do Estado soberano, a decisão do conflito de interesses instaurado com o processo), a menos quando em debate matéria sujeita à reserva de jurisdição, como nos casos de decretações de prisão cautelar, de escuta telefônica, de busca e apreensão, de liberdade provisória, etc. Afigura-se mais consentâneo ao princípio acusatório, evitando-se a colheita de elementos desnecessários, que o titular da ação penal, e não o juiz, oriente a investigação preliminar, atuando em conjunto com a polícia.

Procura-se, com essa estruturação da investigação preliminar, conferir maior efetivação aos preceitos constitucionais, deixando ao magistrado tão-somente a função que lhe cumpre na fase pré-processual, que é a de juiz de garantias ou juiz das liberdades ${ }^{54}$, dependendo suas decisões da iniciativa e das alegações dos sujeitos envolvidos na persecução preliminar, não the sendo reconhecidos poderes investigatórios, a não ser em caráter suplementar, e apenas na fase processual da persecução. Com essa nítida separação de funções - separação que deve ser retraída ao início da fase investigatória -, evita-se que o magistrado, cuja vocação precípua é a de decidir conflitos de interesses, imiscua-se na produção de elementos de convicção que serão, mais tarde, a ele mesmo dirigidos, quando da apreciação da viabilidade da ação penal.

a criação, pela Lei 516, de 15.6.2000, de um juiz específico para os incidentes jurisdicionais ao longo da investigação (o juiz de garantias), mesmo quando desenvolvida por um juiz instrutor.

53 Assim o revela Antonio Scarance Fernandes (Rumos da investigação criminal no direito brasileiro. Boletim do Instituto Manoel Pedro Pimentel, São Paulo, v. 5, n. 21, jul./set. 2001, p. 13): "Há um forte movimento na Europa continental no sentido de migrar de um sistema informado pelo juizado de instrução para outro em que se dá ao Ministério Público a tarefa de supervisionar a investigação. O exame, contudo, dessas realidades mostra que sempre há necessidade de uma atividade típica de investigação realizada pela polícia. A diferença existente é em relação à autoridade para a qual são remetidos os resultados dessa investigação preliminar, autoridade essa que poderá, a partir desse momento, ouvir quem foi apontado como autor do crime, inquirir pessoas e determinar novas diligências".

54 Como bem ensina Aury Lopes Jr. (Sistemas..., cit., p. 162-163), "o fundamento da legitimidade da jurisdição e da independência do Poder Judiciário está no reconhecimento da sua função de garantidor dos direitos fundamentais inseridos ou resultantes da Constituição". Juiz garante, juiz garantidor, juiz de garantias ou juiz das liberdades são expressões indistintamente aptas a designar, no Estado Democrático de Direito, o papel do Juiz na garantia dos direitos do acusado na persecução penal, não podendo ficar inerte diante de violações ou ameaças a direitos fundamentais constitucionalmente consagrados. Quando chamado a atuar no inquérito policial, o juiz deve adotar a posição de garante dos direitos fundamentais do sujeito passivo. Os direitos fundamentais, por sua vez, dirigem-se contra o Estado e, assim, a função do juiz no processo penal passa a ser a de proteção do indivíduo, em seus direitos fundamentais de liberdade e segurança coletiva, contra os atos abusivos do Estado, típicos de um Estado-Policial. Sobre uma proposta de definição do Juiz de garantias em nosso direito processual penal, cf. item 3.3.5. 


\subsection{A afirmação do modelo acusatório pela Constituição de 1988}

A evolução dos sistemas processuais penais demonstra que, ao longo do tempo, houve uma variação entre o autoritarismo, com aniquilação dos direitos do acusado, e o Estado de Direito ${ }^{55}$, no qual se assegura ao imputado uma série de garantias constitucionais. E o processo penal passa a ser verdadeiramente concebido como uma conquista do Estado de Direito, um instrumento não apenas de persecução, mas sobretudo de garantia do acusado ${ }^{56}$.

No Brasil, aos primórdios da colonização, no século XVI, foi marcante a tradição religiosa de Portugal, sobremodo influenciada pelo sistema inquisitório apregoado pela Igreja Católica. Aplicaram-se sucessivamente as Ordenações Manuelinas e Filipinas, com o predomínio das formas canônicas, como as inquirições devassas. Regra geral, portanto, era a inquisitorialidade, fundada na iniciativa de ofício, no emprego da tortura, no sistema de avaliação legal das provas e na predominância da forma escrita. Tal modelo

55 Logo no primeiro artigo da Constituição de 1988, o Estado Democrático de Direito é erigido em um dos pilares da República, semelhante ao que ocorre em outras Cartas Fundamentais (Espanha, Portugal, França, Itália, etc.). A expressão significa "a exigência de reger-se por normas democráticas, com eleições livres, periódicas e pelo povo, bem como o respeito das autoridades públicas aos direitos e garantias fundamentais" (MORAES, Alexandre de. Direito constitucional. 7. ed. atual. São Paulo: Atlas, 2000, p. 49). Nas relações concretas entre o Poder e o indivíduo, pode ser conceituado como "aquele Estado de Direito que se empenha em assegurar aos seus cidadãos o exercício efetivo não somente dos direitos civis e políticos, mas também e sobretudo dos direitos econômicos, sociais e culturais, sem os quais de nada valeria a solene proclamação daqueles direitos" (MENDES, Gilmar Ferreira; COELHO, Inocêncio Mártires; BRANCO, Paulo Gustavo Gonet. Curso de direito constitucional. São Paulo: Saraiva, 2007). Há quem entenda redundante a expressão Estado Democrático de Direito, pois, se é de direito, é porque é democrático. No dizer de Nelson Saldanha (Estado de direito, liberdade e garantias: estudos de direito público e teoria política. São Paulo: Sugestões Literárias, 1980, p. 22), “[o] conceito de democracia, tão discutido e desgastado nos últimos decênios, continua em tela de juízo para complementar a idéia de um Estado de Direito". Com efeito, na origem da fórmula Rule of Law, o conceito de Estado de Direito se equipara ao de Estado Democrático de Direito, porque não significa somente o império da lei, mas a proeminência das leis, das tradições e dos direitos individuais do povo inglês sobre a discricionariedade dos poderes públicos (CANOTILHO, J. J. Gomes. Direito constitucional e teoria da Constituição. 7. ed. Coimbra: Almedina, 2003, p. 93-94). No entanto, algumas experiências demonstram que é possível existir Estados de Direito (sob o aspecto formal) que legalizam um governo autoritário, como foram, entre nós, o Estado Novo (CF/1937) e a Ditadura Militar (CF/1967-1969). Não se fala, nesses casos, em Estado Democrático de Direito, pois neles não havia liberdades individuais ou respeito a direitos fundamentais, e a própria Constituição servia apenas como meio de estabilizar o domínio de determinado grupo no poder. Assim, o Estado constitucional moderno não pode limitar-se a ser apenas um Estado de Direito, mas deve estruturar-se como um Estado de Direito Democrático, uma ordem de domínio legitimada pelo povo (CANOTILHO, J. J. Gomes. Ibidem, p. 98).

56 Nesse sentido, Ada Pellegrini Grinover, valendo-se das lições de Bettiol, afirma que "o processo penal deve ser concebido como uma conseqüência do aparecimento e da consolidação do Estado de direito, como idéia de garantia para as liberdades do cidadão e de limitação da intervenção estatal, no pressuposto de que o Estado deve reconhecer os direitos invioláveis da pessoa" (Liberdades públicas..., cit., p. 16). 
correspondeu a uma concepção absolutista de Estado ${ }^{57}$, com conseqüências culturais e jurídicas que até hoje se fazem sentir.

Após a independência, nossa primeira Carta Política, outorgada em 25 de março de 1824 e com espírito iluminista, representou um avanço para os costumes da época, contendo um título sobre garantias dos direitos civis e políticos dos cidadãos brasileiros. Vieram o Código Criminal do Império, em 16 de dezembro de 1830 (que manteve algumas penas cruéis, como a pena de morte, para atender aos interesses da sociedade burguesa ${ }^{58}$ ), e o primeiro Código de Processo Criminal, em 29 de novembro de 1832. A Justiça eclesiástica passou a decidir unicamente questões espirituais, abolidas de vez as devassas.

Embora de índole mais liberal que o modelo da França, por admitir alguma contrariedade, e não mais o segredo, o Código de Processo do Império não adotou a estrutura de um processo misto, qual o francês, à míngua de um órgão público devidamente estruturado e desenvolvido com incumbência da acusação, por isso que resguardava o procedimento ex officio, permitindo-se ao juiz dar início à ação penal e reunir, ele próprio, as provas necessárias (arts. 138, 154 e 206).

A Lei 261, de 3 de dezembro de 1841, fortaleceu a ação penal ex officio, com amplos poderes instrutórios do juiz, visando ao mais vasto conhecimento da "verdade", somente se implementando restrições à aplicação do procedimento de ofício com a Lei 2.033 , de 20 de setembro de 1871 , que instituiu o inquérito policial ${ }^{59}$.

57 Em linhas gerais, esse modelo pode ser assim caracterizado: sistema autoritário de relações sociais, domínio das elites agrárias, exploração de latifúndios, escravidão, patrimonialismo e clientelismo.

58 A ideologia então predominante no Brasil era o liberalismo, permeado dos princípios iluministas do século XVIII, a preconizar a supremacia das leis, dos direitos do homem, da igualdade perante a lei. Mas, ao contrário da França, não tivemos uma revolução cultural, não houve um embate contra os velhos privilégios dos setores agrários, sendo as idéias liberais meramente formais. A estrutura política permaneceu conservadora (exemplo é a manutenção do Poder Moderador), de sorte que o liberalismo concretizou-se apenas no plano econômico. Ricardo de Brito A. P. Freitas demonstra que o liberalismo brasileiro ajustou-se ao conservadorismo nacional e, como nos países periféricos em geral, foi avesso à efetivação da democracia e da igualdade política entre os indivíduos (As razões do positivismo penal no Brasil. Rio de Janeiro: Lumen Juris, 2002, p. 352-356).

59 Cf. BARROS, Marco Antonio de. A busca da verdade..., cit., p. 80-81. O inquérito foi estruturado pelo Decreto 4.824, de 22 de novembro de 1871, cuja preocupação foi a de coibir abusos na atuação das autoridades policiais, que, até então, em virtude da Lei de 3 de dezembro de 1841 e do Regulamento 120 , de 31 de janeiro de 1842, detinham poderes excessivos, realizando autênticas devassas, pois não se submetiam a qualquer limitação de tempo para remeterem os esclarecimentos obtidos ao juiz. Pelo novo regime, com o investigado preso, o inquérito deveria ser ultimado em cinco dias. Na observação de João de Deus Cardoso de Mello (O inquérito policial em face do Anteprojeto. Revista Brasileira de Criminologia e Direito Penal, Rio de Janeiro, v. 3, n. 9, abr./jun. 1965, p. 48), “o pensamento liberal da lei de 20 de setembro foi codilhado pelo decreto que o regulamentou (...); o inquérito policial, por uma 
A Constituição republicana de 1891 trouxe progressos quanto aos direitos conferidos aos acusados (garantia de plena defesa com todos os meios a ela inerentes, abolição das penas de morte e de banimento) e fracionou o processo penal, conferindo a cada Estado-membro autonomia para legislar em matéria de processo, o que deu azo à coexistência de regras as mais diversificadas. A heterogeneidade, todavia, não foi assimilada pela cultura jurídico-processual e findou abolida pela Constituição promulgada em 1934, que reunificou o direito processual nacional (art. 5. ${ }^{\circ}, \mathrm{XIX}, a$ ). No mesmo ano, foi nomeada a comissão de juristas (Narcélio de Queiroz, Nelson Hungria, Cândido Mendes de Almeida, Vieira Braga, Florêncio de Abreu e Roberto Lyra) para elaboração do que viria a tornar-se o atual Código de Processo Penal, na redação original.

O Decreto-lei 3.689, de 3 de outubro de 1941, instituiu o vigente Código de Processo Penal. Sem prejuízo da mantença de elementos inquisitoriais no processo, avançou na outorga ao Ministério Público do poder de requisição de inquérito policial e de diligências, além de cometer-lhe a titularidade da ação penal pública, embora, como destaca Hugo Nigro Mazzilli, ainda se admitisse o procedimento penal ex officio (nas contravenções penais: arts. 26 e 531 do CPP), somente reconhecido superado, pela jurisprudência, após o advento da Carta de $1988^{60}$ e, no plano positivo, suplantado com a nova redação conferida pela Lei $11.719 / 2008^{61}$.

Sempre foi dominante o entendimento de que o sistema do Código de Processo Penal de 1941 era misto, porque composto de duas fases consecutivas - a primeira, inquisitiva e marcada pelo inquérito policial, e a segunda, acusatória, iniciada com o processo -, não estanques nem incomunicáveis, mas com características mescladas: ao passo que no inquérito é permitido à vítima e ao investigado requerer diligências, na fase processual são muitos os atos escritos, permitindo-se eventualmente o sigilo (arts. 487, 745 e $792, \S 1$. , v.g.) e mesmo a iniciativa judicial para "descobrir a verdade" (arts. 156, I e II, 176 e 209 , por exemplo) $)^{62}$.

dessas ironias com que os deuses costumam zombar dos homens, veio a receber a certidão de batismo exatamente do decreto regulamentador da lei que tencionara reduzi-lo à sua expressão mais simples".

60 MAZZILLI, Hugo Nigro. Regime jurídico do Ministério Público: análise da Lei Orgânica do Ministério Público, aprovada pela Lei n. 8.625, de 12 de fevereiro de 1993. 3. ed. rev. ampl. e atual. São Paulo: Saraiva, 1996, p. 12. Cf., a respeito, STF, RHC 68.314/DF, rel. Min. Celso de Mello, Plenário, v.u., DJ de 15.3.1991; STJ, RHC 2.363/DF, rel. Min. Jesus Costa Lima, 5. Turma, v.u., DJ de 17.12.1992.

61 Subsiste ainda no CPP, porém, o art. 26 em sua redação originária (“A ação penal, nas contravenções, será iniciada com o auto de prisão em flagrante ou por meio de portaria expedida pela autoridade judiciária ou policial"), nitidamente não-recepcionado pela Constituição de 1988.

62 A par da distinção acusatório/inquisitório, impende referir um outro binômio, assaz difundido no direito anglo-saxão, derivado do princípio de gestão da prova adotado pelo sistema, considerando-se o sujeito 
Não obstante, sob os auspícios da Ordem Constitucional de 1988, separadas claramente as funções de julgar, acusar e defender, previsto o amplo contraditório e consignada expressamente a presunção de inocência, pode-se concluir que, conquanto mantido o inquérito policial, está-se diante de um sistema acusatório ${ }^{63}$.

$\mathrm{O}$ verdadeiro processo de partes estaria denunciado em regras inovadoras como a da titularidade exclusiva da ação penal pública ao Ministério Público (art. 129, I, da $\mathrm{CF}^{64}$ ), que se desvincula do Poder Executivo, a constitucionalização da função do advogado (art. 133, CF) e a instituição das defensorias públicas (art. 134, CF). O papel de acusar tocará apenas ao Ministério Público, nas ações penais públicas, ou ao querelante, nas ações penais de iniciativa privada, e o juiz decidirá a imputação formulada, descabendo falar quer em julgamento por parte do acusador, quer em acusação de ofício.

Nesse contexto, a Constituição brasileira de 1988, pródiga na outorga de direitos processuais fundamentais, traçou um modelo de processo penal publicista que se reconhece como acusatório, máxime diante da expressa atribuição, ao Ministério Público, da titularidade exclusiva da ação penal pública e da consagração do devido processo legal

preponderante na direção da marcha processual. O adversarial system é o modelo que se caracteriza pela predominância das partes na determinação da marcha do processo e na produção das provas. Não só é primazia das partes a iniciativa de instaurar o processo, mas também o controle sobre a marcha processual, estimulando-se o duelo, a competição entre elas, com isso se procurando favorecer o julgamento imparcial (sem uma atuação instrutória, o juiz ficaria impossibilitado de formar juízos prematuros). Em contraponto, pelo inquisitorial system, as referidas atividades recaem, preferencialmente, sobre o juiz, desenvolvendo-se o processo por impulso oficial. Ada Pellegrini Grinover (A iniciativa instrutória do juiz no processo penal acusatório. Revista Forense Comemorativa - 100 anos, Rio de Janeiro, t. 7, 2006, p. 796-797) afasta qualquer correspondência entre as dicotomias acusatório/inquisitório e adversarial/inquisitorial. Geraldo Prado, a sua vez, enxerga uma vinculação entre o direito de ação (e defesa) e o direito à prova, concluindo que, pelo princípio acusatório, não tem o juiz poderes de investigação judicial, permitindo-se, quando muito, que intervenha moderadamente na instrução, pesquisando supletivamente provas arrimadas nas teses de defesa (Sistema acusatório..., cit., p. 136-137). José Carlos Barbosa Moreira menciona que, nos Estados Unidos, há quem enxergue no accusatory system uma parte básica do adversary system, repudiando o autor a confiança em terminologias tão vacilantes (O processo penal norte-americano e sua influência. Revista de Processo, São Paulo, v. 26, n. 103, jul./set. 2001, p. 106). E Aury Lopes Jr., na esteira do pensamento de Jacinto de Miranda Coutinho, aponta a gestão da prova como pedra angular da distinção entre os sistemas acusatório e inquisitório (Sistemas..., cit., p. 71, nota 8).

63 Oportuno transcrever a opinião de Luiz Flávio Gomes a respeito: "Quando [a Constituição] se refere ao Judiciário, no Capítulo próprio, inúmeras vezes utilizou a palavra 'jurisdição', que tem o sentido clássico de 'dizer o direito'. Não se trata de um modelo acusatório 'puro' (até porque o juiz ainda pode determinar a realização de prova ex officio), mas é inegável que se aproximou do ideal” (Crime organizado: enfoques criminológico, jurídico (Lei 9.034/95) e político-criminal. 2. ed. rev., atual. e ampl. São Paulo: Revista dos Tribunais, 1997, p. 135).

64 Fauzi Hassan Choukr sugere, inclusive, que a titularidade exclusiva da ação penal pública pelo Ministério Público seja deslocada do art. 129 para o art. 5..$^{\circ}$ da Constituição, perdendo assim o viés aparentemente corporativista e passando a ser "encarada como uma garantia da sociedade na concepção de um modelo acusatório para o processo penal, vindo ao seu lado a idéia de uma polícia judiciária controlada 
(art. 5. ${ }^{\circ}, \mathrm{LV}$, da CF), fórmula originária do direiro anglo-saxônico ${ }^{65}$, e de seus desdobramentos, como a igualdade das partes no processo, a imparcialidade do julgador, a ampla defesa e o contraditório.

A institucionalização do Ministério Público, com o monopólio da ação penal pública, além da constitucionalização da advocacia e das defensorias públicas, fortaleceram a regra da igualdade processual e o chamado "processo de partes", retirando-se o julgador de atividades tipicamente "acusadoras", em prol da indispensável imparcialidade, elementar à garantia do juiz natural.

Por outro lado, na edificação dos fundamentos que norteiam o direito processual penal, nenhuma outra Carta brasileira foi tão generosa quanto a promulgada em 5 de outubro de 1988, um exemplo altamente significativo da assunção, pelo constituinte, dessa interação com o processo, trazendo diversas diretrizes processuais fundamentais, que resultaram beneficiadas pela rigidez do status constitucional, ganhando simbolismo cultural que anteriormente não tinham, por estarem, em grande parte, ao nível da legislação ordinária.

A maioria dessas regras, verdadeiros princípios da ciência processual, são mesmo auto-aplicáveis, porque representativas de direitos fundamentais, prescindindo de disciplina processual ordinária para serem implementadas. Ao revés, sendo regras de interpretação, demandam atenção por parte do legislador ordinário, com vistas a prevenir indesejados embates entre os princípios e as normas infraconstitucionais. Dentro de uma visão garantística, podemos acrescentar que, mesmo não sobrevindo normas que concretizem essas idéias gerais e abstratas (os princípios), cabe ao julgador (ao aplicador em geral), ao utilizar o processo como instrumento ético que é, adaptar as existentes ao pensamento político maior, desconsiderando-as, se for o caso ${ }^{66}$.

externamente por aquele, e tendo como papel fundamental o auxílio na persecução penal" (Garantias constitucionais na investigação criminal. São Paulo: Revista dos Tribunais, 1995, p. 82).

65 Assim como, no direito norte-americano, as cláusulas do due process of law e da equal protection of the laws complementam-se reciprocamente, o devido processo legal e a igualdade perante a lei são, no sistema brasileiro, complementares entre si, pois os princípios da legalidade e da isonomia, essenciais ao Estado de Direito, não fariam qualquer sentido sem um poder capaz de cumprir e pôr em prática, para todos, com a necessária presteza, a Constituição e as leis do país. Portanto, impõe-se que, no devido processo legal, seja assegurada a paridade de armas, visando à igualdade técnica dos sujeitos envolvidos, mediante o equilíbrio entre acusação e defesa.

66 Essa aplicabilidade imediata dos direitos, liberdades e garantias, expressa no art. $5 .^{\circ}, \S 1 .^{\circ}$, da Constituição brasileira e em outras cartas políticas do pós-guerra, J. J. Gomes Canotilho (Estudos sobre direitos fundamentais. São Paulo: Revista dos Tribunais, 2008, p. 146-147) descreve como uma normatividade reforçada, que nem mesmo o legislador pode subverter, devendo ser tais normas aplicadas 
Constitui, assim, tarefa inacabada a adequação do processo ao escopo de garantia de liberdades e sua conjugação à pretendida eficiência da persecução criminal. A busca da (inatingível) verdade real ainda paira como um dogma sobre o atuar dos operadores e, além disso, alguns traços marcadamente inquisitoriais permeiam a legislação ordinária, a exemplo da atribuição, pelo Código de Processo Penal, de amplos poderes de gestão da prova ao juiz, na fase processual, com isso desvanecendo a nota acusatória do sistema, porque abalado o equilíbrio dinâmico que se deve preconizar entre as partes no processo. É o que exemplifica o art. 156 daquele diploma, seja em sua redação primitiva ou, mais ainda, naquela alterada pela Lei $11.690 / 2008^{67}$.

Verifica-se, porém, como tendência geral de nossa legislação, a de purificar gradativamente o sistema acusatório (o modelo puro é algo de difícil, quiçá impossível, alcance), entregando a cada sujeito processual (acusador, acusado e julgador) funções não somente precípuas, mas exclusivas, conferindo-se ao imputado - e também à sociedade - a segurança de um processo penal mais democrático, na medida em que o juiz tem integralmente preservada a sua imparcialidade ${ }^{68}$.

\subsection{Garantias constitucionais e investigação preliminar}

O processo penal acusatório pressupõe um estatuto de garantias individuais e de parâmetros procedimentais ajustados à necessidade de efetivação daquelas, que merecem ser estudadas como premissas também para o tratamento da investigação criminal preliminar, de qualquer espécie que seja. As garantias do processo, representativas de valores éticos e políticos, tanto limitam o poder de julgar (protegendo os diretamente interessados no provimento judicial) como servem ao melhor exercício desse poder, porquanto visam ao justo processo, numa concepção publicista mais ampla, exibindo assim perfil subjetivo e também objetivo - de garantia das partes e da jurisdição ${ }^{69}$.

diretamente, sem necessidade de uma autoridade interposta, ou de lei interposta, constituindo "direito atual e eficaz".

67 "Art. 156. A prova da alegação incumbirá a quem a fizer, sendo, porém, facultado ao juiz de ofício:

I - ordenar, mesmo antes de iniciada a ação penal, a produção antecipada de provas consideradas urgentes e relevantes, observando a necessidade, adequação e proporcionalidade da medida;

II - determinar, no curso da instrução, ou antes de proferir sentença, a realização de diligências para dirimir dúvida sobre ponto relevante."

68 Cf. JARDIM, Afrânio Silva. Direito processual penal, cit., p. 312.

69 GRINOVER, Ada Pellegrini. O juiz natural como órgão constitucionalmente competente. Delegação da competência para a prática de atos instrutórios: limites. A modificação da competência por conexão e 
Se o processo (único meio legítimo posto ao Estado para a imposição de uma pena) constitui, por si, uma garantia, o mesmo se observa quanto à etapa préprocessual, a qual se apresenta como mecanismo de controle para as acusações penais, visando obstar o aforamento de ações temerárias. De fato, a investigação criminal serve como uma espécie de filtro pelo qual somente passarão ao plano processual as condutas revestidas de evidente tipicidade ${ }^{70}$.

A Constituição da República, ao disciplinar, no Título II, a declaração dos direitos e garantias individuais fundamentais, consagra, no caput do art. 5. ${ }^{\circ}$, aos brasileiros e aos estrangeiros residentes no país, a inviolabilidade dos direitos concernentes à vida, à liberdade, à igualdade, à segurança e à propriedade. Explicita, no mesmo artigo, diversos consectários dessa cláusula protetiva, compreendendo uma ampla gama de direitos subjetivos - em rol aberto, ex vi da redação do seu $\S 2 .^{\mathrm{o}^{71}}$ - reconhecidos como fundamentais, muitos dos quais alusivos à persecução criminal.

Além de projetar vários direitos subjetivos, inerentes à própria personalidade e individualidade do ser humano, o constituinte tratou de provê-los de garantias, instrumentos idôneos à sua asseguração e efetivação por órgãos judiciais, independentes e autônomos, protegendo-os sempre que violados, ainda que pelo próprio Estado. Porque sempre que estabelecidos direitos, devem, igualmente, ser previstas as garantias correlatas As garantias constitucionais ostentam tamanha interligação com os direitos individuais que por vezes até se fundem os dois predicativos num mesmo instituto.

continência. Contraditório e necessidade de informação. Capacidade postulatória dos membros do Ministério Público. Impedimento do desembargador que figure como vítima. (parecer). In: A marcha do processo. Rio de Janeiro: Forense Universitária, 2000, p. 415-416.

70 Por isso, como aponta Clèmerson Merlin Clève (Investigação criminal e Ministério Público. Boletim Científico da Escola Superior do Ministério Público da União, Brasília, v. 4, n. 16, p. 157-189, jul./set. 2005, p. 187), "[a] eficácia desse filtro é garantia para os cidadãos, que não terão contra si promovidas ações descabidas, e também para o sistema judicial, que não desperdiçará recursos e esforço em processos natimortos". Especificamente sobre a tipicidade, Maria Thereza Rocha de Assis Moura (Justa causa para a ação penal: doutrina e jurisprudência. São Paulo: Revista dos Tribunais, 2001, p. 188-189) ensina que ela integra o juízo de legitimidade da acusação, de modo que sua falta possibilita o trancamento da ação penal por falta de justa causa - entendida esta como fundamento de fato e de direito para a acusação -, pois "ao ordenamento jurídico importa que a ação penal apenas seja intentada quando for possível imputar ao acusado conduta que se amolde ao tipo, tal como definido em lei. Vale dizer que a acusação somente poderá ser recebida quando respeitado o cânone constitucional da legalidade".

71 "§ 2. ${ }^{\circ}$ Os direitos e garantias expressos nesta Constituição não excluem outros decorrentes do regime e dos princípios por ela adotados, ou dos tratados internacionais em que a República Federativa do Brasil seja parte." 
Fala-se, por exemplo, em direito à tutela jurisdicional e garantia da tutela jurisdicional; direito de defesa e garantia de defesa ${ }^{72}$, etc.

No campo penal, em que o processo judicial tem a finalidade de resolver conflitos de interesses de alta relevância social, tais garantias restaram fortalecidas com a nova ordem jurídica, remodelada que foi a forma de atuação do jus puniendi. Sobressaem direitos e garantias específicas, que encontram no devido processo legal a sua síntese.

Podem ser assim listadas: a) o acesso à Justiça Penal (CF, art. 5. $\left.{ }^{\circ}, \mathrm{XXXV}\right)$; b) o juiz natural em matéria penal (CF, art. 5. ${ }^{\circ}$ XXXVII e LIII); c) o tratamento paritário dos sujeitos parciais do processo penal (CF, art. $5 .^{\circ}$, caput e inc. I); d) a não-consideração prévia de culpabilidade do acusado (CF, art. 5. ${ }^{\circ}$, LVII); e) a plenitude de defesa do imputado, com todos os meios e recursos a ela inerentes (CF, art. $\left.5^{\circ}, \mathrm{LV}\right)$; f) a publicidade dos atos processuais penais (CF, art. 5. $\left.\left.{ }^{\circ}, \mathrm{LX}\right) ; \mathrm{g}\right)$ a motivação dos atos decisórios penais (CF, art. 93, IX); h) a fixação de prazo razoável de duração do processo penal (CF, art. 5. ${ }^{\circ}$, LXXVIII); i) o direito do preso à integridade física e moral (CF, art. 5. ${ }^{\circ}$, XLIX); j) a vedação de identificação datiloscópica quando já existe a identificação civil $\left(\mathrm{CF}, \operatorname{art}^{\circ}\right.$ 5. $^{\circ}$, LVIII); 1) o direito à assistência da família e do advogado (CF, art. 5. $\left.\left.{ }^{\circ}, \mathrm{LXIII}\right) ; \mathrm{m}\right)$ o direito à identificação dos responsáveis pela prisão ou pelo interrogatório (CF, art. 5. $\left.\left.{ }^{\circ}, \mathrm{LXIV}\right) ; \mathrm{n}\right) \mathrm{o}$ direito à liberdade provisória (CF, art. 5., LXVI); o) a previsibilidade de indenização do erro judiciário e da prisão além dos limites da condenação $\left(\mathrm{CF}\right.$, art. 5. $\left.{ }^{\circ}, \mathrm{LXXV}\right)$, entre outros.

Cumpre, nesse passo, situar o tema da investigação criminal entre as garantias constitucionais, estas que, normalmente, são mencionadas como alusivas ao processo propriamente dito, quer no ordenamento interno ou em diplomas internacionais. A respeito, por exemplo, confira-se a redação do art. 8.2 da Convenção Americana sobre Direitos Humanos (Pacto de São José da Costa Rica): "Durante o processo, toda pessoa tem direito, em plena igualdade, às seguintes garantias mínimas: (...)”.

Ora, se as garantias constitucionais são instrumentos pelos quais se procura equacionar os interesses liberdade e segurança ${ }^{73}$, guiando o correto exercício da jurisdição,

72 É de observar que a defesa, por exemplo, constitui um direito do acusado e também uma garantia da jurisdição. Assim, como doutrinam Maria Thereza Rocha de Assis Moura e Cleunice A. Valentim Bastos (Defesa penal: direito ou garantia. Revista Brasileira de Ciências Criminais, São Paulo, v. 1, n. 4, out./dez. 1993, p. 120), a defesa penal, sob a ótica que privilegia o interesse privado sobre o público, é um direito do acusado, que tem disponibilidade quanto às formas de exercê-lo; já sob o enfoque publicístico, a defesa é entendida como garantia não só do acusado, mas do justo processo, e somente se satisfaz se o contraditório for efetivo e a igualdade de armas, real. 
voltado à aplicação dos postulados de uma ordem jurídica justa; se foram elas alçadas a estatura constitucional e postadas de molde a dar coesão ao sistema de matriz acusatória, uma reforma interpretativa do processo reclama conceder-lhes valor mais abrangente. A investigação preliminar, como atividade ligada ao exercício do jus puniendi estatal, freqüentemente invasiva de direitos fundamentais quer do investigado, quer do ofendido ou de terceiros, deve também observância às garantias esculpidas na Constituição e nas declarações de direitos humanos exaradas em diplomas internacionais, a fim de que se possa conferir legitimidade ao início da persecução penal, sem vícios nem ranhuras aos direitos fundamentais do imputado ${ }^{74}$.

Outrossim, a só existência de uma investigação já anuncia certa mácula à pessoa envolvida, à qual deve ser possível defender-se de toda forma de acusação, conquanto não ainda formalizada. Pois de nada adiantaria construir-se um edifício de normas propulsoras de um processo penal garantista se na fase preliminar da persecutio criminis fosse permitido ao Estado cometer todo tipo de arbitrariedade, solapando garantias tão duramente conquistadas. Logo, a extensão de muitas das garantias constitucionais já à fase prévia da persecução é medida crescentemente reconhecida como inafastável de um sistema substancialmente tutelar dos direitos fundamentais do ser humano.

Nessa esteira, vale registrar que a Associação Internacional de Direito Penal, por ocasião do Congresso Internacional realizado em setembro de 1994, no Rio de Janeiro, seguindo recomendações anteriormente adotadas no colóquio preparatório que teve lugar em Toledo, em abril de 1992, traçou diretrizes - correspondentes, em grande parte, a

73 Interesses que estão sempre em tensão na persecução criminal, como estão o jus puniendi e o jus libertatis, a eficiência e o garantismo. Na etapa investigativa prévia, o tema exsurge potencializado, sendo vários os interesses contrastantes, ora públicos (segurança pública, paz social, produção de prova, direito à informação), ora individuais (liberdade, preservação da intimidade e da vida privada das pessoas envolvidas, direito à defesa contra ameaças de acusação), os quais a todo tempo podem entrar em conflito, reclamando sopesamento de modo que um não aniquile o outro. Como bem pontua Francesca Molinari (Il segreto investigativo. Milano: Giuffrè, 2003, p. 244), a limitação a direitos constitucionalmente protegidos é admitida desde que o direito mesmo não seja desnaturado a ponto de tornar árduo ou absolutamente impossível o seu exercício e a limitação deve justificar-se pela exigência de proteger outros valores também de sede constitucional. Ressalte-se ainda a lição, lançada já em 1928, por Diógenes Pereira do Valle (Dos processos policiaes: crimes de alçada. São Paulo: Graphica Rossetti, 1928, p. 9): "A necessidade de exercer a repressão do crime - de interesse social - deve conciliar-se com o respeito ás garantias individuaes, na indagação do facto criminoso e na sua prova e com maior formalismo no julgamento, pois que, as garantias individuaes são de ordem constitucional e doutrinariamente reconhecidas como essenciaes ou fundamentaes ao homem, na co-existencia social".

74 Afinal, como bem destaca José Carlos Barbosa Moreira, em avaliação do processo penal norte-americano, mas igualmente aplicável ao Brasil, "[n]a prática, em mais de um caso, afigura-se menos importante, até certo ponto, a aplicação das normas garantísticas à atividade desenvolvida em juízo. O momento em que várias delas assumem especial relevo é o da investigação policial, mormente no que concerne a medidas de coerção sobre pessoas ou coisas.” (O processo penal..., cit., p. 96). 
garantias consagradas em diplomas internacionais, como a Declaração Universal dos Direitos do Homem (1948) e o Pacto Internacional de Direitos Civis e Políticos (1966) - a serem observadas nos movimentos de reforma do processo penal. Merece relevo aquela que considera, em sentido amplo, como início do processo penal e, portanto, como marco do estabelecimento da proteção dos direitos do homem, qualquer ato de perseguição estatal $^{75}$.

A seguir, enfocaremos algumas das principais garantias diretamente relacionadas à sua temática central - o modelo acusatório de processo e as conseqüências de sua adoção na investigação preliminar, em quaisquer de suas espécies. Conferir-se-á destaque ao devido processo legal, ao juiz natural, à imparcialidade do juiz, à presunção de inocência, à garantia da defesa, ao contraditório, à publicidade e à motivação das decisões, sem prejuízo da extensão do rol de garantias aplicáveis à investigação preliminar $^{76}$.

\subsubsection{O devido processo legal}

Uma das diretrizes esculpidas nas cartas internacionais de direitos humanos e expressa na Constituição da República (art. 5. ${ }^{\circ}$, LIV) é a de que ninguém será privado de sua liberdade e de seus bens sem o devido processo legal. Trata-se de secular garantia do indivíduo, nascida com a Magna Carta, assinada pelo rei João Sem Terra, na Inglaterra, em 1215. A Magna Carta significou a imposição de limites ao poder do soberano (em conseqüência, aos poderes do Estado nele agregados), cuja atuação despótica era contestada pela burguesia e pelo clero, incorporando um acordo pelo qual João Sem Terra assentiu em subordinar o seu poder às leis do país, revelando papel decisivo na afirmação das liberdades públicas inglesas.

75 "Recomendação 1. A proteção dos direitos do homem deve ser garantida em todas as fases do processo penal, ainda que este se inicie através de uma decisão judicial ou de um funcionário público. Para se considerar iniciado o processo penal, deve ser suficiente que um órgão do Estado realize qualquer acto de perseguição criminal." (RECOMENDAÇÕES de Toledo para um processo penal justo. Revista Portuguesa de Ciência Criminal, Coimbra, v. 4. n. 3, jul./set. 1994, p. 438).

76 De fato, são numerosas as garantias constitucionais aplicáveis à investigação preliminar. Marcelo Chiara Teixeira, por exemplo, debruça-se sobre várias delas, nominando-as como "aspectos do devido processo legal na investigação pré-processual penal”: a igualdade, a presunção de inocência, a imparcialidade e a impessoalidade do órgão julgador, a reserva de jurisdição, a motivação, a publicidade, a defesa, o contraditório e o direito à prova (Procedimentos administrativos interna corporis de investigação criminal e o devido processo legal. Tese de Láurea (Graduação em Direito) - Universidade de São Paulo, São Paulo, 2005). 
Originariamente, a garantia foi prevista sob a fórmula law of the land ${ }^{77}$ interpretada como necessidade de observância às leis do país -, depois assimilada pela locução due processo of law, consagrada pelo constitucionalismo estadunidense ${ }^{78}$. Conjuntamente, as expressões deram origem à construção jurisprudencial de proteção dos direitos do indivíduo, especialmente em matéria de garantias processuais penais (compreendendo formas de procedimento e garantias contra a violação do direito de defesa: ninguém poderia testemunhar contra si mesmo; o acusado teria o direito de ouvir as testemunhas de acusação; ninguém poderia ser condenado duas vezes pelo mesmo crime; a instrução criminal seria processada perante juiz; o Poder Legislativo não poderia editar normas retroativas), daí se espalhando para o sistema constitucional de inúmeros países.

A evolução da cláusula do "devido processo legal" coincide com a própria construção do Estado Democrático de Direito, que tem por base as garantias constitucionais e o princípio da legalidade, do qual está indissociado o due processo of $\operatorname{law}^{79}$.

O conteúdo do devido processo legal é de amplitude incompatível com uma definição jurídica fechada, mas consentânea com o desenvolvimento dos valores de cada geração humana. Direciona-se, é certo, sempre a uma relação mantida entre o cidadão e o Estado, servindo de limitador aos atos estatais em face dos direitos e garantias individuais. Pelo evidente clamor semântico, expõe a idéia de um processo legítimo que o Estado deve a seus cidadãos (e por isso mesmo é devido), previsto em lei (por isso que legal) e justo no caso concreto ${ }^{80}$.

77 “Art. 39. Nenhum homem livre será detido ou sujeito à prisão, ou privado de seus bens, ou colocado fora da lei, ou exilado, ou de qualquer modo molestado, e nós não procederemos nem mandaremos proceder contra ele senão mediante um julgamento regular pelos seus pares ou de harmonia com a lei do país."

78 Foi no constitucionalismo norte-americano que se consolidou a garantia fundamental do judicial review, como proteção máxima, na democracia, do indivíduo contra todo e qualquer desmando do titular do poder, diferentemente do que ocorria na Inglaterra, onde o parlamento podia tudo e não se sujeitava a controle judicial. José Alfredo de Oliveira Baracho (Processo e constituição: o devido processo legal. Revista de Direito Público, São Paulo, v. 16, n. 68, out./dez. 1983, p. 69) registra que a garantia processual constituída pela necessidade de aplicação da lei da terra foi acolhida nas primeiras constituições, anteriores à Constituição federal dos Estados Unidos - as de Maryland, Pensylvania e Massachussetts consagram disposição expressa de que ninguém pode ser privado de sua vida, liberdade ou propriedade sem o devido processo legal (due process of law).

79 No dizer de Carlos Roberto Siqueira Castro ( $O$ devido processo legal e os princípios da razoabilidade e da proporcionalidade. 3. ed. Rio de Janeiro: Forense, 2005, p. 3), o postulado do devido processo legal é o primogênito - coroado de êxito e do estigma de permanência - do princípio da legalidade.

80 FRANCO, Alberto Silva; MORAES, Maurício Zanoide. Dos princípios e garantias constitucionais do devido processo legal. In: FRANCO, Alberto Silva; STOCCO, Rui (Coord.). Código de Processo Penal e sua interpretação jurisprudencial. 2. ed. São Paulo: Revista dos Tribunais, 2004, v. 1, p. 240. No mesmo raciocínio, ao tratar do processo penal, Pedro J. Bertolino (El debido proceso penal. La Plata: Platense, 1986, p. 30 e 135) caracteriza o devido processo como verdadeiro direito público subjetivo, dada a 
Na América do Norte, a expressão alcançou notável desenvolvimento, com a melhor compreensão de suas duas dimensões: inicialmente, a procedimental ou formal ${ }^{81}$ (procedural due process); em seguida, a substantiva ou material (substantive due process). Pela primeira, a autoridade estatal tem o dever de respeitar a ordem e as formalidades dos atos prescritos em normas existentes e legítimas, a seqüência de etapas de um procedimento, daí dizer-se que ela é a expressão do princípio da legalidade ${ }^{82}$; pela segunda, deve agir com razoabilidade e justiça para impedir que os indivíduos sejam privados, arbitrariamente, de seus direitos fundamentais, obstando-se outrossim a elaboração, execução ou aplicação de normas materialmente ilegítimas ou injustas. Ambos os aspectos estão relacionados à preocupação em controlar a atividade pública, garantindo que o indivíduo somente seja afetado em sua esfera de direitos por um ato razoável, legítimo conforme os padrões constitucionais.

É antiga, portanto, no cenário internacional, a preocupação em adotar o ideal de justiça mediante o processo, manifestada ainda em diversos documentos históricos de direitos humanos, desde a Declaração dos Direitos do Homem e do Cidadão, de 26 de agosto de 1789 , cuja redação exprimia, com clareza, anseios que viriam incorporar-se às cartas constitucionais de diversos países, com ênfase ao princípio da legalidade ${ }^{83}$.

possibilidade de o indivíduo (governado) exigir que haja processo penal, antes da imposição de qualquer pena (processo devido), e que tal processo seja realizado como é devido segundo a Constituição e as leis, apresentando tal exigência como destinatário natural o Estado (governante).

81 Numa primeira fase, o devido processo legal, nos Estados Unidos, se referia às garantias de natureza processual propriamente ditas, como a proibição, no campo do processo penal, do Bill of Atender (ato legislativo que implica considerar alguém culpado pela prática de crime sem a existência de um processo e julgamento regular, com ampla defesa) e das leis retroativas ex post factum, vedando-se a autoincriminação forçada e o julgamento dúplice pelo mesmo fato.

82 Sobre o princípio da legalidade, evidente limitador da ação estatal, manifestam-se Jean Rivero e Hugues Moutouh (Liberdades públicas. Trad. Maria Ermantina de Almeida Prado Galvão. São Paulo: Martins Fontes, 2006, p. 279): "O princípio de legalidade, que impõe a conformidade de todas as atividades públicas ou privadas ao direito, sob controle do juiz, beneficia necessariamente o direito das liberdades públicas. As regras que o compõem se impõem ao executivo - governo e administração - bem como aos particulares".

83 “Art. $7 .^{\circ}$ Ninguém pode ser acusado, preso ou detido senão nos casos determinados pela lei e de acordo com as formas por esta prescritas. (...)

“Art. 8..$^{\circ}$ A lei apenas deve estabelecer penas estrita e evidentemente necessárias e ninguém pode ser punido senão por força de uma lei estabelecida e promulgada antes do delito e legalmente aplicada.

“Art. 9. ${ }^{\circ}$ Todo acusado é considerado inocente até ser declarado culpado e, se se julgar indispensável prendê-lo, todo o rigor desnecessário à guarda da sua pessoa deverá ser severamente reprimido pela lei." 
Já sob a órbita das Nações Unidas, a importância constitucional da garantia do due process of law foi reconhecida com a inclusão na Declaração Universal dos Direitos Humanos, de $1948^{84}$.

O primeiro de nossos Diplomas Constitucionais a adotar expressamente a fórmula do devido processo legal foi o de 1988, trazendo um rico desdobramento de garantias específicas, como a do juiz natural e a da proibição dos tribunais de exceção.

É certo que, sob a égide de ordens constitucionais anteriores, podia-se inferir a aplicação do devido processo legal no sistema penal ${ }^{85}$. O que se tem de inovação essencial é a positivação, em nosso sistema, do devido processo legal e sua indubitável extensão a todos os procedimentos - penal, civil e administrativo ${ }^{86}$. Ademais, essas garantias passam a ser encaradas sob uma ótica não mais individualista, e sim publicista, instaladas em benefício não só das partes, mas do justo processo. Assim o é porque o processo penal presta-se não apenas a fazer valer as normas materiais que visam à punição do criminoso, mas, precipuamente, a impedir a sua aplicação sobre quem não tenha praticado a infração penal de que se vê acusado ${ }^{87}$. O processo justo é aquele em que sejam respeitados os princípios e garantias que se enfeixam na fórmula do devido processo legal.

Revela-se, pois, como uma garantia conferida por diplomas internacionais e pela Constituição aos membros da coletividade, para a consecução dos direitos denominados fundamentais mediante a efetivação do direito ao processo, com a imprescindível concretização de todos os seus consectários e em um prazo razoável.

84 “Art. VIII - Toda pessoa tem direito a receber dos Tribunais nacionais competentes recurso efetivo para os atos que violem os direitos fundamentais que lhe sejam reconhecidos pela Constituição ou pela lei. (...) “Art. X - Toda pessoa tem direito, em plena igualdade, a uma audiência justa e pública por parte de um Tribunal independente e imparcial para decidir de seus direitos e deveres ou do fundamento de qualquer ação criminal contra ela."

85 Os $\S \S 15$ e 16 do art. 153 da Emenda Constitucional 1, de 17 de outubro de 1969, já consagravam o contraditório, a anterioridade da lei penal, a ampla defesa e o juiz natural, senão vejamos: "§ 15 . A lei assegurará aos acusados ampla defesa com os recursos a ela inerentes. Não haverá foro privilegiado nem tribunais de exceção. $\S 16$. A instrução criminal será contraditória, observada a lei anterior, no relativo ao crime e à pena, salvo quando agravar a situação do réu". Além disso, eram previstas normas sobre a prisão ilegal (art. 153, § 12), assegurando a integridade física e moral do preso (art. 153, § 14), a liberdade de locomoção e o habeas corpus (art. 153, § 20), a isonomia (art. 153, § $1^{\circ}{ }^{\circ}$ ), etc.

86 Mas, como observa Ada Pellegrini Grinover (Do direito de defesa em inquérito administrativo. In: $O$ processo em evolução. Rio de Janeiro: Forense Universitária, 1996, p. 82), as garantias expressas pelas Constituições anteriores para o processo penal, como o contraditório e a ampla defesa, já eram estendidas, pela doutrina e pela jurisprudência, ao processo civil, na interpretação do princípio da proteção judiciária (inscrito no art. 141, § 4..$^{\circ}$, da Constituição de 1946, e mantido pelas posteriores, de 1967 e 1969), e ao processo administrativo, argumentando-se com a extensão do direito de defesa, previsto no art. 141, §14, da CF/1946, e com a isonomia. A explicitação pela Constituição de 1988, embora não sendo inovadora, tem valor didático, agora também resguardando as garantias aos litigantes, em processo administrativo.

87 ZILLI, Marcos Alexandre Coelho. A iniciativa instrutória..., cit., p. 112. 
Esse conjunto de garantias constitucionais que asseguram às partes o exercício de suas faculdades e poderes processuais e o correto exercício da jurisdição constitui o devido processo legal, fórmula que sintetiza outras garantias constitucionais específicas, como a do juiz natural e competente, as do contraditório e da ampla defesa, a da igualdade processual, decorrente do princípio da isonomia, as da publicidade e motivação das decisões judiciárias, a da inadmissibilidade das provas obtidas por meios ilícitos, a da inviolabilidade do domicílio, a do sigilo das comunicações ${ }^{88}$.

Mas vai além. Se, por um lado, o devido processo legal evoluiu para fonte principiológica $^{89}$ e justificadora de todo o sistema de garantias processuais, por outro suplanta a mera soma destas, na medida em que funciona também como uma espécie de "cláusula de reserva" do sistema, ou uma "garantia inominada"90, para que dela possam extrair-se tantos princípios quantos se fizerem necessários na constante tensão entre governantes e governados, em quaisquer das esferas do Poder Público. O cidadão está então legitimado a exigir do governo que atue conforme o devido processo legal, o que pode significar, por vezes, uma conduta que não necessariamente tenha previsão em alguma lei posta pelo Parlamento.

88 “O processo não pode significar qualquer procedimento, mas aquele conjunto de garantias que configura o due process of law (Magna Carta: Law of the land. Art. 39). O processo deve possibilitar às partes a defesa de seus direitos, a sustentação de suas razões, a produção de suas provas. Contraditório, igualdade, publicidade, duplo grau de jurisdição. Coroamento real do Estado de Direito, através desse instrumento processual-constitucional de tutela dos direitos fundamentais do homem. De instrumento meramente técnico, o processo transforma-se em instrumento ético de realização da justiça, em garantia de liberdade.” (FERREIRA FILHO, Manoel Gonçalves; GRINOVER, Ada Pellegrini; FERRAZ, Anna Cândida da Cunha. Liberdades públicas: parte geral. São Paulo: Saraiva, 1978, p. 181).

89 Nelson Nery Junior (Princípios do processo civil na Constituição Federal. 5. ed. rev. e ampl. São Paulo: Revista dos Tribunais, 1999, p. 30) defende ser o devido processo legal o princípio básico, sobre o qual se alicerçam todos os demais: "Bastaria a norma constitucional haver adotado o princípio do due process of law para que daí decorressem todas as conseqüências processuais que garantiriam aos litigantes o direito a um processo e uma sentença justa”. A sua vez, Paulo Fernando Silveira (Devido processo legal. 3. ed. rev., atual. e ampl. Belo Horizonte: Del Rey, 2001, p. 236-237) destaca a abrangência do conceito e a impossibilidade de defini-lo legalmente, admitindo-se apenas tentativas de limitação de suas fronteiras: "O devido processo legal incorpora valores culturais amplos e profundos sentimentos de justiça sedimentados por séculos na cultura do povo anglo-saxão, inclusive em sua progenie americana. Diante da amplitude do conceito, não pode ser definido e dissecado tecnicamente, mas se manifesta e interpenetra no direito, e é sentido naturalmente pelo homem comum e de bom senso, em virtude da carga de evidência que carrega em si mesmo".

90 FERNANDES, Antonio Scarance. Processo penal constitucional. 3. ed. rev., atual. e ampl. São Paulo: Revista dos Tribunais, 2002, p. 44, aludindo à denominação utilizada por Juan Francisco Linares, na Argentina. Paralelamente, Alberto Silva Franco e Maurício Zanoide de Moraes (Dos princípios..., cit., p. 251) qualificam o devido processo legal como "cláusula de segurança" política para os cidadãos e para o sistema de garantias processuais penais previsto na Constituição, "uma vez que é nele que se irá buscar eventual princípio do qual o sistema jurídico sinta falta para sua melhor realização e que não esteja (ainda) expressa e individualmente normatizado". 
Dado o caráter permanentemente expansivo do devido processo legal e sua relevante função dentro do Estado de Direito, pode-se afirmar que essa garantia não se constringe apenas ao âmbito dos processos judiciais, mas permeia todos os procedimentos (sejam eles judiciais, administrativos ou legislativos) em que esteja um cidadão diante do Poder Público, ameaçado em sua liberdade ou em seu patrimônio por qualquer forma de investigação, perscrutação ou julgamento ${ }^{91}$.

Sobre a distinção entre processo e procedimento, Elio Fazzalari explica que o emprego desses dois esquemas foi fruto da necessidade de clareza teórica e das sugestões da normatização positiva. Surgido na doutrina administrativista, o conceito de procedimento equivale a uma seqüência de atos vinculados, os quais são previstos e valorados pelas normas, gerando uma série de posições subjetivas (faculdades, poderes, deveres) também ligadas entre si, numa ordem estabelecida pela lei. Cada ato desenvolve um importante papel na seqüência do procedimento, e sua validade e eficácia, assim como a do ato final, está a depender da regularidade do ato que o precede. Já o processo é uma espécie de procedimento, mas dele se distingue pela estrutura dialética: é necessário que para a formação de cada ato seja contemplada não apenas a participação do seu autor, mas também os destinatários dos seus efeitos, em contraditório ${ }^{92}$. Característica essencial do processo é a celebração contraditória do procedimento, com a participação dos interessados mediante exercício das faculdades e poderes integrantes da relação jurídica processual. E o que legitima o ato final do processo (um provimento que interfere na esfera jurídica das pessoas) é a observância do procedimento, da participação efetiva e equilibrada dos interessados e da cláusula do due processo of law $^{93}$.

91 Porque, sendo o processo "instrumento para o legítimo exercício do poder, ele está presente em todas as atividades estatais (processo administrativo, legislativo) e mesmo não-estatais (processos disciplinares dos partidos políticos ou associações, processos das sociedades mercantis para aumento de capital etc.)" (CINTRA, GRINOVER e DINAMARCO. Teoria geral do processo, cit., p. 278).

92 FAZZALARI, Elio. Instituições de direito processual. Trad. Elaine Nassif. Campinas: Bookseller, 2006, p. 109 e ss. No dizer do autor, “do genus 'procedimento' é possível extrair a species 'processo'. (...) O 'processo' é um procedimento do qual participam (são habilitados a participar) aqueles em cuja esfera jurídica o ato final é destinado a desenvolver efeitos: em contraditório, e de modo que o autor do ato não possa obliterar as suas atividades" (Idem, p. 94 e 118-119). Cândido Rangel Dinamarco ( $A$ instrumentalidade do processo. 9. ed. rev. e atual. São Paulo: Malheiros, 2001, p. 126 e 133), em complemento, ensina que os processualistas do século passado "[j]amais conseguiram demonstrar que o processo fosse algo distinto do procedimento, situado fora dele, e em menos de um século acabou por ressurgir na mente dos processualistas o valor do procedimento no próprio conceito de processo". E arremata, concluindo que "[n]em todo procedimento é processo, mesmo tratando-se de procedimento estatal e ainda que de algum modo possa envolver interesses de pessoas. O critério para a conceituação é a presença do contraditório". Em sentido convergente, no âmbito do processo penal, cf. Siracusano, Galati, Tranchina e Zappalà (Diritto processuale penale, cit., p. 29-31).

93 Cf. DINAMARCO, Cândido Rangel. A instrumentalidade..., cit., p. 67 e 133. 
Cumpre lembrar que a processualidade inerente aos procedimentos administrativos vem sendo cada vez mais ressaltada na doutrina, desde a primeira metade do século XX, afirmando os administrativistas e os processualistas que em toda atividade estatal (não só na função jurisdicional, mas também na legislativa e na administrativa) existe um núcleo processual comum consubstanciado na contenção do poder público ${ }^{94}$. Sobre a preocupação com a idéia de processualidade transcendente da função jurisdicional e ligada ao exercício dos três poderes do Estado, Odete Medauar explica ${ }^{95}$ :

A progressiva aproximação entre Administração e administrado, reflexo do menor distanciamento entre Estado e sociedade, levou à necessidade de tornar conhecidos os modos de atuação administrativa e de propiciar ocasiões para que o cidadão se faça ouvir. Por outro lado, o aumento da ingerência estatal teve como contrapartida o cuidado na fixação de parâmetros para a atividade administrativa, em especial a discricionária. Além do mais, despertou-se a atenção para o aspecto das garantias prévias a serem propiciadas aos cidadãos nas atuações administrativas, daí a tônica sobre os momentos que antecedem a edição dos atos administrativos.

Por isso, surge imperiosa a observância do devido processo legal, sob várias de suas manifestações, na seara dos procedimentos estatais de qualquer natureza (aí incluídas as investigações preliminares para fins penais), donde ser possível enxergar tal garantia pelo prisma do devido procedimento legal ${ }^{96}$, uma exigência de que os princípios e

94 Como preleciona Carlos Ari Sundfeld (Fundamentos de direito público. 3. ed. São Paulo: Malheiros, 1998, p. 88), “o processo é o modo normal de agir do Estado Democrático de Direito”. Daí se falar em processo judicial, processo legislativo e processo administrativo, como fazem, entre outros: HARGER, Marcelo. Princípios constitucionais do processo administrativo. 2. ed. rev. e atual. Rio de Janeiro: Forense, 2008, p. 39; FRANCO, Fernão Borba. Processo administrativo. São Paulo: Atlas, 2008, p. 77. Entre os processualistas, Cândido Rangel Dinamarco ( $A$ instrumentalidade..., cit., p. 63-65) indica a existência de uma complexa diversidade de espécies de processos - estatais e não-estatais, jurisdicionais e não-jurisdicionais. Segundo o autor, os processos estatais exprimem o exercício do poder estatal e, entre suas espécies, o processo administrativo distingue-se do jurisdicional por não ser necessariamente regido pela inércia do órgão condutor, nem pela existência de pessoas em posições contrapostas, sob a autoridade de um diretor imparcial e desinteressado do resultado. Maiores ainda seriam as diferenças entre o processo jurisdicional e o legislativo, porém neste também há procedimentos a serem observados, com a legalidade e participação dos interessados, não sendo mais lícito negar a sua inserção na teoria geral do processo.

95 MEDAUAR, Odete. A processualidade no direito administrativo. 2. ed. rev., atual. e ampl. São Paulo: Revista dos Tribunais, 2008, p. 19-20. Cf., ainda, GRIONOVER, Ada Pellegrini. Do direito de defesa..., cit., p. 83.

96 É usual também a expressão devido processo legal administrativo, visto como a representação do modelo constitucional do processo administrativo, cuja essência seria, no dizer de Vladimir da Rocha França, a conciliação da atividade administrativa com os cânones constitucionais (Contraditório e invalidação administrativa no âmbito da Administração Pública federal. In: FIGUEIREDO, Lucia Valle (Coord.). Devido processo legal na Administração Pública. São Paulo: Max Limonad, 2001, p. 193). Segundo J. J. Gomes Canotilho (Direito constitucional..., cit., p. 514), o sentido garantístico do procedimento pode ter 
normas inerentes ao devido processo tenham lugar nos procedimentos em geral, seja no âmbito criminal, seja no âmbito administrativo, para garantir a conformidade da atuação de todos os agentes estatais com o sistema constitucional.

Mas é no campo penal que o devido processo legal - até por sua raiz histórica - tem especial incidência. Não é à toa que, das várias garantias constitucionais interligadas a essa cláusula, muitas expressamente direcionam-se à atividade de persecução criminal, leito no qual foram mais desafiadas e, por isso mesmo, mais incrementadas. Assim é que se utiliza a expressão qualificadora devido processo penal $l^{97}$ para aludir a essas mesmas garantias individuais, vistas na perspectiva do direito criminal (material ou processual).

A expressão genérica do devido processo penal decompõe-se, entre outras, nas seguintes garantias: a) o juiz natural em matéria penal; b) a paridade de tratamento dos sujeitos parciais; c) o contraditório e a plenitude de defesa do acusado, com os meios e recursos a ela inerentes; d) a publicidade dos atos processuais penais, e) a motivação dos atos decisórios penais; f) o prazo razoável de duração do processo penal; g) o fato de só poder a prisão ser ordenada pela autoridade judiciária competente; h) o direito à liberdade provisória, com ou sem fiança; i) a preservação da integridade física e moral; j) a proibição da incomunicabilidade do preso e a necessidade de informação sobre seus direitos e de assistência do defensor e da família; 1) o direito à identificação dos responsáveis pela prisão ou pelo interrogatório; m) a não-consideração prévia de culpabilidade; n) a previsibilidade de indenização do erro judiciário e da prisão além dos limites da condenação; o) a privacidade domiciliar e de comunicação ${ }^{98}$.

dimensões relevantes para o particular, como o direito de participação no procedimento administrativo e o direito de ser ouvido, e o procedimento justo tende a firmar-se como procedimento comunicativamente justo, obrigando à criação de comunicações pré-procedimentais, cooperação informal mediante avisos, informações, esclarecimentos, instâncias de cooperação entre a administração e os interessados.

97 Cunhada por Pedro J. Bertolino e descrita como "la especificidad penal de la garantía constitucional del debido proceso". O próprio autor adverte que a noção de processo penal muitas vezes pode incluir, em sentido amplo, questões relativas a procedimentos contravencionais, administrativos, imposições de multas, etc., donde o processo legal ser uma garantia válida também para os atos administrativos, formando um plexo de regras e procedimentos que devem ser observados no cumprimento das normas condicionantes das atividades dos órgãos públicos (El debido proceso penal, cit., p. 20-21). No âmbito penal, tal cláusula é reconhecida como princípio informativo de todo o sistema jurídico, tendo influência desde o campo de formulação legislativa da norma penal ou processual penal, seguindo por todo o atuar estatal (persecutório e executório da pena) e terminando com a aplicação das normas ao caso concreto, no agir decisório do poder jurisdicional (FRANCO, Alberto Silva; MORAES, Maurício Zanoide. Dos princípios..., cit., p. 241).

98 Rogério Lauria Tucci (Direitos e garantias individuais no processo penal brasileiro. 2. ed. rev. e atual. São Paulo: Revista dos Tribunais, 2004, p. 67-76) esboça uma diferenciação entre garantias constitucionais e corolários constitucionais do devido processo penal. Entre as garantias, cita o acesso à 
Dentre as máximas suso relacionadas, para o escopo deste trabalho, conforme já se anunciou, serão destacadas, na seqüência, as garantias do juiz natural, da presunção de inocência, da plenitude de defesa e do contraditório, além da publicidade e da motivação das decisões, na configuração em que devem estar presentes na fase préprocessual.

\subsubsection{O juiz natural}

Ensina Ada Pellegrini Grinover que a jurisdicionalidade, nos regimes democráticos, perfaz-se em requisito fundamental ao exercício da função repressiva do Estado, legitimada sobretudo pelas garantias de que se cerca a atividade processual penal, as quais encorpam valores éticos e políticos, a um só tempo limitando e alimentando o exercício desse poder de julgar, no interesse geral da justiça das decisões. Entre essas garantias, encontra-se a do juiz natural, sem a qual "não há função jurisdicional possível"99. Em retrospecto histórico, José Frederico Marques ${ }^{100}$ informa que, embora a origem do princípio se situe em momento assaz anterior, a sua primeira formulação sob essa nomenclatura remonta à Constituição francesa de 1814, que fazia menção aos juges naturels, daí se propagando a outros ordenamentos, como, v.g., a Holanda e a Itália, encontrando-se em algumas legislações denominações outras, quais as de juiz competente, na Espanha, e juiz legal, na Alemanha.

A Constituição de 1988, seguindo uma tradição inaugurada com a Carta Política de 1824 (e excepcionada apenas pela Carta de 1937), consagra, agora de forma mais clara em seu texto ${ }^{101}$, o postulado do juiz natural sob a perspectiva de uma dupla

Justiça Penal; o juiz natural em matéria penal; o tratamento paritário dos sujeitos parciais; a plenitude de defesa, com todos os meios e recursos a ela inerentes; a publicidade dos atos processuais penais; a motivação dos atos decisórios penais; a fixação de prazo razoável de duração do processo penal e a legalidade da execução penal. Não considera o autor, por exemplo, a presunção de inocência, ou o direito à não-consideração prévia de culpabilidade, como garantia constitucional ínsita ao processo penal, mas a situa entre os "corolários constitucionais do devido processo penal". Com a ressalva da classificação do autor, consideramos possível enquadrar a presunção de inocência como um princípio ou garantia do devido processo.

99 GRINOVER, Ada Pellegrini. O juiz natural..., cit., p. 415-416. Por sua vez, Antonio Magalhães Gomes Filho (A motivação das decisões penais. São Paulo: Revista dos Tribunais, 2001, p. 35) define o juiz natural como "a primeira e mais essencial garantia do processo".

100 Tratado de direito processual penal. São Paulo: Saraiva, 1980, v. 1, p. 241-242.

101 A Constituição de 1967 e a Emenda 1 de 1969 - seguindo o modelo das Cartas de 1824, 1891, 1934 e 1946 - referiam-se, respectivamente, nos arts. $150, \S 15$, e $153, \S 15$, apenas à proibição de tribunais de exceção: "§ 15. A lei assegurará aos acusados ampla defesa, com os recursos a ela inerentes. Não haverá fôro privilegiado nem tribunais de exceção". 
garantia individual: a de que "não haverá juízo ou tribunal de exceção" (art. 5. ${ }^{\circ}$, XXXVII) e a de que "ninguém será processado nem sentenciado senão pela autoridade competente" (art. 5. ${ }^{\circ}$, LIII). Desses enunciados se extrai que o juiz natural, em matéria penal, no nosso direito, é a autoridade competente para processar e julgar segundo ditames constitucionais $^{102}$.

E assim o é porque, se no constitucionalismo norte-americano (como na gênese do princípio, na Magna Carta de 1215) a competência do juiz penal esteve sempre atrelada ao critério territorial ${ }^{103}$, no sistema brasileiro a repartição do poder de julgar, pela Carta da República, é feita sem apego necessário ao parâmetro territorial, utilizado pelo Código de Processo Penal para delimitar a competência de foro ${ }^{104}$. Daí não se poder imprimir ao princípio os contornos da territorialidade, qual se verifica no direito anglosaxão, onde ele se desenvolveu.

Por influência da Magna Carta, a garantia visa assegurar a existência de um juízo competente previamente determinado (proibição de tribunais extraordinários) e a inderrogabilidade das regras de competência, com a preocupação de ligar a competência ao local do delito. Mas essa dúplice garantia alcança tamanha amplitude que se the pode atribuir, no dizer de Jorge de Figueiredo Dias, um tríplice significado, pondo em evidência: em primeiro lugar, o plano da fonte, pelo qual só a lei pode instituir o juízo e fixar-lhe a competência; em segundo lugar, o plano temporal, a exigir que a fixação de competência deva ser feita por lei vigente já ao tempo da prática do fato que será objeto do processo; em terceiro, o plano da competência, fixada em uma ordem taxativa, proibindo-se a criação de

102 Assinale-se que vários diplomas internacionais de envergadura dão guarida ao princípio, como a Declaração Americana dos Direitos e Deveres do Homem, de 1948 (art. 26), a Declaração Universal dos Direitos Humanos, de 1948 (arts. 8. ${ }^{\circ}$ e 10), a Convenção Européia para a Proteção dos Direitos Humanos e Liberdades Fundamentais, de 1950 (arts. 5..$^{\circ}$ e 6. ${ }^{\circ}$ ), o Pacto Internacional de Direitos Civis e Políticos, de 1966 (arts. 9.3 e 14), e a Convenção Americana sobre Direitos Humanos, de 1969 (art. 8.1).

103 A Magna Carta de 1215 já estampava as raízes do aludido princípio, no art. 48: "Nenhum homem livre será encarcerado ou exilado, ou de qualquer forma despojado, a não ser pelo julgamento de seus pares, segundo as leis do país." (GANDINI, Jean-Jacques. Les droits de l'homme. Paris: Librio, 2003, p. 36). A Declaração de Direitos do Bom Povo da Virgínia, de 1776, mencionava, na cláusula VIII: "Em todo processo criminal, incluídos aqueles em que se pede a pena capital, o acusado tem direito de saber a causa e a natureza da acusação, ser acareado com seus acusadores e testemunhas, pedir provas em seu favor e a ser julgado, rapidamente, por um júri imparcial de doze homens de sua comunidade..." (Disponível em: $<$ http://www.direitoshumanos.usp.br/frameset.html>. Acesso em 19 ago. 2007). Já a Emenda VI à Constituição americana, em vigor desde 1791, estatuiu: "Em todas as causas criminais, o acusado terá direito a um juízo rápido e público, por um júri imparcial do Estado e distrito onde tenha sido cometido o crime, sendo o distrito o determinado por lei..." (PASTRANA, Ángel Tinoco. Fundamentos del sistema judicial penal en el common law. Sevilla: Universidad de Sevilla, 2001, p. 78).

104 É o art. 70 do CPP que reza: “A competência será, de regra, determinada pelo lugar em que se consumar a infração, ou, no caso de tentativa, pelo lugar em que for praticado o último ato de execução". 
tribunais de exceção ou ad hoc para decidir um caso concreto, com derrogação das regras gerais de competência ${ }^{105}$.

Sobre este último aspecto - o da proibição de juízos de exceção -, curial é anotar que a criação de Justiças Especializadas, tão presentes em nossa realidade judiciária, com prévia distribuição de competências segundo as pessoas ou matérias a elas submetidas, ou ainda a entrega de competência originária aos tribunais para julgar certas pessoas em razão da função, não se perfaz em instituição de tribunais ad hoc, ex post facto ou de exceção $^{106}$.

Ora, se se trata de esferas jurisdicionais constituídas anteriormente aos fatos por ela processados, e se as regras de competência aplicam-se a todos os casos que, sob aquele critério, se enquadrem na alçada dos órgãos especializados, vem daí o seu caráter permanente e orgânico, não se podendo acoimá-las de vulnerantes ao princípio do juiz natural, como esclarece José Frederico Marques ${ }^{107}$ :

Juiz natural, ou juiz legal, ou juiz competente se contrapõe, assim, não a juízo especial, mas a juízos de exceção ou instituídos para contingências particulares, "per giudicare persone o fatti particolari", como disse a Cassação de Roma.

Firma-se, pois, o juiz natural como a garantia do acusado de submeter-se apenas ao juiz competente e imparcial. E de tal modo se entrelaçam tais atributos (competência e imparcialidade) à própria função jurisdicional, que de atributos acabam por ser alçados a sua essência, como elementos ínsitos ao próprio núcleo do exercício da jurisdição e do processo $^{108}$. Daí se afirmar que, sem juiz natural, não há jurisdição, não surge base para o nascimento do processo.

105 DIAS, Jorge de Figueiredo. Direito processual penal. Coimbra: Coimbra, 1974, v. 1, p. 322-323. No Brasil, essa visão encontra a acolhida, entre outros, de Maria Lúcia Karam (Competência no processo penal. 4. ed., rev. atual e ampl. São Paulo: Revista dos Tribunais, 2005, p. 67) e de Antonio Scarance Fernandes (Processo penal constitucional, cit., p. 126-127), que vê no princípio três regras de proteção, quais sejam: a) só podem exercer a jurisdição os órgãos instituídos pela Constituição (poder de comissão); b) ninguém pode ser julgado por órgão constituído após o fato (vedação ao poder de atribuição) e c) uma vez constituídos os juízos e estabelecida uma ordem taxativa de competências, impossível é a evocação ou transferência da causa a outro órgão ou tribunal.

106 O próprio Jorge de Figueiredo Dias o excepciona, ao explicar que o princípio "não obstará a válida existência de tribunais especiais que a Constituição e a lei prevejam, mas proibirá terminantemente o desaforamento de qualquer causa criminal, bem como a sua suspensão discricionária por qualquer autoridade" (Direito processual penal, cit., p. 323).

107 MARQUES, José Frederico. Tratado..., v. 1, cit., p. 243.

${ }^{108}$ Como sintentiza Adelino Marcon (O princípio do juiz natural no processo penal. Curitiba: Juruá, 2004, p. 227-228), o princípio do juiz natural é a expressão da isonomia e um pressuposto da imparcialidade, porque busca dar garantias de certeza nas decisões judiciais, e isto não somente se faz imprescindível para 
$\mathrm{Na}$ investigação preliminar de cunho penal, não sendo o juiz o condutor do procedimento (coordenado, via de regra, por autoridades administrativas), é-lhe reservado um papel compatível com a elevada função que, na tripartição clássica dos poderes estatais, coube claramente ao Poder Judiciário: dizer o direito (ius dicere) e aplicá-lo aos casos concretos. Assim prevê a nossa Constituição, ao dispor, no art. 2. ${ }^{\circ}$, que "são poderes da União, independentes e harmônicos entre si, o Legislativo, o Executivo e o Judiciário", e asseverar, no art. 5. ${ }^{\circ}$, que "a lei não excluirá da apreciação do Poder Judiciário lesão ou ameaça a direito".

Desses dois princípios constitucionais extrai-se a garantia da reserva de jurisdição, a significar, em primeiro plano, que qualquer pessoa tem o direito de recorrer ao Poder Judiciário para que este, aplicando a lei ao caso concreto, assegure a observância dos direitos fundamentais eventualmente desrespeitados; e, em segundo lugar, que determinadas matérias devem ser de apreciação exclusiva dos órgãos jurisdicionais (afastados, portanto, os órgãos dos Poderes Legislativo e Executivo), não apenas para que dêem a última palavra, mas que a sua manifestação ocorra em primeiro plano, como requisito para a legitimidade do ato ${ }^{109}$. Assim é que o Poder Judiciário será o único legítimo a apreciar e adotar medidas que impliquem restrições aos direitos e garantias fundamentais dos cidadãos ${ }^{110}$.

Trata-se de tema a todo instante presente nas investigações preliminares com fins penais, em que é comum a prática de atos de averiguação e de prova, passíveis de ingerir na esfera de direitos fundamentais dos investigados, sobretudo por via de medidas cautelares (prisão cautelar, busca e apreensão domiciliar, indisponibilidade de bens, arresto, quebras de sigilo bancário, fiscal e de dados, interceptação telefônica, etc.).

o cidadão a quem é dirigida a norma, mas também ao próprio julgador, que nela tem a garantia e a tranqüilidade de agir conforme a legalidade". Em diretriz similar, José Celso de Mello Filho afirma que o conceito de juiz natural tem relação estreita com a garantia de liberdade do indivíduo, por isso que "objetiva garantir a independência e imparcialidade do ofício jurisdicional, assegurando, desta forma, ao indivíduo a sua situação ou posição de liberdade" (A tutela judicial da liberdade. Revista dos Tribunais, São Paulo, v. 68, n. 526, ago. 1979, p. 301).

109 FRANCO, Alberto Silva; MORAES, Maurício Zanoide. Dos princípios..., p. 331-332. Nesse sentido, concluem os autores que o princípio da reserva de jurisdição garante ao cidadão, sempre que entender violado ou ameaçado direito seu, por ato de particular ou de ente público, exerça seu direito fundamental de recorrer ao Poder Judiciário "para que este, em primeira ou última manifestação, verifique a legalidade do ato impugnado e, em respeito aos princípios contidos no devido processo legal, profira decisão apta a pacificar o conflito pela mais justa aplicação da norma” (Idem, p. 333).

110 A funcionarem, eles mesmos, como freios à atividade jurisdicional, já que "é no processo penal, entendido como instrumento da persecução, que a liberdade do indivíduo avulta e se torna mais nítida a necessidade de se colocarem limites à atividade jurisdicional. (...) [A] obrigação do Estado de sacrificar na medida 
É certo que algumas matérias já estão especificadas no próprio Texto Constitucional como integrantes da reserva de jurisdição (v.g, os casos de ingresso na casa de alguém sem o seu consentimento; de violação do sigilo das comunicações telefônicas e de prisão de um indivíduo - art. 5. ${ }^{\circ}$, XI, XII e XLI). Outros atos, contudo, embora não expressamente remetidos à prévia intervenção judicial, integrarão igualmente a cláusula de reserva de jurisdição sempre que se tratar de restringir direito fundamental constitucional $^{111}$, sendo de frisar que a jurisprudência do Supremo Tribunal Federal vem tendo importante papel no preenchimento paulatino do conteúdo da cláusula ${ }^{112}$.

Assim, aplicada a garantia do juiz natural à investigação preliminar - na qual existe também "acusação" em sentido amplo, impondo-se, por isso, a existência de um órgão jurisdicional destinado a apreciar os pedidos que interfiram na liberdade do cidadão -, segue-se que, não vigorando entre nós o sistema dos juizados de instrução, todo investigado tem direito a um juiz, previamente determinado em normas de competência e afastado de qualquer atividade propulsora da investigação, a quem deverá tocar tão-

menor possível os direitos de personalidade do acusado se transforma na pedra de toque de um sistema de liberdades públicas” (GRINOVER, Ada Pellegrini. Liberdades públicas..., cit., p. 20).

111 Paulo Castro Rangel, ao analisar a reserva de jurisdição no direito português, explica que a matéria foi-se delineando, sobretudo, pela jurisprudência do Tribunal Constitucional, fixando-se conceitos que expressam níveis diferenciados de jurisdição, pelo que denomina "critério das duas palavras": em primeiro lugar, haveria reserva absoluta de jurisdição para matérias que exigissem a primeira palavra do órgão jurisdicional; em segundo lugar, haveria apenas uma reserva relativa de jurisdição, em que ao juiz competiria apenas a última palavra acerca da matéria. No primeiro caso, quando a reserva estivesse já especificada no texto constitucional ou na lei (reserva absoluta de jurisdição especificada), não haveria maiores dúvidas; fora desse âmbito, a questão se tornaria problemática, havendo ainda certa indefinição sobre o tema (Reserva de jurisdição: sentido dogmático e sentido jurisprudencial. Porto: Universidade Católica Portuguesa, 1997, p. 59-65). Na mesma linha, ver J. J. Gomes Canotilho, ao tratar da reserva de juiz e da reserva de tribunais (Direito constitucional..., cit., p. 667-673).

112 É paradigmático, nesse sentido, o acórdão proferido no julgamento do MS 23.452/RJ (rel. Min. Celso de Mello, DJ de 12.5.2000), pelo qual o Plenário do STF considerou que as Comissões Parlamentares de Inquérito (órgãos não-jurisdicionais) poderiam decretar a quebra dos sigilos bancário, fiscal e telefônico (sobre os dados/registros telefônicos), relativamente a pessoas por elas investigadas, desde que justifiquem a necessidade da medida excepcional, sem prejuízo do controle jurisdicional ulterior desses atos. Ficou gravado em sua ementa: "POSTULADO CONSTITUCIONAL DA RESERVA DE JURISDIÇÃO: UM TEMA AINDA PENDENTE DE DEFINIÇÃO PELO SUPREMO TRIBUNAL FEDERAL. O postulado da reserva constitucional de jurisdição importa em submeter, à esfera única de decisão dos magistrados, a prática de determinados atos cuja realização, por efeito de explícita determinação constante do próprio texto da Carta Política, somente pode emanar do juiz, e não de terceiros, inclusive daqueles a quem se haja eventualmente atribuído o exercício de 'poderes de investigação próprios das autoridades judiciais'. A cláusula constitucional da reserva de jurisdição - que incide sobre determinadas matérias, como a busca domiciliar (CF, art. 5. $\left.{ }^{\circ}, \mathrm{XI}\right)$, a interceptação telefônica $\left(\mathrm{CF}\right.$, art. $\left.5^{\circ}, \mathrm{XII}\right)$ e a decretação da prisão de qualquer pessoa, ressalvada a hipótese de flagrância $(\mathrm{CF}$, art. 5. ${ }^{\circ}$, LXI) - traduz a noção de que, nesses temas específicos, assiste ao Poder Judiciário, não apenas o direito de proferir a última palavra, mas, sobretudo, a prerrogativa de dizer, desde logo, a primeira palavra, excluindo-se, desse modo, por força e autoridade do que dispõe a própria Constituição, a possibilidade do exercício de iguais atribuições, por parte de quaisquer outros órgãos ou autoridades do Estado. Doutrina". 
somente a determinação e controle do alcance e duração das medidas cautelares adotadas nessa fase, coibindo eventuais abusos por parte das demais autoridades envolvidas, seja da Polícia, do Ministério Público ou do Poder Legislativo.

A figura do juiz competente, independente e imparcial, como controlador da legalidade na investigação preliminar e garantidor do respeito aos direitos fundamentais do sujeito passivo, embora ainda não satisfatoriamente definida em nosso Direito, será de suma importância para salvaguarda dessas liberdades, sempre que ameaçadas ${ }^{113}$, não se confundindo com a do investigador ou a do coordenador da investigação.

\subsubsection{A imparcialidade do juiz}

A imparcialidade do julgador representa uma das facetas da garantia do juiz natural. Destaca Aury Lopes Jr., encampando as lições de Aragoneses Alonso, que "a imparcialidade do órgão jurisdicional é um 'princípio supremo do processo' e, como tal, imprescindível para o seu normal desenvolvimento e para a obtenção do reparto judicial justo", sobre ele se estruturando o processo como tipo heterônomo de reparto ${ }^{114}$. O princípio apresenta-se como conseqüência lógica da adoção da heterocomposição, por meio da qual um terceiro imparcial substitui a autonomia das partes, exatamente a posição que o Estado ocupa no processo, por via do juiz ${ }^{115}$.

Sem bem que a Constituição da República de 1988 não estabeleça a imparcialidade do juiz de forma expressa, ela pode ser inferida das garantias do devido processo legal e do juiz natural e, por isso, tida como orientadora do processo penal bem antes da vigência da atual Carta $^{116}$. Inegável, porém, que, com ela, resultou fortalecida a

113 Ao tratar da proteção jurisdicional das liberdades contra o Executivo e os particulares, ou do papel do juiz como protetor da ordem nos Estados liberais, Jean Rivero e Hugues Moutouh (Liberdades públicas, cit., p. 279-280) explicam que o juiz, "mesmo quando reprime, mostra-se o elemento essencial de um sistema de sanções do estatuto das liberdades", pois a experiência prova que é a intervenção do juiz que reduz ao mínimo o risco de abusos da liberdade no âmbito de uma sociedade organizada.

${ }^{114}$ LOPES JR., Aury. Sistemas..., cit., p. 73. Opinião similar expressa Afrânio Silva Jardim (Direito processual penal, cit., p. 40), para quem "os princípios mais importantes para o processo penal moderno são da imparcialidade do Juiz e o do contraditório. Pode-se dizer que os demais princípios nada mais são do que consectários lógicos destes dois princípios reitores".

115 Embora a imparcialidade plena seja um paradigma intangível, um mito que deve ser relativizado, pois o juiz, como qualquer outra pessoa, possui sua escala de valores construída em face de sua origem, formação, cultura, etc., o que, inexoravelmente, influi em suas decisões.

116 Já sob a vigência da Constituição de 1988, o Pacto Internacional de Direitos Civis e Políticos (Nova Yorque, 1966), incorporado em nosso sistema pelo Decreto 592/1992, e a Convenção Americana sobre Direitos Humanos (São José da Costa Rica, 1969), pelo Decreto 679/1992, são explícitos ao consagrar a garantia da imparcialidade do juiz, referindo-se ao direito de toda pessoa, na apuração de qualquer 
garantia, máxime pelo destaque de outras - como o princípio do juiz natural e a correlata proibição dos tribunais de exceção -, às quais está necessariamente relacionada, e também pela reserva, ao Ministério Público, da promoção da ação penal pública, em caráter exclusivo (a privatividade a que alude a redação constitucional ${ }^{117}$ nada mais representa que o resguardo da ação penal privada subsidiária, pelo ofendido).

A parcialidade ou a ausência de imparcialidade do juiz conduz ao descrédito da sociedade em suas instituições, donde necessária a instituição de mecanismos que contribuam à incolumidade dessa garantia. Um deles consiste no princípio da ação, ou da demanda, ou da inércia da jurisdição, segundo o qual cabe à parte a iniciativa de instaurar o exercício da função jurisdicional. A experiência demonstra que o juiz que toma a iniciativa de instaurar o processo, o que é típico do sistema inquisitivo, acaba por ligar-se à pretensão, propendendo a decidir favoravelmente a ela ${ }^{118}$.

Por outro lado, Afrânio Silva Jardim, inspirado nas lições do processualista italiano Liebman, ensina que "a grande dificuldade do processo penal moderno é compatibilizar este indispensável princípio da imparcialidade do Juiz, com a busca da verdade real ou material, na medida em que a outorga de poderes instrutórios pode, ao menos psicologicamente, atingir a sua necessária neutralidade" ${ }^{\text {119. }}$.

No modelo acusatório de processo, o julgador, como representante do Estado-juiz, deve colocar-se entre as partes e além do interesse delas. Deve agir imparcialmente para bem conceder a prestação jurisdicional. Para tanto, são-lhe asseguradas certas garantias (vitaliciedade, inamovibilidade, irredutibilidade de vencimentos), mas também lhe são vedadas certas atitudes, como o exercício de atividade

acusação penal, ser ouvida por um juiz ou Tribunal "competente, independente e imparcial", nos arts. 14.1 e 8.1, respectivamente. Os diplomas internacionais de direitos humanos aos quais o Brasil aderiu são acoplados ao nosso direito interno com o grau de preceito constitucional, por força dos $\S \S 1 .^{\circ}$ e $2 .^{\circ}$ do art. 5. ${ }^{\circ}$ da $\mathrm{CF}$, porquanto veiculam matéria tipicamente constitucional, conclusão reforçada após a inclusão do $\S 3 .^{\circ}$ ao referido artigo pela Emenda Constitucional 45/2004 (cf. PIOVESAN, Flávia. Reforma do Judiciário e direitos humanos. In: TAVARES, André Ramos; LENZA, Pedro; ALARCÓN, Pietro de Jesús Lora. Reforma do Judiciário: analisada e comentada. São Paulo: Método, 2005, p. 71-73).

117 “Art. 129. São funções institucionais do Ministério Público: I - promover, privativamente, a ação penal pública, na forma da lei; (...)".

118 No sistema dos juizados de instrução, marcado pela inquisitividade, compreende-se possível o resguardo da imparcialidade judicial, desde que se criem fases distintas: uma persecutória preliminar e uma acusatória para o julgamento (diferençando-se, pois, o juiz de instrução e o juiz do julgamento). Todavia, isso redundaria em um acoplamento forçado entre os modelos inquisitório e acusatório, mediante fases processuais sucessivas, não oferecendo vantagem alguma tratar o juiz como órgão de investigação em um sistema que dispõe de instituições vocacionadas a essa tarefa, como a Polícia Judiciária e o Ministério Público.

119 JARDIM, Afrânio Silva. Direito processual penal, cit., p. 40. Acrescentaríamos ao adjetivo "instrutórios" o correlato "investigatórios". Sobre a distinção entre investigação e instrução, remete-se ao item 2.6. 
político-partidária, o recebimento de participações no processo ou o exercício de outra profissão (exceto uma de magistério), tudo isso buscando assegurar a sua maior independência e isenção.

Expressa-se a imparcialidade mediante dois ângulos: o subjetivo e o objetivo. O primeiro corresponde a um estado pessoal anímico do juiz, à ausência de préjuízos acerca de determinado assunto de que é conhecedor e que venha influir em sua convicção no caso concreto. O segundo diz com a adoção de garantias necessárias para repelir quaisquer dúvidas sobre sua imparcialidade, colocando-o em uma situação jurídica objetivamente imparcial $^{120}$. As normas de competência definem o aspecto objetivo do aludido princípio. Já sob o prisma subjetivo, a legislação infraconstitucional cuida de preservar a imparcialidade pelas regras de suspeição e impedimento, como são as contidas no Código de Processo Penal (art. 252 e seguintes).

Certo que a imparcialidade plena é algo de difícil (quiçá impossível) alcance, um mito que deve ser relativizado, pois o juiz, como qualquer outra pessoa, possui sua escala de valores construída em face de sua origem, formação, cultura, etc., o que, inexoravelmente, influi em suas decisões ${ }^{121}$. No entanto, um sistema assentado em bases democráticas deve cercar-se de todos os meios institucionais possíveis para evitar sacrifícios a esse caro princípio, não se podendo, por exemplo, endossar atitudes de verdadeira substituição da parte pelo julgador, ou mesmo a tomada de diligências investigativas, na fase pré-processual, pelo sujeito que por lei é incumbido da garantia de

${ }^{120}$ A distinção é referida por Aury Lopes Jr. (Sistemas..., cit., p. 76-77), evocando precedente do Tribunal Europeu de Direitos Humanos, de 1982.

${ }^{121}$ Como explica Plácido Fernández-Viagas Bartolomé (El juez imparcial. Granada: Comares, 1997, p. 6-8), os condicionamentos sociais e ideológicos do juiz são a princípio impossíveis de perceber pois se passam no estrito mundo do psíquico e cultural. A formação e origem social do juiz serão essenciais na determinação de sua ordem de valores, e portanto dos critérios que vão presidir sua atividade interpretativa, porque diretamente relacionados a seu contexto vital. 'Seu sentimento do 'justo' supõe um dado prévio a todo raciocínio que estará determinado pela personalidade do julgador. É impossível que este seja uma máquina e, se não é, sua forma intelectual de reagir será o resultado de um conjunto de influências". E continua o autor, explicando que o grau de aceitação da função do juiz dependerá sempre da coesão do sistema em que inserido. Assim, "num Estado Democrático de Direito, que encontra seu fundamento na soberania popular, sempre que atingido um aceitável nível de estabilidade social, oferecerá em princípio as condições necessárias para proporcionar uma tutela judicial efetiva à cidadania em seu conjunto". Também Luís Roberto Barroso (Interpretação e aplicação da Constituição: fundamentos de uma dogmática constitucional transformadora. 5. ed. rev., atual. e ampl. São Paulo: Saraiva, 2003, p. 289) escreve que "a neutralidade pressupõe algo impossível: que o intérprete seja indiferente ao produto do seu trabalho. É claro que há uma infindável quantidade de casos decididos pelo Judiciário que não mobilizam o juiz em nenhum sentido que não o de burocraticamente cumprir seu dever. Outros tantos casos, porém, envolvem a escolha de valores e alternativas possíveis. E aí, mesmo quando não atue em nome dos interesses de classe ou estamentais, ainda quando não milite em favor do próprio interesse, o intérprete estará promovendo as suas próprias crenças, a sua visão de mundo, o seu senso de justiça”. 
direitos fundamentais dos envolvidos na investigação e do conhecimento e julgamento das causas penais. Como ensina Emilio de Llera Suárez-Bárcena, a atribuição conjunta de atos de investigação e de medidas instrumentais limitativas de direitos (medidas cautelares pessoais e reais) a um mesmo juiz, na fase prévia, anula irremediavelmente a sua imparcialidade como condição estrutural dos órgãos jurisdicionais. Os atos puramente de investigação não só são incompatíveis com o exercício do poder jurisdicional, como também ocasionam a perda da imparcialidade do juiz que os realiza e dirige ${ }^{122}$.

No terreno da investigação preliminar, portanto, há que se preservar a garantia da imparcialidade como essencial vetor da atividade do juiz, chamado a intervir nos incidentes que demandam jurisdicionalização. Calha registrar, todavia, que no plano processual penal brasileiro não existe distinção entre o juiz que analisa medidas cautelares na investigação preliminar, o juiz que efetua o juízo de admissibilidade da acusação e o juiz que efetivamente julga a ação penal. Trata-se, como bem observa Fauzi Hassan Choukr, "de fator de complicação para a aplicação substancial da imparcialidade, na medida em que sua formação de convencimento já está comprometida com o desenrolar dos fatos desde antes do início da ação penal propriamente dita" ${ }^{123}$, a merecer tratamento específico no capítulo 3 deste trabalho.

Incide também a imparcialidade em relação à figura da autoridade condutora da investigação preliminar $^{124}$, atuando, porém, quanto a esta, sob a específica forma de um correlato principío, dirigido a todos os Poderes do Estado, sobretudo à atividade administrativa (como a de investigação de delitos): a impessoalidade.

\subsubsection{A impessoalidade do investigador}

Ao contrário da garantia da imparcialidade, apenas inferida do sistema, está expresso no Texto Constitucional, entre os princípios que regem a Administração Pública na qual, frise-se bem, inserem-se a Polícia Judiciária e o Ministério Público, principais responsáveis pelas investigações preliminares -, o da impessoalidade (art. 37, caput, da

${ }^{122} \mathrm{La}$ inidoneidad constitucional de jueces y fiscales para asumir la investigación oficial. In: El modelo constitucional de investigación penal. Valencia: Tirant lo Blanch, 2001, p. 120-121.

123 Processo penal à luz da Constituição. Bauru: Edipro, 1999, p. 33.

124 Constituições há que, além de referir a imparcialidade do juiz em seu texto, aludem ainda, especificamente, à imparcialidade da Administração, como a italiana, respectivamente nos arts. 111 e 97 ("I pubblici uffici sono organizzati secondo disposizioni di legge, in modo che siano assicurati il buon andamento e l'imparzialità dell'amministrazione"). 
CF). Tal princípio refere-se ao agir, ao móvel do administrador, o qual "não pode atuar impelido por critérios próprios e subjetivos, mas sim, segundo regras objetivas e controláveis racionalmente" ${ }^{\natural 25}$. No dizer de Odete Medauar, o que visa a impessoalidade é “obstaculizar atuações geradas por antipatias, simpatias, objetivos de vingança, represálias, trocos, nepotismo, favorecimentos diversos, muito comuns em concursos públicos, licitações, processos disciplinares, exercício do poder de polícia”. Ele busca fazer predominar o sentido de função, o caráter objetivo nas atuações dos agentes ${ }^{126}$.

Enquanto o particular age na promoção de interesses pessoais, o agente público atua em nome da coletividade, não podendo por isso dispor dos valores que lhe são confiados, nem atuar de forma a perseguir ou privilegiar pessoas. Deve agir de forma serena, despido de paixões ou de tendências, à luz das normas vigentes no ordenamento, filtrando as emoções advindas da proximidade do ocorrido, para assim garantir maior segurança ao resultado do seu trabalho. Verifica-se, portanto, a estreita aproximação entre o significado atribuído à impessoalidade e o de imparcialidade ${ }^{127}$.

Há quem identifique o princípio da impessoalidade com o da finalidade, ou com o princípio da igualdade. Fernão Borba Franco, por exemplo, define-o como o dever de o administrador tratar a todos igualmente pela Administração, sem benefícios ou prejudicialidade, e o fato de os servidores não responderem pessoalmente pelos seus atos perante terceiros, porque imputáveis à Administração Pública ${ }^{128}$. Percebe-se, portanto, que a impessoalidade tem um viés subjetivo (vinculando o atuar do agente público) e outro objetivo, à proporção que espelha o agir da Administração.

125 HARGER, Marcelo. Princípios constitucionais..., cit., p. 113.

126 A processualidade..., cit., p. 93. Valorosa também é a ensinança de Nelson Saldanha (Estado de direito..., p. 11): "Não é possível haver democracia, em sentido pleno, onde subsistam e prevaleçam dominações pessoais; neste caso, também não é possível dar-se o Estado de Direito. Tanto a democracia, ideal social e político discutido há milênios, como o Estado de Direito, solução constitucional pensada e tentada há algumas gerações, implicam o poder impessoalizado...”.

127 Niklas Luhmann (Legitimação pelo procedimento. Trad. Maria Luiza de Carvalho. Rio de Janeiro: Revan, 1999, p. 82), numa visão sociológica dos processos judiciais, aproximando as idéias de impessoalidade e imparcialidade, ensina que todas as organizações sociais complexas exigem do indivíduo mais atuações do que ele pode trazer de uma fórmula pessoal de vida, necessitando de vários dispositivos de descarga que impeçam que cada atuação seja atribuída à personalidade. Assim, no interesse de manutenção de uma organização social complexa e de um sistema de procedimento relativamente autônomo dentro dela, "todos aqueles que têm uma participação profissional no processo como presidentes ou vogais, advogados ou representantes de interesses, secretários ou moços de recados, são obrigados a apresentar uma conduta impessoal. (...) A impessoalidade é estabelecida institucionalmente como filtro de ação unilateral e não como separação completa. Um juiz não deve comprometer qualquer sentimento ou relações, atitudes ou informações no processo jurídico; deve deixar ao processo jurídico o seu caráter como sistema social regido apenas pela lei".

128 Processo administrativo, cit., p. 27. 
Em que pese a ligação também existente com tais princípios, é possível efetuar distinções. Enquanto a impessoalidade diz respeito ao móvel do agente, a igualdade refere-se ao conteúdo do ato. Uma atitude pode agredir a impessoalidade, mas não afrontar a isonomia; por outro lado, pode o agente público agir com impessoalidade, mas efetuar uma discriminação vedada ${ }^{129}$.

Fácil inferir que os órgãos encarregados das investigações preliminares, exercendo função pública, estão todos obrigados a atuar com impessoalidade e com imparcialidade na apuração de condutas criminosas e de sua autoria, assim devendo portarse durante todo o transcurso das investigações. O responsável pela condução de uma investigação preliminar, seja ela procedida no âmbito do Poder Executivo, do Legislativo ou do Judiciário, não pode atuar dirigido apenas a uma linha investigativa, como a de inculpar determinado suspeito, desconsiderando todas as outras que podem fazer considerálo insuspeito, ou vice-versa. É importante que o investigador colete todo o material útil à elucidação do fato e de sua autoria, averiguando também aqueles razoáveis indícios ${ }^{130}$ que lhe chegam a conhecer, apontando no sentido de que a pessoa investigada não cometeu o delito $^{131}$.

No que tange ao inquérito policial, para prevenir subjetivismos por parte da autoridade condutora, o art. 107 do Código de Processo Penal brasileiro dispõe que, muito embora não se lhes possa opor suspeição, "deverão elas declarar-se suspeitas, quando ocorrer motivo legal". Além disso, as regras de impedimento encartadas no art. 252, I,

129 HARGER, Marcelo. Princípios constitucionais..., cit., p. 115.

${ }^{130}$ O Código de Processo Penal estabelece o conceito formal de indício como "a circunstância conhecida e provada, que, tendo relação com o fato, autorize, por indução, concluir-se a existência de outra ou outras circunstâncias" (art. 239). Em sentido técnico-jurídico e com maior precisão, define-o Maria Thereza Rocha de Assis Moura como "todo rastro, vestígio, sinal e, em geral, todo fato conhecido, devidamente provado, suscetível de conduzir ao conhecimento de um fato desconhecido, a ele relacionado, por meio de um raciocínio indutivo-dedutivo" (A prova por indícios..., cit., p. 38). Deve haver uma relação lógica do indício (fato provado) com o fato que se quer provar, uma relação de causalidade que permita o conhecimento do fato ignorado, guiando-se tal raciocínio pelas regras da experiência e da lógica.

131 Antonio Scarance Fernandes (Teoria geral do procedimento..., cit., p. 83-84) relata que o sistema acusatório, no final do século XX, prevaleceu sobre o sistema misto, nos países continentais europeus, que nessa passagem atribuíram ao Ministério Público o poder de dirigir a investigação (Grande Reforma Alemã de 1974, Código de Processo Penal português de 1988 e Código de Processo Penal italiano de 1989), mas prevendo que ele devesse agir de modo favorável à acusação e ao acusado. Anderson Souza Daura (Inquérito policial: competência e nulidades de atos de polícia judiciária. 2. ed. rev. e atual. Curitiba: Juruá, 2008, p. 110-111) é também enfático ao tratar do inquérito policial: “A autoridade policial que o preside age em nome do Estado de forma imparcial podendo produzir prova que não só favoreça à acusação mas também à defesa (...). O 'julgar' imparcial dos fatos pela autoridade policial deve transparecer como uma garantia à cidadania (...). Cinge-se, única e exclusivamente, em elucidar os fatos em sua totalidade. Filtra as emoções advindas da proximidade do ocorrido, no calor dos acontecimentos, para apresentar o caso ao Poder Judiciário de forma serena". 
servem não apenas ao juiz, mas igualmente ao condutor da investigação, sempre que se configure alguma daquelas situações objetivas (v.g., parentesco da autoridade com o investigado ou com a vítima).

O órgão ou agente responsável pela investigação tem o dever de ser imparcial e impessoal em seu mister, o que significa exercê-lo sem vinculação à acusação ou à defesa e sem o pendor pré-concebido para uma ou outra solução, mas de forma a testar todas as respostas inicialmente plausíveis para o fato investigado, a fim de obter o resultado mais justo, o que em muito contribuirá para o desfecho do processo ulteriormente instaurado.

\subsubsection{A presunção de inocência}

Considerado um dos mais importantes reflexos do due processo of law no âmbito penal, em nosso sistema, vige o regramento - expresso claramente nos tratados internacionais sobre direitos humanos ${ }^{132}$ - de que o imputado é considerado inocente até que sobrevenha condenação transitada formalmente em julgado. Há quem defenda que o princípio que primeiro impera no processo penal é o da proteção dos inocentes, de modo que o processo penal seria o direito protetor dos inocentes ${ }^{133}$.

Como afirma Paulo Fernando Silveira, o princípio da inocência decorre direta, lógica e irrefutavelmente da cláusula do devido processo legal, que remonta à Carta Magna de 1215, porque "se nenhuma pessoa pode ser privada antecipadamente de sua liberdade, conseqüentemente não pode ser considerada culpada antes do trânsito em julgado da sentença condenatória",134.

${ }^{132}$ Em diplomas internacionais, vem consagrado na Declaração dos Direitos do Homem e do Cidadão, de 1789 ("Art. 9. ${ }^{\circ}$ Todo acusado é considerado inocente até ser declarado culpado e, se se julgar indispensável prendê-lo, todo o rigor desnecessário à guarda da sua pessoa deverá ser severamente reprimido pela lei”) e na Declaração Universal dos Direitos do Homem, de 1948 (“Art. XI, item 1 - Toda pessoa acusada de um ato delituoso tem o direito de ser presumida inocente até que sua culpabilidade tenha sido provada de acordo com a lei, em julgamento público no qual lhe tenham sido asseguradas todas as garantias necessárias à sua defesa").

${ }^{133}$ LOPES JR., Aury. Sistemas..., cit., p. 26. Destaca Antonio Magalhães Gomes Filho (O princípio da presunção de inocência na Constituição de 1988 e na Convenção Americana sobre Direitos Humanos (Pacto de São José da Costa Rica). Revista do Advogado, São Paulo, v. 42, abr. 1994, p. 31) que tal princípio constituiu reação ao aparato repressivo do ancien régime, herdado do sistema primitivo das ordálias, no qual o acusado já era considerado culpado pela opinião pública, sobre ele recaindo o encargo de provar a própria inocência. Podia-se, inclusive, quando não fosse possível chegar a uma conclusão segura sobre a culpabilidade, aplicar ao réu uma pena extraordinária, ao invés da absolvição, ou suspender-se o processo até se encontrarem provas conclusivas.

134 Devido processo legal, cit., p. 345-346. 
A presunção de inocência foi inserida em nosso ordenamento pelo Pacto de São José da Costa Rica, ao qual o Brasil aderiu, incorporando-o mediante o Decreto 678/1992, com o seguinte teor: "toda pessoa acusada de um delito tem direito a que se presuma sua inocência, enquanto não for legalmente comprovada sua culpa" (art. 8.2, primeira parte). Antes, porém, na Constituição de 1988, veio consagrada a fórmula insculpida no art. 5. ${ }^{\circ}$, LVII, que traduz a regra da não-consideração prévia de culpabilidade do imputado: "ninguém será considerado culpado até o trânsito em julgado de sentença penal condenatória". Assim, o estado de inocência adquire caráter constitucional e deve ser mantido até que exista uma sentença condenatória transitada em julgado.

Há diferença semântica entre os dois postulados, sendo que este último surgiu sob as vozes de um discurso repressor no final do século XIX, para limitar o princípio da presunção de inocência, ao argumento de que o imputado (investigado ou processado criminalmente) não poderia ser tratado como culpado, mas tampouco poderia ser visto como inocente ${ }^{135}$

Atualmente, é visível a complementaridade entre ambos os aspectos, enxergando-se no princípio um duplo significado ${ }^{136}$. De um lado, a presunção de inocência serve como regra processual; de outro, como regra de tratamento do acusado ${ }^{137}$.

No primeiro sentido, dá-se maior destaque aos aspectos referentes à disciplina probatória, funcionando como meio de atribuir e avaliar a prova no processo: o acusado não está obrigado a fornecer provas de sua inocência, pois esta é de antemão presumida até prova em contrário, recaindo exclusivamente sobre a acusação o ônus da prova. Sem prova cabal e resoluta, da qual se possa deduzir, razoavelmente, a existência do

135 Aliás, como bem pontua Luiz Flávio Gomes (Sobre o conteúdo processual tridimensional do princípio da presunção de inocência. In: Estudos de direito processual penal. 1. ed., 2. tir. São Paulo: Revista dos Tribunais, 1999, p. 107), não faz sentido "não considerar que no inc. LVII do art. 5. ${ }^{\circ}$ da CF está inscrito, com todas as letras, o princípio da presunção de inocência, com toda carga liberal e democrática que carrega em sua história, tendo como ponto de arranque (em termos de ius positum) a Declaração dos Direitos do Homem e do Cidadão (1789), de fundo induvidosamente iluminista".

${ }^{136}$ Para Siracusano, Galati, Tranchina e Zappalà (Diritto processuale penale, cit., p. 169), seja por uma ou por outra fórmula, a regra configura, essencialmente, as mesmas garantias de liberdade individual e de proteção da pessoa humana, uma regra seguramente política que se eleva à dignidade constitucional para corroborar e reforçar os valores da pessoa e os seus direitos invioláveis.

137 Trata-se, na observação de Alberto M. Binder (Introducción al derecho procesal penal. 2. ed. actual. y ampl. Buenos Aires: Ad-Hoc, 2002, p. 124-125), das formulações positiva e negativa do princípio, das quais se extraem algumas derivações: a) que só a sentença tem a possibilidade de declarar a culpabilidade; b) que no momento da sentença só existem duas possibilidades - culpado ou inocente -, não havendo uma terceira; c) que a culpabilidade deve ser juridicamente construída; d) que essa construção requer a aquisição de um grau de certeza; e) que o acusado não tem que construir sua inocência; f) que o acusado não pode ser tratado como culpado; g) que não podem existir ficções de culpabilidade, ou partes da culpabilidade que não precisam ser provadas. 
delito e a culpabilidade do acusado, a ponto de afastar o seu estado de inocência, não se pode editar uma sentença condenatória. No Código de Processo Penal brasileiro, embora a redação do art. $156^{138}$ possa, a princípio, conduzir ao equívoco de se pensar que haveria uma repartição formal do ônus da prova, é ao Ministério Público que cabe o ônus substancial da prova, pois deve demonstrar a presença de todos os elementos de fato sobre os quais se erige a acusação, além da inexistência de qualquer elemento que obste o seu surgimento $^{139}$. A dúvida sobre a existência de qualquer fato argüido deve conduzir à absolvição $^{140}$.

Ainda em matéria probatória, várias repercussões podem ser extraídas do princípio. Como ressalta Antonio Magalhães Gomes Filho ${ }^{141}$, a presunção de inocência, antes de inverter o ônus da prova, altera-lhe o objeto, fazendo com que o processo penal vise à verificação dos fatos imputados ao acusado, e não de suas escusas, tampouco à mera ratificação dos dados que serviram de base à imputação, colhidos na investigação preliminar. $\mathrm{O}$ preceito exige que a metodologia da prova esteja orientada à comprovação legal da culpa do acusado, o que somente pode ser feito, idoneamente, em um processo informado pelo contraditório, pela "igualdade de armas", pela proibição da prova ilícita, etc. Outrossim, não se pode obrigar o acusado a colaborar na apuração dos fatos, vigendo amplamente o direito ao silêncio (art. 5..$^{\circ}$ LXIII, da CF), que jamais poderá ser interpretado

138 “Art. 156. A prova da alegação incumbirá a quem a fizer...”.

139 Desse modo, tem-se por salutar a preocupação do legislador reformista (Lei 11.690/2008), que, espancando qualquer aparente distribuição de ônus da prova à defesa, inseriu na redação do art. 386, VI, do CPP, expressa referência à absolvição em caso de dúvida quanto à ocorrência de causas de justificação ou de isenção de pena. É preciso, portanto, “interpretar a cláusula inicial do art. 156 do CPP à luz da Constituição e do modelo acusatório que ela consagra, entendendo-se que, ao dizer 'a prova da alegação incumbirá a quem a fizer', o legislador dispõe tão-somente sobre a iniciativa das provas, sem atribuir qualquer encargo para as partes - muito menos para a defesa - nem estabelecer uma regra de julgamento diversa do in dubio pro reo" (GOMES FILHO, Antonio Magalhães. Provas: Lei 11.690, de 09.06.2008. In: MOURA, Maria Thereza Rocha de Assis (Coord.). As reformas no processo penal: as novas Leis de 2008 e os projetos de reforma. São Paulo: Revista dos Tribunais, 2008, p. 257).

140 Assim: "Nenhuma acusação penal se presume provada. Não compete ao réu demonstrar a sua inocência. Cabe ao Ministério Público comprovar, de forma inequívoca, a culpabilidade do acusado. Já não mais prevalece, em nosso sistema de direito positivo, a regra, que, em dado momento histórico do processo político brasileiro (Estado Novo), criou, para o réu, com a falta de pudor que caracteriza os regimes autoritários, a obrigação de o acusado provar a sua própria inocência (Decreto-lei 88, de 20/12/37, art. 20, n. 5). Não se justifica, sem base probatória idônea, a formulação possível de qualquer juízo condenatório, que deve sempre assentar-se - para que se qualifique como ato revestido de validade ético-jurídica - em elementos de certeza, os quais, ao dissiparem ambigüidades, ao esclarecerem situações equívocas e ao desfazerem dados eivados de obscuridade, revelam-se capazes de informar, com objetividade, o órgão judiciário competente, afastando, desse modo, dúvidas razoáveis, sérias e fundadas que poderiam conduzir qualquer magistrado ou Tribunal a pronunciar o non liquet.” (STF, HC 73.338, rel. Min. Celso de Mello, v.u., DJ de 19.12.1996).

141 O princípio..., cit., p. 31-32. 
em seu desfavor, no processo informado pela presunção de inocência ${ }^{142}$. Por fím, o princípio-garantia funciona como regra de julgamento, pois, em caso de dúvidas ou insuficiência de provas, a solução deve ser a absolvição do acusado, no que se identifica o princípio com a máxima in dubio pro reo (art. 386, VII, do CPP) ${ }^{143}$.

De outro lado, a não-consideração prévia de culpabilidade funciona como regra de tratamento material do imputado, seja no processo ou no pré-processo: até o trânsito em julgado de uma eventual sentença condenatória, o sujeito passivo da persecução penal não pode ser tratado como culpado, nem sofrer qualquer punição antecipada ou medida que implique reconhecimento prévio da culpabilidade ${ }^{144}$. Cuida-se, na visão de Fauzi Hassan Choukr, de verdadeira matriz para a compreensão global do sistema instrumental penal, implicando um compromisso não apenas técnico, mas também ético do modelo utilizado. Ele impõe a mudança de concepção do tratamento do acusado/investigado, impedindo a aplicação de qualquer sanção a título de antecipação de pena $^{145}$.

Esse fundamental preceito de civilidade há de ser observado não apenas pelo Estado, em sua atividade repressiva, mas também pela sociedade. Na prática, porém, não são poucos os exemplos em que as situações, os costumes e as palavras exprimem antecipações do juízo condenatório. Isso ocorre, por exemplo, na disposição física da sala de audiências dos fóruns, em que o acusado é emblematicamente situado em posição

${ }^{142} \mathrm{Na}$ explicação de Fábio Medina Osório (Direito administrativo sancionador. 2. ed. rev., atual. e ampl. São Paulo: Revista dos Tribunais, 2006, p. 502-503), os poderes da Administração Pública não vão tão longe a ponto de autorizar que se force alguém a produzir provas ou declarações contra seus próprios interesses, pois assim se estaria e efetuar um constrangimento incompatível com a garantia de não declarar-se culpado, ligada à presunção de inocência e que não se esgota na formalidade de não ser obrigado a "testemunhar" ou a "prestar declarações verbais" contra os próprios interesses, sendo necessária também a proibição de forçar alguém a adotar comportamentos contrários a seus interesses.

143 Conforme ensinamento de Alberto M. Binder (Introducción..., cit., p. 127), o princípio do in dubio pro reo, aplicado à valoração da prova ou à construção da sentença, é uma das conseqüências diretas mais importantes do princípio da inocência, que consiste em limitação precisa à atividade sancionatória do Estado. Construir com certeza a culpabilidade significa destruir, sem lugar para dúvidas, o status básico de liberdade da pessoa imputada. Se não existe esse grau de certeza, não se pode emitir a decisão de culpabilidade.

144 Também essa faceta do princípio é afirmada no seguinte precedente: "O princípio constitucional da nãoculpabilidade, em nosso sistema jurídico, consagra uma regra de tratamento que impede o Poder Público de agir e de se comportar, em relação ao suspeito, ao indiciado, ao denunciado ou ao réu, como se estes já houvessem sido condenados definitivamente por sentença do Poder Judiciário" (STF, HC 79.812/SP, rel. Min. Celso de Mello, Plenário, v.u., DJ de 16.2.2001).

145 Garantias..., cit., 2006, p. 97-98. Invoca o autor, como uma das conseqüências mais sensíveis do referido princípio, "o deslocamento da figura do ser humano da condição de objeto do processo ou da investigação para a condição de sujeito, com direitos e deveres adequados a essa atividade". Já Luiz Flávio Gomes (Sobre o conteúdo..., cit., p. 110-116) enxerga a presunção de inocência sob uma tripla dimensão, como 
solitária e inferior aos demais sujeitos processuais; no ainda existente "banco dos réus", que expõe o acusado, no tribunal do júri, como se já culpado fosse; no abusivo uso de algemas quando não existe efetiva necessidade, reprimido inclusive por súmula vinculante do $\mathrm{STF}^{146}$; na exploração da imagem, honra e intimidade dos acusados pela mídia ${ }^{147}$.

Há quem identifique ainda como importante corolário da presunção de inocência o direito ao processo célere, correlato da obrigatoriedade de julgamento no mais curto prazo, porquanto a demora do processo, além de prolongar o estado de suspeição e as medidas cautelares tomadas contra o imputado (notadamente a prisão preventiva), termina por esvaziar o sentido e retirar o conteúdo útil daquele princípio ${ }^{148}$.

$\mathrm{Na}$ investigação preliminar, fazem-se presentes ambas as garantias (inclusive podendo ser tratadas como sinônimas, ou como feixes de uma só garantia, tal a aproximação entre elas), ganhando destaque a não-consideração prévia de culpabilidade, que deve operar com todo rigor e amplitude, como uma regra de tratamento que impede tratar-se o investigado como se culpado fosse.

A presunção de inocência do imputado, seja como princípio de avaliação da prova ou como regra de tratamento, não se pode afastar dos procedimentos administrativos de natureza penal (caso da investigação preliminar), neles, ao revés, vigorando com maior abrangência, eis que sequer formado ainda o convencimento do órgão acusador para o oferecimento de denúncia contra o imputado. Aliás, para que seja alcançado tal convencimento ao término da investigação e, enfim, para que seja promovida a ação penal, em estima ao postulado do estado presuntivo de inocência, deve exigir-se do acusador um juízo de probabilidade (que requer um conjunto de razões positivas), não de mera possibilidade de que tenha sido o imputado o autor do crime.

regra probatória, como regra de tratamento e como regra de garantia, a indicar que a comprovação da culpa do réu deve cercar-se de todas as garantias do due processo of law.

146 Súmula vinculante 11: "Só é lícito o uso de algemas em casos de resistência e de fundado receio de fuga ou de perigo à integridade física própria ou alheia, por parte do preso ou de terceiros, justificada a excepcionalidade por escrito, sob pena de responsabilidade disciplinar, civil e penal do agente ou da autoridade e de nulidade da prisão ou do ato processual a que se refere, sem prejuízo da responsabilidade civil do Estado".

${ }^{147}$ Cf. GOMES FILHO, Antonio Magalhães. O princípio..., cit., p. 32-33. Bem ressalta Flávia Rahal Bresser Pereira (Publicidade no processo penal: a mídia e o processo. Revista Brasileira de Ciências Criminais, São Paulo, v. 12, n. 47, mar./abr. 2004, p. 274) que, quando a excessiva publicidade dada aos feitos criminais invade a intimidade das pessoas e expõe-lhes a vida privada, acaba por perecer a presunção de inocência.

148 Cf. CANOTILHO, J. J. Gomes; MOREIRA, Vital. Constituição da República portuguesa anotada. 1. ed. brasileira. 4. ed. portuguesa. São Paulo: Revista dos Tribunais; Coimbra: Coimbra, 2007, v. 1, p. 519. 
Existem casos, todavia, em que ela se postará em confronto com outros valores, quando for preciso restringir a liberdade individual do cidadão durante a persecutio criminis, antes mesmo, portanto, da afirmação de culpa em sentença final condenatória $^{149}$. Nesse quadro, a medida restritiva, para compatibilizar-se à garantia da presunção de inocência, há que ser fundada em elementos concretos e objetivos de cautelaridade que a recomendem, devendo ser adotada em caráter excepcional e cercada de várias outras exigências integrantes do devido processo legal, especialmente a publicidade, a motivação, a legalidade e a ampla defesa ${ }^{150}$.

Outras vezes, o que se tem tornado freqüente na prática, a presunção de inocência é simplesmente ignorada, ao se permitir uma midiatização da investigação preliminar, uma perigosa publicidade que expõe os suspeitos, investigados e imputados em geral, passando à opinião pública a imagem de que são os autores do delito, como que se invertendo o princípio para o da presunção de culpa, impingindo-se uma verdadeira punição e estigma social ao indivíduo que deveria estar sob proteção daquela garantia ${ }^{151}$. Também nesse aspecto, a presunção de inocência ou de não-culpabilidade somente será efetivada se respeitadas, em seu conjunto, todas as demais garantias fundamentais do sujeito passivo de uma investigação preliminar.

\subsubsection{O direito de defesa}

Instrumento amplamente consagrado nos Estados democráticos e arraigado na consciência jurídica dos povos, o regramento da ampla defesa está previsto no art. $5 .^{\circ}$, LV, da Carta da República, juntamente com a idéia da audiência bilateral: "aos litigantes,

149 Como esclarece Antonio Magalhães Gomes Filho (Presunção de inocência e prisão cautelar. São Paulo: Saraiva, 1991, p. 65), à luz do mencionado princípio, não se concebe qualquer forma de encarceramento como antecipação da punição ou corolário automático da imputação. A seu dizer, “[a]s prisões decretadas anteriormente à condenação, que numa visão radical do princípio nem sequer poderiam ser admitidas, encontram justificação apenas na excepcionalidade de situações em que a liberdade do acusado possa comprometer o regular desenvolvimento e a eficácia da atividade processual", somente podendo ter, portanto, caráter cautelar.

150 Cf. FRANCO, Alberto Silva; MORAES, Maurício Zanoide. Dos princípios..., cit., p. 698.

151 Nesse ponto, Ana Lúcia Menezes Vieira (Processo penal e mídia. São Paulo: Revista dos Tribunais, 2003, p. 168-175) destaca que a presunção de inocência é um dos princípios mais violados pela mídia, pois a divulgação indevida pela imprensa da mera possibilidade de acusação formal de um crime já gera no público o valor de efetiva responsabilidade, principalmente se o indivíduo é preso preventivamente. Deveria, contudo, funcionar como um limitador, não excluindo a liberdade de informar dos meios de comunicação, mas exigindo deles cautela e reserva na divulgação dos atos judiciais, de maneira a não induzir a opinião pública à crença de uma definitividade inexistente; narrando, mas sem confirmar ou sustentar a responsabilidade ainda não haurida do investigado ou acusado. 
em processo judicial ou administrativo, e aos acusados em geral são assegurados o contraditório e a ampla defesa, com os meios e recursos a ela inerentes". Cuida-se de garantia já prevista, entre nós, desde a primeira Constituição republicana (1891), porém agora alargada e expandida a todos os processos em que se veja o acusado diante da atividade do Estado, passível de sofrer restrições em sua esfera de direitos.

Assume a defesa papel crucial no campo penal, senão que, pelo problema da culpa e da reprovação ética que a pena comporta, é elevada ao plano da defesa da dignidade essencial de cada pessoa ${ }^{152}$. A razão de ser dessa garantia está na radical desigualdade material entre a acusação (normalmente apoiada no poder institucional do Estado) e a defesa $^{153}$.

Tomando de empréstimo as palavras de Ada Pellegrini Grinover, inspirada nas lições de Calamandrei, "seriam vãs as liberdades do indivíduo, se não pudessem ser reivindicadas e defendidas em juízo, sendo necessário, ademais, para que essas liberdades se tornem reais, que o processo possibilite, efetivamente, à parte a defesa de seus direitos, a sustentação de suas razões, a produção de suas provas"154.

Da própria estruturação da regra constitucional pode-se vislumbrar a estreita ligação entre a defesa e a garantia do contraditório, eis que uma viabiliza o exercício da outra, dando concretude, por sua vez, ao princípio da paridade de armas, reflexo da igualdade no plano processual ${ }^{155}$. Assim, a defesa é a reação, ou a face reversa do direito de ação, que vem albergado no princípio da proteção judiciária (art. 5. ${ }^{\circ}, \mathrm{XXXV}$, da CF) ${ }^{156}$.

152 Cf. RODRIGUES, José Narciso da Cunha. Sobre o princípio da igualdade de armas. Revista Portuguesa de Ciência Criminal, Coimbra, v. 1, n. 1, jan./mar. 1991, p. 87.

153 Paula Bajer Fernandes Martins da Costa (Igualdade no direito processual penal brasileiro. São Paulo: Revista dos Tribunais, 2001, p. 130-131), ressaltando a evidente desigualdade entre sujeitos oficiais e não-oficiais, principalmente na fase investigatória, destaca que "o suspeito, ou acusado, tem a liberdade em risco no processo e, por isso, mais a perder que o Ministério Público. De uma forma ou de outra, absolvido ou condenado, o acusado termina o processo em situação desfavorável. Sempre terá sido acusado, com todas as conseqüências sociais desta situação".

154 GRINOVER, Ada Pellegrini. As garantias constitucionais do direito de ação. São Paulo: Revista dos Tribunais, 1973, p. 15-16. Assim, também, Adauto Suannes: "Basicamente, a noção mais elementar de fair trial, de processo (ou, mais adequadamente, julgamento) justo, aplicado à atuação do juiz criminal, implica na idéia de que uma condenação somente pode sobrevir após ter sido dada ao acusado a oportunidade de ser ouvido e de apresentar sua versão dos fatos. Mais: que na instrução do feito sejam observados certos cuidados que dizem com a dignidade do ser humano. É esse seu fundamento ético." (Os fundamentos éticos do devido processo penal. São Paulo: Revista dos Tribunais, 1999, p. 133).

155 A paridade de armas implica o indispensável equilíbrio de oportunidades que deve existir entre os interessados no provimento, de modo que nenhum deles se ponha em posição de desvantagem em relação à parte contrária. Para tanto, os ofícios da acusação e defesa devem ser postos não em um plano estático de igualdade formal, e sim num plano dinâmico, com simetria na sua idoneidade técnica. Cf. GOMES FILHO, Antonio Magalhães. A motivação..., cit., p. 42. A esse respeito, Cláudio Faranda (La "par condicio" nel processo penale. Milano: Giuffrè, 1968, p. 15) é incisivo: "o equilíbrio funcional entre as 
No processo penal, defesa, em sentido amplo, é toda atividade das partes voltada seja à atuação do direito-dever de punir, ou ao seu impedimento; em sentido estrito, é a oposição, pelo acusado, à atividade persecutória estatal ${ }^{157}$, feita por meio da defesa técnica - exercida por profissional qualificado, de sua confiança ou indicado pelo Estado, quando não puder arcar com suas despesas (a Constituição considera indispensáveis à administração da Justiça o advogado e as defensorias públicas, nos art. 133 e 134) - e da autodefesa, uma exigência constitucional aperfeiçoada no instante de manifestação pessoal do acusado ${ }^{158}$.

A defesa técnica é indisponível e tem singular importância para o cumprimento de outras garantias processuais básicas, pois, ressaltam-no Ada Pellegrini Grinover, Antonio Scarance Fernandes e Antonio Magalhães Gomes Filho, "mais do que garantia do acusado, é condição da paridade de armas, imprescindível à concreta atuação do contraditório e, conseqüentemente, à própria imparcialidade do juiz" ${ }^{\prime 159}$.

A autodefesa, ao contrário, é mera faculdade do acusado, que dela pode dispor; no entanto, quando exercida, não pode ser objeto de restrição, sob pena de sacrificar-se toda a garantia da ampla defesa. Basicamente, é composta dos direitos de audiência - pelo qual o acusado, no momento do interrogatório, busca influir na formação do convencimento do juiz - e de presença, que se traduz na oportunidade de postar-se, a todo tempo, perante as alegações e provas produzidas ${ }^{160}$. Guarda a autodefesa, assim,

partes representa, no processo moderno, um instrumento de atuação de um método de averiguação, considerado, do ponto de vista técnico, o mais válido".

156 Por isso Aury Lopes Jr. (Sistemas..., cit., p. 333-334) a qualifica como um "direito-réplica, que nasce com a agressão que representa para o sujeito passivo a existência de uma imputação ou ser objeto de diligências ou vigilância policial". Ainda que não haja acusação formalizada, qualquer notícia-crime que impute um fato com aparência delituosa a uma pessoa, tornando-a alvo de investigação, constituiu uma imputação em seu desfavor, uma agressão ao seu estado de inocência e de liberdade capaz de gerar uma resistência em sentido jurídico-processual.

157 Cf. TOURINHO FILHO, Fernando da Costa. Processo penal, cit., v. 2, p. 457-458.

158 Aury Lopes Jr. (Sistemas..., cit., p. 335-345) utiliza as expressões defesa pública e defesa privada para aludir, respectivamente, à defesa técnica e à autodefesa, sendo que a primeira é um interesse não só do imputado, mas também da sociedade, em obter uma verificação negativa no caso de o fato não constituir fonte de responsabilidade penal, ao passo que a segunda é uma atuação pessoal do sujeito passivo, fazendo valer seu critério individual e seu interesse privado.

159 As nulidades no processo penal. 10. ed. rev., atual. e ampl. São Paulo: Revista dos Tribunais, 2007, p. 89. Acrescenta Alberto Binder (Introducción..., cit., p. 159) que a defesa técnica não é um direito disponível por parte do imputado, porque está em jogo a legitimidade do juízo e do processo segundo as exigências de um Estado de Direito. Logo, se por razões particulares o imputado entende que exercerá melhor a sua defesa sem a assistência do advogado, o magistrado pode impor-lhe a assistência técnica obrigatória.

160 Nesse sentido, Alejandro D. Carrió (Garantías constitucionales en el proceso penal. 4. ed. Buenos Aires: Hammurabi, 2004, p. 89) destaca que a garantia da defesa abarca não só a possibilidade de ser ouvido, mas de produzir provas e controlar as que possam ser produzidas, segundo vem reafirmando a Corte Suprema de Justiça da Argentina. 
visível complementaridade à defesa técnica, já que não basta à adequada defesa do imputado a participação de profissional com conhecimento da técnica processual, sendo indispensável a intervenção do próprio acusado, que teve, via de regra, maior proximidade aos fatos apurados, apresentando melhores condições de expor a sua versão sobre eles.

Segundo Alberto Binder, o direito de defesa não pode ser posto no mesmo plano que as demais garantias processuais; exprime-se a defesa como a mais importante garantia processual do imputado, por tornar operativas, na prática, todas as demais, daí a sua intangibilidade ${ }^{161}$.

$\mathrm{O}$ direito à ampla defesa especifica-se em várias garantias, dispostas em na Lei Maior e no Código de Processo Penal e complementadas por diplomas internacionais de proteção dos direitos humanos - estes, com estatura constitucional por força da cláusula de salvaguarda do art. 5. ${ }^{\circ}, \S 2 .^{\circ}$, da CF. Assim, a Convenção Americana sobre Direitos Humanos (Pacto de São José da Costa Rica), no art. 8.2, assegura a toda pessoa acusada de um delito as garantias mínimas de: comunicação prévia e pormenorizada da acusação; assistência gratuita por tradutor ou intérprete; concessão do tempo e meios necessários à preparação de sua defesa; assistência de um defensor de sua escolha ou proporcionado pelo Estado, remunerado ou não; não ser obrigado a depor contra si; participar da produção de provas e da inquirição de testemunhas ${ }^{162}$.

A meditação sobre a aplicação do direito de defesa - e, também, do contraditório - à fase da persecução preliminar deve partir da leitura do inciso LV do artigo $5^{\text {. }}$ da Constituição, que em postura garantista os estendeu aos "acusados em geral"163. Por

${ }^{161}$ Quanto ao momento de exercício da defesa, diz Alberto Binder, com acerto, que ela se exerce durante todo o processo e, particularmente, "durante a investigação, já que as possibilidades de afetação de todas as garantias processuais se dão primordialmente nesta etapa" (Introducción..., cit., p. 155 e 162).

162 Também o Pacto Internacional de Direitos Civis e Políticos, adotado pelas Nações Unidas em Nova Iorque em 1966 e ao qual o Brasil aderiu, incorporando-o mediante o Decreto 592/1992, tem imenso relevo na proteção de direitos humanos e faz referências às garantias mínimas da defesa, no art. 14.3.

163 Mas é preciso ressaltar que, antes mesmo da entrada em vigor da Constituição de 1988 , bem antes, vozes autorizadas atentavam à necessidade de defesa no inquérito policial, que não conteria tão-só investigação, mas também, contingencialmente, instrução criminal. Assim, Joaquim Canuto Mendes de Almeida, em 1957, afirmou que "[a] inquisitoriedade não é incompatível com o direito de defesa pelo indiciado durante o inquérito policial. Seu interesse, ali, consiste, ao menos, em demonstrar que não deve ser denunciado" (O direito de defesa no inquérito policial. Revista Forense Comemorativa - 100 anos. Rio de Janeiro: Forense, 2006, t. 7, p. 339, republicação). Igual preocupação é levantada, no início da década de 1960 , por José Barcelos de Souza (A defesa na polícia e em juizo: teoria e prática do processo penal. Belo Horizonte: Bernardo Álvares, 1963, p. 18): "acontece que os elementos do inquérito são aptos e suficientes para a prova dos pressupostos da prisão preventiva, que, quando fôr o caso dela, poderá ser decretada, pelo juiz, em qualquer fase do próprio inquérito; podendo, então, ter o indiciado interêsse em que fique demonstrada a inocorrência daqueles antesupostos e, neste particular, especialmente na obtenção de provas relativas às causas de exclusão do crime". 
esse dispositivo, compatível com leitura extensiva, o indivíduo, quando acusado em processo judicial ou (em procedimento) administrativo, deverá ter meios razoáveis para promover a sua defesa, porquanto não lhe será negado o direito ao conhecimento e tampouco ao debate, em pé de igualdade, das provas contra si aduzidas. Na forma como se expôs anteriormente, a investigação preliminar, como procedimento investigativo que é, não escapa às regras do devido processo legal.

Lembre-se que a instauração do processo judicial penal, em si mesma, corresponde a um pesado ônus ao imputado, o qual é agravado se o processo inicia sem se lhe dar ocasião de contrapor-se aos elementos de conviç̧ão contra ele dirigidos, de trazer elementos que contribuam à elucidação do fato e assim também de interferir na formação da opinio delicti ${ }^{164}$ do titular da ação penal, e mesmo porque, já decidiu o STF, "os elementos do inquérito podem influir na formação do livre convencimento do juiz para a decisão da causa quando complementam outros indícios e provas que passam pelo crivo do contraditório em juízo"165.

Adotando-se um conceito amplo de imputação, qual o destrinçado por Antonio Scarance Fernandes, no início da investigação, não existe imputação (juízo de atribuição a alguém da prática de infração penal) nem imputado, mas a partir de certo momento a pessoa passa a ser tratada como provável autora do crime apurado (pelo juiz, membro do Ministério Público ou autoridade policial), como suspeita e, portanto, como imputado em sentido amplo. Nesse momento, devem-se assegurar ao imputado direitos (de ciência da imputação, de ser ouvido antes da acusação, de ser assistido por advogado, de requerer diligências à autoridade policial, de manter-se em silêncio) advindos do interesse de defender sua liberdade, fazendo jus a uma reação defensiva à imputação ${ }^{166}$.

164 O Ministério Público, titular exclusivo da ação penal pública por injunção constitucional, forma sua opinião sobre a existência de um delito com base na diversidade de elementos, dados de convicção coletados no inquérito ou reunidos em peças outras de informação. Trata-se de um juízo de probabilidade, e não de mera suspeita, visto que a ação penal já é um constrangimento a que se submete a pessoa imputada.

165 RE-AgR 425.734/MG, rel. Min. Ellen Gracie, 2. ${ }^{a}$ Turma, v.u., DJ de 28.10.2005. Reforça esse entendimento a nova redação conferida ao art. 155 do CPP, pela Lei 11.690/2008, segundo a qual o juiz não pode fundamentar sua decisão "exclusivamente nos elementos informativos colhidos na investigação", a significar, a contrario sensu, que tais dados poderão ser considerados pelo julgador para formar o seu convencimento, desde que corroborantes ou complementares das provas produzidas em contraditório judicial.

166 A reação defensiva à imputação. São Paulo: Revista dos Tribunais, 2002, p. 102-105. Paralelamente, Adilson José Vieira Pinto (O inquérito policial à luz dos direitos e garantias individuais da Constituição Federal de 1988. Revista Brasileira de Ciências Criminais, São Paulo, v. 7, n. 27, jul./set. 1999, p. $255-$ 257) aduz que, nesse primeiro momento, em que há uma corrida à cata dos elementos informativos, não existindo, até então, pessoa a justificar ou discordar dos fatos que a ninguém são formalmente 
Com a imputação, mormente a partir da comunicação de sua existência e de seu conteúdo ao investigado, nasce para ele "a possibilidade de resistir à pretensão investigatória e coercitiva estatal", de atuar efetivamente no procedimento, buscando provas que o desonerem ou que possam eventualmente atenuar a pena imposta em futuro processo $^{167}$. Qualquer forma de imputação determinada (como a advinda de uma notíciacrime, de uma representação ou do indiciamento) subsume-se a uma acusação em sentido amplo e, pois, o investigado não pode ser excluído dos "acusados em geral" a quem a Constituição buscou garantir o contraditório e a ampla defesa, com os meios e recursos a ela inerentes. É como se manifesta Paula Bajer Fernandes Martins da Costa ${ }^{168}$ :

...se na fase inquisitiva não há ação em plenitude, nela há atos fiscalizados pelo Poder Judiciário, bem como atos que integram a formação da culpa, ainda que preliminar. A pessoa sobre a qual recaem indícios de autoria de crime tem interesse em se defender, para não ser denunciada. Nesse sentido, pode-se assegurar que também a ela se referiu a Constituição, ao garantir a ampla defesa.

Logo, sua intervenção defensiva na fase preliminar não se faz por mera deferência ou liberalidade da autoridade condutora do procedimento. Antes, deriva de mandamentos constitucionais (art. 5. ${ }^{\circ}, \mathrm{LV}$, LXII e LXIII, da $\mathrm{CF}^{169}$ ) e legal (art. 14 do

endereçados, seria estéril o emprego dos direitos da ampla defesa e do contraditório, havendo de predominar a inquisitio; mas, no segundo momento, coletados os meios de prova da ocorrência da infração e estabelecida a correlata autoria, é mister enxergar o investigado como sujeito de direitos.

${ }^{167}$ Cf. LOPES JR., Aury. Sistemas..., cit., p. 331. Como ensina Fábio Medina Osório (Direito..., cit., p. 525), a ciência do acusado, nos processos administrativos, acerca das imputações que lhe são formuladas é condição básica de validade do feito. "Qualquer acusado, em processo ou procedimento administrativo, tem direito de saber o conteúdo das imputações, dos fatos ilícitos que lhe são atribuídos, e isso implica a ciência não apenas a respeito da peça acusatória, mas também o conhecimento dos atos procedimentais, com possibilidade de manifestação".

168 Inquérito policial e a investigação dos fatos que antecede a ação penal no ordenamento jurídico instaurado pela Constituição de 1988. Revista Brasileira de Ciências Criminais, São Paulo, v. 5, n. 19, jul./set. 1997, p. 175. No mesmo caminhar é a reflexão de Flávia Rahal Bresser Pereira (Publicidade no processo penal..., cit., p. 279): "Ver como fim último do inquérito policial a proteção do Estado é ignorar o avanço de nossa atual Constituição. Na investigação penal prévia divisam-se não só os interesses do Estado, mas também do acusado, da vítima e da sociedade. É, também, o interesse do indivíduo que está em jogo, como indivíduo e membro da coletividade, possuidor de direitos individuais. O inquérito policial não tem por finalidade provar o crime e indicar seu autor. Ele deve apurar o fato e sua autoria, que pode ser inexistente ou impossível de ser atribuída. (...) Assim, o suspeito, o indiciado não pode ser visto como aquele que atrapalha as investigações, mas deve ser visto como indivíduo, titular de direitos subjetivos. Não se pode negar que no inquérito policial pesa uma imputação contra o indiciado, tanto assim que o acusado preso em flagrante será interrogado 'sobre a imputação que lhe é feita' (art. 304 do CPP). Há direito de defesa no inquérito policial”.

169 “Art. 5. ${ }^{\circ}$ (...) LXII - a prisão de qualquer pessoa e o local onde se encontre serão comunicados imediatamente ao juiz competente e à família do preso ou à pessoa por ele indicada; LXIII - o preso será informado de seus direitos, entre os quais o de permanecer calado, sendo-lhe assegurada a assistência da família e de advogado." 
$\mathrm{CPP}^{170}$ ), estendendo-se não apenas ao indivíduo que é formalmente indiciado, mas a todo aquele sobre o qual recaia um juízo concreto de probabilidade de autoria ${ }^{171}$, derivado, sobretudo, da imposição de medidas cautelares restritivas, pessoais ou patrimoniais.

Para o exercício efetivo dessa participação defensiva, impõe-se que o investigado tenha condições de conhecer, sem demora, a imputação que sobre si pesa ${ }^{172}$, que possa ser informado, quando requerer, do andamento da investigação e do encerramento de suas fases, que possa acompanhar as diligências e postular outras junto ao titular da investigação ${ }^{173}$. Aperfeiçoa-se assim sua autodefesa, cujo momento de maior relevo é o do interrogatório, no qual the deve ser assegurado atuar de forma positiva (expressando seus motivos, justificativas, negativas de autoria ou de materialidade do fato, etc.) ou negativa (exercendo seu direito de silêncio).

Importa, ainda, contar o investigado com a assistência de defensor, sem o qual impossível falar em defesa efetiva. Como bem explica Marta Saad, “o tempo muitas vezes trabalha em desfavor do acusado e, em sendo assim, a pronta assistência de advogado garante a juntada de documentos importantes e esclarecedores, a localização de testemunhas ou a formulação de quesitos, para a prova pericial" ${ }^{\text {174 }}$. Logo, na investigação preliminar, ainda que sob o mero risco de acusação, a defesa técnica ganha vez, no direito de o defensor acompanhar o interrogatório, fazer reperguntas, requerer diligências, impugnar atos arbitrários, etc., não podendo ser alijado da coleta dos dados importantes à elucidação do fato tido por criminoso ${ }^{175}$.

170 A previsão do art. 14 ("O ofendido, ou seu representante legal, e o indiciado poderão requerer qualquer diligência, que será realizada, ou não, a juízo da autoridade.”) cria um terreno amplo de atuação para a defesa endógena do imputado, aquela feita nos próprios autos da investigação: pode requerer diligências, indicar testemunhas, formular quesitos, pedir esclarecimentos e complementos a perícias realizadas, juntar documentos e impugnar a autenticidade dos já acostados, atividade que há de ser refreada apenas se meramente protelatória, inapta a contribuir à finalidade da investigação.

171 Sobre o assunto, cf. D'ANGELO, Andréa Cristina; DEZEM, Guilherme Madeira. Acesso aos autos do inquérito policial pelo não formalmente indiciado. Boletim IBCCrim, São Paulo, v. 14, n. 162, maio 2006, p. 13-14.

172 Registre-se que a Portaria 18/2008, do Delegado Geral de Polícia Civil do Estado de São Paulo, ao tratar das garantias constitucionais no âmbito do inquérito policial, demonstra nítida preocupação com a defesa, que tem por pressuposto a ciência da imputação, porquanto determina, no art. $7 .^{\circ}$, que o preso em flagrante deverá ser comunicado pela autoridade policial, "de maneira minudente e destacada", sobre os direitos constitucionalmente assegurados, devendo-lhe ser entregue nota de culpa com a descrição da conduta incriminada e do tipo penal infringido.

173 Nesse sentido, cf. SILVEIRA, Paulo Fernando. Devido processo legal, cit., p. 355-356.

174 O direito de defesa no inquérito policial. São Paulo: Revista dos Tribunais, 2004, p. 203.

175 "A presença do defensor no momento das declarações do suspeito frente à autoridade policial é imprescindível. $\mathrm{O}$ art. 5..$^{\circ}$, LXIII, da Constituição assegura a assistência de defensor no interrogatório do preso e entendemos que este inciso, combinado com o LV, permite afirmar que essa garantia deve ser estendida a toda pessoa submetida ao interrogatório, independente de estar preso ou em liberdade" 
Eis a importância de localizar a garantia de defesa já na investigação preliminar, seja no inquérito policial ou em qualquer outra forma de persecução prévia. Mas preocupações podem surgir, como a de Aury Lopes Jr., que alerta para os riscos de uma defesa exercida sem qualquer limite, podendo inviabilizar o alcance da própria finalidade da investigação ${ }^{176}$. Para equacionamento desse dilema e adequada delimitação do âmbito de participação da defesa, necessário é indagar sobre a medida da aplicação do contraditório à etapa preliminar.

\subsubsection{O contraditório}

O contraditório, segundo Joaquim Canuto Mendes de Almeida, em precisa definição que se tornou célebre e recorrente, significa a "ciência bilateral dos atos e termos processuais e possibilidade de contrariá-los"177. É mediante sua concepção como direito de audiência, "oportunidade conferida a todo o participante processual de influir, através da sua audição pelo tribunal, no decurso do processo", que o princípio do contraditório adquire autonomia substancial perante o direito de defesa ${ }^{178}$.

No âmbito do processo judicial, o princípio do contraditório garante à acusação e à defesa igual plenitude de ação, com a parte julgadora em perfeita eqüidistância. A efetiva participação dos interessados no processo tem a função de racionalizar a argumentação, dar publicidade às medidas judiciais interventivas e, enfim, controlar os atos do juiz ${ }^{179}$. Sua finalidade condiz com que sejam reduzidas ao mínimo as possibilidades do erro judiciário ${ }^{180}$. Ele existe, portanto, em prol de ambas as partes (que

(LOPES JR., Aury. Sistemas..., cit., p. 346). No direito argentino, Alejandro Carrió (Garantías..., cit., p. 413-415) noticia que a Corte Suprema da Nação, majoritariamente, não reconhecia o direito à assistência de um defensor (defesa técnica) quando do interrogatório na Polícia, se essa defesa pudesse ser exercida posteriormente. Em contrapartida, o art. 200 do Código de Processo Penal argentino veio consagrar o direito de o defensor presenciar todos os atos (perícias, reconhecimentos, reconstruções) que, por sua natureza e característica, devam considerar-se definitivos e irreproduzíveis. $\mathrm{O}$ autor cita, entre outros, os casos Payro, Menna e Francomano.

176 Sistemas..., cit., p. 334. Na mesma linha, já advertia Joaquim Canuto Mendes de Almeida (O direito de defesa..., cit., p. 341): "Outorgar ao indiciado o direito de participar do descobrimento da verdade criminal, embora para fins informativos, não encerra nenhum absurdo. O que é preciso é evitar, tanto na instrução criminal, definitiva ou preliminar, quanto no inquérito policial, que a cooperação da defesa perturbe o bom andamento da causa ou o esclarecimento dos fatos. E isso o poder inquisitivo do juiz, bem como o do delegado de polícia, têm meios de evitar".

177 Princípios..., cit, p. 82.

178 Cf. DIAS, Jorge de Figueiredo. Direito processual penal, cit, p. 153.

${ }^{179}$ Cf. COSTA, Paula Bajer Fernandes Martins da. Igualdade..., cit., p. 130.

${ }^{180}$ Cf. CARNEIRO LEÃO, Nilzardo. Princípios..., cit., p. 52-53. 
poderão contradizer, mediante provas, as alegações do sujeito adverso) e também em favor da apuração mais completa dos fatos, favorecendo assim a justa aplicação do direito.

Dado o conceito amplo de acusado ${ }^{181}$, surgem defensores da aplicação irrestrita do contraditório também à etapa administrativa da persecução.

Joaquim Canuto Mendes de Almeida vale-se de um argumento histórico. Para ele, a instrução criminal engloba uma etapa preliminar e uma definitiva. Quando o constituinte de 1937 estatuiu que "a instrução criminal será contraditória, asseguradas, antes e depois da formação da culpa, as necessárias garantias de defesa”, decerto houve de referir-se a ambas as fases. A primeira, destinada a coligir elementos de convicção aptos a embasar a acusação criminal, constituía o chamado sumário de culpa, etapa hoje presente apenas nos processos de competência do Tribunal do Júri, porquanto suprimida, pelo legislador constituinte, nos processos da alçada do juiz singular, ordinários ou sumários. Em contrapartida a tal supressão, deveria ter sido criada uma instrução criminal preliminar, mas, se não o foi, cumpriria admitir deslocadas ao inquérito policial as funções do sumário de culpa, ou o caráter de instrução preliminar (ainda que não "judiciária”), sob pena de incorrer-se em inconstitucionalidade já ao tempo da edição do Código de Processo Penal $^{182}$

Embora respeitável, cremos que tal postura não encontra guarida no sistema processual moderno. A etapa preliminar tem por finalidade investigar a respeito da existência do fato criminoso e de sua autoria. Não visa a provar o crime e seu autor, não se podendo falar até então em partes, em acusador ou em acusado. Não encerra um juízo de formação de culpa ou de pronúncia ${ }^{183}$. Constitui instrução preliminar ou provisória

181 Afinal, todo cidadão investigado é ‘acusado' na acepção ampla da palavra, que abrange a acusação formal ou informal (TUCCI, Rogério Lauria. Direitos e garantias..., cit., p. 174).

182 Princípios..., cit., p. 206-208. O autor distingue ainda o 'contraditório' da 'contrariedade'. Afirma que, no procedimento penal, não há contrariedade a não ser formalmente, correspondendo à ação das partes, ação esta que pressupõe o contraditório, ou seja, a ciência dos atos contrariáveis do procedimento. E, ainda que a contrariedade não se efetive mediante atos das partes, diz o autor, ela sempre terá uma expressão virtual, que é o seu estímulo através de avisos judiciais. O contraditório, por sua vez, será sempre efetivo, pondose as partes em condições de se contrariarem (Idem, p. 78-82). Em outro passo, vale destacar a ferrenha oposição de José Frederico Marques (A investigação policial. O inquérito policial e a instrução criminal contraditória: interpretação do art. 141, § 25, da Constituição Federal. Revista dos Tribunais, São Paulo, v. 47, n. 271, maio 1958, p. 20), em réplica ao artigo publicado em 1957 por Joaquim Canuto Mendes de Almeida, ao tachar a idéia do contraditório no inquérito policial de "inaceitável heresia, que, além de enfraquecer sensivelmente a tutela penal do Estado, não encontra o menor apoio na ciência processual e, muito menos, nos preceitos de nosso Direito Positivo". Para o autor, "abrir uma brecha no inquisitorialismo da investigação policial seria provocar um enfraquecimento irreparável da acusação, com a conseqüente impunidade em maior escala de criminosos e malfeitores, sem aplicação da terapêutica adequada" (Idem, p. 30).

183 Cf. GRECO FILHO, Vicente. Manual de processo penal. 6. ed. São Paulo: Saraiva, 1999, p. 91-92. 
(distinta, porém, do sumário de culpa promovido em juízo nos crimes de competência do Tribunal do Júri), sem ainda um acusado formal, mas com mero investigado ou indiciado.

Assim, admitir-se na investigação, de que é espécie o inquérito policial, o contraditório pleno e irrestrito implicaria o inchaço dessa fase preliminar, com a necessidade de dar-se aos imputados prévia ciência de todos os atos a serem praticados fossem atos de mera investigação ou atos de instrução criminal, distinção a ser explorada no capítulo seguinte -, comprometendo o alcance do seu objetivo: a simples e célere apuração de elementos básicos acerca do fato tido por delituoso, suficientes a fundamentar (ou não) o exercício da ação penal. Ademais, todos os atos praticados no inquérito haveriam de ser novamente efetuados sob o crivo judicial (salvo aqueles não-repetíveis), rendendo ensejo a uma estranha duplicidade de instruções.

A inviabilidade, por outro lado, de uma investigação preliminar toda ela contraditória $^{184}$ (o contraditório, em sentido técnico, somente poderia estabelecer-se se houvesse partes em sentido formal) não significa que o imputado não possa participar ativamente, por si e por seu defensor, de alguns momentos da fase investigativa, aqueles destinados a formar o convencimento do julgador, muitos deles irreproduzíveis na fase judicial - juntada de documentos, perícias, constrições reais ou pessoais.

A investigação, como se explanará adiante, não visa precipuamente colher provas, nem é de sua essência fazê-lo, mas apenas reunir elementos informativos que servem para embasar as decisões interlocutórias tomadas em seu decurso, para fundar o convencimento sobre a existência ou não de um delito e de sua autoria e, outrossim, fundamentar o juízo de admissibilidade da peça inicial. Mercê da natureza sumária, transitória, nela não impera o princípio do contraditório em sua inteireza. A inserção do contraditório na fase extrajudicial da persecução penal será apenas episódica, dada a reconhecida possibilidade de serem produzidas provas já na fase preliminar, a clamar, portanto, pela participação de ambos os interessados, de um lado o Ministério Público ou o ofendido e, de outro, o investigado.

A reconhecida existência de determinados atos na investigação preliminar que têm caráter de definitividade (não sendo repetíveis, ao depois, na fase processual) abre espaço a que se pratique o contraditório já na fase preliminar, não um contraditório pleno,

184 “Ao contrário do que pensam alguns, não se deve tolerar um inquérito contraditório, sob pena de fracassarem as investigações” (MARQUES, José Frederico. Tratado..., cit., v. 1, p. 191). 
mas um contraditório mínimo ${ }^{185}$, que de forma concreta possa garantir ao sujeito passivo a comunicação imediata da existência da imputação, constando nessa missiva a síntese do seu conteúdo e a condição em que é chamado a comparecer perante a autoridade, além da participação ativa na produção antecipada de provas e na feitura de provas técnicas nãorepetíveis.

O contraditório é, pois, inarredável em alguns momentos da investigação, justamente naqueles atos que assumirão verdadeiro status de prova no processo judicial, podendo fundamentar uma condenação. Cumpre salientar que, pela primeira vez, o legislador infraconstitucional, na redação do art. 155 , caput, do $\mathrm{CPP}^{186}$, alterada pela Lei 11.690/2008, diferençou prova e elemento informativo, sendo de destacar que apenas a primeira carrega as notas da participação das partes e da produção em presença do juiz natural. Andou bem o legislador ao ressalvar, ainda, as chamadas provas cautelares, nãorepetíveis ou antecipadas ${ }^{187}$, que, embora produzidas no inquérito, assumem o caráter de prova, por seu caráter de definitividade e pela submissão ao contraditório ${ }^{188}$. Em qualquer desses casos, somente admissíveis em caráter excepcional, a utilização dos elementos de prova resultantes do inquérito depende da observância do contraditório, ainda que em momento posterior ao ato de produção, permitindo-se às partes discutir a sua admissibilidade, regularidade e idoneidade.

185 A expressão é utilizada, entre outros, por Aury Lopes Jr. (Sistemas..., cit., p. 273) e Gustavo Adrián Herbel (La investigación penal preparatoria del fiscal como forma de otorgar eficacia y garantías al sistema punitivo: nuevo código procesal penal bonaerense. Cuadernos de Doctrina y Jurisprudencia Penal, Buenos Aires, v. 4, n. 8B, dic. 1998, p. 699), aduzindo este último que se deve reduzir o caráter contraditório na investigação preliminar, porque se trata de fase preparatória e informal, não podendo utilizar-se para a produção de prova, com exceção das diligências que, pelo caráter definitivo e irreproduzível, imponham a necessidade do adiantamento da prova, instando o contraditório das partes.

186 “Art. 155. O juiz formará sua convicção pela livre apreciação da prova produzida em contraditório judicial, não podendo fundamentar sua decisão exclusivamente nos elementos informativos colhidos na investigação, ressalvadas as provas cautelares, não-repetíveis e antecipadas."

187 Observa Antonio Magalhães Gomes Filho (Provas..., cit., p. 253-255) que a distinção entre provas cautelares e antecipadas não tem importância prática, pois o provimento cautelar é apenas o instrumento para a antecipação da produção da prova. Já menção às provas não-repetiveis foi inspirada no Código de Processo Penal italiano de 1988, que autoriza a leitura, na fase dos debates, de declarações prestadas na fase de investigação ou na audiência preliminar, quando, por fatos ou circunstâncias imprevisíveis, tornou-se impossível a sua repetição. Segundo o autor, a não-repetibilidade da prova em juízo pode ser previsível ou imprevisível, mas no primeiro caso é necessário que a antecipação da prova siga o devido procedimento legal, na presença do juiz e das partes, nomeando-se ao menos um defensor dativo, com o contraditório no momento da produção da prova.

188 A vinculação do conceito de prova à observância do contraditório foi, no dizer de Antonio Magalhães Gomes Filho (Provas..., cit., p. 249 e ss.), a pedra angular da nova disciplina legal da prova penal. 
A produção antecipada da prova, antes disciplinada esparsamente nos arts. $92^{189}, 225^{190}$ e $366^{191}$ do CPP, agora vem ditada no preceito geral do art. 156, I, do CPP (no capítulo das Disposições Gerais do Título "Da Prova”, com a redação conferida pela Lei $11.690 / 2008)^{192}$, abarcando a possibilidade de antecipação qualquer espécie de prova cuja produção se faça urgente já na investigação preliminar, mormente a testemunhal. No instante de sua produção, perante o juiz natural, a prova antecipada há de contar com a presença do titular da ação penal - o Ministério Público ou o ofendido -, bem como da defesa técnica, seja ela representada por um advogado indicado pelo investigado, ou oferecido pelo Estado, mediante a Defensoria Pública ${ }^{193}$. A prova antecipada é produzida em um incidente na etapa preliminar e tem cabimento sempre que se mostrar relevante para o deslinde do fato e houver indícios de provável perecimento, nela se exigindo a observância, já na fase investigativa, das garantias do contraditório, da defesa e da jurisdicionalidade $^{194}$.

189 “Art. 92. Se a decisão sobre a existência da infração depender da solução de controvérsia, que o juiz repute séria e fundada, sobre o estado civil das pessoas, o curso da ação penal ficará suspenso até que o no juízo cível seja a controvérsia dirimida por sentença passada em julgado, sem prejuízo, entretanto, da inquirição das testemunhas e de outras provas de natureza urgente." (grifos acrescidos).

190 "Art. 225. Se qualquer testemunha houver de ausentar-se, ou, por enfermidade ou por velhice, inspirar receio de que ao tempo da instrução criminal já não exista, o juiz poderá, de ofício ou a requerimento de qualquer das partes, tomar-lhe antecipadamente o depoimento." (grifos acrescidos).

191 "Art. 366. Se o acusado, citado por edital, não comparecer, nem constituir advogado, ficarão suspensos o processo e o curso do prazo prescricional, podendo o juiz determinar a produção antecipada das provas consideradas urgentes e, se for o caso, decretar prisão preventiva, nos termos do disposto no art. 312." (grifos acrescidos).

192 “Art. 156. A prova da alegação incumbirá a quem a fizer, sendo, porém, facultado ao juiz de ofício: I ordenar, mesmo antes de iniciada a ação penal, a produção antecipada de provas consideradas urgentes e relevantes, observando a necessidade, adequação e proporcionalidade da medida. (...)". Observe-se que a excepcional produção antecipada da prova testemunhal, mesmo de ofício, era já admitida pelo art. 225 do CPP. Por sua vez, os arts. 92 e 366 do CPP situavam a prova antecipada em momento processual, nas hipóteses específicas de suspensão do processo para apuração de dúvida sobre o estado civil das pessoas e pelo não-comparecimento do acusado citado por edital. A modificação introduzida no art. 156, I, do Código veio ampliar a possibilidade, ao passo que não vincula a prova antecipada a nenhuma situação processual específica. Portanto, agora se permite ao do juiz antecipar a produção da prova em toda e qualquer investigação ou processo penal, desde que preenchidas as exigências legais. Para Antonio Magalhães Gomes Filho (Provas..., cit., p. 255), a inovação contida no art. 156, I, do CPP amplia os poderes instrutórios do juiz para dizer que podem ser utilizados antes mesmo de iniciada a ação penal.

${ }^{193}$ Entende-se mesmo que a Defensoria Pública deve estar presente ao ato, ainda que não se tenha identificado o possível autor do fato, ou seja, ainda que não haja um investigado, pois assim se procura assegurar o contraditório nessa prova que adquirirá traços de definitividade, possivelmente integrando os autos da futura ação penal.

${ }^{194}$ Deve o incidente ser processado em autos apartados aos da investigação criminal, comportando os seguintes requisitos: (i) formulação de requerimento motivado pelo Ministério Público (na ação pública), pelo ofendido (na ação privada) ou pelo investigado; (ii) dirigido ao juízo competente, prevalecendo, na concorrência de mais de um juízo, aquele que já houver praticado algum ato no procedimento investigativo (art. 83, CPP); (iii) se deferido o pedido, o juiz ouvirá a testemunha, com a participação do Ministério Público, do ofendido, do investigado, devidamente acompanhados de advogado, de livre nomeação do interessado ou designado pelo juiz. Os fatos questionados à testemunha, sob o crivo do 
Há, porém, situações em que provas, no inquérito, são unilateralmente produzidas, por exigência de sua própria preservação (caráter cautelar). Ante o perigo de desaparecimento ou de comprometimento da fonte de prova pelo decurso do tempo, autoriza-se, excepcionalmente, uma restrição inicial ao contraditório pleno. Mas nem por isso tais atos deixam de ser contrariáveis, mormente quando se trata de provas nãorepetíveis em juízo. Exemplos são a interceptação telefônica, a quebra do sigilo bancário e a busca e apreensão, que não prescindem de intervenção judicial para sua decretação, porém não comportam a necessária ciência prévia da defesa. Nessas hipóteses, tem lugar o "contraditório diferido" ou postergado para a fase judicial, distinto do contraditório prévio, ou propriamente dito, este que implicaria a ciência prévia do imputado sobre o ato praticado, bem como a possibilidade de participar de sua feitura ${ }^{195}$.

Também constituem provas urgentes e não-repetíveis, impassíveis de renovação na fase judicial, muitas das provas técnicas (destacando-se o exame de corpo de delito, que se torna não-repetível em face do desaparecimento dos vestígios), devendo ser submetidas a contraditório posterior, na fase judicial, para obterem o valor de prova ${ }^{196}$. O contraditório diferido será exercido das mais diversas formas: mediante um pedido de complementação de laudo pericial, de acareação para demonstrar que um laudo ou depoimento é falso, etc. A defesa poderá contestar amplamente as conclusões da perícia realizada na investigação, além de juntar laudos periciais produzidos por profissionais de sua confiança, requerer esclarecimentos do perito e formular quesitos pertinentes ao fato e sua autoria. As partes poderão valer-se, ainda, da indicação de assistente técnico, durante o

contraditório, numa fase em que ainda não delimitada a acusação, dirão respeito à provável imputação do agente descrita no auto de prisão em flagrante ou em outros elementos até então coletados. Cf. AMICO, Carla Campos. A nova redação dos artigos 155 e 156 do Código de processo penal e a produção antecipada da prova testemunhal na fase do inquérito policial. Boletim IBCCrim, São Paulo, v. 16, n. 192, nov. 2008, p. 8.

195 Esclarece Fauzi Hassan Choukr (Garantias..., cit., 2006, p. 133) que "[a] existência de um contraditório tardio em razão das peculiares circunstâncias seria uma distinção substancialmente importante, na medida em que identificar um fenômeno não significaria a supressão da garantia, apenas traduzindo a oportunidade 'correta' de seu exercício".

196 Segundo revela Antonio Scarance Fernandes (Processo penal constitucional, cit., p. 83), o maior problema reside na prova pericial produzida na fase preliminar. Ela é definitiva quando há urgência, postergando-se o contraditório para momento ulterior, em que as partes poderão contestar o laudo e pedir esclarecimentos. Assim ocorre, por exemplo, quando há perigo de desaparecer o corpo de delito, como a lesão produzida no corpo da vítima, que normalmente só permanece por determinado tempo. Defende o autor o contraditório prévio quanto à prova pericial produzida na investigação preliminar e só excepcionalmente o seu diferimento: "Não se justifica, contudo, prova pericial sem contraditório prévio na fase policial se inexiste perigo de os vestígios desaparecerem. Caso venha a ser realizada, as partes têm o direito de requererem, em juízo, nova perícia”. 
curso do processo judicial, novidade inserida no art. $159, \S 5^{\circ}$, do Código de Processo Penal, pela Lei $11.690 / 2008^{197}$.

A partir da distinção entre defesa e contraditório, à qual não passou ao largo o Constituinte, ao apartar, no art. 5. ${ }^{\circ}, \mathrm{LV}$, da CF, litigantes de acusados e contraditório de ampla defesa, Marta Saad explica: "Se é certo que para o exercício da defesa exige-se prévia ciência dos fatos e imputação, tal como ocorre para a efetivação do contraditório, nem por isso ambos se confundem. O contraditório exige partes, em sentidos opostos. Mas, se essas não existem e não se instala o contraditório, nem por isso se pode deixar de dar oportunidade ao acusado informalmente ou acusado sob o ângulo substancial de exercício do direito de defesa",

Porque, iniludivelmente, o investigado é titular de direitos que merecem ser observados, quando mais se está em jogo a sua liberdade individual. A partir do momento em que se lhe dirige a probabilidade de ser tido como agente do fato apurado, surge o interesse em não ser denunciado judicialmente. Os dados do inquérito, insta relembrar, são aptos a basear um pedido de prisão preventiva, de forma que pode o imputado ter legítimo interesse em demonstrar a sua insubsistência, ou em provar em seu favor uma justificativa penal, ou em trazer elementos que contra-indiquem a denúncia, vindo daí a necessidade de garantir-se o exercício do direito de defesa já na investigação preliminar, permitindo-se então uma defesa contínua e unitária.

Enfim, visto que são garantias distintas, muito embora complementares, tem-se possível exercitar o direito de defesa na investigação preliminar, a despeito da ausência de contraditório $^{199}$, reservado apenas aos momentos em que atos de prova são nela praticados. Por outro lado, a impossibilidade de intervenção plena do suspeito ou investigado, pela própria natureza da atividade que se desenvolve, procura-se neutralizar restringindo-se ao máximo a utilização dos elementos colhidos na etapa investigativa, por

197 A redação do $\S 4 .^{\circ}$ do art. 159, incluído pela Lei 11.690/2008 (“O assistente técnico atuará a partir de sua admissão pelo juiz e após a conclusão dos exames e elaboração do laudo pelos peritos oficiais"), traz duas exigências que não encontram razão de ser, pois mais condizente com o princípio do contraditório, que a reforma processual buscou valorizar, seria permitir que o auxiliar técnico da parte ou do investigado (quando ainda não existirem partes em sentido formal) atuasse independente de prévia admissão judicial (regra sem precedente no sistema de prova brasileiro) e pudesse presenciar a realização da prova, garantindo-se assim o contraditório no momento da sua formação, e não a posteriori - salvo, decerto, nas situações em que a urgência da prova não o permitisse.

198 O direito de defesa..., cit., p. 218-219.

199 No mesmo sentido: PEREIRA, Flávia Rahal Bresser. A publicidade no processo penal brasileiro: confronto com o direito à intimidade. Dissertação (Mestrado), Universidade de São Paulo, 2000, p. 191; 
ocasião do provimento judicial final ${ }^{200}$. E por esse caminho atinge-se o equilíbrio esperado da investigação criminal: um ponto em que acusação e defesa (e as correspondentes atividades de imputação e reação defensiva à imputação) estejam equiparados em seus poderes de atuação e de convencimento do julgador.

Não é fácil, todavia, encontrar esse ponto de equilíbrio, eis que, “[d]e um lado, é necessário armar o Estado de poderes suficientes para enfrentar a criminalidade, crescente, violenta, organizada; por outro, deve o cidadão ter garantida a sua tranqüilidade, a sua intimidade, a sua imagem, e, principalmente, ser dotado de remédios eficazes para se contrapor aos excessos e abusos dos órgãos oficiais" ${ }^{\text {201. }}$.

Surge indispensável, como forma de ajuste e de equalização dessas forças, a instituição de uma etapa antecedente ao juízo de admissibilidade da acusação penal, um mecanismo de filtragem entre o oferecimento da inicial acusatória e o seu recebimento. Trata-se da defesa preliminar, inicialmente prevista, entre nós, apenas em casos tópicos como nos processos de crimes de responsabilidade dos funcionários públicos $(\mathrm{CPP}$, art. $514^{202}$ ), dos prefeitos municipais e vereadores (Decreto-lei 201/1967, art. 2. ${ }^{\circ}$, I), do Presidente da República, Ministros de Estado e outras autoridades (Lei 1.079/1950, art. 22), nos crimes da Lei de Imprensa (Lei 5.250/1967, art. 43), no procedimento dos juizados especiais criminais (Lei 9.099/1995, art. 81) e nos processos originários de tribunais (Lei

SAAD, Marta. $O$ direito de defesa..., cit., p. 223; CHOUKR, Fauzi Hassan. Garantias..., cit., 2006, p. 125 .

200 Assim, por exemplo, no sistema italiano, em que o Código de Processo Penal de 1988 procurou fazer com que todo o material recolhido na fase pré-processual fosse utilizado apenas internamente, não podendo fundamentar provimentos na sucessiva fase do juízo, salvo aqueles atos não-repetíveis, conforme previsto no art. 431 (cf. AMODIO, Ennio et al. Il nuovo processo penale: dalle indagini preliminari al dibattimento. Milano: Giuffrè, 1989, p. 6). Com isso, esclarecem Carlos Athayde Buono e Antônio Bentivoglio, evitam-se os riscos, presentes no modelo anterior (do juizado de instrução), "de considerar-se processo a instrução não-dialética e de confundir-se os papéis do acusador e do juiz, com prejuízos para a fase posterior", do debate judicial (A reforma processual penal italiana: reflexos no Brasil. São Paulo: Revista dos Tribunais, 1991, p. 61). No direito pátrio, preocupação similar levou à aprovação da nova regra do art. 155 do Código de Processo Penal. O tema será reavivado no item 2.6 deste trabalho.

201 FERNANDES, Antonio Scarance. Processo penal constitucional, cit., p. 84.

${ }^{202}$ Vale ressaltar, nesse ponto, o teor da súmula 330 do STJ: "É desnecessária a resposta preliminar de que trata o artigo 514 do Código de Processo Penal, na ação penal instruída por inquérito policial”. Referido verbete, consolidando antiga orientação daquele pretório, suprime a fase em que o denunciado, tendo vista de todo o inquérito, poderia oferecer elementos para, desde logo, obviar a persecução judicial através da demonstração da ausência de justa causa para tanto. Parece pressupor que já teve o investigado tal possibilidade de reação defensiva, no decorrer do trabalho policial, o que, todavia, nem sempre ocorre. Por isso cremos que, a despeito de vir a denúncia instruída com inquérito policial, deve ser garantida a oportunidade de defesa preliminar, quando tem o denunciado um prazo razoável para, mediante profissional habilitado, perscrutar o conjunto do material recolhido e a imputação formal a si dirigida, exercendo uma defesa mais efetiva, apta quiçá a evitar a ação penal. 
8.038/1990, art. $\left.4 .^{\circ}\right)$-, mas recentemente estendida, na reforma do Código de Processo Penal, aos procedimentos ordinário e sumário, embora com algumas peculiaridades ${ }^{203}$.

Como defende Maria Thereza Rocha de Assis Moura, o exame prévio da legitimidade da acusação, arrimado não só nas questões de direito, mas também nos elementos de informação colhidos na etapa investigativa, "seria de grande valia, tanto para a preservação da liberdade jurídica do indivíduo como para a segurança da sociedade”, na medida em que contribuiria para "impedir a formulação de imputações precipitadas e temerárias e diminuiria, via de conseqüência, a impetração de habeas corpus, visando ao trancamento da ação penal por falta de justa causa"204.

Por fim, destaque-se que o Supremo Tribunal Federal, embora não concebendo as garantias do contraditório e da ampla defesa como extensíveis ao inquérito policial, reconhece alguns direitos indisponíveis ao investigado, como o de prévio conhecimento dos autos pelo seu advogado e a oportunidade de contrapor-se a exames técnicos ${ }^{205}$.

\subsubsection{A publicidade e a motivação das decisões}

Pela primeira vez escrita numa carta constitucional brasileira em 1988 está a garantia de que "todos os julgamentos dos órgãos do Poder Judiciário serão públicos, e fundamentadas todas as decisões, sob pena de nulidade...” (art. 93, IX, CF). Por outro lado, também as decisões administrativas tomadas pelo Poder Judiciário "serão motivadas e em sessão pública, sendo as disciplinares tomadas pelo voto da maioria absoluta de seus

${ }^{203}$ Referimo-nos à nova redação do art. 396 do CPP, atribuída pela Lei 11.719/2008, segundo a qual o juiz, ao receber a denúncia, ordenará a citação do acusado para responder por escrito à acusação, inserindo a possibilidade de defesa ampla do acusado antes mesmo do início da instrução. Não obstante a má técnica redacional do legislador ordinário, fazendo crer que haveria dois episódios para recebimento da acusação e exprimindo que o acusado deveria ser "citado" para oferecer a resposta preliminar, já existem vozes proclamando, em meio a acirrado dissenso, a aplicação da sistemática de notificação prévia para defesa preliminar, somente após a qual se daria o juízo de admissibilidade da ação penal e, se o caso, a citação do acusado. Cremos que seria esta a opção mais ajustada à garantia de defesa do imputado (como prevista, entre outros procedimentos, nas ações penais originárias de tribunais, conforme a Lei 8.038/1990), por possibilitar ao denunciado ou querelado obstar a instauração do processo, defendendo-se amplamente, e permitir que o juízo de prelibação da ação penal se faça com apoio quer nos elementos trazidos pelo autor, quer nas alegações apresentadas pelo imputado. A se proceder contrariamente, o objetivo da resposta do acusado fica parcialmente esvaziado, porquanto impedida de influenciar no juízo de admissibilidade da peça acusatória.

204 Justa causa..., cit., p. 237.

205 Cf. HC 90.232/AM, rel. Min. Sepúlveda Pertence, 1. ${ }^{\text {a }}$ Turma, v.u., DJ 2.3.2007; AI-ED 494.949/SP, rel. Min. Sepúlveda Pertence, 1. a Turma, v.u., DJ de 25.6.2004. 
membros" (art. 93, X, da CF). Na mesma senda, o art. 5. ${ }^{\circ}, \mathrm{LX}$, prevê que "a lei só poderá restringir a publicidade dos atos processuais quando a defesa da intimidade ou o interesse social o exigirem".

A publicidade e a motivação constituem aquilo que se pode chamar de garantias de encerramento do sistema ${ }^{206}$, porque servem para assegurar o cumprimento de todas as demais garantias nele contidas, complementando-se.

Encontra-se a publicidade na base do Estado Democrático de Direito, vez que por ela a sociedade realiza o controle dos atos e decisões dos órgãos estatais, verificando se agiram com imparcialidade, se observaram a lei, se não incorreram em nenhum abuso ou ferimento a qualquer outra garantia constitucional ${ }^{207}$. Inscreveu-a o constituinte entre os princípios reitores da Administração Pública, no art. 37, caput, da CF, donde ser componente elementar da atividade administrativa, propiciando a participação da sociedade na gestão dos negócios públicos. E se os três Poderes estatais são incumbidos de desempenhar funções públicas, nada mais ajustado que a todos eles se aplique a regra da publicidade de suas ações, dando-lhes visibilidade ${ }^{208}$.

No campo processual penal, cada ato que é praticado atrela-se à garantia da publicidade, que permeia, como regra, toda a persecução. A publicidade, frise-se, está na raiz do sistema processual acusatório, é-lhe intrínseca, sendo que o segredo como regra geral acompanha apenas os regimes autoritários.

Pode-se classificar a publicidade dos atos - quer os do processo propriamente dito ou os da investigação preliminar - em parcial (restrita) ou plena (ampla).

206 Segundo Luigi Ferrajoli (Diritto e ragione..., cit., p. 632 e ss.), a motivação, a publicidade, a oralidade e a legalidade ou ritualidade dos procedimentos constituiriam garantias de encerramento do sistema, garantias de garantias ou garantias de segundo grau, porque instrumentais ou secundárias em relação às outras garantias, ou seja, aptas a propiciar o controle de todas as demais.

207 O surgimento do princípio da publicidade, por ocasião da Declaração dos Direitos do Homem e do Cidadão, na França, teve caráter eminentemente político, como reação ao segredo que, em termos históricos, serviu de instrumento para processos injustos, que aniquilavam qualquer possibilidade de defesa dos cidadãos. Nasceu, portanto, para humanizar o processo, protegendo os direitos do indivíduo e propiciando-lhe a participação na Justiça (Cf. PEREIRA, Flávia Rahal Bresser. Publicidade no processo penal..., cit., p. 271).

208 Como mostra Fernanda Dias Menezes de Almeida (O sigilo no sistema democrático. In: YARSHELL, Flávio Luiz; MORAES, Maurício Zanoide de (Org.). Estudos em homenagem à professora Ada Pellegrini Grinover. São Paulo: DPJ, 2005, p. 240), "salvo hipóteses excepcionais, é aberrante dos padrões democráticos o sigilo no exercício das funções públicas, cuja visibilidade há de ser a regra para que se possa controlar o poder. A isto esteve atento o constituinte, proclamando o princípio da publicidade como vetor da atividade dos poderes públicos". No mesmo sentido já lecionava Nilzardo Carneiro Leão, ao conceber o princípio da publicidade como inerente a qualquer Estado que se fundamenta na liberdade e na igualdade de todos perante a lei. Daí, diz o autor, “onde há preponderância do princípio do segredo, existe a hipertrofia do organismo policial, com todo o seu cortejo de arbitrariedades, detenções, interrogatórios e internações" (Princípios..., cit., p. 68-69). 
No primeiro caso, a publicidade ou o conhecimento dos atos é deferido apenas aos sujeitos do processo ou da investigação, e limitada a os demais. No segundo, os atos são também acessíveis às pessoas que não atuam como partes nem como sujeitos processuais. Onde há publicidade plena, decerto existe também publicidade parcial, pois jamais os atos que são amplamente públicos podem ser secretos para os sujeitos do processo, sobretudo o acusado/investigado e o ofendido ${ }^{209}$.

Essa garantia do indivíduo, quando em confronto com outros valores igualmente protegidos pela Constituição, como é o caso da preservação do direito à intimidade do interessado no sigilo, pode sofrer restrições, daí se falar em publicidade restrita. Mas aí se estará diante de exceções à regra da publicidade ampla, que como tal devem vir fundamentadas pela autoridade determinante do sigilo (antítese da publicidade), o qual não poderá atingir os próprios sujeitos protagonistas do processo ou de sua fase preliminar, salvo em se tratado de atos próprios de investigação.

A investigação preliminar, como a persecução penal em seu todo, é coisa pública $^{210}$, é um drama que interessa a toda a sociedade, aos investigados e às vítimas, não apenas ao Estado. E se, por um lado, nem a Carta de 1988 nem os pactos internacionais aos quais aderiu o Brasil mencionam expressamente a regra da publicidade na investigação ${ }^{211}$, do conjunto de postulados basilares da República, extrai-se que a atividade investigativa (e, em conseqüência, a futura e eventual acusação) será tanto mais legítima quanto mais se pautar em bases de racionalidade, de dialeticidade, de transparência.

O Código de Processo Penal, até pelo contexto histórico em que veio a lume, prestigia o interesse na repressão ao crime ${ }^{212}$. Entretanto, uma imperiosa releitura de

209 Cf., nesse ponto, Aury Lopes Jr. (Sistemas..., p. 118), para quem, “[n]a atualidade, a regra geral inclusive com caráter constitucional em muitos países - é o livre acesso a todos os atos processuais e também da fase pré-processual, de modo que se estabelece uma presunção de publicidade que só é quebrada por expressa norma legal".

210 Contra, Flávia Rahal Bresser Pereira (Publicidade no processo penal..., cit., p. 280-281) entende que no inquérito policial a regra é o sigilo (nos termos do art. 20 do CPP), esclarecendo, todavia, que dito sigilo não pode confundir-se com a privação do direito de defesa ou do conhecimento do inquérito por quem nele tenha fundado interesse (o suspeito, o indiciado e seu advogado, o ofendido, seu representante legal ou advogado).

211 O Pacto de São José da Costa Rica, por exemplo, fala apenas em direitos do 'acusado', restringindo-se à fase processual. $\mathrm{O}$ seu art. 8.5 reza: "O processo penal deve ser público, salvo no que for necessário para preservar os interesses da justiça". Não se pode olvidar, contudo, no tema do sigilo externo, a previsão contida no mesmo Pacto, no art. 11.2, segundo a qual "ninguém sofrerá ingerências arbitrárias em sua vida privada", a funcionar como evidente limitador também aos atos praticados pelas autoridades encarregadas da persecução preliminar.

212 Tanto assim que grande parte dos doutrinadores, ao referir-se ao tema, anteriormente à Constituição de 1988, viam no sigilo uma nota imanente à investigação. É o caso de Hélio Tornaghi, ao tratar do inquérito policial: "A natureza do inquérito não se compadeceria com as formas secundárias que em geral 
seus dispositivos à luz da Constituição não levará a conclusão outra que a da preservação do status dignitatis do indivíduo envolvido numa investigação criminal. Afinal, “[o] processo constitucional confere ao moderno processo penal uma estrutura que alia à eficiência do funcionamento da máquina repressiva, o garantismo, traduzido como respeito absoluto à pessoa humana que, casualmente, é suspeito na investigação"213. Já o segredo para os interessados e seus advogados, implicativo de uma persecução penal unilateral, sem a devida correspondência com o primado da pessoa humana, é uma das notas típicas dos regimes autocráticos ${ }^{214}$.

Todavia, é cediço que muitas vezes há necessidade de preservar-se o objeto da investigação e evitar a superexposição das pessoas ou mesmo o linchamento público, de modo que a investigação preliminar, em alguns de seus atos, pode ficar restrita ao público e mesmo ao imputado, seja por razões ligadas à eficiência ou por motivos atrelados a garantias individuais.

$\mathrm{O}$ interesse de instituir o sigilo na etapa preliminar deve ser compreendido não pelo ponto de vista do bom andamento dos serviços judiciários enquanto serviços públicos - já que, para tal fim, o segredo não é o recomendável -, mas em relação à idoneidade dos institutos processuais a conseguir o resultado a que são dispostos: apenas na medida e no tempo necessários a assegurar o êxito das diligências ${ }^{215}$.

Por outro lado, ocluir por completo a investigação para o sujeito passivo e para o ofendido é deveras problemático, eis que se volta a restrição contra os maiores interessados na investigação, sacrificando-se o seu direito à informação ${ }^{216}$.

Daí a exigência de se compatibilizarem os interesses do Estado (interesse público no cumprimento de seu dever de investigar os aspectos materialísticos de um fato criminoso, como ferramenta de segurança social) e do indivíduo (à imagem, honra e informação), dando-se concretude às normas constitucionais que regem a matéria. No

acompanham o processo acusatório, isto é, a oralidade e a publicidade. Se mesmo na fase judicial, eminentemente acusatória, a lei impõe ou permite o sigilo (...), não é de estranhar que mande assegurar o segrêdo, sem o qual o inquérito seria uma burla ou um atentado..." (Compêndio..., t. I, p. 172).

213 CHOUKR, Fauzi Hassan. Garantias..., cit., 1995, p. 185.

214 Cf. PEREIRA, Flávia Rahal Bresser. A publicidade..., cit., p. 187.

${ }^{215}$ Sobre as possibilidades e as espécies do sigilo (interno e externo) na investigação preliminar, discorrer-seá no item 3.3.7.

216 Eis por que, segundo Fábio Ramazzini Bechara, "a necessidade do sigilo interno nas investigações colocase como medida excepcional, sob pena de o direito à informação ver-se esvaziado. (...) A possibilidade do sigilo interno constitui uma restrição lógica do direito fundamental à informação, posto ser, em determinados casos, imprescindível à segurança da sociedade e do Estado" (Crime organizado e o sigilo 
conflito entre valores tão caros ao ordenamento (direitos fundamentais versus interesse público), não há espaço para soluções genéricas e definitivas, havendo sempre que se buscar, em cada caso, o difícil, porém necessário equilíbrio entre tais interesses.

Em complemento à garantia da publicidade dos atos, caminha a regra da motivação das decisões, pela qual se faz possível atestar o acerto da decisão, o exercício das finalidades da norma. É por ela, também, que transparece o respeito ou não a todas as outras garantias fundamentais, como a legalidade, a presunção de inocência, a ampla defesa, etc., e que se preservam os direitos individuais, porquanto toda restrição a eles permitida deve vir fundamentada ${ }^{217}$.

Na precisa lição de Antonio Magalhães Gomes Filho, a motivação exerce importantes funções política e processual. No campo político, é uma garantia estabelecida na Constituição e que dá sustentação ao Estado Democrático de Direito, em que o poder decorre da soberania popular e os governantes devem prestar contas ao cidadão. Aplica-se, portanto, quer aos atos do Parlamento, quer da Administração, quer do Poder Judiciário, neste último avultando em importância, pois, não sendo eleitos os juízes na maioria dos sistemas, obtêm sua legitimação da observância das leis e motivação de suas decisões, assegurando-se sobre elas um controle popular difuso ${ }^{218}$.

na investigação. Revista Síntese de Direito Penal e Processual Penal, Porto Alegre, v. 6, n. 32, jun./jul. 2005, p. 44).

${ }^{217}$ Nessa linha, o art. 5. ${ }^{\circ}$, LXI, da CF: “ninguém será preso senão em flagrante delito ou por ordem escrita e fundamentada de autoridade judiciária competente...". Trata-se, é bem de ver, de princípio que remonta ao Império, atrelado desde sempre à publicidade: "Decisões do Governo, 78, Justiça, de 31.3.1824. Determina que os juízes fundamentem as sentenças que proferirem. Desejando S. M. o Imperador que os súbditos deste Imperio comecem desde já a gozar de todas as vantagens promettidas na sabia Constituição, ha pouco jurada, e sendo uma das principaes a extirpação dos abusos inveterados no foro, cuja marcha deve ser precisa, clara, e palpavel a todos os litigantes: Manda o mesmo A. S., pela Secretaria de Estado dos Negocios da Justiça, que os Juizes de mór alçada, de qualquer qualidade, natureza e graduação declarem nas sentenças, que proferirem, circumstanciada e especificadamente as razões e fundamentos das mesmas, e ainda nos aggravos chamados de petição, não só por ser isto expressamente determinado no $\S 7 .^{\circ}$ da Ord. do Liv. 3..$^{\circ}$, Tit 66, como por ser conforme ao liberal systema ora abraçado; afim de conhecerem as partes as razões, em que fundaram os julgadores as suas decisões; alcançando por este modo ou o seu socego, ou novas bases para ulteriores recursos, a que se acreditarem com direito." (PIERANGELLI, José Henrique. Processo penal: evolução histórica e fontes legislativas. Bauru: Jalovi, 1983, p. 341-342).

218 Assim se manifesta o autor: "Sem desprezar o fato, também já salientado, de que há sempre entre as várias garantias uma interpenetração recíproca, sob aquele primeiro aspecto de garantia política, a motivação cumpre o importante papel de assegurar a efetividade de alguns valores essenciais do Estado de direito, dentre os quais vale ressaltar a participação popular, a soberania da lei, a certeza do direito, a separação de poderes e a supremacia dos direitos individuais" (A motivação..., cit., p. 83). Associa-se a tal pensamento Ana Paula de Barcellos (Ponderação, racionalidade e atividade jurisdicional. Rio de Janeiro: Renovar, 2005, p. 47), ao enunciar que "o dever de motivar não decorre apenas de uma regra formal (art. 93, IX) ou de uma exigência do direito de defesa das partes. Ele está vinculado à própria necessidade republicana de justificação das decisões do Poder Público". Já Luis Gustavo Grandinetti Castanho de Carvalho (O processo penal em face da Constituição: princípios constitucionais do processo 
Além do referido valor democrático, como fator de publicidade e de responsabilidade (função extraprocessual), a motivação também é uma garantia processual. Vem prevista nos códigos de ritos e possibilita o controle do raciocínio lógico seguido pelo julgador, da sua correção argumentativa, com isso permitindo o exercício do contraditório quanto a todas as decisões relevantes do processo. Exerce assim a motivação importante função endoprocessual, ao transmitir às partes o conhecimento das razões das decisões, a fim de que possam impugná-las, e aos órgãos revisores a exata medida da decisão impugnada, para que se lhes permita julgar o recurso ${ }^{219}$.

A abrangência dessa garantia é a mais larga, devendo permear todas as decisões do processo, máxime as que afetam direitos fundamentais e garantias processuais, tanto que a ausência de fundamentação, seja das decisões interlocutórias ou finais, gera a sua nulidade absoluta. A motivação deve ser prévia ou contemporânea à prática do ato (nunca posterior, sob pena de ser fabricada para justificar atos ilegais) e vir estruturada sob um duplo aspecto, contemplando as questões de fato e de direito que envolvem a decisão, ou seja, exibindo de forma lógica e clara tanto os dados fáticos constantes dos autos quanto os dispositivos legais em que se apóia o julgador no seu posicionamento, para com isso afastar subjetivismos, ponderações genéricas ou calcadas em dados externos ao processo.

Mas não só as decisões tomadas pelo Poder Judiciário estão atreladas a essa exigência. Embora a Constituição da República se refira, expressamente, apenas à motivação das decisões - judiciais ou administrativas - dos juízes e tribunais (art. 93, IX e $\mathrm{X}$ ), força é reconhecer, como conseqüência da extensão do devido processo legal à esfera administrativa, que tal garantia está assegurada em todos os níveis de Poder estatal, portanto nos procedimentos administrativos em geral, como garantidora de uma atividade

penal. 2. ed. ampl. Rio de Janeiro: Forense, 1998, p. 126) proclama que "tanto a publicidade como a motivação encontram sua maior justificação política na legitimação da função jurisdicional”, pois o Poder Judiciário, em regra, não se nutindo da legitimidade advinda das eleições populares, por essas garantias se torna acessível ao público e submete-se a controle social.

219 Escreve Luigi Paolo Comoglio (Giurisdizione e processo nel quadro delle garanzie costituzionali. Rivista Trimestrale di Diritto e Procedura Civile, Milano, v. 48, n. 4, dic. 1994, p. 1100-1102) que a publicidade é um fundamento de justiça e de legalidade procedimental, expressando uma garantia de transparência e de controlabilidade externa, ao passo que a motivação se apresenta como garantia de tipo objetivo e estrutural, na qual coexistem: a correlação finalística com o princípio da legalidade, um controle da sujeição do juiz à lei e sua imparcialidade e o suporte para o adequado exercício do direito de defesa. Cumpre, assim, a motivação uma finalidade extraprocessual, ao prevenir, tal qual a publicidade, abusos do Poder Judiciário, mediante transparência e controlabilidade externa popular, e outra endoprocessual, ao permitir o exame superior dos provimentos, por específicos meios de impugnação. 
processual justa $^{220}$. Conforme Marcelo Harger, a motivação dos atos administrativos seria postulada, implicitamente, por diversos dispositivos constitucionais - pelo exercício de função administrativa, a demandar a existência de um meio eficaz de controle, pelos princípios do Estado de Direito, da tripartição de poderes, da legalidade e do contraditório - e para efetivar outros princípios entabulados no art. 37, caput, da CF, como a impessoalidade, moralidade e publicidade ${ }^{221}$.

Assim, os atos praticados pela Administração Pública, em cujo universo se encontram as decisões tomadas na investigação preliminar, devem também pautar-se pela garantia da motivação.

Os procedimentos realizados pela Administração Pública estão regulados, por exemplo, no âmbito federal, pela Lei 9.784/1999, que estabelece: “Art. 2. ${ }^{\circ}$ A Administração Pública obedecerá, dentre outros, aos princípios da legalidade, finalidade, motivação, razoabilidade, proporcionalidade, moralidade, ampla defesa, contraditório, segurança jurídica, interesse público e eficiência.” (grifos acrescidos).

Na órbita estadual, tampouco se pode desdenhar a garantia de motivação nos processos e procedimentos administrativos. Vale destacar, no ponto, a previsão contida no art. 4. ${ }^{\circ}$ da Constituição do Estado de São Paulo, de que "[n]os procedimentos administrativos, qualquer que seja o seu objeto, observar-se-ão, entre outros requisitos de validade, a igualdade entre os administrados e o devido processo legal, especialmente quanto à exigência da publicidade, do contraditório, da ampla defesa e do despacho ou decisão motivados".

$\mathrm{Na}$ investigação preliminar, todos os atos realizados pela autoridade condutora devem ser motivados, mormente as decisões que impliquem cerceio ou invasão de direitos fundamentais do indivíduo, seja ele o investigado ou terceiro, sob pena de nulidade, por infringência ao devido processo legal ${ }^{222}$. Aqui, além de servir como fonte

${ }^{220}$ Calha trazer à baila, nesse ponto, as palavras de Fernão Borba Franco (Processo administrativo, cit., p. 31): "Há garantia constitucional a respeito da motivação das decisões judiciais, mas não das decisões proferidas em processo administrativo. Contudo, essa garantia constitucional necessariamente se estende ao processo administrativo por força do princípio do devido processo legal, aplicável, como já visto, ao processo administrativo. Afinal, é a motivação das decisões que possibilita seu controle de legalidade, aí incluída a parcela de discricionariedade eventualmente existente".

221 Definir-se-ia a motivação como "a declaração das condições de fato e de direito e do nexo de causalidade entre essas condições e o conteúdo do ato" (HARGER, Marcelo. Princípios constitucionais..., cit., p. 105109).

222 "Ao decidir os pleitos que lhe são feitos (quanto à formulação de quesitos, por exemplo), a função do Delegado de Polícia se assemelha à do magistrado e, de forma mais precisa (para os que interpretem a Constituição literalmente), se impõe a necessidade da motivação, sob pena de se tornar nulo o ato (e mais 
controladora a nível interno, a motivação também permite o controle externo da sociedade sobre o próprio conceito de segurança pública.

A esse respeito, além do mandamento constitucional, convém destacar, de um lado, a obrigatoriedade legal de fundamentação dos pronunciamentos do Ministério Público (art. 43, III, da Lei n. ${ }^{\circ} 8.625 / 1993^{223}$ ) e, de outro, o texto da Portaria 18, de 25.11.1998, do Delegado Geral de Polícia Civil de São Paulo, que representou notável avanço em termos de positivação da garantia da motivação na investigação preliminar especificamente realizada mediante o inquérito policial.

Saudado pela doutrina nacional por sua avançada visão em termos de garantias do investigado ${ }^{224}$, esse diploma, em vários artigos, faz menção à necessidade de motivação ou de fundamentação dos atos e das decisões da autoridade policial no curso da investigação, sejam eles: instauração (art. 1. ${ }^{\circ}$ ) ou não-instauração (art. 2. ${ }^{\circ}$ ) de inquérito policial, arquivamento do boletim de ocorrência (art. $3 .^{\circ}$ ), requerimento de dilação temporal (art. $\left.4 .^{\circ}\right)$, indiciamento (art. 5. ${ }^{\circ}$ ), representação por medida cautelar (art. 6. ${ }^{\circ}$ ) e relatório final (art. 12). No dizer de José Pedro Zaccariotto, a Portaria em questão representa um primeiro, mas decisivo passo rumo à meta de evolução ética e técnica da polícia judiciária, privilegiando a sua integração ao novo processo penal, democrático, com especial ênfase ao devido respeito aos direitos do investigado, a fim de não o tornar vítima do mau funcionamento da máquina repressiva, assegurando enfim transparência e brilho intelectual à primeira fase da persecução penal e afastando quaisquer resquícios de arbítrio $^{225}$.

No mesmo sentido caminha o Projeto de Lei 4.209/2001, que objetiva alterar o Código de Processo Penal no ponto da investigação criminal, instituindo, no art.

uma vez se apresenta a nulidade no inquérito), que, de forma decisiva, pode influenciar o processo. Portanto, a fundamentação dos despachos, mesmo que sem a amplitude do processo, aplica-se ao inquérito policial, o que há de se reconhecer para que prevaleça o espírito garantidor das liberdades individuais, próprio do Estado de Direito, e que impera em nossa Constituição.” (PASSOS, Paulo Roberto da Silva; OLIVEIRA, Thales Cezar de. Princípios constitucionais no inquérito e no processo penal. São Paulo: Themis, 2001, p. 71).

223 “Art. 43. São deveres dos membros do Ministério Público, além de outros previstos em lei: (...) III indicar os fundamentos jurídicos de seus pronunciamentos processuais, elaborando relatório em sua manifestação final ou recursal."

224 Adauto Suannes (Os fundamentos éticos..., cit., p. 174-180) qualifica-o como ato "modelar, no que diz com a edição de uma Miranda warning cabocla. (...) É simplesmente incrível que tais normas, de necessidade inquestionável à vista das garantias constitucionais, não tenham sido baixadas anteriormente pelo Poder Judiciário (ao qual incumbe, em tese, a fiscalização da atuação policial). É a própria autoridade administrativa a suprir as deficiências do Judiciário, a mostrar o grau de desinteresse que esse Poder vota à relevante questão dos direitos fundamentais do ser humano". 
16, a obrigatoriedade de motivação dos atos da autoridade policial e das manifestações do Ministério Público.

Apesar dos ingentes esforços institucionais, constata Fauzi Hassan Choukr, na investigação criminal a motivação tornou-se uma "garantia descartável", à ausência de um mecanismo sancionador para a sua inobservância. Seria, dentre todas as garantias que permeiam a etapa preliminar, a que enfrenta maior crise, esbarrando no manifesto desrespeito e no conseqüente descumprimento de sua função política, no descaso técnico em motivar atos que deveriam vir justificados, como a instauração da investigação, o indiciamento e o arquivamento, os quais, a despeito do vício, continuam a ter a mesma prestabilidade, ou seja, seguem válidos e eficazes ${ }^{226}$.

Também por isso, mostra-se a importância de reafirmar o valor do princípio da motivação dos atos praticados na investigação preliminar com fins penais, em qualquer de suas espécies, sobretudo os que trazem conseqüências gravosas ao indivíduo sob investigação, sejam eles realizados pela Polícia Judiciária, por magistrados ou por membros do Ministério Público, durante o inteiro percurso da fase investigativa.

225 ZACARIOTTO, José Pedro. Portaria DGP 18/98 e polícia judiciária democrática. Revista dos Tribunais, São Paulo, v. 88, n. 769, nov. 1999, p. 473.

${ }^{226}$ CHOUKR, Fauzi Hassan. Garantias..., cit., 2006, p. 96. A inquietação do autor leva-o a concluir que, "[n]a medida em que os atos desmotivados continuam a ter ampla repercussão no mundo jurídico, surge a falsa idéia da descartabilidade da garantia, como se falta alguma fizesse ao sistema globalmente considerado". 


\section{CAPÍTULO 2: A investigação preliminar no direito brasileiro}

Delimitadas as linhas-mestras da investigação preliminar no processo penal moderno de tipo acusatório, cujo perfil democrático valoriza a figura do indivíduo frente ao Estado, tutelando a sua liberdade e a sua dignidade como pessoa, assentou-se que as garantias constitucionais decorrentes do devido processo legal têm incidência cogente nos procedimentos de investigação preliminar com fins penais, eis que traduzem uma aguda forma de invasão do Estado na liberdade do cidadão.

Cumpre focalizar, a partir de então, a investigação preliminar no modelo brasileiro, sua estrutura descrita no direito positivo, examinando-se as principais dificuldades encontradas para a inserção, na prática, daqueles valores de garantia do investigado acobertados explicitamente na Constituição, para em seguida ingressar no objeto imediato deste estudo, concernente à investigação dos delitos de competência originária dos tribunais.

\subsection{Caracteres e funções da investigação preliminar}

A prática de uma infração penal faz surgir para o Estado o jus puniendi, que depende, para sua concretização, de instrumento específico, o processo. Mecanismo de autolimitação do poder punitivo estatal, o processo penal compreende intensa atividade, deflagrada, em regra, por iniciativa do Ministério Público, ao expor em juízo o fato revestido de aparência delituosa, apontando o seu possível autor, a fim de que o magistrado verifique, ao final da instrução, a procedência ou não de suas alegações.

A propositura da ação penal de natureza condenatória, por sua vez, até pela carga de simbolismo deletério para quem sofre o processo ${ }^{227}$, deve estar atrelada à prévia demonstração, pelo autor, de requisitos mínimos de viabilidade da acusação deduzida. Tais elementos são coligidos mediante uma atividade conhecida por investigação criminal, ou investigação preliminar, que envolve exames, vistorias, avaliações, buscas, coleta de

${ }^{227}$ Ressalta Antonio Magalhães Gomes Filho (O princípio..., cit., p. 32) que, conforme destacado em estudos sociológicos, "o processo penal é sobretudo um cerimonial de degradação do status social do indivíduo submetido à persecução. E os sistemas jurídicos freqüentemente se utilizam da humilhação do acusado como sanção pouco custosa e, ao mesmo tempo, de grande força nos mecanismos simbólicos da repressão". 
testemunhos, declarações, etc. ${ }^{228}$ É a investigação criminal que vai fornecer os elementos probatórios mínimos para a instauração da ação penal na qual se pede, em juízo, a aplicação da sanção criminal ao acusado pelo delito.

Pode-se dizer, assim, que a persecução criminal comporta dois momentos distintos: um prévio, investigativo (a fase pré-processual), e outro concernente à ação penal, o processo propriamente dito. É na fase da investigação preliminar que são colhidos os elementos que apontem a existência ou não de um delito e sua autoria, conferindo base à formação da opinio delicti pelo acusador, seja pela deflagração da ação penal ou, modo inverso, pelo arquivamento do caso.

Na doutrina de Francesco Carnelutti, "assim como o homem antes de nascer tem uma vida intra-uterina, igualmente ocorre com o processo penal; antes de formalizar a acusação realizam-se certos atos preparatórios a ela: por exemplo, se é encontrado um cadáver e há razão para suspeitar que a morte provenha de um crime, fazem-se as indagações preliminares destinadas a estabelecer, a priori, as causas da morte, e $a$ posteriori, se é resultante ou se trata de homicídio, e quem pode tê-lo cometido",229.

Mas a existência de uma investigação preliminar encontra fundamento não apenas na busca de dados elucidativos do fato possivelmente criminoso. Funciona, antes de mais, como salvaguarda da sociedade (no interesse geral de paz social) e como meio de evitar acusações infundadas - assegurando-se, por via transversa, à sociedade que não haverá abusos na atividade persecutória estatal. Daí por que, observa Antonio Scarance Fernandes, a investigação assume relevo tanto para a acusação quanto para a defesa: "[q]uem acusa dela depende para poder aparelhar a imputação e obter os elementos que permitam a produção da prova. Quanto à defesa, a prévia investigação é essencial para evitar acusações apressadas e injustas" 230 .

${ }^{228}$ Como leciona Afrânio Silva Jardim (Direito processual penal, cit., p. 54), a necessidade de condições mínimas de viabilidade da pretensão é decorrência do princípio da dignidade da pessoa humana, tutelado no art. 1. ${ }^{\circ}$, III, da Carta da República, podendo a sua falta caracterizar coação ilegal a ser arrostada por habeas corpus (arts. 647 e 648, I, do Código de Processo Penal). Ainda, segundo destaca Maria Thereza Rocha de Assis Moura (Justa causa..., cit., p. 222), tais elementos, quando existentes, conferem legalidade à acusação e, pois, justa causa à ação penal, não tolerando o ordenamento "que a acusação se faça sem que encontre lastro nas provas colhidas no inquérito policial ou nas peças de informação" ou que narre fato atípico.

229 CARNELUTTI, Francesco. Como se faz um processo. Trad. Ricardo Rodrigues Gama. Campinas: Russell, 2008, p. 47.

${ }^{230}$ O equilíbrio na investigação criminal. In: YARSHELL, Flávio Luiz; MORAES, Maurício Zanoide (Org.). Estudos em homenagem à professora Ada Pellegrini Grinover. São Paulo: DPJ, 2005, p. 319. 
Portanto, a investigação exerce duas evidentes funções: uma preservadora (cautelar ou preventiva) e outra preparatória ${ }^{231}$.

Consiste num procedimento cautelar, na medida em que impede se percam os elementos de convicção sobre o fato supostamente criminoso, muitos deles rapidamente deterioráveis no tempo. Preserva também o indivíduo contra acusações e assaques tendenciosos, e o organismo judicial, contra o custo do seu processamento ${ }^{232}$. Desse norte, aliás, não discrepou a Exposição de Motivos do Código de Processo Penal de 1941, ao exaltar, no item IV, o inquérito policial como processo preliminar ou preparatório da ação penal, por ser "uma garantia contra apressados e errôneos juízos, formados quando ainda persiste a trepidação moral causada pelo crime ou antes que seja possível uma exata visão de conjunto dos fatos, nas suas circunstâncias objetivas e subjetivas”.

A investigação tem, ainda, caráter preparatório da ação penal de conhecimento de natureza condenatória, levando ao titular da ação o lastro probatório necessário ao seu exercício. Diante desse caráter eminentemente informativo, diz-se que a investigação preliminar é uma informatio delicti ${ }^{233}$.

${ }^{231} \mathrm{Na}$ aglutinadora observação de José Antonio Pimenta Bueno (Apontamentos sôbre o processo criminal brasileiro. Atual. e compl. por José Frederico Marques. São Paulo: Revista dos Tribunais, 1959, p. 76), a investigação não passa do exercício do poder cautelar que o Estado exerce, para preparar a ação penal e impedir que se percam os elementos de convicção sobre o crime cometido. Galdino Siqueira (Curso de processo criminal. 2. ed. rev. e aum. São Paulo: Magalhães, 1924, p. 306) também destacara o duplo aspecto funcional da investigação, especificamente do inquérito policial, ao defini-lo como "uma informação preparatória e preventiva feita emquanto não intervem a autoridade judiciaria competente, ou em synthese, uma peça de instrucção ou instrumento, para servir de base á denuncia, á queixa ou ao procedimento ex-officio". No mesmo rastro, Diógenes Pereira do Valle (Dos processos policiaes..., cit., p. 16) ressalta que a competência da polícia, outrora abrangente, pela legislação de 1841 e 1843 , do processo e julgamento dos "crimes de alçada" - chamados de "crimes policiais" - quedou restringida, sobretudo a partir das reformas de 1871 e 1907, à "informação preparatória e preventiva", feita enquanto não intervém a autoridade judiciária, para base da ação penal.

232 Também Joaquim Canuto Mendes de Almeida (Princípios..., cit., p. 30) efetua uma distinção entre as funções preparatória e preservadora da instrução preliminar, a primeira determinada pela necessidade de produção de provas dificilmente realizáveis no tempo e no local de concentração do processo; a segunda, pela necessidade de fundamentar um juízo de acusação, um julgamento prévio dos elementos acusatórios, em garantia tanto da inocência contra a leviandade ou calúnia, quanto do organismo jurisdicional contra dispêndios inúteis de trabalho. Embora distintas, arremata, "as duas funções de instrução preliminar não vivem, na prática, necessariamente separadas. Ao contrário, quase sempre se confundem, tornando-se, não raro, trabalho sutil de análise distingui-las num mesmo procedimento".

233 A função preparatória é destacada por José Frederico Marques (Tratado..., cit., v. 1, p. 167-168), ao entoar que o Estado, antes de levar a juízo a pretensão punitiva, deve preparar adequadamente a propositura da ação penal, podendo ser também necessário assegurar os atos investigatórios e a realização dos fins do processo penal, por via de medidas cautelares levadas a efeito na fase preliminar. Ressalta ainda que, se na demanda cível a ação deve ser precedida de uma investigação sobre os fatos que se pretende afirmar em juízo, com maior razão se o tem no processo penal, para dar fundamento à acusação. 
Não se converte a investigação preliminar, no nosso sistema ${ }^{234}$, em estágio obrigatório da persecução ${ }^{235}$, podendo o titular da ação penal dela prescindir, valendo-se de quaisquer peças de informação que objetivamente encerrem a formação da culpa ${ }^{236}$, desde que atendam ao binômio: prova da materialidade do delito e indícios de sua autoria, coautoria ou participação. No entanto, a experiência vem demonstrando um incremento contínuo de sua importância, seja para a verificação do fato em tese delituoso, seja para a prevenção de acusações infundadas, donde a progressiva essencialidade da etapa préprocessual, como modo de coibir o arbítrio do acusador ${ }^{237}$.

Despontam como características determinantes da investigação preliminar a sua autonomia e instrumentalidade em relação ao processo penal ${ }^{238}$.

Autônoma o é porque, da mesma maneira que o processo pode prescindir da etapa procedimental prévia, quando o sistema jurídico lhe atribui caráter facultativo,

${ }^{234}$ Diferentemente, por exemplo, o sistema espanhol, em que o sumario, forma de investigação preliminar para infrações graves (cuja pena seja superior a 9 anos), é obrigatório. Nos termos do art. 300 da Ley de Enjuiciamiento Criminal: "Cada delito de que conozca la autoridad judicial será objeto de un sumario. Los delitos conexos se comprenderán, sin embargo, en un solo proceso".

${ }^{235}$ É o que prevê o art. 27 do Código de Processo Penal: "Qualquer pessoa do povo poderá provocar a iniciativa do Ministério Público, fornecendo-lhe, por escrito, informações sobre o fato e a autoria e indicando o tempo, o lugar e os elementos de convicção". E ainda o art. 39, § 5. . "O órgão do Ministério Público dispensará o inquérito, se com a representação forem oferecidos elementos que o habilitem a promover a ação penal, e, neste caso, oferecerá a denúncia no prazo de 15 (quinze) dias". A esse respeito, oportuna é a ponderação de Sérgio Habib (Brasil: quinhentos anos de corrupção: enfoque sóciohistórico-jurídico-penal. Porto Alegre: Sergio Antonio Fabris, 2004, p. 131): "Uma coisa é a prescindibilidade do inquérito policial quando o representante do parquet assim o entende. Outra, bem diversa, é a sua desnecessariedade. A primeira hipótese, remete à idéia de renunciar-se à sua utilidade, por entender-se que já há prova suficiente da autoria e da materialidade do delito. Já a segunda, importaria em dizer-se que as provas seriam obtidas mesmo sem ele". Contra, Luiz Roberto Salles de Souza (Da atuação do Ministério Público brasileiro na fase pré-processual: uma análise crítica. Dissertação (Mestrado em Direito) - Universidade de São Paulo, São Paulo, 2002), entendendo que no ordenamento brasileiro a investigação preliminar é obrigatória, embora o sistema não preveja que a investigação seja realizada por um órgão específico e sob determinada forma, aceitando-se qualquer informação que dê respaldo e justifique a acusação.

${ }^{236}$ A expressão formação da culpa é utilizada aqui no sentido amplo a que se refere Sérgio Marcos de Moraes Pitombo (Inquérito policial: novas tendências. Belém: Cejup, 1987, p. 18-19): "a culpa se forma por meio do exame de corpo de delito, prisão e flagrante, inquirição de suspeito e de testemunhas, bem assim mediante outros elementos de conviç̧ão", e não no sentido estrito ou técnico que serve para designar a primeira fase do procedimento especial do júri. É Joaquim Canuto Mendes de Almeida (Principios..., cit., p. 192-193) quem alerta para a necessidade de não confundir-se a formação da culpa com o processo judicial de formação da culpa, hoje existente nos processos do Tribunal do Júri (o sumário de culpa) e outrora, também, no inquérito da Lei de Falências. O inquérito policial cumpriria um estágio extrajudicial de formação da culpa, servindo de base à denúncia ou queixa.

${ }^{237}$ Porque, na sagaz observação de Sérgio Marcos de Moraes Pitombo (Inquérito policial: exercício do direito de defesa. Boletim IBCCrim, São Paulo, v. 7, n. 83, edição especial, out. 1999, p. 14), "[o] imputado sofre o processo. Suporta-lhe e para sempre os efeitos sociais, ainda que termine absolvido. (...) A função simbólica do processo de conhecimento traz-lhe, também, a marca da infâmia", por isso a necessidade de prévia apuração do fato, como "meio inafastável, em regra, de reduzir o risco de acusações formais, infundadas, temerárias e até caluniosas".

${ }^{238}$ Cf. LOPES JR., Aury. Sistemas..., cit., p. 40-44. 
também a investigação pode findar sem que se canalize, necessariamente, ao processo. Os seus elementos são distintos daqueles encontrados no processo decisório. Os sujeitos são diferentes e a postura de cada um deles também; o objeto, a notitia criminis, é deveras distinto daquele de que se ocupará o processo, diferençando-se ainda o grau de cognição sobre a materialidade e a autoria do delito; os atos realizados são também diferentes daqueles concretizados no processo, tendo sujeitos, objetos e formas distintas, além de discrepar o grau de verificação da defesa e do contraditório. A despeito de sua autonomia, a investigação preliminar apresenta instrumentalidade quanto à fase judicial, na proporção em que "tem como objetivo imediato garantir o eficaz funcionamento da justiça", fator que é condizente com as suas funções preservadora e preparatória, atrás mencionadas.

Cada sistema processual desenvolveu ou adotou modos próprios de apuração prévia, consoante lhe pareceu adequado, nominando-os das mais variadas formas (indagine preliminare, na Itália; inquérito preliminar, em Portugal, enquête préliminaire e instruction, na França; sumario, diligencias previas e instrucción complementaria, na Espanha; prosecution e preliminary inquiry, na Inglaterra), variáveis conforme o tempo, os aspectos sociais, políticos e culturais dos Estados ${ }^{239}$.

No direito brasileiro, as investigações se fazem, ordinariamente, na forma de inquérito policial, etapa administrativa dirigida pela autoridade encarregada de sua feitura $^{240}$. Para tanto, criou o Estado órgão incumbido precipuamente de tal missão: a Polícia Judiciária, "cuja finalidade é a de investigar o fato infringente da norma e quem tenha sido o seu autor, colhendo os necessários elementos probatórios a respeito" ${ }^{\text {241 }}$.

239 Ao analisar a fase preparatória do processo penal no direito comparado, Jean Pradel (La phase préparatoire..., cit., p. 628-630) divide as diversas legislações em três grupos, considerando os agentes que atuam na investigação: no primeiro, é a polícia que conduz, sozinha, as pesquisas, com recurso ao juiz nos aspectos de liberdades individuais (caso dos países da common law); no segundo, a polícia é associada ao Ministério Público (como na Alemanha, em alguns Estados árabes e africanos, em alguns cantões suíços e em quase todos os Estados socialistas); no terceiro, coexistem polícia, Ministério Público e juiz de instrução (a exemplo da França, Espanha, alguns Estados africanos e árabes). Itália, Bélgica e Portugal ainda eram incluídos no terceiro grupo, eis que à época da publicação do artigo, em 1983, ainda mantinham a figura do juiz de instrução.

${ }^{240}$ Embora podendo esgotar-se em peças de informação, quando a notícia de infração penal de ação pública é levada diretamente e por escrito ao Ministério Público, assim ocorrendo, por exemplo, quando o Tribunal de Contas da União ou a Controladoria-Geral da União enviam seus relatórios de tomada de contas quanto às administrações municipais e o Ministério Público tem por bem oferecer a acusação em face do administrador público que, por exemplo, não presta contas, no prazo legal, de verbas recebidas da União. $\mathrm{O}$ inquérito policial - assim estabelece o CPP, nos arts. $39, \S 5 .^{\circ}$, e $46, \S 1 .^{\circ}$ - não é indispensável à instauração da persecução judicial.

241 TOURINHO FILHO, Fernando da Costa. Processo penal, cit., v. 1, p. 185-186. Em referência histórica, o autor anota que, já ao tempo da cognitio extra ordinem, no Império Romano, havia funcionários incumbidos de levar as primeiras informações sobre a infração penal aos magistrados, com papel semelhante ao da nossa Polícia Judiciária. 
Não é, porém, o inquérito policial a única forma procedimental de investigação preliminar em nosso sistema. A seguir, ver-se-á que a investigação é realizada em todas as esferas de Poder. Procurar-se-á, todavia, uma reflexão sobre a compatibilidade dessas espécies ao texto constitucional, bem como sobre os regramentos básicos aplicáveis ao gênero investigação preliminar no sistema criminal brasileiro, nos aspectos de estrutura (natureza jurídica, procedimentalização) e dos atos nela praticados.

\subsection{Natureza jurídica da investigação preliminar}

A investigação preliminar é a primeira fase da persecução penal, envolvendo a participação, principalmente, de órgãos administrativos do Estado, sem se olvidar a intercalação de alguns incidentes cuja intervenção judicial é de rigor. Tem importante função instrumental, para a busca de elementos probatórios mínimos sobre o fato supostamente delituoso e de seu autor, o que servirá de base para instauração da ação penal ou o seu arquivamento.

A definição da natureza jurídica da investigação está vinculada à análise de sua função, estrutura e do órgão por ela encarregado. Também os atos praticados nessa etapa influem na configuração de sua natureza, porém são de várias espécies os atos encontradiços na investigação preliminar criminal. Há atos administrativos, atos judiciais e atos jurisdicionais ${ }^{242}$, por isso sendo necessário dar realce, no fixar de sua natureza, aos atos predominantemente verificados nessa atividade.

Consiste a investigação preliminar na etapa preparatória do processo penal, tendo por isso caráter pré-processual. Ostenta natureza procedimental ${ }^{243}$, e não processual, porque - mesmo quando dirigida por autoridade dotada de poder jurisdicional - nela não há partes em posições contrapostas, nem contraditório pleno, nem uma acusação formal a ser decidida por um terceiro sujeito imparcial, o juiz.

${ }^{242}$ Os atos judiciais distinguem-se dos jurisdicionais. Ambos são praticados por integrantes do Poder Judiciário, porém os atos judiciais (ou judiciários) compreendem atividade não-jurisdicional (assim são os atos praticados em procedimentos, sem o caráter de processo, e que não decidem conflitos de interesses), ao passo que os atos jurisdicionais somente são praticados quando a autoridade judicial (com potestade jurisdicional) atua num processo em sentido próprio ou decide, na fase preliminar, alguma medida implicativa da restrição de liberdade individual.

243 Tanto assim o é que o Projeto de Código Processual Penal-Tipo para Ibero-América utiliza a expressão procedimento preparatório para designar a etapa pré-processsual da persecução penal (Capítulo IV do Título I, do Livro Segundo). 
A investigação preliminar exterioriza-se num procedimento formado de acordo com as diretrizes extraídas dos princípios e regras do devido processo penal, procedimento este que, avesso a uma ritualização fechada, pode variar em cada situação concreta conforme a espécie de investigação prévia, mas sempre representando uma sucessão de atos dirigidos a um objeto final, devendo observar as garantias básicas do due processo of $\operatorname{law}^{244}$.

Exibe, portanto, a etapa investigativa a natureza de procedimento, visto que é possível separar, ao menos para fins didáticos, a fase preliminar da judicial propriamente dita, e que a concatenação dos atos praticados na investigação preliminar - convergentes, todos eles, à mesma finalidade de formar o convencimento do titular da ação penal, distinta, portanto, daquele fim visado no procedimento judicial (a sentença, ou o provimento jurisdicional) - permite também agrupá-los em um todo harmônico e ordenado segundo regras pré-constituídas ${ }^{245}$. Ademais, se pensarmos nos casos em que se desenvolve a investigação preliminar, mas não se desencadeia, após o seu findar, o processo penal (como nas corriqueiras hipóteses de arquivamento da investigação), ver-se-á que não existiu processo e, no entanto, existiu um procedimento.

Os agentes responsáveis pela investigação prévia não prescindem do procedimento para materializar a sua atividade, sempre que ela for provocada ${ }^{246}$. Também

${ }^{244}$ Ressalve-se a visão de Antonio Scarance Fernandes (Teoria geral do procedimento..., cit., p. 31 e ss.), que, embora asseverando o direito ao procedimento, põe-se contrariamente à natureza procedimental da investigação preliminar. Para o autor, uma visão unitária do procedimento redunda na inadequação técnica do uso das expressões "procedimento parcial" ou "procedimento em sentido estrito", preferindo falar em "fases do procedimento", sendo três fases processuais (postulatória, instrutória e decisória) e uma prévia (a investigação). Explica como os atos sucessivos do procedimento são postos em seqüência formal e lógica, para alcançar o mesmo resultado, daí a sua unidade para a consecução do mesmo fim: o provimento jurisdicional.

245 Vale recordar, com Celso Antônio Bandeira de Mello (Curso de direito administrativo. 15. ed. São Paulo: Malheiros, 2003, p. 444): “O reconhecimento de que haverá sempre um iter - inclusivo de começo, meio e fim - necessário, de direito, para o despertar e o concluir das manifestações estatais levou autores da maior qualificação intelectual a reconhecerem que processo e procedimento não são patrimônio exclusivo, monopólio (para referirmo-nos às expressões usualmente utilizadas) da função jurisdicional. Existem, também nas funções legislativa e administrativa, permitindo até que se fale, hoje, em um Direito Processual Administrativo".

246 José Alfredo de Oliveira Baracho, acentuando o procedimento como mecanismo democrático de efetivação das decisões administrativas, reconhece: "A implantação do procedimento, assentado na pretederminação do devido processo, foi grande conquista do Estado de Direito, com sujeição da Administração à lei e ao direito. Ocorre, paradigmaticamente, a efetivação das exigências da democracia, de conformidade de procedimentos que garantem os direitos inerentes à cidadania. Visa-se servir de garantia dos direitos dos administrados e a obtenção da maior eficácia das decisões administrativas, propiciando a democratização dos mecanismos da administração." (Teoria geral dos procedimentos de exercício da cidadania perante a Administração Pública. Revista dos Tribunais, São Paulo, v. 86, n. 743, set. 1997, p. 39). 
o sujeito passivo da investigação vale-se desse procedimento para demonstrar que não está envolvido no fato apurado.

Como já realçado, a investigação preliminar apresenta relativa autonomia quanto ao processo, senão que visa, de forma imediata, não a ser vir de base à decisão final da causa, mas a filtrar as acusações, recolhendo e selecionando o material que poderá servir para o juízo; logo, justificando ou eliminando a fase processual.

Toda vez que levada a efeito por órgãos estatais não-integrantes da estrutura do Poder Judiciário, a investigação preliminar terá natureza de um procedimento administrativo pré-processual, como é o caso do inquérito policial, que prepondera no sistema de investigação pátrio ${ }^{247}$, instrumentalizado pela chamada Polícia Judiciária órgão integrante do Poder Executivo que, apesar do qualificativo "judiciária”, exerce atividades de cunho administrativo ${ }^{248}$. Não se trata de atividade jurisdicional, nem sequer

${ }^{247}$ Sem embargo, encontra-se também no direito brasileiro a investigação preliminar como procedimento judicial pré-processual, na hipótese prevista no art. 33, parágrafo único, da Lei Orgânica da Magistratura Nacional (Loman), em que a lei comete expressamente a órgão do Poder Judiciário a atividade preparatória da ação penal. Há aqui uma aproximação com os sistemas em que a investigação do juiz instrutor é prioritária (v.g., França e Espanha), sobretudo porque, nestes, o juiz instrutor recebe diretamente a notícia-crime e conduz a investigação preparatória, podendo exercer diretamente os poderes de investigação ou determinar que a polícia judiciária realize diligências. Em nosso país, mesmo nas investigações envolvendo magistrados, há grande margem de atuação do Ministério Público, sobretudo no requerimento e fiscalização de diligências, muitas das quais efetivadas pela Polícia Judiciária, sendo que a formação da opinio delicti e o conseqüente encerramento das investigações não podem ser determinados por decisão do juiz, como ocorre no sistema espanhol.

248 Anderson Souza Daura (Inquérito policial..., cit., p. 62-63) explica que as atribuições policiais se dividem em dois grandes ramos: a polícia administrativa, que atua de forma preventiva, para evitar a prática de infrações lesivas à sociedade, e a polícia judiciária, que tem função repressiva, agindo após o cometimento do ilícito, colhendo informações que possibilitem a repressão pelo Poder Judiciário, sendo portanto sua auxiliar. Tal divisão clássica, segundo o autor, nascera após a Revolução Francesa, quando a Assembléia Nacional Francesa, pela Lei 3 do Brumário, em 1791, efetuou a separação entre a Polícia e a Justiça, separando também a Polícia Administrativa da Polícia Judiciária. Sobre a adjetivação da polícia como civil ou militar no Brasil, Bismael Batista de Moraes (Polícia, segurança pública, governo e sociedade. In: MORAES, Bismael Batista de (Coord.). A polícia à luz do direito. São Paulo: Revista dos Tribunais, 1991, p. 131) explica que, em sua origem, a polícia é apenas Polícia, e por se destinar à segurança dos indivíduos que compõem a sociedade, é por natureza civil. Polícia Militar seria uma polícia interna corporis para fiscalizar os próprios militares das Forças Armadas, daí a crítica do autor à militarização do policial ostensivo no Brasil. Dalmo de Abreu Dallari (A polícia civil no Estado brasileiro. Ibidem, p. 70-71) prefere a distinção, existente em nosso direito desde o Regulamento 120/1842, entre polícia administrativa (responsável pela prevenção de crimes e manutenção da ordem) e polícia judiciária, expressão que entende melhor definida por Cirne Lima, ao descrevê-la como a polícia que tem por fim investigar os crimes e descobrir seus autores, e daí o seu nome, por ser "uma auxiliar do Poder Judiciário". Reputamos, todavia, equivocada a nomenclatura, que apenas denota as raízes inquisitoriais ainda presentes em nosso sistema, no qual a polícia ainda é adjetivada pelo Poder Judiciário. Recorde-se, por outro lado, que algum ranço histórico pode estar a justificar a nomenclatura: o Código de Processo Criminal de 1832 outrora consagrou a polícia como órgão do Poder Judiciário, na medida em que o chefe de polícia era um juiz de direito (cf. PIERANGELLI. José Henrique. Processo penal..., cit., p. 104), paradoxo que foi revertido com a Lei 261/1841. Ora, a função da polícia judiciária (seja ela a civil ou a federal) não é - e aqui se diz precipuamente - produzir provas para o Poder Judiciário (tampouco para o processo judicial, que pode sequer ser instalado); a tarefa investigativa, em verdade, está voltada ao 
judicial, tampouco processual. Os atos praticados pela polícia são meramente administrativos, porque não se está diante de um procedimento judicial, mas do exercício do poder-dever de garantia da segurança pública ${ }^{249}$.

Mesmo quando a investigação for realizada ou coordenada por órgão do Ministério Público ou do Poder Legislativo, exibirá natureza de procedimento administrativo, no sentido mais amplo do termo, eis que os atos nela praticados têm natureza administrativa, ou não-judicial.

Somente nos países em que o Ministério Público está constitucionalmente integrado à estrutura do Poder Judiciário (como ocorre, por exemplo, na Itália e em Portugal) é possível atribuir natureza judicial ${ }^{250}$ a sua atividade investigativa prévia e aos atos nela praticados. Nesses casos, como em todos aqueles em que a investigação preliminar estiver a cargo de um órgão integrante do Poder Judiciário (quer sejam eles juízes ou magistrados do Ministério Público), considerada será um procedimento judicial pré-processual.

O exemplo por excelência desse sistema é o juiz de instrução, que representa a máxima autoridade dirigente das investigações nos países que o adotam. O juiz instrutor, que tem raízes históricas ligadas à figura do inquisidor (embora dela se tenha desgarrado na medida em que os sistemas atuais não permitem que ele desencadeie a acusação em sentido estrito, nem julgue a causa que instruiu), não apenas presencia a produção da prova, mas efetivamente a produz, podendo atuar de ofício na prática de atos de investigação (interrogatório, oitiva de vítima e testemunha) e de instrução e também na adoção de medidas cautelares e na tutela da liberdade ${ }^{251}$, tendo o comando total da etapa preliminar.

Mas no ordenamento brasileiro, que não contempla, como regra, o juizado de instrução, o papel do juiz na investigação circunscreve-se ao de garantidor de direitos

convencimento do titular da ação penal, quem irá, em primeiro lugar, valorá-la, submetendo-a somente em seguida à análise judicial. No entanto, pela já consagração da expressão no direito brasileiro, será a utilizada em todo o trabalho.

${ }^{249}$ LOPES JR., Aury. Sistemas..., cit., p. 37.

${ }^{250}$ Mas, ainda assim, vale esclarecer, trata-se de atividade não-jurisdicional, pois os magistrados do Ministério Público não têm, nesses países, atribuições da jurisdictio, que é o poder-dever de aplicar o direito ao caso concreto, exclusivo dos juízes.

${ }^{251}$ Nos países que adotam o modelo do juizado de instrução, caso da Espanha, embora exercida a investigação por juízes, não é correto classificar o procedimento investigatório como jurisdicional, mas sim como judicial mesmo, pois, conquanto dirigido por autoridade dotada de poder jurisdicional, não se pode classificar como processo em sentido estrito, à míngua de características básicas à atividade puramente processual, como a existência de partes com interesses potencialmente contrapostos, que atuam mediante o exercício da ação penal e sob controle de um órgão supra-ordenado, com plena garantia de contraditório, dirigindo-se a uma sentença (LOPES JR., Aury. Sistemas..., cit., p. 39). 
fundamentais do imputado, jamais o de investigador ou de condutor dos rumos da investigação. E, não se ajustando o procedimento judicial de investigação aos sistemas predominantemente acusatórios, como o nosso (em que a função do juiz é visivelmente separada das dos demais sujeitos, cingindo-se à de julgar ou de dizer o direito no caso concreto), a natureza jurídica da investigação prévia - inclusive, aquela realizada nos delitos de competência originária de tribunais ${ }^{252}$ - somente pode ser a de um procedimento administrativo pré-processual, em que os atos investigatórios praticados são meramente administrativos.

\subsection{Modalidades de investigação preliminar segundo o condutor}

Passemos à tarefa de classificar as espécies de persecução criminal prévia em nosso ordenamento, para que se possa, mais adiante, identificar em qual delas se localiza a investigação preliminar dos crimes submetidos ao foro especial. Advirta-se, de antemão, que o labor classificatório, típico dos estudos jurídicos, é sempre revestido de dificuldades, dada a diversidade de critérios doutrinários, a refletir a variedade dos pontos de vista com que determinado fenômeno pode ser considerado. Além disso, apreender a dinâmica realidade em um quadro tipológico traz sempre o risco de falhas, por nem sempre se conseguir abarcar todas as modalidades. Não obstante tais aspectos, as classificações têm o mérito de fornecer uma visão ampla da matéria, com isso auxiliando a compreensão de suas peculiaridades.

Embora a atividade voltada à perquirição dos contornos do fato supostamente típico e ilícito e de sua autoria seja conduzida, na maioria dos casos, pelos órgãos de polícia judiciária, não há desconhecer a existência de outras esferas de investigação preliminar, todas elas também apontando, direta ou secundariamente, para o mesmo escopo de coleta de elementos aptos a fundamentar quer a acusação, quer o arquivamento, quer a decretação de medidas acautelatórias das finalidades da investigação e mesmo de um futuro processo. $\mathrm{O}$ inquérito policial constitui somente uma (embora a mais encontrada em nosso cotidiano) espécie do gênero investigação preliminar.

${ }^{252}$ Com exceção, é bom repetir, da investigação prevista no art. 33, parágrafo único, da Loman, que ainda guarda, por força de lei, a natureza judicial, muito embora destoante de nosso sistema, como se analisará no item 2.4.1.1. 
Segundo Rogério Lauria Tucci, podendo ser realizada a investigação criminal, no direito brasileiro, também por “órgãos não administrativos”, são dintinguíveis, segundo o órgão que as dirige, três espécies de investigação criminal: a administrativa, a legislativa e a judiciária ${ }^{253}$. Vemos possível ir além e, fugindo ao critério do poder estatal, classificar os diversos tipos de persecução criminal prévia em quatro gêneros, conforme a natureza do órgão/pessoa que a promove: a investigação administrativa, a investigação parlamentar, a investigação judicial e a investigação particular.

Desde logo se pontue que tal classificação não pressupõe qualquer regra de unicidade da investigação preliminar, à mingua de norma legal que discipline qual investigação deve prevalecer sobre a outra. Isso significa que as investigações são autônomas ${ }^{254}$, nas esferas de atribuição de cada órgão condutor - mormente à luz da separação de poderes estatais e da verificação de atividades investigatórias em todos eles -, mas não são estanques, podendo correr em paralelo mais de uma investigação de espécies distintas, ou até atuar de forma complementar uma em relação à outra.

Verificar-se-á duplicidade de investigações sempre que tramitarem simultaneamente, versando sobre os mesmos fatos e os mesmos imputados, duas ou mais investigações preliminares (de espécies diversas), presididas por autoridades diferentes, desde que detenham, cada uma, atribuição para tanto. Não existe, como na esfera processual, a regra da prevenção, pela qual prevalece o órgão que praticou o ato mais antigo, afastando-se os demais. Basta que, pelo conjunto de peças informativas que the chega a conhecer, materializadas ou não em inquérito policial, convença-se o titular da

253 Persecução penal, prisão e liberdade. São Paulo: Saraiva, 1980, p. 42.

${ }^{254}$ No tocante à autonomia, esclarece José Celso de Mello Filho (Investigação parlamentar estadual: as comissões especiais de inquérito. Justitia, São Paulo, v. 45, n. 121, abr./jun. 1983, p. 160): “A investigação legislativa constitui procedimento jurídico-constitucional dotado de autonomia. Conseqüentemente, a existência de investigações desenvolvidas pela autoridade policial (inquérito policial) ou mesmo a instauração de processo penal perante o Judiciário, ainda que referentes aos mesmos fatos objeto da atuação da Comissão Especial de Inquérito, não inibem e nem impedem a realização do inquérito parlamentar". No mesmo sentido, destacando a autonomia da investigação parlamentar, pontuou o Supremo Tribunal Federal: "O inquérito parlamentar, realizado por qualquer CPI, qualifica-se como procedimento jurídico-constitucional revestido de autonomia e dotado de finalidade própria, circunstância esta que permite à Comissão legislativa - sempre respeitados os limites inerentes à competência material do Poder Legislativo e observados os fatos determinados que ditaram a sua constituição - promover a pertinente investigação, ainda que os atos investigatórios possam incidir, eventualmente, sobre aspectos referentes a acontecimentos sujeitos a inquéritos policiais ou a processos judiciais que guardem conexão com o evento principal objeto da apuração congressual. Doutrina. Precedente: MS 23.639-DF, Rel. Min. Celso de Mello (Pleno).” (MS 23.652/DF, rel. Min. Celso de Mello, Plenário, v.u., DJ de 16.2.2001). 
ação penal do cometimento em tese de um delito de materialidade provada e de autoria provável, para exercitar o direito de ação ${ }^{255}$.

Nesse toar, a pendência de investigação administrativa ou mesmo de ação penal não impede o desenvolvimento da investigação parlamentar sobre os mesmos fatos, porquanto distintos são os fins institucionais colimados em cada uma das esferas ${ }^{256}$. Tem sido fenômeno, inclusive, bastante verificado na prática ${ }^{257}$. O relatório de uma investigação parlamentar, outrossim, após encaminhado ao Ministério Público para promover a responsabilização penal cabível (art. $58, \S 3 .^{\circ}$, da $\mathrm{CF}$ ), pode, senão de pronto basear uma acusação formal, dar ensejo à requisição de instalação de inquérito policial (caso ainda não exista inquérito dessa natureza em andamento), com o fim de aprofundar as apurações sobre os fatos, se não satisfatoriamente esclarecidos.

Contudo, para coibir a dupla persecução pelo mesmo fato - vedada em nosso sistema -, impõe-se que o titular da ação penal, ao tomar conhecimento da duplicação de investigações de diferentes espécies, versando sobre o mesmo fato, promova-lhes a complementaridade, seja por anexação dos autos de um inquérito parlamentar findo aos de uma investigação policial ainda em curso (quando reputar necessária a continuidade das investigações), ou vice-versa, se já formada a opinio delicti pela leitura do inquérito parlamentar, abreviando o curso do inquérito policial, mediante

255 Pelo princípio da obrigatoriedade do exercício da ação penal pública, se o Ministério Público já tem presentes todas as condições da ação penal, seja com base em inquérito policial ou peças de informação, deve propor a ação, com as peças que lhe estão disponíveis, não cabendo aguardar o encerramento do inquérito policial, a menos que ainda não formado o seu convencimento sobre o caso. A sua inércia pode provocar o exercício da ação penal privada subsidiária, quando decorridos mais de quinze dias do recebimento das peças de informação (arts. 29 c/c 39, § 5. ${ }^{\circ}$, do CPP). Se o titular da ação não vislumbra reunidas as condições para o seu exercício, restam-lhe apenas duas alternativas legais: o pedido de arquivamento das peças - caso convicto da inexistência de crime ou da impossibilidade de delimitação de autoria, ou ainda da prescrição - ou a requisição de novas diligências indispensáveis ao esclarecimento do fato (art. 16 do CPP), devendo fundamentar também a opção de aguardar o final do inquérito.

256 Jorge Ferreira lembra a exceção do direito francês (durante algum tempo acompanhada pelo direito português): se em curso processo judicial sobre os mesmos fatos, a CPI cessa suas funções. A explicação está em ser a Constituição de 1958 omissa quanto aos inquéritos parlamentares, deixando ao legislador ordinário legislar sem constrangimentos, absorvendo a influência de uma experiência histórica em que as CPIs se erigiram em tribunais de apelação de decisões dos juízes de instrução, sobretudo durante as III e IV Repúblicas (Regime jurídico dos inquéritos parlamentares. Coimbra: Almedina, 1999, p. 29-30).

257 A problemática poderá instaurar-se quando tramitarem duas investigações paralelas com a mesma finalidade precípua, integrantes do mesmo gênero (p. ex., duas investigações administrativas, com escopo principal de apuração criminal, como a investigação policial e a ministerial). Nesse cenário, Mauro Fonseca Andrade (Ministério Público..., cit., p. 276) indica que um caminho para resolver o problema das investigações paralelas com fins penais passa pela manutenção da primeira investigação que houver sido instaurada, com o conseqüente arquivamento daquela que foi instaurada a posteriori. Já René Ariel Dotti propõe que a investigação criminal seja totalmente revista, criando-se o que chama de inquérito criminal, em oposição ao inquérito civil, um procedimento investigatório único para todo o país, eliminando assim 
pedido de vista, e acoplando-o ao primeiro, para de logo ofertar a denúncia ou promover o arquivamento das peças.

Delimitemos a feição de cada uma dessas espécies de persecução prévia.

\subsubsection{Investigação administrativa}

Nesse grupo, existem diversos órgãos e entidades da Administração Pública direta e indireta que podem ser enquadrados, dando ensejo às seguintes modalidades de investigação preliminar:

\subsubsection{Inquérito policial}

O inquérito policial é o instrumento de investigação de infrações penais conduzido pela Polícia Judiciária. Conquanto não se apresente, no sistema pátrio, como a única forma de persecução preliminar estatal, afirma-se, indiscutivelmente, como a mais freqüente em nosso cotidiano, considerado por alguns como "a mais completa e eficiente das formas de investigação existente na persecutio criminis ${ }^{258}$.

No decorrer da persecução criminal extrajudicial, etapa anterior à instauração do processo, a intervenção policial é a mais freqüente, conduzidos que são os inquéritos pelas polícias civil e federal. É nessa fase preliminar que serão reunidos os elementos informativos atinentes à materialidade e à autoria delitivas, por meio de exames, vistorias, avaliações, buscas, coleta de testemunhos, declarações, etc. A colheita dos elementos que deram forma ao delito (informatio delicti) está compreendida nos trabalhos

a concorrência de apurações, o que aponta ser "fonte material de insegurança e injustiça" (O desafio da investigação criminal. Boletim IBCCrim, São Paulo, v. 12, n. 138, mai. 2004, p. 8).

258 PIMENTA BUENO, José Antônio. Apontamentos..., cit., p. 71. O autor ressalta que, por tais atributos, por ser a polícia judiciária o órgão específico da investigação criminal e estar melhor aparelhada para exames de corpo de delito e outras perícias, a investigação policial funciona, muitas vezes, como complemento de outras investigações. A questão está, contudo, longe de ser pacificada, porquanto, em outro pólo, há os que, como Édson Luís Baldan, criticam a anomia reinante na fase de investigação preliminar, classificando o inquérito policial como "o pior meio de investigação; à exceção de qualquer outro" (Investigação defensiva: o direito de defender-se provando. Revista Brasileira de Ciências Criminais, São Paulo, v. 15, n. 64, jan./fev. 2007, p. 254). 
de investigação e instrução inicial, realizados, em regra, pela Polícia Judiciária e que se materializam no inquérito policial, "embrião fático do nosso processo criminal" ${ }^{, 259}$.

Os arts. $4 .^{\circ}$ a 23 do CPP disciplinam o inquérito policial, mas não o definem. Pode-se extrair, pelo desenho imprimido no Codex, que o inquérito policial é atividade desenvolvida pela Polícia Judiciária, tocante à fase preliminar ou preparatória da ação penal, cujo objetivo é apurar as infrações penais e sua autoria, tendo por destinatário o Ministério Público ou o acusador privado, titulares da ação penal de conhecimento de natureza condenatória.

No campo doutrinário, porém, encontram-se várias tentativas de definição, valendo ressaltar, pela clareza e analiticidade, a de Sérgio Marcos de Moraes Pitombo, para quem "o inquérito policial é o procedimento administrativo, cautelar, tendente à apuração preliminar de fato que se desenha (parece) infração penal e ao menos indícios de autoria, co-autoria e participação, em tutela a direitos individuais”. É procedimento, diz o autor, pela inexistência do contraditório em toda completude do processo judicial, embora preservado o direito de defesa; administrativo, na forma e no órgão responsável pela feitura, apesar da finalidade judiciária; por ser obra da polícia civil (judiciária), instituição da administração pública; cautelar, por preservar provas que não poderiam ser repetidas durante o processo criminal; tendente à apuração preliminar de fato que se desenha (parece) infração penal e ao menos indícios de autoria, co-autoria e participação, porque não tem por finalidade última (absoluta) provar a existência desse fato e autoria, senão que, ao contrário, poderá revelar a inexistência ou impossibilidade de atribuição da autoria; e, em tutela a direitos fundamentais, porque no inquérito policial se divisam interesses do acusado, da vítima e da sociedade ${ }^{260}$.

Entre nós, a organização policial é bastante complexa e varia da esfera federal para a estadual. A Carta Republicana relaciona, no art. 144, os órgãos que exercem a segurança pública, quais sejam a polícia federal, a polícia rodoviária federal, a polícia ferroviária federal, as polícias civis, militares e os corpos de bombeiros militares. Há uma sensível divisão entre as polícias civis e militares, aquelas com atribuição de investigação criminal e estas, preponderantemente, com funções ostensivas de segurança. A atividade

${ }^{259}$ MORAES, Bismael Batista de. O inquérito policial é o vilão no direito brasileiro? Revista Brasileira de Ciências Criminais, São Paulo, v. 7, n. 28, out./dez. 1999, p. 257.

260 Trata-se de conceito transmitido em sala de aula da Faculdade do Largo de São Francisco, aos alunos do 3. ${ }^{\circ}$ ano de Graduação, período matutino, no ano de 2000, e reproduzido por Benedito Roberto Garcia 
investigativa prévia (salvante a apuração de infrações penais militares, que, pela Constituição, encontra-se nas atribuições da própria Polícia Militar) é legada às polícias civis, dirigidas por delegados de polícia de carreira, ressalvada a competência da União, cuja polícia judiciária fica a cargo de órgão próprio - a Polícia Federal.

Não obstante a investigação criminal se pratique secularmente ${ }^{261}$, a implantação do inquérito policial no Brasil deu-se na Reforma Judiciária orquestrada pela Lei 2.033, de 20 de setembro de 1871, regulamentada pelo Decreto 4.824, de 22 de novembro de $1871^{262}$. O instituto guardava forte herança do velho sistema inquisitivo lusitano, embora não fosse referido expressamente pelas Ordenações do Reino.

Pouco tempo após instituído, o inquérito policial já alimentava críticas e discussões sobre a sua manutenção ou não no Brasil. Já em 1874, o Ministro da Justiça colhia pareceres sobre a conveniência de acabar com o inquérito, e todas as respostas foram pela abolição do procedimento, inclusive com o beneplácito do então Presidente do Supremo Tribunal Federal, Joaquim Marcelino de Brito ${ }^{263}$.

Pozzer (Uma, dentre muitas, lição do professor Pitombo. Boletim IBCCrim, São Paulo, v. 11, n. 125, abr. 2003, p. 3).

${ }^{261}$ No período colonial, aplicaram-se as regras de investigação do Reino de Portugal. Na fase imperial, por muito tempo, a polícia teve a incumbência de investigar crimes, embora em algumas etapas da história os juízes de paz também a tivessem: a partir de 15 de outubro de 1827 , com a promulgação da lei que criou os juizados de paz, até o advento da Lei 261, de 3 de dezembro de 1841, que transferiu o poder dos juízes de paz para os então criados delegados de polícia. Sobre as formas de persecução criminal preliminar adotadas no direito brasileiro a partir da independência, em 1822, vide a primorosa pesquisa de Marta Saad ( $O$ direito de defesa..., cit., p. 26 e ss).

262 Joaquim Canuto Mendes de Almeida (Princípios..., cit., p. 200 e ss.), no entanto, afirma que já se encontrava um embrião do inquérito na Lei 261/1841, que passou o sumário de culpa da competência do juiz de paz para os chefes, delegados e subdelegados de polícia, permitindo-lhes assim praticar vários atos que hoje se encerram no inquérito policial. O fato é que, até o advento da Lei 2.033 e do Decreto 4.824, em 1871, que criaram a nomenclatura "inquérito policial", as autoridades policiais agiam sem qualquer regulamentação.

263 Cf. PELLEGRINO, Laércio. Substituição do inquérito pelo juizado de instrução. Revista dos Tribunais, São Paulo, v. 68, n. 527, set. 1979, p. 462. Registre-se que o inquérito policial, com tal nomenclatura, chegou a ser abolido pelo Código de Processo Penal do Distrito Federal (Decreto 16.751/1924), substituindo-o pela chamada investigação, que abrangia "os atos preliminares da ação penal". Contudo, o Decreto 5.415/1928 restabeleceu o inquérito policial (cf. PIMENTA BUENO, José Antônio. Apontamentos..., cit., p. 74). Bem antes do surgimento do atual CPP, já havia quem apregoasse o fim do inquérito policial. É o caso de Galdino Siqueira (Curso..., cit, p. 306), ao afirmar: "Effectivamente, o que se tem observado é a existência de um processo duplicado, o do inquérito e o da formação da culpa, dando, em regra, como resultado, prejuízos á causa da justiça, quer pelo tempo quer pela acção da chicana e do suborno, frequentemente vendo-se retractações de confissões ou de declarações de testemunhas, colhidas no inquerito, como expressão da verdade (...). É bem de ver que uma tal pratica não póde perdurar, assim o reclamando os interesses sociaes em jogo, dia a dia se impondo, como necessidade imperiosa a creação de juizes especiaes para a instrucção criminal". Observe-se também que na primeira redação do Anteprojeto que deu origem ao Projeto de Lei 4.209/2001 substituía, no Título II do CPP, a expressão "Do Inquérito Policial” por "Da Investigação Criminal” (cf. AMBOS, Kai; CHOUKR, Fauzi Hassan. A reforma do processo penal no Brasil e na América Latina. São Paulo: Método, 2001, p. 47). 
Em 1935, o Projeto Vicente Ráo tentou substituir o inquérito policial brasileiro pelo instituto do juizado de instrução, mantendo a atuação da polícia na forma de “diligências policiais", tese acolhida na comissão responsável pelo Anteprojeto de Código de Processo Penal, mas que não vingou. Na Exposição de Motivos do CPP de 1941, ponderou-se que a criação dos juizados de instrução, limitadores do poder policial de prender criminosos, averiguar a materialidade dos crimes e indicar testemunhas, só seria praticável sob a condição de que as distâncias dentro do seu território de jurisdição fossem fácil e rapidamente superáveis ${ }^{264}$.

O sistema (criado pelo direito gaulês e muito tempo considerado ponto intocável do processo penal) consagra a imersão do juiz já nos autos das investigações penais. A iniciativa da persecução judicial é cometida ao Ministério Fiscal, parte acusadora que exerce a ação penal e exige a aplicação da lei, tendo sob sua vigilância os atos dos oficiais e da polícia judiciária. Podem os fiscais dirigir a atividade dos oficiais da polícia judiciária, que buscarão elementos a lastrear o exercício da ação penal contra o investigado. Entretanto, na fase investigatória, escrita e sigilosa, iniciada por denúncia do Ministério Fiscal ou por querela da vítima, o juiz exerce função também de investigador, incumbindolhe reunir as provas das infrações, desvendar-lhes a autoria, instruir o processo a favor e contra o investigado, realizando as diligências pessoalmente ou com o apoio da polícia judiciária $^{265}$.

Em que pese a visível incompatibilidade entre o modelo do juizado de instrução e o sistema acusatório brasileiro, por consagrar (aquele modelo) a imersão do

${ }^{264}$ O signatário da Exposição de Motivos, Ministro Francisco Campos, não enfrentou a discussão sobre as anunciadas vantagens do juízo de instrução; apenas apontou a falta de possibilidade material de criação de um juizado de instrução em cada sede de distrito, explicando, no item IV da Exposição, que o sistema tradicional, com o inquérito preparatório, assegura uma justiça "menos aleatória, mais prudente e serena". Toledo Piza (O inquérito no processo penal brasileiro. Niterói: [s.n.], 1953, p. 19) diz que o juiz, investido das funções de investigador, encarregado de recolher as primeiras provas da infração penal, não teria a maleabilidade necessária para agir. Seria "um deslocado naquele ambiente de investigação, febricitante de dúvidas e interrogações, de pistas e caminhos tortuosos". Acrescenta que o inquérito policial pode ter, na sua feitura, defeitos e falhas graves, mas é ainda a melhor solução, entre nós, a que atende aos imperativos da nossa realidade geográfica e econômica.

${ }^{265}$ A instrução dos processos é, pois, de regra, dirigida pelo juiz de instrução, sendo a sentença prolatada por um juízo singular ou colegiado, conforme a natureza do crime. Como explica Mireille Delmas-Marty, o artigo 81.1 do Código francês garante ao juiz de instrução realizar todos os atos que considere úteis ao descobrimento da verdade, diligências que podem ser postuladas pelo Ministério Fiscal, sendo que a parte privada somente pode requerer determinados atos taxativamente enumerados (DELMAS-MARTY, Mireille. Procédures pénales d'Europe. Paris: Presses Universitaires de France, 1995, p. 253 e ss.). 
magistrado já nos autos da etapa preliminar, com amplos poderes de investigador, vez por outra ressurgem propostas de sua instalação ${ }^{266}$.

As críticas dirigidas ao inquérito policial têm pertinência no que revelam uma investigação preliminar burocratizada e anacrônica, que constitui, por muitas vezes, empeço à averiguação de fatos delituosos, sobretudo devido ao tempo despendido no desenlace da investigação, com idas e vindas ao Judiciário em busca de prorrogações de prazo, repetições infrutíferas de diligências e atos escritos envoltos em uma fórmula complexa que finda por atravancar aquela que deveria ser a etapa mais célere da persecutio.

As principais objeções estão centradas na feição inquisitorial do procedimento $^{267}$, revelada pela característica do sigilo, sendo que essa nota esmaeceu após o advento da Constituição de 1988 e seu rol de garantias, à luz do qual deve a matéria ser pautada. O dispositivo que positivou o due process of law, por exemplo, não tem aplicação restrita ao processo judicial, mas aos acusados em geral (art. 5. ${ }^{\circ}, \mathrm{LV}$, da CF). E, para darlhe validade, por evidente não se pode conviver com um sigilo absoluto das atividades e dos atos investigativos, ou mesmo com um sigilo apenas eventual, mas ditado por propósitos genéricos: um sigilo imotivado. Uma terceira objeção, igualmente resquício do modelo inquisitório, refere-se à participação, direta ou indireta, do juiz no curso do inquérito, o que se tentou superar, em parte, no plano legislativo, com o Projeto encaminhado ao Congresso Nacional em 1983, bem como se cogita, no presente, em proposta da Comissão de Reforma do CPP instalada em 2008, que estuda reservar ao

${ }^{266}$ Os Ministros do Superior Tribunal de Justiça Nilson Naves e José Arnaldo da Fonseca já fizeram coro a essas propostas: NAVES defende criação de juizado de instrução criminal para crimes de maior potencial ofensivo. Notícias do Superior Tribunal de Justiça. Disponível em: <www.stj.gov.br/webstj>. Acesso em: 2 maio 2006; FONSECA, José Arnaldo da. Juizado de Instrução Criminal. Propostas da Comissão de Altos Estudos da Justiça Federal. Brasília: CJF, Centro de Estudos Judiciários, 2002, v. 1, p. 31-43. Nesse ponto, Fauzi Hassan Choukr (Processo penal..., cit., p. 64-65) explica que os doutrinadores não apresentam um projeto exato do que seria tal juizado, por vezes confundindo o modelo em vigor na Itália, fazendo-o vincular, impropriamente, à figura do juizado de instrução, quando justamente a abolição de tal fase é considerada o grande avanço efetuado pela longa reforma a que submetido aquele país. Lá, a preparação da ação penal é feita por meio das indagini preliminari, cuja condução é própria do Ministério Público, com o apoio da Polícia Judiciária. O autor atribui a erronia à provável tradução do termo "magistrado" (os promotores italianos também fazem parte da magistratura) para "juiz".

267 Essa natureza inquisitorial, mostra-nos Antonio Scarance Fernandes, esteve presente em praticamente toda a história do processo criminal, expressando-se sobremaneira no impedimento ou restrição à participação do investigado (Teoria geral do procedimento..., cit., p. 83). Urge, todavia, rever tal característica, sobretudo diante dos contornos publicistas imprimidos pela Constituição à persecução penal. 
julgador, no inquérito policial, apenas o provimento incidental de medidas cautelares e de contracautela $^{268}$.

Do ponto de vista estrutural, o inquérito policial pode ser direcionado a cumprir satisfatoriamente a sua finalidade - demonstrar a existência ou não de fundamento razoável para o exercício da ação penal ${ }^{269}$. Ocorre que, operacionalmente, por vezes cai em disfunção, em virtude não apenas da resistência em adequá-lo ao perfil traçado na Carta Magna, mas da própria vetustez do procedimento investigativo policial tradicional, que ainda opera em reduzido âmbito da criminalidade, encontrando grande dificuldade em documentar a materialidade ou identificar agentes (e seu modus operandi) nos delitos mais complexos, como os crimes financeiros e de informática ${ }^{270}$. Ao tempo em que se sofisticam as ações criminosas, têm-se mostrado cada vez mais efetivas as investigações administrativas procedidas por outros órgãos, como o Banco Central e o COAF (Conselho de Controle de Atividades Financeiras, do Ministério da Fazenda), que muitas vezes complementam eficazmente o trabalho policial.

Parece ponto sensível da estrutura atual da persecução criminal no Brasil a ineficiência do inquérito policial. Mas uma tal verificação não autoriza a conclusão precipitada de que sua substituição se impõe, ou que deveria dar-se necessariamente pelo juizado de instrução, porque é este um instituto tão ligado ao sistema inquisitório quanto o inquérito policial na forma vigente - ou até mais, já que exclui qualquer ingerência real da defesa. Oportuno rememorar, nessa esteira, a cátedra de Frederico Marques ${ }^{271}$ :

268 O Projeto de Lei 1.655/1983, do Poder Executivo, elaborado por comissão composta, entre outros, por Rogério Lauria Tucci, ao disciplinar o inquérito policial nos arts. 213 a 224, eliminava da ordem jurídica alguns preceitos que consagravam a ingerência do juiz na atividade investigatória, resquícios do inquisitorialismo, como os constantes dos arts. 5. ${ }^{\circ}$, II, 26, 531, estes últimos já superados (Disponível em: $<$ http://www.senado.gov.br/novocpp/pdf/PL-1655-1983.pdf >. Acesso em 7 out. 2008). Já Comissão de Reforma do Código de Processo Penal criada em 5 de junho de 2008, pelo presidente do Senado Federal, Garibaldi Alves, e coordenada pelo Ministro Hamilton Carvalhido, do STJ, discute a criação, no Brasil, do Juiz de garantias, existente em outros países, o qual teria o papel de controlar as ações policiais e decretar atos como prisões preventivas, buscas e apreensões, quebras de sigilo, etc. (Disponível em: $<$ http://www.conjur.com.br/static/text/73165,1>. Acesso em: 6 jan. 2009).

${ }^{269}$ Nesse sentido: MORAES, Bismael Batista de. O inquérito policial..., cit., p. 255-264.

${ }^{270}$ Cf. HABIB, Sérgio. Brasil..., cit., p. 132-133.

${ }^{271}$ MARQUES, José Frederico. Estudos de direito processual penal. Rio de Janeiro: Forense, 1960, p. 60. João de Deus Cardoso de Mello (O inquérito policial..., cit., p. 48-52), relembrando que o direito brasileiro conhecera a figura do juiz instrutor no regime do Código de Processo Criminal do Império (em que o juiz de paz era incumbido de uma série de atos que a lei chamava de "formação da culpa", similares aos que o direito francês e o italiano denominavam de "instrução preliminar"), entende desaconselhado o sistema por três razões: "a primeira delas, a impraticabilidade. O sistema reclamaria, antes do mais, a criação da justiça criminal especializada. Sem isso, estaria fadado ao insucesso. (...) A segunda razão, a da inconveniência, decorre de imperativos da realidade nacional. (...) $\mathrm{O}$ terceiro argumento, julgo eu, liquida, 
Logo após deflagrar-se o crime, há necessidade de ação enérgica, decisiva, segura e bem orientada, não só para a descoberta do autor do delito, como ainda para a colheita e apuração dos elementos probatórios que demonstrem a prática da infração. Pensar que um magistrado togado possa, sozinho, dirigir toda essa série de pesquisas, com o ânimo sereno e imparcial que se exige na judicatura, é extrema ingenuidade ou desconhecimento completo dos fatos e fenômenos que se desenrolam na fase preambular da informatio delicti.

O desafio, portanto, é manter-se um instituto que possa garantir efetividade à investigação criminal prévia e, ao mesmo tempo, assegurar integralmente os direitos fundamentais alinhados constitucionalmente.

Também não abraçando o instituto do juizado de instrução, a Comissão instituída pela Portaria 61/2000, do Ministério da Justiça, encarregada de elaborar propostas de alteração do Código de Processo Penal, sob a presidência de Ada Pellegrini Grinover, sugeriu mudanças no inquérito policial brasileiro, de modo a adequá-lo à estrutura implementada pela Carta Republicana atual, redundanno no Projeto de Lei $4.209 / 2001$.

Percebe-se que o inquérito policial, instituto de longa tradição histórica em nosso direito, passa por crises episódicas, muito embora seja uma figura já incorporada à cultura pátria. Longe, porém, de apregoar-se a sua extinção ou a simples substituição pelos juizados de instrução (modelo este também em crise nos países que o adotaram), é de rigor que se implementem soluções pra mitigação dos seus problemas, com um esforço de adequação do nosso vetusto Código de Processo Penal ao arcabouço constitucional e de busca pelo maior equilíbrio na distribuição dos poderes dos agentes envolvidos na persecução criminal. Tais soluções passam pela maior celeridade da investigação, agilizando-se o caminhar do procedimento entre Polícia e o Ministério Público; pela simplificação dos atos do inquérito, eliminando-se o excesso de formalismo; pelo constante aperfeiçoamento técnico e formação ética dos profissionais que dela participam; pela efetiva estruturação das delegacias (sobretudo de polícia civil), pela valorização do papel da defesa e dos direitos do investigado e do ofendido, etc ${ }^{272}$.

definitivamente, o assunto. Se quisermos atribuir a instrução preliminar ao juiz, ela teria de ser, por força do dispositivo constitucional expresso, contraditória".

272 É de salientar que o Projeto de Lei 4.209/2001, na redação aprovada na Câmara dos Deputados, em 11 de dezembro de 2008, já contempla algumas dessas medidas, como o estabelecimento de que as informações no inquérito deverão ser colhidas de forma objetiva e célere, podendo os depoimentos ser tomados em qualquer local, inclusive informalmente (art. $6^{\circ}, \S 4 .^{\circ}$ ); a possibilidade de o registro das declarações e depoimentos dar-se por gravação magnética, inclusive audiovisual, sem necessidade de transcrição (art. 


\subsubsection{Inquérito policial militar}

O inquérito policial militar é a modalidade de persecução penal prévia a cargo da Polícia Judiciária Militar (art. 8..$^{\circ}$, a, do Código de Processo Penal Militar Decreto-lei 1.002, de 21.10.1969), para investigação de crimes militares, afetos à competência da Justiça Militar (art. 124 da $\mathrm{CF}^{273}$ ), quais sejam: os crimes militares, próprios ou impróprios ${ }^{274}$, os crimes contra a segurança nacional, a ordem política e social, se o agente for militar ou assemelhado, e ainda determinados crimes previstos na Lei 7.170, de $14.12 .1983^{275}$. Diferencia-se do inquérito policial civil, basicamente, pela natureza da infração apurada e pelas autoridades condutoras dos respectivos procedimentos.

Lembre-se que o Código de Processo Penal, no art. $4 .^{\circ}$, após definir a função da polícia judiciária, resguarda, no parágrafo único, a atribuição de outras autoridades administrativas a quem seja por lei cometido o mister de investigar infrações penais.

Assim, a lei processual penal castrense enumera, no art. $7 .^{\circ}$, quais as autoridades que exercem o poder de polícia judiciária militar, dentro do qual está a atribuição (art 8. $\left..^{\circ}, a\right)$ de apurar os crimes militares, bem como os que estão sujeitos à jurisdição militar, praticados por militares ou civis, submetidos à Justiça Militar da União.

6. ${ }^{\circ}, \S 5^{\circ} .^{\circ}$; a obrigação de a autoridade policial informar ao ofendido seus direitos e comunicar-lhe os principais atos do procedimento, admitindo-se inclusive o meio eletrônico (art. 14); o reforço à obrigação de as autoridades fazerem preservar a intimidade, vida privada, honra e imagem do investigado, do ofendido e das testemunhas (art. 20, parágrafo único); a possibilidade de a autoridade ordenar a realização de diligências em outra circunscrição policial, independente de requisição ou precatória (art. 22).

273 Ao contrário da Constituição de 1967, que se utilizava de critério subjetivo para fixar a competência da Justiça Militar (ligado à condição do agente, militar ou assemelhado: art. 129), a Carta de 1988 vale-se de requisito objetivo, estabelecendo, no art. 124, que compete à Justiça Castrense "processar e julgar os crimes militares definidos em lei”. Franqueou, assim, ao legislador ordinário a criação das figuras típicas dos crimes militares. O Código Penal Militar define os crimes militares, nos arts. 9. ${ }^{\circ}$ e 10.

274 Conforme Maria Lúcia Karam (Competência..., cit., p. 20-21), crimes propriamente militares são os que, não previstos na lei penal comum e tipificados na lei penal militar em razão de violação dos deveres próprios dos militares, só podem ser praticados por militar. Já os impropriamente militares são: (a) os crimes gerais ou comuns, previstos com igual definição na lei penal comum ou tipificados exclusivamente na lei penal militar, que afetem diretamente bens jurídicos das Forças Armadas; (b) os crimes praticados por militares que, previstos com igual definição na lei penal comum, envolvem violação de dever militar e (c) aqueles que, afetando diretamente bens jurídicos das forças Armadas, recebem na lei penal militar tratamento mais abrangente que na lei penal comum, criando-se tipos derivados ou de modalidade culposa não previstos na lei penal comum.

275 Cf. SAAD, Marta. $O$ direito de defesa..., cit., p. 101. A Lei 7.170/1983, que define os crimes contra a segurança nacional, a ordem política e social, estabelece, no art. 32, que "será instaurado inquérito Policial Militar se o agente for militar ou assemelhado, ou quando o crime: I - lesar patrimônio sob administração militar; II - for praticado em lugar diretamente sujeito à administração militar ou contra militar ou assemelhado em serviço; III - for praticado nas regiões alcançadas pela decretação do estado de emergência ou do estado de sítio". 
Entre elas, estão o Ministro de Estado da Defesa, os Comandantes da Marinha, do Exército e da Aeronáutica, que podem delegar tal atribuição, dentro dos limites da lei. Também a Polícia Militar dos Estados e do Distrito Federal estadual realiza inquéritos policiais militares, conduzidos por seus oficiais, nos casos de crimes militares praticados por policiais militares, sujeitos à competência da Justiça Militar Estadual (art. 125, § 4. ${ }^{\circ}$, da $\mathrm{CF})$.

Portanto, a par de atribuir-se, em caráter precípuo, às Forças Armadas e às Polícias Militares as atividades, respectivamente, de defesa da Pátria e dos poderes constitucionais (art. 142 da CF) e de polícia ostensiva e preservação da ordem pública (art. $144, \S 5 .^{\circ}$, da $\mathrm{CF}$ ), ou seja, atividades de polícia preventiva ou administrativa, também estão autorizadas a investigar os crimes de natureza militar, o que se reconhece como "atividade de polícia repressiva ou judiciária, cujo objeto tem identidade com aquele afeto à polícia civil, ou seja, de coletar indícios de autoria e prova da materialidade de um crime, de modo a oferecer, assim, ao Ministério Público, elementos mínimos de convencimento para que este, se for o caso, dê início à respectiva ação penal pública, uma vez que a própria Constituição Federal excetuou a apuração destas infrações penais do âmbito da polícia civil na parte final do $\S 4 .^{\circ}$ do art. $144^{, 276}$.

$\mathrm{Na}$ descrição do CPPM, tal modalidade de inquérito, similarmente ao inquérito policial civil, tem natureza de instrução provisória, “cuja finalidade precípua é a de ministrar elementos necessários à propositura da ação penal" (art. 9. ${ }^{\circ}$, caput). No entanto, o parágrafo único do art. 9. ${ }^{\circ}$ deixa claro que são "efetivamente instrutórios da ação penal os exames, perícias e avaliações realizados regularmente no curso do inquérito, por peritos idôneos e com obediência às formalidades previstas neste Código". Trata-se dos atos que se revestem de caráter definitivo já ao tempo do inquérito. Sobre a diferenciação entre os atos praticados na investigação preliminar, remete-se ao item 2.6 deste trabalho.

Alexandre José de Barros Leal Saraiva aponta-lhe como características: (i) a provisoriedade, por ser um procedimento destinado a apurar a existência do ilícito e sua autoria, e não aplicar uma pena; (ii) a instrumentalidade, por seu caráter propedêutico, informativo e preparatório da ação penal; (iii) a não-contraditoriedade; (iv) o sigilo, nos

${ }^{276}$ LIMA, Walberto Fernandes de. Considerações sobre a criação do $\S 2 .^{\circ}$ do art. 82 do Código de Processo Penal Militar e seus reflexos na Justiça penal comum (Lei n. ${ }^{\circ}$ 9.299/96). Revista Brasileira de Ciências Criminais, São Paulo, v. 5, n. 20, out./dez. 1997, p. 154. Reza o art. 144, § 4. o, da Constituição: “Às polícias civis, dirigidas por delegados de polícia de carreira, incumbem, ressalvada a competência da 
termos do art. 16 do CPPM, ao enunciar que "[o] inquérito é sigiloso, mas seu encarregado pode permitir que dele tome conhecimento o advogado do indiciado"; (v) a discricionariedade nas investigações, por não obedecer a um rito determinado, variando as diligências de acordo com as necessidades objetivas da investigação; (vi) e a inquisitoriedade, característica que reflete o conjunto das demais ${ }^{277}$. Nada obstante, valem aqui as mesmas observações quanto ao sigilo e à inquisitoriedade expostas em relação ao inquérito policial $^{278}$.

\subsubsection{Investigação administrativa em sentido estrito}

A investigação estritamente administrativa é a levada a efeito pelos órgãos estatais nos três níveis de Poder, tendo por objeto a apuração de ilícitos administrativos. Casualmente, pode reunir elementos que abriguem o suporte mínimo necessário a gerar uma ação penal, já que, muitas vezes, o ilícito administrativo nela apurado constitui também ilícito penal. Classificam-se tais procedimentos em disciplinares (quando visam à apuração de responsabilidade de servidores, a exemplo das sindicâncias administrativas ${ }^{279}$ ) e não-disciplinares (quando envolvem a apreciação de pedidos dos administrados, a aplicação de penalidades administrativas ou o exercício do poder regulador das agências administrativas). Devido à já demonstrada processualidade inerente aos procedimentos administrativos (sobretudo os que ostentam carga punitiva ou sancionadora) e seu maior

União, as funções de polícia judiciária e a apuração de infrações penais, exceto as militares" (grifo acrescido).

277 SARAIVA, Alexandre José de Barros Leal. Inquérito policial e auto de prisão em flagrante nos crimes militares. São Paulo: Atlas, 1999, p. 14 e ss. Contudo, o autor adita que "somente se defende o sigilo quando este for imprescindível para o desenrolar das investigações, sendo que qualquer restrição ao advogado configura ato abusivo passível de correção mediante mandado de segurança, por ferir direito líquido e certo do causídico, assegurado por lei federal" (Idem, p. 17).

${ }^{278}$ A nota do sigilo, embora traçada como regra no CPPM (diploma datado de 1969, que veio a lume em regime autoritário), não pode mais ser vista, conforme se explanou no item 1.4.6, como absoluta em qualquer espécie de investigação preliminar com fins penais, à luz dos reclamos democráticos de nossa Constituição.

${ }^{279}$ Nas ações penais instauradas para apurar crimes funcionais, o art. 513 do CPP prevê que "a queixa ou a denúncia será instruída com documentos ou justificação que façam presumir a existência do delito ou com declaração fundamentada da impossibilidade de apresentação de qualquer dessas provas", donde se infere que o inquérito policial pode, eventualmente, ser dispensado nesses casos. Assim também se conclui por interpretação a contrario sensu do verbete sumular 330 do Superior Tribunal de Justiça, que reza: "É desnecessária a resposta preliminar de que trata o artigo 514 do Código de Processo Penal, na ação penal instruída por inquérito policial”. Isso significa que, no entender do STJ, se a ação penal for instruída com inquérito policial, como de regra, será despicienda a responda preliminar; modo inverso, nos casos em que não for o inquérito a servir de base à denúncia, mas sim outras peças de informação ou justificação, a regra do art. 514 do CPP terá inteira aplicabilidade. 
realce pela doutrina administrativista, vêm-se denominando de "processos administrativos" em sentido amplo ${ }^{280}$.

Quanto ao procedimento disciplinar, pode desenvolver-se na forma de sindicância (inquérito administrativo em sentido estrito) ou de processo, sendo que este último é o que mais se aproxima do processo jurisdicional, em suas formas e garantias ${ }^{281}$. Já a sindicância, como observa Ada Pellegrini Grinover, é meio de apuração sumária, destinada a colher elementos informativos para a instauração, ou não, do processo administrativo stricto sensu, por isso freqüentemente assemelhada ao inquérito policial ou ao inquérito civil preparatório da ação civil pública ${ }^{282}$. A sindicância funciona como um procedimento preparatório e prévio à abertura do processo administrativo disciplinar, porém dispensável quando já houver elementos para a instauração deste último ${ }^{283}$.

Destaque-se, ainda, a previsão do art. 154, parágrafo único, da Lei $8.112 / 1990$, pela qual, se o relatório da sindicância concluir que a infração está capitulada como ilícito penal, a autoridade competente remeterá cópia dos autos ao Ministério Público, independentemente da imediata instauração do processo disciplinar.

${ }^{280}$ Odete Medauar (A processualidade..., cit., p. 44) conclui: “A despeito do difundido uso do termo procedimento no âmbito da atividade administrativa, mais adequada se mostra a expressão processo administrativo. A resistência ao uso do vocábulo processo no campo da Administração Pública, explicada pelo receio de confusão com o processo jurisdicional, deixa de ter consistência no momento em que se acolhe a processualidade ampla, isto é, a processualidade associada ao exercício de qualquer poder estatal".

${ }^{281}$ Cf. DINAMARCO, Cândido Rangel. A instrumentalidade..., cit., p. 65. As sanções disciplinares, como explica Fábio Medina Osório (Direito..., cit., p. 159-160), são espécies de sanções administrativas que adquirem coloração própria dentro do Direito Administrativo Sancionador. Assim como as sanções penais, são facetas do poder punitivo estatal e buscam restaurar a paz no ordenamento jurídico, reprimindo o transgressor e tutelando determinados valores sociais. Ambas se submetem a princípios constitucionais que norteiam o poder punitivo estatal. No entanto, no âmbito disciplinar, resulta mais específica a necessidade de proteção de uma ordem administrativa interna, de valores de hierarquia, subordinação, coordenação entre os funcionários públicos ou a tutela de peculiares deveres profissionais, muito mais que a preocupação com valores externos, pertencentes diretamente à coletividade.

${ }^{282}$ Do direito de defesa..., cit., p. 85. Destaca ainda a autora que, embora não tendo, em geral, caráter punitivo, a sindicância não deixa de ser processo administrativo, com a agravante de que, às vezes, por meio dela, pode-se chegar à aplicação de uma penalidade, como ocorre com alguns estatutos de funcionários públicos.

${ }^{283}$ Nesse sentido: STJ, MS 9.788/TO, rel. Min. Maria Thereza de Assis Moura, 3. ${ }^{\text {a }}$ Seção, v.u., DJ de 7.10.2008). Nos termos da Lei 8.112/1990, a sindicância é o procedimento investigativo, assegurada ampla defesa, com prazo de conclusão não excedente a trinta dias, findos os quais, se a decisão não for pelo arquivamento dos autos ou pela imposição de penalidade de advertência ou suspensão de até trinta dias, será instaurado processo administrativo disciplinar, obrigatório sempre que o ilícito praticado ensejar sanção mais grave. O processo administrativo é um instrumento apuratório mais complexo, sendo instruído pelos autos da sindicância (quando houver) e desenvolvido em três fases: a instauração, o inquérito e o julgamento. A fase do inquérito desenvolve-se sob os princípios do contraditório e da ampla defesa, facultando-se ao servidor acompanhar o processo, pessoalmente ou mediante advogado, arrolar e inquirir testemunhas, produzir provas e contraprovas, formular quesitos se houver perícia, ser ouvido ao final (cf. BANDEIRA DE MELLO, Celso Antônio. Curso..., cit., p. 296-297). 
Todas as agências reguladoras (criadas para disciplinar e controlar certas atividades, como é o caso da Agência Nacional de Energia Elétrica e a Agência Nacional de Saúde Suplementar), autarquias e órgãos da administração direta e indireta que tenham atribuição para realizar procedimentos administrativos apuratórios de fatos que constituam, ao mesmo tempo, ilícito administrativo e penal, podem produzir, nessas atividades, elementos que sirvam de base à instauração da ação penal condenatória.

O Banco Central, por exemplo, como entidade pública que tem a missão de exercer o poder de polícia no que concerne ao sistema financeiro nacional, realiza inquéritos e processos administrativos que objetivam apurar a ocorrência de ilícitos administrativos e sancionar os culpados. Assim, há os inquéritos realizados por essa autarquia em procedimentos de liquidação extrajudicial de instituições financeiras (art. 41 da Lei 6.024/1974).

Trata-se de procedimento administrativo singular, instaurado imediatamente à decretação da intervenção ou da liquidação extrajudicial, ou ao recebimento da comunicação da falência. Nele são conferidos vários poderes ao Banco Central: examinar a contabilidade, os arquivos, os documentos, os valores e mais elementos da instituição bancária; solicitar informações a qualquer autoridade ou repartição pública, ao juiz da falência, ao órgão do Ministério Público, ao síndico, ao liquidante; tomar depoimentos, para tanto solicitando o auxílio policial, se necessário; examinar os autos da falência; obter cópias de peças e certidões; examinar a contabilidade e os arquivos dos administradores e de terceiros com que a empresa houver negociado, etc. ${ }^{284}$

Além disso, os administradores podem acompanhar o inquérito, oferecer documentos e indicar diligências, ao final sendo instados a apresentar suas explicações de fato e de direito, somente ao cabo das quais o inquérito é encerrado por relatório. O prazo previsto na lei para encerramento do inquérito é de cento e vinte dias, prorrogáveis por igual, desde que constatada a absoluta necessidade (art. 40, § 2. ${ }^{\circ}$, da Lei 6.024).

Conquanto a finalidade primordial desse inquérito seja a de apurar as causas que levaram a instituição bancária à intervenção, liquidação extrajudicial ou à falência, não é possível descartar que, no curso de uma intervenção ou liquidação extrajudicial, infrações

${ }^{284}$ Cf. SIQUEIRA, Francisco J. de. O Papel do Banco Central no processo de intervenção e liquidação extrajudicial. In: SADDI, Jairo (Org.). Intervenção e liquidação extrajudicial no Sistema Financeiro Nacional: 25 anos da Lei 6.024/74. São Paulo: Textonovo, 1999, p. 103. Tais poderes restaram convalidados em julgado do STF: HC 87.167/BA, rel. Min. Gilmar Mendes, 2. ${ }^{\text {a }}$ Turma, v.u., DJ de 17.11.2006 
administrativas e mesmo ilícitos penais sejam verificados. Além disso, o mesmo fato pode consubstanciar tanto ilícito administrativo quanto ilícito penal. Nesse caso, o Banco Central - como toda autoridade pública que, no exercício de suas funções, tiver conhecimento de fato que possa configurar infração penal de iniciativa pública - deve encaminhar cópia do inquérito também ao titular da ação penal (servindo assim de notitia criminis).

E, se o Ministério Público vislumbrar nele encorpados os elementos mínimos de convicção quanto à materialidade delitiva e aos indícios de autoria, suficientes à propositura da ação penal, poderá formular a acusação ${ }^{285}$. Por outro lado, caso haja necessidade de outros elementos probatórios para complementação do acervo que lhe foi apresentado, deverá requisitar a instauração de inquérito policial.

Ora, se o inquérito policial não é peça obrigatória para a propositura da ação penal, e se, com base em notícia crime popular, o Ministério Público pode dispensar o inquérito e exercer a ação penal - o que se depreende da leitura dos arts. 12,39 , § 5. , e 46, $\S 1^{\circ}$, do Código de Processo Penal ${ }^{286}$-, com mais razão o fará baseando-se em informações prestadas por órgãos estatais. Como explana Rogério Lauria Tucci, "até mesmo agentes outros do Poder Público, que não os da Administração, e entidades privadas podem apresentar, ao órgão do Ministério Público, os elementos suficientes (e necessários) ao ajuizamento da ação penal" 287 .

Ainda no âmbito do Poder Executivo, podem-se citar os procedimentos administrativos dos órgãos do SBDC - Sistema Brasileiro de Defesa da Concorrência (Lei 8.884/1994), do SNDC - Sistema Nacional de Proteção ao Consumidor (Lei 8.078/1990), do Sisnama - Sistema Nacional do Meio Ambiente (Lei 9.065/1998), da Comissão de Valores Mobiliários, etc.

285 A Lei 6.024/1974, que dispõe sobre “a intervenção e a liquidação extrajudicial de instituições financeiras", não criminaliza condutas. Dessa tarefa se encarregou, embora com considerável distância temporal, a Lei 7.492/1986, ao definir os crimes contra o sistema financeiro nacional, fazendo inclusive menção ao liquidante como possível sujeito ativo de várias infrações penais. Antes mesmo, porém, da criminalização de delitos contra o sistema financeiro nacional, a Lei 6.024/1974 previu, no art. 41: "Decretada a intervenção da liquidação extrajudicial ou a falência de instituição financeira, o Banco Central do Brasil procederá a inquérito, a fim de apurar as causas que levaram a sociedade àquela situação e a responsabilidade de seu administradores e membros do Conselho Fiscal".

286 "Art. 12. O inquérito policial acompanhará a denúncia ou a queixa, sempre que servir de base a uma ou a outra.”; “Art. 39. (...) §5. ${ }^{\circ} \mathrm{O}$ órgão do Ministério Público dispensará o inquérito, se com a representação forem oferecidos elementos que o habilitem a promover a ação penal...”; “Art. 46. (...) § 1. ${ }^{\circ}$ Quando o Ministério Público dispensar o inquérito policial, o prazo para o oferecimento da denúncia contar-se-á da data em que tiver recebido as peças de informação ou a representação."

287 Persecução penal..., cit., p. 42. 
A Receita Federal dispõe de Escritórios de Pesquisa e Inteligência (ESPEI) em cada região físcal; o Banco Central conta com o Departamento de Combates a Ilícitos Cambiais e Financeiros (DECIF); o Conselho de Coordenação de Atividades Financeiras (COAF) realiza atividades investigatórias, atuando como órgão responsável pela coordenação de ações voltadas ao combate à lavagem de dinheiro; a Controladoria-Geral da União e a Corregedoria-Geral da União também encetam diligências investigatórias, e tantos outros órgãos e entidades de fiscalização e arrecadação do Governo coletam, em seus âmbitos de atuação, elementos informativos que podem, eventualmente, basear uma notícia-crime ou uma representação ao titular da ação penal pública.

De ressaltar-se, por fim, que em todo o âmbito da atuação administrativa, seja nos procedimentos preparatórios os nos processos propriamente ditos, o direito de defesa não pode deixar de ser assegurado ${ }^{288}$, conforme ditado, v.g., nos arts. $2 .^{\circ}$ da Lei 9.784/1999 e 156 da Lei 8.112/1990. Todos eles, porém, tal qual o inquérito policial, colhem - salvantes as provas que assumem caráter de definitividade - apenas elementos de convicção ou de informação, que podem ser contrastados em juízo, sob a garantia do contraditório.

\subsubsection{Investigação ministerial}

A investigação ministerial com fins penais é a deflagrada pelo Ministério Público, instituição que se encarta, no perfil constitucional, entre as funções essenciais à justiça. Trata-se de atividade de perfil administrativo, por não se constituir o Ministério Público num Poder estatal autônomo, malgrado sua independência institucional.

Tirante a hipótese, ulteriormente analisada, em que a própria lei atribuiu ao Ministério Público a investigação preliminar de crimes cometidos por seus membros (art. 41, parágrafo único, da Lei 8.625, de 12.2.1993, e art. 18, parágrafo único, da Lei Complementar 75, de 20.5.1993), nos demais casos, a legitimidade do Ministério Público para a investigação criminal - e a sucessiva validade dos atos investigatórios até então

${ }^{288}$ Cf. SAAD, Marta. $O$ direito de defesa..., cit., p. 116; PEREIRA, Flávia Rahal Bresser. A publicidade..., cit, p. 254. No entanto, em relação à defesa técnica, o Supremo Tribunal Federal, por meio da súmula vinculante 5, assentou que "a falta de defesa técnica por advogado no processo administrativo disciplinar não ofende a Constituição". Considerou o STF que, se devidamente garantidos os direitos à informação, à manifestação e à consideração dos argumentos manifestados, a ampla defesa foi exercida em sua plenitude, atendendo ao art. 5. ${ }^{\circ}, \mathrm{LV}$, da $\mathrm{CF}$, não importando nulidade do processo disciplinar a ausência de advogado constituído. 
perpetrados sob sua condução - é questão bastante conflituosa assim na doutrina como na jurisprudência brasileira. Tal dissídio, pela minuciosa análise que requer, não será aprofundado nos limites e objetivos deste trabalho.

Anota-se, contudo, ser possível identificar duas claras vertentes doutrinárias formadas em torno de argumentos pró e contra a investigação direta pelo Ministério Público. Apenas para situá-las, a primeira vertente sustenta que ele retira sua legitimidade para tanto não só da Constituição, que não veda tal proceder, mas de preceitos legais expressos (art. 129, I, VI e VIII, da CF; art. 26, I, da Lei 8.625/1993 e art. 8. ${ }^{\circ}$, V e VII, da Lei Complementar 75/93), acrescentando que seria um contra-senso negar ao único titular da ação penal pública a competência para encetar ele próprio diligências que lhe confiram o suporte probatório mínimo à persecução penal in judicio, máxime nos casos em que envolvidos policiais ${ }^{289}$. Contrariamente à atuação ministerial investigatória, a segunda corrente, a partir de uma interpretação conjugada dos dispositivos constitucionais dos arts. 144, IV e $\S 4 .^{\circ}$, e 129, VIII, indica caber à Polícia Judiciária, como regra geral e guardadas apenas as exceções previstas em lei, a instauração da etapa investigatória, ficando ao Ministério Público o poder de requisitar diligências e de fiscalizá-las, tudo visando à melhor formação da sua opinio delicti. Ao Ministério Público tocaria apenas provocar e supervisionar, não efetuar propriamente a investigação ${ }^{290}$.

A par das controvérsias instauradas em sede de controle difuso (aguarda-se julgamento em importante precedente no STF, o HC 84.548), a questão está pendente de desate em controle concentrado de constitucionalidade, sendo várias as ações diretas de inconstitucionalidade contra resoluções do Conselho Nacional do Ministério Público (CNMP) e de Ministérios Públicos Estaduais que regulamentaram o poder investigatório ministerial, à espera de julgamento do Supremo Tribunal Federal sobre a validade desse poder (p. ex., ADIs 3301, 3309, 3317, 3318, 3329, 3584 e 3724). A expectativa, inclusive, é de que o Tribunal julgue diretamente o mérito das ações, sem apreciar-lhes os pedidos de

289 Assim: FONTES, Paulo Gustavo Guedes. Investigação criminal pelo Ministério Público: discussão dos principais argumentos em contrário. Boletim dos Procuradores da República, São Paulo, ano VII, n. 69, jan. 2006; FELDENS, Luciano; SCHMIDT, Andrei Zenkner. Investigação criminal e ação penal. 2. ed. rev., atual. e ampl. Porto Alegre: Livraria dos Advogados, 2007, p. 58-62; LIMA, Marcellus Polastri. Ministério Público..., cit.

${ }^{290}$ Cf.: TUCCI, Rogério Lauria. Ministério Público e investigação criminal. São Paulo: Revista dos Tribunais, 2004; FERNANDES, Antonio Scarance. Processo penal constitucional, cit.; MORAES, Maurício Zanoide. Esgrimando com o Professor Sérgio Marcos de Moraes Pitombo: os inexistentes poderes investigatórios criminais do Ministério Público. Revista do Advogado, São Paulo, v. 24, n. 78, p. 67-74, set. 2004. 
liminar, ante o decurso de já vasto prazo desde seu ajuizamento e por assim permitir o art. 12 da Lei 9.868/1999, dada a relevância da matéria envolvida.

No bojo da polêmica, há que se atentar, como faz Aury Lopes $\mathrm{Jr}^{291}$, que mais importante do que decidir quem vai fazer a inquisição (MP ou Polícia) é definir como será ela feita, estando a questão mais centrada nos limites do poder investigatório do Ministério Público que propriamente na sua legitimidade para a investigação.

\subsubsection{Investigação parlamentar}

Também no âmbito do Poder Legislativo encontram-se normas que atribuem a determinadas autoridades a condução de investigações que podem assumir, eventualmente, finalidade criminal. Em primeiro lugar, há de referir a existência de um específico inquérito parlamentar com fins penais, aquele atinente aos delitos praticados nas dependências da Câmara dos Deputados ou do Senado Federal, cuja realização é cometida a essas Casas, nos termos dos respectivos regimentos e do verbete sumular 397 do STF ${ }^{292}$.

Em segundo lugar e com maior incidência prática, o Parlamento também atua investigando mediante a instituição de Comissões Parlamentares de Inquérito, cujo objetivo é apurar, de forma ampla, fatos relacionados ao exercício das funções desempenhadas pelos seus integrantes.

291 Sistemas..., cit., p. xxxii.

${ }^{292}$ Referido enunciado sumular dispõe: "O poder de polícia da Câmara dos Deputados e do Senado Federal, em caso de crime cometido nas suas dependências, compreende, consoante o regimento, a prisão em flagrante do acusado e a realização do inquérito". Foi aprovado na sessão plenária de 3 de abril de 1964, tendo como precedentes julgados que versaram sobre episódio em que dois senadores trocaram disparos de armas de fogo dentro do Senado Federal, culminando com o óbito de um terceiro senador. O Regimento Interno da Câmara dos Deputados traz correlata previsão: “Art. 269. Quando, nos edifícios da Câmara, for cometido algum delito, instaurar-se-á inquérito a ser presidido pelo diretor de serviços de segurança ou, se o indiciado ou o preso for membro da Casa, pelo Corregedor ou Corregedor substituto". Já o Regimento Interno do Senado Federal não contempla tal atribuição para a polícia legislativa. Cremos ser possível a lavratura do flagrante pela autoridade na presença de quem for cometida uma infração penal (como, aliás, dispõe o art. 307 do CPP), o que já basta para resguardar o Poder Legislativo de qualquer atentado, em nome de sua independência; não, contudo, a realização do inquérito, que deveria ficaria a cargo da Polícia Judiciária, provocada pela autoridade que efetuou a prisão. A súmula 397 do STF, portanto, merece ser revista, ao menos no que diz com "a realização do inquérito". Como referência mais recente, consta em nota pública da Câmara dos Deputados haver sido instaurado inquérito pela Câmara dos Deputados no episódio de invasão daquela Casa por manifestantes do Movimento de Libertação dos Sem Terra (MLST), em 6 de junho de 2006, inquérito que foi, em seguida, transferido à Polícia Federal, a pedido do Ministério Público Federal (Disponível em: $<$ http://www2.camara.gov.br/homeagencia/materias.html?pk=90252>. Acesso em: 8 jan. 2009). 
$\mathrm{O}$ inquérito parlamentar constitui espécie de informatio delicti de origem inglesa, provavelmente remontando ao século XVI, ampliando-se depois de 1688, quando o Parlamento assumiu a supremacia, passando daí para os Estados Unidos, França, Alemanha, Áustria e Brasil ${ }^{293}$.

O poder de investigar constitui uma das principais funções institucionais do Poder Legislativo, permitindo-lhe, nos três níveis (federal, estadual e municipal), exercer um efetivo controle e fiscalização sobre as pessoas, instituições e órgãos sujeitos a sua competência normativa, nos aspectos político-administrativo, financeiro e orçamentário ${ }^{294}$.

Segundo Nelson de Souza Sampaio, a investigação parlamentar não se apresenta como uma tarefa isolada do Poder Legislativo, mas consiste em reflexo ou sucedâneo de cada uma das demais funções que lhe são próprias, como as de legislar, organizar seus próprios serviços, processar e julgar crimes de responsabilidade, controlar a administração e o governo, servir de fórum de opinião pública, etc. $\mathrm{O}$ "poder de inquérito" surge como um mecanismo auxiliar para que o parlamento possa cumprir as suas finalidades, independente de consagração em texto legal ${ }^{295}$.

Afora o sobredito inquérito com finalidade penal (súmula 397/STF), são três as espécies de inquérito parlamentar, ainda na lição do mencionado autor: o administrativo (destinado a apurar a responsabilidade dos seus funcionários, já englobado, portanto, no item anterior ${ }^{296}$ ), o judicial (representado tipicamente pelo inquérito que instrui os processos de impeachment) e o parlamentar propriamente dito, que não tem natureza administrativa nem judicial, sendo realizado pelas comissões parlamentares de inquérito e

293 Cf. TUCCI, Rogério Lauria. Persecução penal..., cit., p. 55. Por sua vez, Caio Tácito (Comissão Parlamentar de Inquérito - requisição de informações - sigilo bancário. (parecer). Revista de Direito Administrativo, Rio de Janeiro, v. 208, abr./jun. 1997, p. 400) indica haverem sido inspiradas em precedente histórico da Câmara dos Comuns, em 1614.

294 Cf. MELLO FILHO, José Celso de. Investigação parlamentar estadual..., cit., p. 155.

295 SAMPAIO, Nelson de Souza. Do inquérito parlamentar. Rio de Janeiro: Fundação Getulio Vargas, 1964, p. 2-3. Constitui-se, portanto, numa competência auxiliar ou instrumental às legítimas tarefas do Congresso. Nas palavras de Gustavo Henrique Righi Ivahy Badaró (Limites aos poderes das comissões parlamentares de inquérito. Boletim IBCCrim, São Paulo, v. 7, n. 83 (esp.), out. 1999, p. 11), o poder de investigar é inerente ao poder de legislar, essencial para que o Legislativo possa bem desenvolver suas atividades.

296 Veja-se, por exemplo, a investigação de caráter disciplinar prevista no art. 25 do Regimento Interno do Senado Federal: "Art. 25. Se algum Senador praticar, dentro do edifício do Senado, ato incompatível com o decoro parlamentar ou com a compostura pessoal, a Mesa dele conhecerá e abrirá inquérito, submetendo o caso ao Plenário, que deliberará em sessão secreta, no prazo improrrogável de dez dias úteis”. 
bastante utilizado "para o fim de controlar o Executivo ou influir sobre a opinião pública" ${ }^{297}$.

Essa última modalidade de inquérito, entre nós, veio prevista nas Constituições de 1934 (art. 36), 1946 (art. 53), 1967/1969 (arts. 39 e 37) e, atualmente, é afirmada no art. 58, § 3. ${ }^{\circ}$, da Constituição da República ${ }^{298}$ como um importante meio de investigação a cargo do Parlamento, para apurar fatos determinados, sempre que preenchidos os seus requisitos. É incumbência do presidente de cada Casa legislativa viabilizar a composição das CPIs.

O inquérito parlamentar regula-se pelas Leis 1.579, de 18.3.1952, e 10.001, de 8.5.2000 299 , e pelos regimentos internos da Câmara dos Deputados e do Senado Federal. Esclarece Juliana Belloque ${ }^{300}$ ter ele relevante função instrumental, porque voltado ao bom desempenho da função precípua do parlamento, ao permitir a percepção de fatos que devem ser levados em consideração ao legislar, além de servir de controle sobre os demais Poderes e negócios públicos.

Os fins das investigações parlamentares não podem afastar-se dos fins do Poder Legislativo. Mas seu caráter eminentemente parlamentar, destinado à sindicância de atos do governo, não obsta venha servir, eventual e secundariamente, para subsidiar a persecução criminal, na medida em que as conclusões da investigação são encaminhadas ao Ministério Público, que poderá, com base nelas, promover, de logo, a ação penal. Funciona, assim, como mais uma forma de investigação preliminar que pode ter reflexos na seara penal ${ }^{301}$.

${ }^{297}$ Do inquérito parlamentar, cit., p. 4-5. Note-se que o autor não incluiu, em sua classificação, aquele inquérito peculiar, inicialmente referido.

298 “Art. 58 (...) § 3..$^{\circ}$ As comissões parlamentares de inquérito, que terão poderes de investigação próprios das autoridades judiciais, além de outros previstos nos regimentos das respectivas Casas, serão criadas pela Câmara dos Deputados e pelo Senado Federal, em conjunto ou separadamente, mediante requerimento de um terço de seus membros, para a apuração de fato determinado e por prazo certo, sendo suas conclusões, se for o caso, encaminhadas ao Ministério Público, para que promova a responsabilidade civil ou criminal dos infratores."

${ }^{299}$ A Lei 11.001/2000 instituiu a prioridade dos processos ou procedimentos instaurados em função das conclusões da CPI sobre os demais, exceto os de habeas corpus, habeas data e mandado de segurança.

${ }^{300}$ BELLOQUE, Juliana Garcia. Sigilo bancário: análise crítica da LC 105/2001. São Paulo: Revista dos Tribunais, p. 146-147.

301 Segundo observa Rogério Lauria Tucci (Persecução penal..., cit., p. 56), ostentando tal inquérito "caráter investigatório e informativo, não abrange, a atuação do órgão dele encarregado, certamente, a classificação de infrações apuradas, nem a formulação de acusação pelos crimes elucidados". No entanto, existe o dever de encaminhamento do relatório final da comissão ao Ministério Público, que, como ressalta Juliana Garcia Belloque (Sigilo bancário..., cit., p. 149), é eventual, surgindo apenas "quando emergentes nos trabalhos da comissão elementos que demonstrem a prática de ilícitos penais ou civis, lembrando que qualquer exercente de função pública tem o dever de comunicar à autoridade o conhecimento da prática de crime de ação penal de iniciativa pública". 
Para o bom desempenho de suas funções - precipuamente investigativas -, são as CPIs investidas do poder de decretar algumas medidas cautelares de natureza penal, como vem decidindo o Supremo Tribunal Federal ${ }^{302}$. A reflexão sobre os poderes exercidos pelas comissões, sua extensão e seus limites, é, sem dúvida, o que de mais instigante há nessa temática, na medida em que a Constituição da República, no art. 58, § 3. , lhes atribui "poderes de investigação próprios das autoridades judiciais".

Apesar de existir, a nosso ver, uma imperfeição técnica na atribuição de poderes que o juiz não detém em nosso sistema (o dispositivo foi reproduzido do texto da Constituição Portuguesa de $1976^{303}$, que à época de sua promulgação adotava o sistema dos juizados de instrução, no qual exerce, sim, o juiz poderes investigatórios) ${ }^{304}$, ficou claro, pela redação do sobredito $\S 3 .^{\circ}$, que suas investigações podem servir para que o Ministério Público promova a responsabilização criminal dos infratores.

Os poderes de investigação da comissão parlamentar de inquérito abrangem todos aqueles que autoridades policiais e outras responsáveis por apurações prévias (não as judiciais, repita-se) detêm ao presidir uma investigação. Isso significa que, "em vista da limitação dos poderes da Comissão Parlamentar aos de uma autoridade policial quando determinado direito fundamental está em jogo, tal como a liberdade ou a privacidade,

${ }^{302}$ Tornou-se parâmetro dessa postura o seguinte julgado: "O sigilo bancário, o sigilo fiscal e o sigilo telefônico (sigilo este que incide sobre os dados/registros telefônicos e que não se identifica com a inviolabilidade das comunicações telefônicas) - ainda que representem projeções específicas do direito à intimidade, fundado no art. 5. ${ }^{\circ}, \mathrm{X}$, da Carta Política - não se revelam oponíveis, em nosso sistema jurídico, às Comissões Parlamentares de Inquérito, eis que o ato que lhes decreta a quebra traduz natural derivação dos poderes de investigação que foram conferidos, pela própria Constituição da República, aos órgãos de investigação parlamentar. As Comissões Parlamentares de Inquérito, no entanto, para decretarem, legitimamente, por autoridade própria, a quebra do sigilo bancário, do sigilo fiscal e/ou do sigilo telefônico, relativamente a pessoas por elas investigadas, devem demonstrar, a partir de meros indícios, a existência concreta de causa provável que legitime a medida excepcional (ruptura da esfera de intimidade de quem se acha sob investigação), justificando a necessidade de sua efetivação no procedimento de ampla investigação dos fatos determinados que deram causa à instauração do inquérito parlamentar, sem prejuízo de ulterior controle jurisdicional dos atos em referência (CF, art. 5. $\left.{ }^{\circ}, \mathrm{XXXV}\right)$." (MS 23.452/RJ, rel. Min. Celso de Mello, Plenário, DJ de 12.5.2000). Mais recentemente, vale conferir, entre outros: ACO 730/RJ, rel. Min. Joaquim Barbosa, DJ de 11.11.2005; e MS 24.217/DF, rel. Min. Maurício Corrêa, DJ de 18.10.2002.

303 “Art. 178.5. As comissões parlamentares de inquérito gozam de poderes de investigação próprios das autoridades judiciais." [Constituição da República Portuguesa].

304 Gustavo Henrique Righi Ivahy Badaró interpreta a cláusula por outro ângulo. Diz que, certamente, não houve total equiparação dos poderes das CPIs às autoridades judiciais, pois que estas não praticam apenas atos de investigação. No processo penal, utilizado como referência para os poderes das comissões, quem realiza tal atividade é, em princípio, a autoridade policial, sem embargo de que os juízes, no exercício da função jurisdicional, tenham poderes de determinar a produção de provas, para instrução do processo. "Estes poderes, e somente estes poderes, é que foram conferidos às comissões de inquérito. As comissões de inquérito, portanto, não dispõem de todos os poderes de que são investidas as autoridades judiciais, mas apenas dos seus poderes instrutórios" (Limites aos poderes..., cit., p. 12). 
somente a autoridade judicial poderá autorizar a sua restrição, explicitando os motivos e os fundamentos da medida"305.

A Lei 1.579/1952, no art. 2. ${ }^{\circ}$, enumera, exemplificativamente, como inerentes à atividade investigativa parlamentar os poderes de colher depoimentos, ouvir indiciados, inquirir testemunhas, notificando-as a comparecimento, requisitar informações e documentos de repartições públicas, requerer a convocação de ministros de Estado, entre outros meios de investigação legalmente admitidos.

Mas a sua atribuição investigatória encontra limites na Constituição e nas leis. Pela análise do texto constitucional, da doutrina e da jurisprudência sobre o assunto, Gustavo Henrique Righi Ivahy Badaró sintetiza esses limites em cinco níveis: limites quanto ao objeto; limites temporais; limites quanto ao âmbito de atuação; limites quanto aos meios investigatórios utilizados e limites formais ${ }^{306}$.

Sob outra ótica, pode-se dizer que constituem limitações aos poderes conferidos às CPIs a colegialidade, o prazo certo de duração, a apuração de fato determinado, o propósito legislativo válido e a reserva de jurisdição ${ }^{307}$. Foram-se delineando, assim como o estatuto geral da CPI, pelos julgados do Supremo Tribunal Federal, a quem compete julgar, originariamente (art. 102, I, $d$ e $i$, da CF), os mandados de segurança e os habeas corpus contra comissões instauradas no âmbito do Congresso Nacional ou de suas Casas, por se tratar de mera projeção orgânica do Poder Legislativo da União. São esses, aliás, os remédios jurídicos disponíveis ao cidadão para defender-se de qualquer abuso de poder exercido pelas comissões de inquérito.

A colegialidade, que norteia as deliberações de qualquer comissão parlamentar, impera assim na criação da CPI - a depender de quorum qualificado de um

305 SAAD, Marta. $O$ direito de defesa ..., cit., p. 120-121, grifo acrescido. Em igual diretiva, Luciano Feldens e Andrei Zenkner Schmidt (Investigação criminal..., cit, p. 66): “A CPI tem autonomia para praticar atos de investigação, independentemente de prévia autorização do Poder Judiciário, naqueles casos em que o ato poderia ser praticado por outros titulares de investigações (a polícia judiciária, por exemplo) independentemente da mesma autorização. Daí a legitimidade, por exemplo, para determinar-se a condução coercitiva de uma testemunha".

306 Registra o autor que os limites de atuação das comissões parlamentares precisam ser muito bem definidos, pois elas podem ter notável influência na vida política de um país, como ocorreu na história recente brasileira (Limites aos poderes..., cit., p. 11-12).

307 Cf. LACAVA, Thaís Aroca Datcho. O sigilo nas Comissões Parlamentares de Inquérito e as garantias individuais. In: FERNANDES, Antonio Scarance; MORAES, Maurício Zanoide de; ALMEIDA, José Raul Gavião de (Coord.). Sigilo no processo penal: eficiência e garantismo. São Paulo: Revista dos Tribunais, 2008, p. 119-127. 
terço dos membros da Casa legislativa ${ }^{308}$ - como na tomada de suas decisões, notadamente quanto às medidas restritivas de direitos que lhe são reconhecidas, que somente podem ser adotadas por aprovação da maioria absoluta dos parlamentares ${ }^{309}$.

Além do quorum qualificado para instalação, há muito acompanha as CPIs a regra do prazo certo de duração. Comissões transitórias que são, devem concluir seus trabalhos dentro do prazo adrede constante do requerimento de sua instalação. Uma vez encerrado tal lapso, é admitida a prorrogação por decisão plenária, tendo sempre, porém, como termo final o encerramento da legislatura em que instituída a comissão (art. 5. ${ }^{\circ}, \S 2 .^{\circ}$, da Lei $1.579 / 1952)^{310}$.

Outrossim, por exigência constitucional, as CPIs são instaladas para apurar fatos determinados ${ }^{311}$ e individualizados, ainda que múltiplos, em tese ilícitos e de interesse público (exigência implícita no art. 58 da CF), limitação esta compatível inclusive com a amplitude dos instrumentos e dos poderes coercitivos de que dispõem. A limitação do objeto opera no plano horizontal, quanto a sua extensão, não no plano vertical, em que tudo que se relacione direta ou indiretamente ao fato originário da comissão deve ser amplamente investigado. Funciona como barreira negativa à sua atividade investigativa, impedindo que haja alteração superveniente do mandato da comissão. A especificidade investigatória da CPI vai balizar todas as medidas adotadas no inquérito, do início ao fim,

308 A instauração do inquérito é feita desde que requerida por um terço dos membros da Câmara ou do Senado, independentemente de votação. Assim, o Regimento Interno do Senado Federal estabelece que a criação de comissão parlamentar de inquérito será feita mediante o requerimento de um terço de seus membros (art. 145). Uma vez que o requerimento atenda a todos os requisitos da instalação da comissão (descrição do fato apurado, do número de membros, do prazo de duração e do limite das despesas), há o dever de criá-la, não cabendo falar em submeter o pleito ao Plenário da Casa.

309 Assim ficou expresso no julgamento do MS 23.669/DF, pelo STF (rel. Min. Celso de Mello, DJU de 17.4.2000), sendo também extraído da leitura do art. $4 .^{\circ}, \S 2 .^{\circ}$, da Lei Complementar 105/2001: “As solicitações de que trata este artigo [requisição de informações e documentos sigilosos diretamente das instituições financeiras ou por meio do Banco Central ou da Comissão de Valores Mobiliário] deverão ser previamente aprovadas pelo Plenário da Câmara dos Deputados, do Senado Federal, ou do plenário de suas respectivas comissões parlamentares de inquérito".

310 "A duração do inquérito parlamentar (...) é um dos pontos de tensão dialética entre a CPI e os direitos individuais, cuja solução, pela limitação temporal do funcionamento do órgão, antes se deve entender matéria apropriada a lei do que aos regimentos: donde, a recepção do art. $5 .^{\circ}, \S 2 .^{\circ}$, da Lei 1.579/52, que situa, no termo final de legislatura em que constituída, o limite intransponível de duração, ao qual, com ou sem prorrogação do prazo inicialmente fixado, se há de restringir a atividade de qualquer comissão parlamentar de inquérito.” (HC 71.261/RJ, rel. Min. Sepúlveda Pertence, Plenário, v.u., DJ de 24.6.1994.

311 Nesse ponto, Thaís Aroca Datcho Lacava (O sigilo..., cit., p. 120) ressalta que "as comissões parlamentares não são dotadas de poderes tão grandes para investigar 'hipóteses' desvinculadas da ocorrência real de fatos determinados. Se assim fosse, as comissões poderiam investigar qualquer coisa, porque tudo cabe dentro de hipóteses. Vejamos, nesse sentido, alguns exemplos de CPIs que versaram sobre hipóteses, e que, por sua generalidade, são freqüentemente apontadas como CPIs descabidas: a CPI da Prostituição Infantil, a CPI do Sistema Penitenciário, a CPI da Pistolagem, etc. Tais CPIs apenas 
mostrando-se indispensável, no dizer de Caio Tácito, o "nexo causal entre a finalidade de sua criação e a pertinência dos depoimentos, diligências ou requisição de documentos que se destinam a compor a prova no procedimento" a ela atribuído ${ }^{312}$.

Como se afirmou inicialmente, o inquérito parlamentar possui caráter instrumental e auxiliar da função principal do Parlamento (qual seja, a legiferante), de modo que a investigação não é uma atividade substancialmente autônoma ou fiscalizatória em sentido amplo, mas deve estar sempre atrelada a um propósito legislativo válido, inserido na esfera de competência legislativa do órgão que a instaurar, não se dirigindo, portanto, a assuntos que são de exclusiva competência de outro órgão de soberania, nem à esfera privada do cidadão, a menos que possuam uma ligação inextricável com os interesses públicos ${ }^{313}$.

Por fim, expressivas limitações aos poderes inerentes às comissões parlamentares de inquérito são a reserva de jurisdição e os demais princípios vinculativos de qualquer procedimento administrativo estatal, entre os quais exsurge o limite formal da motivação de suas decisões, sob pena de nulidade ${ }^{314}$. Já se viu que a reserva de jurisdição, no aspecto relativo, significa o poder de o Judiciário dar a "última palavra" em qualquer caso e, no aspecto absoluto, envolve a garantia de que o Poder Judiciário seja chamado a dar a "primeira palavra" nos episódios de tensão envolvendo direitos fundamentais individuais, muitos deles expressamente detalhados na Constituição (mediante as expressões “por ordem judicial” ou "por determinação judicial").

Não podem as CPIs, portanto, investir com medidas cautelares contra a liberdade e o patrimônio dos indivíduos sem o necessário e prévio controle jurisdicional. Seus poderes encontram limites nos direitos fundamentais do cidadão, como os da inviolabilidade do domicílio, do sigilo de correspondência, etc.

cumprem um papel político, revelando à população uma simbólica 'atuação' do governo para combater os principais males que assolam a sociedade".

312 Comissão Parlamentar de Inquérito..., cit., p. 401.

313 Cf. CANOTILHO, José Joaquim Gomes. Direito constitucional..., cit., p. 637.

314 Como ressaltam Alberto Silva Franco e Maurício Zanoide de Moraes (Dos princípios..., cit., p. 989), as Comissões Parlamentares de Inquérito, "por decorrência constitucional (art. 58, $\S 3 .^{\circ}$, da $\mathrm{CF}$ ), ao receberem os poderes jurisdicionais de investigação, devem, também, receber os encargos e atribuições dispostos pela Constituição aos órgãos judiciários, dentre os quais se insere o dever de motivar suas decisões (art. 93, inc. IX, CF)". Nesse sentido, o Supremo Tribunal Federal decidiu: "Sem definir-se a competência, em face da dispersão de votos quanto aos fundamentos da concessão da segurança, todo e qualquer ato a alcançar interesses de pessoas naturais e jurídicas há de fazer-se devidamente fundamentado, pouco importando a natureza política do órgão que o implemente. Formalidade enquadrável como essencial no que viabilizadora do exercício do lídimo direito de defesa." (MS 23.454/DF, rel. Min. Marco Aurélio, Plenário, v.u., DJ de 23.4.2004). 
A despeito dessa limitação, vem-se desenhando na jurisprudência ${ }^{315} \mathrm{e}$ também na legislação infraconstitucional (Lei Complementar 105/2001) um paradoxal espectro de atribuições da CPI abrangente da quebra dos sigilos bancário ${ }^{316}$, fiscal e telefônico (este último restrito aos dados ou registros telefônicos). Nessas medidas, assim excluídas da cláusula de reserva absoluta de jurisdição na investigação parlamentar, não dependeriam as comissões de prévia autorização judicial, bastando o cumprimento dos requisitos da motivação concreta, aprovação da maioria absoluta dos membros da comissão, pertinência e necessidade da medida em relação aos fatos constitutivos da investigação ${ }^{317}$.

Por outro lado, não escapam as Comissões Parlamentares, como de resto nenhuma autoridade condutora de procedimentos investigatórios, ao dever de preservar os direitos e garantias individuais, assegurando o direito ao silêncio das pessoas que nelas prestarem depoimento, no que possam produzir a auto-incriminação ${ }^{318}$, e o direito de se fazerem assistir por advogado, relembrando-se que a incidência do due process of law é expansiva a todos os procedimentos estatais.

Quanto ao regime em que transcorrem os trabalhos da CPI, em regra, as suas reuniões são amplamente públicas, como as sessões parlamentares em geral, até para

315 Ver precedentes referidos na nota 302, pelos quais o Supremo Tribunal Federal tem interpretado que a reserva de jurisdição só existe nos casos em que assim determina explicitamente o próprio texto constitucional.

316 Quanto ao sigilo financeiro, de que é espécie o sigilo bancário, a Lei 4.595/1964 permitiu, no art. 38, § $3 .^{\circ}$, o acesso das CPIs (apenas as federais, não as estaduais), mediante requisição, às informações das instituições financeiras, não distinguindo entre públicas e privadas. O preceito foi revogado pela Lei Complementar 105/2001, que manteve a obrigação de sigilo pelas instituições financeiras, porém alargou as hipóteses de quebra, ampliando as exceções ao sigilo, permanecendo a obrigação de fornecimento de informações sigilosas ao Poder Legislativo Federal (art. 4. $^{\circ}$ ). A constitucionalidade de tal diploma encontra-se pendente de solução, há vários anos, no Supremo Tribunal Federal, onde tramitam as ADIs 2.386, 2.389, 2.390, 2.397 e 2.406. A julgar pelos precedentes já citados em relação aos poderes das CPIs, é possível que o Excelso Pretório convalide tais poderes, conferindo caráter meramente relativo à reserva de jurisdição em casos tais.

317 Contra a outorga de tais poderes, Flávia Rahal Bresser Pereira (A publicidade..., cit., p. 225): "Inaceitável, de outro lado, que o parlamentar presidente da comissão venha a ter mais poderes do que aqueles atribuídos ao presidente do inquérito policial, autoridade (essa sim), que possui a função precípua de investigar”. Também: Juliana Garcia Belloque (Sigilo bancário..., cit., p. 181) e Thaís Aroca Datcho Lacava (O sigilo..., cit., p. 134): "Dado o caráter eminentemente político da atividade investigatória das CPIs, não se pode admitir que estas venham a ter a primeira palavra quanto à lesão de direitos fundamentais, como é o caso da quebra do sigilo bancário, da quebra do sigilo telefônico, da busca e apreensão etc. Pela própria natureza das matérias relativas aos direitos fundamentais, entende-se que deve haver uma reserva de apreciação pelo Poder Judiciário".

318 Pois, se é de incriminação que se trata, nenhuma pessoa é obrigada a depor contra si, nem a fornecer à autoridade papéis ou documentos em que a autoridade suspeite esteja comprovada a incriminação (cf. MELLO FILHO, José Celso de. Investigação parlamentar estadual..., cit., p. 157). 
controle da população, dada a sua natureza política ${ }^{319}$. O sigilo somente será aplicado de forma excepcional, se fundado em interesses de relevância, que justifiquem afastar o acesso do povo ao seu funcionamento. O sistema francês é o único caso de secretismo total no funcionamento das comissões de inquérito, proibindo-se qualquer divulgação até a conclusão do relatório final ${ }^{320}$.

Nelson de Souza Sampaio adverte quanto ao perigo de a publicidade desvirtuar os fins da comissão, pois seus membros "são mais facilmente tentados a desempenhar o papel de grandes inquisidores, sequiosos de manchetes. Acobertados com as imunidades parlamentares, não vacilariam em cortejar a opinião pública, à custa do atassalhamento da reputação alheia". No entanto, o mesmo doutrinador lembra que o inquérito parlamentar muitas vezes só alcança seu objetivo quando mobiliza, com presteza, a opinião pública, entendendo que o meio-termo seria a melhor solução: a regra da publicidade, conferindo à maioria da comissão o direito de decidir o contrário, podando-lhe os excessos, especialmente o televisionamento que não visa senão fins midiáticos, estranhos aos objetivos da comissão ${ }^{321}$.

A possibilidade de os membros da comissão terem acesso a documentos relativos a dados bancários e fiscais não os autoriza a divulgá-los ${ }^{322}$. O sigilo que recobre tais informações, quando lhes são transmitidas, estende-se aos membros integrantes da Comissão, criando-lhes o dever de preservá-lo. Com esse propósito, existe, no direito português, salutar medida inserida na Lei regulamentadora das comissões (Lei 5/1993):

319 A publicidade das sessões das CPIs é diretriz que ficou assentada no julgamento do MS-MC 24.832/DF, rel. Min. Cezar Peluso, Plenário, por maioria, DJ de 18.8.2006. Noutro precedente, agora monocrático, ao apreciar a medida cautelar no MS 25.832-DF (DJ de 20.2.2006), em que o impetrante pretendia a interdição de uso, por membros de CPI, de dados sigilosos a que tiveram acesso, além da vedação do acesso da imprensa e de pessoas estranhas à inquirição do impetrante na Comissão, o relator, Min. Celso de Mello, deixou claro não ser dado ao Poder Judiciário restringir a publicidade do ato de investigação, determinando sessão reservada de inquirição, sob pena de inaceitável censura judicial. Destacou que "[o] novo estatuto político brasileiro - que rejeita o poder que oculta e que não tolera o poder que se oculta consagrou a publicidade dos atos e das atividades estatais como expressivo valor constitucional, incluindo-o, tal a magnitude desse postulado, no rol dos direitos, das garantias e das liberdades fundamentais, como o reconheceu, em julgamento plenário, o Supremo Tribunal Federal (...). Impende assinalar, ainda, que o direito de acesso às informações de interesse coletivo ou geral - a que fazem jus os cidadãos e, também, os meios de comunicação social - qualifica-se como instrumento viabilizador do exercício da fiscalização social a que estão sujeitos os atos do poder público".

320 FERREIRA, Jorge. Regime jurídico..., cit., p. 29.

321 Do inquérito parlamentar, cit., p. 43-44.

322 Em manifesto contra os excessos das CPIs, David Teixeira de Azevedo é enfático: “Tem-se assistido aos mais formidáveis desvarios nos trabalhos desenvolvidos pelas CPIs, que avançam sobre documentos revestidos de sigilo e dão-lhe publicidade as escâncaras, como na 'CPI do Sistema Financeiro'. Caminhando e progredindo na falta de metro, pretende-se chamar a depor até mesmo os advogados 
"Art. 12.4. O deputado que violar o dever de sigilo em relação aos trabalhos da comissão de inquérito (...) perde a qualidade de membro da comissão". Além disso, é prevista uma investigação sumária pela comissão, que, por maioria de dois terços, delibera se houve violação e quem foi seu autor, informando-o ao presidente da Casa para que aplique a sanção ${ }^{323}$.

Reconhecida é ainda, em abono do princípio federativo, a possibilidade de instauração de inquéritos parlamentares pelos Legislativos estadual e municipal, cujos poderes em tudo se espelharão no modelo do Congresso Nacional, limitados naquilo que os extravasar. No âmbito do Estado de São Paulo, a Lei Estadual 1.759/1978 disciplina a atuação das Comissões Especiais de Inquérito (denominação conferida ao instrumento, no plano estadual, no seio das Assembléias Legislativas), conferindo-lhes ampla ação nas pesquisas e nas investigações visando apurar os fatos determinados que ensejaram sua criação. Entre seus poderes, encontram-se os de requerer a convocação de secretários de Estado ${ }^{324}$, tomar depoimentos de quaisquer autoridades, inquirir testemunhas sob compromisso, requisitar documentos e informações da administração pública estadual e interrogar os indiciados ${ }^{325}$.

\subsubsection{Investigação judicial}

A Constituição da República não exibe nenhuma menção nítida sobre qualquer mister investigativo criminal dos juízes singulares ou dos tribunais, nem se pode enxergá-lo implícito no leque de funções institucionais do Poder Judiciário. Ao contrário, o juiz não foi programado constitucionalmente para investigar delitos. Por isso, a

atuantes no interesse dos investigados e testemunhas." (A CPI: Estado de Direito ou direito sem fronteiras do Estado? In: Atualidades no direito e processo penal. São Paulo: Método, 2001, p. 105).

323 FERREIRA, Jorge. Regime jurídico..., cit., p. 50.

${ }^{324}$ Cujo comparecimento não é obrigatório, podendo, todavia, a falta implicar crime de responsabilidade, assim como ocorre com os Ministros de Estado (Lei 1.079/1950, art. 13.3 c/c art. 74).

325 No julgamento da ACO 730/RJ, o Supremo Tribunal Federal, por apertada maioria (rel. Min. Joaquim Barbosa, Plenário, DJ de 11.11.2005), estendeu às CPIs estaduais os mesmos poderes de investigação das comissões federais: "Federação. Inteligência. Observância obrigatória, pelos estados-membros, de aspectos fundamentais decorrentes do princípio da separação de poderes previsto na Constituição federal de 1988. Função fiscalizadora exercida pelo Poder Legislativo. Mecanismo essencial do sistema de checks-and-counterchecks adotado pela Constituição federal de 1988. Vedação da utilização desse mecanismo de controle pelos órgãos legislativos dos estados-membros. Impossibilidade. Violação do equilíbrio federativo e da separação de Poderes. Poderes de CPI estadual: ainda que seja omissa a Lei Complementar 105/2001, podem essas comissões estaduais requerer quebra de sigilo de dados bancários, com base no art. 58, § 3. , da Constituição. Mandado de segurança conhecido e parcialmente provido". 
investigação de natureza judicial constitui uma atipia em nosso sistema, que não contempla a figura do "juiz de instrução" 326 - esta, aliás, em franca extinção nos países que a adotavam, caso de Portugal, que a aboliu em 1988.

No plano infraconstitucional, porém, a investigação conduzida por autoridade judicial, em nosso direito, era instituto bem visualizado no extinto inquérito judicial, outrora previsto pelo Decreto-lei 7.661/1945 como modalidade de apuração prévia dos crimes praticados no estado de falência, mas proscrito do ordenamento com a Lei de Falências e de Recuperação de Empresas (Lei 11.101/2005), que prevê que os indícios de crimes falimentares serão comunicados ao Ministério Público ${ }^{327}$.

Embora justificado o tramitar do inquérito perante o juízo universal da falência como "uma forma de concentrar todos os interesses da massa falida num único órgão judiciário, inclusive as eventuais repercussões de ordem criminal, justamente com o propósito de permitir uma melhor e mais ampla identificação da situação do falido" ${ }^{\text {, } 28, ~ o ~}$ fato é que se incidia no paradoxo de cometer uma atividade investigativa criminal a um juiz cível, que por sua vez forneceria subsídios para futuro e eventual processamento do feito no juízo penal ${ }^{329}$. Apenas para o processamento, já que também a decisão sobre a admissibilidade da ação penal ficava a cargo do juízo cível da falência (verdadeira atividade jurisdicional penal), o qual, somente se recebesse a denúncia ou a queixa subsidiária, encaminhava os autos ao juízo criminal competente (art. 109, § 2. ${ }^{\circ}$, do Decreto-lei 7.661/1945) ${ }^{330}$. Ainda funcionava o juiz da quebra como o "juiz de garantias"

${ }^{326}$ Como bem ressalta Aury Lopes Jr. (Sistemas..., cit., p. 164), no sistema brasileiro “o juiz não investiga nada, não existe a figura do juiz instrutor e por isso mesmo não existe a distinção entre instrutor e julgador".

327 O art. 187 da Lei 11.101/2005 é o marco dessa abolição: “Art. 187. Intimado da sentença que decreta a falência ou concede a recuperação judicial, o Ministério Público, verificando a ocorrência de qualquer crime previsto nesta Lei, promoverá imediatamente a competente ação penal ou, se entender necessário, requisitará a abertura de inquérito policial. (...) $\S 2 .^{\circ}$ Em qualquer fase processual, surgindo indícios da prática dos crimes previstos nesta Lei, o juiz da falência ou da recuperação judicial ou da recuperação extrajudicial cientificará o Ministério Público".

${ }^{328}$ BECHARA, Fábio Ramazzini. Inquérito judicial: procedimento contraditório ou inquisitivo? Revista Sintese de Direito Penal e Processual Penal, Porto Alegre, v. 4, n. 23, dez./jan. 2004, p. 11.

329 Ao analisar as disposições legais incompatíveis com o sistema acusatório, Sergio Demoro Hamilton (A ortodoxia..., cit., p. 205) classifica o inquérito presidido por juiz na antiga Lei de Falências como "monstrengo processual".

${ }^{330}$ Como explica Roberto Barcellos de Magalhães (Prática do processo falencial. 3. ed. rev., atual. e aum. Rio de Janeiro: Freitas Bastos, 1977, v. 1, p. 97-98), a denúncia recebida pelo juiz da falência dava início à ação penal, não se tornando necessário renová-la no juízo criminal, mesmo porque, nos termos do então vigente art. 504 do CPP, funcionava na ação penal o mesmo órgão do Ministério Público que exercera a curadoria da massa falida. No mais, a rejeição da denúncia ou da queixa oferecida no inquérito judicial não obstava o exercício da ação penal, que poderia ser intentada no juízo criminal, quer quanto aos mesmos fatos ou a fatos distintos. 
da investigação, eis que lhe cabia decidir sobre todas as medidas cautelares requeridas pelo síndico (buscas, seqüestros, perícias e mesmo prisões) - havendo, ademais, o agravante de, nas comarcas de vara única ou de varas não-especializadas, ser ele também o juiz da ação penal (e, portanto, do julgamento) ${ }^{331}$.

Na vigência da antiga lei, caberia ao síndico (art. 103) apresentar uma exposição circunstanciada do procedimento do devedor, instruída com laudo contábil e outros documentos, especificando eventuais atos que constituíssem crimes, indicando-lhes os possíveis autores e requerendo, ao final, o inquérito. Os credores habilitados também detinham legitimidade para requerer o inquérito (art. 104), em seguida abrindo-se vista ao Ministério Público para parecer (art. 105). Destacava-se a previsão de o falido ser intimado para oferecer contestação e para requerer o que lhe conviesse no curso do inquérito judicial (art. 106), antes de o juiz definir sobre a realização de novas diligências ${ }^{332}$, norma a

331 Tal hipótese, inclusive, chegou a positivar-se com a aprovação da Lei Estadual 3.947/1983, modificativa da Organização Judiciária do Estado de São Paulo, passando os crimes falimentares a ser julgados pelo juízo universal da falência, e poderia ter-se generalizado caso houvesse sido aprovado o Projeto de Lei federal 4.376/1993, que instituía como juízo do julgamento dos crimes falimentares o mesmo órgão judicial que se encarregara da investigação preliminar. Assim, o juiz (cível) instrutor seria também o juiz competente para instrução e julgamento da ação penal, proposta que, a bem das garantias do sistema constitucional penal, não vingou. Mauro Fonseca Andrade (O inquérito judicial frente à imparcialidade do julgador. Revista do Ministério Público do Rio Grande do Sul, Porto Alegre, n. 43, jul./out. 2000, p. $142-$ 145) entende que o STF desperdiçou a oportunidade de inserir a regra do "juiz que instrui não julga" entre as hipótese de impedimento do julgador, ao apreciar um recurso que censurava a validade da regra prevista na lei estadual (RHC 63.787/SP, rel. Min. Rafael Mayer, 1. ${ }^{\text {a }}$ Turma, DJ de 22.8.1986), decidindo o Pretório que a competência do juízo da falência decorreria da matéria tratada na ação penal, que é falimentar, e utilizando ainda o argumento da praticabilidade na manutenção da competência no juízo falimentar, critério este que, no lúcido desabafo do autor, jamais se poderia sobrepor à possibilidade de mácula à imparcialidade do juiz, que "partiria do zero em termos de conhecimento e posicionamento sobre o fato denunciado". Embora o acórdão seja anterior à Constituição de 1988, o tema merecerá ser retomado, à luz do ordenamento atual, no item 3.3.6.

332 Chegou-se a cogitar que tal procedimento fosse contraditório, e não inquisitivo, ante a previsão de intimação do falido para contestar as argüições do inquérito. Assim se explanou em pareceres que basearam alguns julgados (v.g., STF: RHC 52.112/SP, rel. Min. Djaci Falcão, 1. ${ }^{\text {a }}$ Turma, DJ de 4.10.1974; RHC 43.029/GB, rel. Min. Antonio Villas Boas, 2. ${ }^{\mathrm{a}}$ Turma, DJ de 8.6.1966) e na doutrina encampada por Frederico Marques, Nelson Hungria e Heleno Cláudio Fragoso (cf. Jurisprudência criminal. 4. ed. Rio de Janeiro: Forense, 1982, v. 1, p. 188). Fábio Ramazzini Bechara (Inquérito judicial..., cit., p. 11-12), no entanto, esclarece que tal previsão legal não retiraria o caráter inquisitivo e meramente informativo do inquérito judicial, eis que não assume a condição de processo, não havendo nenhuma imputação formal ao investigado, nem constituindo o único meio de apuração dos crimes falimentares. No mesmo sentido: ANDRADE, Mauro Fonseca. O inquérito judicial..., cit., p. 125. Também a jurisprudência consolidou tal entendimento, vislumbrando no art. 106 do Decreto-lei $7.661 / 1945$ providência equivalente à do art. 14 do CPP, no inquérito policial, o que não desautoriza o reconhecimento do direito de defesa do investigado já na fase preliminar, como dantes examinado. Alguns precedentes do STF, inclusive, ressaltam a indispensabilidade da manifestação do investigado previamente ao oferecimento e ao recebimento da denúncia (RHC 90.632/DF, rel. Min. Sepúlveda Pertence, 1. ${ }^{\mathrm{a}}$ Turma, v.u., DJ de 22.6.2007; HC 79.106/SP, rel. Min. Nelson Jobim, 2. ${ }^{\mathrm{a}}$ Turma, por maioria, DJ de 17.8.2001). 
consagrar o direito de defesa nesse procedimento judicial preliminar. Somente após, seria dada vista ao titular da ação para oferecer ou não a denúncia (art. 108).

Atualmente, reformulada que foi a etapa preliminar nos crimes falimentares, apenas na hipótese de delito atribuído a magistrado subsiste previsão expressa de uma investigação preliminar conduzida por juízes, extraída do art. 33, parágrafo único, da Lei Complementar 35/1979 - Lei Orgânica da Magistratura Nacional (Loman). Coincidentemente, a hipótese abrange delitos situados na competência originária de tribunais, e nesse universo (da competência criminal originária tribunalícia) constitui o único caso em que a lei atribuiu, expressamente, a própria investigação preliminar ao Poder Judiciário, malgrado a existência de tantas outras menções a foros especiais na Constituição da República e nas Constituições dos Estados.

Há quem entenda, porém, que a investigação preliminar dos delitos atribuídos aos demais agentes públicos com prerrogativa de foro criminal, por esse só fato, teria natureza judicial, sendo conduzida pelo Ministro ou Desembargador Relator, no Tribunal $^{333}$. Contudo, não obstante a imprecisão jurisprudencial a respeito, como se explicitará adiante, nada há no direito positivo que assim o consagre, merecendo-se estudar tais investigações, com as peculiaridades que ostentam, sendo conduzidas pela Polícia Judiciária e oportunamente autuadas no Tribunal competente para a ação penal, de cujo crivo dependerá a efetivação de todas as medidas que demandem jurisdicionalização.

Força é referir, ainda, a curiosa previsão regimental ${ }^{334}$ (análoga à existente para o Parlamento) do poder de polícia do Presidente de Tribunal quanto às infrações penais cometidas na sede ou nas dependências da Corte, no sentido de caber àquela autoridade instaurar inquérito, se o investigado for pessoa sujeita à sua jurisdição (casos de

${ }^{333}$ É o que afirma Luiz Flávio Gomes (Nova lei de falência: procedimento penal. Disponível em: $<$ http://www.faceb.edu.br/faceb/RevistaJuridica/m196-018.htm>. Acesso em: 9 out. 2008): "Não foi adotado no Brasil o sistema dos juizados de instrução. As duas últimas possibilidades (ainda hoje) que autorizam o juiz a investigar são: (a) investigação contra os próprios juízes; e (b) investigação de crimes atribuídos a pessoas com prerrogativa de função (a investigação contra um deputado federal, por exemplo, é conduzida por um Ministro do STF). Algo também precisa e deve ser feito para acabar com essas excrescências". Já Roberto Luis Luchi Demo (Competência penal originária: uma perspectiva jurisprudencial crítica. São Paulo: Malheiros, 2005, p. 195) sustenta que o inquérito penal e todos os atos promovidos pela Polícia Judiciária, enquanto medidas pré-processuais de persecução penal, haverão de ter curso perante o órgão judiciário competente. Ora, ter curso perante o Tribunal não significa ser conduzido ou dirigido por ele. No item 3.3, após devidamente separadas as espécies de apuração prévia, defender-seá que a investigação não-interna corporis dos agentes públicos com prerrogativa de função seja dirigida não pela autoridade judicial, mas pela autoridade policial, tendo seu curso no órgão judiciário apenas quando necessário o chamamento deste para a apreciação de alguma medida restritiva de direitos fundamentais.

${ }^{334}$ Cf., v.g., os Regimentos Internos do STF (art. 43, caput e $\S 1 .^{\circ}$ ), do STJ (art. 58, caput e $\S 1 .^{\circ}$ ). 
prerrogativa de foro criminal) e, se não for, poder proceder de igual forma ou requisitar a instauração à autoridade competente ${ }^{335}$ (diga-se: policial). Tal previsão, constante dos regimentos internos dos Tribunais, carece de adequação ao modelo constitucional acusatório, já que implica nítida admissão da figura do juiz-investigador, entendendo-se, portanto, como não-recepcionada pela Lei Maior ${ }^{336}$.

Quando o juiz está à frente da condução da investigação preliminar penal, conduzindo esses atípicos inquéritos judiciais (ouvindo pessoas, determinando diligências, controlando prazos e ainda apreciando pedidos de restrição de liberdade), avizinha-se o agir do magistrado que com o daquele juiz (de primeiro ou de segundo grau) que, pela Lei $9.034 / 1995^{337}$, poderia, em procedimentos investigatórios a respeito de ilícitos praticados por organizações criminosas, quebrar pessoalmente o sigilo do investigado (não apenas decidir sobre a quebra) e ir buscar ele mesmo os elementos requeridos em busca e apreensão, os quais poderiam servir, mais tarde, como fundamento de sua própria decisão. O magistrado da Lei 9.034 estaria atuando, na etapa prévia da persecução, como verdadeiro juiz inquisidor, como se o nosso sistema fosse o dos juizados de instrução, discrepância enfim reconhecida ao ensejo do julgamento da Ação Direta de Inconstitucionalidade $1.570^{338}$.

Em quaisquer desses casos, todavia, não se identifica possível ao magistrado assumir as vestes de investigador, seja por existirem órgãos próprios com perfil constitucional mais adequado a essas tarefas, seja por comprometer uma das principais garantias do devido processo penal - a imparcialidade do juiz -, tanto quanto expressou o STF na ADI 1.570, cujo acórdão obteve a seguinte ementa:

335 O que se perfaz em ainda maior distorção, pois, como retrata Eduardo Pereira da Silva (Prerrogativa de foro no inquérito policial. Revista CEJ, Brasília, n. 36, jan./mar. 2007, p. 3), "haveria assim a possibilidade de Ministro do Supremo Tribunal Federal investigar crimes que só seriam julgados por aquela corte na via extraordinária. E até mesmo de Desembargador do Tribunal Regional Federal investigar crimes cometidos em suas dependências cujo processo deva ser julgado por um Juiz de Direito (não sendo o caso de crime que afete interesse da União). Também teríamos que admitir um Ministro de Corte Superior ter que representar a um Juiz de primeira instância pela prática de ato sujeito a reserva jurisdicional, já que a sua atribuição para investigar jamais poderia se converter em competência para julgar e decretar medidas cautelares".

336 Nesse sentido: GOMES, Rodrigo Carneiro. O inquérito policial na investigação de parlamentar. Disponível em: <http://www.ibccrim.org.br>, Seção Artigos. Acesso em: 15 abr. 2007.

337 A qual dispôs sobre a utilização de meios operacionais para a prevenção e repressão de ações praticadas por organizações criminosas.

338 Quando o Supremo Tribunal Federal, por maioria, declarou a inconstitucionalidade do art. 3. ${ }^{\circ}$ da Lei 9.034, de 3 de maio de 1995, no que se refere aos dados "fiscais" e "eleitorais". 
AÇÃO DIRETA DE INCONSTITUCIONALIDADE. LEI 9034/95. LEI COMPLEMENTAR 105/01. SUPERVENIENTE. HIERARQUIA SUPERIOR. REVOGAÇÃO IMPLÍCITA. AÇÃO PREJUDICADA, EM PARTE. "JUIZ DE INSTRUÇÃO". REALIZAÇÃO DE DILIGÊNCIAS PESSOALMENTE. COMPETÊNCIA PARA INVESTIGAR. INOBSERVÂNCIA DO DEVIDO PROCESSO LEGAL. IMPARCIALIDADE DO MAGISTRADO. OFENSA. FUNÇÕES DE INVESTIGAR E INQUIRIR. MITIGAÇÃO DAS ATRIBUIÇÕES DO MINISTÉRIO PÚBLICO E DAS POLÍCIAS FEDERAL E CIVIL. 1. Lei 9034/95. Superveniência da Lei Complementar 105/01. Revogação da disciplina contida na legislação antecedente em relação aos sigilos bancário e financeiro na apuração das ações praticadas por organizações criminosas. Ação prejudicada, quanto aos procedimentos que incidem sobre o acesso a dados, documentos e informações bancárias e financeiras. 2. Busca e apreensão de documentos relacionados ao pedido de quebra de sigilo realizadas pessoalmente pelo magistrado. Comprometimento do princípio da imparcialidade e conseqüente violação ao devido processo legal. 3. Funções de investigador e inquisidor. Atribuições conferidas ao Ministério Público e às Polícias Federal e Civil (CF, artigo 129 , I e VIII e $\S 2 .^{\circ}$; e $144, \S 1 .^{\circ}$, I e IV, e $\left.\$ 4 .^{\circ}\right)$. A realização de inquérito é função que a Constituição reserva à polícia. Precedentes. Ação julgada procedente, em parte. ${ }^{339}$

Cumpre ainda afastar dessa categoria alguns institutos que com ela não se identificam. Não há confundir com investigação judicial o chamado procedimento judicialiforme, antes previsto para as contravenções penais e para as lesões e homicídios culposos com autoria conhecida nos primeiros quinze dias, não recepcionado pela Constituição por refletir uma atividade do juiz que, na fase preliminar, implicaria a assunção de tarefas não-jurisdicionais, para cuja execução existem já órgãos específicos. Nesses casos, segundo a Lei 4.611/1965 ${ }^{340}$ e os arts. 26 e 531 do CPP $^{341}$, a ação penal podia ser iniciada por portaria da autoridade judiciária ou policial, o que, nitidamente, não foi recepcionado pela vigente Constituição, à luz do que dispõe o art. 129, I, da Carta Magna.

339 ADI 1.570/DF, rel. Min. Maurício Corrêa, Plenário, por maioria, DJ de 22.10.2004, grifos acrescidos. Nos termos do voto do Relator, a ação foi julgada parcialmente procedente, em relação aos sigilos fiscal e eleitoral (quanto aos sigilos bancário e financeiro, deu-se por prejudicada a ação, porquanto haviam sido disciplinados pela Lei Complementar 105/2001), sob o fundamento de que instituía a figura do juiz de instrução, inexistente na legislação brasileira, não se tratando de mera participação do julgador na coleta da prova (como ocorre na inspeção judicial), mas se lhe atribuindo funções de investigador e inquisidor, que, no sistema acusatório, devem ser reservadas ao Ministério Público e à Polícia Judiciária, vedando-se a atuação de ofício do órgão julgador.

340 Diploma que foi revogado expressamente pela Lei 9.099/1995, embora não mais aplicado desde o advento da Constituição de 1988, por não recepcionado.

341 “Art. 26. A ação penal, nas contravenções, será iniciada com o auto de prisão em flagrante ou por meio de portaria expedida pela autoridade judiciária ou policial.’”

“Art. 531. O processo das contravenções terá forma sumária, iniciando-se pelo auto de prisão em flagrante ou mediante portaria expedida pela autoridade policial ou pelo juiz, de ofício ou a requerimento do Ministério Público.” [dispositivo alterado pela Lei 11.719/2008.] 
Outrossim, não se incluem na espécie ora analisada algumas ações judiciais extrapenais que, tomando embora o nome de "investigações", não representam senão o exercício do direito de ação e a provocação do Estado a exercer a função jurisdicional. É o caso, v.g., do inquérito judicial para apuração de falta grave do empregado estável, previsto nos arts. 853 a 855 da Consolidação das Leis do Trabalho, e da investigação judicial eleitoral, instituída pela Lei Complementar 64, de 18.5.1990, que não se perfaz em procedimento administrativo, seja criminal ou eleitoral, mas tem natureza de ação judicial, cujo objeto é coletar provas para a interposição de recurso contra a diplomação de candidatos que interfiram com o poder econômico ou o abuso do poder de autoridade na liberdade de votos. Reclama, como ação que é, a iniciativa da parte e a prova de suas alegações em um verdadeiro processo, assegurados o contraditório e a ampla defesa ${ }^{342}$.

Feitas essas distinções, convém assentar que as anteditas hipóteses excepcionais e remanescentes de investigação preliminar judicial com fins penais não se compatibilizam com o sistema constitucional.

Guarda inúmeros inconvenientes a investigação preliminar de natureza judicial, pois mais se afeiçoa ao modelo inquisitório de processo, ao permitir o atuar de ofício e a busca de provas sem provocação dos demais atores. O modelo acusatório de processo penal pugna pela máxima preservação da imparcialidade do juiz e conseqüente igualdade entre as partes, devendo o magistrado manter-se como um terceiro alheio ao trabalho de investigação. O juiz que investiga está promovendo, em sentido amplo, a acusação, na medida em que seu trabalho poderá servir, em último caso, para munir o futuro acusador. "Essa é a intima contradição que desaconselha a instrução preliminar judicial",343.

${ }^{342}$ Cf. BARRETTO, Lauro. A investigação judicial eleitoral e a ação de impugnação de mandato eletivo. 2. ed. rev. e ampl. Bauru: Edipro, 1999, p. 30-31. Como sustenta José Carlos Pimenta (Processo eleitoral e controle jurisdicional. Belo Horizonte: Mandamentos, 2002, p. 154), a representação impulsionadora da investigação judicial não se confunde com o juizado de instrução nem com o inquérito policial. "Tem natureza da ação, como a possui o inquérito judicial para a apuração de falta grave do empregado estável, no Direito do Trabalho. Desenvolve-se sob o crivo do contraditório e gera demanda".

${ }^{343}$ LOPES JR., Aury. Sistemas..., cit., p. 84-85. O autor aponta ainda como desvantagens do sistema do juiz investigador: a lenta administração da justiça que acarreta nos países onde adotado, já que a instrução judicial tende a se tornar plenária; o fato de uma mesma pessoa decidir sobre um ato de investigação e valorar a sua legalidade; a inadmissível conversão da instrução preliminar em uma fase geradora de provas, pela maior credibilidade que geram os atos do juiz instrutor, levando a que a prova não seja produzida no processo, mas apenas ratificada, valorando-se em sentença condenatória os atos produzidos na investigação. As mesmas críticas são lançadas por Gustavo Adrián Herbel (La investigación..., cit., p. 697-698), ao comentar o antigo sistema do juiz instrutor na província argentina de Buenos Aires. Diz ele que a investigação judicial do antigo Código havia transformado a etapa plenária em acessória do sumário escrito, o qual, por sua vez, tornara-se uma atividade lenta e descontínua, marcada pela simples 
Tomada a premissa de que o nosso sistema qualifica-se como preponderantemente acusatório, a inclusão de magistrados (juízes de primeiro grau ou membros de tribunais) como dirigentes ou mesmo coordenadores/supervisores da fase investigatória afigura-se, a nosso sentir, uma incongruência, fomentando o desafio de ajustar-se esse tipo de investigação preliminar às linhas-mestras do Texto Constitucional, com a melhor delimitação do papel do magistrado nessa etapa, de maneira que se possa garantir eficiência à investigação criminal prévia e, ao mesmo tempo, valorizar as garantias fundamentais traçadas na Lei Maior.

\subsubsection{Investigação particular}

Ao contrário do que se possa imaginar, a investigação criminal não é privativa de mecanismos estatais ou públicos. Investigar um crime, coletar elementos que delineiem a sua materialidade e apontem indícios de sua autoria, é atividade que bem pode ser feita por qualquer particular, desde que disponha de aparato para tanto e que não viole direitos fundamentais, merecendo regulamentação por lei e encontrando-se indissociada do problema da efetividade da defesa técnica penal.

Já ensinava Pimenta Bueno que a investigação pode ser pública ou particular, a primeira sendo aquela praticada por órgãos do Estado e a segunda, por pessoas ou entidades não-estatais. Assim, nos exemplos dados pelo autor, um estabelecimento bancário pode averiguar, mediante perícia contábil, o desfalque de um empregado, com isso provocando a ação do Ministério Público; o indivíduo que logre obter, licitamente, documentos que provem a prática de um delito por determinada pessoa também pode remetê-los ao titular da ação penal, dando causa a que se inicie o processo $^{344}$.

A investigação particular apresenta-se sob duas vertentes: uma, aquela feita pela pessoa que se pretende vítima de um delito; outra, aquela encetada pelo sujeito imputado da prática de um crime ${ }^{345}$.

acumulação de atas, longe de atender à necessidade de uma investigação rápida e dúctil, que responda a conflitos crescentes em quantidade e complexidade. Tais investigações, excessivamente formalizadas e burocratizadas, acabavam por converter o debate numa espécie de simulacro onde se verificavam apenas formalmente os elementos recolhidos durante a instrução.

344 Apontamentos..., cit., p. 67.

345 Como ressalta Antonio Scarance Fernandes, “[a] possibilidade de investigação paralela pelo próprio suspeito, autorizada e regulada por lei, constitui tentativa de equilibrar a atuação dos órgãos de repressão 
Se bem que no Brasil não exista ainda disposição legal permitindo expressamente quaisquer dessas situações, considera-se possível, no primeiro caso, a coleta de elementos pelo particular, desde que disponha de meios de prova lícitos a seu alcance (p. ex., gravação de conversa telefônica em que seja um interlocutor), com os quais possa, diretamente, formular um pedido de acusação, se se tratar de ação privada, ou, em caso de ação pública ou de investigação apenas parcial dos fatos, canalizá-los aos autos do inquérito policial em andamento, com isso exercendo importante papel investigativo subsidiário $^{346}$.

Já a investigação exclusiva da defesa, definida como aquela realizada pelo imputado por meio de seu defensor, embora se constitua prática antiga da Common Law, foi introduzida apenas topicamente em sistemas continentais, como na Itália, pela Lei 479, de 16 de dezembro de 1999, sendo regulamentada pela Lei 397, de 7 de dezembro de 2000. Referido diploma, ao alterar os arts. 327 e 391 do Código de Processo Penal, possibilitou ao advogado: entrevistar pessoal e informalmente potenciais testemunhas; colher declaração escrita de pessoas; requerer laudos periciais ou produzi-los por seus assistentes técnicos; vistoriar coisas e lugares públicos ou privados; solicitar documentos em poder da Administração Pública; formar o instrumento que documenta essa atividade ${ }^{347}$. Investigação defensiva, no dizer de Édson Luís Baldán, “é o complexo de atividades de natureza investigatória desenvolvido, em qualquer fase da persecução

penal e a atuação da defesa", sobretudo porque "as alternativas procedimentais modernas apóiam-se em elementos obtidos durante a investigação" (Teoria geral do procedimento..., cit., p. 86-87).

${ }^{346}$ No direito argentino, Alberto Bovino e Federico Pinto (La prueba preconstituida por particulares: su incorporación y valoración en el procedimiento penal. In: PLAZAS, Florencia G.; HAZAN, Luciano A. (Comp.). Garantías constitucionales en la investigación penal: um estudio crítico de la jurisprudencia. Buenos Aires: Editores del Puerto, 2006, p. 279-296) destacam o dever legal de quem pretende constituirse em querelante, em uma ação penal privada, de investigar com seus próprios meios o fato que se imputa. Já nos delitos de ação pública, após ressaltarem que as normas do procedimento penal só prevêem a intervenção da vítima a partir do início formal da persecução, afirmam que a tendência da jurisprudência da Câmara Nacional de Cassação Penal é de aceitar como meios de prova válidos as gravações sonoras ou audiovisuais realizadas antes do início do procedimento penal por particulares, demandando, no entanto, regulamentação legal para afastar insegurança jurídica, sobretudo dando-se ênfase às garantias que não podem ser violadas para se obterem tais elementos de convicção.

347 Nesse ponto, Siracusano, Galati, Tranchina e Zappalà (Diritto processuale penale, cit., p. 222-224) esclarecem que o modelo processual inaugurado em 2000 valoriza o papel do investigatore privato, e de certa forma torna-o indispensável, na medida em que, reconhecendo às partes o direito à prova e autorizando a parte privada a defender-se provando, garante-lhe toda iniciativa que possa dar eficácia à realização daquele direito. Pode desenvolver investigações a seu favor, adquirir informações, procurar fontes de prova e elementos idôneos a consolidar a tese da defesa ou enfraquecer a da acusação. A lei, para tanto, concede-lhe liberdade e garantia de segredo profissional (oponível também aos órgãos de polícia). Mas, dizem os autores, os princípios constitucionais que somente permitem à autoridade de segurança pública interferir sobre a esfera subjetiva individual, praticando atos de fundamental importância para a investigação, parecem subtrair tal área da atividade da investigação privada. 
criminal, inclusive na antejudicial, pelo defensor, com ou sem assistência de consultor técnico, tendente à coleta de elementos objetivos, subjetivos e documentais de convicção, no escopo de construção de acervo probatório lícito que, no gozo da parcialidade constitucional deferida, empregará para pleno exercício da ampla defesa do imputado em contraponto à investigação ou acusação oficial”348.

Nos Estados Unidos da América, em que há longa tradição de preponderância do papel das partes processuais na investigação preliminar do crime e na gestão da prova durante a fase de julgamento, surge o dever de investigação (duty to investigate) como mandamento ético para o advogado de defesa criminal, fixado no standard 4-4.1 ${ }^{349}$ das "Normas para a Justiça Criminal: Funções Persecutória e Defensiva", editadas pela American Bar Association. A doutrina norte-americana indica como pressuposto do dever de investigação defensiva o correlato direito ao acesso amplo e irrestrito aos elementos de convicção amealhados pela polícia judiciária ou pela parte acusadora. A Suprema Corte, por sua vez, reafirma que a investigação defensiva inexistente ou inadequada enseja uma defesa técnica não-efetiva, violando-se o direito à defesa técnica (right to counsel) previsto na Sexta Emenda à Constituição ${ }^{350}$.

Em Portugal, a investigação pela defesa ganha foros de discussão, embora não abraçada expressamente pelo Código de 1987. Como argumentos favoráveis à investigação pelos meios próprios da defesa, Francisco da Costa Oliveira cita, entre outros, o fato de que, salvantes as situações em que o argüido sequer sabe do que tratam as

${ }^{348} \mathrm{O}$ autor cita vários benefícios diretos ou reflexos dessa atividade, entre eles: o aprimoramento da investigação policial como contraponto eficaz às provas produzidas pelo defensor, favorecendo a busca contínua por aperfeiçoamento técnico-científico dos órgãos estatais; a criação da categoria profissional dos investigadores privados; a maior proximidade do processo penal com o esclarecimento dos fatos; a permissão de preparar-se adequadamente a defesa e sustentar a própria tese; a garantia do direito à prova em qualquer etapa do procedimento e a maior serenidade do magistrado ao exercer o juízo de prelibação da acusação, cotejando também as razões produzidas pelo imputado (Investigação defensiva..., cit., p. 269-271).

349 Dispõe a Norma 4-4.1: “(a) O advogado de defesa deve conduzir uma pronta investigação das circunstâncias do caso e explorar todos os caminhos que levem a fatos relevantes para o julgamento do mérito da causa e a aplicação da pena, em caso de condenação. A investigação deve incluir esforços para obter informação na posse da parte acusadora e da polícia judiciária. $\mathrm{O}$ dever de investigar existe independente da confissão do acusado, ou de afirmações para o advogado de defesa sobre fatos que configuram culpa, ou da declarada intenção do acusado de se afirmar culpado." (ESTADOS UNIDOS DA AMÉRICA. ORDEM DOS ADVOGADOS. ABA Standards for Criminal Justice: Prosecution and Defense Function. 3. ed. Washington DC: American Bar Association, 1993. Disponível em: $<$ http://www.abanet.org/crimjust/standards/dfunc_toc.html $>$. Acesso em 8 out. 2008).

350 Cita-se, por exemplo, o caso Wiggins v. Smith, de 2003, a partir do qual se vem notando a criação jurisprudencial de critérios cada vez mais rigorosos para a aferição do cumprimento do dever de investigar por parte do defensor técnico. Cf. MALAN, Diogo. Investigação defensiva nos Estados Unidos 
investigações, é ele quem parte em vantagem para a investigação criminal, uma vez que saberá ao menos situar as ocorrências nos fatos relativos à sua pessoa, encontrando, todavia, em seu desfavor o obstáculo da escassez dos meios de obtenção de prova ${ }^{351}$.

Deveras, e embora não lhe recaia tal ônus, o investigado pode ter o interesse de comprovar o seu álibi, de afastar sua responsabilização em face da atuação de terceiros, de explorar fatos que impliquem causa de exclusão da ilicitude; pode não ter interesse em seguir linhas de investigação que suponha de logo infrutíferas; pode ter mais facilidade em identificar e localizar possíveis testemunhas, etc., daí sua legitimidade para conduzir investigações próprias do imputado, voltadas precipuamente não à elucidação do crime, mas à comprovação dos fatos de que depende sua defesa.

Partindo da premissa de que a democratização da investigação preliminar passa pela implementação de uma igualdade efetiva de armas também nessa etapa, Manuel Monteiro Guedes Valente, embora ressaltando que a doutrina portuguesa não se mostra receptiva à idéia, defende ser necessária a regulamentação legal da "atividade privada de investigação probatória". Assim, para evitar as emoções próprias de quem investiga, para promover a imparcialidade de quem deve julgar e de quem defende, é preciso que se conceda ao defensor pelo menos a possibilidade de contratar investigadores privados obrigados a um código de conduta legal, ou mesmo um advogado, conferindo-lhe os mesmos direitos e deveres dos órgãos da investigação ${ }^{352}$.

A legislação brasileira apenas permite a requisição de diligências pelo "indiciado" nos autos do inquérito policial (art. 14 do CPP), sendo de compreender-se que estas não poderão ser indeferidas pela autoridade policial, a menos que imotivadas ou

da América e reflexos no processo penal brasileiro. Palestra proferida nas VII Jornadas Brasileiras de Direito Processual Civil e Penal do Instituto Brasileiro de Direito Processual (IBDP). Florianópolis, 2008.

351 OLIVEIRA, Francisco da Costa. A defesa e a investigação do crime: guia prático para a análise da investigação judiciária e para a investigação pelos recursos próprios da defesa criminal. Coimbra: Almedina, 2004, p. 58. O Código de Processo Penal português, assim como o italiano, traz um título sobre os meios de obtenção da prova, neles enquadrando os exames (inspeções), as revistas e buscas, as apreensões e as escutas telefônicas (arts. $171 .^{\circ}$ a $190 .^{\circ}$ ). Com fundamento na doutrina italiana, pode-se distinguir entre meios de prova e meios de obtenção de prova. Leciona Juliana Belloque (Sigilo bancário..., cit., p. 87-88) que meios de prova "são modelos procedimentais descritos em lei, que quando atuados pelo juiz e pelas partes, em contraditório - geram a introdução no processo de elementos aptos a influenciar o convencimento do magistrado sobre os fatos pertinentes à causa penal. Assim, o meio de prova documental, testemunhal, pericial". Já os meios de obtenção de prova são ferramentas que possibilitam o "recolhimento de fontes de provas", como é o caso da quebra do sigilo financeiro.

352 VALENTE, Manuel Monteiro Guedes. Regime jurídico da investigação criminal. 3. ed. rev. e aum. Coimbra: Almedina, 2006, p. 35-40. 
impertinentes à investigação, e por ato fundamentado ${ }^{353}$. Sequer o dever de investigação por parte do defensor técnico como critério de aferição de uma defesa efetiva está previsto nos estatutos deontológicos dos advogados brasileiros. Nada obstante, a regulamentação do direito à investigação defensiva ou mesmo o seu amadurecimento na jurisprudência viria contribuir à efetivação da garantia da ampla defesa no campo criminal.

\subsection{Modalidades de investigação preliminar de foro especial segundo o investigado}

$$
\text { Para o estudo do regime jurídico das investigações preliminares }
$$

tribunalícias, que será aprofundado no capítulo seguinte, faz-se pertinente trazer, já aqui, uma outra classificação, agora dirigida apenas aos crimes sujeitos a foro por prerrogativa de função ${ }^{354}$, diferençando-se as várias espécies de investigação desse gênero passíveis de

353 Entrementes, o Supremo Tribunal Federal já corroborou a atividade investigatória complementar da defesa: "Habeas Corpus. 1. Operação Navalha'. Inquérito n. 544/BA, do Superior Tribunal de Justiça. 2. Alegação de indispensabilidade da juntada de laudo pericial encomendado e de cópia de reportagem. 3. A defesa não reivindica a produção de prova extemporânea ou providência que implique tumulto processual, mas apenas a juntada de elementos que entende pertinentes à elucidação dos fatos e ao convencimento do Ministério Público. 4. Ausência de razão jurídica plausível para que a Corte Especial do STJ indefira pedido de juntada do laudo pericial já produzido pela defesa do paciente. 5. Ordem deferida para, mantidos os efeitos da medida liminar, determinar a juntada dos expedientes 00127270/2007 e 00126577/2007 aos autos do Inquérito n. 544/BA, em trâmite perante o STJ.” (HC 92.599/BA, rel. Min. Gilmar Mendes, 2. ${ }^{\mathrm{a}}$ Turma, v.u., DJ de 25.4.2008).

${ }^{354} \mathrm{Na}$ linguagem forense comum, utiliza-se a expressão "foro privilegiado" para aludir ao foro por prerrogativa de função, muito embora se trate, como se explicitará adiante, de uma impropriedade, pois o que se pretende indicar é uma espécie de competência fundada na prerrogativa da função pública, não denotando, em tese, qualquer privilégio do sujeito passivo da persecução penal. Romeu Pires de Campos Barros (O procedimento nos crimes de competência originária. Revista de Processo, São Paulo, v. 8, n. 30, abr./jun. 1983, p. 169) acrescenta que, bem examinados os procedimentos, "não há qualquer vantagem para a pessoa sujeita à competência funcional, a começar que neste caso inexiste duplo grau de jurisdição, não prevendo a lei qualquer recurso ordinário para o julgamento da competência originária dos Tribunais". Ao que parece, o qualificativo "privilegiado" é reminiscência dos idos coloniais, em que se previam os delitos "privilegiados", sujeitos ao julgamento dos corregedores e ouvidores, autoridades hierarquicamente superiores aos juízes locais. No Código do Processo Criminal do Império não havia tal expressão, sendo que, por já consagrada no uso comum, continuou utilizada pelos doutrinadores. Tanto assim que Vicente Alves de Paula Pessoa (Código do processo criminal de primeira instância do Império do Brasil. Rio de Janeiro: Cruz Coutinho, 1882, p. 194), por exemplo, em suas anotações ao processo dos crimes de responsabilidade dos empregados públicos (Capítulo V do Título II), alude aos "funcionários públicos privilegiados no foro criminal", como sendo os juízes de direito, os chefes de polícia, os comandantes militares (que responderiam perante a Relação), os desembargadores, os ministros do Supremo Tribunal de Justiça, os empregados do corpo diplomático, os presidentes de província, os bispos e arcebispos (que responderiam perante o Supremo Tribunal). Por sua vez, João Mendes de Almeida Junior (O processo criminal brasileiro, cit., v. 2, p. 138), ao distinguir as espécies de competência criminal, incluía um critério de divisão entre competência comum (dos juízes e tribunais de instâncias comuns) e competência privilegiada (a dos Tribunais, Juízes excepcionais, Juízes do foro militar, STF e Tribunais Estaduais, quando funcionam em única instância). 
se praticar em nosso direito, conforme seja o sujeito passivo determinante da prerrogativa. Visualiza-se, nessa ordenação, o cargo ocupado pelo agente, que pelas normas constitucionais atribuidoras de competência pode ser um cargo eletivo ou não-eletivo, efetivo, temporário (em comissão) ou vitalício ${ }^{355}$.

Pelo modo com que se conduzem as investigações preliminares envolvendo os diferentes titulares da prerrogativa, é possível distinguir duas espécies de procedimentos investigativos nos crimes submetidos ao foro especial: (i) aqueles que se realizam interna corporis, sendo conduzidos pela própria instituição que integra o suspeito da prática da infração penal e (ii) os demais procedimentos preliminares, que englobam, maciçamente, titulares de cargo de mandato eletivo ou políticos.

Nesse último grupo de investigações preliminares, além dos agentes políticos, devem-se mencionar os Ministros do Tribunal de Contas da União, cujas prerrogativas se equiparam às dos Ministros do Superior Tribunal de Justiça ${ }^{356}$, gozando, portanto, de foro por prerrogativa de função para o processo e julgamento dos delitos por si cometidos. Muito embora sejam equiparados, em garantias e prerrogativas, aos magistrados, tal aproximação não vai a ponto de lhes conferir a peculiaridade da investigação interna corporis, por uma razão lógica: não são eles organizados em carreira, de forma a existir um tribunal de contas superposto "competente para o julgamento", ao qual possa ser remetido o inquérito, para prosseguimento, conforme cogitado na Loman (art. 33, parágrafo único, da Lei Complementar 35/79).

355 Cargo público, conforme ensinança de Celso Antônio Bandeira de Mello (Curso..., cit., p. 233), consiste nas "mais simples e indivisíveis unidades de competência a serem expressadas por um agente, previstas em número certo, com denominação própria, retribuídas por pessoas jurídicas de Direito Público e criadas por lei...". São classificáveis, quanto à vocação para retenção dos ocupantes, em cargos de provimento em comissão, cargos de provimento efetivo e cargos de provimento vitalício, cujos ocupantes são, respectivamente, transitórios, permanentes, ou têm uma mais acentuada garantia de permanência. Os primeiros são vocacionados para serem ocupados de forma transitória por pessoa da confiança da autoridade competente para preenchê-los, tanto assim que demissíveis ad nutum. Os segundos, que correspondem à grande maioria, são predispostos a receber ocupantes em caráter definitivo, sendo preenchidos por concurso público. Os últimos também se inclinam à retenção dos ocupantes, mas essa vocação é ainda maior, uma vez vitaliciado o titular. Resumem-se aos cargos de Magistrado, de Ministro de Tribunal ou Conselheiro do Tribunal de Contas e de membro do Ministério Público (Idem, p. $277-$ 279). Existem ainda alguns cargos que, fugindo à classificação ora referida, estabelecem entre seus ocupantes e o Estado um vínculo de natureza política, que serão definidos mais adiante.

356 É o que prevê o art. 73, § 3. ${ }^{\circ}$, da CF: “Os Ministros do Tribunal de Contas da União terão as mesmas garantias, prerrogativas, impedimentos, vencimentos e vantagens dos Ministros do Superior Tribunal de Justiça, aplicando-se-lhes, quanto à aposentadoria e pensão, as normas constantes do art. 40". No âmbito dos Estados, do Distrito Federal e dos Municípios, iguais prerrogativas têm lugar, por força da norma do art. 75 da CF. 
Quanto ao Ministério Público junto ao Tribunal de Contas, também chamado de Ministério Público especial, não foi previsto pela Constituição de 1988 como instituição própria e, embora seus integrantes sejam dotados de estatuto jurídico especial, com os mesmos direitos, vedações e forma de investidura dos membros do Ministério Público da União e dos Estados ${ }^{357}$ - inclusive a previsão de foro criminal por prerrogativa de função -, não integram a instituição do Ministério Público da União nem dos Estados, mas sim a organização administrativa do próprio Tribunal de Contas ${ }^{358}$. Por isso, não se lhes aplicam as disposições relativas às investigações interna corporis ministeriais, eis que não sujeitos à direção do respectivo procurador-geral, a quem competiria, nos termos das respectivas leis orgânicas (art. 41, parágrafo único, da Lei 8.625/1993 e art. 18, parágrafo único, da Lei Complementar 75/1993), presidir a investigação interna.

Deveras, as investigações preliminares envolvendo Ministros e Conselheiros das Cortes de Contas, bem como os membros do Ministério Público nelas atuantes, mais se aproximam das referentes ao segundo grupo, dos agentes políticos.

Existe, por fim, uma pequena parcela de detentores de foro por prerrogativa de função que, fugindo ao grupo das investigações intestinas, tampouco se enquadram entre os agentes políticos ou os mandatários eletivos (são eles: os comandantes da Marinha, do Exército e da Aeronáutica e os chefes de missão diplomática de caráter permanente - art. 102, I, c, da CF). No entanto, reputamos igualmente desnecessário agrupá-los em uma categoria à parte, visto que, além de diminuta sua ocorrência prática (se comparada aos demais investigados), não despontam as suas investigações com diferença relevante para o segundo grupo, que as faça configurar um terceiro gênero. Devem, portanto, seguir as mesmas diretrizes procedimentais das investigações envolvendo agentes políticos (nãointerna corporis).

357 “Art. 130. Aos membros do Ministério Público junto aos Tribunais de Contas aplicam-se as disposições desta seção pertinentes a direitos, vedações e forma de investidura."

358 Após objeção inicial da doutrina (v. MAZZILLI, Hugo Nigro. Regime jurídico..., cit., p. 109-110), no sentido de que o Ministério Público junto ao Tribunal de Contas deveria constituir um quadro especial, dentro da mesma carreira do Ministério Público da União e dos Estados (conseqüentemente, com unidade de chefia e de corregedoria), o Supremo Tribunal Federal, no julgamento da ADI 789/DF (rel. Min. Celso de Mello, Plenário, v.u., DJ de 19.12.1994), dirimindo a quizila instaurada quanto à natureza jurídica do Ministério Público junto ao Tribunal de Contas, deixou claro: “O Ministério Público junto ao TCU não dispõe de fisionomia institucional própria e, não obstante as expressivas garantias de ordem subjetiva concedidas aos seus Procuradores pela própria Constituição (art. 130), encontra-se consolidado na 'intimidade estrutural' dessa Corte de Contas, que se acha investida - até mesmo em função do poder de autogoverno que lhe confere a Carta Política (art. 73, caput, in fine) - da prerrogativa de fazer instaurar o processo legislativo concernente à sua organização, à sua estruturação interna, à definição do seu quadro de pessoal e à criação dos cargos respectivos". 


\subsubsection{Investigações interna corporis}

\section{Entre os diversos sujeitos titulares de foro especial por prerrogativa de}

função para o julgamento criminal, destacam-se duas categorias nas quais a investigação

preliminar se realiza não pelo trabalho da Polícia Judiciária, que é o investigador-padrão de

todos os cidadãos, mas pela própria instituição a que pertence o indivíduo sobre que recai

indício da prática de ilícito penal, conforme previsão em norma especial: trata-se das investigações de delitos atribuídos a membros da Magistratura e do Ministério Público ${ }^{359}$.

Essa espécie de investigação consiste, segundo Damásio Evangelista de

Jesus, em "imunidade processual que acoberta o Juiz de Direito e o membro do Ministério

${ }^{359}$ No direito estrangeiro, o Código de Processo Penal português traz norma expressa consagradora da investigação diferenciada: "Art. 265.1. Se for objecto da notícia do crime magistrado judicial ou do Ministério Público, é designado para a realização do inquérito magistrado de categoria igual ou superior à do visado. 2. Se for objecto da notícia do crime o procurador-geral da República, a competência para o inquérito pertence a um juiz do Supremo Tribunal de Justiça, designado por sorteio, que fica impedido de intervir nos subsequentes actos do processo". Insta ressaltar, contudo, que embora a investigação preliminar seja protagonizada, naquele sistema, pelo Ministério Público, coadjuvado pelos órgãos de polícia criminal (art. 263.1), não se descarta a possibilidade de o juiz da instrução também praticar, mediante provocação, alguns atos específicos de investigação (previstos no art. 268 do CPP). Trata-se, portanto, de "um sistema misto, em que na instrução preliminar - apesar de estar atribuída ao MP - atua o juiz como garante e também como investigador, praticando pessoalmente alguns atos tipicamente investigatórios." (LOPES JR. Aury. Sistemas..., cit., p. 259). Na Espanha, a Ley de Enjuiciamento Criminal previa, nos arts. 757 a 778, um estágio procedimental específico para a persecução de delitos cometidos por juízes e magistrados no exercício de suas funções, toda vez que o acusador fosse um particular. No dizer de Manuel M. Gómez del Castillo e José I. Ugalde González (Procesos penales ordinarios y especiales. 2. ed. Madrid: Tecno, 1991, p. 60), tais delitos não se perseguiam mediante procedimentos especiais, mas se adotava o procedimento ordinário adornado com a particularidade do chamado antejuicio. Este consistia numa garantia especial, estabelecida pelo legislador em função das qualidades do imputado, erigida em pressuposto de admissibilidade da querela (notícia-crime) e que tinha por objeto a análise pormenorizada desta para sua admissão ou não, exigindo-se maiores formalismos que os normalmente previstos na LECrim. Iniciava-se mediante petição escrita, com as mesmas formalidades da querela (art. 227 da LECrim), por meio de procurador e assinada por advogado. Miguel Fenech ( $E l$ proceso penal. 4. ed. Madrid: Agesa, 1982, p. 203) destaca que a especialidade do antejuicio consistia em antepor ao processo em sentido amplo uma espécie de pré-processo, no qual se decidiria sobre a concorrência dos suficientes caracteres do delito, para dar início ao sumário. O sumário é a fase de investigação preliminar do procedimento ordinário espanhol, funcionando, aqui, como filtro prévio para impedir a possibilidade de se iniciarem processos penais contra juízes e magistrados por supostos delitos cometidos em suas funções, toda vez que alguém, descontente com sua atuação, pretendesse intentar contra eles uma denúncia ou querela (modalidades de notícia-crime). O antejuicio era marcado pela nãoparticipação do querelado e pela limitação dos meios de investigação a documentos e testemunhas. Era promovido perante o próprio tribunal competente para o julgamento da causa penal, que, ao final das diligências, se admitisse a querela, mandaria proceder ao sumário, designando entre seus membros um "juiz instrutor especial", que atuaria por delegação do tribunal e ficaria impedido de intervir na fase do juízo oral. O antejuicio foi revogado pela Lei Orgânica 5/1995, porém ficou mantida, no art. 410 da Lei Orgânica do Poder Judiciário, de 1985, a prerrogativa de designação de instrutor especial pelo tribunal (distinto do que resultaria pela aplicação das regras gerais de competência), para realizar uma espécie de 
Público da possibilidade de ser contra eles instaurado inquérito policial pelo Delegado de Polícia ou de, no curso de investigação policial, vir a ser apurada infração penal a eles atribuída. Não é um privilégio odioso colocado acima da lei. É um desdobramento do foro especial concedido em razão da prerrogativa de função"360.

A justificativa que move tal atribuição diferenciada para o múnus investigatório é a de garantir a imparcialidade dos procedimentos, sem o risco de pressões políticas de outros órgãos durante a atividade - valendo, aqui, as mesmas preocupações que levaram à instituição do foro especial. Segundo Marcelo Chiara Teixeira, a autorização legal, nesses casos, "busca garantir a imparcialidade na investigação e a própria independência entre os poderes" ${ }^{361}$.

Ocorre que o argumento da prerrogativa de serem julgados originariamente por um tribunal ou corte superior, em matéria criminal, não basta para justificar as investigações interna corporis, porquanto todas as demais hipóteses de foro especial prescindem de norma similar na etapa investigativa, ficando a atribuição das investigações na esfera da Polícia Judiciária ${ }^{362}$. Outrossim, o risco de mácula à imparcialidade e

investigação prévia ao sumário, verificando se haveria verossimilhança na imputação contra o juiz ou magistrado. A investigação prévia, portanto, continua a cargo do tribunal competente para o julgamento.

${ }^{360}$ Inquérito policial contra promotor de justiça e juiz de direito. Justitia, São Paulo, v. 47, n. 129, abr./jun. 1985, p. 103. Denise Neves Abade (Garantias..., cit., p. 177), por sua vez, sugere que, se o pressuposto da prerrogativa de função implicar a retirada do delegado de polícia da presidência dessas investigações, "não haveria qualquer óbice que ferisse a prerrogativa de foro especial na investigação procedida por membro do Ministério Público de segunda instância".

361 TEIXEIRA, Marcelo Chiara. Procedimentos administrativos..., cit., p. 102. No mesmo toar, a observação de Jesus Zarzalejos Nieto (El proceso penal contra jueces y magistrados: la especialidad del antejuicio. Madrid: Arias Montano, 1992, p. 3): “A finalidade das especialidades orgânicas e processuais instauradas no regime da responsabilidade criminal judicial não é a impunidade do julgador que viola a missão de restabelecer a ordem entre os sujeitos enfrentados, mas impedir que a coação que pode sofrer o julgador pela promoção temerária e abusiva de processos em que seja acusado de algum delito, altere a serenidade de ânimo imprescindível para ministrar justiça; e por outro, garantir ao cidadão a repressão do delito cometido pelo juiz".

362 Ressalte-se que, nos regimentos internos dos Tribunais, não se encontra prevista a nomenclatura de "inquérito judicial". Tanto as investigações levadas a efeito sobre fatos imputados a magistrados (as quais seriam, por disposição da Loman, internas ao Poder Judiciário - portanto, judiciais), quanto as demais investigações envolvendo outros sujeitos com foro por prerrogativa de função são tratadas, pura e simplesmente, como "inquéritos", característica que faz acenar para uma possível aproximação formal entre ambos os procedimentos, a ser evidenciada quer mediante certa abertura das investigações intestinas à participação de órgãos de Polícia Judiciária (via delegações/requisições), quer mediante o maior controle, pelo magistrado relator, das investigações policiais sobre agentes políticos. Assim, por exemplo: "Habeas corpus. Inquérito judicial. Superior Tribunal de Justiça. Investigado com prerrogativa de foro naquela Corte. Interpretação do art. 33, parágrafo único, da Loman. Trancamento. Ausência de constrangimento ilegal. Precedentes. (...) Não se sustentam os argumentos da impetração, ao afirmar que o inquérito transformou-se em procedimento da Polícia Federal, porquanto esta apenas exerce a função de Polícia Judiciária, por delegação e sob as ordens do Poder Judiciário. Os autos demonstram tratar-se de inquérito que tramita no Superior Tribunal de Justiça, sob o comando de Ministro daquela Corte Superior de Justiça, ao qual caberá dirigir o processo sob a sua relatoria, devendo tomar todas as decisões 
impessoalidade do investigador poderá estar presente, ainda com maior vigor, nas investigações internas, dada a marca do corporativismo associada a esses procedimentos, e o sistema precisa prever uma estrutura de coerência para investigações criminais, para que não haja rompimentos injustificáveis ao princípio da isonomia entre os indivíduos submetidos à persecução criminal.

É bem de ver que não são apenas esses os casos de investigação criminal preliminar interna corporis verificáveis em nossa experiência jurídica, existindo também procedimentos internos dentro da própria Polícia Judiciária (Polícia Civil ou Polícia Federal) e da Polícia Militar, quando se trata de crimes praticados por integrantes de cada uma dessas corporações ${ }^{363}$.

No entanto, para o objetivo do presente estudo, apenas os procedimentos intestinos realizados no âmbito da Magistratura e do Ministério Público guardam pertinência temática, eis que os demais investigados não ostentam a prerrogativa do foro criminal especial e, portanto, refogem ao subsistema de investigação preliminar ora desenhado.

\subsubsection{Investigações envolvendo membros da Magistratura}

De início, têm-se as investigações criminais que recaem sobre membros da Magistratura, as quais constituem, no direito brasileiro, forma própria de inquérito judicial e cujo procedimento vem servindo, na prática (e a nosso ver de forma inadequada, sob o ponto de vista da judicialização dos procedimentos investigatórios, ou da maior ingerência do magistrado na fase pré-processual em matérias que não dizem estritamente com

necessárias ao bom andamento das investigações.” (STF, HC 94.278/SP, rel. Min. Menezes Direito, Plenário, por maioria, DJ de 28.11.2008).

363 Assim, por exemplo, Marcelo Chiara Teixeira (Procedimentos administrativos..., cit., p. 144) alude às investigações interna corporis realizadas na Polícia Civil de São Paulo, para apurar infrações penais atribuídas a policiais civis. Tais apurações, nos termos do Decreto estadual 47.236, de 18.10.2002, cabem privativamente à Corregedoria-Geral da Polícia Civil, em específico, na capital, à Divisão de Crimes Funcionais e, no interior, às Corregedorias Auxiliares. A sua vez, Arthur Pinto de Lemos Júnior (A investigação judicial no âmbito da Corregedoria da Polícia Judiciária e a titularidade da ação penal do Ministério Público. Revista da Escola Paulista da Magistratura, São Paulo, v. 5, n. 2, jul./dez. 2004) realça a anômala função do Juiz Corregedor da Polícia Judiciária, no Estado de São Paulo, de investigar crimes cometidos por membros da Polícia Civil, numa espécie de procedimento apuratório judicial, previsto na Resolução 11 do Órgão Especial do Tribunal de Justiça de São Paulo, de 5.7.1985. Cuida-se, porém, de documento anterior à Constituição atual e, portanto, carente de sustentabilidade no ordenamento vigente, em que o juiz se desvencilha de tarefas investigativas, deixadas à Polícia Judiciária, sob supervisão do Ministério Público. 
questões jurisdicionais), de parâmetro para as investigações dos demais sujeitos albergados no foro por prerrogativa de função.

Em grande parte dos tribunais brasileiros, a persecução de infrações penais atribuídas a magistrados não representa, dentro do universo de titulares da prerrogativa de foro, a sua maior parcela, mesmo porque, numericamente, sobressaem os prefeitos e outras autoridades públicas detentoras de cargo eletivo no âmbito dos indivíduos sindicáveis criminalmente perante o foro originário ${ }^{364}$. Todavia, reveste-se de singular importância a investigação dos membros do Poder Judiciário, pois, dentre todas, é a que encontra previsão legal expressa há mais tempo em nosso ordenamento.

O estabelecimento da investigação preliminar no foro natural de julgamento dos magistrados ocorre por força da Lei Orgânica da Magistratura Nacional - Lei Complementar 35, de 14 de março de 1979 -, que determina, no art. 33, parágrafo único, a remessa dos autos da investigação ao tribunal respectivo sempre que houver indício da prática de crime por parte do magistrado ${ }^{365}$.

O preceito é abrangente, referindo-se a "crime" no sentido mais lato, não comportando interpretação restrita que o faça englobar apenas os delitos verificados no exercício da função pública ${ }^{366}$. Demanda, por outro lado, compreensão ampla, para abranger também as contravenções penais, por isso melhor seria, tecnicamente, a utilização do termo "delitos" ou "infrações penais" para definir tal competência, nas normas constitucionais dos arts. 96, III, 105, I, $a$, e 108, I, $a^{367}$. A Constituição, aliás, ao estabelecer a competência dos tribunais por prerrogativa de função, fê-lo em razão da dignidade do cargo ocupado (competência funcional), não distinguindo matéria ou espécie de delito. Dessa forma, desde as infrações penais definidas como de menor potencial ofensivo, passando pelos mais diversos tipos previstos no Código Penal (próprios ou não de

364 A observação não vale para o Superior Tribunal de Justiça, sob cuja jurisdição (art. 105, I, a, da CF/1988) não estão os milhares de prefeitos dos Municípios brasileiros, mas apenas os vinte e sete governadores dos Estados e do Distrito Federal, encontrando-se em maior número, preponderante e potencialmente, os magistrados (desembargadores dos Tribunais de Justiça e juízes dos Tribunais Regionais Federais, Eleitorais e do Trabalho) ou equivalentes (Conselheiros dos Tribunais de Contas dos Estados e do Distrito Federal).

365 “Art. 33. São prerrogativas do magistrado: (...)

IV - não estar sujeito a notificação ou a intimação para comparecimento, salvo se expedida por autoridade judicial; (...)

Parágrafo único. Quando, no curso de investigação, houver indício da prática de crime por parte do magistrado, a autoridade policial, civil ou militar, remeterá os respectivos autos ao Tribunal ou órgão especial competente para o julgamento, a fim de que prossiga na investigação."

$366 \mathrm{O}$ mesmo ocorre com o inquérito contra magistrados do direito português, previsto no art. 265 do CPP lusitano, adrede transcrito. 
funcionários públicos), até as espécies delituosas constantes de leis esparsas, todos esses ilícitos se enfeixam na jurisdição da Corte a quem compete processar e julgar os magistrados pelos crimes comuns e de responsabilidade ${ }^{368}$.

Muito embora a Loman faça referência à remessa dos autos da investigação ao respectivo Tribunal ou órgão especial competente para o julgamento, "a fim de que prossiga na investigação", não traça normas de procedimento para a referida atividade préprocessual, de modo que os tribunais vêm aplicando, também nas investigações interna corporis, os parcos preceitos contidos na Lei 8.038/1990 e nos seus regimentos internos ${ }^{369}$. Tal investigação interna, além disso, não impede a atuação do Ministério Público - como já decidiu o Supremo Tribunal Federal ${ }^{370}$ - nem a participação da Polícia Judiciária, que atuará, todavia, excepcionalmente e mediante requisição específica, jamais de ofício.

Diferentemente das investigações interna corporis ministeriais (nas quais as leis orgânicas expressamente prevêem que a investigação prosseguirá pela condução do

367 A propósito, confira-se o item 3.1, adiante.

368 Sobre a possibilidade de as autoridades judiciárias serem sujeitos ativos de crime de responsabilidade, registre-se que a Lei 1.079/1950, na redação originária, previa apenas que os Ministros do Supremo Tribunal Federal pudessem figurar em tal condição, ao praticarem as condutas tipificadas no art. 39. A Lei 10.028/2000, todavia, ampliou esse espectro subjetivo, estabelecendo que autoridades judiciárias outras pudessem cometer crimes de responsabilidade, desde, porém, que exercessem funções administrativas. Assim, foram incluídos no raio de incidência da Lei 1.079/1950 (como sujeitos ativos dos crimes de responsabilidade contra a lei orçamentária, descritos no art. 10) os Presidentes, e respectivos Substitutos quando no exercício da Presidência, dos Tribunais Superiores, dos Tribunais de Contas, dos Tribunais Regionais Federais, do Trabalho e Eleitorais, dos Tribunais de Justiça e de Alçada dos Estados e do Distrito Federal, e os Juízes Diretores do Foro ou função equivalente no primeiro grau de jurisdição (art. 39-A, parágrafo único), bem como o Advogado-Geral da União, os Procuradores-Gerais do Trabalho, Eleitoral e Militar, os Procuradores-Gerais de Justiça dos Estados e do Distrito Federal, e os membros do Ministério Público da União e dos Estados, da Advocacia-Geral da União, das Procuradorias dos Estados e do Distrito Federal, quando no exercício de função de chefia das unidades regionais ou locais das respectivas instituições (art. 40-A, parágrafo único).

369 Refira-se o precedente do Superior Tribunal de Justiça pelo qual o inquérito foi remetido à Corte Especial daquele sodalício (Inq 529/RO), em virtude da figuração, como investigados, de desembargador de Tribunal de Justiça e Conselheiro de Tribunal de Contas do Estado. Ao receber a denúncia e dar início à ação penal, o Órgão Especial deixou esclarecido que: "Nos termos da Lei 8.038/90 (art. $1 .^{\circ}, \S 1 .^{\circ}$ ) e do Regimento Interno desta Corte (art. $217, \S \S 1 .^{\circ}$ e $2 .^{\circ}$ ), cabe ao relator, como juiz da instrução, ordenar diligências complementares, da mesma forma como atua o juiz de $1 .^{\circ}$ grau na fase pré-processual das investigações (precedentes do STF e do STJ).” (APn 460/RO, rel. Min. Eliana Calmon, rel. p/ acórdão Min. João Otávio de Noronha, por maioria, DJ de 25.6.2007).

370 “O que previsto no artigo 33, parágrafo único, da Lei Orgânica da Magistratura Nacional não obstaculiza a atuação interna e externa do Ministério Público. Na primeira, mediante exame de dados que lhe tenham chegado às mãos e, na segunda, formalizando denúncia junto ao Tribunal competente, visando à persecução criminal.” (HC 88.280/SP, rel. Min. Marco Aurélio, 1. a Turma, v.u., DJ de 8.9.2006); "Não há intromissão indevida do Ministério Público Federal, porque como titular da ação penal (art. 129, incisos I e VIII, da Constituição Federal) a investigação dos fatos tidos como delituosos a ele é destinada, cabendolhe participar das investigações. Com base nos indícios de autoria, e se comprovada a materialidade dos crimes, cabe ao Ministério Público oferecer a denúncia ao órgão julgador. Por essa razão, também não há falar em sigilo das investigações relativamente ao autor de eventual ação penal." (HC 94.278/SP, rel. Min. Menezes Direito, Plenário, por maioria, DJ de 28.11.2008). 
respectivo Procurador-Geral ${ }^{371}$ ), bem assim das persecuções calcadas, unicamente, na Lei 8.038/1990 (que faz menções à atuação de um relator, na fase pré-processual: p. ex., art. $1 .^{\circ}, \S \S 1 .^{\circ}$ e $\left.2 .^{\circ}, b\right)$, discute-se se a determinação de remessa dos autos "ao Tribunal ou órgão especial competente para o julgamento, a fim de que prossiga na investigação", contida no parágrafo único do art. 33 da Loman, implica a obrigatoriedade de que o impulsionamento da investigação, doravante, dependa em tudo da manifestação prévia do órgão colegiado (plenário ou especial).

Ora, o dispositivo da Loman apenas elegeu o Tribunal como o locus da investigação, como todo dispositivo que atribui competência em geral o faz, ficando ao regimento interno a regulamentação sobre a distribuição interna, entre seus membros, das atribuições de condução do inquérito. Não se erige em condição de procedibilidade da investigação de magistrados, nem em condição de validade para a prática de cada ato no procedimento, o prévio crivo do órgão colegiado (Tribunal Pleno ou Corte Especial) para continuidade das investigações. A garantia contida no art. 33, parágrafo único, da Loman, foi esculpida para não se submeterem os juízes a investigação de delegados de polícia. Assim, ela se aperfeiçoa com a só condução do inquérito por membro do colegiado (Relator), sem necessidade de que todo o colegiado o dirija ${ }^{372}$.

Afora a ausência de causa jurídica para tanto, tal entendimento, se adotado com os atos de mero impulsionamento a depender de julgamento em sessões, com possibilidade de pedidos de vista, além de as oitivas de investigados e testemunhas ser procedida por todos os membros do colegiado -, iria de encontro a qualquer perspectiva de eficiência dessas investigações preliminares que já perdem muito em sua dinâmica pelo só fato de serem conduzidas por profissionais julgadores (não investigadores).

Razoável, assim, que o inquérito seja submetido ao Tribunal (ou Órgão Especial), para nele ser distribuído a um Relator, ao qual competirão os atos próprios do inquérito, ficando a palavra do órgão colegiado adstrita apenas às questões mais relevantes

371 Vide item 2.4.1.2.

372 Nesse sentido, Therezinha Astolphi Cazerta (Ação penal originária: apontamentos: reflexões. Revista TRF 3. ${ }^{a}$ Região, São Paulo, v. 80, nov./dez. 2006, p. 25): “Apenas o que se impõe é a remessa ao órgão competente, que passará a presidir o inquérito, não sendo necessária ordem escrita do tribunal para que a persecução prossiga, bastando a distribuição ao relator, a que são delegadas as funções de instrução processual". Outra importante diretriz nesses feitos criminais é a de que, para a tomada de decisões colegiadas em ações e inquéritos penais envolvendo magistrados, haja a composição da maioria absoluta de integrantes efetivos do Tribunal competente. O Supremo Tribunal Federal anulou condenação em que a maioria absoluta do colegiado prolator do acórdão era composta por Juízes de Direito convocados para substituir Desembargadores ausentes por motivos diversos (HC 78.051/PB, rel. Min. Sepúlveda Pertence, 1. Turma, por maioria, DJ de 17.9.1999). 
da investigação, como é o caso de algumas medidas cautelares (como a decretação de prisão temporária ou preventiva de magistrado, que a própria norma especial estabelece depender de decisão do colegiado ${ }^{373}$ ) e decisões de arquivamento ${ }^{374}$.

É fora de dúvida que um dos mais sensíveis problemas que cercam a investigação penal dos magistrados reside na persecução de condutas delituosas praticadas no exercício da atividade jurisdicional ${ }^{375}$. Isso porque o princípio do livre convencimento do julgador, ao tempo em que funciona como sustentáculo do nosso sistema processual em que todos os meios lícitos de prova são admitidos no processo, podendo o julgador formar o seu convencimento com apoio em qualquer deles, desde que motive a sua

373 É o que dispõe o art. 33, II, da Loman: “Art. 33. São prerrogativas do magistrado: (...) II - não ser preso senão por ordem escrita do Tribunal ou do órgão especial competente para o julgamento, salvo em flagrante de crime inafiançável, caso em que a autoridade fará imediata comunicação e apresentação do magistrado ao Presidente do Tribunal a que esteja vinculado" (grifo acrescido). No Regimento Interno do Tribunal de Justiça do Estado de São Paulo, que dedica capítulo próprio à prisão e investigação criminal contra magistrado, consta interessante dispositivo ressaltando a necessidade de que a prisão do juiz seja decretada pelo Órgão Especial (art. 312), muito embora a investigação seja presidida pelo relator sorteado, em cujos poderes investigatórios estão compreendidos "os de requisitar diligências e perícias às autoridades policiais, bem como o de determinar a quebra de sigilo postal, telegráfico, telefônico, fiscal, de dados e bancário" (art. 314, § 1. ${ }^{\circ}$ ). Nos Regimentos Internos dos Tribunais Regionais Federais não há capítulo próprio sobre a investigação de magistrados, exceto o Regimento da 4. ${ }^{\mathrm{a}}$ Região, que atribui sua competência a um relator, observadas as normas que disciplinam o inquérito policial (arts. 198 a 200).

${ }^{374}$ No HC 77.355/RS, julgado em 1998, o relator, Min. Marco Aurélio, consignara - embora obiter dicta, porque o habeas terminou provido por falta de justa causa, ou seja, por questão substancial, tanto que os Min. Jobim e Maurício Corrêa dissentiram da formalidade apontada o relator - uma espécie de direito do magistrado, extraído do art. 33 da Loman, de "não haver seqüência de investigação sem o crivo do tribunal ou órgão especial", pois o relator teria encaminhado os autos ao Ministério Público sem submetêlos previamente ao órgão especial. Dez anos depois, no julgamento do HC 94.278/SP (rel. Min. Menezes Direito, DJ de 28.11.2008), no qual um magistrado envolvido no Inquérito 547, em trâmite no STJ, sustentara que o seu relator, ao agir sem ouvir a Corte Especial do STJ, teria desrespeitado o que prevê o art. 33 da Loman, o Plenário do STF, vencido apenas o Ministro Marco Aurélio, decidiu que o relator do inquérito exerce as funções atribuídas a um juiz de primeiro grau na condução do processo, podendo, no entanto, seus despachos serem contestados perante o tribunal. Na ementa do aresto, está consignado: "A remessa dos autos do inquérito ao Superior Tribunal de Justiça deu-se por estrito cumprimento à regra de competência originária, prevista na Constituição Federal (art. 105, inc. I, alínea 'a'), em virtude da suposta participação do paciente, Juiz Federal do Tribunal Regional Federal da 3. ${ }^{a}$ Região, nos fatos investigados, não sendo necessária a deliberação prévia da Corte Especial daquele Superior Tribunal, cabendo ao Relator dirigir o inquérito".

375 Entre os precedentes que rechaçam a tipificação de conduta atribuída a magistrados, encontra-se o acórdão proferido pela Corte Especial do STJ na Rp 357/SP (rel. Min. Luiz Fux, Corte Especial, v.u., DJ de 4.6.2007), em cuja ementa reluz trecho das Obras Completas de Rui Barbosa, v. XXIII, t. III, p. 228: "Para fazer do magistrado uma impotência equivalente, criaram a novidade da doutrina, que inventou para o Juiz os crimes de hermenêutica, responsabilizando-o penalmente pelas rebeldias da sua consciência ao padrão oficial no entendimento dos textos. Esta hipérbole do absurdo não tem linhagem conhecida: nasceu entre nós por geração espontânea. E, se passar, fará da toga a mais humilde das profissões servis, estabelecendo, para o aplicador judicial das leis, uma subalternidade constantemente ameaçada pelos oráculos da ortodoxia cortesã. Se o julgador, cuja opinião não condiga com a dos seus julgadores na análise do Direito escrito, incorrer, por essa dissidência, em sanção criminal, a hierarquia judiciária, em vez de ser a garantia da justiça contra os erros individuais dos juízes, pelo sistema dos recursos, ter-se-á convertido, a benefício dos interesses poderosos, em mecanismo de pressão, para substituir a consciência 
operação intelectiva -, pode servir de anteparo a infrações cujo desvendamento se vê, por isso mesmo, bastante dificultoso ${ }^{376}$.

Nesse ponto, não há confundir o error in procedendo e o error in judicando, falhas passíveis de cometer qualquer magistrado em seus atos jurisdicionais e sanáveis por mecanismos intraprocessuais (os recursos), com ilícitos penais, pois o erro judicial, decorrência da natural falibilidade humana, não constitui em si mesmo um fato delituoso, devendo-se identificar a eventual presença dos elementos específicos que se complementam na definição típica do delito ${ }^{377}$.

De outro vértice, nessa espécie de investigação, é comum criticar-se o fato de se deixar à própria instituição a que pertence o investigado dirigir o procedimento investigativo, com maior propensão a desfechos de cunho eminentemente corporativo e protecionista. Tal distorção, porém, é passível de verificar-se em quaisquer dos modelos de investigação interna corporis, e mesmo nos inquéritos policias não está o investigador imune a pressões externas que possam comprometer a sua impessoalidade. Os desvios porventura verificados não derivarão do modelo em si, mas da pontual complacência, também em tese criminosa, dos encarregados da persecução.

A questão é anterior e não diz tanto com o fato de partir da própria instituição a investigação dos agentes, mas sim, como já ressaltado, de ser um órgão do Poder Judiciário que está à frente da investigação criminal, cujo rumo em tudo dele depende, o que vem deturpar a tripartição de papéis preconizada pelo modelo acusatório de processo penal $^{378}$. O magistrado responsável pela presidência da investigação preliminar

pessoal do magistrado, base de toda a confiança na judicatura, pela ação cominatória do terror, que dissolve o homem em escravo".

376 Como refere Ricardo Aronne (O principio do livre convencimento do juiz. Porto Alegre: Sergio Antonio Fabris, 1996, p. 34), “[a] convicção do julgador não se forma imotivadamente, de forma arbitrária. Adstrito à lei, e na forma dela, o juiz deve ter em vista, apenas, o que consta do processo, sendo-lhe vedada a narco-análise. Sua liberdade não é de decisão no sentido de desapego, podendo decidir conforme bem entender, independente de tudo e de todos. A liberdade a que se refere o Princípio do Livre Convencimento é a de apreciar os dados apresentados pelas partes, ou por ela buscados, acerca dos fatos controvertidos, ou seja, dos elementos de prova, a fim de embasar e formar seu convencimento, repise-se, na forma da lei".

377 De peça redigida pelo Ministério Público Federal no bojo da APn 425, no STJ, em que se apuravam notícias de práticas lesivas ao erário, por possível organização criminosa, incluindo-se burla à livre distribuição, extrai-se interessante passagem a demonstrar o esforço do órgão acusador em tentar enquadrar a conduta de magistrado em tipo penal: "Parecem inverossímeis as histórias de determinados processos e seus desdobramentos. A trajetória processual de alguns feitos é tão fantástica que beira o caricato. Sempre suspeita, a postura dos magistrados ora denunciados, embora flagrantemente incomum, protegia-se no dogma da independência da prestação jurisdicional e no princípio do livre convencimento".

378 Convém trazer à baila as palavras de Aury Lopes Jr., ao tratar do juiz instrutor nos sistemas que adotam o juizado de instrução, as quais podem ser referidas, por argumento analógico, ao magistrado dirigente da investigação preliminar nos crimes atribuídos a juízes: "O juiz instrutor, por vício da atividade 
não apenas participa da decisão de recebimento ou rejeição da denúncia, mas é o relator do processo, proferindo o primeiro voto, também no julgamento final ${ }^{379}$.

Ademais, não se pode tolerar a anomia reinante para tais procedimentos investigatórios, a denotar ultraje à garantia do devido processo legal no seu aspecto procedimental. Nesses casos, fica totalmente a critério da autoridade dirigente da investigação definir o modus agendi em vários aspectos, muitos dos quais de tamanha importância que mereceriam tratamento específico do legislador: momento de ciência do investigado, acesso aos autos pela defesa e pela vítima, possibilidade de requerimento de diligências, sigilo ou publicidade dos atos, prazo de duração do procedimento, etc.

Pode-se ainda antever que a investigação, assim judicializada, quedará ainda mais burocratizada e lentificada, envolta em formalidades incompatíveis com a própria natureza da atividade investigativa, aumentando as possibilidades de malogro em sua missão ${ }^{380}$. Seja pela sentida sobrecarga de atribuições dos tribunais - mormente os de jurisdição nacional, como o Supremo Tribunal Federal e o Superior Tribunal de Justiça -, seja pela falta de vocação e mesmo de inclinação pessoal de alguns magistrados pelas lidas

jurisdicional, acaba por converter a instrução preliminar em plenária, pois não se contenta com a mera probabilidade: quer chegar à certeza e para isso gera um atraso injustificado e contrário à própria natureza da instrução preliminar" (Sistemas..., cit., p. 83).

379 Eduardo Pereira da Silva (Prerrogativa de foro..., cit., p. 12), abonando a tese de incompatibilidade dos poderes investigatórios dos magistrados ao sistema vigente, explica que "eventuais receios da magistratura existentes quando da edição da Lei Complementar n. 35/1979, bem como da origem das normas regimentais acerca da atribuição para investigação de crimes cometidos nas dependências de Tribunais, não se justificam diante das inovações da Constituição atual. Com efeito, não é mais possível à polícia judiciária a prática, sem ordem judicial, de um grande número de atos que antes a dispensavam: busca domiciliar, quebra de sigilo bancário, fiscal, telefônico, prisão para averiguação, etc. De tal maneira, a simples garantia de não indiciamento em inquérito policial e a sua necessária 'supervisão' judicial e ministerial são suficientes para legitimá-lo como instrumento de investigação pré-processual de quaisquer crimes". Denise Neves Abade (Garantias..., cit., p. 178), por sua vez, sobreleva que, ao se conferir a investigação e o julgamento a um mesmo órgão do Estado, afronta-se flagrantemente a garantia da imparcialidade, caindo-se num intolerável processo inquisitivo.

380 Vladimir Passos de Freitas, após relatar o aumento de casos em que magistrados se envolvem em crimes, divulgados inclusive na mídia, ressalta a dificuldade de sua apuração. O mesmo fato criminoso, quando praticado por um juiz, diz o autor, dá ensejo à responsabilidade civil, administrativa e penal. No caso de juízes de primeira instância, a responsabilidade administrativa é apurada pelas Corregedorias dos Tribunais, mas em se tratando de desembargadores e ministros, é perquirida pelo próprio tribunal (ressalvada a competência suplementar do Conselho Nacional de Justiça), mediante regras estabelecidas em seus regimentos. A investigação aí se revela complexa, eis que "o convívio cria laços de amizade que tornam difícil, de um momento para o outro, passar de colega a inquisidor". Já na investigação criminal, passando o relator, no tribunal competente, a presidir o inquérito, "sem conhecimentos teóricos ou práticos dessa atividade, muitas vezes sem jurisdição criminal há anos, sem doutrina ou jurisprudência para consultar, sem apoio de órgãos técnicos, debate-se em dificuldades. Então o inquérito, que deveria ser simples, informal (CPP, art. $6^{\circ}$ ), sem contraditório, passa a ter andamento lento e burocrático." (Julgando os juízes. Boletim IBCCrim, São Paulo, v. 13, n. 154, set. 2005, p. 19). 
criminais ou pela dinâmica investigativa ${ }^{381}$, seja pela carência ou insuficiência de aparato logístico direcionado à investigação de delitos, ou, ainda, pelo desequilíbrio quantitativo entre membros de tribunais e processos a si submetidos, a manutenção de uma espécie de inquérito judicial, realizado pelas cortes de julgamento, parece ser um retrocesso na esperada eficiência da etapa prévia da persecução ${ }^{382}$.

\subsubsection{Investigações envolvendo membros do Ministério Público}

Malgrado persista ainda forte celeuma doutrinária e jurisprudencial em torno dos poderes investigatórios do Ministério Público, dúvidas não pairam sobre a incumbência legal de tal mister quando se trate de investigado membro da instituição. De forma similar ao ocorrido em relação aos magistrados, o procedimento de investigação de delitos cuja prática se atribui a membro do Ministério Público (seja da União ou dos Estados) é conduzido, com base em invocação legal expressa, pela própria instituição a que pertence o procurador ou promotor.

A Lei Orgânica Nacional do Ministério Público (LONMP) - Lei 8.625, de 12 de fevereiro de 1993 - é clara a esse respeito, estatuindo, no art. 41, parágrafo único, a obrigatoriedade de remessa dos autos de inquérito policial ao Procurador-Geral de Justiça desde que haja indício da prática de infração penal por membro do Ministério Público ${ }^{383}$. A

381 Assim o ponderava João de Deus Cardoso de Mello (O inquérito policial..., cit., p. 50), ao justificar sua discordância à idéia de implantação do sistema de juizado de instrução no Brasil: "Em geral nossos juízes (e não vai nisso uma censura), têm, digamos assim, mentalidade civilística. São homens de gabinete, não de ação. Entendem que a função do juiz é julgar, não descobrir e prender criminosos. O pensamento que os domina neste particular, ninguém os traduziu melhor, que o ministro da Justiça José de Alencar, em discurso que proferiu no parlamento ao discutir-se a Reforma Judiciária, de 1869: 'A judicatura, disse ele, deve ser essencialmente passiva; ela deve revestir-se da calma, da placidez que representa e do que é a imagem viva. O juiz não pode nem deve rastejar o crime, correr após ele"”.

382 Realça-se o aspecto negativo de investigações afetas à supervisão de tribunais, sob o ponto de vista da celeridade e da simplicidade, notas que se têm por essenciais à etapa pré-processual. Mesmo nas Casas em que o Plenário constituiu órgão especial, a competência deste é bastante ampla e diversificada, não ficando restrita à matéria penal, o que vem representar certo empeço à apuração mais expedita das condutas delituosas sujeitas à competência originária dos tribunais. Como exemplo, tem-se a Corte Especial do Superior Tribunal de Justiça, composta de vinte e dois Ministros e com vastas atribuições, de ordem jurisdicional e administrativa, delimitada no art. 11 do Regimento Interno. No Supremo Tribunal Federal a situação é ainda mais preocupante, pois todas as atribuições do Plenário enfeixam-se nos apenas onze Ministros que o compõem, não havendo sido criado, pelo reduzido número de integrantes, órgão especial. O mesmo se diga quanto a algumas Cortes de segundo grau desprovidas de órgão especial que concentre a competência penal originária, como é o caso do Tribunal Regional Federal da 5. Região, composto de apenas quinze membros, com sede na cidade de Recife e jurisdição sobre seis Estados brasileiros.

383 “Art. 41. Constituem prerrogativas dos membros do Ministério Público, no exercício de sua função, além de outras previstas na Lei Orgânica: (...) 
Lei Orgânica do Ministério Público da União (LOMPU) - Lei Complementar 75, de 20 de maio de 1993 -, a sua vez, estabelece, no art. 18, parágrafo único, semelhante procedimento para o caso de envolvimento de seus membros, devendo ser o inquérito remetido ao Procurador-Geral da República ${ }^{384}$.

Em tais dispositivos, é prevista uma investigação diferenciada para os crimes atribuídos a membros do Ministério Público: é presidida pelo Chefe da instituição (o respectivo procurador-geral) ou por membro por ele designado, que tem liberdade na prática das investigações, sem prejuízo de requisitar a atuação da Polícia Judiciária para a realização de determinados atos, como perícias. O tribunal competente para $o$ processamento da causa somente tomará conhecimento da investigação nos episódios inseridos no espectro da reserva de jurisdição (decretação de medidas restritivas de direitos e correlatos pedidos de liberdade ${ }^{385}$ ) ou, mais adiante, na oportunidade do oferecimento da denúncia ou na apreciação do requerimento de arquivamento do caso, naqueles casos em que é necessária uma decisão jurisdicional para formar a coisa julgada (prescrição, atipicidade do fato, etc.).

Tanto na investigação de magistrado como de membro do Ministério Público, parece haver consenso de que os poderes do relator (condutor) são maiores, "atuando diretamente na condução da investigação, como presidente instrutor, sem a participação da polícia judiciária, salvo requisição específica. A investigação, ou inquérito, será conduzida exclusivamente pelo Poder Judiciário ou Ministério Público"386.

II - não ser indiciado em inquérito policial, observado o disposto no parágrafo único deste artigo; (...) Parágrafo único. Quando no curso de investigação, houver indício da prática de infração penal por parte de membro do Ministério Público, a autoridade policial, civil ou militar remeterá, imediatamente, sob pena de responsabilidade, os respectivos autos ao Procurador-Geral de Justiça, a quem competirá dar prosseguimento à apuração."

384 “Art. 18. São prerrogativas dos membros do Ministério Público da União: (...)

II - processuais: (...)

f) não ser indiciado em inquérito policial, observado o disposto no parágrafo único deste artigo; (...)

Parágrafo único. Quando, no curso de investigação, houver indício da prática de infração penal por membro do Ministério Público da União, a autoridade policial, civil ou militar, remeterá imediatamente os autos ao Procurador-Geral da República, que designará membro do Ministério Público para prosseguimento da apuração do fato."

385 Com relação à prisão dos membros do Ministério Público, a LOMPU estabelece como prerrogativa processual a de "ser preso ou detido somente por ordem escrita do tribunal competente ou em razão de flagrante de crime inafiançável, caso em que a autoridade fará imediata comunicação àquele tribunal e ao Procurador-Geral da República, sob pena de responsabilidade", ao passo que a LONMP prevê como prerrogativa dos membros do Ministério Público "ser preso somente por ordem judicial escrita, salvo em flagrante de crime inafiançável, caso em que a autoridade fará, no prazo máximo de vinte e quatro horas, a comunicação e a apresentação do membro do Ministério Público ao Procurador-Geral de Justiça” (grifos acrescidos).

386 CAZERTA, Therezinha Astolphi. Ação penal originária..., cit., p. 20. 
Hugo Nigro Mazzilli, ao analisar o art. 41, parágrafo único, da Lei $8.625 / 1993$, assim resume as regras diferenciadas na investigação de infrações penais envolvendo membro do Ministério Público: “ $a$ ) ao respectivo procurador-geral de justiça, ou a seu substituto legal, caberá prosseguir nas investigações, até denúncia ou pedido de arquivamento, conforme o caso, pouco importando o locus delicti commissi; b) será o Tribunal de Justiça o competente para apreciar o pedido de arquivamento ou para receber a denúncia (excetuadas as hipóteses de crimes de responsabilidade do procurador-geral de justiça, que, simetricamente ao modelo federal, deverão caber no julgamento do Poder Legislativo local, e as de crimes eleitorais); c) a regra do art. 96, III [da Constituição], só faz exceção à competência da Justiça Eleitoral, não à do tribunal do júri ou de outros foros ou tribunais, seja em razão da matéria ou não"387.

O procedimento investigativo criminal de membros do Ministério Público aproxima-se do verificado nos crimes atribuídos a magistrados, principalmente no que tange aos aspectos negativos. Nele, ecoam as mesmas críticas lançadas contra a persecução preliminar de membros da Magistratura, sobretudo a de ausência de um regramento legal para a investigação preliminar $^{388}$ e o fato de a atribuição ser da alçada da própria

${ }^{387}$ Regime Jurídico..., cit., p. 347-348. Anote-se que o art. 41, parágrafo único, da Lei 8.625/1993 foi objeto da ADI 1.115/DF, em que indeferida a medida cautelar por ausência do periculum in mora. O Ministro Paulo Brossard votou, vencido, pela concessão da liminar, destacando, em aparte, que se autoridades como o Vice-Presidente da República, um Ministro de Estado, um Deputado ou um Senador - integrantes de Poderes da República - cometem delitos, o inquérito é feito pela Polícia Judiciária, de modo que também deveria sê-lo no caso dos membros do Ministério Público (STF, ADI-MC 1.115/DF, rel. Min. Néri da Silveira, Plenário, por maioria, DJ de 17.11.1995). Ao depois, o Ministro Relator negou seguimento à ação direta, por ilegitimidade da parte autora (DJ de 20.3.2001).

${ }^{388}$ Nem mesmo o recurso à analogia aos procedimentos investigatórios de magistrados se faz possível na fase preliminar, à míngua de um rito legal em um ou em outro campo. A analogia é utilizada apenas quando existe regra legal, a exemplo do que ocorre no ato de rebecimento da acusação, em que se vem aplicando a regra do art. 29 da Loman ("Quando, pela natureza ou gravidade da infração penal, se torne aconselhável o recebimento de denúncia ou de queixa contra magistrado, o Tribunal, ou seu órgão especial, poderá, em decisão tomada pelo voto de dois terços de seus membros, determinar o afastamento do cargo do magistrado denunciado") também aos membros do Ministério Público. Trata-se de medida cautelar em matéria penal, matéria jurisdicional, não referida propriamente ao estatuto de direitos e deveres de magistrados. O STJ já decidiu, em mais de uma oportunidade, que é possível a aplicação analógica da Loman para afastamento cautelar de membro do Ministério Público, sem prejuízo do recebimento dos vencimentos e vantagens, em razão da imposição constitucional de tratar os membros do Ministério Público da mesma forma como são tratados os magistrados, como na APn 244/DF (rel. Min. Ruy Rosado de Aguiar, Corte Especial, por maioria, DJ de 1.7.2003), decisão esta que foi, posteriormente, reformada pelo STF ante a inobservância do quorum necessário. Mas em julgamento recente, o Supremo Tribunal Federal, ao receber denúncia ofertada contra Ministro do STJ e Desembargadores de Tribunais Regionais Federal e do Trabalho, determinou, à unanimidade, fossem eles afastados do cargo até julgamento final da ação penal, não estendendo, porém, por deliberação majoritária, a mesma providência cautelar ao Procurador Regional da República também processado, por considerar que o art. 29 da Loman não é aplicável aos membros do Ministério Público (Inq 2.424/RJ, rel. Min. Cezar Peluso, Plenário, DJ de 27.11.2008). Contra o recurso à analogia nesse caso, João Cláudio Couceiro (Prerrogativas..., cit., p. 67). 
instituição, donde seu traço corporativista ${ }^{389}$. Nele está ausente, todavia, deve-se reconhecer, a agravante de ser o julgador também o dirigente da investigação.

Mas se, de um lado, pode anunciar-se problemático deixar à Policia Judiciária conduzir tais apuratórios envolvendo magistrados e membros do Ministério Público, por implicar a investigação de autoridades a que Polícia Judiciária é servil em muitas de suas missões (tanto assim que veio adjetivada, historicamente, pelo termo “judiciária”), de outro, tampouco é viável o resguardo de um modelo de investigação diferenciada apenas para membros dessas duas instituições.

É possível e necessário promover avanços, com a previsão, por exemplo, de departamentos especializados dos setores policiais para os crimes de competência originária de tribunais - cujo controle externo e coordenação das investigações seja cometido a um membro do Ministério Público atuante junto ao próprio tribunal competente para a ação penal -, da participação da vítima (quando existente), retirando-se-a do ostracismo a que relegada, propiciando-lhe requerer diligências, apresentar informações e documentos que contribuam à elucidação dos fatos, enfim, um efetivo procedimento legal que faça inserir já na fase preliminar dessas apurações o conteúdo garantístico plasmado na Constituição.

\subsubsection{Investigações envolvendo agentes políticos}

No segundo grupo das investigações dos delitos submetidos a foro especial, encontram-se as investigações em que envolvidos titulares de cargos de natureza política, os agentes políticos. Sob tal insígnia, reúnem-se os agentes públicos titulares de cargos estruturais à organização política do país, cargos que compõem o esquema fundamental do poder (o governo propriamente dito), formadores da vontade superior do Estado. Tais agentes qualificam-se para o exercício das correspondentes funções não pela habilitação

${ }^{389}$ Para ilustrar as críticas a tal modelo, observe-se o caso da NC 358/DF, em que o Procurador-Geral da União apresentou representação contra dois Procuradores da República junto ao Procurador-Geral, aforada no Superior Tribunal de Justiça apenas para que fosse apreciado o pedido de arquivamento. Em decisão final publicada no DJ em 23.2.2007, o relator, Min. Ari Pargendler, anotou que a representação feita contra os Procuradores da República, para apurar possível crime de violação do sigilo funcional, "foi protocolada na Procuradoria-Geral da República no dia 28 de março de 2001 (fl. 18A), tendo sido recebida no Superior Tribunal de Justiça com pedido de arquivamento em 03 de junho de 2004 (fl. 02). Quer dizer, o Ministério Público Federal consumiu mais de 03 anos, 02 meses e 06 dias do prazo de prescrição de 04 anos. Com esse registro, defiro o pedido de arquivamento, porque extinta a punibilidade pela prescrição desde 07 de dezembro de 2004 (fl. 296)". 
profissional, e sim pelo fato de haverem sido eleitos para conduzirem os destinos da sociedade. Seus direitos e deveres não se regulam por normas estatutárias, mas derivam diretamente da Constituição e das leis. São agentes políticos, apenas: o Presidente da República, os Governadores, Prefeitos e respectivos vices, Ministros e Secretários das diversas Pastas, além dos Senadores, Deputados Federais e Estaduais e Vereadores ${ }^{390}$.

Todos eles ostentam, em nosso país, segundo regras encampadas ora na Constituição Federal, ora em Constituições Estaduais, o foro especial por prerrogativa de função, motivo pelo qual os delitos em que envolvidos serão objeto de processo e julgamento por tribunais ${ }^{391}$. Nas hipóteses de cargo eletivo, a prerrogativa de foro tem início a partir da diplomação, e não da posse ${ }^{392}$; já nos cargos não-eletivos (e também nos

${ }^{390}$ Cf. BANDEIRA DE MELlo, Celso Antônio. Curso..., cit., p. 229-230; DI PIETRO, Maria Sylvia Zanella. Direito administrativo. 12. ed. São Paulo: Atlas, 2000, p. 417. Entre os agentes políticos, portanto, não se encontram os Magistrados, membros do Ministério Público e Conselheiros e Ministros de Contas. Carlos Ayres Britto ressalta serem estes "servidores civis a quem a Constituição deferiu funções governativas", cujo estatuto funcional específico apenas lhes realça as peculiaridades, permitindo a fixação de direitos complementares aos de índole constitucional. Não se confundem com os agentes estatais exclusivamente políticos, de investidura eletiva, que "não se alojam na tipologia dos servidores e não têm outro estatuto funcional que não a própria Lei Maior" ("Direitos subjetivos" e "prerrogativas" constitucionais. Revista de Direito Público, São Paulo, v. 22, n. 90, abr./jun. 1989, p. 75). De referir-se, por outro lado, a existência de definição doutrinária mais abrangente, formulada por Hely Lopes Meirelles (Direito administrativo brasileiro. 24. ed. atual. São Paulo: Malheiros, 1999, p. 367) e encampada, entre outros, por João Cláudio Couceiro (Prerrogativas de agentes políticos no processo penal. Tese (Doutorado em Direito) - Faculdade de Direito, Universidade de São Paulo, São Paulo, 2006, p. 37), segundo a qual os agentes políticos englobariam, além dos titulares de cargos eletivos (chefes dos Poderes Executivo e membros do Legislativo) e seus auxiliares imediatos, em comissão (Ministros e Secretários de Estado), também os membros da Magistratura, do Ministério Público e dos Tribunais de Contas, titulares de cargos públicos vitalícios, submetidos a regime de natureza peculiar, bem como os representantes diplomáticos e demais autoridades que atuem com independência funcional no desempenho de atribuições governamentais, judiciais ou quase judiciais, estranhas ao quadro do servidor público. Acostamo-nos, contudo, à primeira definição, por basear-se em critério mais objetivo, restritivo e adequado à idéia de agente político como aquele diretamente vinculado à atuação política do governo.

391 Há ainda, relembre-se, lei ordinária federal equiparando alguns funcionários do alto escalão do Poder Executivo Federal ao status de Ministro de Estado. A Lei 10.683/2003, que dispõe sobre a organização da Presidência da República e dos Ministérios e cujo art. 25, parágrafo único, já ostentou diversas redações, como as veiculadas pela MP 207/2004 (Lei 11.036/2004) - que no rol de "Ministros" incluiu o Presidente do Banco Central - e, a mais recente, pela Lei 11.754/2008, assim versando: "Parágrafo único. São Ministros de Estado os titulares dos Ministérios, o Chefe da Casa Civil da Presidência da República, o Chefe do Gabinete de Segurança Institucional da Presidência da República, o Chefe da Secretaria-Geral da Presidência da República, o Chefe da Secretaria de Relações Institucionais da Presidência da República, o Chefe da Secretaria de Comunicação Social da Presidência da República, o Advogado-Geral da União, o Ministro de Estado do Controle e da Transparência, o Ministro de Estado Chefe da Secretaria de Assuntos Estratégicos da Presidência da República e o Presidente do Banco Central do Brasil”. Contra tal ampliação posiciona-se Rodrigo Carneiro Gomes (As prerrogativas processuais na investigação criminal. Revista CEJ, Brasília, v. 12, n. 41, abr./jun. 2008, p. 48): "O dogma da essencialidade do foro por prerrogativa de função há de ser revisto e remodelado, coibidas as fórmulas milagrosas de sua ampliação para abranger e proteger figuras políticas próximas do rei, o que muitas vezes é proporcionado pela criação de cargos públicos de livre investidura (cargos comissionados), com status de Ministro de Estado".

392 Assim é que o art. 53, § 1. ${ }^{\circ}$, da CF, estatui: "Os Deputados e Senadores, desde a expedição do diploma, serão submetidos a julgamento perante o Supremo Tribunal Federal”. O Supremo Tribunal Federal 
suplentes dos cargos eletivos), a prerrogativa vigora desde a posse, em ambos os casos perdurando somente durante o exercício atual e efetivo do cargo ou mandato.

Esse segmento, das investigações não-intestinas, assume destaque no estudo do tema, pois, como dito anteriormente, o espectro de competências penais originárias de tribunais dirige-se, em sua maioria, à categoria de agentes políticos - membros do Poder Executivo e seus respectivos vices, além dos Secretários e Ministros das diversas Pastas, e membros do Poder Legislativo. Se levarmos em consideração que todos os prefeitos dos 5.564 municípios brasileiros ${ }^{393}$ estão sujeitos, em nas infrações penais comuns e nos crimes de responsabilidade, a julgamento perante o Tribunal de Justiça (art. 29, X, da CF) - ou, conforme seja o delito praticado contra os interesses da União, ao Tribunal Regional Federal respectivo -, já daí se perceberá que a classe política representa, numericamente, a mais expressiva entre a totalidade dos agentes sindicáveis originariamente por tribunais.

Ressalte-se, de pronto, que a garantia de imunidade em sentido formal ${ }^{394}$, traduzida na possibilidade de sustação, pelo Legislativo, de eventual processo criminal, instaurado contra Senador ou Deputado, por crime ocorrido após a diplomação (art. 53, § 3. ${ }^{\circ}$, da CF ${ }^{395}$, e na indispensabilidade de autorização do Poder Legislativo para processamento dos membros do Poder Executivo (licença prévia) ${ }^{396}$, em nosso ordenamento, não interfere no procedimento de investigação preliminar - que em nenhum momento pode ser obstado por deliberação do órgão legislativo -, tendo lugar apenas

confirmou tal regra: "STF: competência penal originária por prerrogativa de função que, cuidando-se de titular de mandato eletivo, firma-se na data de diplomação e faz nulo o recebimento da denúncia posterior a ela." (AP-QO 371/MG, rel. Min. Sepúlveda Pertence, Plenário, v.u., DJ de 4.6.2004).

393 Número obtido pelo Instituto Brasileiro de Geografia e Estatística, no ano de 2006, no trabalho "Perfil dos Municípios Brasileiros". Disponível em: $<$ http://www.ibge.gov.br/home/estatistica/economia/perfilmunic/2006/default.shtm>. Acesso em: 20 set. 2007.

394 Segundo Alexandre de Moraes, tal prerrogativa, calcada em razões de interesse público, "protegerá os parlamentares contra a violência dos demais poderes constitucionais ou dos indivíduos em geral", havendo sido instituída, como as imunidades parlamentares em geral, em penhor da democracia e da existência e independência do Parlamento (Direito constitucional, cit., p. 390). Frise-se que não se trata de um privilégio do deputado, mas de uma prerrogativa do órgão legislativo e, portanto, não é uma garantia individual.

395 A significar que, pelos delitos ocorridos anteriormente à diplomação, o parlamentar responde penalmente, sem qualquer limitação referente à possibilidade de sustação pela respectiva Casa, observando-se apenas a prerrogativa de foro enquanto durar o mandato. Os Deputados Estaduais também usufruem das imunidades outorgadas aos Deputados Federais e Senadores, por conta da norma extensiva do art. 27, § 1. ${ }^{\circ}$, da CF. Já os Vereadores não tiveram tal imunidade assegurada na Constituição, de forma que podem ser presos e submetidos a processo penal, não havendo falar em anuência ou em possibilidade de sustação por parte da Câmara a que pertencem.

396 À Câmara dos Deputados cabe autorizar a instauração de processos contra o Presidente e o VicePresidente da República e os Ministros de Estado (arts. 51, I, e 86, caput, da CF); paralelamente, à 
depois de oferecida a acusação penal (para os membros do Executivo) ou depois de recebida a acusação (para os membros do Legislativo) ${ }^{397}$.

Por outro lado, a imunidade à prisão é ampla para os congressistas, que só estarão os sujeitos à prisão processual em caso de flagrante delito de crime inafiançável, devendo a respectiva Casa decidir sobre a manutenção da custódia (art. 53, $\S 3 .^{\circ}$, da CF), regra esta que, vale dizer, já foi excepcionada ante a singularidade do caso concreto ${ }^{398}$. O Presidente da República goza de prerrogativa semelhante, eis que não está sujeito à prisão, nas infrações penais comuns, enquanto não sobrevier sentença condenatória definitiva (art. 86, $\S 3 .^{\circ}$, da CF). Os demais membros do Poder Executivo (governadores, prefeitos, secretários e ministros de Estado) estão sujeitos à prisão processual, embora tendo direito à prisão cautelar especial (art. 295 do CPP).

As investigações preliminares agrupadas nessa espécie apresentam um traço comum, a diferenciá-las das primeiras: não se encontra em qualquer norma (constitucional ou infraconstitucional) uma referência à natureza ou ao órgão condutor da investigação dos delitos imputados a titulares de cargos político, cumpridores de mandato eletivo ${ }^{399}$, tampouco às regras procedimentais que devem norteá-las. Cumpre repisar que a Loman

Assembléia Legislativa, reservam as Constituições Estaduais idêntico juízo de admissibilidade para as infrações penais imputadas aos Governadores de Estado.

${ }^{397} \mathrm{Na}$ Espanha, os Deputados e Senadores, por norma constitucional (art. 71.3 da Constituição espanhola), também gozam de foro por prerrogativa de função, sendo processados criminalmente apenas perante o Tribunal Supremo, com a particularidade - lá ainda existente - de o Tribunal dever solicitar autorização da Câmara a que pertence o imputado para processsá-lo (art. 71.2 da Constituição). Como explica María José Magaldi Paternostro (Procedimientos especiales y actuación de oficio del juez: análisis del procedimiento especial para el enjuiciamiento de diputados y senadores. In: Cuadernos y Estudios de Derecho Judicial, San Sebastián: Consejo General del Poder Judicial, 1995, p. 7), interpretando-se restritivamente tal prerrogativa, a licença - direcionada à preservação da imunidade parlamentar e a garantir o correto funcionamento das Casas legislativas, sem o risco de grave perturbação pela possível subtração do deputado ou senador de seus deveres parlamentares - torna-se necessária a partir do momento em que se dirige contra o agente uma acusação formal, ou seja, somente após a finalização da investigação preliminar.

398 "A norma constitucional que cuida da imunidade parlamentar e da proibição de prisão do membro de órgão legislativo não pode ser tomada em sua literalidade, menos ainda como regra isolada do sistema constitucional. Os princípios determinam a interpretação e aplicação corretas da norma, sempre se considerando os fins a que ela se destina. A Assembléia Legislativa do Estado de Rondônia, composta de vinte e quatro deputados, dos quais, vinte e três estão indiciados em diversos inquéritos, afirma situação excepcional e, por isso, não se há de aplicar a regra constitucional do art. $53, \S 2^{\circ}$, da Constituição da República, de forma isolada e insujeita aos princípios fundamentais do sistema jurídico vigente." (STF, HC 89.417/RO, rel. Min. Cármen Lúcia, 1. a Turma, por maioria, DJ de 15.12.2006).

399 Exceção apenas aos deputados estaduais paulistas, que fizeram inserir na Constituição do Estado de São Paulo, pela Emenda Constitucional 15/2002, tratamento semelhante ao dos magistrados, quando da investigação criminal, com a condução do inquérito diretamente pelo relator no Tribunal de Justiça: "Art. 14 (...) § 11. Salvo as hipóteses do $\S 10$, os procedimentos investigatórios e as suas diligências de caráter instrutório somente serão promovidos perante o Tribunal de Justiça, e sob seu controle, a quem caberá ordenar toda e qualquer providência necessária à obtenção de dados probatórios para demonstração de alegado delito de deputado". 
menciona deva ser o inquérito remetido ao tribunal, no caso de indício de crime cometido por magistrado, não fazendo (nem podendo fazer, por discrepar da matéria a que se destina regular) qualquer referência a atribuição similar para os demais detentores de foro especial.

Por isso, conquanto ostentando a prerrogativa de foro para processamento e julgamento dos crimes de que se vejam acusadas, nem por isso tais autoridades atraem para as Cortes a investigação criminal correlata, sendo de aplicar-lhes a regra geral da investigação em nosso sistema, que é a policial civil. Cuida-se de atribuição nãojurisdicional, que a Constituição não subtraiu da esfera da Polícia Judiciária, posto não estabeleça, em nenhuma passagem, a exclusividade da atuação investigativa pela polícia. Logo, a ausência de norma atribuindo ao Poder Judiciário tal mister investigativo (qual seja, instaurar e instruir inquéritos) não significa senão uma omissão proposital do constituinte, que não poderia, por escapar às funções típicas dos Tribunais, cometer-lhes tarefas de investigação criminal, cabendo-lhes tão-somente o "processo e julgamento" de determinados delitos.

Tal dedução, embora extraída com limpidez do sistema processual e afirmada, em diversas ocasiões, pelo Supremo Tribunal Federal - em que esta Corte afirma caber-lhe tão-somente o controle jurisdicional direto da investigação ${ }^{400}$, não é acolhida com mansidão pelos tribunais. No próprio STF e em outros Pretórios, há vozes dissidentes, que creditam às investigações de crimes sujeitos ao foro especial (em geral) tratamento análogo ao imprimido às investigações de membros do Poder Judiciário. Veja-se:

(...) O voto do Ministro Gilmar Mendes, por sua vez, abriu divergência do Relator para apreciar se caberia, ou não, à autoridade policial investigar e indiciar autoridade dotada de predicamento de foro perante o STF. Considerações doutrinárias e jurisprudenciais acerca do tema da instauração de inquéritos em geral e dos inquéritos originários de competência do STF: i) a jurisprudência do STF é pacífica no sentido de que, nos inquéritos policiais em geral, não cabe a juiz ou a Tribunal investigar, de ofício, o titular de prerrogativa de foro; ii) qualquer

400 Assim, no Inquérito 1.504/DF (rel. Min. Celso de Mello, DJ de 28.6.1999), afirmou-se que o parlamentar "pode ser submetido a atos de investigação criminal promovidos pela Polícia Judiciária, desde que tais medidas pré-processuais sejam adotadas no âmbito de procedimento investigatório em curso perante órgão judiciário competente"; no HC 80.592/PR (rel. Min. Sydney Sanches, DJ de 22.6.2001), fixou-se que o parlamentar "pode ser convidado a comparecer para o interrogatório no Inquérito Policial (podendo ajustar, com a autoridade, dia, local e hora, para tal fim - art. 221 do Código de Processo Penal)"; no RHC 84.903/RN (rel. Min. Sepúlveda Pertence, DJ de 4.2.2005), assentou-se que "1. A competência penal originária por prerrogativa não desloca por si só para o tribunal respectivo as funções de polícia judiciária. 2. A remessa do inquérito policial em curso ao tribunal competente para a eventual ação penal e sua imediata distribuição a um relator não faz deste 'autoridade investigadora', mas apenas lhe comete as funções, jurisdicionais ou não, ordinariamente conferidas ao juiz de primeiro grau, na fase préprocessual das investigações". 
pessoa que, na condição exclusiva de cidadão, apresente 'notitia criminis', diretamente a este Tribunal é parte manifestamente ilegítima para a formulação de pedido de recebimento de denúncia para a apuração de crimes de ação penal pública incondicionada. Precedentes: (...); iii) diferenças entre a regra geral, o inquérito policial disciplinado no Código de Processo Penal e o inquérito originário de competência do STF regido pelo art. 102, I, b, da CF e pelo RI/STF. A prerrogativa de foro é uma garantia voltada não exatamente para os interesses do titulares de cargos relevantes, mas, sobretudo, para a própria regularidade das instituições em razão das atividades funcionais por eles desempenhadas. Se a Constituição estabelece que os agentes políticos respondem, por crime comum, perante o STF (CF, art. 102, I, b), não há razão constitucional plausível para que as atividades diretamente relacionadas à supervisão judicial (abertura de procedimento investigatório) sejam retiradas do controle judicial do STF. A iniciativa do procedimento investigatório deve ser confiada ao MPF contando com a supervisão do Ministro-Relator do STF.

10. A Polícia Federal não está autorizada a abrir de ofício inquérito policial para apurar a conduta de parlamentares federais ou do próprio Presidente da República (no caso do STF). No exercício de competência penal originária do STF (CF, art. 102 , I, $b$ c/c Lei ${ }^{\circ} 8.038 / 1990$, art. $2 .^{\circ}$ e RI/STF, arts. 230 a 234), a atividade de supervisão judicial deve ser constitucionalmente desempenhada durante toda a tramitação das investigações desde a abertura dos procedimentos investigatórios até o eventual oferecimento, ou não, de denúncia pelo dominus litis.

11. Segunda Questão de Ordem resolvida no sentido de anular o ato formal de indiciamento promovido pela autoridade policial em face do parlamentar investigado.

12. Remessa ao Juízo da 2. ${ }^{\text {a }}$ Vara da Seção Judiciária do Estado do Mato Grosso para a regular tramitação do feito. ${ }^{401}$

COMPETÊNCIA - TRAMITAÇÃO DE INQUÉRITO - ENVOLVIMENTO DE DEPUTADO FEDERAL. Uma vez envolvido deputado federal, cumpre ao Supremo os atos próprios ao inquérito. ${ }^{402}$

PROCESSUAL PENAL. QUESTÃO DE ORDEM, PREFEITO. FORO POR PRERROGATIVA DE FUNÇÃO. INQUÉRITO. COMPETÊNCIA.

Ao tribunal, através do relator, compete dirigir o inquérito instaurado contra pessoas que gozam do foro privilegiado por prerrogativa de função.

O procedimento investigatório, tanto ou até mais do que a própria ação penal, traz constrangimento à pessoa do investigado. $\mathrm{O}$ privilégio de foro perderia $\mathrm{o}$ sentido

401 PET-QO 3.825/MT, DJ de 4.4.2008. Ficaram vencidos, além dos Ministros Joaquim Barbosa, Carlos Britto e Celso de Mello, o relator, Ministro Sepúlveda Pertence, ao entender que: "i) a instauração de inquérito policial para a apuração de fato em que se vislumbre a possibilidade de envolvimento de titular de prerrogativa de foro do STF não depende de iniciativa do Procurador-Geral da República, nem o mero indiciamento formal reclama prévia decisão de um Ministro do STF; ii) tanto a abertura das investigações de qualquer fato delituoso, quanto, no curso delas, o indiciamento formal, são atos da autoridade que preside o inquérito; e iii) a prerrogativa de foro do autor do fato delituoso é critério atinente, de modo exclusivo, à determinação da competência jurisdicional originária do Tribunal respectivo, quando do oferecimento da denúncia ou, eventualmente, antes dela, se se fizer necessária diligência sujeita à prévia autorização judicial".

402 STF, Inq-AgR 2.291/DF, rel. p/ acórdão Min. Marco Aurélio, Tribunal Pleno, por maioria, vencido o Min. Carlos Britto, DJ de 14.11.2007. 
de salvaguardar a dignidade de função se não resguardasse a pessoa detentora do privilégio de ver-se compelida a comparecer perante autoridade policial. ${ }^{403}$

A prática forense longe está de exprimir uma uniformidade entre todos os tribunais de segunda instância no trato do assunto. Ao contrário, o fato de não existir norma expressa atribuindo o mister da investigação preliminar de integrantes dos Poderes Executivo e Legislativo ao tribunal onde detêm foro criminal permite se dê azo à mais imprevisível rotina de procedimentos, alguns tribunais não intervindo no inquérito policial instaurado envolvendo prefeitos, por exemplo, e outros avocando para si o controle integral da investigação nesses casos, com uma postura concentradora de poderes no órgão jurisdicional. Verifica-se uma subliminar preocupação em assegurar a prerrogativa de foro - inclusive de ser ouvido extrajudicialmente apenas perante o "juízo natural” - já no seio do inquérito policial, ao menos quanto aos investigados determinantes da competência hierárquica, postura que, no entanto, reflete-se em evidente inconstitucionalidade e precisa ser contida mediante o estabelecimento de regras claras sobre o assunto.

A carência de diretrizes procedimentais sob as quais se uniformizem as investigações preliminares nos crimes de competência dos tribunais é o problema que se buscará sanar com as reflexões trazidas no capítulo 3 deste trabalho.

\subsection{O sujeito passivo da investigação preliminar: a posição do investigado e o problema do indiciamento}

$\mathrm{Na}$ investigação preliminar, como já aventado, não existem partes, mas apenas sujeitos, por não se estar diante de uma fase processual, a qual somente terá início após formulada e admitida a acusação.

Consoante Aury Lopes Jr., parte em sentido formal é a "pessoa que, no processo, formula contra outra uma pretensão acusatória ${ }^{404}$ - resistida ou não -, segundo as

403 TRF-5. ${ }^{\text {a }}$ Região, Rep-QO 28/CE, rel. Des. Fed. Ridalvo Costa, Plenário, por maioria, DJ de 4.5.1998.

${ }^{404}$ O uso do termo "pretensão" no processo penal, como aqui faz Aury Lopes Jr., é comum para designar ora o interesse ou poder-dever estatal na persecução penal (pretensão punitiva), ora na execução da pena (pretensão executória). No entanto, jamais poderá ter a mesma conotação que obtém no processo civil, porque no processo penal não se vislumbra uma parte que exige da outra a satisfação de um interesse ou a espontânea submissão à sanção penal. Ao contrário, como leciona Rogério Lauria Tucci (Teoria..., cit., p. 36), "o autor da ação penal condenatória não efetiva nenhuma exigência, em face de quem quer que seja (nem antes, nem quando da propositura e no desenrolar do respectivo processo), mas, apenas, requer a imposição de sanção penal ao processado; por certo que os conceitos de pretensão punitiva, ou, ainda, de pretensão executória, não se adequam ao processo penal, sendo-lhe de todo estranhas". 
formas previstas na norma processual e sob a direção do órgão jurisdicional competente" ${ }^{\natural 05}$. Já segundo Rogério Lauria Tucci, as partes compõem o elemento subjetivo da ação penal, sendo elas os sujeitos ativo e passivo da relação jurídica a ser definida ou realizada, cada uma refletindo apenas uma parte daquela relação (interesse punitivo e interesse de liberdade) ${ }^{406}$.

Por outro lado, fala-se também em sujeitos processuais, definidos por Giovanni Leone como as pessoas entre as quais se constitui a relação processual, englobando, portanto, o acusador, o acusado e o juiz ${ }^{407}$.

Ainda, sob outra ótica, pode-se aludir àqueles que, embora não sendo partes nem sujeitos no processo, são de todo modo considerados participantes, na medida em que contribuem para o desenvolvimento do processo penal.

Assim, teríamos, num raio ampliado, os participantes, compreensivos de todos os sujeitos processuais e também de outras pessoas que exercem algum papel no decorrer do processo, como as testemunhas e peritos, os auxiliares do juízo, as autoridades administrativas, o assistente de acusação, etc.; num grau mais reduzido, os sujeitos do processo, que são as pessoas cuja presença é imprescindível e sem as quais é impossível falar em processo, e noutro âmbito, ainda mais estrito, haveria as partes em sentido processual, que se resumem aos sujeitos ativo e passivo, status jurídico que implica a atribuição de direitos e cargas de natureza processual.

Observe-se que para a formação do processo, torna-se necessária, além da existência das partes, a presença de um terceiro sujeito, o juiz, chamado a dirimir a controvérsia instaurada entre o sujeito que solicita a decisão (acusador) e aquele contra quem a decisão é solicitada (acusado), situando-se num plano distinto dos sujeitos parciais e a eles supra-ordenado, afastado para preservar a sua imparcialidade ${ }^{408}$.

405 Sistemas..., cit., p. 283. Rogério Lauria Tucci (Teoria..., cit., p. 185-186) define as partes no processo penal como as pessoas detentoras de situações jurídicas justapostas, sendo uma a titular do jus puniendi $\mathrm{e}$ outra a detentora do jus libertatis, acentuando-se a alta relevância dos interesses em conflito no processo. $\mathrm{Na}$ ação penal de conhecimento de caráter condenatório, o Ministério Público é uma das partes em sentido processual, somente cedendo seu lugar ao particular (ofendido ou seu representante legal) na ação penal condenatória de iniciativa privada. A outra parte em sentido processual é o acusado.

406 Teoria..., cit., p. 87.

407 LEONE, Giovanni. Manuale di diritto processuale penale. 10. ed. Napoli: Jovene, 1978, p. 119.

408 No dizer de Aury Lopes Jr. (Sistemas..., cit., p. 283): "É evidente que o juiz se destaca dos demais [sujeitos] porque está em um plano superior, distinto, pois, enquanto os outros sujeitos comparecem ante ele solicitando a atuação da lei ou com um pedido de abertura do procedimento penal, o juiz está chamado a dirimir tais postulações. É uma distinção fundamental, que o coloca como órgão supra-ordenado aos demais e em posição superior, para que possa decidir sobre a pretensão formulada. A heterocomposição 
O mesmo não ocorre na investigação preliminar, que constitui estágio préprocessual, não conhecendo - ainda que o sistema de investigação seja o do juiz instrutor partes processuais, mas meros sujeitos do procedimento, os quais, contrariamente ao que se dá no processo, não compõem um rol necessariamente presente, pois, se é sempre preciso existir o sujeito coordenador da investigação, não é essencial, por outro lado, a existência do sujeito passivo, podendo transcorrer toda a investigação sem a figuração daquele.

A investigação preliminar pode começar, como sói ocorrer, sobre pessoa incerta, pois sua função é justamente a de aclarar o fato e identificar seu suposto autor. Somente se e quando descoberto o autor do delito é que a investigação passará a contar com um sujeito passivo. Já a intervenção do juiz na investigação preliminar, como órgão suprapartes destinado a assegurar a observância de direitos fundamentais, será meramente contingente e excepcional ${ }^{409}$, podendo nem mesmo ser provocado a ingerir em seu curso, muitas vezes aparecendo apenas ao final, para a apreciação do pedido de arquivamento do inquérito (arts. 18 e 28 do Código de Processo Penal).

Entre os sujeitos envolvidos na investigação preliminar, podem-se identificar os diversos agentes estatais encarregados quer da realização dos atos investigativos (órgãos da Polícia Judiciária), quer do controle do ritmo da investigação (órgãos do Ministério Público), quer do controle da legalidade dos atos praticados (órgãos do Poder Judiciário). Além deles, existem o sujeito passivo e o ofendido, ambos detentores de um plexo de direitos que cumpre sejam observados na investigação.

Ponto fulcral de qualquer estudo sobre a investigação preliminar é a situação jurídica do sujeito passivo, denominação genérica que serve para indicar, em qualquer nível e grau, a pessoa que se acha submetida a um procedimento pré-processual.

Como primeira etapa da persecução penal, de natureza administrativa, a investigação não conta com um acusado formal, mas com mero investigado ou, na linguagem do Código de Processo Penal brasileiro, indiciado.

São, em geral, várias as nomenclaturas que o sujeito passivo, ao qual se atribui a prática de um delito, pode assumir na etapa prévia da investigação: acusado (em sentido amplo), investigado, suspeito, indiciado, inculpado, todas elas funcionando para indicar a pessoa sobre quem recai uma investigação.

exige esse afastamento, para lograr a imprescindível imparcialidade do juiz e consagrar o sistema acusatório".

${ }^{409}$ Cf. LOPES JR., Aury. Sistemas..., cit., p. 164. 
A denominação utilizada deve ser adequada ao momento processual ou procedimental a que se reporta, não se havendo confundir os termos destinados ao processo com aqueles utilizados na fase preparatória da investigação, pois em cada momento ou escala da persecução penal há um diferente status jurídico para o sujeito passivo, refletindo o grau de diminuição do seu status libertatis, de submissão à persecução estatal ${ }^{410}$. Doutrinariamente, na investigação preliminar, fala-se apenas em investigado ou imputado; após o indiciamento, costuma-se denominá-lo de indiciado; formada a opinio delicti pelo Ministério Público, momento decisivo para o início da ação penal, tem-se a figura do acusado ou processado (especificamente, denunciado ou querelado, a depender do tipo de ação penal, de iniciativa pública ou privada); enfim, após o trânsito em julgado da sentença penal condenatória, surge o condenado ou apenado.

Ao contrário de países como Portugal, que usa simplesmente o termo

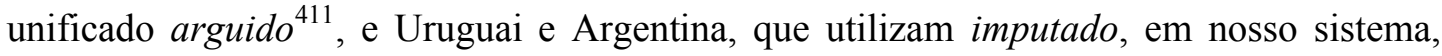
diversos vocábulos são aplicados, na prática, para denominar o sujeito passivo na etapa pré-processual. Os mais vulgarmente empregados são os vocábulos suspeito, investigado e indiciado $^{412}$, sendo que sua separação, na legislação processual, não é precisa, já que o CPP não prevê um ato formal de indiciamento, tampouco estabelece diferença de tratamento a ser conferido em cada caso, sequer mencionando, em quaisquer de suas passagens, as palavras "investigado" e "suspeito" para aludir ao sujeito passivo da investigação.

$\mathrm{Na}$ doutrina, o indiciamento de determinada pessoa é visto como decisão motivada pela qual "a autoridade policial exterioriza seu positivo entendimento acerca da

${ }^{410}$ Cf. LOPES JR., Aury. Sistemas..., cit., p. 286.

411 Cabe esclarecer, porém, que arguido e suspeito não são sinônimos no direito luso, pois somente ao argüido é conferido o estatuto jurídico próprio de direitos e deveres na investigação criminal, a partir de um determinado marco. A peculiaridade está na informalidade da constituição de argüido, terminologia que perpassará também à fase judicial, denominando a pessoa que for formalmente acusada.

412 Todos eles podem enfeixar-se sob o mesmo status de imputado, em sentido amplo, no entanto preferiu o legislador brasileiro utilizar o vocábulo indiciado. Imputar é atribuir a alguém um fato que constitui delito. O termo "imputado", como bem esclarece Antonio Scarance Fernandes (A reação defensiva..., cit., p. 99 105), significa qualquer indivíduo contra o qual sejam dirigidos, ainda que indireta e informalmente, juízos de provável autoria ou participação delitiva, ou quaisquer tratamentos como se investigado fosse, pelas autoridades encarregadas da persecução (vide item 1.4.4 deste trabalho). Doutrinariamente, é bem claro que constitui gênero contemplativo de todo cidadão submetido à investigação penal preliminar. Nesse sentido, o Código-Modelo de Processo Penal para Ibero-América adota o conceito amplo de imputado, ao definir, no art. $6 .^{\circ}$, como imputada "a pessoa a quem se atribui a prática de um fato punível, desde o primeiro ato do procedimento dirigido contra a sua pessoa até sua finalização", conservando tal designação de imputado até o momento em que, mediante decisão judicial, determina-se a abertura do julgamento, passando a acusado (arts. 31 e 274). 
possível responsabilidade penal daquela com o fato infracional objeto da investigação" ${ }^{\text {413 }}$. Não se trata, todavia, de ato imprescindível ou irreversível da investigação. Imprescindível não é porquanto a denúncia, peça inicial da ação penal, pode ser ofertada mesmo antes do indiciamento, prejudicando-o, ao antecipar-se às conclusões policiais. Tampouco é definitivo, eis que pode ser revertido dentro da etapa prévia - na hipótese, por exemplo, de ser efetuada uma prisão em flagrante (que pressupõe haver uma opinião formada sobre o fato tido por delituoso, trazendo por isso o auto do flagrante, implícito e automático, o indiciamento do encarcerado) e, mais adiante, concluir o titular da ação penal pela atipicidade do fato ensejador da detenção ${ }^{414}$. Por outro lado, não seria ato privativo da polícia judiciária, mas revelaria situação passível de ocorrer em qualquer procedimento de investigação preliminar com fins penais, quer presidido por autoridade administrativa, parlamentar ou judicial ${ }^{415}$. Pois, em qualquer deles, seria possível formar-se um juízo valorativo fundado em base indiciária, atribuindo-se a alguém a possível prática da infração penal.

${ }^{413}$ PINTO, Adilson José Vieira. O inquérito policial..., cit., p. 257. Sérgio Marcos de Moraes Pitombo conceitua o indiciamento como o ato de mostrar por indícios, representando "o resultado concreto da aludida convergência de indícios, que assinalam incriminando certa pessoa, ou determinadas pessoas, qual praticantes de ato, ou de atos, havidos pela legislação penal como típicos, antijurídicos e culpáveis”. Para o autor, o indiciamento deve emergir em ato formal de polícia judiciária, um momento posterior ao estado de suspeito, baseado num juízo de probabilidade (calcado em um feixe de indícios convergentes no sentido de a pessoa haver perpetrado uma infração penal), e não de mera possibilidade, fundado em meras conjeturas, frágeis indícios a respeito de alguém (Inquérito policial..., cit., p. 37 e ss). No mesmo sentido, Bonni dos Santos diz ser intuitivo que, "também o inquérito, haja exigência legal da justa causa para a prática do ato jurídico de indiciação do agente da infração penal, consubstanciando-se esta em verdadeiros indícios e não em mera suposição, feita pela autoridade policial." (Sistemas processuais e interpretação da lei penal na persecução criminal: uma contribuição ao debate. Revista da EMERJ, Rio de Janeiro, v. 6, n. 21, 2003, p. 201).

414 Como preceitua Sérgio Marcos de Moraes Pitombo (Inquérito policial..., cit., p. 41), “[a] existência, ou não, do ato de indiciamento, de outro lado, impossui a marca de definitividade, em relação à sorte futura do inquérito, no juízo penal”. E no dizer de Fauzi Hassan Choukr (Garantias..., cit., 2006, p. 111), “o indiciado de hoje não é, necessariamente, o denunciado de amanhã".

415 Tanto assim que é bastante comum o uso dos termos indiciamento e indiciado, por exemplo, em investigações parlamentares (cf. STF: MS-MC 24.832/DF, rel. Min. Cezar Peluso, Plenário, por maioria, DJ de 18.8.2006; HC 71.039/RJ, rel. Min. Paulo Brossard, Plenário, v.u., DJ de 6.12.1996). Já no que tange às investigações envolvendo agentes que gozam de foro por prerrogativa de função, o Supremo Tribunal Federal, embora reconhecendo que podem ser eles investigados por órgãos policiais, tem condicionado a abertura do inquérito à supervisão do Tribunal e o indiciamento, à sua autorização. No julgamento da Pet-QO 3.825/MT (rel. Min. Sepúlveda Pertence, Plenário, por maioria, DJ 4.4.2008), o voto-vista do Min. Gilmar Mendes, acompanhado pela maioria do Tribunal, foi no sentido de que "a Polícia Federal não está autorizada a abrir de ofício inquérito policial para apurar a conduta de parlamentares federais ou do próprio Presidente da República (no caso do STF)”, hipóteses em que a "supervisão judicial deve ser constitucionalmente desempenhada durante toda a tramitação das investigações desde a abertura dos procedimentos investigatórios até o eventual oferecimento, ou não, de denúncia", findando por anular o ato formal de indiciamento promovido pela autoridade policial em face do parlamentar. De semelhante teor, outro precedente exarado na mesma sessão de julgamento: Inq-QO 
O escalonamento do sujeito passivo sob diferentes denominações poderia assumir relevo para a detecção do momento a partir do qual lhe serão assegurados direitos de maior intensidade, como os de informação, produção de elementos de convicção em seu favor, de defesa, enfim, tudo que permita o resguardo da dignidade e da liberdade do sujeito que, por exemplo, comparece perante a autoridade policial como testemunha, quando deveria fazê-lo, pelos elementos já reunidos, na condição de investigado, com as garantias inerentes a esse estado. No campo doutrinário, costuma-se distinguir entre suspeito e indiciado, a depender do maior ou menor grau de submissão à atividade persecutória estatal, sendo que o primeiro indica a pessoa contra a qual se atribui a prática de um fato aparentemente delituoso e que ainda não foi formalmente indiciada pela autoridade policial.

Etimologicamente, suspeito e indiciado não são sinônimos, como não o são suspeita e indício. Suspeita vem do latim suspicio, do verbo suspicere, significando "um movimento duvidoso da mente em direção a uma opinião". Já indício tem várias origens possíveis: do latim indicium, que provém de index, do verbo indicere, significando "dar a saber, manifestar, anunciar, divulgar"; do verbo indicare, significando indicar, manifestar, dar a entender; do verbo inducere, que significa conduzir a. Todavia, qualquer que seja a compreensão do termo, está intimamente ligado à revelação, mostra, indicação ${ }^{416}$. Eis por que não se confunde a mera suspeita, que não passa de conjetura a respeito de algo ou de alguém, fundada no juízo do possível e despida de qualquer força probatória, com o indício, que é fulcrado em proposição contingente, no juízo do provável, podendo dar lugar, se convergente às demais provas, à condenação ${ }^{417}$.

Ocorre que a legislação brasileira, além de não prever um ato formal a servir de marco para o exercício de direitos do investigado, carece de rigor técnico na descrição da terminologia atribuída ao sujeito passivo da investigação preliminar. Por vezes o Código de Processo Penal emprega o termo indiciado; outras vezes, impropriamente, acusado (art. 41 do CPP) ou réu (art. 46 do CPP), isso antes mesmo da admissão da ação penal (pública ou privada).

2.411/MT, rel. Min. Gilmar Mendes, Plenário, por maioria, DJ de 25.4.2008. O problema será enfrentado ainda no item 3.3.1.

416 Cf. MOURA, Maria Thereza Rocha de Assis. A prova por indícios..., cit., p. 4-6 e 52.

417 Idem, p. 54. No mesmo raciocínio distintivo das duas categorias, ao tratar da fase procedimental da persecutio, Sérgio Marcos de Moraes Pitombo (Inquérito policial..., cit., p. 38) explica: “O suspeito, sobre o qual se reuniu prova da autoria da infração, tem que ser indiciado. Já aquele que, contra si, possui 
É de ressaltar que o Código de Processo Penal, desde o início da investigação, faz repetidas menções à palavra indiciado (art. $6^{\circ}$, V, VIII e IX), exigindo inclusive que o requerimento originário do inquérito policial contenha a individualização do indiciado (art. 5. ${ }^{\circ}, \S 1 .^{\circ}, b$, do CPP). Tal opção legislativa, em que pese não atrelar necessariamente a acepção do termo indiciado ao seu significado etimológico (ou seja, aquele contra quem há indícios), serve para reforçar a afirmação de que, desde o primeiro momento, enquanto considerado como provável autor, o sujeito passivo faz jus aos direitos decorrentes dessa condição, entre os quais, v.g., o de silenciar às perguntas que lhe forem dirigidas (arts. 6. ${ }^{\circ}, \mathrm{V}$, e 186 do CPP) e o de requerer diligências (art. 14 do CPP - que também faz referência apenas ao indiciado).

De toda forma, o manejo do termo indiciado, em nosso sistema de investigação preliminar, à míngua de previsão legal sobre um ato formal de indiciamento, afigura-se problemático. Sérgio Marcos de Moraes Pitombo propugna por lei que regulamente a passagem do degrau de suspeito, contra o qual existem frágeis indícios de autoria, para o de indiciado, sobre o qual se reuniu um conjunto de fatos objetivos indicadores do cometimento da infração. Sugere o autor, de lege ferenda, a inclusão de um dispositivo que determine o indiciamento do suspeito, "mediante ordem fundamentada da autoridade policial e tanto que verificada a autoria"418. De fato, a se instituir o indiciamento como ato administrativo vinculado (porquanto jamais poderia ser discricionário), dependerse-ia de previsão legal expressa quanto a todos os seus elementos (agente capaz, objeto, finalidade, forma e motivação).

É o que objetiva fazer, no eco da lição de Sérgio Pitombo, o Projeto de Lei 4.209/2001, que trata da investigação criminal. Na redação aprovada pela Câmara dos Deputados em 11.12.2008 ${ }^{419}$, referido Projeto veicula uma nova redação para o art. $8 .^{\circ}$ do

frágeis indícios, ou outro meio de prova esgarçado, não pode ser indiciado. Mantém-se ele como é: suspeito".

418 Inquérito policial..., cit., p. 45. No mesmo sentido, Aury Lopes Jr. (Sistemas..., cit., p. 288) esclarece que a situação de suspeito supõe a atribuição, a pessoa certa e determinada, de uma aparente responsabilidade penal, atribuição esta que pode decorrer da atitude de um particular, ao levar à autoridade a notitia criminis, da autoridade que requisita a instauração de inquérito ou do ofendido que requer a sua iniciação. Seriam considerados suspeitos: o sujeito passivo de uma notícia-crime; aquele que está em situação de flagrância, mas ainda não foi lavrado o auto; aquele que sofre perseguição policial, etc. $\mathrm{O}$ estado de suspeito antecederia cronologicamente o de indiciado, sendo por este substituído, passando o sujeito passivo a um grau mais elevado de submissão ao procedimento persecutório estatal. No entanto, esse escalonamento poderia também ser regressivo, hipótese em que a situação do sujeito passivo tornaria ao estágio anterior, quando, por exemplo, é decretada uma prisão cautelar e, posteriormente, o inquérito é arquivado.

419 Disponível em: <http://www.camara.gov.br/sileg/Prop_Detalhe.asp?id=26556>. Acesso em: 15.12.2008. 
$\mathrm{CPP}$, in verbis: "Reunidos os elementos informativos tidos por suficientes, a autoridade policial cientificará o investigado, atribuindo-lhe, fundamentadamente, a situação jurídica de indiciado, com as garantias dela decorrentes". Estabelece, ainda, nos parágrafos sucessivos, que o indiciado será interrogado, com observância das garantias constitucionais e legais $\left(\S 1 .^{\circ}\right)$, e que a autoridade deverá colher informações sobre sua vida pregressa e condição econômica $\left(\S 2^{\circ}\right)$, bem como informá-lo da importância de comunicar qualquer mudança de endereço $\left(\S 3 .^{\circ}\right)$.

A nosso sentir, entretanto, gera problemas a vagueza de critérios para o juízo de indiciação (a qual já existe atualmente, na rotina policial), eis que o Projeto traz como requisito para o indiciamento "elementos informativos tidos por suficientes", fórmula genérica que faz concentrar nas mãos da autoridade policial a decisão, segundo seu critério valorativo, sobre quando praticar tal ato, já que a "suficiência" dos indícios não é característica objetivamente descrita na lei. Ademais, a redação proposta ao art. $7 .^{\circ}$ do CPP, pelo mesmo Projeto, estabelece que "[o]s elementos informativos da investigação deverão ser colhidos na medida necessária à formação do convencimento do Ministério Público ou do querelante sobre a viabilidade da acusação", a denotar que é do titular da ação penal o juízo de suficiência da coleta dos elementos informativos para a imputação formal, modulado pelo convencimento que venha formar sobre a existência e a autoria do delito.

Assim, pensamos que o estabelecimento de um ato e um momento formal para o indiciamento não neutralizará os problemas já existentes com a distinção doutrinária entre suspeito, investigado e indiciado, pois, erigindo-se em ato administrativo, ficará a cargo da autoridade policial analisar quando se tem verificada a submissão formal de alguém à investigação preliminar, a reunião de elementos suficientes para o indiciamento. Enfim, deixar-se-á ao alvedrio da autoridade condutora (em regra, policial) determinar o momento a partir do qual o titular dessa situação jurídica poderia exercer todos os direitos a ela inerentes, opção que não se compadece ao modelo garantista de processo penal.

Veja-se o exemplo do direito espanhol. Analogamente ao que se pretende com a instituição de um ato formal de indiciamento no Brasil, a legislação espanhola contemplava duas situações passivas na fase pré-processual: imputado e processado. A qualificação de imputado deriva da só circunstância de se indicar uma pessoa como possível responsável de uma infração penal. O sistema espanhol, de forma clara, estatui a partir de que momento alguém é considerado imputado, nascendo o dever de comunicar- 
lhe a imputação e marcando-lhe o início do direito de defesa ${ }^{420}$. Adquire-se a qualidade de imputado pela adoção de qualquer medida cautelar, pela comunicação da existência de um procedimento no qual se lhe atribui um delito, ou por chegar à autoridade instrutora uma suspeita razoável contra pessoa determinada, com a autuação da notícia-crime.

A categoria do imputado, como se depreende, protege o indivíduo desde os primeiros momentos da investigação ${ }^{421}$, marcando a posição do sujeito passivo como detentor de direitos e submetido a determinadas cargas (obrigação de comparecer, submeter-se a interrogatórios, acareações, etc.). Trata-se de técnica salutar, pois não se espera por um ato formal da autoridade condutora da investigação para se conferir a posição de sujeito de direitos ao investigado. Ao contrário, resguarda-se até o direito do indivíduo de assumir a posição de imputado, tomar ciência da imputação e ser ouvido como tal, exercendo seu direito constitucional de defesa ${ }^{422}$.

A instrução preliminar espanhola empregava ainda o termo processado para fixar o momento a partir do qual a pessoa se considerava como "submetida ao processo", daí decorrendo direitos e outras cargas processuais e um maior grau de sujeição aos atos da investigação, deixando de ser o possível autor da infração para converter-se em provável autor, mediante uma decisão interlocutória (do juiz instrutor) fundamentada em indícios razoáveis de autoria e materialidade. Percebe-se a aproximação do ato de procesamiento, quanto ao conteúdo, com o que parte da doutrina brasileira pretende esboçar para o ato

${ }^{420}$ Assim, a possibilidade de atuar no procedimento e defender-se é admitida a partir de diversos momentos previstos no art. 118 da Ley de Enjuiciamiento Criminal: "Art. 118. Toda pessoa a quem se impute um ato punível poderá exercitar o direito de defesa, atuando no procedimento, qualquer que seja este, desde que lhe comunique sua existência, tenha sido objeto de detenção ou de qualquer outra medida cautelar. A admissão de uma notícia-crime ou qualquer atuação policial ou do Ministério Público, da qual resulte a imputação de um delito contra uma pessoa ou pessoas determinadas, será levada imediatamente ao seu conhecimento. Para exercitar o direito de defesa, a pessoa interessada deverá designar um defensor e, não o fazendo, deverá ser-lhe nomeado um, que o assistirá em todos os atos da instrução preliminar".

${ }^{421}$ Conforme ensinamento de María José Magaldi Paternostro (Procedimientos especiales..., cit., p. 8, tradução livre), o direito de defesa (e as garantias que o acompanham), ampliativamente configurado, pode ser definido como o direito fundamental pelo qual se outorgam a todas as pessoas, no preciso momento em que contra elas se dirige uma imputação criminal, ainda que em sede policial, as faculdades necessárias para fazer-lhe frente eficazmente, incluindo-se o imediato conhecimento de dita imputação. Aparece a defesa, portanto, como "um direito latente que se atua no preciso instante em que tem lugar uma imputação criminal contra uma pessoa determinada, que por tal fato se torna 'imputado', amparandoa, então, o rol de faculdades que possibilitam o exercício desse direito". E, nessa perspectiva, "imputado" não corresponde a "processado", tampouco a "inculpado", que significa aquela pessoa à qual se dirige um ato formal de imputação, como é o caso, no direito espanhol, do auto de procesamiento (no procedimento ordinário) e do auto de apertura de juicio oral (no procedimento abreviado).

422 Tal faculdade, bastante positiva, está prevista também no Código de Processo Penal, de Portugal, que garante, no art. 59.2, a possibilidade de o indivíduo assumir a posição de argüido, sempre que praticadas diligências destinadas a comprovar a imputação e que pessoalmente o afetem. Com isso, a pessoa pede 
formal de indiciamento, como segundo degrau na escala de submissão do sujeito passivo à investigação.

Sucede que, mesmo na Espanha, o processamento era bastante criticado, pois implicava a submissão do sujeito passivo a determinadas cargas como a suspensão da função ou cargo público ocupado, a privação temporária da carteira de habilitação e do direito de sufrágio passivo (correspondente à elegibilidade ou à capacidade de receber votos dos eleitores no pleito por um mandato eletivo), passando a lei ainda a tratar o processado como presumível autor do delito ${ }^{423}$. O instituto apenas subsistia por ser o marco do nascimento da situação jurídica do sujeito passivo e do direito de defesa. No entanto, com a nova redação conferida ao art. 118 da LECrim pela Reforma de $1978^{424}$, ele perdeu razão de ser, passando o sujeito passivo a ser amparado desde os primeiros estágios da investigação preliminar, bastando que exista qualquer ato com conteúdo de imputação para que se atribua o status jurídico de sujeito passivo do procedimento ${ }^{425}$.

Pensamos ser essa a postura mais adequada ao tratamento do sujeito passivo na investigação, para dar concretude às garantias constitucionais que incidem nessa fase. $\mathrm{O}$ investigado, ou suspeito, ou - para utilizar o termo do CPP brasileiro - indiciado erige-se em sujeito passivo e, portanto, titular de direitos na investigação, sem a necessidade de um ato formal assim o declarando (ato este que pode sequer vir a existir), bastando a situação subjetiva de lhe ser dirigida alguma suspeita na investigação, mediante a prática de algum

para assumir o status de sujeito passivo, passando a exigir-se dos órgãos estatais a observância a uma série de direitos.

${ }^{423}$ Diante isso, Aury Lopes Jr. (Sistemas..., cit., p. 319-320) aponta o caráter estigmatizante e degradante do processamento, resquício autoritarista severamente criticado pela doutrina, pois traduz um etiquetamento prematuro do sujeito passivo, sobre o qual, ainda no decurso da investigação, recai verdadeira presunção de culpabilidade, contrária aos postulados garantistas do moderno processo penal, que apenas admite a presunção de inocência.

424 Vide nota 420

${ }^{425} \mathrm{Na}$ Itália, em que o imputato é a pessoa acusada de um crime, já submetida ao processo penal, designa-se como persona sotoposta alla indagini preliminari o sujeito passivo da investigação preliminar, sem qualquer variação mais restritiva do seu estado. Como observam Siracusano, Galati, Tranchina e Zappalà (Diritto processuale penale, cit., p. 157-168), o imputado é sujeito fundamental do processo penal, ele é parte no processo, com interesse de defender-se de uma acusação; com essa qualidade permanece durante todo o processo, até a sentença não mais sujeita a recurso. No curso da investigação preliminar, todavia, não se fala de imputado, mas apenas em pessoa submetida à investigação (alguns falam em indagato, utilizando-se de neologismo). A ela são expressamente estendidos todos os direitos e garantias do imputado (art. 61 do CPP italiano), além de outras disposições relativas ao imputado, naquilo que opere em seu favor, jamais em seu prejuízo. O novo Código abandonou a expressão persona indiziata, contida no projeto preliminar, porque passível de causar equívocos interpretativos. Procurou assim evitar a atribuição de uma etiqueta que poderia trazer significados desfavoráveis ao investigado. E para que a pessoa seja considerada submetida à investigação preliminar, basta que exista uma notícia-crime, recebida pelo Ministério Público ou pela Polícia Judiciária, ou uma investigação instaurada, ou uma medida 
ato específico de investigação pela autoridade condutora do procedimento, ameaçando-lhe ou comprimindo-lhe direitos ${ }^{426}$.

Note-se que a já existente praxe policial do indiciamento por decisão da autoridade, a rigor, não exerce qualquer interferência no desenho da opinio delicti do titular da ação penal (verdadeiro avaliador da maturação da prova na investigação), não o vinculando em seu convencimento nem lhe sendo antecedente necessário, podendo ocorrer a propositura da ação penal sem que tenha exarado a autoridade condutora do procedimento qualquer juízo formal de valor quanto à autoria do fato ${ }^{427}$. Na prática, além do mais, um indiciado costuma ser visto com maior rigor que um suspeito ou investigado, indo mesmo de encontro ao princípio da presunção de inocência, e para evitar tal confusão entre os estatutos de suspeito, investigado e indiciado, a solução está em se assegurar os direitos à defesa (pessoal e técnica), ao silêncio, à informação, a ser ouvido, a prestar declarações, etc. desde que exista algum juízo de atribuição contra determinada pessoa, ainda que decorrente apenas da notícia-crime ${ }^{428}$. Em lugar de prever um ato formal de indiciamento guiado pela convicção da autoridade policial, melhor seria que a lei definisse apenas a regra de tratamento aplicada ao sujeito passivo da investigação preliminar; não o

cautelar pessoal adotada, ou uma invocação do ofendido nos delitos que a exigem (por meio da querela, istanza ou richiesta).

${ }^{426}$ Giovanni Leone (Manuale..., cit., p. 211), em obra escrita anteriormente ao vigente CPP italiano, já dizia que a indicação de investigado [o antigo indiziato di reità da legislação italiana] "não deve ser feita com uma fórmula sacramental ou explícita; é suficiente que do ato surja a determinação de uma pessoa como suspeita de ser autora de um crime. À luz dessa consideração, os órgãos de polícia judiciária e os órgãos judiciários examinam com extrema sensibilidade e amplitude a existência do suspeito em relação aos direitos do indivíduo". Assim, o ordenamento italiano considera que uma pessoa assume as vestes de imputado no momento em que é presa e colocada à disposição da autoridade ou, antes, no momento em que é indicada como tal em qualquer notícia-crime. Não é necessário um ato formal, mas uma situação objetiva de dirigir-se a investigação contra uma pessoa determinada. Antonio Scarance Fernandes $(A$ reação defensiva..., cit., p. 105), todavia, entende que um conceito excessivamente amplo de imputação terminaria por esvaziá-lo. Não seria suficiente, para alguém ser considerado o provável autor da infração penal, que seja indicado como responsável em notícia-crime por qualquer do povo ou pelo ofendido, pois a pessoa imputada, além de titular de direitos, está sujeita a restrições. Mas, reconhece o autor, nem sempre o juízo de imputação externa-se por ato certo e determinado, podendo na investigação manifestarse pela maneira como a pessoa suspeita é tratada em várias manifestações da autoridade policial, tratamento este revelado pelas diversas diligências realizadas, às vezes confirmadas por notícias da imprensa, uma representação pela decretação de prisão temporária, etc. (Idem, p. 102-103).

${ }^{427}$ Nesse sentido: "A alegação de ser o inquérito policial inconclusivo, por ser peça meramente informativa, não impede que o titular da ação penal, caso entenda presente justa causa, ofereça a denúncia." (STJ, REsp 702.757/SC, rel. Min. Felix Fischer, 5. Turma, v.u., DJ de 20.6.2005).

428 A reforçar esse entendimento, Alberto Binder (Introducción..., cit., p. 156) é bastante claro, ao afirmar: "O direito de defesa está relacionado com a existência de uma imputação, e não com o grau de formalização de tal imputação. Ao contrário: quanto menor é o grau de formalização da imputação, maior é a necessidade de defesa. Portanto, o direito de defesa deve ser exercido desde o primeiro ato do procedimento em sentido lato, ou seja, desde o momento em que a imputação exista, por mais vaga e informal que seja. Isso inclui as etapas 'pré-processuais' ou policiais". 
fazendo, entende-se que, desde o início, o apontado como autor do fato deve ser tratado como investigado, com todos os direitos inerentes a essa condição ${ }^{429}$.

Assim é que, no direito português, o Código de Processo Penal estabelece, no art. 58, as hipóteses que ensejam a constituição do argüido, e com ela o estatuto jurídico do sujeito passivo. São situações diversas, não atreladas a um ato formal nem um momento predeterminado: (a) a pendência de inquérito contra pessoa determinada, que vem a prestar declarações perante a autoridade judiciária ou órgão de polícia criminal; (b) a aplicação de uma medida cautelar pessoa ou patrimonial contra qualquer pessoa; (c) a detenção em flagrante delito; (d) o recebimento de uma notícia-crime escrita que lhe impute a autoria de um delito e (e) o surgimento, durante a inquirição de pessoa que não é argüido, de fundada suspeita de crime por ela cometido, ocasião em que o ato deve suspender-se de imediato. Tão-logo verificada alguma dessas situações, a autoridade deve externar, oralmente ou por escrito, comunicação ao argüido da sua condição (esse o primeiro dos direitos do investigado, que é o de informação sobre a imputação que se lhe pesa), bem como dos direitos e cargas processuais dela decorrentes ${ }^{430}$.

O ordenamento jurídico brasileiro não associa qualquer função ao indiciamento, tanto que, por vezes, trata o sujeito passivo como indiciado desde o início da investigação, significando "aquele contra quem há indícios", e assim até os confundindo (os indícios) com a mera suspeita, pois não se exigem indícios de autoria para a instauração da investigação criminal $^{431}$. Não serve o indiciamento, por si só, para gerar medidas

${ }^{429}$ Com a mesma preocupação de afastar a correlação entre o indiciamento como hoje posto e as garantias do sujeito passivo da investigação, Fauzi Hassan Choukr (Garantias..., cit., 2006, p. 129): "Seria tão grave tornar o indiciamento como ato instaurador do conflito de interesses entre indivíduo e Estado na atual estrutura do Código que basta lembrar as hipóteses de ausência da medida, ou os casos em que o denunciado não foi o indiciado, o que é de todo possível. Nessas situações não teria havido a instauração do conflito e, por conseguinte, não se operaria a garantia em tela. Certamente seria uma forma sem riscos de se esvaziar a materialização de fundamental peça na estrutura do devido processo legal".

430 Assim, a constituição de argüido, no direito português, dá-se ope legis ou mediante simples comunicação, oral ou escrita, feita por uma autoridade judiciária ou órgão de polícia criminal. Kai Ambos e Fauzi Hassan Choukr (A reforma..., cit., p. 33) destacam que o argüido, seja na fase judicial ou preliminar, será sujeito de direitos e deveres dentro do momento processual em que se encontra, como o direito de presença, direito à audiência, direito ao silêncio, a defensor, informação e recurso. "Tem, entretanto, dever de comparecimento aos atos do inquérito ou do processo, bem como o dever de dizer corretamente sua identificação e sujeitar-se a medidas constritivas e diligências probatórias".

431 Veja-se que a doutrina, quando tenta definir a figura do suspeito, para apartá-la do indiciado, insere-o num momento prévio ao inquérito, ou seja, em situações em que ainda não formalizada a abertura de inquérito policial, como é o caso do sujeito passivo de uma notícia-crime; da pessoa que está sendo perseguida (art. 290, CPP); da que está em situação de flagrância, mas ainda não foi lavrado o auto "e todas as demais situações prévias ao indiciamento formal que resultem da atribuição da prática de um ato aparentemente punível" (LOPES JR., Aury. Sistemas..., cit., p. 288). No entanto, uma vez instaurado formalmente o inquérito, já recaem sobre o individualizado suspeito, porventura existente, todas as cargas 
cautelares contra o indiciado; não funciona, como querem alguns, como marco preciso para o exercício de direitos do investigado, como o de requerer diligências e o de ter acesso à investigação (os direitos devem existir já antes, desde que seja ele tratado como autor do delito, prescindindo de um ato de indiciamento que pode sequer ser exarado); não vincula a opinião do titular da ação penal, portanto não significando, no plano concreto, uma maior sujeição à persecução estatal.

De resto, a previsão de um segundo estágio de submissão do sujeito passivo à investigação, quando se sabe que a formação de um estatuto de direitos se verifica desde o primeiro momento, pode servir apenas para criar um desnecessário estigma àquele que ainda sequer foi denunciado, muito menos condenado ${ }^{432}$. É isso que acontece na prática, em que os investigados que recebem a rotulação de "indiciados" têm potencializada a sua estigmatização social. A ser visto como instrumento de garantia de direitos, o indiciamento deveria consistir em posição natural do investigado, sem qualquer marca deletéria que o onerasse ainda mais pelo fato de já estar sofrendo a investigação criminal do Estado ${ }^{433}$.

Assim, cumpre uniformizar e imprimir cuidado técnico ao tratamento ${ }^{434}$, quer legal ou factual, do sujeito passivo da investigação preliminar, utilizando-se, para tanto, denominação uniforme, de preferência a de investigado - que serve para abranger todos os estágios do sujeito passivo da etapa preliminar -, abolindo-se a de indiciado. Enquanto não for denunciado, ele não passa disso, de investigado, recaiam sobre ele meras

e os direitos reconhecidos ao sujeito passivo da investigação, cujo exercício não pode ser postergado ao sabor da conveniência policial.

432 Porque, como adverte Fauzi Hassan Choukr (Garantias..., cit., 2006, p. 111), "significativa magnitude social envolve o indiciamento. Para comprovar tal afirmação, basta que se abra qualquer jornal ou se assista às notas policiais em telejornais para que se constate, de forma até estarrecedora, que ele tem mais repercussão junto à comunidade do que a confirmação de uma sentença condenatória pelo Supremo Tribunal Federal".

${ }^{433}$ Em convergência a esse pensamento, destaque-se a avaliação de Eduardo Reale Ferrari (Código de Processo Penal: comentários aos projetos de reforma legislativa. Campinas: Millennium, 2003, p. 26-27) sobre a proposição do art. $8 .^{\circ}$ do PL 4.209/2001: “A nosso ver, o indiciamento constitui uma medida meramente indicativa ao promotor de justiça; a exigir, antes da enunciação sobre sua fundamentação ou não, reflexão sobre sua utilidade processual penal, já que sequer vinculativo ao Promotor de Justiça, parecendo-nos constituir ato investigativo-administrativo totalmente dispensável em um Estado de Direito Democrático e Social, certo de que arbítrios hoje ultimados por alguns Delegados de Polícia, sob o argumento da ameaça de um indiciamento, poderiam ser evitados, caso suprimido tal ato da novel legislatura, retirando da autoridade policial a formalização de que aquele investigado constitui o provável - e não possível - autor da infração, figurando as provas investigativas muito mais relevantes ao acusador do que o mero etiquetamento denominado indiciado, ressalvando, entretanto, por cautela, no art. $8 .^{\circ}$, caput, do Projeto, a exigência acerca do seu fundamento, em estrita observância à legalidade, não tendo o legislador, ao nosso ver, refletido sobre a causa, mas apenas dourado a pílula, ainda que boa tenha sido sua intenção". E quanto às garantias que o PL diz serem concedidas ao investigado junto com o indiciamento, indaga: “antes do etiquetamento como indiciado não possuía o investigado tais garantias?". 
suspeitas ou indícios. Sua situação jurídica somente será alterada se exercida a ação penal, quando então se avaliará a existência ou não de indícios em seu desfavor, gerando-lhe, aí sim, a relevante mudança de status para acusado ${ }^{435}$. Não será um ato formal de indiciamento que terá o condão de gerar conseqüências jurídicas próprias, alterando o estatuto jurídico ao sujeito passivo, mas sim a mera submissão da pessoa à investigação preliminar, tratada, objetiva e determinadamente, como se autora fosse da infração. $\mathrm{O}$ reconhecimento desse estatuto jurídico poderia quedar ameaçado caso subordinado ao formalismo de um ato específico a cargo da autoridade condutora do procedimento, que poderia postergá-lo ao final das investigações, quando já praticada toda sorte de ingerência na esfera individual do investigado, manietado em seus direitos e garantias procedimentais.

Seria importante, outrossim, vir inscrito na lei o direito de o indivíduo averbar-se a condição de investigado, como ocorre em Portugal e na Espanha, para poder auferir todas as conseqüências jurídicas do status de sujeito passivo, postando-se sob o manto protetivo das garantias constitucionais a ele destinadas, evitando-se adiamento porventura intencional e arbitrário na observância daquelas.

Não há negar que a autoridade investigadora efetua juízos de valor quanto ao fato, alguns deles importantes, como é o caso da provisória classificação jurídica do delito, que servirá de parâmetro, ainda no bojo das investigações, para o arbitramento de fiança, a inauguração de inquérito policial ou a mera lavratura de termo circunstanciado ${ }^{436}$, a competência do juízo a que se reportar quando da necessidade de decretação de medidas cautelares, etc.

Já o indiciamento, se não exerce função específica na investigação, não precisa emergir em ato formal da autoridade investigadora, bastando que se reconheça a situação jurídica atribuída a todo aquele contra o qual existam, ainda que informalmente, suspeitas, objetivamente externadas, da prática de um delito. Reclamar-se-ia da autoridade apenas o dever de informar, pronta e oficialmente ${ }^{437}$, ao sujeito passivo da assunção desse

${ }^{434}$ O CPP imprime tratamento quase totalmente uniforme ao sujeito passivo da investigação, ao tratá-lo como indiciado em todo momento, com exceção dos arts. 41 e 46, que mereceriam adequação semântica.

435 Certo que o desgaste da expressão indiciado, apreendido pela população num contexto pejorativo, praticamente representando a "condenação social" do suposto autor do crime, quiçá recomende a sua substituição por outro termo, menos prodigalizado, como é o investigado. Dependeria, contudo, de reforma processual mais ampla, já que em vários momentos o legislador utiliza-se do termo indiciado.

436 Previsto para as infrações penais de menor potencial ofensivo, conforme o art. 69 da Lei 9.099/1995.

437 Semelhantemente ao que ocorre na Itália, com a obrigação de envio ao investigado, por via postal, com aviso de recebimento, da informazione di garanzia (art. 369 do CPP italiano) antes da realização de qualquer ato em que imprescindível a presença do defensor, como sendo: investigações de caráter técnico 
status, correlato ao primeiro de seus direitos, que é o de ser cientificado da imputação que lhe recai tão-logo seja ela manifestada.

Em havendo uma detenção em flagrante delito ou uma prisão cautelar no curso do inquérito (preventiva ou temporária), a autoridade é obrigada a fornecer ao preso a nota de culpa, no primeiro caso (art. 306, CPP), e a cópia da ordem judicial lastreadora da prisão, nos demais casos (art. 286, CPP), assim concedendo ao investigado a ciência formal da imputação que se lhe paira e dos motivos que justificam a medida ${ }^{438}$, sendo o que basta para cumprir esse dever de informação inicial ao sujeito passivo. Mas nos casos em que não existe uma prisão cautelar ou esta só se efetiva em momento assaz ulterior ao início das investigações, é necessário garantir ao sujeito passivo todos os direitos inerentes dessa condição desde o princípio, quando tratado como suposto autor do delito.

Aury Lopes Jr. entende que tal momento seria após o interrogatório do suspeito, que concretizaria, a seu ver, o indiciamento, à míngua de um ato formal ${ }^{439}$. Cremos que aí tampouco terá função o indiciamento, pois já bem antes do interrogatório (às vezes somente realizado após anos de investigação, de coleta de elementos sem conhecimento nem participação do investigado) deverá ser garantido ao sujeito passivo o estatuto que deriva da posição de investigado, sobretudo os direitos ao silêncio, à assistência de advogado, ao conhecimento da imputação que se lhe pesa e dos elementos que a embasam. O ideal é que a autoridade, tão-logo esteja diante de uma imputação formal a alguém da autoria de um delito (notícia-crime), que dê base ao surgimento de uma investigação preliminar, expeça a necessária cientificação ao sujeito passivo, a fim de que possa ele participar da investigação, ressalvada a necessidade de medidas cautelares praticadas com sigilo interno.

Nesse prisma, basta a materialização de um juízo de valor, formal ou não, contra pessoa determinada, atribuindo-lhe, com bases objetivas, o tratamento de possível autor de um delito, basta a existência de um ato específico de investigação contra determinada pessoa, ou o seu comparecimento espontâneo nessa condição, para que exista investigado, sujeito passivo na investigação. Em vez de indiciado, portanto, seria suficiente

não-reproduzíveis (art.s 259 e 260); interrogatórios, inspeções e acareações (art. 364); atos de inspeção ou seqüestro pelo Ministério Público (art. 365).

${ }^{438}$ E esses instrumentos representariam, no dizer de Aury Lopes Jr. (Sistemas..., cit., p. 301), o próprio indiciamento, marcando o nascimento do direito de defesa.

439 Sistemas..., cit., p. 306. 
falar-se em investigado para aludir ao sujeito passivo da investigação preliminar, com todos os direitos atinentes a essa condição.

\subsection{Os atos praticados na investigação preliminar e seu valor probatório}

Em que pese a natureza da persecução preliminar seja de uma instrução provisória, precipuamente investigatória, orientada a buscar elementos mínimos para a demonstração da ocorrência do fato tipo por criminoso e de sua autoria, não são realizados nessa fase apenas atos típicos de investigação.

A atividade tendente à averiguação do fato e de sua autoria, encorpada na investigação preliminar, perfaz-se de atos de diferentes naturezas, que podem ser classificados, conforme permitam ou não a participação da defesa do investigado e a valoração pelo juiz ao proferir sentença na fase processual, em atos de investigação, atos de instrução e atos de prova.

Malgrado ainda persista, em alguns, a dificuldade em aceitar essa composição heterogênea, multifacetada da investigação preliminar ${ }^{440}$, certo é que abalizada doutrina vem contribuindo para a elaboração de importante distinção dos tipos de atos encontradiços na etapa prévia. Joaquim Canuto Mendes de Almeida, em artigo publicado no ano de 1957 , lançou a idéia, pontificando ${ }^{441}$ :

Consiste a investigação, em procura daquilo que está oculto: a colheita das provas, não raro, depende de investigação. (...) Tudo isso indica que quaisquer elementos de convicção pressupõem uma investigação mais ou menos intensa, como dado antecedente à sua produção, tanto na Polícia quanto em Juízo (...). A investigação produz resultados pré-processuais: o delegado ou o subdelegado de polícia, após

440 É o que retrata Sérgio Marcos de Moraes Pitombo, referindo-se ao inquérito policial (Inquérito policial: exercício do direito de defesa, cit., p. 14): "O pensamento vencedor persistiu em assentar que o inquérito policial desponta, em essência inquisitivo: contém, tão-só, investigação e se exibe qual peça meramente informativa. O equívoco perdura desde há quarenta e dois anos”. A visão de José Frederico Marques (A investigação policial..., cit., p. 28-29) exemplifica tal dificuldade: "A investigação e a instrução não se distingue pelo maior ou menor número de atos probatórios que em uma e outra se pratiquem, e sim pelos fins e objetivos dêsses atos. A Polícia investiga para o Ministério Público instaurar o processo penal; o juiz instrui a causa para construir a sua decisão. Se a Polícia, ao investigar, ouve testemunhas, interroga o indiciado e o ofendido, produz enfim provas relativas ao crime - nada disto altera o caráter investigatório de suas funções. (...) Basta que se encare tudo o que se realiza na Polícia como tendo somente caráter investigatório, para que a liberdade do réu inocente esteja mais que assegurada".

441 O direito de defesa..., cit., p. 336-337. Acompanhando-o, João de Deus Cardoso de Mello (O inquérito policial..., cit., p. 54): "Distingo investigação e instrução. Investigação é tôda atividade destinada à elucidação do fato e sua autoria. Instrução é a atividade tendente a registrar por escrito os resultados obtidos por aquela". 
sentir em si mesmo êsses resultados, é que, empreendendo o registro escrito dêles, cria, por assim dizer, os elementos informativos de convicção.

Investigação deriva do latim investigatio, do verbo investigare, que significa indagar com cuidado, seguir o rastro, perscrutar ${ }^{442}$. É a operação de perquirir, rastrear, pesquisar, seguindo vestígios, informações necessárias à elucidação do fato. Instrução, a sua vez, vem do latim instructio, que quer dizer transmissão de conhecimentos. Consiste na atividade que visa a produzir a prova do fato incriminado, para deles dar conhecimento ao Poder Judiciário ${ }^{443}$. Instruir é materializar o que se investigou, para dá-lo a conhecer a alguém. Assim é que, tão-logo a autoridade condutora da investigação obtenha informações ou meios de prova, tratará de reduzir a escrito o resultado de suas pesquisas, com a finalidade documentá-los em um instrumento (v.g., o inquérito policial ${ }^{444}$ ) que servirá a instruir o convencimento do titular da ação penal e da autoridade judicial. Passa-se, então, da investigação à instrução, surgindo o inquérito como o corpo da investigação, o "instrumento organizatório das investigações realizadas" $" 445$.

É com base nesses dados, subministrados pelos atos de instrução, que o juiz decidirá se existe ou não fundamento para a acusação, bem como se se encontram preenchidos os requisitos das medidas cautelares porventura requeridas no curso do procedimento. É com supedâneo nesse acervo, ainda, que o titular da ação penal, se não encontrar base suficiente para oferecer a acusação, requererá o arquivamento do caso.

$\mathrm{O}$ inquérito policial, portanto, como a investigação preliminar em geral, abriga não só atos de investigação (aqueles de procura de vestígios do delito e de seu

442 SILVA, De Plácido e. Vocabulário jurídico. 27. ed. Rio de Janeiro: Forense, 2008, p. 776.

443 Conforme Julio B. J. Maier (La investigación penal preparatoria del Ministerio Público. Buenos Aires: Córdoba, 1975, p. 24), a instrução é, "genericamente e sem aplicação a lei determinada, a etapa preparatória do procedimento penal cumprida por escrito e de forma parcialmente pública e contraditória com o fim de dar base ao requerimento de persecução ou ao encerramento do procedimento".

${ }^{444}$ Nesse ponto, o Código de Processo Penal determina que todas as peças devem ser reduzidas a escrito e rubricadas pela autoridade (art. 9. ${ }^{\circ}$ ), que fará minucioso relatório de suas apurações e enviará os autos ao juiz competente (art. 10, $11^{\circ}$ ).

445 DAURA, Anderson Souza. Inquérito policial..., cit., p. 102. Com clareza, Carlos Laet de Souza (Da investigação policial e da instrução criminal provisória. Revista Brasileira de Ciências Criminais, São Paulo, v. 6, n. 21, jan./mar. 1998, p. 162) expõe ser natural que, inadvertidamente, se confundam essas atividades, na medida em que são desempenhadas pela mesma autoridade. No entanto, ressalta que "investigação policial e instrução criminal são funções inconfundíveis. A primeira como método de esclarecimento dos delitos, seja de forma independente de qualquer procedimento formal, seja no bojo de um inquérito policial. A segunda como procedimento de coleta de provas para a formação do suporte probatório da ação penal". 
autor $^{446}$ ), mas também atos de instrução criminal (como os probatórios e periciais, com carga de definitividade ${ }^{447}$ ), que consistem na redução a escrito dos resultados das diligências efetuadas, destinando-se a convencer o titular da ação penal e também o juiz sobre se há ou não fundamento para a acusação ${ }^{448}$.

Daí ser preciso diferençar os atos de investigação e os atos de instrução ${ }^{449}$, passíveis de realizar-se na atividade persecutória extrajudicial, cada um deles guardando conseqüências diversas quanto à sua validade na etapa processual e à sua abertura à participação e ao conhecimento do sujeito passivo da investigação ou de terceiros.

Nos atos propriamente de investigação, em que a autoridade apenas perscrute, acompanha os vestígios, indaga, mas ainda sem documentar o resultado de sua atividade, não há razão para a defesa acompanhar a diligência ${ }^{450}$ (algumas vezes, há razão mesmo para que não acompanhe, como no decorrer de uma providência cautelar

446 "Os atos de investigação estatal, quando da ocorrência de um ilícito penal, são a exteriorização do exercício do Poder de Polícia do Estado que de forma incondicional age visando combater a criminalidade dando sustentação à denúncia criminal e colhendo cautelarmente provas da autoria e materialidade delitiva que poderiam se perder até o momento da instrução processual em juízo.” (DAURA, Anderson Souza. Inquérito policial..., cit., p. 101).

447 "As perícias constituem prova de grande valia, sendo mesmo indispensável o exame de corpo de delito, quando a infração deixar vestígios (...). Serão levadas a efeito, em regra, na polícia, as mais das vêzes definitivamente. Sob êsse aspecto, o inquérito serve, de modo geral, para fins de prova." (SOUZA, José Barcelos de. A defesa..., cit., p. 22-23). No mesmo rumo, José Geraldo da Silva ( $O$ inquérito policial e a polícia judiciária. 4. ed. Campinas: Millenium, 2002, p. 65) leciona que "o inquérito policial, mesmo como informativo da instrução criminal, transcende, em certos casos, de importância, eis que vários de seus elementos podem revestir o caráter de prova definitiva, como os exames periciais, a prova documental e por vezes influir na própria aplicação da pena”.

448 SAAD, Marta. O direito de defesa..., cit., p. 166-170. A autora registra que tal distinção entre atos de investigação e atos de instrução remonta ao período imperial, em que o Código de Processo Criminal de Primeira Instância estabelecia que a autoridade formadora da culpa, antes de escolher as testemunhas numerárias, ouviria várias testemunhas, a fim de poder escolher, quantitativa e qualitativamente, a prova que iria produzir. No mais, a própria consagração do inquérito policial pela Lei 2.033/1871 fez realçar ainda mais as diferenças entre as diligências propriamente ditas e a sua redução a escrito, atividade que se fez necessária com a delegação aos chefes de polícia da função de recolher os meios de prova, a fim de informar o juiz competente para a formação da culpa.

449 A preocupação é também externada por Sérgio Marcos Moraes Pitombo (Breves notas sobre o Anteprojeto de Lei, que objetiva modificar o Código de Processo Penal, no atinente à investigação policial. Revista Cejap, Campinas, v. 1, n. 2, set. 2000, p. 9-10): "Sempre aflora o embaraço em distinguir investigação e instrução preliminar, prejudicando a construção dos dispositivos. A investigação consiste no indagar, de modo metódico e continuado, a respeito de certa noticiada ocorrência. Quem investiga só rastreia o fato - que lhe pareceu ilícito e típico -, suas circunstâncias, bem como possível autoria. A investigação, ou averiguação pode levar a uma proposição simples; cabendo à instrução concluir se verdadeiro ou falso o mero enunciado. Em regra e por isso, a investigação antecede à instrução preliminar. (...) $\mathrm{Na}$ fase preliminar, prévia, ou preparatória da ação penal, de índole condenatória, a polícia judiciária pratica atos de investigação e outros de instrução criminal, suscetíveis de se repetirem, ou não, em juízo".

$450 \mathrm{Na}$ arguta observação de Joaquim Canuto Mendes de Almeida (O direito de defesa..., cit., p. 337), "evidente se patenteia o absurdo que seria advogados de defesa colados a detetives particulares ou a investigadores, a serviço da Polícia, do Ministério Público ou do juiz, a espiarem as pesquisas sôbre as infrações, seus autores e os elementos de convicção, anteriores, contemporâneos ou posteriores ao inquérito policial, ao 'sumário de culpa' ou à instrução definitiva". 
necessariamente sigilosa em sua execução, qual a interceptação telefônica), sendo suficiente o seu conhecimento posterior. Porém, à proporção em que as informações por ela reunidas passam a ser materializadas, por escrito, em autos e termos que dão forma ao procedimento investigativo, é de rigor proceder à abertura das informações aos principais interessados, sejam eles o investigado e o ofendido ${ }^{451}$.

O sigilo interno porventura admitido na etapa preliminar é, portanto, aquele que recobre os atos de investigação, os quais retratam a dinâmica investigativa, enquanto praticados os atos próprios da investigação; descabe, porém, ser estendido aos atos de instrução, que constituem o registro obrigatório dessa atividade, em relação aos quais deve ser permitido o exercício da defesa na etapa prévia, inclusive para proporcionar ao investigado agregar elementos que afastem ou contradigam as hipóteses até então levantadas, democratizando a fase da persecução prévia.

Quanto ao valor probatório dos atos realizados, lembre-se que a finalidade principal da investigação preliminar é coletar elementos esclarecedores de eventual prática delituosa, para possibilitar o exercício da ação penal ou o arquivamento do caso. Ao mesmo tempo em que serve para preparar a acusação, a investigação erige-se também em garantia contra acusações desprovidas de justa causa, prestando-se a espancar dúvidas que pairem sobre a conduta de indivíduos suspeitos, ainda que informalmente, da prática de infrações penais ${ }^{452}$.

A teleologia da atividade investigativa (fundamentar a justa acusação), condizente, inclusive, com a sua almejada simplificação, obsta a que os dados nela

451 Antonio Scarance Fernandes (A reação defensiva..., cit., p. 132-133) identifica, como importante passo a ser adotado para proporcionar a reação defensiva do imputado, "distinguir os atos próprios de investigação de outros atos praticados durante a fase pré-processual. Antes do Código vigente, João de Deus Cardoso de Mello lembra interessante solução do Código do antigo Distrito Federal, de 1924, que distinguia a 'investigação da inquirição'. (...) Com inspiração nessa regra, ao tratar da participação da defesa no inquérito, o autor realçava a importância de se distinguir o que é 'investigação' do que é 'instrução'. A antiga solução do Distrito Federal indica caminho a ser percorrido e aprofundado no sistema legislativo brasileiro". Com igual sentir, Marta Saad ( $O$ direito de defesa..., cit., p. 175) assesta que "nas diligências de investigação, que precedem ao registro escrito no inquérito policial, o acusado, por óbvio, não pode participar. Mas o acusado pode participar, por ele próprio e por seu defensor, dos atos de instrução, que se destinam a convencer ao juiz".

452 Daí que, em nosso direito, a princípio, nenhum édito condenatório pode embasar-se em provas que não hajam passado pelo crivo do contraditório e da mais ampla defesa, direitos fundamentais da pessoa humana. É o que veio reconhecido na pré-citada redação do art. 155 do Código de Processo Penal, conferida pela Lei 11.690/2008: “O juiz formará sua convicção pela livre apreciação da prova produzida em contraditório judicial, não podendo fundamentar sua decisão exclusivamente nos elementos informativos colhidos na investigação, ressalvadas as provas cautelares, não-repetíveis e antecipadas". 
amealhados sejam utilizados na fase judicial para basear uma sentença condenatória ${ }^{453}$. Além do aspecto teleológico, justifica-se a limitação probatória também sob o ponto de vista funcional, já que são diversas as estruturas de procedimentos empregados em cada uma das fases (na investigação preliminar, a maioria dos sistemas processuais mantêm os rasgos do segredo, da forma escrita e da ausência ou excessiva limitação do contraditório). Delineia-se, assim, uma separação entre a fase prévia de apuração e a fase posterior, de produção da prova e julgamento, de modo que os atos produzidos na primeira fase da persecução não são idôneos a produzir efeitos na segunda fase.

A exceção estará nas provas não-repetíveis - sujeitas, por isso mesmo, a contraditório diferido e não dispensando, a menos que urgentes, a participação da defesa em sua formação ${ }^{454}$. Tal panorama cumpre ser melhor assimilado, a fim de evitar-se superestimação ou subestimação dos elementos ministrados pela investigação preliminar.

Um dos pilares do edifício do sistema acusatório, já se afirmou, é o princípio do contraditório. No entanto, permeando-se a etapa da persecução prévia pela inquisitorialidade, fez-se necessário o estabelecimento de regras que impedissem a projeção direta dos dados colhidos durante a investigação no julgamento.

Como recorda Antonio Scarance Fernandes, durante o século XX, ampliouse a participação do investigado no inquérito ou no sumário, entabulando-se restrições ao uso do material neles obtido para o julgamento, exigindo-se, em regra, a renovação da prova, com observância do contraditório. Contudo, aduz o autor, "nunca se conseguiu afastar inteiramente a influência dos elementos informativos obtidos durante a investigação pela polícia, pelo juiz instrutor, sobre o julgamento, pois, em virtude de serem colhidos próximos do fato, têm maior poder de convencimento a respeito da realidade dos acontecimentos. Até hoje, é comum sustentar-se o aproveitamento desses elementos com

${ }^{453}$ A respeito da sentença absolutória, é pertinente a colocação de Paulo Cláudio Tovo (O inquérito policial em sua verdadeira dimensão. In: TOVO, Paulo Cláudio (Org.). Estudos de direito processual penal. Porto Alegre: Livraria do Advogado, 1995, p. 148-149): “Com efeito, se o juiz, ao sentenciar, pode aplicar o in dubio pro reo, por que não pode, ao reconhecer a inocência do acusado, aceitar provas obtidas fora do contraditório, quando confrontadas com as judicializadas, estas não resistem ao choque da dúvida, como diria Dellepiane?".

454 Enrique Ruíz Vadillo visualiza, nas várias facetas em que se decompõe o "conceito poliédrico" da presunção de inocência no processo penal, as exigências de que: só se deve entender como prova a praticada em juízo, sob imediação do órgão decisório e com observância dos princípios do contraditório, oralidade e publicidade; e desta regra geral somente se excetuam os casos de prova preconstituída e antecipada, cuja reprodução em juízo seja ou se preveja impossível, e sempre que se garanta o exercício do direito de defesa ou a possibilidade de contradição (Valor de las diligencias practicadas por la policía judicial en el proceso penal. Eguzkilore: Cuaderno del Instituto Vasco de Criminología, San Sebastián, n. 13 ext., mar. 1999, p. 299). 
base no princípio da verdade real” ${ }^{\text {"45 }}$. Mesmo países que inseriram em seus ordenamentos a garantia de que os informes colhidos na investigação não valeriam como prova no julgamento $^{456}$ não conseguem evitar que, na prática, exerçam eles influência sobre os julgadores.

Importante é distinguir, para esse efeito, dentre os chamados atos de instrução - ou seja, no universo de todas aquelas diligências reduzidas a escrito, destinadas ao convencimento do juiz -, aqueles atos que esgotarão sua eficácia dentro do procedimento (exercem função apenas intraprocedimental, estendendo seu valor probante apenas até o momento da decisão sobre a admissibilidade da denúncia ou o pedido de arquivamento) e aqueles que, indo além, terão sua eficácia probatória perpassada a todo o iter processual, valendo como genuínos atos de prova.

O principal critério visualizado na divisa entre o ato de instrução e o ato de prova reside no seu caráter de transitoriedade ou definitividade. É que os atos de instrução, contidos na fase prévia, podem ser transitórios ou definitivos, de cunho perecível ou de caráter perene ${ }^{457}$.

455 Teoria geral do procedimento..., cit., p. 89-90.

$456 \mathrm{Na}$ Espanha, construção jurisprudencial não admite, em regra, que se considerem no julgamento provas anteriormente colhidas, salvo quando irrepetíveis, preocupação que levou à aprovação da Lei 38/2002, que regula a preconstituição da prova para ser utilizada no juízo oral. Enrique Ruíz Vadillo é categórico ao afirmar que, em princípio, somente servirá para provar o fato delitivo aquilo que se produza no juízo oral, e não o que "teoricamente" se haja provado extramuros do processo propriamente dito. Na visão mais radical do autor, "só pode servir de plataforma de condenação aquilo que o juiz ou tribunal que vai sentenciar vê, ouve e capta por seus olhos, por seus ouvidos e seus sentidos", de modo que uma prova testemunhal, para ser valorada por um órgão recursal que reveja uma sentença absolutória para condenatória, deve ser repetida perante ele (Valor de las diligencias..., cit., p. 294-295). Na Inglaterra e nos Estados Unidos também se criaram regras tendentes a impedir a influência desses elementos informativos colhidos na investigação ou na audiência preliminar, embora se admitindo exceções (a confissão extrajudicial perante a polícia ou o Ministério Público pode ser utilizada). Na Itália, o art. 526 do Código de 1988 obsta a utilização dos dados colhidos na investigação durante a fase de julgamento, e a Constituição fixou, no art. 111, a imprescindibilidade do contraditório para a formação da prova, conquanto guardando exceções - casos em que há consentimento do imputado, impossibilidade objetiva de repetição ou conduta ilícita que a impede (cf. FERNANDES, Antonio Scarance. Teoria geral do procedimento..., cit., p. 89-91).

457 SAAD, Marta. O direito de defesa..., cit., p. 176; CHOUKR, Fauzi Hassan. Garantias..., cit., 2006, p. 132. Aury Lopes Jr. (Sistemas..., cit., p. 130-131), aproximando-se ao esboço classificatório ora traçado, entende, com base na doutrina de Ortels Ramos, bipartida a divisão dos atos praticáveis na investigação preliminar, quanto a sua eficácia probatória. Haveria, no seu dizer, atos de prova e atos de investigação (ou de instrução preliminar). Os atos de prova assim se caracterizam: destinam-se a convencer o juiz da verdade de uma afirmação, servem e integram o processo penal, dirigem-se a formar um juízo de certeza, servem à sentença, exigem observância da publicidade, contradição e imediação e são praticados perante o juiz que julgará o processo. Os atos de investigação ou de instrução preliminar (o autor identifica as duas categorias), por sua vez, espelham apenas uma hipótese, servem à instrução preliminar para cumprimento de seus objetivos, destinam-se a formar um juízo de probabilidade, admitem restrição da publicidade, contradição e imediação, não se destinam à sentença, mas a formar a opinio delicti do acusador e demonstrar a probabilidade do fumus commissi delicti para justificar o processo ou o não- 
Em geral, os atos do procedimento preliminar - seja ele conduzido por autoridade policial, parlamentar, judicial ou qualquer outra - são transitórios, guardam valor meramente preparatório, sendo aptos a formar um juízo provisório ou de verossimilitude suficiente para a decisão sobre medidas cautelares e sobre a abertura ou não do processo. Não podem, por isso, ser aproveitados para substituir a instrução definitiva (processual) e basear uma sentença condenatória, porque despidos da estrutura dialética do processo e das garantias de contraditório e defesa, com a amplitude que lhes é conferida na fase judicial $^{458}$. Têm valor probatório limitado, direcionado às decisões interlocutórias exaradas no curso da investigação preliminar (pedidos de medidas cautelares e de outras providências restritivas) e na etapa intermediária de admissibilidade da acusação. Servem apenas ao procedimento investigativo, daí sua função endoprocedimental. Não passam de elementos informativos sobre a probabilidade de existência do delito e de seu autor, a serem confirmados ou não com provas produzidas em juízo ${ }^{459}$.

Afinal, "a prova deve ser realizada dentro da dialética processual, sempre inserida no processo, e qualquer outra investigação fora deste não tem caráter probante, devendo ser rediscutida, dentro e exclusivamente no processo" ${ }^{\$ 60}$. Nesse sentido, vale recordar a pertinente distinção procedida pelo legislador brasileiro, no caput do art. 155 do

processo, ou ainda para basear a adoção de medidas cautelares, podendo ser praticados pelo Ministério Público ou pela Polícia Judiciária.

${ }^{458}$ Heleno Cláudio Fragoso (Jurisprudência criminal, cit., p. 508-509) ensina que "[o] princípio do livre convencimento do julgador sofre limitações decorrentes da garantia constitucional do sistema contraditório e da observância das prescrições legais na obtenção da prova. Em conseqüência, não pode o juiz formar o seu convencimento com base em prova do inquérito, não confirmada em Juízo. (...) A prova colhida sem participação da defesa, comumente viciada pela violência e pelo temor, com o réu preso, jamais poderia fundar uma sentença condenatória. (...) Somente uma justiça penal de opereta, própria de regimes totalitários e adequada aos tribunais de segurança nacional poderia aceitar esse tipo de prova. Ele é, por princípio, excluído da área de elementos de convicção sobre os quais deve o juiz formar seu convencimento".

459 Como bem destaca Aury Lopes Jr. (Sistemas..., cit., p. 208-209), os elementos de convicção renováveis obtidos na fase preliminar, como os testemunhos, acareações, reconhecimentos, etc., para ingressarem no mundo dos informes valoráveis na sentença, devem necessariamente ser produzidos, ou repetidos, na fase processual, sob os critérios que regem a produção da prova no processo penal. Por repetição entende-se "a nova realização ou declaração de algo que já se disse ou se fez. A repetição exige que a pessoa que originariamente praticou o ato volte a realizá-lo da mesma forma. (...) Não configura repetição a mera leitura do testemunho anteriormente realizado, seja pelo juiz ou pelas partes. Isto é reprodução, e não repetição. (...) Tampouco pode ser considerada repetição a ratificação do depoimento anteriormente prestado. (...) A oralidade garante a imediação e ilumina o julgador, que, com o contato direto, dispõe de todo um campo de reações físicas imprescindíveis para o ato de valorar e julgar. $\mathrm{O}$ ato de confirmar o anteriormente dito, sem efetivamente declarar, impede alcançar os fins inerentes ao ato. A ratificação ou retificação deve ser aferida ao final, após a declaração integral, pelo confronto com a anterior. O simples fato de dizer 'ratifico o anteriormente alegado' é um nada jurídico".

${ }^{460}$ BUONO, Carlos Eduardo de Athayde; BENTIVOGLIO, Antônio Tomás. A reforma ..., cit., p. 25. 
CPP, ao apartar prova (produzida em contraditório judicial) de elementos informativos (colhidos na investigação).

Todavia, não se pode desconhecer a existência de atos de instrução marcados pela definitividade, ou seja, insuscetíveis de se repetir na fase processual, possuindo assim efeito judiciário absoluto, tanto que - além de servirem de base à acusação e à decretação de medidas cautelares restritivas de direito - transmitem-se, de forma indelével, para o bojo de eventual ação penal ${ }^{461}$. Costumam ser referidos pela doutrina, indistintamente, como permanentes, irrepetíveis, irrenováveis, definitivos, elementos de cunho perene, ou peças de real valor ${ }^{462}$. Integram, portanto, a categoria de atos de prova, cuja utilização na fase processual vem expressamente ressalvada no art. 155, caput, do CPP, sob as especificações de "provas cautelares, não repetíveis e antecipadas" ${ }^{463}$.

A não-suscetibilidade de repetição de tais atos decorre de fatores como a ação do tempo, a transitoriedade própria da situação ou mesmo a inconveniência. Como exemplos de atos definitivos, citam-se o reconhecimento de pessoa ou de coisa, a juntada de documentos, a busca e apreensão e as perícias (exames, vistorias e avaliações) ${ }^{464}$,

461 A propósito, explica Carla Campos Amico (A nova redação..., cit., p. 7): “A prova colhida exclusivamente na fase de inquérito policial não passa pelo crivo do contraditório, com a presença das partes e, em razão disso, está sujeita ao contraditório diferido ou deve ser repetida em juízo para ser considerada apta a fundamentar o convencimento do julgador. Algumas provas produzidas na fase policial, embora não sujeitas ao contraditório prévio tais como as perícias realizadas em infrações que deixam vestígios (CPP, art. 158), guardam a presunção relativa de veracidade capaz de atestar a materialidade da infração e, em regra, não são repetidas em juízo em face do desaparecimento dos vestígios, embora seja admitida prova em contrário". Assim vem decidindo o STF: "Contraditório e devido processo legal: perícia extrajudicial, realizada na fase do inquérito policial: é da jurisprudência da Corte que 'a perícia não é um simples indício e sim prova técnica e, por isso, pode ser considerada pelo julgador na sentença, sem que caracterize cerceamento de defesa, pois o acusado, ciente da sua juntada ao inquérito policial que instruiu a ação penal, poderia pugnar por elidi-la' (v.g., HC 73.647, 2. ${ }^{a}$ T., Maurício Corrêa, DJ 6.9.96)." (RE 230.020/SP, rel. Min. Sepúlveda Pertence, 1. Turma, v.u., DJ de 25.6.2004).

462 SAAD, Marta. O direito de defesa..., cit., p. 177-178. Nesse ponto, Paulo Cláudio Tovo (O inquérito policial..., cit., p. 148) salienta que "não é absolutamente inviável que toda a prova incriminatória esteja no bojo do procedimento preparatório chamado inquérito policial. Basta que se tratem de elementos de convicção já prontos quando da colheita dos mesmos, como no caso da carta amorosa do sedutor à seduzida ou do bilhete do mandante ao executor do crime de homicídio, ou ainda mais recentemente, dos cheques objeto de rastreamento pela CPI do Congresso Nacional (os quais sejam de induvidosa ou verificada autenticidade)".

${ }^{463}$ Cf., a respeito, o item 1.4.5.

464 O Código de Processo Penal Militar, no art. 9. ${ }^{\circ}$, destaca que, apesar de o inquérito policial militar ter caráter de instrução provisória, são “efetivamente instrutórios da ação penal os exames, perícias e avaliações realizados regularmente no curso do inquérito, por peritos idôneos e com obediência às formalidades legais". João de Deus Cardoso de Mello (O inquérito policial..., cit., p. 59-60), a seu turno, expõe que "[a]s provas do inquérito podem ser classificadas em dois grupos: perícias e declarações. As perícias têm valor denec probetur contrarium. As segundas pesarão nas sentenças definitivas, se confirmadas em juízo. É a velha lição de João Mendes Junior, segundo o qual, as declarações do inquérito valem para a prevenção, não para o julgamento. (...) Provas que se esfarelam ou derretem ao embate da 
inclusive exame de corpo de delito, de importante figuração na etapa prévia, eis que, sem prova da materialidade da infração, afastada estará a propositura da ação penal. Alguns deles são não-repetíveis por natureza ${ }^{465}$ (caso das perícias em objetos perecíveis, ou explosivos, e dos documentos, salvo falsidade documental); outros, pelas circunstâncias, como o reconhecimento e a busca e apreensão, a envolver situações transitórias, que não voltam ao estado anterior. Em todo caso, dada a não-repetibilidade desses atos, devem ser eles realizados, sempre que faticamente possível, na presença e com a participação dos interessados ${ }^{466}$ - o titular da ação penal e o investigado -, a menos que a urgência do ato ou o perigo de frustração da diligência recomende o contraditório posterior, e não concomitante. A marca do contraditório, imediato ou diferido, ser-lhes-á ínsita, para que se convolem em atos de prova ${ }^{467}$.

Logo, relevante conseqüência da distinção entre atos de instrução e os atos de prova está em que, embora inarredável de ambas as categorias o direito de defesa do investigado, somente nos atos de prova o contraditório se mostra imperioso (exercido de forma concomitante ou, excepcionalmente, diferida), retomando-se aqui a diferença entre direito de defesa e contraditório, adrede esboçada nos itens 1.4 .4 e 1.4.5.

Para visualizar-se a classificação tripartite dos atos verificáveis na etapa preliminar, adote-se o seguinte exemplo: a procura de uma testemunha que venha trazer esclarecimentos ao fato, seguida de sua notificação e da tomada de seu depoimento pela autoridade condutora do procedimento, revela-se um ato de investigação; a lavratura do termo de declarações dessa testemunha, por ela assinado e acoplado aos autos da investigação, passa a constituir ato de instrução, permitindo o pleno conhecimento do investigado; no entanto, não consistirá, a princípio, em ato de prova, porque, não observando o contraditório em sua formação - já que não realizado em presença do juiz,

contraditoriedade não podem, nem devem influir no convencimento do juiz penal". Com esse pensamento, elogia a previsão do art. 247 do Anteprojeto de Código de Processo Penal de Hélio Tornaghi, in verbis: "É vedado ao juiz fundar sua convicção em provas que não hajam passado pelo crivo do contraditório ou que hajam sido infirmadas pela prova colhida em juízo".

465 O que não significa não possam ser objeto de impugnação do investigado, ou do acusado, permitindo-se amplo debate quanto às conclusões da perícia na fase judicial, pelo chamado contraditório diferido.

466 Julio B. J. Maier (La investigación penal..., cit., p. 58) é quem esclarece: "aqueles atos que por sua natureza sejam irreproduzíveis ou, por suas circunstâncias, definitivos, devem solicitar-se à autoridade jurisdicional para praticar-se por antecipação o debate e com direito à presença do defensor e do imputado, que serão noticiados oportunamente para o exercício do direito de controle que lhes compete".

467 Como ressalta José Frederico Marques (Tratado..., cit., v. 1, p. 194), “em face da Constituição, não há prova (ou como tal não se considera), quando não produzida contraditoriamente. O inquérito, por isso, deve ser apenas um elemento subsidiário, ou para reforço do que em juízo for apurado, ou para a colheita 
nem com a obrigatória participação da defesa técnica - e sendo ato, por natureza, repetível na fase processual, não valerá senão como elemento de convicção, com eficácia apenas interna e restrita à etapa preliminar ${ }^{468}$.

Não há confundir, a essa altura, os atos de prova com aqueles atos de instrução que, transitórios por natureza, venham tornar-se, acidentalmente, irreproduzíveis em juízo, como é o caso do depoimento de uma testemunha que faleça antes da instrução processual ou que não seja mais encontrada. Nessas hipóteses, o depoimento testemunhal colhido na investigação, embora se tenha tornado irreproduzível em juízo por fato superveniente, continuará com valor probatório meramente relativo ou interno à investigação, não se transmudando em prova, porque não submetido a contraditório judicial em sua formação.

Diz-se "a princípio" porque, em alguns casos, estando ainda em curso a investigação, mas se verificando o temor de que a testemunha não mais exista ou não seja encontrada ao tempo da instrução criminal - seja por velhice, ou por padecer de doença grave, ou por sofrer ingentes ameaças de morte -, ou quando a testemunha tenha de ausentar-se da sede do juízo para lugar incerto, é possível que se instaure o contraditório judicial já na etapa prévia, mediante a produção antecipada de prova, instituto previsto em nosso ordenamento no art. 156, I, do Código de Processo Penal ${ }^{469}$. No ordenamento português, tal instituto denomina-se "declarações para memória futura" (art. 271. o do CPP lusitano ${ }^{470}$ ), revestido igualmente de natureza cautelar, marcado pela jurisdicionalidade e

de dados circunstanciais que posteriormente possam ser comprovados. (...) Só excepcionalmente é que o juiz poderá encontrar no inquérito alguma base para estruturar o seu convencimento".

468 Assim já prelecionava João Mendes de Almeida Junior (O processo criminal brasileiro, cit., v. 2, p. 96), ao recordar os princípios que se foram desenvolvendo, a partir do século XIII, no processo inquisitório e nas legislações nele baseadas, quanto à coleta dos testemunhos: " $1^{\circ}$, Os depoimentos das testemunhas inquiridas sem citação da parte ou extrajudicialmente não fazem prova (...); $2^{\circ}$, As testemunhas inquiridas sem citação da parte, ou por oficiais inquisidores e não por juízes, fazem-se judiciais pela reiteração do depoimento perante o juiz, ou havendo-as a parte por legítimas. Nestes princípios funda-se o simples valor preventivo da inquirição de testemunhas no inquérito policial: aquêles depoimentos, sendo extrajudiciais, enquanto não forem reiterados, confirmados, confrontados e, se preciso fôr, acareados em juízo, não podem ser considerados com fôrça probante".

469 Sobre tal circunstância, pontua Carla Campos Amico (A nova redação..., cit., p. 7-8): “Aguardar a conclusão das investigações policiais para a adequada propositura da ação penal, resguardando a dignidade da pessoa humana que não deve ser atingida por denúncia temerária, por vezes, no entanto, leva ao perecimento da prova testemunhal colhida na fase investigatória. Daí a necessidade e urgência, ainda na fase de inquérito policial, da produção antecipada da prova testemunhal perante o juiz quando atendidos os requisitos para a concessão da cautelar: fundado receio de que a demora e a incerteza quanto ao comparecimento da testemunha em juízo possam determinar o perecimento da prova".

470 “Art. 271.1. Em caso de doença grave ou de deslocação para o estrangeiro de uma testemunha, que previsivelmente a impeça de ser ouvida em julgamento, o juiz de instrução, a requerimento do Ministério 
pela participação de todos os interessados (o Ministério Público, do argüido, do defensor, do advogado do assistente e das partes civis), que são previamente cientificados do ato, resguardando-se com amplitude o direito de defesa do argüido. Assim, o elemento de convicção é jurisdicionalizado e, portanto, não se corre o risco de perdê-lo futuramente, como prova a convencer o julgador.

A produção antecipada de provas é medida excepcional, sujeita a reserva de jurisdição, realizada perante o juiz natural ${ }^{471} \mathrm{e}$ em contraditório efetivo, permitindo-se ao sujeito passivo o mesmo grau de intervenção que lhe seria dado no processo, para resguardar o direito à prova ${ }^{472}$. Pode ser requerida por quaisquer dos interessados e, para ser deferida, há que atender aos requisitos da urgência, relevância e da necessidade, adequação e proporcionalidade ${ }^{473}$. O juiz avaliará, a par do perigo concreto de perecimento ou desaparecimento daquele elemento de convicção, a sua provável importância para o desvendamento do caso, decidindo fundamentadamente sobre a antecipação ou não da prova. Deve ser utilizada com moderação, sob pena de se converter a prova antecipada em regra, em detrimento da eficiência da investigação preliminar ${ }^{474}$.

Vale notar ainda que o que distingue o ato de prova do mero ato de investigação ou de instrução preliminar não é a autoridade que o preside, e sim, como dito, a sua teleologia e estrutura, sua vocação finalística e ritualidade. Para tornar clara tal

Público, do argüido, do assistente ou das partes civis, pode proceder à sua inquirição no decurso do inquérito, a fim de que o depoimento possa, se necessário, ser tomado em conta no julgamento.”

${ }^{471}$ Nos sistemas que adotam a investigação de natureza judicial, é realizada perante o juiz instrutor. Aqui vale retomar a observação de Aury Lopes Jr. (Sistemas..., cit., p. 135), ao atentar ao "grave problema que representa, no direito brasileiro, o fato de ser o julgador o mesmo juiz que atua como garante no inquérito policial, como conseqüência de ser a prevenção um critério definidor de competência, e não uma causa de exclusão, como defendemos, sob inspiração das reiteradas decisões do Tribunal Europeu de Direitos Humanos". Mas a colheita da prova antecipada na fase de investigação, em si e desde que não decretada ex officio, não agride o modelo acusatório de processo penal, senão que mantém íntegros os seus corolários, assim descritos: "al) os elementos probatórios colhidos na investigação prévia servem exclusivamente para a formação do convencimento do acusador, não podendo ingressar no processo e ser valorados como provas; a2) o exercício da jurisdição depende de acusação por órgão diverso do juiz; a3) todo o processo deve desenvolver-se em contraditório pleno, perante o juiz natural." (GRINOVER, Ada Pellegrini. A iniciativa instrutória..., cit., p. 803).

472 Recorde-se, com Antonio Scarance Fernandes (Processo penal constitucional, cit., p. 73-74), o desdobramento do direito à prova em vários direitos da parte: a) direito a requerer a produção da prova; b) direito a que o juiz decida sobre o pedido de produção da prova; c) direito a que, deferida a prova, seja ela realizada com todas as providências necessárias à sua produção; d) direito a participar da produção da prova; e) direito a que a prova seja produzida em contraditório; f) direito a que a prova seja produzida com a participação do juiz; g) direito a que, realizada a prova, possa manifestar-se a respeito; h) direito a que a prova seja objeto de avaliação pelo julgador.

473 É o que determina o art. 156, I, do CPP, com a redação que lhe deu a Lei 11.690/2008: “Art. 156. A prova da alegação incumbirá a quem a fizer, sendo, porém, facultado ao juiz de ofício: I - ordenar, mesmo antes de iniciada a ação penal, a produção antecipada de provas consideradas urgentes e relevantes, observando a necessidade, adequação e proporcionalidade da medida." 
distinção, cite-se o exemplo do interrogatório e das oitivas testemunhais pré-processuais nas investigações de delitos de competência originária de Tribunais. Eles não se transmudam em ato de prova, mesmo nos casos em que - fugindo às diretrizes procedimentais adequadas à investigação tribunalícia ${ }^{475}$ - é o magistrado Relator do procedimento que pratica tal ato. Tanto quanto o seu sucedâneo judicial, o interrogatório realizado na fase preliminar, seja nas investigações preliminares ordinárias ou naquelas envolvendo titulares de prerrogativa de foro, erige-se, máxime após a entrada em vigor das atuais regras do interrogatório (Lei 10.792/2003), em genuíno ato de defesa, não podendo aqui, sequer subsidiariamente -, exercer o papel de prova, sobretudo porque situado em momento anterior ao processo (em que o contraditório é mitigado) e à acusação formal, sujeito a nova realização na fase processual da persecução. Impossível será considerar como prova os elementos provisórios colhidos nessa fase, porquanto não submetidos à atividade jurisdicional propriamente dita e aos íntegros reclamos do devido processo legal ${ }^{476}$.

Em nosso direito, atribui-se relativa importância processual aos subsídios coligidos na investigação preliminar marcados pela transitoriedade, ao se estatuir que o juiz não poderá utilizá-los exclusivamente para basear sua decisão (art. 155, caput, do CPP), o que significa que neles poderá buscar fundamento, mas apenas de forma complementar ou subsidiária aos elementos de prova produzidos em contraditório. A prática judiciária, todavia, fornece inúmeros casos de supervalorização dos informes colhidos nessa etapa, moldando o juiz a sua convicção, em desfavor do acusado, a partir de elementos que, na maioria das vezes, foram produzidos unilateralmente, sem a participação daquele, o que

474 Cf. HERBEL, Gustavo Adrián. La investigación..., cit., p. 700.

475 Assim entendida aquela praticada nos crimes de competência originária de tribunais, porque "aforada" (no sentido de autuada) no tribunal e a ele dirigida sempre que esgotadas as etapas a cargo da polícia judiciária e do Ministério Público, ou quando necessária alguma medida constritiva de direitos individuais, mas não se confundindo, ponha-se claro, com qualquer investigação levada a efeito por órgãos judiciais.

${ }^{476}$ Em sentido contrário, a sugestão de Therezinha Astolphi Cazerta (Ação penal originária..., cit., p. 25): "De todo modo, sem avançar contra entendimentos respeitáveis, considerando que o inquérito é judicial, ou, quando não, se desenvolve perante o tribunal, nos casos de prerrogativa de foro, poderíamos pensar na produção da prova oral, interrogatório e depoimentos, na fase de investigação preliminar, com observância dos princípios do contraditório e da ampla defesa, com assistência dos defensores e oportunidade de reperguntas, evitando-se, assim, desnecessária repetição no curso da futura ação penal, com economia de trabalho e tempo, resultando em eficiência e celeridade processuais". 
gera da doutrina objeções contra o inquérito policial nos termos como atualmente realizado $^{477}$.

Eis um ponto crítico do modelo brasileiro de persecução penal, em que usualmente se cometem distorções, ante a indevida valoração, pelo julgador, no curso da ação penal, de elementos informativos colhidos na investigação, chegando-se a admitir como prova judicial, e por vezes única fonte de convencimento do juiz, o interrogatório policial, máxime quando nele se verificou uma confissão, utilizando-se-a como fundamento para condenação do acusado. Acaba-se por transformar a jurisdição penal em mero desdobramento ou apêndice da investigação preliminar, simples repetidora de tudo quanto foi feito na etapa investigativa ${ }^{478}$.

É sobretudo a partir da adequada distinção entre os atos de investigação, os atos de instrução e os atos de prova que se permite dar relevo à real finalidade da investigação preliminar, em quaisquer de suas modalidades, bem como se viabilizam mecanismos para prevenir a indevida utilização de elementos colhidos na etapa extrajudicial como fundamento de uma sentença condenatória.

No propósito de assegurar pertinente valoração a cada tipo de ato praticado na investigação preliminar, para além da previsão, nas constituições modernas, de garantias processuais visando assegurar que a sentença condenatória somente tenha fundamento em prova validamente produzida na fase processual (sob a égide da publicidade, imediação, contraditório e ampla defesa) ${ }^{479}$, e da consagração de tais garantias em diplomas internacionais, como a Convenção Americana sobre Direitos Humanos (art. 8. ${ }^{\circ}$ ), o Pacto Internacional de Direitos Civis e Políticos (arts. 14.1 e 14.3) e a Convenção Européia de Direitos Humanos (arts. 6.1 e 6.3, $d$ ), sistemas há que adotam a providência de eliminar ou excluir, dos autos que formarão o processo penal, todas as peças da investigação prévia,

477 Cita-se, por exemplo, a ferrenha oposição de Jacinto Nelson de Miranda Coutinho: "Não conseguimos, destarte, evoluir, algo que só seria possível com o abandono da essência inquisitória de nosso sistema. (...) Para tanto, entre outras coisas, é preciso acabar com o inquérito policial, na forma como temos hoje (...). É preciso acabar com a burocracia da fase preliminar, ou seja, com a produção de provas", de modo a evitar-se uma inaceitável duplicidade de instruções (O sigilo no inquérito policial e os advogados. Revista Brasileira de Ciências Criminais, São Paulo, v. 5, n. 18, abr./jun. 1997, p. 127).

478 A conclusão é esposada por Fauzi Hassan Choukr (Garantias..., cit., 2006, p. 134), que enfatiza haver "manifesta distorção dos mais comezinhos princípios processuais, considerando-se como prova algo que tecnicamente não o é, e buscando a manutenção de um decreto condenatório parido dentro de uma relação processual onde prova tecnicamente falando alguma houve, apenas e tão-somente porque o "inquérito incriminou" o condenado. Dentro desse padrão de comportamento pode-se concluir sombriamente que a Justiça criminal em si foi absolutamente dispensável, satisfazendo-se a repressão penal com o simples trabalho policial".

${ }^{479}$ No Brasil, é o que se extrai dos arts. 5. ${ }^{\circ}$, LIII, LIV, LV e LVI, e 93, IX, da CF. 
com exceção daquelas provas definitivas, produzidas em incidente probatório específico. É o caso da Itália, em que o art. 526 do Código de Processo Penal impõe ao juiz utilizar, na sentença, apenas as provas legitimamente produzidas na fase do processo ${ }^{480}$. Assim, observa Ada Pellegrini Grinover, "[n]enhum valor probatório é atribuído aos elementos colhidos durante o inquérito, que serve exclusivamente para formar o convencimento do MP para a acusação, salvo no que tange à produção antecipada de provas, em contraditório" 481 .

Com esse expediente, permite-se restituir à investigação preliminar a sua verdadeira função (que é a de ministrar elementos imprescindíveis ao exercício ou nãoexercício da ação penal) e se confere originalidade ao processo penal, na medida em que se obsta a transferência, para a esfera judicial, dos elementos renováveis obtidos na fase prévia - excetuados aqueles que, por natureza, não poderão ser mais repetidos -, evitandose a contaminação inconsciente do julgador por aqueles informes e reservando-se ao estágio processual a efetiva oportunidade de coleta da prova, perante o juiz natural e sob o manto de todas as garantias inerentes ao exercício da jurisdição ${ }^{482}$.

${ }^{480}$ Paola Felicioni (Le ispezioni e le perquisizioni. Milano: Giuffrè, 2004, p. 401-402) anota que o legislador de 1988 guiou-se pelo princípio da separação das fases, distinguindo nitidamente a fase das indagini preliminari, na qual se recolhem as fontes de prova, do dibattimento, fase dos debates orais, na qual se forma as provas. Na prática, tal princípio é efetivado pela disciplina do "duplo fascículo" (arts. 431 e 433 do CPP italiano): separa-se o conjunto de elementos que podem ingressar na fase processual, formado pelos atos não-repetíveis, daqueles que servirão apenas ao Ministério Público quando do ajuizamento da ação penal, aos quais pode ter acesso também o defensor. Trata-se, no dizer da autora, de uma "precisa escolha epistemológica: qualificar o dibattimento como sede do contraditório e, por conseguinte, garantir a imparcialidade do juiz evitando que venha conhecer de atos de investigação produzidos fora do contraditório das partes”. Também na Espanha, refere Aury Lopes Jr. (Sistemas..., cit., p. 133) que, na nova lei do Tribunal do Júri, o legislador de 1995 justifica a necessidade de exclusão física das peças do sumario (instrução preliminar) dos autos do processo, evitando com isso "indesejáveis confusões de fontes cognoscitivas atendíveis, contribuindo assim a orientar sobre o alcance e a finalidade da prática probatória realizada no debate (ante os jurados)".

481 Influência do Código-Modelo de Processo Penal para Ibero-América na legislação latino-americana: convergências e dissonâncias com os sistemas italiano e brasileiro. In: O processo em evolução. Rio de Janeiro: Forense Universitária, 1996, p. 227.

${ }^{482}$ No mesmo toar, Fauzi Hassan Choukr (Garantias..., cit., 2006, p. 136) prevê que a situação seria diferente se, num primeiro momento, tivéssemos a separação saudável dos autos da investigação dos definitivos e, ainda, se dentro de uma reestruturação do sistema judiciário, houvesse a diferenciação de julgadores para cada uma dessas etapas. João de Deus Cardoso de Mello (O inquérito policial..., cit., p. 48-49) registra um precedente histórico, remontado à fase pluralista da legislação processual pátria, quando o código de processo penal para o antigo Município Neutro (o Distrito Federal, à época o Rio de Janeiro), de 1924, distinguindo a investigação da inquirição, estabeleceu que a primeira seria formada pelo auto de flagrante e os laudos periciais, devendo acompanhar a denúncia ou queixa para fundamentá-la. Já os autos de inquirição somente seriam conhecidos do Ministério Público, proibida expressamente sua juntada ao processo da ação, quer em original ou mediante certidões. Outra referência, feita por Paulo Cláudio Tovo (O inquérito policial..., cit., p. 149-150), vem dos anteprojetos de reforma setorial do Código de Processo Penal, propostos pela comissão presidida pelo Min. Sálvio de Figueiredo Teixeira, publicados no DOU de 16.3.1994 e 25.11.1994, em que constava uma inovação inspirada no CPP italiano: o dever de o juiz, ao 
julgar viável a ação penal, determinar o desentranhamento das peças do procedimento preparatório, as provas obtidas fora do contraditório e que sejam renováveis em juízo, afastando-se a sua influência psicológica no espírito do julgador, ficando tais peças em cartório, para melhor condução da acusação e da defesa. O Projeto de Lei 4.209/2001 não contempla proposição similar. 


\section{CAPÍTULO 3: A investigação preliminar nos delitos de competência originária de tribunais}

Após uma exposição sobre a evolução histórica e gradativa pela qual a acusação passou das mãos do particular para as do Estado, descortinando-se, no direito brasileiro, o atual perfil acusatório do processo penal, foram analisadas as principais garantias processuais agasalhadas na Constituição e a sua extensão à persecução préprocessual. Ainda, expuseram-se as formas de investigação preliminar praticadas em nosso sistema, definindo a sua natureza jurídica e demarcando a posição do sujeito passivo, bem como a natureza dos atos praticados na investigação e a medida de sua vocação probatória. Afirmou-se o direito do cidadão ao procedimento de investigação preliminar adrede traçado pelo Estado para a persecução das infrações penais, eclodindo como uma garantia de que a acusação venha amparada em prévia apuração do fato, revelando-se, assim, um instrumento a serviço de outro instrumento (o processo) ${ }^{483}$.

Passemos, agora, ao exame da investigação preliminar realizada nos crimes de competência originária de tribunais, experiência peculiar do sistema brasileiro, tal qual o instituto do foro por prerrogativa de função, que lhe deu ensejo à particularização. Não que outros sistemas não concedam prerrogativas processuais a determinadas autoridades; é que não o fazem com a amplitude aqui deferida.

A razão do estudo dessa espécie de investigação preliminar prende-se à existência de um fator comum em todos os delitos a que tal apuração se destina: a determinação da competência jurisdicional pelo critério da prerrogativa de função ${ }^{484}$. Por isso, antes de ingressar no âmago da investigação preliminar realizada sobre determinada categoria de delitos, quais sejam, os que tocam à competência originária de tribunais, cabe tecer uma referência, ainda que breve, sobre o critério determinador dessa competência, ou seja, o marco divisor da jurisdição penal entre os vários órgãos do Estado, a justificar a entrega, em mãos dos tribunais, de uma parte dela, assim fomentando o específico estudo da persecução criminal pré-processual nesses casos.

${ }^{483}$ Daí ser a investigação preliminar considerada por Aury Lopes Jr. (Sistemas..., cit., p. 43-44) uma instrumentalidade eventual e qualificada. Eventual, porque a investigação tem caráter facultativo, não obrigatório; qualificada, porque é um instrumento de segundo grau, a serviço de outro instrumento, servindo para tutela mediata do eficaz funcionamento da justiça. 


\subsection{A prerrogativa de função como critério definidor de competência jurisdicional}

Ao avocar o Estado para si, na era moderna, o monopólio da administração da justiça - com a correlata proibição da atuação autodefensiva -, segue-se que a jurisdição, poder-dever de realizar a justiça, ficou cometida a funcionários estatais, integrantes do Poder Judiciário, encarregados de materializar normas pré-existentes no ordenamento jurídico ${ }^{485}$.

O conteúdo multifacetário da jurisdição permite conceituá-la, a um só tempo, como poder, função e atividade ${ }^{486}$. Considerada sob o aspecto de poder soberano estatal, apresenta-se como ferramenta destinada ao cumprimento de um dos principais escopos sociais e políticos do Estado, a pacificação com justiça ${ }^{487}$, preservando assim valores caros à existência humana. A jurisdição é tão una quanto soberano é o Estado no qual exercida. Não pode ser cindida nem pluralizada, muito embora costume a doutrina, para fins didáticos, diferençar entre jurisdição penal e civil, superior ou inferior, especial ou comum $^{488}$, técnicas de compartimentalização que mais atinem à competência, já que fundadas não no critério da diversidade funcional, mas no da variedade de objetos ${ }^{489}$.

${ }^{484} \mathrm{O}$ traço definidor de competências aqui explorado (funcional) é suficiente para excluir desse estudo a investigação dos crimes de competência do tribunal do júri, que são distribuídos por critério distinto, de natureza material.

${ }^{485}$ De lembrar-se, contudo, que a jurisdição é atividade precípua e específica, mas não exclusiva do Poder Judiciário, valendo referir - embora se trate de atividade jurisdicional atípica - a existência de órgão nãojudiciário (Senado Federal) que processa e julga os crimes de responsabilidade do Presidente da República, dos Ministros de Estado, do Procurador-Geral da República, dos Ministros do STF, etc. Sobre a chamada "jurisdição política”, cf. MARQUES, José Frederico. Da competência em matéria penal. 1. ed. atual. por José Renato Nalini e Ricardo Dip. Campinas: Millennium, 2000, p. 190-193.

486 "Como poder, é manifestação do poder estatal, conceituado como capacidade de decidir imperativamente e impor decisões. Como função, expressa o encargo que têm os órgãos estatais de promover a pacificação de conflitos interindividuais, mediante a realização do direito justo e através do processo. E como atividade ela é o complexo de atos do juiz no processo, exercendo o poder e cumprindo a função que a lei lhe comete." (CINTRA, GRINOVER e DINAMARCO. Teoria geral do processo, cit., p. 131). Na mesma esteira, Rogério Lauria Tucci (Teoria..., cit., p 19-20) define a jurisdição, "a par do mencionado dever, como o poder conferido a determinados agentes estatais para solucionar os conflitos de interesses que lhes sejam submetidos à apreciação, bem como para fazer cumprir suas próprias resoluções".

487 Sobre o tema, cf. ainda CINTRA, GRINOVER e DINAMARCO. Teoria geral do processo, cit., p. 24-25.

488 O Código de Processo Penal pátrio utiliza a palavra jurisdição para distinguir quer as diferentes espécies de juízes e tribunais (arts. 78, II e IV, e 79), quer os "graus" ou "categorias" do poder de julgar desses tribunais e juízes (arts. 78, II, e 79).

489 Aliás, na prática, é muito comum o emprego dos termos jurisdição e competência em sinonímia, hábito que atinge mesmo os órgãos legislativos, bastando uma consulta aos arts. 113 e ss. do CPP para que o verifiquemos (fala-se em "conflito de jurisdição" para resolver questões relativas à competência). 
Diante da impossibilidade física de um só juiz reunir a atribuição de julgar todas as causas, o ordenamento distribui a jurisdição entre vários órgãos do Poder Judiciário, traçando também os limites dentro dos quais poderão atuar no exercício dessa função. Tem-se, então, a divisão de competência, que, nessa ótica, vem a ser a medida e o limite do poder jurisdicional do Estado, conforme determina a lei, referida no sentido mais amplo $^{490}$. E, correlacionando-se os dois institutos, surge a competência como a expressão, em concreto, daquele poder abstrato de julgar, o âmbito (funcional, material, temporal) em que ele pode ser validamente exercido.

Para o rateio da jurisdição penal entre os órgãos judiciários, o nosso sistema positivo, mediante a coexistência de diplomas (Constituição da República, leis processuais, Constituições estaduais, leis de organização judiciária, regimentos internos ${ }^{491}$ e súmulas de tribunais), oferece vários critérios, no que se podem identificar diversos níveis, planos ou fases de distribuição desse poder-dever. Não cabe aqui esmiuçar as competências de cada órgão, mas apenas expor as linhas de divisão da competência em matéria penal, em particular a que diz com a prerrogativa de função.

Pela observação da estrutura judiciária brasileira (que tem seus alicerces no texto constitucional, mantidas as linhas básicas do modelo federativo exposto nas Cartas precedentes), podem-se detectar fases de concretização da jurisdição em mãos do juiz competente.

Como primeiro passo, a Constituição oferece a técnica de divisão de competências de jurisdição, pela qual se permite identificar, entre as Justiças compartimentadas administrativamente pelo constituinte, aquela a que cabe conhecer da causa penal. O critério para tanto utilizado é, precipuamente, o ratione materiae, que implica perquirir a natureza da infração (ou da causa) submetida a julgamento, de forma

490 Assim é a visão clássica, inspirada em Liebman e destacada por José Frederico Marques ( $D a$ competência..., cit., p. 40), segundo a qual a competência é a medida usada no distribuir-se a jurisdição entre os vários magistrados ou órgãos judiciários; é o poder de julgar organizado, e a jurisdição, o poder de julgar constituído.Também Maria Lúcia Karam (Competência..., cit., p. 16) expõe que, ao determinar a quantidade de juridição cujo exercício é atribuído a cada órgão ou grupo de órgãos jurisdicionais, as regras de competência fixam limites àquele exercício: só estão autorizados os órgãos jurisdicionais a exercer a jurisdição na medida estabelecida pelas regras de competência. E na lição de João Mendes de Almeida Junior (O processo criminal brasileiro, cit., v. 2, p. 127-128), enquanto a jurisdição é a função de dizer o direito aplicável aos fatos, a competência é esse mesmo poder em seu exercício, considerandose a atividade de suas funções em determinado território, a espécie dos fatos e as pessoas sobre as quais é exercido.

491 Quanto aos regimentos internos, têm importante papel na fixação da competência interna do tribunal. Nos termos do art. 96, I, $a$, da CF, compete privativamente aos tribunais "elaborar seus regimentos internos, 
que a Justiça Eleitoral julga, grosso modo, as infrações penais de natureza eleitoral; a Justiça Militar, os crimes militares definidos em lei; a Justiça Comum Federal, as causas descritas no art. 109, IV, V, VI, VII, IX e X, e a Justiça Comum Estadual, os demais delitos, em caráter residual. Também pelo critério material, os crimes dolosos contra a vida têm seu juízo natural no tribunal do júri, da jurisdição federal ou estadual, conforme o caso.

Encontra-se ainda na Lei Maior outro nível de repartição de competências, tomando por base a hierarquia dos órgãos agrupados em uma determinada Justiça, a chamada competência hierárquica ou funcional ${ }^{492}$. Observando-se o grau do órgão jurisdicional (superior ou inferior), a Constituição delimita competências ratione personae, atribuindo prerrogativa de foro para o julgamento criminal a determinados agentes públicos, altos dignitários da República. O foro mencionado pela norma constitucional para a competência originária é um tribunal (Tribunal de Justiça ou Tribunal Regional Federal) ou uma corte superior (Supremo Tribunal Federal, Superior Tribunal de Justiça, Tribunal Superior Eleitoral, Superior Tribunal Militar ${ }^{493}$ ). Assim, por exemplo, os membros do Ministério Público e os Juízes de Direito são sempre julgados pelo Tribunal de Justiça respectivo, independente da natureza e do local de consumação do delito imputado ${ }^{494}$, salvante a competência da Justiça Eleitoral, no que se submetem a julgamento pelo Tribunal Regional Eleitoral ${ }^{495}$. Já os membros do Congresso Nacional são julgados, nas

com observância das normas de processo e das garantias processuais das partes, dispondo sobre a competência e o funcionamento dos respectivos órgãos jurisdicionais e administrativos".

492 Também chamada competência originária, ou hierárquico-funcional, a competência determinada por prerrogativa de função vem regulada ainda nos arts. 84 a 87 do Código de Processo Penal. As regras fixadas na lei ordinária devem, em todo caso, ajustar-se às normas constitucionais que regem a competência originária dos tribunais. Cf. MOURA, Maria Thereza Rocha de Assis. Competência por prerrogativa de função. In: FRANCO, Alberto Silva; STOCCO, Rui (Coord.). Código de Processo Penal e sua interpretação jurisprudencial. 2. ed. São Paulo: Revista dos Tribunais, 2004, v. 2, p. 1075.

493 Segundo a Lei 8.457/1992, que organiza a Justiça Militar da União, compete ao Superior Tribunal Militar processar e julgar originariamente os oficiais-generais das Forças Armadas, nos crimes militares definidos em lei (art. 6. $\left.{ }^{\circ}, \mathrm{I}, a\right)$. Pelo mesmo diploma, compete ao Conselho Especial de Justiça processar e julgar oficiais, exceto oficiais-generais, nos delitos previstos na legislação penal militar (art. 27, I) e ao Conselho Permanente de Justiça, processar e julgar acusados que não sejam oficiais, nos mesmos crimes (art. 27, II). Tal fixação de competência foi feita mediante autorização da norma do art. 124, parágrafo único, da CF.

${ }^{494}$ Consoante magistério de Hugo Nigro Mazzilli (Regime jurídico..., cit., p. 339), "[a] verdade é que o foro por prerrogativa de função é simplesmente uma exceção ao foro do local do crime. Em outras palavras: aqui o critério de competência deixa de ser o locus delicti e passa a ser ratione personae. Nos casos de foro por prerrogativa de função, assegurados diretamente na Constituição, pouco importa o local de consumação ou de prática do último ato de execução do crime".

495 Os Tribunais Regionais Eleitorais também têm competência originária determinada ratione personae: processar e julgar os crimes eleitorais cometidos pelos juízes eleitorais, bem como aqueles praticados por autoridades estaduais que, em crimes comuns, tenham como foro por prerrogativa de função o Tribunal de Justiça. Logo, os deputados estaduais, os Prefeitos municipais, os juízes eleitorais e os membros do Ministério Público deverão ser julgados pelos Tribunais Regionais Eleitorais quando lhes for atribuída a 
infrações penais comuns ${ }^{496}$, pelo Supremo Tribunal Federal e os Governadores dos Estados e do Distrito Federal, pelo Superior Tribunal de Justiça.

Passa-se, a partir daí, ao terceiro nível de especificação, que consiste em precisar qual o foro do processamento da causa, utilizando-se o critério ratione loci. Ante a vastidão territorial do nosso país, a competência de foro assume relevo na prática, ao permitir a determinação da comarca ou da seção judiciária competente, com exclusão de outras. Nessa fase, prescindimos do recurso à Constituição da República, ficando à lei ordinária federal estabelecer a divisão do poder de julgar. E assim o faz o art. 70 do CPP, ao estatuir o locus commissi delicti como elemento de fixação de competência ${ }^{497}$.

No mesmo foro, todavia, haverá sempre, ao menos, dois juízos: o do juiz singular e o do júri, este que, por ser prevalente, atrai para si o julgamento dos crimes conexos aos de sua competência (dolosos contra a vida). Existindo, porém, na mesma comarca, mais de uma vara com iguais competências, a competência de juízo será determinada pela lei de organização judiciária local, que pode, por exemplo, definir varas especializadas, guiando-se ora pelo critério material (julgamento de determinados crimes, como os falimentares), ora por sua combinação com outros critérios, como o territorial, a exemplo das varas distritais. Sempre, contudo, deverá respeitar, por anterioridade lógica, os parâmetros estabelecidos para a competência territorial, nos termos da súmula 206 do Superior Tribunal de Justiça ${ }^{498}$.

prática de crimes eleitorais, em face dos arts. 29, X, e 96, III, da CF. Já o Tribunal Superior Eleitoral, que teria competência para o conhecimento e julgamento dos crimes eleitorais e conexos cometidos pelos seus próprios juízes e pelos dos TREs (art. 22, I, $d$, do Código Eleitoral - Lei 4.737/1965), teve sua competência criminal originária esvaziada com a Constituição de 1988. Em se tratando de governadores dos Estados e do Distrito Federal, desembargadores dos Tribunais de Justiça e membros dos Tribunais de Contas dos Estados e do Distrito Federal, membros dos Tribunais Regionais Eleitorais e do Trabalho, membros dos Conselhos ou Tribunais de Contas do Município e os do Ministério Público da União que oficiam perante os tribunais, a competência não é do TSE, mas do STJ, em face dos termos dos arts. 105 , I, $a$, da CF. Já os membros do próprio TSE serão julgados perante o STF, inclusive nos crimes eleitorais (art. 102, I, c, da CF). Cf. GOMES, Suzana de Camargo. A Justiça Eleitoral e sua competência. São Paulo: Revista dos Tribunais, 1998, p. 127-132.

496 Incluídos os crimes eleitorais, seja porque "a locução crime comum compreende, na abrangência do seu sentido conceitual, os delitos de natureza eleitoral” (STF, Pet 673/RJ, rel. Min. Carlos Velloso, Plenário, por maioria, DJ de 17.9.1993), seja porque não houve ressalva expressa, nos arts. 102, I, $b$ e $c$, e 105, I, $a$, da Constituição, à competência da Justiça Eleitoral.

497 "É, pois, no foro (território) onde a infração penal se consumou que o culpado deve ser processado e julgado. É aí, como dizia Garraud, que se fazem sentir os efeitos de sua atividade ou inação criminosa e onde cumpre tranqüilizar os interesses alarmados." (TOURINHO FILHO, Fernando da Costa. Processo penal, cit., v. 2, p. 95).

498 Súmula 206: “A existência de vara privativa, instituída por lei estadual, não altera a competência territorial resultante das leis de processo". Pode a lei de organização judiciária (federal ou estadual) valerse de diferentes critérios para a divisão por especialização: a qualidade da pena principal (reclusão, detenção ou multa), o elemento subjetivo (crimes dolosos ou crimes culposos), a natureza da infração 
Por fim, determinado o juízo competente, convém ainda indagar qual o juiz competente para a causa, na hipótese em que mais de um magistrado compuser o mesmo órgão (p. ex., nos órgãos colegiados, ou em uma mesma vara, que tenha juízes titular e substituto). Em casos tais, a competência interna será deslindada pela técnica da distribuição, mecanismo de indicação aleatória que assegura o cumprimento do postulado do juiz natural.

Quanto à competência recursal, é ela que demarca o órgão ao qual toca apreciar o recurso: se o mesmo órgão prolator da decisão profligada ou um de grau superior. Nesse estágio, tanto a Constituição Federal, como as Estaduais, bem assim as leis ordinárias e regimentos internos, ao tratarem de recursos criminais, estabelecem regras disciplinadoras de competência para os recursos.

Os crimes processados e julgados, em caráter originário, por tribunais - cuja fase persecutória preliminar é objeto de nossa atenção - assim o são mercê da distribuição vertical de competência funcional, que é perpetrada, no Brasil, pelas Constituições Federal e Estaduais ${ }^{499}$, em tributo da defesa do cargo ou da função exercida por algumas autoridades, com vistas à preservação da higidez do princípio da hierarquia e da independência do agente público. Tanto assim é que, cessada a função, cessa também a competência especial $^{500}$, em obediência à regra da atualidade ou da contemporaneidade do

penal (crimes ou contravenções), o bem jurídico protegido (vida, patrimônio, fé pública, etc.), entre outros.

499 As competências do STF e do STJ têm caráter restrito e decorrem da Constituição Federal, limitando-se aos casos enumerados nos arts. 102 a 105, não podendo o legislador ordinário ampliar-lhes o espectro. A propósito, o Anteprojeto de reforma do CPP de autoria de Hélio Tornaghi, surgido em 1963, trazia regras tocantes à competência por prerrogativa de função, entre elas a seguinte proposição: "Art. 164. As normas sobre competência por prerrogativa de função devem ser interpretadas estritamente e não admitem aplicação analógica”. Deve-se lembrar, por outro vértice, que o Supremo Tribunal Federal reconhece a possibilidade de os Estados-Membros incluírem, nas Constituições Estaduais, novas hipóteses de prerrogativa de foro, perante os respectivos Tribunais de Justiça, vislumbrando a existência de autorização constitucional para tanto, no art. $125, \S 1 .^{\circ}$, da CF (competência do Tribunais de Justiça). No julgamento da ADI 2.587/GO (rel. Min. Maurício Corrêa, rel. p/ acórdão Min. Carlos Britto, Plenário, por maioria, DJ de 6.11.2006), passou-se inclusive a admitir que as Cartas estaduais fugissem ao modelo federal na instituição desses foros (relativização do critério da simetria). Assim, não só Secretários de Estado e Vereadores, mas procuradores de Estado, da Assembléia Legislativa e Defensores Públicos poderiam ter gravada a prerrogativa na Constituição estadual - entendeu-se, porém, inconstitucional a prerrogativa para Delegados de Polícia. À luz do voto condutor, uma vez que os delegados são, por expressa disposição constitucional (art. 144, $\S 6 .^{\circ}$, da $\mathrm{CF}$ ), agentes subordinados, hierarquizados administrativamente aos Governadores de Estado, do Distrito Federal e dos Territórios, devem ser excluídos do foro especial, ratione personae. Tal prerrogativa, outrossim, denotaria incompatibilidade substancial com outras regras constitucionais, em especial a que trata das atribuições do Ministério Público, a quem incumbe o controle externo da atividade policial.

500 A prerrogativa processual no âmbito penal é há muito conhecida de nosso ordenamento. Já no tempo do Brasil-colônia, por força das Ordenações do Reino português, vigorava uma divisão dos crimes em privilegiados, eclesiásticos e comuns, os primeiros a cargo dos corregedores e ouvidores; os segundos, 
mandato/cargo ${ }^{501}$. Nesse sentido, antiga orientação jurisprudencial do Supremo Tribunal

Federal, consolidada na súmula 394, foi cancelada pelo Plenário daquele sodalício em

25.8.1999 ${ }^{502}$.

das autoridades eclesiásticas, e os terceiros, dos juízes locais. A Constituição de 1824 já atribuía ao Supremo Tribunal de Justiça (art. 164, II) conhecer dos delitos cometidos por seus Ministros, os das Relações, os empregados no Corpo Diplomático e os Presidentes de Províncias. O foro especial concedido a deputados federais e senadores, por exemplo, estava previsto na Constituição de 1824 (art. 47, I), foi extinto pela Constituição de 1891 e revigorado com a Emenda 1/1969 (art. 119, I, a). O Ministro Sepúlveda Pertence, em voto-vista no Inquérito 687/SP, consignou, após pesquisa em Direito Comparado, que regra semelhante somente se encontraria nas Constituições da Espanha e da Venezuela, nesta última restringindo-se a competência da Suprema Corte a declarar se há procedência ou não para o julgamento e, em caso afirmativo, remeter o caso ao tribunal comum competente, onde o processo dependeria de licença da Câmara (Inq-QO 687/SP, rel. Min. Sydney Sanches, Plenário, v.u., DJ de 9.9.1999). Algo similar ao que propôs, no Brasil, o Deputado Regis Oliveira, ao apresentar substitutivo à Proposta de Emenda à Constituição 130-A de 2007, que deixa ao tribunal apenas o juízo de prelibação da ação penal e a decisão sobre providências cautelares, ficando, o mais, a cargo do juízo de primeira instância. Além disso, é deslocada a competência (agora territorial) do locus commissi delicti para a capital dos Estados em que tiverem domicílio os agentes, remanescendo, portanto, uma prerrogativa para a autoridade. O modelo constitui uma junção forçada entre duas esferas de competência jurisdicional, a rigor inconciliáveis, oferecendo diversos inconvenientes: ou bem se processa a autoridade no juízo de primeiro grau, como todo e qualquer cidadão, ou bem se lhe confere a prerrogativa de ter o juiz natural no tribunal. Deixar ao tribunal a competência para adotar, originariamente, decisões de que depende o próprio andamento do processo na primeira instância, e reservar ao juízo de primeiro grau o papel de colher a prova e julgar o caso, fatalmente criará uma dualidade de instâncias revisoras: o recurso das decisões cautelares será cabível, em tese, para outro tribunal, ao passo que o recurso da sentença será julgado pelo próprio órgão que já entrou em contato com a causa nos incidentes anteriores, inclusive tendo decidido sobre a viabilidade da ação penal. Cremos que tal esquema é sobremodo confuso e ineficiente, por criar uma dualidade de juízos sobre o mesmo processo e tumultuar a sistemática de recursos, além de funcionar como desgarantia sob o prisma da isenção do órgão revisor, que por vezes terá de analisar, em recurso de apelo, a repercussão processual de medidas que foram por ele mesmo deferidas. Registre-se, por fim, que a nova Constituição venezuelana, promulgada em 20.12.1999, agora concentra por inteiro o processamento dos delitos de competência originária na Corte Suprema, desde a admissão da acusação até a sentença definitiva (art. 266).

${ }^{501}$ Cf. DEMO, Roberto Luis Luchi. Competência..., cit., p. 205; MORAES, Alexandre de. Direito constitucional, cit., p. 451.

${ }^{502}$ A súmula 394 estendera a competência hierárquica a todo crime cometido durante o exercício funcional, ainda que o inquérito ou a ação penal tivessem início posteriormente à cessação do exercício da função pública. Consolidou-se ainda a diretriz de que não se aplicaria a prerrogativa aos crimes cometidos após cessação definitiva do exercício funcional (súmula 451 do STF). A súmula 394 foi revogada no julgamento do Inq-QO 687/SP, ocorrido em 25.8.1999, quando passou o Supremo Tribunal Federal a entender que, uma vez cessado o exercício funcional, cessaria também a competência por prerrogativa de função, sendo válidos todos os atos até então praticados em decorrência da aplicação da regra de competência. Frisou o relator, Min. Sydney Sanches, em seu voto, que as prerrogativas de foro "não devem ser interpretadas ampliativamente, numa Constituição que pretende tratar igualmente os cidadãos comuns, como são, também, os ex-exercentes de tais cargos ou mandatos". Na observação de Maria Thereza Rocha de Assis Moura (Competência..., cit., p. 1076), "o princípio da perpetuatio jurisdictionis se aplica quando a competência houver sido determinada ratione loci, mas não se for fixada pelo critério ratione materiae ou ratione personae, pela relevância da função pública". No mais, pretendendo revigorar a diretriz constante da já revogada súmula 394 do STF, a Lei $10.628 / 2002$ alterou os $\S \S 1 .^{\circ}$ e $2 .^{\circ}$ do art. 84 do CPP, estabelecendo que a competência especial prevaleceria, ainda que o inquérito ou a ação penal iniciassem após o fim do exercício da função pública e ampliando o raio da prerrogativa de foro para as ações civis de improbidade administrativa. Tais modificações resultaram expungidas do sistema por declaração de inconstitucionalidade em controle concentrado, no qual o STF pontificou que "a competência originária dos Tribunais é, por definição, derrogação da competência ordinária dos juízos de 
Não existe, pelo critério funcional, qualquer distinção entre a natureza dos fatos em tese delituosos remetidos ao julgamento colegiado, abrangendo desde os mais simples e de menor reflexo do ponto de vista do sistema jurídico-penal em seu todo ${ }^{503}$, até os mais complexos e decisivos para os setores político e econômico do país ${ }^{504}$, sejam previstos no Código Penal ou em leis esparsas, próprios ou não de funcionários públicos, crimes ou contravenções, ou infrações penais definidas como de menor potencial ofensivo $^{505}$, cometidos ou não no exercício das funções ${ }^{506}$, todos esses ilícitos se enfeixam na jurisdição da Corte a quem a Constituição atribui competência ratione personae.

Com efeito, os dispositivos constitucionais que atribuem a prerrogativa de foro, não sendo congruentes entre si, ora se referem a "infrações penais comuns e crimes de responsabilidade" (no STF: art. 102, I, $b$ e $c$, da $\mathrm{CF}$ ), ora a "crimes comuns e de responsabilidade" (nos TJs: art. 96, III; no STJ e TRFs: arts. 105, I, $a$, e 108, I, $a$, da CF). Nada obstante, entende-se que o foro por prerrogativa de função, fixado ratione personae, não se prende à potencialidade do perigo ou da maior ou menor afetação do bem jurídico,

primeiro grau, do que decorre que, demarcada a última pela Constituição, só a própria Constituição a pode excetuar" (ADI 2.797/DF, rel. Min. Sepúlveda Pertence, Plenário, por maioria, DJ de 19.12.2006).

${ }^{503}$ Para estampar tal afirmativa, relembre-se o pitoresco caso, noticiado na Revista Istoé, no qual um subprocurador-geral do trabalho viu-se envolvido, quando um vizinho seu levou à Justiça criminal o fato de dois cães do subprocurador haverem matado seus dois papagaios, ao pularem a cerca que separava as propriedades. Por não ter havido acordo entre as partes no Juizado Especial Criminal, e percebendo-se a prerrogativa de foro do suposto autor do fato, o caso acabou remetido ao STJ, no qual esperou um desfecho por cinco anos, findando ao reconhecimento da prescrição da pretensão punitiva. Conferir em: $<\mathrm{http}: / /$ www.terra.com.br/istoe/1831/brasil/1831_papagaio_e_a_lei.htm>. Acesso em: 13 maio 2007.

${ }^{504}$ Como foi o "escândalo do Mensalão", suposto esquema de compra de votos por parlamentares, acompanhado publicamente, desde o início, com as investigações na esfera parlamentar, paralelas à formação de inquérito no STF, em 2005; a denúncia ofertada pelo Procurador-Geral da República em 11/4/2006 e, enfim, a sessão de recebimento da acusação pelo Supremo Tribunal Federal, em agosto de 2007, após cinco dias ou trinta e cinco horas de julgamento, contando, atualmente, mais de uma centena de apensos.

505 Assim: "Na hipótese de cometimento de crimes comuns, sem atingir interesses da União, o prefeito municipal, que possui prerrogativa de foro constitucionalmente estabelecida, deve ser processado e julgado pelo Tribunal de Justiça local, sem prejuízo da aplicação dos institutos da Lei n. ${ }^{0}$ 9.099/95, quando se tratar de crimes de menor potencial ofensivo." (STJ, CC 41.659/MT, rel. Min. Laurita Vaz, 3. ${ }^{a}$ Seção, v.u., DJ de 21.9.2005).

${ }^{506}$ Há sistemas que, diferentemente do brasileiro, adotam regimes híbridos. Na Espanha, por exemplo, a competência ratione personae cria um duplo regime de aforamento: o absoluto (para magistrados do Tribunal Supremo, da Audiência Nacional e dos Tribunais Superiores de Justiça, que são julgados, em qualquer infração penal, pela Sala Especial do Tribunal Supremo) e o relativo (para os juízes e magistrados dos demais órgãos jurisdicionais, que são julgados, apenas nas infrações penais cometidas no exercício da função, pela Sala Penal dos Tribunais Superiores de Justiça, sendo que as outras infrações se determinam conforme as regras gerais de competência). Cf. DEL CASTILLO, Manuel M. Gómez; González, José I. Ugalde. Procesos penales..., cit., p. 61-62. Já em Portugal, o regime é o do aforamento relativo para o Presidente da República (que somente responde, perante o plenário do Supremo Tribunal de Justiça, "pelos crimes praticados no exercício de suas funções" - art. 11.1, $a$, do CPP), ao passo que para as autoridades do Poder Judiciário e do Ministério Público, a prerrogativa é ampla (arts. 11.2, a, e $12.2, a$, do CPP). 
mas se vinca na significação da função social do autor da conduta apontada como delituosa. "Assim, no texto constitucional enunciado, a expressão crimes comuns, por si, não espelha a exclusão das contravenções; mas, isto sim, na expressão axiológica, que o direito punitivo em relação a determinadas pessoas, por suas funções, reclama a fixação de itinerário processual individualizado. É opção político-criminal, não para ferir a isonomia e sim para proteger situações no seio dos valores institucionais do cargo ou função pública. Restringir-se, no STJ, a competência somente aos crimes seria desprestigiar a própria simetria constitucional, postura político-filosófica na ordenação do foro privilegiado"507.

O que se apresenta fundamental nesse método de reparto de competência é a confiança do julgamento dos titulares de determinados cargos, pelo relevo da função pública ocupada, a órgãos jurisdicionais em tese mais experientes especificamente previstos na Constituição, evitando-se que juízes de primeiro grau possam constranger

${ }^{507}$ PEREIRA, Milton Luiz. Foro privilegiado: contravenções penais. Revista Síntese de Direito Penal e Processual Penal, Porto Alegre, v. 2, n. 7, abr./maio 2001, p. 19. Na conclusão do autor, "edificada a estrutura conceitual do foro por prerrogativa de função, não é exigido muito esforço para concluir-se que, pela guia das infrações penais, compreendendo-se que as contravenções estão albergadas pela natureza conceitual dos crimes comuns, afirma-se a competência do STJ para processar e julgar originariamente ação criminal instaurada contra Subprocurador-Geral do Trabalho". Assim, igualmente, concluiu a Corte Especial do STJ: "Penal e Processual Penal. Contravenções (art. 31). Representação. SubprocuradorGeral do Trabalho. Competência STJ. Recebimento da Denúncia. Suspensão do Processo. CF, artigo 105, I, a. Lei n. ${ }^{\circ}$ 9.009/95, artigos 60, 61, 72, 73, 74, 76, 77, 89 e 92. CPP, artigo 41. 1. O STJ tem competência para processar e julgar Subprocurador-Geral do Trabalho denunciado pela prática de contravenção penal. 2. Superada a fase de composição amigável dos danos civis e não ocorrendo a transação, é recebida a denúncia formalmente apresentada. 3. Suspensão do processo (art. 31, LCP; arts. 89, Lei 9.009/95; art. 77, Cód. Penal)" (Rp 179/DF, rel. Min. Milton Luiz Pereira, v.u., DJ de 10.6.2002). Em sentido convergente, o Supremo Tribunal Federal há muito assentou que "a expressão crime comum, na linguagem constitucional, é usada em contraposição aos impropriamente chamados crimes de responsabilidade, cuja sanção é política, e abrange, por conseguinte, todo e qualquer delito, entre outros, os crimes eleitorais. Jurisprudência antiga e harmônica do STF.” (CJ 6.971/DF, rel. Min. Paulo Brossard, Plenário, v.u., DJ de 21.2.1992). Cf., ainda, MARQUES, José Frederico. Tratado..., cit., v. 1, p. 330. 
essas autoridades ${ }^{508}$. Trata-se de uma forma especial de modificação da competência comum, que prevalece e se substitui ao critério territorial ${ }^{509}$.

Presume assim o legislador que os tribunais de maior categoria teriam mais isenção e, portanto, seriam plenos de independência e imparcialidade, para julgar os ocupantes de determinadas funções públicas, detendo maior capacidade de resistir quer à influência do próprio acusado, quer às ingerências que atuarem em seu desfavor. O foro por prerrogativa de função seria, portanto, uma garantia bilateral, contra e a favor do acusado $^{510}$.

É de se observar que toda essa engrenagem de repartição de competências, inclusive a que diz com o critério funcional, não se refere senão a regras de distribuição do poder-dever de julgar, de estabelecer o direito aplicável ao conflito de interesses judicializado (a competência, no sentido técnico-jurídico), entre os órgãos jurisdicionais legitimamente previstos na Constituição e nas leis. Não se reporta a qualquer atividade

${ }^{508}$ Sobre as razões que animam a divisão de competência em razão da função, enuncia Romeu Pires de Campos Barros (O procedimento..., cit., p. 168): "A expressão competência funcional é, por si mesma, eloqüente no sentido de demonstrar que o seu uso não leva em consideração a pessoa e sim o cargo; a importância da função exercida por determinadas autoridades; a hierarquia funcional; a garantia precípua que a lei empresta a determinadas funções, evitando àqueles que exercem certos cargos de serem processados e julgados por seus subalternos, com objetivo de afastar represálias destes, ou a influência daqueles, com relação aos seus subordinados. O que visa a lei é a segurança e independência na distribuição da justiça. Não é a importância da pessoa, e sim a do cargo que ela ocupa. Tanto assim que deixando o cargo cessa a competência superior”. Nessa linha, o Anteprojeto de Hélio Tornaghi, mais uma vez referido, assim definia o alcance da prerrogativa de foro: "Art. 163. A competência por prerrogativa de função não acarreta privilégio, em favor de qualquer pessoa, nem exceção, em seu desfavor; não decorre da natureza do crime e sim da dignidade da função exercida pelo agente; a prerrogativa é da função e a competência especial em razão dela cessa, para cada pessoa, quando essa deixa de exercê-la".

${ }^{509}$ É o que ensina Hugo Nigro Mazzilli (Foro por prerrogativa de função: crime praticado por promotor de justiça em Estado da Federação diverso daquele onde exerce suas atribuições. Justitia, São Paulo, v. 48, n. 136, out./dez. 1986, p. 40-41), ao escrever que "quando a lei excepciona a regra comum do locus delicti, para firmar o critério da competência ratione personae, passa a ser totalmente irrelevante a competência em razão do local do crime, pela suficiente razão de que o critério eleito deixou de ser este, passando a ser o ratione personae". E arremata o autor: "Dessa forma, os autos de inquérito policial, onde envolvido órgão do Ministério Público estadual, devem ser remetidos, para prosseguimento, ao Procurador Geral de Justiça do Estado onde o indiciado exerce suas funções de Ministério Público". Também no caso dos Prefeitos, João Cláudio Couceiro (Prerrogativas..., cit., p. 108) entende que ele é processado perante o Tribunal onde está localizado o município em que exerce sua função, ainda que o crime se tenha consumado em município pertencente a outro Estado da Federação. No mesmo sentido, André Medeiros do Paço (Foro por prerrogativa de função: prefeitos municipais. Belo Horizonte: Del Rey, 2000, p. 50) proclama que o juiz natural de quem tem foro por prerrogativa de função é o Tribunal de Justiça do seu Estado, não prevalecendo a competência territorial prevista no CPP. Contra, entendendo que a competência hierárquica, afora os casos de magistrados, fica subordinada ao território em que o delito foi praticado: MARQUES, José Frederico. Tratado..., cit., v. 1, p. 332.

510 Cf. MAZZILLI, Hugo Nigro. O foro por prerrogativa de função e a Lei n. ${ }^{\circ}$ 10.628/02. Revista Síntese de Direito Penal e Processual Penal, Porto Alegre, v. 3, n. 18, fev./mar. 2003, p. 33-34; DEMO, Roberto Luis Luchi. Competência..., cit., p. 181. 
investigativa pré-processual, não distribuindo nem concentrando atribuições administrativas de investigação nas mãos dos órgãos judiciais ${ }^{511}$.

Há quem sustente, nada obstante, que os agentes que gozam da prerrogativa de foro não podem ser investigados em inquérito policial, mas sim em procedimento investigatório próprio, que tramite perante a corte competente para o julgamento, nomeando-se um relator (membro do tribunal) para dirigir a investigação ${ }^{512}$.

${ }^{511} \mathrm{Na}$ mesma guia, diversas Cartas Constitucionais que estatuem foros criminais por prerrogativa de função reportam-se unicamente à função de julgar, não aludindo a tal prerrogativa na investigação preliminar. Assim, as Constituições da Argentina ("Art. 59. Al Senado corresponde juzgar a los acusados por la Cámara de Diputados...”; "Art. 116. Corresponde a la Corte Suprema... el conocimiento y la decisión... de las causas concernientes a embajadores, ministros públicos y cónsules extranjeros..."; “Art. 117. ...en todos los asuntos concernientes a embajadores, ministros y cónsules extranjeros... la ejercerá originaria y exclusivamente."); Estados Unidos da América ("Article III, Section 2. In all Cases affecting Ambassadors, other public Ministers and Consuls, and those in which a State shall be Party, the supreme Court shall have original Jurisdiction.”); França ("Article 68-1. Les membres du Gouvernement... sont jugés par la Cour de justice de la République.”); Itália (“Art. 134. La Corte costituzionale giudica: (...) sulle accuse promosse contro il Presidente della Repubblica, a norma della Costituzione.”); e Portugal (“Art. 130.1. 1. Por crimes praticados no exercício das suas funções, o Presidente da República responde perante o Supremo Tribunal de Justiça."). Também o CPP português, ao delimitar as competências originárias do Supremo Tribunal de Justiça (art. 11.1,a), do Plenário das seções criminais do Supremo Tribunal de Justiça (art. 11.2,a) e do plenário das relações (art. 12.2, a), refere-se apenas à função de "julgar", muito embora contemple, para os magistrados e membros do Ministério Público, um inquérito a cargo da própria instituição a que pertence o investigado (art. 265 do CPP). Como exceção, na Espanha, ao lado de regras constitucionais que atribuem competência por prerrogativa de função ("Art. 71.3. En las causas contra Diputados y Senadores, será competente la Sala de lo Penal del Tribunal Supremo.”; Art. 102.1. "La responsabilidad criminal del Presidente y los demás miembros del Gobierno será exigible, en su caso, ante la Sala de lo Penal del Tribunal Supremo.”), encontram-se dispositivos na Ley Orgánica del Poder Judicial, de 1985, pelos quais, após esmiuçada a competência de cada Tribunal e de seus órgãos fracionários, atribui-se a cada tribunal também a faculdade de designar um "instrutor especial" para o sumário, designação que pode recair sobre qualquer membro da Casa e que impede a sua intervenção nos atos do processo propriamente dito (arts. 57.2, 61.2 e 73.2). Deve-se lembrar que na Espanha predomina o modelo do juiz instrutor, não causando estranheza a designação de magistrados para dirigir a instrução preliminar.

512 Por exemplo, Julio Fabbrini Mirabete (Processo penal. 8. ed. São Paulo: Atlas, 1998, p. 582) aduz: “As pessoas que, pela Constituição Federal e pelas Cartas Estaduais, ficam sujeitas ao processo e julgamento perante órgãos judiciários de superior instância não estão sujeitas, em regra, a inquérito policial, sendo formada a informatio delicti por procedimentos disciplinares administrativos, legislativos ou judiciais ou por outras peças de informação. Evidentemente, porém, não fica afastada a lavratura dos autos de prisão em flagrante contra aqueles que gozam do foro por prerrogativa de função, mas tão logo ele seja lavrado, deve ser remetido ao presidente do Tribunal a que couber o processo criminal". Similarmente, Célio Silva Castro Sobrinho (Foro especial por prerrogativa de função e a garantia do juiz natural. Dissertação (Mestrado em Direito) - Pontifícia Universidade Católica de São Paulo, São Paulo, 2004, p. 201) afirma que "a competência originária dos tribunais alcança toda a fase do inquisitório, desde a requisição e distribuição do inquérito policial ou peças de informação, até as medidas incidentais restritivas de direitos dos investigados", tramitando não só o processo, mas também o inquérito, perante os tribunais. Therezinha Astolphi Cazerta (Ação penal originária..., cit., p. 11), por sua vez, escreve que "[a] prerrogativa de foro se estende às investigações preliminares, sendo mister a instauração do procedimento perante o órgão competente, sob cuja orientação seguirão as diligências, ou a remessa posterior, no caso de instauração por outro órgão, anteriormente à suspeita de envolvimento da autoridade". 
Certo que tal prática, sob ordens jurídicas pregressas, havia-se disseminado com apoio em antigo precedente do Supremo Tribunal Federal, que formou jurisprudência e estendeu-se pelas demais cortes do país ${ }^{513}$.

No entanto, sob os auspícios de uma Constituição democrática que já comemora vinte anos de vigência, cremos que somente é possível uma diretriz procedimental de condução para a investigação praticada nos crimes de competência originária dos tribunais: deve dar-se, em paralelismo ao que ocorre na investigação policial comum, perante os órgãos administrativos da persecução penal (a Polícia Judiciária, sob controle externo do Ministério Público atuante junto ao Tribunal), sendo "judicializada" apenas para a atribuição, a um relator, do papel de juiz de garantias, postura que, a nosso ver, é a única a caber-lhe num sistema acusatório, como é o caso brasileiro ${ }^{514}$.

Dir-se-á que a atribuição de investigação criminal não é matéria reservada à norma constitucional, mas sim à legislação ordinária em matéria processual. Decerto, particularidades referentes à investigação preliminar, atividade administrativa préprocessual de averiguação do delito, enquanto representem prerrogativas de determinadas categorias, do ponto de vista formal, bem cabem nas leis orgânicas das instituições a que destinadas (o que ocorre, por exemplo, na Loman, na LOMPU e na LONMP); na mesma linha, traços procedimentais diferenciados para a investigação preliminar de determinadas

513 Ao apreciar Reclamação em habeas corpus impetrado por Heráclito Fontoura Sobral Pinto e Antônio de Brito Alves, em favor do ex-governador do Estado de Pernambuco Miguel Arraes de Alencar, decidiu o Tribunal, em 28 de abril de 1965, que, enquanto no exercício da função, o agente detentor da prerrogativa de foro estaria imune à investigação policial, cabendo à autoridade julgadora também a investigação do fato criminoso. Eis, para aclaração, o teor do aresto em comento: "Habeas corpus. Competência. Não fica imune a qualquer investigação policial ou policial militar o funcionário, que tem fôro privativo por prerrogativa de função, desde que não esteja mais no exercício do cargo. Quando o funcionário está no exercício da função, à autoridade, competente para julgar, cabe, também, a investigação do fato criminoso que lhe é atribuído. Reclamação julgada procedente em parte" (STF, HC-Rcl 42.108/PE, rel. Min. Evandro Lins, Plenário, v.u., DJ de 18.8.1965). O decisório significou a admissão, praeter legem, de uma espécie de "investigação por prerrogativa de função", ou de inquérito penal realizado pelo tribunal nos crimes de sua competência originária. Se bem que lançado o precedente sob a égide da Constituição de 1946 (quando ainda não implementado o sistema acusatório de processo penal em nosso país), o que em parte explica a orientação, o fato é que as mesmas razões que o informaram vêm servindo, desde então, a justificar a manutenção, mais de meio século depois, daquela tese em alguns pretórios, sempre com o argumento fulcral de o agente estar no exercício da função determinante do foro e, portanto, dever-se adotar o paralelismo da atribuição investigativa com a competência processual determinada pelo foro privativo da autoridade. Inadmissível, todavia, a pertinência da orientação frente ao redesenho constitucional propiciado pela Carta de 1988 e às garantias do devido processo penal.

514 Também Aury Lopes Jr. (Sistemas..., cit., p. 164) assim se manifesta, ao indicar que, tanto nos casos de crimes de competência originária de Tribunais, como no Tribunal do Júri, não existe instrução preliminar judicial, sendo a fase processual inteiramente realizada pela polícia judiciária, o órgão encarregado da investigação. Somente com o exercício da ação penal, dá-se a necessária intervenção judicial. Obviamente, o autor não se referiu ao procedimento de investigação de magistrados, que, pela Loman, 
pessoas ou de certos delitos é matéria que pode ser veiculada por lei ordinária, seja no Código de Processo Penal ou em leis extravagantes. O problema está em não preverem, quer a Constituição, quer o CPP, ou a legislação processual esparsa (ressalva, uma vez mais, às investigações interna corporis previstas nas Leis Orgânicas da Magistratura e do Ministério Público), quaisquer normas que traduzam prerrogativas ou derrogação das regras gerais de tramitação da investigação preliminar, dispostas, substancialmente, no Código de Processo Penal e na própria Constituição.

No mais, a norma concessiva de prerrogativa "deve ser interpretada considerando a harmonia do sistema jurídico" ${ }^{~} 515$. Cumpre afastar quaisquer tentativas de, interpretando extensiva ou analogicamente normas constitucionais criadoras de direito estrito (como as que estabelecem a competência originária por prerrogativa de função) ${ }^{516} \mathrm{e}$ atribuindo a membros do Poder Judiciário funções que, à toda evidência, não lhes pertencem num sistema processual de cariz acusatório, enxergar nas fontes definidoras de competência por prerrogativa de função a entrega ao órgão judicial de poderes outros, concernentes à prática da investigação pré-processual, atividade de cunho nitidamente administrativo e dedicada, por regra, em nosso sistema, à Polícia Judiciária ${ }^{517}$.

continua tendo natureza judicial. Sobre a definição e o papel do juiz de garantias, como proposta para a investigação preliminar tribunalícia, cf. item 3.3.5.

${ }^{515}$ COUCEIRO, João Cláudio. Prerrogativas..., p. 48-49. O autor explica, com espeque na lição de Vicente Ráo, que o "direito das prerrogativas" é um direito especial (regulando apenas determinados grupos e relações, constituindo exceção aos princípios gerais) e não excepcional. Ao contrário das normas de exceção ou restritivas de direito, que não podem ser interpretadas por extensão ou analogia, a norma de direito especial, como a concessória da prerrogativa, em alguns casos, pode comportar interpretação extensiva ou analógica, estendendo-se ao agente político que não foi diretamente beneficiado, por merecer o seu cargo proteção idêntica, atendendo-se à ratio legis. Assim, v.g., a Constituição Federal é omissa quanto à competência para o julgamento dos membros do Conselho Nacional de Justiça e do Conselho Nacional do Ministério Público, criados pela EC 45/2004, e dos membros dos Tribunais Militares, de existência reconhecida no art. 122, II. Nesses casos, entende o autor que pode estender-se a prerrogativa, pelo princípio ubi eadem ratio, ibi eadem legis dispositio, de modo que os membros do CNJ e do CNMP seriam julgados pelo STF e os dos Tribunais Militares, pelo STJ. Para a aplicação do recurso da interpretação extensiva, contudo, é importante que se esteja diante do mesmo direito (no caso, a mesma prerrogativa processual, para casos não compreendidos no texto legal, porém equivalentes), e não da criação de direito novo sequer previsto na Constituição ou nas leis processuais, como é o caso da condução e tramitação da investigação preliminar.

${ }^{516}$ No histórico julgamento da Questão de Ordem no Inquérito 687/SP (rel. Min. Sepúlveda Pertence, Plenário, por maioria, DJ de 9.11.2001), o Supremo Tribunal Federal assentou que "as prerrogativas de foro, pelo privilégio que, de certa forma, conferem, não devem ser interpretadas ampliativamente".

517 Conforme pertinente raciocínio de Eduardo Pereira da Silva (Prerrogativa de foro..., cit., p. 7), não se pode ignorar que "a investigação pré-processual, tendo como destinatário o órgão acusador, também deve ser desempenhada por órgão diverso ao do julgamento, sob pena de ofensa ao sistema acusatório. No Brasil, tradicionalmente a investigação pré-processual é atribuída às polícias judiciárias (polícia civil e polícia federal). A preocupação em assegurar a imparcialidade do juiz inspirou o artigo 252, inc. II, do Código de Processo Penal, que prevê o impedimento do juiz de atuar em processos em que tenha atuado anteriormente, não só como defensor e órgão do Ministério Público (acusação), mas também como autoridade policial (investigação pré-processual)". 


\subsection{A ausência de parâmetros procedimentais e de terminologia legal para a investigação: a uniformização necessária}

Luigi Ferrajoli aponta, entre as "garantias das garantias" do sistema penal (também chamadas de sobregarantias processuais), a ritualidade dos procedimentos, ou seja, a sua obediência a formas procedimentais predeterminadas em lei ${ }^{518}$. O conjunto dessas formalidades ou ritos serviria para pôr freio a atividades arbitrárias quer por parte do juiz, na etapa processual, quer do administrador ou do investigador, na fase procedimental.

A investigação preliminar encerra sim um rito, um conjunto de atos seqüenciados, todos previstos em lei e realizados segundos padrões predeterminados pelo legislador, destinados ao mesmo objetivo, o de efetuar uma apuração sumária do fato que em tese se afigura delituoso. Porém esse rito não se comporta num procedimento-padrão ou procedimento-tipo que atue como caminho obrigatório a ser seguido pela autoridade condutora.

Por isso, na investigação preliminar, ao contrário do que se tem no processo judicial, não se aplica a garantia da ritualidade estrita do procedimento, ou mesmo as suas vertentes do procedimento tipificado e do procedimento integral ${ }^{519}$, voltadas que são, essencialmente, aos processos judiciais. Nada obstante, é preciso que haja diretrizes legais procedimentais a que se reportar o titular da investigação criminal (e seus demais

${ }^{518}$ FERRAJOLI, Luigi. Diritto e ragione..., cit., p. 638. Ao lado da doutrina de Ferrajoli, de caráter mais geral e aplicável a todo procedimento penal, independentemente da definição que se tenha sobre esse instituto, tem-se a lição de Antonio Scarance Fernandes (Processo penal constitucional, cit., p. 114-115), para quem não haveria falar em vários procedimentos dentro de um mesmo processo, mas em apenas um, com distintas fases. Segundo Scarance, as garantias decorrentes do devido processo legal aplicáveis ao procedimento apresentar-se-iam sob duas vertentes: a garantia do procedimento integral (não se permitindo a supressão de atos ou fases do procedimento) e a garantia do procedimento tipificado, no sentido de não se admitir a troca de um procedimento por outro ou a inversão na ordem procedimental. Veja-se que aos procedimentos de investigação preliminar não é possível nem adequado adotar-se tais desdobramentos, pois se trata de garantias direcionadas ao processo judicial, em que a abreviação do procedimento, a inversão da ordem dos atos ou a substituição de um procedimento por outro pode cercear os direitos de ação e de defesa e também o direito à prova. Já no que tange à investigação preliminar, impossível se faz a tipificação de atos, ritos e fases que devam seguir estrita seqüência; ao contrário, tal atividade é incompatível com uma ritualística fechada, pois a ordem e os tipos de diligências praticadas dependerá dos rumos ditados por cada caso concreto, sob pena de se engessarem as investigações, frustrando mesmo a sua finalidade.

519 Que significam, no dizer de Antonio Scarance Fernandes (Processo penal constitucional, cit., p. 114115), mais uma vez lembrado, a garantia de que o juiz irá observar integralmente os procedimentos, não invertendo a ordem nem suprimindo nenhum ato ou fase da série procedimental, nem adotando um procedimento por outro. 
protagonistas), parâmetros mínimos que confiram, no exercício de tão importante atividade persecutório-criminal, segurança aos cidadãos e estabilidade ao sistema jurídico.

Existem, nesse contexto, algumas diretrizes básicas que o próprio Código de Processo Penal cuidou de estabelecer no art. $4 .^{\circ}$; no entanto, pela natureza da atividade investigativa, as diligências que compõem o procedimento preliminar serão seqüenciadas conforme objetivamente se mostrarem necessárias, no desenvolver das investigações. Observe-se que muitos dos atos legalmente praticáveis numa investigação podem não ser, no caso concreto, necessários, ao passo que outros, rotineiramente previstos como ocorrentes logo ao início do procedimento, podem ser praticados apenas ao final, e viceversa, atos havendo também que precisam ser repetidos a depender da situação.

$\mathrm{Na}$ determinação do ritmo a seguir a investigação preliminar, sobressai a discricionariedade da autoridade responsável pela coordenação do procedimento, que dispõe de alguma liberdade para ordenar diligências tendentes ao esclarecimento do fato, não ficando atrelada a uma seqüência ou enumeração necessária de atos, porém tendo limitado o seu agir aos parâmetros traçados em lei ${ }^{520}$.

É valioso memorar que a discricionariedade administrativa (atuação da autoridade administrativa dentro dos limites oferecidos pelos parâmetros legais) não se confunde com arbitrariedade ou abuso de poder. A discricionariedade é característica de certos atos administrativos e deve estar sempre autorizada pelo direito, exercendo-se sob a égide de todos os princípios e garantias outorgados aos indivíduos que participam dessa atividade, como é o caso dos investigados, ofendidos e testemunhas, cujos direitos subjetivos impende ser observados.

Para a investigação prévia dos delitos enfeixados na competência originária de tribunais, reclama-se, tal qual nas demais experiências de persecução preliminar, o estabelecimento desses parâmetros procedimentais a guiar os sujeitos envolvidos nessa etapa.

Ocorre que a Lei 8.038/1990, ao tratar do processo e julgamento dos crimes inseridos na competência penal originária do Supremo Tribunal Federal e do Superior Tribunal de Justiça (aplicável, por força da Lei 8.658/1993, às ações penais que tramitem

${ }^{520}$ Logo, apesar da discricionariedade da atividade policial, a ela se opõem limites negativos representados pelos direitos fundamentais do ser humano e pelos princípios e garantias integrantes do devido processo legal, assegurados na Constituição, os quais devem, necessariamente, ser observados. No mais, "os atos produzidos na investigação policial decorrem de lei e baseiam-se em padrões predeterminados pelo 
perante os Tribunais de Justiça e os Tribunais Regionais Federais ${ }^{521}$ ), cuida do rito a ser seguido na ação penal originária, mas nada diz sobre a investigação preliminar, não a cometendo nem a atrelando, expressa ou implicitamente, aos órgãos - singulares ou colegiados - das Cortes, nem estabelecendo regra alguma sobre a tramitação do procedimento investigatório nesses casos (por exemplo, sobre o modo de iniciação dos procedimentos, a fiscalização destes, o regime do sigilo investigativo, a atuação do órgão do Ministério Público, a intervenção do órgão jurisdicional, etc.).

Os regimentos internos dos tribunais tampouco exercem um papel integrador, favorecendo apenas a pulverização da matéria, a começar pela tipologia adotada para as investigações dos crimes afetos à sua competência originária. E nem mesmo os arts. 556 a 560 do Código de Processo Penal, que tratavam "dos processos de competência do Supremo Tribunal Federal e dos Tribunais de Apelação" e foram revogados pela Lei 8.658/1993, ofereciam normas especiais para a investigação preliminar no caso das ações penais originárias.

Historicamente, é de registrar que o Projeto de Lei 1.655/1983, afastando-se claramente do sistema acusatório, criava um anômalo inquérito judicial nas infrações penais de competência originára dos tribunais. A autoridade policial, segundo o art. 477, apenas colheria os elementos de prova, de forma sumária, e remeteria o expediente ao tribunal, no qual o Relator, de ofício ou a requerimento do Procurador-Geral, determinaria a instauração de inquérito, presidido pelo primeiro (o qual seria também o relator do processo eventualmente instaurado, conforme o art. 478) e acompanhado pelo Ministério Público e pelo investigado ${ }^{522}$.

Por sua vez, o Anteprojeto Frederico Marques - transformado no Projeto de Lei 633/1975, aprovado pela Câmara dos Deputados em 29.11.1977, mas retirado da tramitação parlamentar pelo próprio Poder Executivo, que o remetera ao Congresso - trazia normas sobre o procedimento especial por prerrogativa de função, nos arts. 557 a 562 , atribuindo a presidência da investigação preliminar ao Procurador-Geral ${ }^{523}$.

legislador e não pela livre vontade daquele que o dirige.” (DAURA, Anderson Souza. Inquérito policial..., cit., p. 111).

521 Também se aplica a Lei 8.038 aos processos que tramitem perante os Tribunais Regionais Eleitorais. Já nos casos de competência originária do Superior Tribunal Militar, segue-se o rito dos arts. 489 a 497 do CPPM.

${ }^{522}$ Disponível em: <http://www.senado.gov.br/novocpp/pdf/PL-1655-1983.pdf>. Acesso em 7 out. 2008.

523 Disponível em: <http://www.senado.gov.br/novocpp/pdf/PL-633-1975.pdf>. Acesso em: 7 out. 2008. Também no sentido da presidência do inquérito pelo Procurador-Geral, a quem caberá oferecer a denúncia ou decidir pelo arquivamento, é a opinião de Afrânio Silva Jardim (Direito processual penal, 
Mas, afora a peleja jurídica que paira sobre a legitimação do Ministério Público para presidir investigações independentes, a rigor, como adrede exposto, restringindo-se a prerrogativa de foro à competência jurisdicional, portanto à fixação do juiz natural em matéria penal, segue-se que toda atribuição para procedimento investigativo preliminar nesses casos será, por natureza, administrativo-policial, e não judicial. Porque “a restrição ao trabalho da Polícia Judiciária, além de não encontrar justificação razoável, ferindo, portanto, o princípio da isonomia, afasta da investigação funcionários que estão habituados tal atividade, para nela introduzir juízes, que, muitas vezes, estão afastados da jurisdição criminal há anos. O inquérito envolvendo agente político, portanto, à luz do ordenamento atualmente em vigor, deve ser presidido por Delegado de Polícia",524.

E, ante o patente déficit normativo verificado quanto ao procedimento preliminar, há de ser aplicado, subsidiariamente, o Código de Processo Penal, no que toca ao inquérito policial.

cit., p. 186). João Cláudio Couceiro (Prerrogativas..., cit., p. 59) rebate tal proposta, anotando ser discutível a isenção do Procurador-Geral da República, quando o investigado for o presidente da República que o escolheu e nomeou, ou quando se tratar de Ministro do governo deste, o mesmo ocorrendo com o Procurador-Geral de Justiça, quanto ao Secretário de Estado do Governador que o nomeou. Por isso, defende a extensão da legitimidade para propor a ação penal a qualquer do povo, quando o autor do crime for agente político (a chamada "ação penal popular", que somente foi acolhida em nosso ordenamento na Constituição de 1891 , art. $72, \S 9 .^{\circ}$, mas que, a seu ver, deveria ser admitida sobretudo nos casos em que interesses governamentais pudessem comprometer a iniciativa dos órgãos oficiais), ou então prever-se a nomeação, pelo Poder Legislativo ou pelo Judiciário, de promotor de justiça independente, para investigar especificamente tais fatos. Como precedente histórico, nos Estados Unidos da América, foi criado o Special Prosecutor, mais tarde chamado de Independet Counsel. Consistia em um advogado, nomeado pela Federal DC Appeals Court, a pedido do US Attorney General, para tratar da investigação e eventual processamento de altos funcionários do Governo (inclusive o Presidente, o Vice-Presidente e o Procurador-Geral), ou diretores de campanhas eleitorais presidenciais, depois se estendendo também para investigar membros do Congresso. O Special Prosecutor foi criado pelo Ethics in Government Act, de 1978, e buscava retirar do Executivo (Departamento de Justiça) a investigação de pessoas que teriam influência sobre o governo. O instituto foi previsto com um prazo de vigência e restaurado pelos Independent Counsel Reauthorization Acts de 1987 e 1994, sendo que a validade deste último perdurou até junho de 1999. O Independent Counsel recebeu, durante a sua existência, diversas críticas, sobretudo por se questionar sua irresponsabilidade, motivação política, seus excessos de poder e um orçamento ilimitado, mas sua constitucionalidade foi reconhecida pela Suprema Corte, em 1988, quando se decidiu que a nomeação de um Independent Cousel não viola a Appointments Clause da Constituição (art. II, 2) nem o princípio da separação dos poderes. Entre os casos mais famosos investigados pelo advogado independente, estão o Iran-Contra Affair, o Whitewater Scandal e o Monica Lewinsky Affair. Sobre o tema, cf. TREANOR, William Michael. Independent counsel and vigorous investigation and prosecution. Law and contemporary problems, v. 61, n. 1, p. 149-164, 1998; e ROOF, Judith. Investigating the Special: the symbolic function of the Independent Counsel. Indiana Law Journal, v. 77, p. 277-293, 2002.

${ }^{524}$ COUCEIRO, João Cláudio. Prerrogativas..., cit., p. 58. Por evidente, não está o autor a referir as investigações interna corporis, que constituem exceção a essa regra, não pertencendo a direção dos respectivos inquéritos à autoridade policial, e sim judicial ou ministerial, conforme o caso. No mesmo rumo, Rodrigo Carneiro Gomes (As prerrogativas processuais..., cit., p. 55) diz que "o inquérito autuado no STF, para investigação de conduta, em tese, típica penal de autoridades detentoras de prerrogativa de 
Sobre a questão da terminologia do procedimento investigativo previsto para as ações penais de julgamento tribunalício, o chamado "inquérito penal originário", autuado ou tombado simplesmente como "Inquérito" (Inq) perante os vários tribunais com competência penal originária, a nosso ver, não refletiria senão o registro da existência de uma investigação no âmbito policial, voltada contra um sujeito passivo que detenha o predicativo do foro especial, para que se firmasse, desde aquela autuação, o juiz natural da investigação ${ }^{525}$, atuante nos vários casos em que necessária a movimentação do Poder Judiciário. Não se caracterizaria, portanto, como um inquérito "originário" - que nasce, se desenvolve e se encerra pela direção do órgão judicial -, eis que não se originaria no tribunal, nem teria nele a sede dos seus atos, encontrando ali apenas o reduto das decisões que, no bojo da etapa investigativa, demandem controle jurisdicional.

No Supremo Tribunal Federal, os expedientes que materializam informações diversas que podem ensejar investigação preliminar criminal são autuados, precipuamente, na classe "Inquérito" (art. 55, XIV, do RISTF) ${ }^{526}$, existindo ainda, porém, as classes Comunicação $(\mathrm{Cm})$, Petição (Pet) e Representação $(\mathrm{Rp})^{527}$. Apenas os expedientes que não tenham classificação específica nem que sejam acessórios ou incidentes serão incluídos na classe "Petição", se contiverem requerimento (art. 56, IX, do RISTF). Já no Superior Tribunal de Justiça, a classificação de feitos é a mais variegada dentre todas, prevendo seu Regimento Interno o registro de informações diversas, sob várias modalidades. Depara-se, no STJ, com pelo menos cinco classes cujo conteúdo pode assumir o de uma investigação preliminar, todas sendo direcionadas, de igual modo, por distribuição, aos membros componentes da Corte Especial, órgão interno a quem incumbe o processamento dos feitos

função, observadas as exceções legais, há de ser o inquérito policial, conduzido pela polícia judiciária e presidido por autoridade policial".

${ }^{525}$ Será ele o juiz $d a$ instrução preliminar, e não o juiz de instrução, figura esta que, não prevista em nosso ordenamento, teria plenos poderes de investigação na fase prévia.

${ }^{526}$ É o próprio Regimento Interno do STF que estatui: “Art. 56 (...) V - na classe Inquérito serão incluídos os policiais e os administrativos, de que possa resultar responsabilidade penal, e que só passarão à classe Ação Penal após o recebimento da denúncia ou queixa" (grifo acrescido). Não consta, portanto, nessa classe, qualquer inquérito judicial. Com redação idêntica, o RISTJ, no art. 67, parágrafo único, V, prevê: "V - na classe Inquérito (Inq), são incluídos os policiais e os administrativos que possam resultar em responsabilidade penal, e que só passarão à classe Ação Penal (APn) após oferecimento da denúncia ou queixa". É bem verdade que há investigações envolvendo magistrados (portanto, realizadas interna corporis, logo judiciais) e também são autuadas como "Inquérito", porém a diferença que se verifica é apenas quanto à autoridade condutora, vez que, quanto ao procedimento, também padecem da falta de normatização, tanto quanto as demais investigações de foro especial, findando por se aproximarem, nesse ponto, ambas as espécies.

${ }^{527}$ Art. 55, incisos IX, XVIII e XXIII, do RISTF, respectivamente. 
penais originários. São elas: Inquérito (Inq), Notícia-crime (NC), Sindicância (Sd), Representação (Rp) e Petição criminal (Pet) ${ }^{528}$.

Visam tais expedientes a materializar formas de perquirição de fatos com aparência delituosa, os quais estejam sendo atribuídos, com maior ou menor base probatória, a agentes detentores de foro por prerrogativa de função. Trata-se de estágios não-obrigatórios da persecução criminal pré-processual nos delitos dessa estirpe, mas não existe uma definição clara sobre quais expedientes serão autuados/convertidos em uma ou em outra classe. Com isso, um mesmo procedimento pode assumir diversas roupagens na trajetória da investigação criminal originária. Da mesma forma que uma sindicância, a certa altura de seu percurso, pode ser convertida, a pedido dos interessados ou a critério do Relator, em notícia-crime, e esta, posteriormente, em inquérito ${ }^{529}$, também a notícia-crime pode ser convertida em sindicância ${ }^{530}$.

O controle quanto ao enquadramento em notícia-crime, sindicância ou representação apresenta, contudo, parâmetros demasiado subjetivos, não existindo uma linha divisora clara entre as diversas categorias investigativas.

Ademais, a pluralização de classes dos procedimentos com caráter investigativo criminal nos tribunais vai de encontro ao perfil garantista da investigação preliminar. A multiplicidade de roupagens dos procedimentos e a indefinição de seu critério distintivo criam uma insegurança para o sujeito passivo da investigação, reclamando um tratamento uniforme que permita a aplicação de regras procedimentais a todos eles (guardadas, evidentemente, as imunidades estabelecidas em norma específica apenas para determinados agentes ${ }^{531}$ ).

${ }^{528} \mathrm{O}$ art. 67 do RISTJ contempla, atualmente, apenas quatro das cinco classes referidas. A Notícia-crime (NC), na qual se incluía a sindicância administrativa ou policial, assim como quaisquer informações relativas à prática de ilícito, embora excluída pela Emenda Regimental 7, de 1.3.2004, apresenta um acervo remanescente de feitos ainda em tramitação.

${ }^{529}$ O que aconteceu com a Sd 19, sindicância instaurada pelo Ministério Público Federal no Estado do Acre, em face de supostas irregularidades na arrecadação e transferência de recursos do Imposto de Renda Pessoa Física de Conselheiros e servidores do Tribunal de Contas daquele Estado. Distribuída no Superior Tribunal de Justiça em 13.12.2004, a primeira decisão do Ministro Relator, publicada no DJ de 1.2.2005, foi a de autuar-se o feito como notícia-crime, ao tempo em que deferiu as diligências requestadas pelo MPF. Passou, assim, a tramitar como NC 369, até que, em 6.12.2005, novo despacho do Relator, publicado no DJ de 15.12.2005, determinou sua autuação como Inquérito, passando agora a tramitar como Inq 512.

${ }^{530}$ Cf. STJ, NC 372, convertida em 7.2.2007 para Sd 105.

531 Como nos casos em que se proíbe que o agente político seja preso cautelarmente (art. $86, \S 3 .^{\circ}$, da CF), ou que seja lavrado auto de prisão em flagrante, quando o crime for afiançável (deputados federais e senadores - art. 53, § 2. ${ }^{\circ}$, da CF; juízes - art. 33, II, da LC 35/1979; membros do Ministério Público - art. 18, II, $d$, da LC 75/1993 e art. 40, III, da Lei 8.625/1993; ministros e conselheiros dos tribunais de contas - art. $73, \S 3 .^{\circ}$, e art. 75 da CF). 
É importante a configuração de regras básicas para o procedimento preliminar nos crimes de competência especial, traçado em lei e com a previsão de garantias que o ajustem aos preceptivos constitucionais integrantes do sistema acusatório. Alvitra-se, ainda, a identificação dessas investigações com um nome próprio, para diferenciá-las, operacionalmente, das investigações comuns: Inquérito policial especial. Com isso, e para conferir racionalização a essa etapa investigativa, por vezes bem mais complexa que os inquéritos policiais comuns, as delegacias de Polícia Civil ou de Polícia Federal poderiam destacar funcionários específicos para dedicar-se a essas investigações, que se reportariam, em suas atividades, também a órgãos distintos, quais sejam: os membros de Tribunais e os integrantes do Ministério Público atuantes junto aos respectivos pretórios.

Passaremos, a seguir, a delimitar algumas diretrizes que se lançam como propostas para a sistematização e o aperfeiçoamento das investigações preliminares em delitos de competência originária de tribunais, contrastando-as com o que hoje se pratica nos referidos procedimentos. Cumpre frisar, desde logo, que os parâmetros adiante propostos se destinam, regra geral, às investigações envolvendo agentes políticos ${ }^{532}$, porquanto constituem o procedimento-padrão nesse gênero. No entanto, vez por outra, farse-á menção aos procedimentos interna corporis, mormente quando for para destacar-lhes as peculiaridades e discrepâncias em relação aos demais.

\subsection{Visão crítica da praxe judicial e propostas de diretrizes para a investigação preliminar}

Já se disse que o Código de Processo Penal, no que tange à investigação preliminar (e, propriamente, em relação ao inquérito policial), não estabelece nenhum rito específico a ser seguido pela Polícia Judiciária, com isso prestigiando a sua necessária simplificação. Chegando, por qualquer forma, ao conhecimento da Polícia a existência de infração penal (art. 5..$^{\circ}$ do CPP), é seu dever agir, efetuando as diligências listadas no art. $6 .^{\circ}$ do Codex. Nisso consiste a discricionariedade legada à autoridade policial: dadas as variantes de cada caso e a especificidade do objeto da pesquisa, é-lhe permitido escolher o ritmo a ser imprimido e os caminhos a serem adotados na investigação, não lhe escapando,

${ }^{532}$ Referidas no item 2.4.2. 
porém, o dever de obediência às garantias constitucionais e a parâmetros procedimentais mínimos, ajustados àquelas garantias.

Não é diferente nos procedimentos preliminares de investigação de crimes submetidos à competência hierárquica. No entanto, em que pese a impossibilidade de se enclausurar o procedimento investigativo em fórmulas fechadas, é possível e necessário que se estabeleçam as suas diretrizes básicas, também no caso em que a competência para o seu processamento seja deixada, originariamente, a órgãos colegiados, diretrizes procedimentais que garantam ao investigado a observância do devido processo legal na fase preliminar, não deixando ao alvedrio da autoridade condutora o seu regramento.

Uma premissa, já antes esquadrinhada, deverá estar sempre presente nesse estudo: a de que, mesmo em se tratando de crimes processados e julgados por órgãos colegiados, constitui a Polícia Judiciária o investigador-padrão de todos os cidadãos, inclusive os submetidos à competência hierárquica - sendo o produto da sua atividade o já historicamente conhecido inquérito policial.

Outrossim, por medida de racionalização das atividades policiais, tal investigação mereceria um corpo destacado de servidores na sua realização e uma autuação em livro específico com outro nome, aqui sugerido como Inquérito policial especial, que não deixa de pertencer ao gênero do inquérito policial comum, mas que seja instrumentado, sempre que possível, por policiais que estejam treinados e atentos às particularidades desse tipo de investigação preliminar.

\subsubsection{Instauração do procedimento investigatório e seu aforamento no tribunal}

Relevante questão que se lança no trato do tema ora enfocado, pela efervescência jurisprudencial que vem provocando, diz respeito à necessidade de alguma espécie de ordem ou autorização prévia para instaurar-se a investigação preliminar nos delitos de competência originária de tribunais, principalmente a realizada na forma de inquérito.

Quadra saber se, para a instauração do inquérito ou da investigação preliminar nesses casos (que pode dar-se por outras roupagens, como já noticiado), é 
necessário haver algum tipo de "autorização", seja judicial (emanada do tribunal competente para julgamento da ação penal), ou legislativa, ou ainda ministerial.

Inicialmente, no que tange à participação do Poder Legislativo, não há que se cogitar de qualquer autorização parlamentar para dar início às investigações. Mesmo a licença prévia, ainda existente para o processamento dos membros do Poder Executivo (arts. 51, I, e 86, caput, da CF), ou a autorização para processar criminalmente autoridades do Poder Legislativo detentoras de foro especial, antes exigida pelo art. 53, $\S 1$. $^{\circ}$, da $\mathrm{CF}^{533}$ e proscrita pela Emenda Constitucional 35/2001, não interferem, como já explanado, na investigação preliminar.

A licença, em ambos os casos, era solicitada anteriormente ao recebimento da denúncia, ou seja, depois de já encerrado o inquérito policial. Por sua vez, a Emenda Constitucional 35, abolindo a licença prévia para processamento, manteve uma forma de imunidade processual aos parlamentares, ao tornar possível deliberação legislativa suspensiva do processo (art. 53, § 3..$^{\circ}$, da $\mathrm{CF}^{534}$ ), o que tampouco empeça o desenvolvimento da investigação preliminar, que continua sem depender de autorização da respectiva $\mathrm{Casa}^{535}$. Logo, a necessidade de licença não impede (para os chefes do Poder Executivo), nem no passado impedia (para os congressistas) a instauração de inquérito policial, tampouco o oferecimento de denúncia formal, tendo apenas o condão de obstar seu recebimento, que é o primeiro ato de prosseguimento praticado pelo Magistrado ${ }^{536}$.

Em segundo lugar, sobre a figuração do Ministério Público na instauração do procedimento, ela pode ocorrer de forma acidental ou eventual (quando o membro do Parquet requisita a instauração de inquérito policial), mas não emerge necessária. Embora toque ao Chefe do Ministério Público a plena titularidade da ação penal pública originária dos tribunais, tal legitimação não absorve a etapa prévia, que pode iniciar-se, conforme

${ }^{533}$ Era a seguinte a redação originária do art. 53, § 1.." "Desde a expedição do diploma, os membros do Congresso Nacional não poderão ser presos, salvo em flagrante de crime inafiançável, nem processados criminalmente, sem prévia licença de sua Casa".

534 “Art. 53 (...) $\S 3 .^{\circ}$ Recebida a denúncia contra o Senador ou Deputado, por crime ocorrido após a diplomação, o Supremo Tribunal Federal dará ciência à Casa respectiva, que, por iniciativa de partido político nela representado e pelo voto da maioria de seus membros, poderá, até a decisão final, sustar o andamento da ação."

535 Assim ficou claro no seguinte precedente do STF: "A garantia da imunidade parlamentar em sentido formal não impede a instauração do inquérito policial contra membro do poder legislativo, que está sujeito, em conseqüência - e independentemente de qualquer licença congressional -, aos atos de investigação criminal promovidos pela polícia judiciária, desde que essas medidas pré-processuais de persecução penal sejam adotadas no âmbito de procedimento investigatório em curso perante órgão judiciário competente: o STF, no caso de os investigandos serem congressistas (CF, art. 102, I, b)". (Rcl 511/PB, rel. Min. Celso de Mello, Plenário, v.u., DJ de 15.9.1995). 
entendemos, a pedido de qualquer autoridade, ou por comunicação de qualquer do povo, ou ainda por requisição ministerial. No caso específico dos inquéritos penais especiais, envolvendo agentes com prerrogativa de foro, o membro do Ministério Público com atribuição para acompanhar, desde o início das investigações, será o Procurador-Geral de Justiça, nos Estados, ou o Procurador-Geral da República, nos tribunais superiores ${ }^{537}$. Nos demais tribunais, os Procuradores da República com atribuição para atuar perante eles ${ }^{538}$.

Analisemos, na seqüência, o ponto mais polêmico, concernente ao cabimento ou à necessidade de ordem ou de autorização judicial para instauração do procedimento preliminar.

No regime geral do Código de Processo Penal, o inquérito inicia-se de ofício, pela autoridade policial, ou mediante provocação - oral ou escrita - denominada de notitia criminis, o conhecimento que a autoridade tem acerca de um fato aparentemente criminoso, a qual pode ser levada por qualquer pessoa ou pelo próprio ofendido ou seu representante (a chamada delatio criminis). Pode iniciar-se ainda, segundo o art. 5. ${ }^{\circ}$, II, do CPP, por requisição do Ministério Público, nos crimes de ação pública incondicionada ${ }^{539}$, eis que nos de ação privada somente o ofendido ou seu representante legal podem incitá-lo (arts. 5. ${ }^{\circ}, \S 5 .^{\circ}$, e 30 do CPP).

536 MORAES, Alexandre de. Direito constitucional, cit., p. 392.

537 Opondo-se à legitimação do Procurador-Geral da República, mesmo que por delegação ao Subprocurador-Geral da República, nas ações penais públicas originárias junto ao Superior Tribunal de Justiça, Cláudio Lemos Fonteles (A legitimação para propositura da ação penal pública originária no Superior Tribunal de Justiça. Universitas/Jus, Brasília, n. 2, p. 23-27, jul./dez. 1998) entende - em postura, vale registrar, suplantada na jurisprudência - ser inconstitucional o art. 48, II, e parágrafo único da Lei Complementar 75/1993, porquanto transbordaria os limites excepcionais e constitucionais da atutação do Chefe do Ministério Público, que seria restrita, a seu ver, ao Plenário da Suprema Corte.

538 Quanto à atribuição para funcionar nas ações penais originárias de tribunais, ela vem delimitada pelas leis orgânicas do Ministério Público. É o que prevê a Lei Complementar 75/1993: “Art. 46. Incumbe ao Procurador-Geral da República exercer as funções do Ministério Público junto ao Supremo Tribunal Federal, manifestando-se previamente em todos os processos de sua competência. (...) Art. 47. O Procurador-Geral da República designará os Subprocuradores-Gerais da República que exercerão, por delegação, suas funções junto aos diferentes órgãos jurisdicionais do Supremo Tribunal Federal. (...) Art. 48. Incumbe ao Procurador-Geral da República propor perante o Superior Tribunal de Justiça: (...) II - a ação penal, nos casos previstos no art. 105, I, $a$, da Constituição Federal. Parágrafo único. A competência prevista neste artigo poderá ser delegada a Subprocurador-Geral da República". Por outro lado, prevê a Lei 8.625/1993: “Art. 29. Além das atribuições previstas nas Constituições Federal e Estadual, na Lei Orgânica e em outras leis, compete ao Procurador-Geral de Justiça: (...) V - ajuizar ação penal de competência originária dos Tribunais, nela oficiando". Nos Tribunais Regionais Federais, atuam os Procuradores Regionais da República (art. 68 da LC 75/1993) e, nos Tribunais Regionais Eleitorais, atua o Procurador Regional Eleitoral, designado pelo Procurador-Geral Eleitoral entre os Procuradores Regionais da República, para um mandato de dois anos, podendo ser reconduzido por uma vez (arts. $76 \mathrm{e}$ 77 da LC 75/1993).

539 Nas infrações penais de ação pública condicionada, necessária será, para o início da persecução criminal (judicial ou extrajudicial), a representação do ofendido ou a requisição do Ministro da Justiça (art. 5. ${ }^{\circ}, \S$ 4..$^{\circ}$, e art. 24 do CPP). 
No tocante à subsistência da possibilidade de que a autoridade judiciária atue como agente propulsor da abertura das investigações, o art. 5. $^{\circ}$, II, do Código de Processo Penal não resistirá a uma interpretação à luz da Constituição ${ }^{540}$, levando à incompatibilidade da requisição judicial de inquéritos, por permitir ao magistrado dar início, ele mesmo, à persecução estatal, que somente não desembocará numa ação penal se promovido, por alguma causa legal, o arquivamento do apuratório ${ }^{541}$.

Crê-se que tal postura não é afeiçoada ao modelo acusatório, cumprindo ao magistrado afastar-se da iniciativa de procedimentos persecutórios, ainda que préprocessuais, dirigindo os documentos ensejadores de possível prática delituosa, com que porventura se deparar em suas funções, com base no art. 40 do $\mathrm{CPP}^{542}$, para análise cabível do Ministério Público - que poderá, aí sim, requisitar a instauração do inquérito ${ }^{543}$.

${ }^{540}$ Nesse sentido: SILVA, Edimar Carmo da. Princípio acusatório e a repercussão no processo penal brasileiro: a legitimidade para restrição de direito fundamental. Monografia (Pós-graduação em Sistema de Justiça Criminal) - Universidade Federal de Santa Catarina, Florianópolis, 2006, p. 35; SILVA, Danielle Souza de Andrade e. A atuação..., cit., p. 109; ABADE, Denise Neves. Garantias..., cit., p. 174176; LOPES JR., Aury. Sistemas..., cit., p. 181.

541 “Ora, se não é permitido ao juiz diretamente provocar sua jurisdição - ne procedat iudex ex officio - a mesma vedação deve acontecer quando indiretamente tende a provocá-la.” (MOSSIN, Heráclito Antonio. Aspectos relevantes no projeto de reforma do Código de Processo Penal em tema de investigação. Revista Cejap, Campinas, v. 3, n. 5, nov. 2002, p. 4).

${ }^{542}$ Disposições correlatas à do art. 40 do CPP se encontram no art. 8. ${ }^{\circ}, \mathrm{IV}$, do RISTF (“Art. 8. ${ }^{\circ}$ Compete ao Plenário e às Turmas, nos feitos de sua competência: (...) IV - representar à autoridade competente quando, em autos ou documentos de que conhecer, houver indício de crime de ação pública.") e no art. 15, IV, do RISTJ (“Art. 15. À Corte Especial, às Seções e às Turmas cabe, ainda, nos processos de sua competência: (...) IV - representar à autoridade competente, quando, em autos ou documentos de que conhecer, houver indício de crime de ação pública.”).

$543 \mathrm{O}$ art. 40 do CPP ("Quando, em autos ou papéis de que conhecerem, os juízes ou tribunais verificarem a existência de crime de ação pública, remeterão ao Ministério Público as cópias e os documentos necessários ao oferecimento da denúncia.”) contém uma norma de ordem pública dirigida aos juízes e tribunais, cometendo-lhe atribuição de natureza administrativa, consistente no poder-dever de noticiar infrações penais de ação pública incondicionada conhecidas no exercício de sua função. Trata-se, como observa Sérgio Marcos de Moraes Pitombo (Do art. 40, do Código de Processo Penal. Revista do Instituto dos Advogados de São Paulo, São Paulo, v. 3, n. 2, 1977, p. 69-70) de notitia criminis oficial, fincada no princípio da legalidade, não abrindo margem a discricionariedade ao juiz. E essa notícia dada ao Ministério Público, por juiz ou tribunal, não vincula nem obriga, sob pena de restaurar-se, de modo oblíquo, a promoção ex officio da demanda. "Como o órgão judiciário, que assim procede, não está exercendo qualquer atividade judiciária, e como o Ministério Público, e não o juiz, é no sistema acusatório, que o Código consagra, o titular único, dentre os órgãos estatais, do jus persequendi in judicio, é claro, e lógico que nenhum promotor de Justiça está vinculado a essa notitia criminis emanada do juiz, no sentido de ser obrigado a dar denúncia, mesmo que entenda inexistir motivo para isso.” (Idem, p. 68). Já Geraldo Prado (Sistema acusatório..., cit., p. 174-175) posiciona-se contrariamente a qualquer modalidade de comunicação judicial da existência de provável infração penal, seja a do art. $5 .^{\circ}$, II, ou a do art. 40 do CPP, porquanto ambas vulnerariam a imparcialidade judicial, pilar básico do sistema acusatório. Reconhece o autor, porém, que tais medidas correspondem ao anseio de não deixar de fora da persecução penal fatos que, de ordinário, não chegariam ao conhecimento da autoridade policial ou do Ministério Público, e que se poderia equilibrar o sistema, com base no princípio da proporcionalidade, afastando do feito aquele juiz que noticiou a infração. 
O Anteprojeto Frederico Marques já previa tal vedação ${ }^{544}$, recomendando ao magistrado que, se tomasse conhecimento de fato delituoso, noticiasse ao Ministério Público $^{545}$. Na mesma direção caminha o Projeto de Lei 4.209/2001, atualmente em tramitação no Congresso Nacional, igualmente retirando a possibilidade de instauração do procedimento preliminar mediante requisição judicial ${ }^{546}$.

Logo, diante da extrema importância e magnitude da função exercida pelo Magistrado no Estado moderno, e para que a exerça com a necessária imparcialidade, há que se excluir, primeiramente, a possibilidade de a instauração da investigação preliminar, em nosso sistema, partir de ordem do magistrado, seja daquele que atuará como juiz da investigação, decidindo os incidentes que nela reclamarem sua intervenção, ou, menos ainda, daquele que processará e relatará o julgamento da ação penal.

E quanto à necessidade de prévia autorização do Poder Judiciário para dar início ao inquérito contra agentes titulares de prerrogativa de foro?

Já se viu que, no direito brasileiro, somente a instrução prévia dos delitos praticados por magistrados é reservada, por lei, à esfera do Poder Judiciário, que tratará de instaurar a investigação e presidi-la, autorizando as diligências necessárias, com a colaboração, muitas vezes, da Polícia Judiciária. Além disso, a investigação de delitos envolvendo membros do Ministério Público também tem particularidades legais, realizando-se sob direção da própria instituição a prática dos atos de instauração e desenvolvimento do inquérito.

Mas há que distinguir esses dois modelos (excepcionais em nosso sistema, por força das respectivas leis orgânicas) dos demais casos de investigação de agentes com foro especial, que constituem a regra geral e o objeto principal deste estudo, e que têm como única baliza a Lei 8.038/1990, afora as escassas disposições regimentais dos tribunais. Nesse segundo grupo, o silêncio normativo sobre vários aspectos do procedimento investigatório, entre eles a forma de iniciação, vem provocando dissídio na jurisprudência, que longe está de firmar uma orientação estabilizada.

544 “Art. 251. O inquérito policial será iniciado com portaria da autoridade policial, ordem do Ministério Público ou com o auto de prisão em flagrante delito." (MARQUES, José Frederico. Anteprojeto de Código de Processo Penal: publicado no DOU, suplemento, de 29.6.1970. São Paulo: Sugestões Literárias, [s.d.]).

545 Trata-se do art. 249 do Anteprojeto, cuja dicção é reproduzida no art. 40 do estatuto em vigor.

$546 \mathrm{O}$ art. $4 .^{\circ}$ do aludido Projeto de Lei, na redação aprovada pela Câmara dos Deputados em 11 de dezembro de 2008, ao se referir às formas de instauração de inquérito nos crimes de ação penal pública, não mais contempla a requisição da autoridade judiciária. 
É cada vez mais explícita em nossos pretórios (sobretudo no Supremo Tribunal Federal) a dissensão quanto à ingerência do Tribunal, competente para a ação penal, no ato de instauração do inquérito (e, numa perspectiva mais abrangente, também nos atos administrativos praticados em seu bojo, como o indiciamento) envolvendo agentes políticos, como Deputados e Senadores. Vêm-se tornando recorrentes os julgados, noticiados inclusive na mídia, que acenam com a necessidade de uma espécie de “autorização" judicial do respectivo Tribunal, que com isso estaria a exercer apenas a “supervisão" da investigação preliminar tribunalícia.

Em alguns precedentes, embora não vergastando diretamente a atuação ex officio da Polícia Judiciária, o Pretório Excelso decidira ora que "[c]ompete ao Supremo Tribunal Federal supervisionar inquérito policial em que Senador tenha sido intimado para esclarecer imputação de crime que lhe fez indiciado"547; ora que "[u]ma vez envolvido deputado federal, cumpre ao Supremo os atos próprios ao inquérito",548 - adotando assim posturas inconciliáveis, porquanto supervisionar atos é, evidentemente, diferente de praticar atos próprios do inquérito.

E com relação, especialmente, ao tema da instauração do inquérito envolvendo agentes políticos, no aresto proferido em Questão de Ordem no Inquérito 2.411/MT, o relator, Ministro Gilmar Mendes, consignou:

i) a jurisprudência do STF é pacífica no sentido de que, nos inquéritos policiais em geral, não cabe a juiz ou a Tribunal investigar, de ofício, o titular da prerrogativa de foro; (...) A prerrogativa de foro é uma garantia voltada não exatamente para os interesses dos titulares de cargos relevantes, mas, sobretudo, para a própria regularidade das instituições. Se a Constituição estabelece que os agentes políticos respondem, por crime comum, perante o STF (CF, art. 102, I, b), não há razão constitucional plausível para que as atividades diretamente relacionadas à supervisão judicial (abertura de procedimento investigatório) sejam retiradas do controle judicial do STF. A iniciativa do procedimento investigatório deve ser confiada ao MPF contando com a supervisão do Ministro-Relator do STF. 5. $\underline{A}$ Polícia Federal não está autorizada a abrir de ofício inquérito policial para apurar a conduta de parlamentares federais ou do próprio Presidente da República (no caso do STF). No exercício de competência penal originária do STF (CF, art. 102, I, $b$ c/c Lei n. ${ }^{\circ} 8.038 / 1990$, art. $2 .^{\circ}$ e RI/STF, arts. 230 a 234), a atividade de supervisão judicial deve ser constitucionalmente desempenhada durante toda a tramitação das

${ }^{547}$ Rcl 2.349/TO, rel. Min. Carlos Velloso, rel. p/ acórdão Min. Cezar Peluso, 2. ${ }^{\text {a }}$ Turma, por maioria, DJ de 5.8.2005, grifos acrescidos. Também: Rcl 1.258/DF, rel. Min. Ilmar Galvão, rel. p/ acórdão Min. Marco Aurélio, Plenário, por maioria, DJ de 6.2.2004.

${ }^{548}$ Inq-AgR 2.291/DF, rel. Min. Carlos Britto, rel. p/ acórdão Min. Marco Aurélio, Plenário, por maioria, DJ de 14.11.2007, grifos acrescidos. 
investigações desde a abertura dos procedimentos investigatórios até o eventual oferecimento, ou não, de denúncia pelo dominus litis. ${ }^{549}$

Vale registrar ainda que, no julgamento da Questão de Ordem na Petição 3.825/ $\mathrm{MT}^{550}$, conquanto tenha prevalecido idêntico posicionamento, a partir da divergência do Ministro Gilmar Mendes, o relator, Ministro Sepúlveda Pertence (que ficou vencido, ao lado dos Ministros Joaquim Barbosa, Carlos Britto e Celso de Mello), asseverara, em seu voto, que "a instauração de inquérito policial para a apuração de fato em que se vislumbre a possibilidade de envolvimento de titular de prerrogativa de foro do STF não depende de iniciativa do Procurador-Geral da República, nem o mero indiciamento formal reclama prévia decisão de um Ministro do STF", de modo que "tanto a abertura das investigações de qualquer fato delituoso, quanto, no curso delas, o indiciamento formal, são atos da autoridade que preside o inquérito".

No entanto, por veredicto majoritário, embora ressalvasse a jurisprudência pacífica no sentido de que, nos inquéritos policiais em geral, não cabe ao juiz ou ao Tribunal investigar, de ofício $^{551}$, o titular de foro especial, o Supremo decidiu, naquela oportunidade, que nem a instauração do inquérito nem o indiciamento do agente político poderiam ser efetuados por ato de ofício da autoridade policial, devendo antes subordinarse ao crivo do Tribunal (do Ministro-relator).

Cumpre fazer referência, de outra parte, a arestos que, emanados da mesma Corte, apontam para a não-subordinação da instauração do inquérito a ato do Tribunal, como são os ora destacados:

${ }^{549}$ Inq-QO 2.411/MT, rel. Min. Gilmar Mendes, Plenário, por maioria, DJ de 25.4.2008, grifos acrescidos. Nesse precedente, o próprio Procurador-Geral da República postara-se contra a instauração ex officio de inquérito pela autoridade policial. Extraído de sua manifestação, o seguinte trecho consta no voto condutor (fl. 128): "Permitir que o procedimento de investigação predisposto à colheita de elementos probatórios, que suportarão eventual imputação penal contra titular de cargo a que se assegura foro especial, possa ser aberto por autoridade policial que integra o Departamento de Polícia Federal, e é órgão integrante da estrutura administrativa do Ministério da Justiça, certamente enfraquece a garantia que a Constituição consagra".

550 Pet-QO 3.825/MT, Rel. Min. Sepúlveda Pertence, rel. p/ acórdão Min. Gilmar Mendes, Plenário, por maioria, DJ de 4.4.2008, julgamento ocorrido na mesma sessão plenária em que apreciado o Inq-QO 2.411/MT, em 10.10.2007.

551 A locução "de ofício", ou ex officio, significa aquilo que se executa em razão do ofício ou por dever de ofício (SILVA, De Plácido e. Vocabulário jurídico, cit., p. 586), aquilo que se faz em virtude da função ou cargo, daí a sua impropriedade para indicar a atuação do juiz ao exercer atividade investigatória criminal. Como bem pontua Sergio Demoro Hamilton (A ortodoxia..., cit., p. 204), atribuir tal nomenclatura para definir função anômala exercida pela autoridade judiciária em um sistema que se diz 
1. Para instauração de Inquérito Policial contra Parlamentar, não precisa a Autoridade Policial obter prévia autorização da Câmara dos Deputados, nem do Supremo Tribunal Federal. Precisa, isto sim, submeter o Inquérito, no prazo legal, ao Supremo Tribunal Federal, pois é perante este que eventual ação penal nele embasada poderá ser processada e julgada. E, no caso, foi o que fez, após certas providências referidas nas informações. Tanto que os autos do Inquérito já se encontram em tramitação perante esta Corte, com vista à Procuradoria Geral da República, para requerer o que lhe parecer de direito. 2. Por outro lado, o Parlamentar pode ser convidado a comparecer para o interrogatório no Inquérito Policial, (podendo ajustar, com a autoridade, dia, local e hora, para tal fim - art. 221 do Código de Processo Penal), mas, se não comparecer, sua atitude é de ser interpretada como preferindo calar-se. Obviamente, nesse caso, não pode ser conduzido coercitivamente por ordem da autoridade policial, o que, na hipótese, até foi reconhecido por esta, quando, nas informações, expressamente descartou essa possibilidade. ${ }^{552}$

Entre as funções institucionais que a Constituição Federal outorgou ao Ministério Público, está a de requisitar a instauração de inquérito policial (CF, art. 129, VIII). Essa requisição independe de prévia autorização ou permissão jurisdicional. Basta o Ministério Público Federal requisitar, diretamente, aos órgãos policiais competentes. Mas não a esta Corte Suprema. Por ela podem tramitar, entre outras demandas, ação penal contra os membros da Câmara dos Deputados e Senado. Mas não inquéritos policiais. Esses tramitam perante os órgãos da Polícia Federal. Eventuais diligências, requeridas no contexto de uma investigação contra membros do Congresso Nacional, podem e devem, sim, ser requeridas perante esta Corte, que é o juiz natural dos parlamentares federais, como é o caso da quebra do sigilo fiscal. Mas o inquérito tramita perante aqueles órgãos policiais e não perante o Supremo Tribunal Federal. Não parece razoável admitir que um ministro do Supremo Tribunal Federal conduza, perante a Corte, um inquérito policial que poderá se transformar em ação penal, de sua relatoria. Não há confundir investigação, de natureza penal, quando envolvido um parlamentar, com aquela que envolve um membro do Poder Judiciário. (...) Mas quando se trata de parlamentar federal, a investigação prossegue perante a autoridade policial federal. Apenas a ação penal é que tramita no Supremo Tribunal Federal. Disso resulta que não pode ser atendido o pedido de instauração de inquérito policial originário perante esta Corte. E, por via de conseqüência, a solicitação de indiciamento do parlamentar, ato privativo da autoridade policial. (...) Diante do exposto, determino sejam os autos devolvidos à Procuradoria-Geral da República para as providências que entender cabíveis. ${ }^{553}$

acusatório constitui equivocada postura doutrinária. Quando o juiz julga, aí sim, ele atua de ofício, pois este é o seu ofício.

${ }^{552}$ STF, HC 80.592/PR, rel. Min. Sydney Sanches, 1. ${ }^{\text {a }}$ Turma, v.u., DJ de 22.6.2001, grifos acrescidos.

${ }^{553}$ STF, Pet 3.248/DF, rel. Min. Ellen Gracie, DJ de 23.11.2004, grifos acrescidos. Trata-se de decisão monocrática indeferindo requerimento do Procurador-Geral da República no sentido de que fosse o procedimento administrativo autuado como inquérito penal originário no STF, com o indiciamento de deputado federal e a quebra do seu sigilo fiscal. O entendimento foi seguido pelo Min. Gilmar Mendes, no Inq 2.285/DF, DJ de 13.3.2006, e pelo Plenário, no julgamento do AgRg na Pet 2.805/DF, rel. Min. Nelson Jobim, por maioria, DJ de 27.2.2004. Já no âmbito do STJ, também existe julgado não admitindo o oferecimento de notícia-crime à autoridade judicial, ao fundamento de que o art. 5. ${ }^{\circ}$, II, do CPP não pode ser utilizado para reduzir ou constranger o órgão jurisdicional, que deve estar o mais alheio possível à investigação: "Consoante recente entendimento esposado pelo STF, não é admissível o oferecimento de notícia crime à autoridade judicial visando à instauração de inquérito policial. O art. 5. ${ }^{\circ}$, II, do CPP confere ao Ministério Público o poder de requisitar diretamente ao delegado de polícia a instauração de 
Diante desse quadro, há de se pôr as coisas em seu devido lugar. Já se discorreu que a garantia do foro especial não se estende à investigação preliminar, o que, longe de esvaziar a prerrogativa processual ou usurpar a competência jurisdicional, vem em resguardo do preceito da eficiência na persecução penal, pois pensamento contrário contribuiria essencialmente para a burocratização da investigação, com reflexos como a impunidade e a prescrição ${ }^{554}$.

Não restam dúvidas, também, de que a atividade investigativa policial é submetida a controle externo do Ministério Público (art. 129, VII, da CF), que a fiscaliza em sua execução e em seus prazos, podendo requerer e acompanhar a realização das diligências, para o efetivo alcance de sua finalidade. Como, então, estabelecer um novo (duplo) controle, agora na forma de supervisão da autoridade judicial? Os papéis de cada um dos sujeitos da investigação preliminar nos delitos de competência hierárquica - Polícia Judiciária, Ministério Público e Tribunal - hão de ser devidamente esclarecidos, para que não haja sobreposição de funções ${ }^{555}$.

"Autorizar" ${ }^{556}$ pressupõe um consentimento prévio ao ato que se visa praticar, ao passo que "supervisionar" ${ }^{\text {"557 }}$ exprime uma atividade de inspeção, posterior ao ato a ser controlado, como que o homologando. Não se poderia enxergar, portanto, a nosso entender, a necessidade de autorização para instauração de inquérito contra agentes políticos, como simples decorrência da supervisão em tese exercida pelo Tribunal nesses inquéritos, visto que são ações distintas. Basta dizer que, no primeiro grau de jurisdição, a chamada supervisão que a autoridade judicial exerce sobre os inquéritos policiais não engloba tal autorização para instalar-se o procedimento investigatório, donde não caber aqui o argumento da analogia com as funções do juiz de primeira instância.

inquérito policial com o fim de apurar supostos delitos de ação penal pública, ainda que se trate de crime atribuído à autoridade pública com foro privilegiado por prerrogativa de função. Não existe diploma legal que condicione a expedição do ofício requisitório pelo Ministério Público à prévia autorização do Tribunal competente para julgar a autoridade a ser investigada." (AGRNC 317/PE, rel. Min. Francisco Peçanha Martins, Corte Especial, v.u., DJ de 23.5.2005).

554 GOMES, Rodrigo Carneiro. As prerrogativas processuais..., cit., p. 54.

555 A esse respeito, cf. o item 3.3.4.

556 "Em qualquer sentido jurídico, que se lhe dê, autorização significa sempre a permissão ou consentimento dado ou manifestado por certa pessoa, seja física ou jurídica, pública ou privada, para que se pratique ato ou se faça alguma coisa, que não seriam legalmente válidos, sem essa formalidade" (SILVA, De Plácido e. Vocabulário jurídico, cit., p. 176).

557 No Dicionário eletrônico Houaiss da língua portuguesa (versão 1.0.7, Rio de Janeiro: Objetiva, set. 2004), "supervisionar" vem com o sentido de "dirigir, inspecionando (um trabalho), controlar, supervisar". 
Logo, guardada a exceção atinente à magistratura (art. 33, parágrafo único, da Loman), a única forma de supervisão, inspeção ou controle exercido pelo Tribunal sobre o inquérito, admissível em nosso sistema, corresponde àquela participação que o juiz de primeiro grau deve exercer nos inquéritos policiais comuns ${ }^{558}$ e que consiste, precisamente, na apreciação das medidas cautelares e providências outras que demandem intervenção judicial, como é o caso do acesso aos autos de inquérito após negativa pela autoridade policial. Exasperado esse diâmetro, possivelmente estar-se-á confundindo a função judicial ora com a do investigador (condução e execução de atos próprios de investigação), ora com a do Ministério Público (controle externo da atividade policial).

O inquérito envolvendo agentes com prerrogativa de função, por ser policial, e não judicial - ressalva feita, diga-se mais uma vez, às investigações interna corporis, envolvendo magistrados e membros do Ministério Público, que são extrapoliciais em sua essência -, há de seguir, a nosso ver, as mesmas regras do inquérito policial comum, devendo ser instaurado e instruído, com a prática de todos os atos a ele pertinentes (os atos próprios do inquérito), pelo órgão de Polícia Judiciária, como é de sua natureza.

Propõe-se então que sua instalação não fique a depender de autorização ou permissão nem de ulterior homologação judicial; que não se perfaça mediante ato judicial de natureza administrativa, mas por ato administrativo-policial ${ }^{559}$. Assim, a rigor, o inquérito não tramitará perante o tribunal ${ }^{560}$, mas a ele deverá ser dirigido apenas quando necessária alguma providência reservada ao Poder Judiciário pela Constituição, entre as quais não se encontra, por exemplo, a abertura de uma investigação criminal ou a

${ }^{558}$ Bem expressa tal postura: "Foro por prerrogativa de função: inquérito policial. 1. A competência penal originária por prerrogativa não desloca por si só para o tribunal respectivo as funções de polícia judiciária. 2. A remessa do inquérito policial em curso ao tribunal competente para a eventual ação penal e sua imediata distribuição a um relator não faz deste "autoridade investigadora", mas apenas lhe comete as funções, jurisdicionais ou não, ordinariamente conferidas ao juiz de primeiro grau, na fase pré-processual das investigações.” (HC 82.507/SE, rel. Min. Sepúlveda Pertence, 1. Turma, v.u., DJ de 19.12.2002). No mesmo sentido: RHC 84.903/RN, rel. Min. Sepúlveda Pertence, 1. Turma, v.u., DJ de 4.2.2005).

559 Vale destacar aqui a lúcida observação de Hélio Ivo Angrisani Dória (Ação e jurisdição no Código do Processo Penal: notas sôbre duas inconstitucionalidades. Estudos de direito processual in memoriam do Ministro Costa Manso. São Paulo: Revista dos Tribunais, 1965, p. 24), no sentido de que "se determinado ato do poder público, mercê dos fins que persegue, se caracteriza como administrativo, não há razão para a Magna Carta proscrever expressamente a sua execução pelo Poder Judiciário. Tal proibição constituiria mera superafetação, dado que da sua ausência não seria lícito inferir a faculdade do Poder para praticar um ato, que se não enquadrasse entre suas atribuições fundamentais".

560 Em sentido oposto, Therezinha Astolphi Cazerta (Ação penal originária..., cit., p. 17), após analisar alguns julgados do STF e do STJ, insiste que a investigação preliminar deve ter curso, necessariamente, perante a autoridade judicial competente, segundo as regras da prerrogativa de foro, sem que se afaste, contudo, "a possibilidade de serem realizados atos de investigação pela autoridade policial, inclusive com poderes de condução". Nessa assertiva, há uma indefinição quanto à natureza jurídica do inquérito, já que a polícia guardaria poderes de condução, mas o inquérito teria curso perante a autoridade judicial. 
homologação das diligências efetuadas pela Polícia. Com isso não fica tolhido, frise-se bem, o controle jurisdicional sobre quaisquer dos atos do inquérito (inclusive o de instalação), porém tal controle não prescinde de provocação do interessado, por exemplo, mediante o habeas corpus e o mandado de segurança.

Não há falar, por conseguinte, em um "inquérito penal originário" de existência autônoma no Tribunal. O registro do inquérito no Tribunal é mera projeção, no âmbito do Poder Judiciário, do inquérito policial, cuja existência e desenvolvimento dão-se na esfera da Polícia Judiciária. Quando se diz que o inquérito policial tramita "perante" o Tribunal, está-se referindo apenas à autuação e remessa ocorridas nos momentos de jurisdicionalização necessária, e não à afetação de todas as inúmeras providências meramente impulsionadoras da investigação ao crivo do Relator.

Enfim, sobre caber ou não à autoridade policial investigar (e, por via de conseqüência, indiciar ${ }^{561}$ ), a despeito de qualquer tipo de autorização prévia, autoridades dotadas de predicamento de foro não sujeitas à investigação interna corporis, responde-se positivamente, não se enxergando óbice legal para tanto.

Com essa exegese, entende-se possível coadunar os variados precedentes exarados, em distintos momentos, pelo Excelso Pretório, extraindo-se deles a máxima compatibilidade entre si e com o sistema constitucional. Na evolução do tema, que ainda suscitará muitos embates, haverá bastante espaço para construir jurisprudência. Caberá ao Poder Judiciário prestigiar as funções que lhe competem por mandato da própria Constituição ${ }^{562}$, bem como ao Ministério Público velar para que não haja retrocesso nessa missão.

Passemos, agora, a examinar as formas com que se poderá dar impulso a um inquérito policial especial, propostas à luz das conclusões acima alinhadas.

Poderá o inquérito inaugurar-se seja a partir de notitia criminis ou de requisição do Procurador-Geral da República ou do Procurador-Geral de Justiça. Tal requisição deverá ser dirigida não ao Tribunal, mas à autoridade policial, que instaurará o inquérito e, uma vez encerradas as diligências ou se necessária dilação de prazo, dirigi-lo-á para ser aforado no Tribunal, assim se firmando o juiz natural de eventuais medidas cautelares penais praticadas no curso da investigação.

${ }^{561}$ Sobre indiciamento, vide o item 2.5. 
Analogamente ao que ocorre nos inquéritos comuns, em que nem toda ocorrência registrada nas delegacias de polícia gera, forçosamente, a abertura de inquérito policial $^{563}$, também nem toda notícia ou imputação de um fato que se alegue infração penal, ao chegar ao conhecimento do Ministério Público ou da Polícia Judiciária, envolvendo um titular da prerrogativa de função, deve ser tratada como hábil à instauração de um inquérito.

Mas a atribuição para desencadear o procedimento não deverá sair da esfera da autoridade policial e a ela tocará o juízo técnico sobre sua instauração, pautado pelo princípio da legalidade ${ }^{564}$. Não cabe ao Ministério Público (aqui entendido como o Procurador-chefe com atribuição para o caso) inaugurar inquérito policial, embora tenha o poder (localizado entre suas funções institucionais - art. 129, VIII, da CF) de requisitar sua instauração, devendo dirigir tal requisição, esclareça-se, à Polícia Judiciária, não ao Tribunal. Tampouco vemos razão para que se rogue ao Tribunal autorização para instaurar o inquérito, pois não se encarta nas atribuições dos Relatores efetuar o juízo de valor sobre a iniciação de procedimentos policiais, devendo manter-se o tanto quanto possível alheio às investigações ${ }^{565}$.

${ }^{562}$ Assim o exorta Hélio Ivo Angrisani Dória (Ação e jurisdição..., cit., p. 27): "É, por conseguinte, menos um direito que um dever do Judiciário - intérprete e guarda da Constituição - repelir as imposições de atribuições estranhas à sua função primária e fundamental de julgar".

${ }^{563}$ Nesse ponto, tem crucial aplicação a garantia da motivação dos atos do procedimento, pois a decisão sobre instaurar ou não instaurar o inquérito há de ser fundamentada. E o Código de Processo Penal prevê, no art. $5 .^{\circ}, \S 2 .^{\circ}$, um recurso administrativo ao superior hierárquico da autoridade, com competência para rever o ato. Outra solução para a omissão da autoridade policial em instaurar o inquérito é a renovação da notitia criminis perante o órgão do Ministério Público teoricamente com atribuição para funcionar no futuro processo instaurado em ação penal deduzida a partir do caso apurado no inquérito policial, nos termos do art. 27 do CPP. Note-se, porém, que ainda aqui o Ministério Público não estará obrigado a requisitar a instauração do inquérito, pois nosso sistema preserva a sua opinio delicti, tanto quanto preserva o poder de decisão, ainda aqui, da autoridade policial. Cf. COUTINHO, Jacinto Nelson de Miranda. $\mathrm{O}$ ato administrativo de instauração do inquérito policial. In: BARRA, Rubens Prestes; ANDREUCCI, Ricardo Antunes. Estudos em homenagem a Manoel Pedro Pimentel. São Paulo: Revista dos Tribunais, 1992, p. 173-175. Aury Lopes Jr. (Sistemas..., cit., p. 184) refere ainda a possibilidade de ingressar-se com mandado de segurança contra $\mathrm{o}$ ato do delegado.

${ }^{564}$ Nas palavras de Flávio Meirelles Medeiros (Princípios de direito processual penal. Revista Forense Comemorativa - 100 anos, Rio de Janeiro, t. 7, 2006, p. 507), "[o] princípio da legalidade não incide apenas sobre a ação e o processo penal; sua eficácia se estende para abranger toda a atividade estatal de persecução. Assim, o princípio se aplica também à atividade investigatória policial. Diante da ocorrência do fato com aparência de crime, tem a autoridade policial o dever jurídico de iniciar as investigações em torno dele e de sua autoria".

${ }^{565}$ Afrânio Silva Jardim (Direito processual penal, cit., p. 320) conclui, nesse rastro, ser "vedada aos órgãos do Poder Judiciário qualquer atividade persecutória na fase inquisitória, pré-processual. Não é mais o juiz um dos destinatários da notitia criminis, em qualquer de suas modalidades. Não pode mais o magistrado requisitar a instauração de inquérito policial, desempenhando função anômala dentro do sistema acusatório, que se apresenta como pressuposto do 'devido processo legal'. Tais poderes são incompatíveis com a nobre função de julgar, julgar com neutralidade e imparcialidade". 
Basta, portanto, em nosso entender, que seja noticiado à autoridade policial um fato típico, independentemente da atribuição de autoria, para que se iniciem as investigações. Ocorre que nem todo fato noticiado constitui, em tese, infração penal, podendo, em inúmeros casos, configurar um indiferente penal. Assim, em se tratando de conduta típica, terá lugar um ato de instauração do inquérito policial, que é um ato de procedimento administrativo, emoldurado com todas as exigências a ele pertinentes (sobretudo a da motivação), no qual a autoridade policial exercerá um juízo de valor, limitado pela tipicidade aparente ${ }^{566}$. Se a notícia da infração penal for manifestamente infundada, se o fato não tiver dignidade penal, o ato de instauração não deverá ser praticado. Poderá ainda a autoridade, antes de adotar tal postura, verificando a ausência de indícios que justifiquem a imediata instauração de inquérito, praticar a chamada investigação extra-inquérito $^{567}$, que no âmbito da Polícia Federal é denominada de investigação policial preliminar ${ }^{568}$ e que no Projeto de Lei 4.209/2001, em discussão parlamentar, passa a ser prevista como "verificação preliminar de procedência da notícia crime" $" 569$.

566 Segundo Jacinto Nelson de Miranda Coutinho (O ato administrativo..., cit., p. 171-172), cuida-se de um juízo de conteúdo científico (discricionariedade técnica), dirigido a estabelecer se a notitia criminis, chegada à autoridade policial de que forma for, é adequada à expressão crime (art. 5. ${ }^{\circ}, \mathrm{CPP}$ ) ou à expressão infração penal (art. 6. ${ }^{\circ}, \mathrm{CPP}$ ), ou à expressão delito (art. 301, CPP), salientando-se que nessas passagens o legislador refere-se ao tipo, ao modelo de infração penal previsto na norma. Esse juízo há de ser adequado, para que não se volte contra cidadãos inocentes nem se entulhem as delegacias, desprestigiando a Polícia.

${ }^{567}$ Carlos Laet de Souza esclarece que, na prática policial, as investigações podem ocorrer no bojo do inquérito policial (investigação intra-inquérito) ou de maneira independente de um procedimento formal (investigação extra-inquérito). Esta última pode ter o objetivo de desvendar a autoria de um crime (como nos casos de furtos de rua, roubos a estabelecimentos comerciais, etc.) a fim de que o inquérito policial seja instaurado; ou pode visar apurar a conveniência da instauração do inquérito policial, investigando-se preliminarmente a veracidade da informação, ou se o fato constitui um ilícito penal. Segundo o autor, "[é] imperativo que a autoridade policial exerça uma triagem de ocorrências para que a persecução penal se mantenha como instrumento de garantia da segurança da sociedade e não como mera formalidade de utilidade duvidosa" (Da investigação policial..., cit., p. 160).

568 A Instrução Normativa 1/1992, do Departamento de Polícia Federal, que consolida normas internas sobre a condução de procedimentos de investigação policial naquele órgão, dispõe, no Título II, sobre a Investigação Policial Preliminar (IPP), definida como "um instrumento excepcional destinado a verificar a procedência de notícias de infração penal levadas ao conhecimento da autoridade policial, mas que, pela escassez de indícios, não justifiquem, de imediato, instauração de inquérito" (art. 183). Trata-se de "um procedimento singelo, sem excesso de formalismo, evitando-se expressões dogmáticas, termos e atos consagrados ao inquérito policial" (art. 184). Cf. SIRINO, Sérgio Inácio; TAGGESELL, Hildegard. Inquérito policial federal. Curitiba: Juruá, 2006, p. 102-103.

569 O Substitutivo do Deputado Marcelo Itagiba ao PL 4.209, aprovado em 11.11.2008 na Câmara dos Deputados, confere a seguinte redação ao art. 9. ${ }^{\circ}$ do CPP: "Art. 9..$^{\circ} \mathrm{O}$ inquérito policial deverá ser instaurado imediatamente após a autoridade policial tomar conhecimento da infração penal de que trata $o$ art. $4 .^{\circ}$, salvo quando a investigação depender de verificação preliminar de procedência da notícia crime. (...) $\S 2 .^{\circ}$ Constatada a procedência da notícia crime, a verificação preliminar de que trata o caput converter-se-á em inquérito policial, caso contrário, será arquivada pela autoridade policial”. 
Na casuística, são diversas as possibilidades de iniciar-se um procedimento investigatório perante tribunais com competência penal originária, em nosso sistema. Entre outras, pode o procedimento investigatório principiar pelo desmembramento de uma ação penal já em curso - quando o Ministério Público denuncia alguns agentes e postula a extração de cópias para continuação das investigações quanto a outros, a partir daí requerendo a autuação de novo inquérito; pode eclodir de verificações extraídas de procedimento administrativo fiscal realizado, por exemplo, no âmbito da Receita Federal, quando se trata de práticas lesivas ao erário comunicadas ao Parquet; pode partir de notícia-crime ou de representação endereçada quer à Polícia, quer ao Ministério Público oficiante junto ao Tribunal que jurisdiciona o sujeito imputado ${ }^{570}$; ou pode mesmo advir de desdobramentos de inquérito policial comum, quando em seu decurso se aventa a possibilidade de responsabilização penal de agente com foro especial.

Normalmente, a investigação policial se inicia por notitia criminis de uma única fonte. No entanto, quando se lida com agentes detentores de prerrogativa de foro, sobretudo os agentes políticos e no que concerne aos crimes funcionais, é comum que a mesma conduta aparentemente criminosa (por exemplo, do chefe do Poder Executivo Municipal) seja noticiada - à autoridade policial ou ao titular da ação penal pública originária - pela Câmara Municipal, pela Promotoria de Justiça ou Juízo de Direito locais, pelo Tribunal de Contas, pelo sucessor do investigado, por Comissão de Inquérito instalada pelo Legislativo, ou mesmo por qualquer cidadão, o que obriga a um controle rigoroso para evitar-se a duplicidade de procedimentos investigatórios ${ }^{571}$.

A provocação dos órgãos de persecução pré-processual com base em correspondência anônima é algo verificável, na prática, em procedimentos que tais, nos

${ }^{570}$ No caso de ser a notícia direcionada ao Tribunal, como visto, não deverá ser admitida pelo Relator a que distribuída, devolvendo-se-a ao peticionante. Assim se manifestou, com acerto, o Ministro Gilmar Mendes, em decisão monocrática no Inq 2.285/DF, DJ de 13.3.2006: 'Não cabe a esta Corte 'determinar' a instauração de inquérito policial para apuração de crime de ação pública incondicionada, ressalvados aqueles praticados no âmbito da própria Corte e que possam dizer respeito ao exercício de sua própria competência, constitucional ou legal (RISTF, art. $8 .^{\circ}$, inciso IV). Aliás, o próprio $\S 3 .^{\circ}$ do art. $5 .^{\circ}$ do Código de Processo Penal, invocado pelo autor deste procedimento como fundamento jurídico de sua pretensão, diz expressamente que a comunicação de crime de ação pública far-se-á à 'autoridade policial'. Anote-se, outrossim, que conforme assentado pelo Pleno da Corte na Pet n. ${ }^{\circ} 2805$ AgR (Rel. Min. Nelson Jobim), a intervenção desta Corte é especialmente descabida quando a mesma notícia crime foi (ou pode ser) diretamente encaminhada ao Ministério Público, tendo 'a apresentação da mesma neste Tribunal a finalidade de causar repercussão (...) eleitoral'. Por estas razões, não conheço ao pleito e nego-lhe seguimento (RISTF, art. 21, $1^{\circ} .^{\circ}$ ). Conseqüentemente, deixo de aplicar ao caso o art. 40 do CPP, inclusive por não se tratar de conhecimento eventual ou fortuito de fato potencialmente criminoso mas sim de representação direta manifestamente impertinente".

571 Cf. PAÇO, André Medeiros do. Foro por prerrogativa ..., cit., p. 71. 
quias há o temor de represálias por parte de autoridades públicas envolvidas. No entanto, deve-se recordar que denúncia anônima é instituto próprio da inquisição e que a Constituição da República veda o anonimato (art. 5. ${ }^{\circ}$, IV), motivo pelo qual deve ser proscrita, haja vista limitar o investigador (e também os demais agentes envolvidos na investigação) na averiguação da licitude das ações de coleta dos elementos de prova porventura ali carreados, oficiosamente ${ }^{572}$. As cartas anônimas endereçadas ao Poder Judiciário, ao Ministério Público ou à Polícia Judiciária, despidas de qualquer fundamento, devem ser, de plano, arquivadas.

Uma vez instaurado o inquérito policial, mediante portaria específica, seja de ofício ou por requisição do Procurador-Geral, cumpre à autoridade condutora, de logo e independentemente de ter sido já o inquérito aforado no Tribunal competente para a ação penal, cientificar o sujeito passivo (caso este já venha identificado na notícia-crime e não esteja pendente nenhuma medida cautelar a ser efetuada sob sigilo) sobre a existência da investigação, com cópia da portaria respectiva, que lhe dará a delimitação do fato investigado, a tipificação provisória, as diligências iniciais da autoridade policial e os elementos identificadores da autoria. Tal providência deve ser adotada o quanto antes, de modo a propiciar o eventual controle administrativo e judicial dos atos do inquérito, contribuindo ao efetivo exercício da defesa do investigado, levando-o à igualdade ou ao menos à aproximação de posições com o investigador.

Por fim, ressalte-se que, também nas infrações penais entregues à competência originária dos tribunais, nada impede a dispensa do inquérito e sua substituição por peças de informação. Afinal, é bem firme em nosso sistema processual o preceito de que, embora o procedimento investigativo prévio à ação penal constitua importante sede de coleta de elementos que permitam infirmar ou confirmar, com elementos mínimos, a existência de um crime e sua provável autoria, não constitui o inquérito policial estágio obrigatório à formação da opinio delicti nem é essencial a

\footnotetext{
572 Assim o previa o Anteprojeto Frederico Marques, inserindo no CPP, no Título "Da notícia de infração penal", o art. 16: "Não se admitirá notícia anônima de qualquer infração penal". No mesmo sentido, já decidiu o Supremo Tribunal Federal: "ANONIMATO - NOTÍCIA DE PRÁTICA CRIMINOSA PERSECUÇÃO CRIMINAL - IMPROPRIEDADE. Não serve à persecução criminal notícia de prática criminosa sem identificação da autoria, consideradas a vedação constitucional do anonimato e a necessidade de haver parâmetros próprios à responsabilidade, nos campos cível e penal, de quem a implemente." (HC 84.827/TO, rel. Min. Marco Aurélio, 1. ${ }^{a}$ Turma, por maioria, DJ de 23.11.2007). Também André Medeiros do Paço (Foro por prerrogativa..., cit., p. 71) encalça igual preocupação, ao asseverar a necessidade de que "o responsável pela opinio delicti acautele-se sempre em relação a toda espécie de notícias de crimes sem fundamento, frutos de ódios pessoais e disputas políticas locais, procurando sempre a resolução técnica da questão".
} 
acompanhar a denúncia ou queixa, podendo o acusador valer-se das peças informativas de que dispuser se entender suficientes para, de pronto, promover a ação penal.

Calha anotar, porém, que, ante a rotineira complexidade das infrações penais envolvendo autoridades sujeitas ao foro especial, além da especificidade do juízo prelibatório da acusação (exercido por um órgão colegiado, o que tem conferido maior rigor à análise dos requisitos de admissibilidade da peça inicial) e da dificuldade, senão impossibilidade, de se cumprir a finalidade garantística da etapa investigativa suprimindose o inquérito policial, cada vez mais se recomenda a sua instauração, com posterior e oportuno aforamento junto ao tribunal, fornecendo assim uma mais ampla possibilidade de o sujeito passivo contribuir também aos seus resultados.

Como aduz Rodrigo Carneiro Gomes, "sem perder de vista o interesse social e o combate à criminalidade organizada, a grande maioria dos inquéritos submetidos ao STF ('mensalão', 'sanguessugas', caso 'PC Farias', dentre outros), especialmente os emblemáticos, a atuação do MP não dispensou a requisição de diligências policiais ou a instauração de inquérito policial, o que revela, de fato, quem desempenhou atos de investigação e colheita de indícios e prova material do delito e sua autoria. A Polícia Judiciária é constitucionalmente vocacionada, preparada e aparelhada para as investigações criminais de delitos, seja os de pequeno potencial ofensivo, seja os praticados por complexas organizações criminosas" ${ }^{\circ 73}$.

\subsubsection{Aquisição ou perda superveniente da prerrogativa de foro: 0 art. 567 do CPP}

Entre os obstáculos que volteiam o processamento e, com igual intensidade, a investigação preliminar dos ilícitos penais de julgamento originário de tribunais, está o nomadismo característico desse tipo de foro.

Já se anotou que a garantia do juiz natural permeia a atuação da jurisdição na medida em que se estabelece, prévia e taxativamente, o órgão jurisdicional competente para julgar uma causa penal - seja o processo propriamente dito ou as medidas cautelares que o antecedem, na fase investigativa.

573 As prerrogativas processuais..., cit., p. 49. 
Mas a competência por prerrogativa de função em matéria criminal - que leva em consideração a altivez do cargo, a eminência da função do agente, por isso não ofendendo o juiz natural - estabelece, casuisticamente, um juízo vacilante, precário, nãodefinitivo, assim nos cargos efetivos (quando ocorre aposentadoria, promoção, mudança de carreira, etc.) como, principalmente, nos eletivos, provocando, com certa freqüência, o deslocamento de inquéritos e processos, conforme o investigado adquire ou perde o mandato determinante da prerrogativa (por normal expiração, por cassação ou por renúncia ${ }^{574}$ ) e, sucessivamente, recupera-o, no mesmo ou em outro cargo, que implique ser novamente alçado a juízo colegiado, num movimento de constante de ratificação ou até refazimento de atos já praticados ${ }^{575}$.

É que a prerrogativa, como visto, não acompanha o indivíduo, o agente, e sim a função que ele exerce. Não é fato inusual o de, instaurado inquérito pela autoridade policial, a determinada altura deparar-se o Delegado de Polícia com o envolvimento de autoridade submetida a foro especial. Até então, o inquérito policial estava sob a

${ }^{574}$ É sabido que as prerrogativas constitucionais, protegendo exclusivamente a instituição, são insuscetíveis de renúncia (MORAES, Alexandre de. Direito constitucional, cit., p. 399). O seu titular não pode delas dispor, a menos que disponha do cargo ou função que lhe dá ensejo. Assim, é possível que o agente detentor da prerrogativa renuncie ao cargo e, com este, perca também as garantias que o acompanham. A questão foi debatida no STF, que se dividiu ante a renúncia de deputado federal ao seu mandato, cinco dias antes do julgamento pelo Tribunal. O caso é emblemático ao revelar as vicissitudes por que pode passar a competência hierárquica: o então deputado Ronaldo Cunha Lima, acusado de crime doloso contra a vida em tese ocorrido em 1993, até então não fora julgado. Primeiro, porque, de início, sendo governador do Estado da Paraíba, só podia ser processado mediante autorização da Assembléia Legislativa, que não veio. Em 1994, já como senador, também o Senado não concedeu a então necessária licença para processamento. Só em 2001, com a edição da Emenda Constitucional 35, afastando a autorização prévia do Legislativo, é que o STF - agora seu juízo natural - deu continuidade ao processo. Após a dissidência inaugurada pelo Min. Marco Aurélio, o STF decidiu pelo deslocamento do juízo natural como efeito da renúncia ao cargo: "1. O réu, na qualidade de detentor do mandato de parlamentar federal, detém prerrogativa de foro perante o Supremo Tribunal Federal, onde deve ser julgado pela imputação da prática de crime doloso contra a vida. 2. A norma contida no art. $5 .^{\circ}$, XXXVIII, da Constituição da República, que garante a instituição do júri, cede diante do disposto no art. 102, I, $b$, da Lei Maior, definidor da competência do Supremo Tribunal Federal, dada a especialidade deste último. Os crimes dolosos contra a vida estão abarcados pelo conceito de crimes comuns. Precedentes da Corte. 3. A renúncia do réu produz plenos efeitos no plano processual, o que implica a declinação da competência do Supremo Tribunal Federal para o juízo criminal de primeiro grau. Ausente o abuso de direito que os votos vencidos vislumbraram no ato. 4. Autos encaminhados ao juízo atualmente competente.” (AP 333/PB, rel. Min. Joaquim Barbosa, rel. p/ acórdão Min. Marco Aurélio, Plenário, por maioria, DJ de 11.4.2008). Com isso, da mesma forma que não pode o acusado eleger o seu juízo natural, tampouco cabe ao juízo, mediante critérios de conveniência e oportunidade da administração da Justiça, escolher os casos que julgar, prorrogando competência que, por norma constitucional, não mais lhe toca. Não é dado ao Judiciário ingressar na análise subjetiva sobre os motivos que levaram o acusado à renúncia ao cargo dotado de prerrogativa de foro.

575 É o fenômeno que João Cláudio Couceiro denomina de "competência móvel” (Prerrogativas..., cit., p. 43). 
supervisão do Ministério Público e a garantia do Juízo de primeira instância, eis que os investigados não ocupavam postos contemplados com a prerrogativa de foro.

Todavia, diante da mera possibilidade de envolvimento de um governador, prefeito, parlamentar, ou qualquer outra autoridade detentora do foro especial, a autoridade policial deve adotar uma mudança de postura: remeterá os autos ao novel Juízo natural (agora, um tribunal) sempre que necessária a intervenção judicial para alguma medida invasiva de direitos fundamentais, e passará a reportar-se, nas diligências de impulsionamento, ao membro do Ministério Público atuante perante aquele juízo colegiado $^{576}$

Embora tal conduta deva ocorrer, via de regra, ex officio, a remessa também pode efetivar-se a pedido do Ministério Público, ou fazer-se diretamente pelo juiz de primeiro grau, quando este, apreciando os incidentes da investigação - pedidos de quebra de sigilo, de busca e apreensão, de liberdade provisória, etc. - ou mesmo manuseando os autos pela atividade meramente burocrática do deferimento de dilação de prazo para diligências ${ }^{577}$, abrevia o curso do apuratório naquela sede, ante a verificação da prerrogativa de foro a impor a remessa do procedimento ao tribunal.

O inquérito policial, que havia principiado sob a garantia do juiz de primeiro grau, prossegue agora sob a égide do desembargador ou ministro Relator. É que, assumindo o agente um cargo com prerrogativa de foro especial, a persecução deve ter seguimento perante o Tribunal competente, que será o seu juiz natural ${ }^{578}$.

Mas nem mesmo o envio do inquérito ao tribunal é apto a fincar em definitivo o abrigadouro da investigação. Sucede que, tratando-se de competência atrelada ao cargo ou à função do investigado, uma vez obtida a aposentadoria, encerrado ou cassado ou abdicado o mandato, ou havendo subseqüente mudança do posto até então ocupado, por

576 Relembre-se, porém, que, no caso de envolvimento de magistrado, por imperativo do art. 33, parágrafo único, da Loman, a remessa dos autos implicará o desencargo da atribuição de dirigir o procedimento deixada, por lei, à própria instituição a que pertence o investigado -, cessando a presidência da autoridade policial, que somente atuará, doravante, caso lhe requisite alguma diligência específica o magistrado Relator, mas aí atuará por delegação deste. Peculiar também será a sua conduta no caso de vislumbrar envolvimento de algum membro do Ministério Público, cabendo à autoridade dirigente do inquérito encaminhá-lo para o chefe da instituição, que doravante assumirá a sua condução (art. 18, parágrafo único, da LOMPU e art. 41, parágrafo único, da LONMP).

577 Trata-se de prática ainda pontualmente persistente, embora destoada do sistema acusatório, eis que não cabe ao magistrado, na etapa preliminar, dizer sobre a suficiência ou não de cada pedido de dilação de prazo para continuidade das diligências na etapa administrativa, o que demandará a manifestação prévia do Ministério Público, a quem cabe o juízo sobre a suficiência das diligências investigativas, bem como a conveniência de se abreviá-la ou de aguardar ainda alguma medida essencial à formação da opinio delicti.

578 Cf. CASTRO SOBRINHO, Célio Silva. Foro especial..., cit., p. 191. 
promoção ou nova eleição (em outro cargo) do titular da prerrogativa, deverá o inquérito estabelecer-se, caso ainda não encerrado, no novo Juízo ditado pela regra de fixação do foro conforme o atual status do imputado 579 .

Em todos os casos, e salvantes as já conhecidas exceções ditadas pelas Leis Orgânicas da Magistratura e do Ministério Público, o órgão investigador continuará o mesmo: a Polícia Judiciária, mediante direção da autoridade que instaurou o inquérito policial e encetou a coleta de informações sobre o fato investigado, mudando, agora, apenas o juiz natural do caso, o que traz repercussões também para os investigados, que deverão reportar-se, em seus rogos de liberdade, ao relator do inquérito distribuído no Tribunal.

Tal situação gera para a investigação preliminar um nomadismo destoante da natureza mesma dessa fase inicial da persecução estatal, afeta à simplificação e à celeridade na reunião dos elementos mínimos a apontar a ocorrência ou não do delito. As dificuldades causadas ao Magistrado e ao órgão do Ministério Público ao se depararem com um inquérito policial inaugurado originariamente sob outra esfera são certamente maiores, implicando a revisão de atos e, quando exigível, a sua repetição.

Essa errância ou imprevisibilidade da rota dos inquéritos e processos sujeitos à competência funcional de tribunais é decorrência da própria causa determinativa do foro: se a função ou o cargo são transitórios, a competência ratione muneris, iniludivelmente, também o será, afastando-se, pois, o princípio da perpetuatio jurisdictionis $^{580}$. Circunstâncias de fato (como as já citadas posse ou aposentadoria em

579 Assim, imagine-se a seguinte hipótese (deveras factível no cenário político): o prefeito, que era investigado na delegacia de polícia da cidade onde ocorrido o fato tido por delituoso, teve sua investigação aforada no Tribunal de Justiça do Estado onde localizado o Município em que exerce suas funções; posteriormente, assume o cargo de Governador, provocando a remessa do inquérito ao Superior Tribunal de Justiça, com a possibilidade, ainda, de, vindo a eleger-se Senador ainda no curso da etapa preliminar ou da ação penal, transferirem-se os autos para o Supremo Tribunal Federal, de onde retornarão ao juízo de primeiro grau desde que, em não sobrevindo decisão definitiva no processo penal de conhecimento, perca o agente o mandato ou não seja reeleito em nenhum outro cargo digno de prerrogativa processual.

580 Isso ocorre porque a competência em razão da pessoa, atrelada que é à função, prevalece sobre qualquer outra, ressalvadas as exceções constitucionalmente instituídas. Mas, uma vez cessada a função, a mantença da prerrogativa de foro implicaria conferir garantias a quem não mais detenha a sua causa jurígena. Em sentido contrário, João Cláudio Couceiro (Prerrogativas..., cit., p. 42-43) entende que a mutabilidade do juízo é incompatível com o princípio do "juiz estabelecido em lei”, por permitir ao acusado o direito de escolher o tribunal em que quer ser julgado (quando, por exemplo, um deputado federal renuncia a seu mandato, deixando de ser julgado pelo Supremo Tribunal Federal para sê-lo perante o juiz singular). Para o autor, a garantia do acusado de ser ouvido por um juiz ou tribunal "estabelecido anteriormente por lei” (art. 8.1 da $\mathrm{CADH}$ ) impõe que a definição do órgão julgador (competência e rito adequados) deva dar-se no momento da prática do fato, não mais se modificando, operando-se a perpetuatio jurisdictionis. No entanto, admite ele que, quando o crime seja cometido antes 
cargo efetivo; encerramento, cassação ou renúncia a mandato eletivo determinante de foro especial), quando modificadas, repercutirão sobre a competência, provocando idas e vindas de inquéritos que, não raramente, deixam e retornam à mesma Corte donde partiram, sem que se possa de antemão prever o seu itinerário.

Mas não apenas circunstâncias de fato são capazes de provocar essa movimentação. Fatores jurídicos também influem no percurso da investigação preliminar, pois é sabido que as disposições normativas concernentes à jurisdição e competência aplicam-se imediatamente, regendo o processo e o julgamento de fatos anteriores à sua promulgação $^{581}$. Basta referir, como exemplos, a posição jurisprudencial de fixação (e posterior cancelamento) da súmula 394 do Supremo Tribunal Federal ${ }^{582}$ e, ainda, a aprovação da Lei 10.628/2002, que pretendeu revigorar as disposições daquele verbete sumular, sendo objeto de Ação Direta de Inconstitucionalidade julgada procedente em sessão plenária de $15.9 .2005^{583}$. No período de quase três anos em que vigorou a mencionada lei, várias foram as declinações de foro nos inquéritos e processos por ela abrangidos (ações cíveis por atos de improbidade administrativa e ações criminais contra

da assunção do cargo especial, haja deslocamento do juiz natural para o Tribunal. Igualmente, entendendo que a competência se firma no momento da prática da infração, não podendo ser admitida qualquer alteração posterior, nem ficando à mercê do réu ou de qualquer outra pessoa ou órgão do poder público, Fernando da Costa Tourinho Filho (Da competência pela prerrogativa de função. Revista Síntese de Direito Penal e Processual Penal, Porto Alegre, v. 5, n. 28, out./nov. 2004, p. 18) e José Frederico Marques (Da competência..., cit., p. 293).

${ }^{581}$ No processo penal, à luz do art. $2 .^{\circ}$ do CPP, vigora o princípio tempus regit actum, que é hábil à solução das questões apresentadas em matéria de alteração de competência funcional. Foi o que ocorreu, por exemplo, ao advento da Constituição da República de 1988, que previu, no art. 29, VIII [depois renumerado para inciso X], a competência do Tribunal de Justiça para processar e julgar prefeito municipal, de modo que os processos eventualmente em curso na primeira instância tiveram de ser remetidos aos Tribunais de Justiça. Essa é a lição de Maria Lúcia Karam (Competência..., cit., p. 39): "Por se considerar não a pessoa, mas o cargo, incidem as regras que determinam a competência originária de órgãos superiores, quando a infração penal atribuída ao ocupante do cargo tenha ocorrido antes de sua investidura e a ação penal se desenvolva posteriormente a esta, deslocando-se a competência para o órgão superior, caso já proposta a ação penal, hipótese em que permanecerão íntegros os atos praticados anteriormente a tal modificação da competência, provocada pela investidura no cargo durante o curso do processo, incidente, aqui, o princípio tempus regit actum".

582 A súmula 394, aprovada em sessão plenária do STF em 3.4.1964, estabelecia: "Cometido o crime durante o exercício funcional, prevalece a competência especial por prerrogativa de função, ainda que o inquérito ou a ação penal sejam iniciados após a cessação daquele exercício". Desde o seu cancelamento, em 25.8.1999, operado com efeitos ex nunc, a cessação do exercício funcional faz com que o agente perca o foro especial. "Daí se entender que na eventualidade de ser [o agente] investido noutro cargo, também com previsão de foro por prerrogativa de função, o deste último é que valerá, já que o seu juiz natural de então." (CASTRO SOBRINHO, Célio Silva. Foro especial..., cit., p. 191). Na mesma direção, inclusive se opondo à limitação dos efeitos da declaração de invalidade dos atos então praticados sob a orientação anterior, em desconformidade com as regras constitucionais, Maria Lúcia Karam (Competência..., cit., p. 44-46).

${ }^{583}$ STF, ADI 2.797/DF, rel. Min. Sepúlveda Pertence, Plenário, por maioria, DJ de 19.12.2006. 
ex-titulares de mandato eletivo), provocando fatalmente o inchaço dos tribunais e o moroso caminhar dos novos feitos originários.

Diante desse painel, muitos procedimentos investigativos e mesmo ações penais, ao experimentarem sucessivas mudanças de foro, de competência ou de rito, quando finalmente se estabilizam em mãos daquele que seria o seu juízo natural constitucional, não sobrevivem a uma análise de sua viabilidade, fatalmente comprometida pela prescrição.

Para amenização dos efeitos negativos desse nomadismo sobre a eficiência da persecução preliminar, sugere-se adotar, como regra, a tramitação direta dos autos de inquérito entre a Polícia Judiciária e o órgão do Ministério Público oficiante no Tribunal, enquanto se praticarem atos não-sujeitos à intervenção jurisdicional, e a pronta ciência ao investigado ${ }^{584}$ sobre o aforamento do inquérito em cada instância a que deslocado, para o caso de necessitar recorrer ao juiz natural, redefinido em cada umas das instâncias.

Invariavelmente, por conta das vicissitudes supra-alinhadas, poderão ocorrer casos de inadequada intervenção, no inquérito, de órgão jurisdicional incompetente. Logo, importante conseqüência a ser examinada nesse fenômeno de mutação do juiz natural são os efeitos dos atos por ele praticados.

Para que exista o processo enquanto entidade jurídica, fazem-se necessários alguns pressupostos, entre os quais um órgão investido de jurisdição e partes com capacidade processual. Sem órgão regularmente investido de jurisdição, haveria mero "simulacro de processo", um processo apenas aparente, um “não-processo" "585. Ao lado dos pressupostos de existência, haveria os pressupostos de validez do processo, condicionantes não da sua existência, mas do seu regular desenvolvimento, concernentes mais aos efeitos jurídicos dos vários atos praticados dentro do processo.

A garantia do juiz natural reclama que se tenha um órgão investido de jurisdição e que esse órgão detenha competência para a causa ${ }^{586}$ e seja imparcial.

${ }^{584}$ É certo que o momento em que se dá essa ciência ao interessado não é imediato em todos os casos. O inquérito especial muitas vezes somente é aforado no tribunal quando da necessidade de alguma medida restritiva contra o investigado e, toda vez que o seu conhecimento prévio puder frustrar a eficácia da medida, recomendado é que somente venha tomar conhecimento dela quando finalizada - e tão-logo finalizada.

585 As terminologias aspeadas são utilizadas, respectivamente, por Afrânio Silva Jardim (Direito processual penal, cit., p. 55) e por Ada Pellegrini Grinover, Antonio Scarance Fernandes e Antonio Magalhães Gomes Filho (As nulidades..., cit., p. 50).

586 A competência, então, no dizer de José Frederico Marques (Da competência..., cit., p. 40), determina "a capacidade jurisdicional do juiz. Na esfera que lhe traçam as leis, ele se encontra perfeitamente apto a processar e julgar”. Edgard de Magalhães Noronha (Curso de direito processual penal. 6. ed. São Paulo: 
Há quem sustente, assim, que a competência ditada em regra constitucional, como atributo indispensável do juiz natural, constitui pressuposto de existência do processo, de modo que, sendo incompetente o juízo de uma causa, sequer se poderia falar em processo, que não chegaria mesmo a existir no mundo jurídico ${ }^{587}$. Outros distinguem, entre os pressupostos processuais relativos ao juiz, a investidura na jurisdição, que seria elementar à própria existência do processo, e a competência, necessária para a sua validade $^{588}$. Há ainda quem negue a existência de pressupostos de validade do processo, falando apenas em condição para o seu regular desenvolvimento, como sendo a validade dos seus atos ${ }^{589}$. Por fim, uma outra corrente enquadra a competência como pressuposto para a apreciação do mérito, não gerando a sua falta a extinção ou nulidade do processo, mas invalidando unicamente os atos decisórios ${ }^{590}$.

Cremos que o problema dos atos praticados por juiz constitucionalmente incompetente resolve-se no plano da nulidade, não no da inexistência jurídica, pois o processo existirá, ainda que nele tenha intervindo um órgão jurisdicional diverso daquele a que o ordenamento entregou a competência de decidir o caso. À luz da garantia do juiz natural, necessário é perquirir quanto à extensão dos efeitos da declaração de

Saraiva, 1973, p. 130), no mesmo sentido, fala em "capacidade funcional” do juiz, que englobaria a aptidão para provimento no cargo (regida pelas leis de organização judiciária e necessária à investidura no cargo), a competência e a ausência de impedimentos ou suspeição, à míngua dos quais os atos decisórios seriam "nulos ou inexistentes".

587 Para Ada Pellegrini Grinover, Antonio Scarance Fernandes e Antonio Magalhães Gomes Filho (As nulidades..., cit., p. 49 e ss.), acompanhados de Célio Silva Castro Sobrinho (Foro especial..., cit., p. 197), uma vez revigoradas as garantias processuais com a Constituição de 1946, passou a cogitar-se da inexistência do processo instaurado perante Justiça incompetente. $\mathrm{O}$ ato inexistente, assim, não seria passível de anulação, pois sequer ingressaria no mundo jurídico. A teoria da inexistência, todavia, não está aperfeiçoada em nosso direito e não foi acolhida na jurisprudência, que não chega a enfrentá-la, preferindo trilhar a tipologia tradicional das nulidades (absoluta ou relativa) e meras irregularidades.

588 Maria Lúcia Karam (Competência..., cit., p. 70-72), com apoio nas lições de José Carlos Barbosa Moreira, explica que, diante do princípio da unidade da jurisdição, o órgão competente não se confunde com o órgão dotado de jurisdição, não se podendo afirmar que o órgão jurisdicional que inadequadamente atue no processo, por ser constitucionalmente incompetente, não seja dotado de jurisdição, não se podendo negar a validade de determinados atos por ele praticados, inclusive de cunho decisório, como os atos de declaração de incompetência, recebimento de eventual recurso e manutenção da decisão impugnada. Logo, "[a] inexistência jurídica do processo só se dá quando se desenvolve perante pessoa que, por não estar investida no cargo judiciário ou por já ter dele se desligado, não é órgão dotado de jurisdição". De anterior lição de Ada Pellegrini Grinover (O juiz natural..., cit., p. 425-426), extrai-se que o exercício da função jurisdicional pressupõe, fundamentalmente, a capacidade geral, que decorre da regular investidura no cargo, após regular nomeação. "Mas isso não basta para que o juiz possa validamente funcionar em determinado processo, como sujeito processual: ao lado daquela capacidade geral, é exigida também uma capacidade especial, relacionada à causa a ser julgada. Esta pode ser encarada sob um aspecto objetivo, confundindo-se com a competência, e também sob o prisma subjetivo, caracterizando-se então pela ausência de incompatibilidades específicas ou motivos de suspeição que impeçam o magistrado de conhecer o caso específico".

589 JARDIM, Afrânio Silva. Direito processual penal, cit., p. 56-57.

${ }^{590}$ Cf., a respeito: DEMO, Roberto Luis Luchi. Competência..., cit., p. 326-327. 
incompetência sobre os atos já praticados no processo, ou seja, a medida da contaminação desses atos pelo vício processual referente à competência.

No ponto, uma primeira solução é esboçada no art. 567 do CPP, que prescreve: "A incompetência do juízo ${ }^{591}$ anula somente os atos decisórios, devendo o processo, quando for declarada a nulidade, ser remetido ao juiz competente”, com redação semelhante à do art. $113, \S 2 .^{\circ}$, do Código de Processo Civil ${ }^{592}$.

A norma processual permite que o juízo ao qual seja encaminhado o processo ratifique os atos não-decisórios já praticados perante o juízo incompetente, o que de resto vem positivado no art. $108, \S 1 .^{\circ}$, do CPP, referente ao procedimento da exceção de incompetência. Mas a exegese desses preceitos não pode, como nos alertam Ada Pellegrini Grinover, Antonio Scarance Fernandes e Antonio Magalhães Gomes Filho ${ }^{593}$, dissociar-se do momento histórico em que editado o Código, em 1941, em um período de exceção democrática, no qual suprimidas mesmo, pela Constituição de 1937, as garantias do juiz natural em seu duplo aspecto ${ }^{594}$. É preciso diferenciar, sob a ótica do devido processo penal, os casos em que o órgão jurisdicional é constitucionalmente incompetente dos casos de em que a incompetência resulta tão-somente da inobservância de regras infraconstitucionais.

No estágio atual, partindo-se do princípio de que o juiz natural é aquele constitucionalmente competente para processar e julgar a causa (art. 5. ${ }^{\circ}$, LIII, da CF), sempre que se tratar de competência estabelecida constitucionalmente, se uma causa for encaminhada (aqui incluídos os pedidos de medidas cautelares em investigações preliminares) a juízo diferente daquele que a Constituição estabelece como o juiz natural (como é o caso da fixação de foros especiais criminais), não terá vez a regra do art. 567 do CPP. É que, atingida a garantia do juiz natural, afronta-se o núcleo do devido processo penal, daí a maior abrangência da declaração da nulidade, que deverá estender-se também aos atos instrutórios. A relação processual poderá nascer, mas a inidoneidade dos atos praticados pelo juiz incompetente repercutirá sobre todo o processo.

591 Melhor dizendo, incompetência de foro. Parece-nos que o art. 567, como o art. 108, caput, do CPP, merecem ser lidos como se referindo à incompetência de foro, ou territorial.

592 “Art. 113 (...) $§ 2^{\circ} .^{\circ}$ Declarada a incompetência absoluta, somente os atos decisórios serão nulos, remetendo-se os autos ao juiz competente."

593 As nulidades..., cit., p. 54.

594 Não há qualquer referência, na seção dos "Direitos e Garantias Individuais" da Carta de 1937 (arts. 122 e 123), à garantia do juiz competente ou à proibição dos tribunais de exceção. 
Não existe - aliás, nem poderia existir - ressalva do constituinte aos atos não-decisórios praticados por juízo constitucionalmente incompetente. A contrario sensu, força é concluir que a regra do aproveitamento dos atos não-decisórios (os decisórios, enfim, não poderão ser aproveitados) somente tem serventia aos casos de incompetência infraconstitucional, com ferimento a normas legais que estabelecem competência de foro (territorial), a regras de prevenção, de conexão e de continência, ou a normas regimentais que fixam substituições automáticas de juízos, ficando a conseqüência ao seu descumprimento no plano da nulidade relativa ${ }^{595}$.

No âmbito da competência ratione personae, faz-se ainda mais imperioso conferir segurança jurídica ao tratamento do assunto, o que, no campo processual penal, "se vincula ao máximo respeito ao direito de liberdade do indivíduo" ${ }^{\text {596 }}$. Pelo seu caráter cambiante segundo circunstâncias de fato ou de direito, será importante diferenciar os casos de incompetência ab initio dos casos de incompetência superveniente do juiz natural, o que ocorre quando lei nova (no sentido amplo do termo) vem instituir o foro especial, ou quando há assunção ou perda do cargo determinante da prerrogativa no curso da investigação já aforada.

No caso de lei nova que cria prerrogativa de foro até então inexistente, temse questão instigante, referente ao direito intertemporal: se as normas processuais possuem, via de regra, aplicação imediata, como tratar as normas que modificam a competência hierárquica, sob o prisma da validade dos atos já praticados pelo juízo até então natural e da própria vedação de juízos ad hoc? O Supremo Tribunal Federal já externou serem as normas de competência de aplicação imediata, alcançando os processos em curso, salvo aqueles em que já haja sido proferida sentença ${ }^{597}$. Por outro lado, se houver mudança de competência entre Justiças diversas (comum X especializada, v.g.), a imediata aplicação da nova norma implica atribuir juízo ex post facto, já que se altera a natureza do crime (militar, comum, eleitoral); mas se a modificação implicar mera atribuição a órgão superior da mesma Justiça, cabe a sua pronta aplicação, sem que se configure tribunal ad hoc, devendo-se, porém, preservar os atos anteriores praticados sob o juízo até então

595 Por exemplo, os casos em que a Lei 6.368/1976 (diploma revogado pela Lei 11.343/2006) atribuía ao primeiro grau da Justiça Estadual a competência para os crimes de tráfico de entorpecentes com o exterior praticados em comarcas em que não houvesse vara federal, com recurso para o Tribunal Regional Federal.

596 KARAM, Maria Lúcia. Competência..., cit., p. 46.

${ }^{597} \mathrm{HC} 77.783 / \mathrm{SP}$, rel. Min. Moreira Alves, 1. ${ }^{\mathrm{a}}$ Turma, v.u., DJ de 13.11.1998. 
competente, em homenagem ao postulado tempus regit actum ${ }^{598}$ e ao princípio da indisponibilidade da ação penal.

$\mathrm{Na}$ hipótese, portanto, de lei nova instituidora de prerrogativa de função, todos os atos praticados pelo então Juízo natural da investigação preliminar, antecedentes à alteração de competência inicial, serão válidos, segundo o estado de coisas anterior ao fato determinante do deslocamento, não havendo fundamento para se os acometer de nulos ou inválidos ${ }^{599}$. Idêntico raciocínio se pode estender às hipóteses de aquisição ou perda (também superveniente) do cargo determinante da prerrogativa ${ }^{600}$. E, mesmo se já instaurado o processo, caso o órgão do Ministério Público agora legitimado para prosseguir na ação penal perante o Tribunal venha entender equivocada a denúncia, terá a independência funcional para requerer a improcedência da acusação, fundamentadamente.

Diferentemente, se um investigado já contava, desde o início das apurações e mesmo durante a ação penal, com a prerrogativa de foro, que, no entanto, findou desrespeitada, sendo investigado e processado sob a égide de juiz singular; ou, ainda, se perdera tal prerrogativa de foro no curso da investigação ou do processo criminal e, mesmo assim, continuou o Tribunal a praticar os atos jurisdicionais respectivos, sem atentar à perda superveniente da sua competência, dever-se-á reconhecer a insanável nulidade dos

598 Trata-se de postulado de direito processual intertemporal segundo o qual a lei nova tem eficácia imediata, incidindo sobre os atos processuais praticados a partir do momento em que se torna obrigatória, sem alcançar, todavia, os atos consumados sob o império da legislação anterior. Nesse sentido: "PROCESSO PENAL. FORO ESPECIAL POR PRERROGATIVA DE FUNÇÃO. DENÚNCIA RECEBIDA. ACÓRDÃO NÃO PUBLICADO. PERDA DA FUNÇÃO. CANCELAMENTO DA SÚMULA 394, DO STF. ALEGAÇÃO DE INVALIDADE OU INEXISTÊNCIA DA DECISÃO ACOLHEDORA DA DENÚNCIA. Incidência do princípio tempus regit actum. Remessa, contudo, dos autos ao juízo competente para processar e julgar a ação como entender de direito. Pedido concedido, em parte." (STJ, HC 11.322/SP, rel. Min. Gilson Dipp, rel. p/ acórdão Min. José Arnaldo da Fonseca, 5. ${ }^{a}$ Turma, por maioria, DJ de 11.9.2000).

599 Esse, inclusive, o posicionamento atual do Supremo Tribunal Federal: "A diplomação do paciente, eleito prefeito municipal, no curso do processo, acarreta o deslocamento imediato deste para o tribunal de justiça do Estado (artigo 29-X da CF/88). Entretanto, permanecem válidos os atos praticados antes da alteração da competência inicial: tempus regit actum (precedente: Inquérito 571). Ordem concedida para que, cassada a decisão do Tribunal de Alçada Criminal de São Paulo, sejam os autos da Apelação n. 795.519/4 encaminhados ao Tribunal de Justiça." (HC 73.196/SP, rel. Min. Francisco Rezek, 2. Turma, v.u., DJ de 31.5.1996). No mesmo sentido: Inq-QO 1.028/RS, rel. Min. Moreira Alves, Plenário, v.u., DJ de 16.5.1997.

${ }^{600}$ Há muito decidiu o Supremo Tribunal Federal que "alteração de competência dessa natureza [no caso, tratava-se de Ministro de Estado que deixara o cargo e se tornara Governador] não interfere na validade dos atos processuais já praticados pelo juízo até então competente.” (Inq-QO 427/DF, rel. Min. Moreira Alves, Plenário, por maioria, DJ de 12.8.1992). Em igual sentido, cf.: STF, RE 270.379/MS, rel. Min. Maurício Corrêa, 2. ${ }^{\mathrm{a}}$ Turma, v.u., DJ de 29.6.2001; STJ, HC 39.377/PB, rel. Min. Felix Fischer, 5. ${ }^{\mathrm{a}}$ Turma, DJ de 20.3.2006. 
atos praticados em desacordo com a norma constitucional de competência funcional ${ }^{601}$, que, portanto, haverão de ser refeitos.

Resta claro, assim, o primeiro e importante papel do juiz natural nas investigações aforadas nos tribunais: por ter a sua competência raiz constitucional, há de redobrar a cautela de evitar o trâmite de procedimentos que estejam à margem do seu poder jurisdicional, sob pena de os seus atos serem tidos por irremediavelmente nulos, com indesejáveis reflexos do ponto de vista da garantia do juiz natural e da eficiência da etapa investigativa.

\subsubsection{A competência por conexão ou continência e a separação de autos na investigação}

Importante diretriz procedimental nas investigações preliminares dos titulares de prerrogativa de função diz com a possibilidade e os limites da reunião ou disjunção de feitos ligados à competência de um mesmo juízo, pela aplicação das diversas normas processuais sobre o tema.

De regra, a jurisdição não se prorroga, não podendo o juiz estender a sua competência além do traçado previsto no ordenamento. Em princípio, a cada crime corresponde um processo. No entanto, por razões de economia e maior segurança e coerência, para se evitarem decisões divergentes e contraditórias e se propiciar uma visão mais completa do fato ao julgador - condição necessária a um rápido julgamento - , existem causas legais de modificação ou de prorrogação dessa competência, aconselhandose que haja um só processo nos casos de conexão e continência ${ }^{602}$, para serem decididos por uma mesma sentença, nas hipóteses previstas taxativamente em lei.

Dá-se a conexão quando duas ou mais infrações estiverem relacionadas por um vínculo, um nexo, um liame que aconselha a junção dos processos, propiciando ao

${ }^{601}$ Como ensina Maria Lúcia Karam (Competência..., cit., p. 46), “o princípio da nulidade dos atos inconstitucionais se afirma em sua integralidade no que o juízo de inconstitucionalidade possa repercutir favoravelmente na situação jurídica do indivíduo, a declaração de inconstitucionalidade sempre havendo de ter aí eficácia retroativa, todo pronunciamento condenatório efetuado em desacordo com a Constituição podendo e devendo ser impugnado e desconstituído".

602 Como ensina Francisco Manoel Xavier de Albuquerque (Aspectos da conexão. Manaus: Sergio Cardoso, 1956, p. 78), a conexão não é uma forma especial de competência, mas uma causa de modificação das normas gerais que a regulam. Tal modificação constitui corolário da unidade do processo, compreendendo um duplo fenômeno: derrogação de competência em relação ao juiz que, sendo competente de início, 
julgador perfeita visão do quadro probatório, e por conseguinte de todos os fatos, podendo assim entregar a prestação jurisdicional com firmeza e justiça ${ }^{603}$. A continência de causas penais, que tem os mesmos efeitos jurídico-processuais da conexão, é estabelecida no art. 77 do CPP, quando "duas ou mais pessoas forem acusadas pela mesma infração" (inciso I), ou nos casos de infrações cometidas em concurso formal, erro na execução ou resultado diverso do pretendido (inciso II).

Discute-se se as prerrogativas do agente público, quando acusado da prática de um delito, estendem-se ou não para o co-autor ou partícipe, ou co-investigado. Há quem responda negativamente ${ }^{604}$. Mas, no que tange à prerrogativa de foro criminal ostentada por um deles, segundo os critérios da conexão e da continência, ditados nos arts. 76 e 77 do Código de Processo Penal, impõe-se a reunião de infrações penais a princípio submetidas a juízos diferentes para serem processadas por um só deles, o de jurisdição prevalente - que é a de maior graduação, quando o concurso se dá entre jurisdição de categorias diversas (art. 78, III, do CPP) ${ }^{605}$ - e em um só processo (art. 79, caput, do CPP). E, se por

deixa de o ser, e prorrogação de competência em relação ao juiz que, em princípio não competente, passa a sê-lo ex ratione connexitatis.

${ }^{603}$ TOURINHO FILHO, Fernando da Costa. Processo penal, cit., v. 2, p. 184.

${ }^{604}$ Para Maria Lúcia Karam (Competência..., cit., p. 101-102), "da mesma forma que não se pode afastar quanto ao cidadão comum acusado de crime doloso contra a vida a competência do júri - seu juiz natural, tampouco se poderia afastar quanto ao cidadão comum acusado de infração penal de diversa natureza a competência de outro órgão jurisdicional de $1 .^{\circ}$ grau - igualmente seu juiz natural, nenhuma diferença havendo no fato de não estar tal competência, no que se refere aos juízes estaduais, explicitada em regra constitucional específica. A competência originária dos órgãos jurisdicionais de $1 .^{\circ}$ grau das justiças estaduais é, tanto quanto a competência do júri, constitucionalmente estabelecida, sendo apenas, porque residual, implícita e não explicitamente atribuída. Induvidoso que o cidadão comum tem como seu juiz natural o órgão jurisdicional de $1 .^{\circ}$ grau, não podendo a vinculação de causas levá-lo a ser originariamente processado perante órgão superior". Também Fernando da Costa Tourinho Filho (Processo penal, cit., v. 2, p. 196) defende a disjunção dos processos, por entender "ser impossível o simultaneus processus envolvendo uma pessoa que deva ser julgada pelo STF, STJ, ou TRF, e outra sem foro privativo. Não pode uma regra de lei ordinária, infraconstitucional portanto, alterar o texto constitucional, nem pode a norma constitucional ser interpretada extensivamente de molde a permitir que o STF e outros Tribunais Federais julguem outras pessoas que não aquelas taxativamente previstas na Lei Maior". Também defendendo a cisão da competência, Célio Silva Castro Sobrinho (Foro especial..., cit., p. 139 e ss.). É certo que o STF sumulou o entendimento pelo qual "[a] imunidade parlamentar não se estende ao co-réu sem essa prerrogativa" (verbete 245), no entanto a modificação de competência por conexão ou continência não implica concessão de imunidades ao co-réu (como a imunidade material, a imunidade à prisão, a possibilidade de sustação do processo pela Casa do parlamento, ou a licença prévia exigida para processamento de governadores de Estados), que somente se fez processado perante a Corte superior em vista da aplicação de norma processual de ordem pública.

${ }^{605}$ Nesse sentido, pronunciamento recente do STJ: "1. 'A teor do disposto nos arts. 77, I, c/c 78, III, ambos do Código de Processo Penal, havendo conexão ou continência entre infrações envolvendo competência de foro por prerrogativa de função, impõe-se o julgamento simultaneus processus, prevalecendo, in casu, a vis attractiva para o julgamento dos fatos imputados ao co-réu que não detém a prerrogativa de função.' (PExt no HC 57.341/RJ, Rel. Ministro Arnaldo Esteves Lima, Quinta Turma, DJ de 23.06.2008). 2. Encontrando-se os co-réus na mesma situação fático-processual e, também, não existindo qualquer circunstância de caráter exclusivamente pessoal que justifique diferenciação, pois deve prevalecer na 
inadvertência, forem instaurados, em casos de conexão ou continência, processos ou procedimentos diferentes, a autoridade de jurisdição prevalente deverá avocar os feitos que corram perante outros juízos (art. 82 do CPP) ${ }^{606}$.

Para além da melhor qualidade da prestação jurisdicional, acresce que, no campo penal, "somente o simultaneus processus pode garantir um exercício efetivo do direito de defesa, na medida em que propicia o confronto entre os protagonistas do contraditório em um contexto unitário, com a valoração homogênea e completa das provas por um único juiz competente" ${ }^{607}$. Embora sua operatividade seja apenas eventual, a competência por conexão ou continência, prevista em lei com anterioridade, é também obrigatória $^{608}$, integrando, tanto quanto os critérios material, funcional e territorial, a finalidade garantística da instituição do juiz natural, do qual não se pode subtrair o acusado ou investigado.

Assim, o foro por prerrogativa de função será competente para processar e julgar todos os envolvidos num delito, ainda que não detentores da prerrogativa. Havendo dois ou mais sujeitos com foro especial, o processo tramitará no de maior graduação, para todos os denunciados ou acusados ${ }^{609}$, desde que existente o liame de conexidade. Se entre eles a graduação for equivalente (p. ex., pessoas sujeitas à competência originária do TRF

hipótese, nos termos do entendimento acima apresentado, a vis attractiva, cabe, a teor do Princípio da Isonomia e do art. 580, do Código de Processo Penal, deferir pedido de extensão de julgado benéfico obtido por um deles. 3. Pedido de extensão deferido para, nos termos da ordem concedida por esta Corte, nos autos do presente habeas corpus ( $\mathrm{HC} \mathrm{n} .^{\circ}$ 57.340/RJ), ao co-réu Antônio Porto Filho, declarar a nulidade da ação penal movida contra os ora Peticionários, desde a denúncia, determinando, assim, em razão da via atrativa, a remessa dos autos ao Tribunal de Justiça do Estado do Rio de Janeiro, órgão competente ara processar e julgar o feito, a teor do disposto no art. 161, IV, $d$, da Constituição Estadual do Rio de Janeiro." (PExt no HC 57.340/RJ, rel. Min. Laurita Vaz, 5. a Turma, v.u., DJ de 15.9.2008). Também o STF, historicamente, tem proclamado a atração dos processos pela conexão, quando se trata de prerrogativa de foro de um dos envolvidos (v.g., HC-QO, 76.628/DF, rel. Min. Moreira Alves, Plenário, por maioria, DJ de 12.6.1998).

606 A avocação de inquérito que corria em primeiro grau foi determinada, por exemplo, pelo STF (Rcl 1.258/DF, rel. Min. Ilmar Galvão, rel. p/ acórdão Min. Marco Aurélio, Plenário, por maioria, DJ de 6.2.2004).

607 GRINOVER, Ada Pellegrini. O juiz natural..., cit., p. 420.

${ }^{608}$ A previsão do art. 79, caput, do CPP é taxativa: “A conexão e a continência importarão unidade de processo e julgamento". José Frederico Marques (Da competência..., cit., p. 372) conclui que se trata "de regra imperativa e obrigatória, e não simplesmente dispositiva. Sendo assim, os preceitos sobre a conexão e a continência obrigam o juiz a proceder à unificação dos procedimentos, salvo nos casos e exceções expressamente consignadas".

${ }^{609}$ É o que destaca Luiz Roberto Biló (Da competência no processo penal. Dissertação (Mestrado em Direito) - Pontifícia Universidade Católica de São Paulo, São Paulo, 2000, p. 179-180): "Parece-nos que a junção dos processos no órgão superior é inevitável dada a continência por cumulação subjetiva. Embora não exista hierarquia entre os órgãos jurisdicionais a cisão seria desastrosa no momento da prestação da tutela jurisdicional. É o caso da continência por cumulação subjetiva - concurso de agente entre uma pessoa que possua a prerrogativa de função junto ao Supremo Tribunal Federal e outra junto ao Superior Tribunal de Justiça. Prevalecerá a primeira". 
da 1. ${ }^{a}$ Região e do TRF da 4. ${ }^{a}$ Região), aplica-se a regra da prevenção. Se somente um deles ostentar a prerrogativa de foro, todos os demais, envolvidos no mesmo delito, ou em outros a ele relacionados por conexão ou continência, igualmente serão processados e julgados pelo foro jurisdição prevalente ${ }^{610}$.

Essas alterações no âmbito da competência jurisdicional repercutem, $a$ fortiori, sobre o tramitar da investigação, pois, com ela, alteram-se tanto a figura do membro do Ministério Público com atribuição para atuar na fase investigativa, quanto a do órgão judiciário responsável pelas medidas invasivas de direitos fundamentais. Até para que se atinja a finalidade preparatória da persecução prévia, elucidando-se os fatos objetos de pesquisa em seu todo, também a investigação preliminar de um delito de competência originária de tribunal há de ser unificada no mesmo procedimento $^{611}$, e não repartida em função dos sujeitos nela envolvidos. Dessa forma, se um dos co-investigados tiver prerrogativa de foro criminal, a investigação a ele pertinente, bem como a de todos os demais investigados desprovidos da prerrogativa, que por critérios de continência ou conexão se enfeixaram no mesmo procedimento pré-processual, será aportada no Tribunal competente, onde prosseguirá sob a coordenação do órgão do Ministério Público atuante perante aquela Corte, que acompanhará as diligências policiais praticadas.

Como exemplo, pode acontecer de uma investigação iniciar-se em uma Delegacia de Polícia, civil ou federal, na forma de inquérito policial, envolvendo pessoas não-titulares de prerrogativa de foro. Num segundo momento, com o avançar das investigações preliminares, caso descobertos indícios, ainda que isolados, de envolvimento de pessoa com foro especial (por exemplo, um deputado estadual ao qual a Constituição do Estado atribua a prerrogativa de foro), é prudente que a autoridade policial passe a reportarse, nos seus pedidos de prorrogação de prazo e de medidas cautelares, não mais aos membros do Ministério Público e do Poder Judiciário atuantes em primeiro grau, mas que peticione pela remessa do feito à instância cabível, no caso, o Tribunal de Justiça, onde o inquérito receberá autuação e será conhecido do Chefe do Ministério Público Estadual, ali oficiante, para que passe a acompanhar as investigações, requerendo diligências e exercendo o controle externo da atividade investigativa.

${ }^{610}$ Acerca da predominância do foro por prerrogativa de função para o processo e julgamento do co-réu, em caso de conexão ou continência, o Supremo Tribunal Federal editou a súmula 704: "Não viola as garantias do juiz natural, da ampla defesa e do devido processo legal a atração por continência ou conexão do processo do co-réu ao foro por prerrogativa de função de um dos denunciados". 
Também se faz possível à autoridade policial, ao perceber a presença de investigado com prerrogativa de foro, reportar-se diretamente ao Tribunal em que ele tenha seu juízo criminal originário, caso em que necessite lançar mão, mediante pedido fundamentado, de alguma medida cautelar restritiva de direitos fundamentais, precisando acudir ao juiz natural da investigação, agora estabelecido em função do agente público titular da prerrogativa. Tal procedimento - de reportar-se a autoridade policial, diretamente, não ao juiz singular, mas ao Tribunal - somente será cabível se não houver o inquérito ainda sido autuado no Poder Judiciário em primeira instância, pois, do contrário, é preciso que o juiz de primeiro grau aprecie a causa de deslocamento das investigações, ao menos para que seja procedida a baixa do inquérito naquela instância (evitando-se a duplicidade de registros), e em seguida faça a sua remessa ao foro por prerrogativa de função, sob o qual continuarão as investigações.

Indo mais além, se num terceiro momento, prosseguindo as investigações, surgirem novos indícios, agora dando conta da possível participação, nos mesmos fatos até então perquiridos ou em outros a eles imbricados, de um desembargador de Tribunal de Justiça, cujo foro especial criminal é firmado no Superior Tribunal de Justiça (art. 105, I, $a$, da CF), nova postura será exigida das autoridades envolvidas na investigação, a de encaminhar a investigação para ser autuada perante o STJ e acompanhada pelo membro do Ministério Público que oficia perante aquela Corte.

Problema que se põe, no tocante à conexão ou continência de feitos, diz respeito a eventual investigação preliminar em que tramitem diferentes detentores de prerrogativa de investigação interna corporis, ou seja, membro da Magistratura e membro do Ministério Público. Embora, a princípio, cada um desses agentes públicos detenha prerrogativa própria de investigação preliminar, esboçada em diferentes leis orgânicas, uma vez que se configure hipótese legal de conexão ou continência, a prevalência - com conseqüente atração dos feitos - se dá pelo foro de maior graduação (art. 78, III, do CPP) e, além disso, o procedimento interna corporis sairá da esfera do Ministério Público para a do Poder Judiciário, porquanto envolvido magistrado ${ }^{612}$.

${ }^{611}$ Sem prejuízo de que haja procedimentos diferentes, de distintas naturezas, cuidando dos mesmos fatos, como é o caso dos procedimentos paralelos de investigação parlamentar e policial.

${ }^{612}$ Foi o que ocorreu, por exemplo, no Inq 529/RO (que originou a Ação Penal 460/RO), remetido ao Superior Tribunal de Justiça por envolver, além de parlamentar estadual, juiz de direito e procurador de justiça do Estado de Rondônia (que têm foro especial no Tribunal de Justiça do Estado de Rondônia), também desembargador do TJ/RO e conselheiro do Tribunal de Contas do Estado (estes, com foro no $\mathrm{STJ}$ ). Ao receber a denúncia, a Corte Especial do STJ asseverou que: "1. Quando várias pessoas unidas 
Como regra, aplica-se aos casos de conexão ou continência (art. 79 do CPP)

o princípio da unidade de processo e de julgamento (simultaneus processus), que leva ao fenômeno da prorrogação de competência do juízo prevalente. Ressalvam-se as situações de separação obrigatória, que incidem ope legis (quando em concurso a jurisdição comum e a militar, ou a jurisdição comum e a de menores, quando um dos co-réus estiver foragido ou preso, e o processo anunciar-se demasiado prolongado para os demais, ou quando for algum réu acometido de doença mental superveniente, ou na hipótese do art. $469, \S 1$. $^{\circ}$, do $\mathrm{CPP}^{613}$, ou ainda no concurso com delito da competência do Tribunal do Júri ${ }^{614}$ ), e de

entre si por um único propósito praticam diversas infrações em prol do mesmo desiderato, tem-se concurso subjetivo e objetivo, ensejando a conexão subjetiva e instrumental, o que leva à unidade de processo. 2. A CF/88 dispensa tratamento diferenciado aos Deputados Federais, prerrogativa que é repetida, por simetria, nas Constituições Estaduais para os Deputados Estaduais, só permitindo a prisão em flagrante com a apresentação do parlamentar preso à Assembléia Legislativa. Impossibilidade de cumprir-se o mandamento constitucional porque dos 24 (vinte e quatro) deputados, 23 (vinte e três) estão envolvidos em delitos conexos com os praticados pelo Deputado Presidente da Assembléia Legislativa do Estado, aqui denunciado. 3. Foro Especial do STJ para 2 (dois) dos denunciados (Desembargador e Conselheiro do Tribunal de Contas do Estado), o que atrai a competência para o processo e julgamento dos demais, nos termos do art. 78, III, do CPP. 4. Desmembramento dos feitos conexos diante da complexidade dos fatos para apuração, como facultado pelo art. 80 do CPP." (APn 460/RO, rel. Min. Eliana Calmon, rel. p/ acórdão Min. João Otávio de Noronha, por maioria, julg. 4.9.2006, DJ de 25.6.2007). O Supremo Tribunal Federal ratificou a reunião do procedimento sob a égide do foro especial no STJ: "1. A atração do caso ao Superior Tribunal de Justiça Tribunal é perfeitamente explicada e adequadamente fundamentada pela autoridade coatora em razão da presença de um Desembargador e de um Conselheiro do Tribunal de Contas do Estado nos fatos investigados na ação penal, todos interligados entre si, subjetiva e objetivamente. Conexão entre os inquéritos que tramitaram perante o Superior Tribunal de Justiça, que exerce a vis attractiva. Não configuração de afronta ao princípio do juiz natural. Decisão em perfeita consonância com a jurisprudência deste Supremo Tribunal Federal. Súmula 704.” (HC 89.417/RO, rel. Min. Cármen Lúcia, 1. ${ }^{\mathrm{a}}$ Turma, por maioria, DJ de 15.12.2006). O caso motivou ainda Pedido de Providências junto ao Conselho Nacional do Ministério Público, por suposta afronta ao art. 41 da Lei 8.625/1993. O CNMP exarou acórdão afirmando não constituir lesão à prerrogativa conferida em lei ao membro do Ministério Público a investigação realizada pela Superintendência da Polícia Federal do Estado de Rondônia, a requerimento do Ministério Público do Estado de Rondônia, já que todos os atos tiveram autorização judicial, inicialmente de desembargador Tribunal de Justiça e, posteriormente, de ministro do Superior Tribunal de Justiça, observada assim a prerrogativa funcional (Processo 590/2006-74, rel. Cons. Francisco Uchoa Lima, por maioria, DJ de 29.3.2007).

613 “Art. 469. Se forem 2 (dois) ou mais os acusados, as recusas [aos jurados sorteados no Tribunal do Júri] poderão ser feitas por um só defensor. $\S 1 .^{\circ}$ A separação dos julgamentos somente ocorrerá se, em razão das recusas, não for obtido o número mínimo de 7 (sete) jurados para compor o Conselho de Sentença."

614 "Habeas Corpus. 2. Co-réu, militar da Polícia Militar, denunciado, por infringir o art. 121, § 2. , incisos I, II e IV, do Código Penal, juntamente com ex-Secretário de Segurança Pública do Estado, e outros. 3. Desmembramento do processo, que atende à orientação do STF definida pelo Plenário, no julgamento do HC 69.325-GO. 4. O envolvimento de co-réus em crime doloso contra a vida, havendo em relação a um deles foro especial por prerrogativa de função, previsto constitucionalmente, não afasta os demais do juiz natural, $u t$ art. 5. ${ }^{\circ}$, XXXVIII, alínea $d$, da Constituição. 5. Hipótese em que o paciente servia no Gabinete Militar do Governo do Estado e a arma não pertencia à Polícia Militar, mas, sim, a órgão da Governadoria estadual. Não cabe falar em competência da Justiça Militar do Estado. 6. Habeas Corpus conhecido como recurso ordinário contra decisão em habeas corpus, originariamente, impetrado no STJ. Recurso desprovido.” (STF, HC 73.235/DF, rel. Min. Néri da Silveira, 2. ${ }^{a}$ Turma, v.u., DJ 18.10.1996). 
separação facultativa, que, a par da previsão legal (art. 80 do $\mathrm{CPP}^{615}$ ), operam por discrição do magistrado.

Embora bastante discutida a questão da prevalência ou não da competência por prerrogativa de função sobre a competência do Tribunal do Júri, também com sede constitucional (art. 5. ${ }^{\circ}$, XXXVIII, da CF), resta pacificado o entendimento pelo qual, tratando-se ambas de competências determinadas pela Constituição da República, prevalecerá aquela de natureza específica (prerrogativa de função) sobre a de caráter genérico (instituição do Júri), esta que terá preponderâcia, todavia, se a outra competência (funcional) vier amparada apenas na Constituição Estadual ou em lei ordinária ${ }^{616}$.

A revogabilidade, portanto, constitui o primeiro corolário da conexão e da continência, a significar que a atuação da unidade de processo não importa a sua permanência em toda a marcha processual, podendo haver a separação de processos inicial ou sucessivamente unificados ${ }^{617}$.

Surge indagar como devem comportar-se os tribunais quando, em seus feitos penais originários (especialmente, no que importa a este estudo, nas investigações preliminares), deparam-se com crimes praticados em conexão ou continência (critério que abrange o concurso de pessoas), envolvendo, ao menos um deles, o agente com a prerrogativa de foro, sendo que os co-investigados e posteriormente co-acusados não o teriam. O foro especial atribuído a um dos envolvidos na mesma investigação sobre vários sujeitos e delitos unidos pela conexão ou continência implica a atração, para o mesmo procedimento investigativo - portanto, também para o mesmo juiz natural -, de todos os demais sujeitos passivos, não detentores da prerrogativa. Ou seja, deve-se estabelecer,

615 “Art. 80. Será facultativa a separação dos processos quando as infrações tiverem sido praticadas em circunstâncias de tempo ou de lugar diferentes, ou, quando pelo excessivo número de acusados, e para não lhes prolongar a prisão provisória, ou por outro motivo relevante, o juiz reputar conveniente a separação". Segundo Ada Pellegrini Grinover (O juiz natural..., cit., p. 421), a separação facultativa, nas duas primeiras hipóteses, não importa derrogação da garantia do juiz natural, desde que verificado o tipo legal, as circunstâncias objetivas previstas em lei. No entanto, a terceira hipótese, que faz menção genérica a "outro motivo relevante", diz ser incompatível com a previsão do art. $5 .^{\circ}$, LIII, da CF, porque a competência aqui seria fixada ao sabor das circunstâncias, contrariando a índole da garantia individual em liça.

${ }^{616}$ Cuida-se da orientação cristalizada no verbete sumular 721 do STF: "A competência constitucional do Tribunal do Júri prevalece sobre o foro por prerrogativa de função estabelecido exclusivamente na Constituição Estadual".

${ }^{617}$ Cf. XAVIER DE ALBUQUERQUE, Francisco Manoel. Aspectos..., cit., p. 76-77. Como decidiu o STF, a atração, por conexão ou continência, do processo contra co-réus do dignitário não é absoluta, "admitindose a separação, entre outras razões, se necessária para obviar o risco de extinção da punibilidade pela prescrição, cujo curso só se suspende em relação ao titular da imunidade parlamentar, desde a data do pedido de licença prévia." (Inq-QO 1.720/RJ, rel. Min. Sepúlveda Pertence, Plenário, v.u., DJ de 14.12.2001). 
nesses casos, a junção dos autos da investigação perante o mesmo órgão jurisdicional, que atuará como juiz natural de todos eles: o detentor da prerrogativa de foro e os demais coenvolvidos, atados por conexão ou continência.

A separação, como dito, é permitida em nosso direito, apresentando-se como obrigatória ou facultativa. Os casos de separação obrigatória não deixam margem a tergiversações. Mas é a separação facultativa, verificável com maior incidência nos fatos sujeitos à investigação tribunalícia, que vem oferecendo dificuldade de sistematização. Isso porque é natural que os crimes submetidos ao foro por prerrogativa de função apresentemse por vezes de apuração complexa, com fatos imbricados a inúmeros outros, interligando vários sujeitos investigados, o que dificulta sobremaneira a atividade investigativa, formando autos volumosos e de difícil manuseio.

Sobreleva esclarecer, nesse ponto, que a faculdade a que remete o art. 80 do Código de Processo Penal, embora deva ser sempre aquilatada no caso concreto, é uma medida organizacional que tem sua razão de ser inspirada na conveniência da investigação ou do processo, para não serem prejudicados em sua efetividade, evitando-se todas deletérias conseqüências do excesso de prazo, seja na investigação ou no processamento de crimes com imputados presos, revelando perigo de prescrição para alguns deles. Não vem calcada, portanto, em motivos de ordem pessoal do investigador, do magistrado ou do Ministério Público.

As regras previstas nos arts. 76 a 82 do CPP, ao instituírem o simultaneus processus, visam evitar decisões contraditórias sobre os mesmos fatos, proferidas com base em diferentes provas. Como explica João Cláudio Couceiro, é o interesse público que torna obrigatória a reunião dos processos (ressalvadas as hipóteses do art. 80 do CPP, de separação facultativa), sendo que tais normas têm reflexo constitucional, "pois definem o 'juiz natural' do processo, não podendo ser derrogadas por decisão judicial. Afinal, não pode o mesmo órgão ser julgador e revisor dos mesmos fatos, ao mesmo tempo"618. Não pode, por exemplo, o Tribunal decidir, com base num juízo de conveniência e oportunidade da administração da justiça, em quais processos ou para quais pessoas sua competência será prorrogada. Sua discrição recairá apenas sobre a aplicação do instituto da unidade de processos.

${ }^{618}$ Prerrogativas..., cit., p. 45. 
Assim, a separação facultativa, feita com base no art. 80 do CPP, implicará mera cisão de autos, com a finalidade de que encontre cada qual um andamento mais célere e racional, não dizendo, em hipótese alguma, com a revogação da modificação de competência ou a quebra da hierarquia determinante da atração dos fatos sob o mesmo juízo, o que importaria sério vilipêndio à garantia do juiz natural ${ }^{619}$. Devem os autos ligados pelo liame da conexão ou continência - permanecer sob o mesmo juízo ${ }^{620}$. Sob tal aspecto, destaca-se a irrevogabilidade da modificação de competência derivada da conexão, que, uma vez operada, "logo se desvencilha da dependência de origem e por via desse fenômeno perdura, ainda que não o faça o primeiro consectário. Em outras palavras, prorrogada a competência para permitir a unidade de processo, prorrogada continuará ainda que se revogue a unidade pela separação superveniente" ${ }^{\text {} 621}$. O que se pode desfazer é a unidade de processo, não a modificação de competência. A lição, de resto, é há muito entoada por José Frederico Marques ${ }^{622}$ :

A prorogatio fori não passa de um corolário da unidade de processo e julgamento, pois as modificações de competência produzidas pela conexão e continência

${ }^{619}$ A propósito, elucidativo é o seguinte julgado do Superior Tribunal de Justiça: "1. O reconhecimento da prerrogativa de função de um dos co-réus em processo da competência do Juiz singular impõe, à luz dos arts. 77, I, 78, III, e 79, caput, do CPP, a modificação da competência pela continência e a unidade dos processos na jurisdição predominante, qual seja, a de maior graduação. 2. A eventual e justificada necessidade de separação dos processos de co-réus prevista no art. 80 do CPP somente pode se dar no âmbito do mesmo órgão jurisdicional. Precedentes desta Corte e do STF. 3. Recurso a que se dá provimento para determinar a competência do Tribunal Regional Federal da $4 .^{\mathrm{a}}$ Região para processar e julgar o co-réu, ora paciente, no Processo n. ${ }^{\circ}$ 2003.70.00.084229-4, anulando-se todos os atos praticados pelo Juízo de primeiro grau a partir do recebimento da denúncia, inclusive.” (RHC 17.377/PR, rel. Min. Arnaldo Esteves Lima, 5. ${ }^{\text {a }}$ Turma, v.u., DJ de 10/10/2005). Com igual diretriz, em inquérito envolvendo 84 pessoas, sendo apenas uma delas titular de prerrogativa de foro (Conselheiro de Tribunal de Contas estadual), assentou o STJ que a separação dos processos (desmembramento) somente é permitida quando permanecerem eles no mesmo órgão jurisdicional, sem alteração da competência, porque não se trata de hipótese de exceção na Constituição (Inq-QO 282/RJ, rel. Min. Cesar Asfor Rocha, Corte Especial, por maioria, DJ de 12.11.2001).

${ }^{620}$ De interessante julgado do STF (embora não lançado em feito de competência originária), extrai-se que a prevenção de um juízo para o processamento de vários feitos ligados em conexão não obriga a sua reunião, podendo o magistrado utilizar-se ou não da mera faculdade de jungi-los, desde que, no entanto, se mantenha a submissão de todos ao mesmo juízo natural: "Prevento é o juízo da 1." Vara Federal Criminal de São Paulo, por ter, antes de qualquer outro, despachado, determinando a quebra do sigilo bancário de co-réus em processo conexo anterior, o que impede a livre distribuição de denúncias posteriores. Excluída a competência originária do STJ para proceder à perquirição, em razão da prerrogativa de função do réu, ante o cancelamento da Súmula/STF 394. 3. Desde que submetidos ao mesmo juízo, pode o magistrado utilizar-se da faculdade de não reunir processos conexos, por força do que dispõe o art. 80 do CPP.” (HC 80.717/SP, rel. Min. Sepúlveda Pertence, rel. p/ acórdão Min. Ellen Gracie, Plenário, por maioria, DJ de 5.3.2004, grifos acrescidos).

621 Cf. XAVIER DE ALBUQUERQUE, Francisco Manoel. Aspectos..., cit., p. 81-82. Essa irrevogabilidade, porém, não valerá para os casos de prorrogação de competência territorial, que se desfaz com a separação dos processos.

${ }^{622}$ Da competência..., cit., p. 379-380. 
decorrem precipuamente dessa unificação processual. Tanto isso é verdade que o código quando quer abrir exceções à improrrogabilidade da competência, só alude às restrições sobre a unidade de processo e julgamento (art. $79, \mathrm{n} .^{\circ}$ I e II). Isso não quer dizer, porém, que, nos casos mencionados no artigo $79, \S \S 1 .^{\circ}$ e $2 .^{\circ}$, e artigo 80 , de separação respectivamente obrigatória e facultativa do processo, haja derrogação às normas e preceitos sobre a competência derivada da conexidade e continência. Malgrado a disjunção dos procedimentos, mantida fica a alteração provocada pela prorogatio fori.

\section{Nesse sentido, é adequada a redação do Código de Processo Penal} português, que, após regular as hipóteses de competência determinada por conexão (arts. 24 a 28) e positivar a regra da unidade dos processos (art. 29) e os casos de separação possível (art. $30^{623}$ ), estabelece clara determinação sobre a prorrogação da competência ${ }^{624}$.

Logo, o desmembramento da investigação preliminar (a ser guiado, como se disse, pela conveniência da persecução penal, e não dos órgãos persecutores ou judicantes), toda vez que implique separar, em autos distintos, sujeitos com e sem prerrogativa de foro, nem por isso poderá retirar aos co-investigados não-titulares da prerrogativa - e agora apartados, por razões utilitaristas, do feito que motivou a fixação de competência ratione muneris - o seu juiz natural já de antemão firmado pelas regras de competência expostas no sistema (na Constituição, em caso de prerrogativa de foro) ${ }^{625}$, com as modificações operadas pelas regras legais de conexão e continência.

623 “Art. 30. 1. Oficiosamente, ou a requerimento do Ministério Público, do arguido, do assistente ou do lesado, o tribunal faz cessar a conexão e ordena a separação de algum ou alguns processos sempre que: a) Houver na separação um interesse ponderoso e atendível de qualquer arguido, nomeadamente no não prolongamento da prisão preventiva; b) A conexão puder representar um grave risco para a pretensão punitiva do Estado, para o interesse do ofendido ou do lesado; c) A conexão puder retardar excessivamente o julgamento de qualquer dos argüidos; ou d) Houver declaração de contumácia, nos termos do art. 336. ${ }^{\circ}$, n. $^{\circ} 2 . "$

624 “Art. 31. A competência determinada por conexão, nos termos dos artigos anteriores, mantém-se: a) Mesmo que, relativamente ao crime ou aos crimes determinantes da competência por conexão, o tribunal profira uma absolvição ou a responsabilidade criminal se extinga antes do julgamento; b) Para o conhecimento dos processos separados nos termos do art. $30 .^{\circ}$, n. $^{\circ} 1$ '.

${ }^{625}$ Somente a prolação de sentença (ou acórdão) faz obstar a aplicação da regra do simultaneus processus. Nada obstante, inusitado precedente do STF reconheceu cessada a competência por conexão pelo só fato de haver sido já recebida a denúncia no processo que exercia a vis attractiva, no qual figurava agente com prerrogativa de foro. A pedido do Ministério Público, o relator, Ministro Eros Grau, devolveu ao Juízo da 4. ${ }^{a}$ Vara da Seção Judiciária de Belo Horizonte os autos de processo em que 29 pessoas são investigadas por supostos crimes contra o Sistema Financeiro Nacional (Lei 7.492/1986); contra a ordem tributária, econômica e contra as leis de consumo (Lei 8.137/1990); lavagem ou ocultação de bens, direitos e valores (Lei 9.613/1998); formação de quadrilha (art. 288 do CP) e falsificação de moeda (art. 289 do CP). A investigação desses crimes foi iniciada pela Polícia Federal, a partir de representação fiscal para fins penais na qual foi autuada a empresa Universal Comércio e Distribuição Ltda. Referida representação já dera origem a inquérito (Inq 2.635), em curso no STF, no qual foi denunciado o deputado federal Juvenil, por suposta prática de "blindagem patrimonial" de várias empresas, dentre elas a Universal Comércio, cuja extinção teria sido feita pela incorporação à Menzel Representações Ltda. O relator acolheu manifestação do Ministério Público Federal segundo a qual o fato de já existir denúncia contra o deputado 
Igual raciocínio deve aplicar-se às situações em que o agente motivador da competência especial tiver, em relação aos demais, seu julgamento abreviado, seja pela rejeição da denúncia, pelo decreto de extinção da punibilidade ou por outra forma de extinção do processo $^{626}$. Outrossim, da característica da irrevogabilidade da competência derivada de conexão ou continência, refletida no art. 81 do $\mathrm{CPP}^{627}$, extrai-se que "a sentença absolutória, ou desclassificação da infração atrativa, não desfaz a prorrogação de competência operada em razão da conexão; tal prorrogação sobrevive e por via dela o juiz, que se tornou competente sem o ser a princípio, manterá a sua competência em relação aos processos atraídos" ${ }^{\prime 628}$.

O desmembramento ou disjunção de procedimentos investigativos aforados em tribunais, portanto, não pode implicar senão a divisão de um só procedimento em vários (dois ou mais), devendo-se distribuir os feitos cindidos por dependência ao primeiro, mantendo-se assim o respeito à regra de conexão ou continência que lhes impusera, $a b$ initio, a competência perante o tribunal, a qual somente cessará mediante a perda da prerrogativa de função que lhe fora determinante. Qualquer prática diversa, reveladora de

federal, "afasta a competência desta Corte [o STF] para prosseguir na investigação dos fatos em relação aos demais envolvidos." (Pet 4.232/MG, DJ de 5.11.2008).

${ }^{626}$ Ensina Roberto Luis Luchi Demo (Competência..., cit., p. 282) que "o Tribunal continua competente para julgar co-réus submetidos a processo e julgamento perante ele em virtude de conexão, ainda quando no início do julgamento haja reconhecido a existência de circunstância extintiva da punibilidade com relação ao réu que gozava de foro por prerrogativa de função". Na mesma senda, colhe-se excerto de julgado do Superior Tribunal de Justiça: "Caracterizada, in casu, a justa causa para o óbice ao cargo público, o que afasta a tipicidade da conduta da denunciada. Quanto à co-denunciada, mesmo não sendo detentora de prerrogativa de foro, esta Corte deve rejeitar a acusação também quanto a ela. Precedente do STF." (APn 324/SP, rel. Min. Gilson Dipp, Corte Especial, v.u., DJ de 13.6.2005). E do Supremo Tribunal Federal: "Competência por prerrogativa de função. Não nega vigência ao artigo 81 do Código de Processo Penal acórdão que entende que continua competente o Tribunal de Justiça para julgar co-réus submetidos a processo e julgamento perante ele em virtude de conexão, ainda quando, no início de julgamento, haja reconhecido a existência de circunstancia extintiva de punibilidade com relação ao réu que gozava de foro por prerrogativa de função. Foro por prerrogativa de função não é foro privilegiado, nem, quando se estende por conexão ou continência, cerceia a ampla defesa dos acusados.” (RE 86.709/MG, rel. Min. Moreira Alves, 2. ${ }^{a}$ Turma, v.u., DJ de 15.9.1978).

627 “Art. 81. Verificada a reunião dos processos por conexão ou continência, ainda que no processo da sua competência própria venha o juiz ou tribunal a proferir sentença absolutória ou que desclassifique a infração para outra que não se inclua na sua competência, continuará competente em relação aos demais processos."

${ }^{628}$ XAVIER DE ALBUQUERQUE, Francisco Manoel. Aspectos..., cit., p. 82. José Frederico Marques (Da competência..., cit., p. 380) explica que "essa desclassificação só alterará a competência se tratar-se de tipificação que obste a prorrogação do poder de julgar do juiz então com o processo. É o que aconteceria, verbi gratia, na hipótese de uma extorsão, desclassificada do artigo 158 do Código Penal para o art. 18 da lei de imprensa, pois em virtude da desclassificação, a competência para o julgamento passa a ser do júri de imprensa". Assim, afora hipótese de improrrogabilidade (delito de competência do júri - art. 81, parágrafo único, do CPP), deve aplicar-se, em conjugação com o art. 81, caput, o que prescreve o art. 74, $\S 2 .^{\circ}$, do CPP ("Se, iniciado o processo perante um juiz, houver desclassificação para infração da 
separação facultativa que vise à simples remessa dos feitos envolvendo não-titulares da prerrogativa a instâncias diferentes, como que para desafogo do órgão sob o qual se reuniam os fatos $\operatorname{conexos}^{629}$, será, iniludivelmente, inconstitucional e ilegal. Porque sobre regras de competência penal não há lugar para casuísmos e, sendo a conexão e a continência causas de modificação da competência, uma vez modificada (e, portanto, reunidos os casos pela vis attractiva do foro por prerrogativa de função), com as alterações o feito deverá prosseguir ${ }^{630}$.

\subsubsection{A condução da investigação e controle externo da atividade policial pelo Ministério Público}

Resta analisar como se deve desenvolver a condução do procedimento investigativo, ou seja, a direção e a prática dos atos e diligências que o encorpam. Já se propôs que a instauração do procedimento preliminar envolvendo agentes políticos (excluídas, portanto, as investigações de membros da Magistratura e do Ministério Público)

competência de outro, a este será remetido o processo, salvo se mais graduada for a jurisdição do primeiro, que, em tal caso, terá sua competência prorrogada.").

629 Nesse ponto, vale relembrar o caso conhecido como “a máfia do Mensalão" (Inq 2.245/MG). Após longa investigação, perpetrada inclusive no campo parlamentar, o Procurador-Geral da República denunciou no STF quarenta pessoas, entre empresários e integrantes do parlamento e do governo, sendo a acusação encaminhada ao Relator, Ministro Joaquim Barbosa. Chegou o Relator a propor o desmembramento da ação e o envio à primeira instância dos casos de acusados sem direito a foro especial, pleito que não encontrou acolhida no Plenário. A preocupação do Relator era a lentidão no processamento desse tipo de feito, com a exigência de que a admissibilidade da denúncia seja decidida pelo plenário da Corte, o que avulta problemático em se tratando de autos com múltiplos volumes, como no caso. Segundo noticiado na revista eletrônica Consultor Jurídico, o próprio ministro relator reconheceu que, "[a]lém da quantidade de investigados, há um fator importante a ser observado no inquérito do mensalão. O Supremo não tem tradição nem estrutura para conduzir inquéritos criminais. A vocação do tribunal é julgar ações em que é questionada a constitucionalidade de leis e atos governamentais - não processos criminais”. Disponível em: <http:/conjur.estadao.com.br/static/text/50181,1>. Acesso em: 18 dez. 2006. Já no caso conhecido como "Furacão" (Inq 2.424/RJ), que chegou ao Supremo Tribunal Federal em 2006, o Relator, Ministro Cezar Peluso, deferiu pedido do Procurador-Geral da República e desmembrou o inquérito, de modo que os investigados que não possuíam foro originário no STF tiveram os autos remetidos ao Juízo da 6 . $^{\mathrm{a}}$ Vara Federal do Rio de Janeiro, onde se iniciaram as investigações. Logo em seguida, também a pedido do Procurador-Geral, o Relator reincluiu como investigado no Inq 2.424 apenas o irmão do membro da Magistratura envolvido. Ao ser levada a questão ao Plenário, na sessão de admissibilidade da denúncia, juntamente com o agravo regimental contra decisão do Relator, o Tribunal rejeitou o remembramento do feito, mantendo-o, portanto, com os cinco acusados que detinham foro especial, além do sexto acusado, já referido, irmão de um deles.

${ }^{630}$ Assim, acertadamente, a Corte Especial do Superior Tribunal de Justiça fixou a seguinte diretriz: "Ação penal. Número excessivo de réus. Desmembramento. Permanência no STJ apenas do julgamento referente ao réu com foro por prerrogativa de função. Declínio de competência com relação aos demais réus. Impossibilidade. A Corte Especial, por maioria, rejeitou a questão de ordem proposta pelo Sr. Ministro Relator, no sentido de se desmembrar os autos para que somente o Conselheiro fosse processado e julgado perante o Superior Tribunal de Justiça” (APN-QO 206, julg. em 19.10.2005). 
deverá dar-se por atribuição da Polícia Judiciária, Civil ou Federal, a qual apenas solicitará ao Tribunal competente ratione personae a autorização para diligências dependentes do prévio crivo jurisdicional, encaminhando-lhe os autos para que seja o inquérito autuado na Corte e assim se fixe o juiz natural da investigação.

No que tange, por sua vez, à condução dos inquéritos policiais especiais, ou à materialização dos diversos atos que compõem a investigação, novamente se verifica que, na prática, não há uma uniformidade de conduta dos órgãos colegiados com competência criminal originária. Não existe um modelo de procedimento que paute o agir de todos eles. Como exemplo da divergência, veja-se que, a depender do tribunal, o cumprimento das diligências consistentes em tomadas de depoimentos de testemunhas e interrogatórios é feito pela Polícia (maioria das vezes), ou por carta de ordem ao juiz de primeiro grau (muitas vezes) ou pelo próprio Relator (caso de alguns ministros do STJ e desembargadores de TJs e TRFs), numa falta de sistemática que impressiona e, ao mesmo tempo, preocupa. Sem um regramento, ainda que mínimo, sobre os passos a serem seguidos nessa etapa que antecede a ação penal, restará a discricionariedade do Magistrado e do membro do Ministério Público atuante na investigação, gerando no investigado uma insegurança jurídica sobre as decisões e os atos que venham interferir em sua esfera de direitos.

Analisemos, então, qual o modelo que se propõe seja adotado, como regra, para o desenvolvimento das investigações preliminares envolvendo agentes políticos detentores de foro por prerrogativa de função.

Como princípio, entendemos deva ser excluída a possibilidade de o membro de tribunal (Juiz, Desembargador ou Ministro) praticar diretamente atos de investigação, como o de tomar depoimentos na etapa investigativa, pois aqui não se está diante da investigação interna corporis de membros da Magistratura, exceção em nosso sistema. Relembre-se que o fato de a Constituição cometer ao órgão colegiado o processo e julgamento, em caráter originário, de determinados delitos não significa atribuir-lhe também o múnus de realizar a investigação preliminar, não cabendo vislumbrar nessas hipóteses uma espécie de regra de inquérito judicial, caso em que se estaria trilhando a contra-mão do sistema acusatório constitucional, dada a assunção de tarefas investigativas por magistrados ${ }^{631}$.

${ }^{631} \mathrm{Na}$ feliz síntese de Romeu Pires de Campos Barros (O procedimento..., cit., p. 191), “[f]unções investigatórias por parte do relator, importam em quebra do sistema que nele se procura resguardar". No 
A nosso ver, como se trata de inquéritos de natureza policial, e não judicial, tampouco deveria ter o magistrado Relator a sua direção, quer total ou parcial, em aspectos burocráticos ou meramente administrativos, como o controle cadenciado de prazos e mesmo o deferimento ou a realização direta de oitivas, pois são puros atos de investigação que não requerem, para serem efetuados, a interferência jurisdicional. Por conseguinte, se não tem tais atribuições, tampouco lhe cabe delegá-las (como sói, indevidamente, acontecer) aos juízos de instâncias inferiores, mediante cartas de ordem ou cartas precatórias $^{632}$.

A delegação ${ }^{633}$ ocorre quando o juiz competente - detentor de competência jurisdicional, frise-se - transfere a outro a prática de determinados atos processuais. Normalmente se faz por estar o órgão jurisdicional impedido de praticar determinado ato, em razão do lugar de sua realização, no qual não tem jurisdição. Constitui, ao lado da prorrogação e do desaforamento, uma forma de modificação de competência, que não viola o juiz natural porquanto vem prevista em lei ${ }^{634}$. A possibilidade de delegação de competência, pelo tribunal, para a prática de atos instrutórios pelos juízes de primeiro grau, nas ações penais originárias, encontra-se expressa no art. 9. ${ }^{\circ}, \S 1$. $^{\circ}$, da Lei 8.038/1990635.

entanto, não são poucos os precedentes que destoam do sistema acusatório. Veja-se, por exemplo: “Com a instalação do Superior Tribunal de Justiça, a competência para o processamento originário de inquérito penal em que um dos indiciados é Conselheiro de Tribunal de Contas Estadual é daquela Corte, por força do disposto no artigo 105, I, $a$, da atual Constituição. Inquérito não conhecido, determinando-se sua remessa ao Superior Tribunal de Justiça que é o competente para processá-lo originariamente.” (Inq-QO 438/RO, rel. Min. Moreira Alves, Plenário, v.u., DJ de 5.5.1989). Bem de ver, contudo, que, na prática, muitos atos continuam sendo realizados pela polícia judiciária, porém sob a inusitada "supervisão" do respectivo Tribunal.

${ }^{632}$ Conforme o art. 201 do Código de Processo Civil, expedir-se-á carta de ordem se o juiz for subordinado ao tribunal de que ela emanar, carta rogatória à autoridade judiciária estrangeira, e carta precatória nos demais casos. Assim, por exemplo, se o Tribunal Regional Federal da 3. ${ }^{a}$ Região, com jurisdição nos Estados de São Paulo e Mato Grosso do Sul, necessita, para a instrução de ação penal originária, da prática de ato na cidade de Niterói/RJ, que não se inclui na sua área de jurisdição, expedirá não carta de ordem, e sim carta precatória.

633 Delegação vem do latim delegatio, de delegare (confiar, enviar, atribuir, constituir), exprimindo, na linguagem jurídica, em sentido amplo, “a concessão ou a transmissão de um poder, atribuído ou inerente a uma pessoa, promovida por esta a outrem para que pratique atos, que lhe eram confiados, ou exerça função, que lhe era atribuída ou confiada" (SILVA, De Plácido e. Vocabulário..., cit., p. 425).

${ }^{634}$ O Código de Processo Penal admite a delegação de competência para a prática de atos instrutórios nos arts. 174, IV (colheita de material para exame grafotécnico), 177 (exames periciais), 222 (inquirição de testemunhas) e 230 (acareação), sempre se referindo a ato que se deva realizar em outra localidade. A delegação não pode ser arbitrária, mas tem lugar em "situações em que a competência somente se transfere em razão da impossibilidade de que o juiz competente realize atos instrutórios fora dos limites territoriais de sua jurisdição" (GRINOVER, Ada Pellegrini. O juiz natural..., cit., p. 418).

${ }^{635}$ Reza o mencionado preceito: "Art. 9. ${ }^{\circ}$ A instrução obedecerá, no que couber, ao procedimento comum do Código de Processo Penal. $\S 1 .^{\circ} \mathrm{O}$ relator poderá delegar a realização do interrogatório ou de outro ato da instrução ao juiz ou membro de tribunal com competência territorial no local de cumprimento da carta de ordem". O STJ entendeu que o Relator, ao delegar competência, pode inclusive designar especificamente 
Nesses casos, observe-se que nem sempre é a ausência de jurisdição do tribunal no local da diligência que autoriza a delegação. Pois há tribunais com jurisdição nacional, como é o caso do STF e do STJ, e que, no entanto, podem (e muitas vezes precisam) valer-se da delegação de competência de atos instrutórios a juízes ou tribunais com competência territorial no local onde deva ser o ato ser praticado ${ }^{636}$.

A delegação de atos instrutórios é permitida, logicamente, quando se trata de atos que cumpre ao Magistrado praticar, por estarem no seu raio de competência, como é o caso da notificação do denunciado/querelado para oferecer resposta preliminar (art. 4. ${ }^{\circ}$, Lei $8.038 / 1990$ ) e da coleta de provas na fase da instrução processual ${ }^{637}$. Mas no procedimento de investigação preliminar de natureza administrativo-policial, os atos praticados, em sua maioria de cunho investigatório (existindo, eventualmente, como já explicitado, atos de prova antecipada), não são da atribuição ou competência do Relator, de modo que não lhe caberá delegá-los. Aqui se tratará de atos praticados originariamente pela Polícia Judiciária, e não por delegação, pois não há transmissão de poderes pelo Juiz ao Delegado de Polícia.

Toda vez que o Tribunal receber expediente que consubstancie a abertura de inquérito, a continuidade ou o encerramento de investigações envolvendo titulares de prerrogativa de foro criminal, deverá prontamente autuá-lo e distribuí-lo a um Relator - a funcionar como juiz natural da investigação -, que incontinenti abrirá vista ao Ministério Público, titular da ação penal de iniciativa pública, o qual terá 15 (quinze) dias para oferecer denúncia ou, se vislumbrar de plano a absoluta falta de suporte fático ou jurídico para a persecução, pedir o seu arquivamento (art. $1^{\circ}{ }^{\circ}$, caput, da Lei 8.038). Modo inverso, caso o Ministério Público entenda pela necessidade de maiores pesquisas para elucidação dos fatos apurados, poderá solicitar diligências complementares, a serem efetuadas pela Polícia. É o Procurador-Geral, titular da ação penal pública, que tem a liberdade de apreciar

o juiz ou membro de Tribunal para ser o delegatário da realização do ato, sem que isso importe violação ao juiz natural (APn-QO 206/RJ, rel. Min. Cesar Asfor Rocha, Corte Especial, v.u., DJ de 12.8.2002).

${ }^{636}$ Nas palavras do Ministro Celso de Mello, "essa delegação se justifica, porque, possuindo os Tribunais Superiores jurisdição sobre o território nacional, muitas vezes, em razão da sobrecarga de processos e do número dos envolvidos, a celeridade do processo fica prejudicada. Com essa delegação não passa o juízo deprecado a ser o juiz natural do processo. Há, no caso, apenas a delegação da prática de determinado ato processual. O juiz natural do processo continuará sendo o relator, a quem competirá a direção da instrução criminal, a avaliação dos depoimentos, bem como a decisão de qualquer incidente processual, ainda que relativo à diligência" (STF, HC 82.111/RJ, 2. ' Turma, v.u., DJ de 25.9.2002).

${ }^{637}$ Inclusive, os atos praticados por delegação pelos juízes de primeiro grau, em sendo impugnados, estarão sujeitos ao controle jurisdicional do órgão constitucionalmente competente para apreciar os atos do órgão delegante, e não do delegatário (STF, MS 27.045/DF, rel. Min. Menezes Direito, DJ de 19.12.2007). 
esses elementos de investigação, sabendo se deve oferecer denúncia, pedir novas diligências ou, simplesmente, encerrar o caso.

No entanto, a Lei 8.038/1990 estabelece que as diligências complementares requeridas pelo Ministério Público - as quais interrompem o prazo para a formação da opinio delicti - serão "deferidas pelo relator" (art. 1. ${ }^{\circ}, \S 11^{\circ}$ ). Tal previsão, segundo pensamos, embora veiculada em diploma posterior à Carta de 1988, não guarda adequação ao nosso sistema de persecução penal ${ }^{638}$, em que a fase pré-processual tem natureza eminentemente administrativa, sendo conduzida pela autoridade policial, sob o controle externo do Ministério Público ${ }^{639}$, e não do Magistrado - cuja atuação deveria ser reservada, no modelo constitucional acusatório, tão-somente aos pedidos implicativos de lesão a direitos fundamentais, o que não é o caso das diligências investigatórias ordinárias requeridas pelo Parquet.

Sobre a participação mais ativa e direta do Ministério Público na investigação preliminar, ela tem raízes no direito estrangeiro, assim ocorrendo, v.g., nos Estados Unidos, na França, na Itália, na Espanha, em Portugal, no México, na Venezuela, no Peru e na Alemanha ${ }^{640}$, em que se prevê a colaboração e, em alguns casos, até a

638 Porque não se pode cogitar, à luz da Constituição de 1988, de "o magistrado examinar e aferir a imprescindibilidade de diligências requisitadas pelo Ministério Público em sede de procedimento inquisitorial, o que atenta contra a Carta Magna e desvirtua o princípio acusatório adotado pela legislação pátria...” (LIMA, Marcellus Polastri. Ministério Público..., cit., p. 78). Como bem define Wallace Paiva Martins Júnior (A exclusividade do 'jus postulandi’ do Ministério Público na ação penal pública e no inquérito policial. Justitia, São Paulo, v. 53, n. 156, out./dez. 1991, p. 16), "se o inquérito policial é expediente administrativo de investigação para servir a opinio delicti do Promotor de Justiça, e que não presta como prova hígida em Juízo porque dispensa o contraditório, inexiste razão para o Juiz de Direito exercer o controle de seus prazos, ou mesmo de deferir as diligências requeridas pelo Promotor de Justiça, porque o procedimento é extraprocessual por natureza".

639 Deve-se registrar que, em 12 de junho de 2007, a Associação dos Delegados de Polícia do Brasil Adepol ajuizou no Supremo Tribunal Federal a ADI 3.904/DF, sob relatoria do Ministro Celso de Mello, visando obter interpretação conforme à Constituição das normas constantes do art. $1 .^{\circ}, \S 1 .^{\circ}$, da Lei $8.038 / 1990$ e do art. $217, \S 1^{\circ} .^{\circ}$, do RISTJ ("Diligências complementares poderão ser deferidas pelo relator, com interrupção do prazo deste artigo.”), ação esta que se encontra na fase de prestação de informações. Dispositivo de idêntico teor, embora não citado na ação, está no art. $231, \S 1 .^{\circ}$, do RISTF (“As diligências complementares ao inquérito podem ser requeridas pelo Procurador-Geral ao Relator, interrompendo o prazo deste artigo, se deferidas.").

${ }^{640}$ A propósito, cf. FREYESLEBEN, Márcio Luis Chila. O ministério público e a polícia judiciária: controle externo da atividade policial. Belo Horizonte: Del Rey, 1993, p. 69 e ss. Como retrata o autor, o promotor, nos Estados Unidos, depende da polícia para uma investigação rigorosa, ao tempo em que pode orientar a polícia na coleta de provas; na França, como na Itália, os oficiais e agentes da polícia judiciária são encarregados de investigar as infrações penais, agindo sob as instruções do Ministério Público; na Espanha, o Ministério Público dirige os trabalhos investigatórios, com auxílio da polícia judiciária, que lhe é subordinada nesse mister; em Portugal, a direção do inquérito cabe ao Ministério Público, assistido pelos órgãos de polícia criminal, que atuam sob sua orientação direta; também no México, a polícia está sob autoridade imediata do Ministério Público na função investigadora; na Venezuela, a vigilância dos corpos policiais é importante atribuição legal do Ministério Público, visando principalmente evitar detenções arbitrárias e propiciar o exercício das liberdades públicas; no Peru, ao Ministério Público cabe 
subordinação da Polícia ao Parquet. É por essa participação que se exerce o controle externo da atividade policial, que entre nós alcançou estatura constitucional no art. 129, VII, da Carta de $1988^{641}$, atribuído com viés de exclusividade ao Ministério Público, a ser disciplinado na forma da lei complementar. As Leis Orgânicas do Ministério Público da União e dos Estados tratam do controle externo, sem, todavia, definir o conteúdo dessa atividade fiscalizatória, de modo que seu conceito vem sendo tratado mais no plano doutrinário, com algumas tentativas de delimitar os seus contornos, sabendo-se que não poderá invadir a independência e as atribuições da Polícia Judiciária, estabelecidas no art. 144 da Constituição.

O controle externo (cujo próprio nome indica ser realizado por órgão estranho à administração responsável pelo ato controlado ${ }^{642}$ ) da atividade policial faz parte de todo um sistema de freios e contrapesos instituído pelo ordenamento, um sistema de fiscalização recíproca para controle dos Poderes entre si, ao qual não poderia escapar tão importante tarefa estatal ${ }^{643}$. A "atividade policial" a que visa o controle refere-se à

fiscalizar e intervir na investigação do delito desde a etapa policial; também na Alemanha, os agentes de polícia, quando no exercício da polícia judiciária, são dirigidos e fiscalizados pelo Ministério Público. Na Suíça, Japão e Colômbia, o quadro é similar, com o Ministério Público coordenando diretamente os trabalhos dos oficiais e agentes da polícia judiciária (cf. RODRIGUES, Adilson et al. Reforma judiciária e persecução penal: papel do Ministério Público. Justitia, São Paulo, v. 60, n. esp., 1999, p. 681).

641 Antes disso, dispositivos infraconstitucionais previstos na então Lei Orgânica Nacional do Ministério Público (Lei Complementar 40/1981) outorgavam ao Ministério Público poderes de ingerência na fase investigatória (promover diligências e requisitar documentos, certidões e informações de qualquer repartição ou órgão público, expedir notificações e acompanhar atos investigatórios: art. 15), no entanto a atribuição do controle externo ainda não havia sido colocada de forma explícita.

${ }^{642} \mathrm{O}$ controle não decorre, portanto, do poder disciplinar ou hierárquico, não podendo o Ministério Público ser transformado em corregedor de polícia nem devendo existir qualquer vinculação entre as duas instituições. Do voto do Ministro Néri da Silveira na ADI-MC 1.115/DF (STF, rel. Min. Néri da Silveira, Plenário, por maioria, DJ de 17.11.1995), extrai-se que a atribuição para o controle externo aludido no art. 129, VII, da CF não tem o sentido de estabelecer uma hierarquia ou subordinação entre o Ministério Público e a Polícia Civil, pois o que se cria é uma função fiscalizadora. "Pode o Ministério Público tomar conhecimento de qualquer inquérito, examinar documentos, no âmbito policial, dentre outras atividades, mas não pode, por exemplo, afastar ou punir uma autoridade policial, porque isto é próprio da relação hierárquica (...). O Ministério Público pode requisitar diligências, o que é mais eficaz do que simplesmente requerer diligências, e isso está preso à idéia da exclusividade na titulação da ação penal pública (...). No momento em que a Constituição assegura ao Ministério Público controle externo da atividade policial, cria certa situação de interdependência funcional, que não compõe, todavia, relação de subordinação hierárquica".

${ }^{643}$ Cf. MAZZILLI, Hugo Nigro. Regime jurídico..., cit., p. 425. Como explica o autor, embora veiculada em norma constitucional de eficácia limitada (a depender, para sua plena efetivação, de leis futuras), a instituição do controle externo da atividade policial pelo Ministério Público, na Constituição de 1988, produziu de imediato o efeito da ab-rogação de leis, atos ou normas que o contrariassem, como era o caso das que impunham a corregedoria da polícia judiciária exercida pelo Poder Judiciário, patentemente incompatível com o sistema de controle externo atribuído ao Ministério Público (Idem, p. 425-426). Outras normas que se entendem superadas por força da vigência do art. 129, VII, da CF/1988 são os arts. 13, II, e 16 do CPP, que traduzem resquício do processo inquisitório, atualmente só sendo possível a realização de diligência determinada pelo juiz na fase do processo, e não na investigação (LIMA, 
investigação de fatos tidos como criminosos (área em que há conexão entre as atividades exercidas pelas instituições), ao cuidado com pessoas sob sua custódia (preservação dos direitos e garantias constitucionais dos presos sob responsabilidade das autoridades policiais) e ao cumprimento das determinações judiciais ${ }^{644}$.

Pode-se conceituar o controle externo como "um conjunto de normas que disciplinam as relações entre o Ministério Público e a Polícia Civil [Polícia Judiciária, Civil, Federal ou Militar], objetivando a efetiva participação do Promotor de Justiça na atividade de polícia judiciária e na apuração de infrações penais" ${ }^{\text {"645 }}$. Trata-se de atividade administrativa $^{646}$ que supõe um maior comprometimento do Ministério Público com a investigação criminal, especificando quais medidas a Polícia deve tomar para obter maior eficiência nessa tarefa, velando pelo respeito ao princípio da legalidade e coibindo práticas arbitrárias, como tortura, abusos de poder e corrupção, assim propiciando o aperfeiçoamento da colheita da prova, que lhe servirá de respaldo na propositura da ação penal pública.

Concretiza-se o controle sob duas vertentes: (i) uma ordinária, consistente na corriqueira atividade de verificação do trâmite dos inquéritos policiais e do cumprimento das diligências requisitadas para esclarecimento do fato e de sua autoria, além do zelo pela observância do prazo para sua conclusão - concedendo, se preciso, a sua prorrogação -, mediante a manutenção de sistema especial de acompanhamento dos inquéritos devolvidos às delegacias e visitas periódicas aos organismos policiais, para

Marcellus Polastri. Ministério Público..., cit., p. 76-77). Afrânio Silva Jardim (Direito processual penal, cit., p. 328) acrescenta que, pela interpretação dos textos da atual Constituição, revogados estão a parte final do $\S 1 .^{\circ}$ e todo o $\S 3 .^{\circ}$ do art. 10, além do art. 23 do CPP, pois, em se tratando de infração de ação penal pública, o inquérito policial deve ser encaminhado ao Ministério Público para formulação da opinio delicti, fixação dos prazos para prosseguimento do retorno ao Parquet e demais atividades persecutórias de sua atribuição. No mesmo sentido, afirmando que a permanência da autoridade judiciária como destinatária final da investigação afronta a titularidade privativa para a promoção da ação penal pública e para o controle externo da autoridade policial, assim como a exigência de imparcialidade do juiz, Edimar Carmo da Silva (Princípio acusatório..., cit., p. 38).

${ }^{644}$ Cf. GUIMARÃES, Rodrigo Régnier Chemim. Controle externo da atividade policial pelo Ministério Público. Curitiba: Juruá, 2002, p. 64.

${ }^{645}$ FREYESLEBEN, Márcio Luis Chila. O ministério público..., cit., p. 82-83. Sua execução, é bem verdade, como destacam Andrei Koerner, Célia Soibelman Melhem e Flávia Schilling, encontra múltiplas dificuldades de ordem legal, institucional e cultural. No entanto, põe-se à instituição o desafio de exercer seu papel constitucional, atuando no sentido de universalizar a efetividade dos direitos fundamentais da pessoa e melhorar a qualidade técnica dos inquéritos (A garantia dos direitos fundamentais no processo penal: a implementação do controle do inquérito policial pelo Ministério Público no Estado de São Paulo. Revista Brasileira de Ciências Criminais, São Paulo, v. 7, n. 28, out./dez. 1999, p. 266).

${ }^{646}$ Contra, Afrânio Silva Jardim (Direito processual penal, cit., p. 321), que entende não se tratar de controle de natureza meramente administrativa, mas de natureza processual, motivo pelo qual os seus instrumentos deveriam ser disciplinados em lei federal, e não nas leis complementares dos Estados. 
averiguar a regularidade dos procedimentos e da custódia dos presos, e (ii) uma extraordinária, quando da verificação de algum ato ilícito por parte de autoridade policial no exercício de suas funções ${ }^{647}$.

E entre os vários instrumentos pelos quais se exerce o controle externo, trazidos quer na LONMP, quer na LOMPU, quer nas Constituições e leis orgânicas estaduais (como a requisição de instauração de inquéritos e diligências investigatórias, o livre ingresso nas delegacias de polícia, a fiscalização de estabelecimentos prisionais, a promoção de medidas judiciais, cíveis ou criminais, contra agentes policiais, a fiscalização do cumprimento dos mandados de prisão, etc. $)^{648}$, está o mecanismo de tramitação direta do inquérito policial entre o Ministério Público e a Polícia, previsto, por exemplo, na Constituição do Estado de Minas Gerais (art. 125) (449 $^{\text {. }}$

Naquele Estado, o Ministério Público está autorizado a receber diretamente da autoridade policial (sem intermediação do Magistrado) os inquéritos e quaisquer outras peças de informação, devendo fixar prazo para o prosseguimento das investigações, caso ainda haja necessidade de diligências para formar-se a opinio delicti. Desse modo se tenta superar um dos fatores de morosidade na tramitação dos inquéritos, que consiste na prática de encaminhar os autos ao Juiz - o qual, de resto, não interfere na investigação - para que os remeta ao Ministério Público, que os analisa e, evidenciando a necessidade de novas diligências, devolve-os ao magistrado, assinalando o prazo razoável em que devem ser cumpridas, sendo que o Juiz, por seu turno, os envia à autoridade policial, às vezes se

${ }^{647}$ Em São Paulo, a Procuradoria-Geral de Justiça editou o Ato Normativo 409/2005, que revogou o anterior Ato 98/1996, estabelecendo: “Art. 2. ${ }^{\circ}$ O controle externo da atividade de polícia judiciária será exercido pelos promotores de Justiça e materializado por meio de procedimentos administrativos criminais e medidas judiciais de cunho preparatório, inerentes à qualidade de destinatários dessa função, competindolhes, em especial: I - averiguar a regularidade do inquérito policial; II - visitar as delegacias de polícia, os distritos policiais e as respectivas carceragens e os estabelecimentos da Polícia Científica (Instituto Médico-Legal e Instituto de Criminalística); III - examinar quaisquer documentos relativos à atividade de polícia judiciária; IV - receber representação ou petição de qualquer pessoa ou entidade, por desrespeito aos direitos assegurados na Constituição da República e na Constituição do Estado de São Paulo, relacionados com o exercício da atividade policial; V - representar à autoridade competente para adoção de providências que visem a sanar omissões ou prevenir ilegalidade ou abuso de poder relacionados com a atividade de investigação penal; VI - instaurar procedimento administrativo criminal e requisitar à autoridade competente a abertura de inquérito policial tendo em vista omissão ou fato ilícito ocorrido no exercício da atividade policial".

648 GUIMARÃES, Rodrigo Régnier Chemim. Controle externo..., cit., p. 73.

649 “Art. 125. É facultada ao Procurador-Geral de Justiça a iniciativa de lei complementar que disponha sobre: (...) II - controle externo da atividade policial, por meio do exercício das seguintes atribuições, entre outras: a) fiscalizar o cumprimento dos mandados de prisão; b) receber, diretamente da autoridade policial, os inquéritos e quaisquer outras peças de informação; c) fixar prazo para prosseguimento de inquérito policial; d) requisitar diligência à autoridade policial; e) inspecionar as unidades policiais civis ou militares; f) receber cópia de ocorrência lavrada pela Polícia Civil ou pela Polícia Militar”. 
consumindo meses sem que nada de efetivo se produza no inquérito. Cabe ao Ministério Público assumir essa função fiscalizatória que lhe foi entregue pela Lei Maior.

Vigendo assim, por mandato constitucional, o controle externo da atividade policial pelo Ministério Público, cremos não serem mais aplicáveis os dispositivos legais que ainda outorgam ao Poder Judiciário qualquer controle ou poder correicional sobre a atividade de polícia judiciária. A análise do inquérito pelo Magistrado deveria ficar, então, reservada a casos tópicos, quando postulada a sua atividade jurisdicional cautelar, em que necessário lançar mão de medidas preventivas, ou, mais adiante, quando do oferecimento de denúncia ou pedido de arquivamento. Cuida-se de orientação que já vem sendo aplicada, na prática, em vários Estados, como Paraná, Rio de Janeiro e Bahia, apesar da ausência de previsão legal expressa ${ }^{650}$. Mas como ensina Afrânio Silva Jardim ${ }^{651}$, a Constituição de 1988, embora de forma implícita, já provocara a tramitação direta, pois, adotando o sistema acusatório, considerou que a ingerência do Magistrado na fase pré-processual macula tal sistema. No mesmo sentido, clara é a exposição de Francisco Dias Teixeira ${ }^{652}$ :

Antes da propositura da ação, ao Judiciário cabe apenas conhecer de eventuais lesões a direito do investigado ou de terceiros, que poderão valer-se do habeas corpus, do mandado de segurança ou do incidente de restituição de coisas. $\mathrm{Ou}$, ainda, decidir sobre medidas investigatórias que importem no cerceamento à liberdade e privacidade do investigado, tais como as prisões cautelares e a quebra do sigilo das comunicações telefônicas. De resto, essas questões já são, normalmente, objeto de procedimentos apartados dos autos do inquérito.

É da natureza do Judiciário manifestar-se quando para tal for provocado; mas não acompanhar a atividade dos agentes públicos. No inquérito policial, sempre que o juiz, fora das hipóteses acima referidas, imiscui-se nas investigações (...), dizendo qual diligência deve ou não ser realizada, indeferindo pedido de prazo formulado

${ }^{650}$ Além disso, vários órgãos de Corregedoria Judiciária baixaram provimentos autorizando a tramitação direta dos inquéritos entre Polícia Judiciária e Ministério Público, reservando a interferência judicial apenas aos casos de recebimento de denúncia ou queixa, pedido de arquivamento, procedimento de ação penal privada, requerimento de medidas cautelares (prisão, antecipação de provas, seqüestro, etc.), comunicação de prisão em flagrante delito ou qualquer outra forma de constrangimento aos direitos fundamentais do cidadão. Vide, por exemplo, o Provimento 47/1996, do Corregedor do TRF da 1. Região; o Provimento 95/1998, do Corregedor da Justiça Federal da 2. ${ }^{a}$ Região; o Provimento 7/1997, do Corregedor da Justiça do Distrito Federal; o Provimento 7/1997, do Corregedor-Geral da Justiça do Estado de Pernambuco. Todos eles foram objeto de Ações Diretas de Inconstitucionalidade ajuizadas pela Adepol - Associação dos Delegados de Polícia do Brasil e pelo Partido Liberal. As ADIs 1.579 e 1.869 tiveram seu seguimento negado pelo Relator, Ministro Sepúlveda Pertence, que recusou legitimidade à Adepol para propor ADI junto ao STF. O mesmo ocorreu em relação à ADI 1.875, em manifestação do Ministro Celso de Mello. Já a ADI 1.815, proposta pelo Partido Liberal, foi julgada prejudicada, por perda de objeto, já que o dispositivo atacado fora revogado por outro provimento da Corregedoria do TJDFT (Provimento 7/1999), que passou a disciplinar a matéria.

651 Direito processual penal, cit., p. 328 e ss.

${ }^{652}$ A titularidade da ação penal e o arquivamento do inquérito. Revista Brasileira de Ciências Criminais, São Paulo, v. 4, n. 14, abr./jun. 1996, p. 175. 
pela autoridade policial para continuação das investigações, estará excedendo-se de suas funções e usurpando as do Ministério Público.

Nada justifica, pois, a passagem dos autos do inquérito pelo juiz. A tramitação do inquérito diretamente entre a Polícia e o Ministério Público é daquelas conclusões que emanam da própria Constituição, da lógica ou simplesmente do bom-senso, prescindindo de lei que o declare.

Portanto, propõe-se reforma legislativa no art. $1 .^{\circ}, \S 1 .^{\circ}$, da Lei 8.038/1990, de modo que ao Relator do inquérito no Tribunal não mais exerça a função (meramente administrativa) de apreciar o pedido de diligências complementares requeridas pelo titular da ação penal, aquelas praticáveis de ordinário pelo dirigente de qualquer investigação (oitiva de testemunha que reside em outro Estado, ofício a determinado órgão para que preste informações não-sigilosas, etc.) e cuja requisição se enquadra dentro da atribuição do controle externo da atividade policial ${ }^{653}$. Pois, tratando-se de requisições, verdadeiras ordens dirigidas à Polícia Judiciária, a esta devem ser diretamente encaminhadas, para cumprimento.

Por outro lado, em permanecendo o modelo atual, no qual o Relator adota a postura de filtração de todos os pedidos de diligências complementares do Ministério Público, na hipótese de indeferir a providência de impulsionamento da investigação (a oitiva de determinada testemunha, o esclarecimento de determinada prova técnica, etc.), haverá de fundamentar o seu decisório e, com isso, indevidamente externará seu juízo de valor sobre os indícios e as provas colhidas e a ser produzidas, cujo momento apropriado é o da admissibilidade da ação penal ${ }^{654}$. Como conseqüência do indeferimento de diligências complementares, ter-se-á a não-obtenção daquele elemento de convicção pretendido pelo

653 "Nem se diga que cabe ao magistrado avaliar a pertinência ou a prescindibilidade das diligências probatórias. Com efeito, se tem o Ministério Público a exclusividade para o exercício da ação penal pública, não tem sentido o juiz querer formar sua opinião sobre o quadro probatório com vistas ao oferecimento da denúncia.” (LEMOS JÚNIOR, Arthur Pinto. A investigação judicial..., cit., p. 186). "Se o Ministério Público goza de parcela da soberania estatal para dizer a palavra final sobre se é ou não caso de promover a ação penal pública, consectário disso é que estabeleça quando e em que medida as informações o satisfazem para formar sua opinio delictis. (...) Ressalvadas hipóteses estritas, como falta de competência, ilegalidade, desvio de poder ou finalidade - caso em que poderá haver controle jurisdicional sobre as requisições ministeriais (...) -, no mais a avalliação sobre a imprescindibilidade da diligência é apenas afeta ao Ministério Público." (MAZZILLI, Hugo Nigro. Considerações sobre a aplicação analógica do art. 28 do Código de Processo Penal. Justitia, São Paulo, v. 63, n. 193, jan./mar. 2001, p. 62).

${ }^{654}$ Por isso defende-se impossível o indeferimento, pelo juiz-Relator, das diligências ordinárias requeridas pelo titular da ação penal, aquelas que não constituem verdadeira reserva de jurisdição. A propósito do controle judicial passível de exercer-se em tais etapas, cf. nota 660. 
titular da ação penal, com prejuízo à avaliação sobre a existência do delito a ser por ele exercida mais adiante, além da quebra da imparcialidade do juiz ${ }^{655}$.

E é curial relembrar que o deferimento, pelo Poder Judiciário, de tais pedidos não tem caráter jurisdicional ${ }^{656}$. Tê-lo-á apenas quando o requerimento consistir em medida de restrição de direitos (quebra de sigilo, busca e apreensão, prisão preventiva, etc.), aquelas para as quais a intervenção judicial é de rigor e nas quais se faz plausível vislumbrar quer a concessão, quer a negativa.

É bem verdade que o Supremo Tribunal Federal procurou, em alguns precedentes, estabelecer certo distanciamento da posição do juiz-investigador nos inquéritos especiais envolvendo agentes políticos, utilizando o termo "supervisão" em lugar de "condução", ou de "controle jurisdicional", para identificar a atividade exercida pelos tribunais nessa fase da persecutio criminis ${ }^{657}$. Ressentem-se, todavia, de maior nitidez o significado e a amplitude desses genéricos vocábulos, ao designar alguma forma de intervenção do magistrado Relator sobre a investigação criminal. O termo "supervisão" (em seu conteúdo, identificado com o próprio controle externo entregue ao Ministério Público ${ }^{658}$ ) não poderá, em nosso entender, justificar uma interferência maior que a

${ }^{655}$ O que importa, no dizer de Wallace Paiva Martins Júnior (A exclusividade..., cit., p. 17), em "cerceamento da formação da opinio delicti e da acusação pública, cujos atributos constitucionais são a imparcialidade e a independência", por isso que aponta o autor a impossibilidade de o Magistrado indeferir as diligências pretendidas pelo Ministério Público e o inconveniente do trâmite judicial dos inquéritos policiais. Já para Marcellus Polastri Lima (Ministério Público..., cit., p. 76), o exame da imprescindibilidade das diligências investigatórias pelo magistrado é um contra-senso, se observada a redação do art. 47 do CPP, que permite ao membro do Ministério Público requisitar diretamente diligências e documentos complementares. Assim, o indeferimento seria inútil, uma vez que as diligências poderiam ser requisitadas de qualquer forma, não podendo o magistrado denunciar ou arquivar o inquérito, nem obrigar o órgão ministerial a fazê-lo. Sob a ótica da quebra da imparcialidade, Andrés de Oliva Santos (Jueces imparciales, fiscales “investigadores", y nueva reforma para la vieja crisis de la justicia penal. Barcelona: PPU, 1998, p. 44-45) explica que, ao indicar o julgador tais ou quais diligências a serem praticadas ou pelo investigador/instrutor, somente pode fazê-lo mediante um estudo dos autos da investigação, donde formar uma idéia do caso, a qual, sem dúvida, constitui um pré-juízo de intensidade considerável.

${ }^{656}$ Nesse sentido: "Consistindo o inquérito policial em procedimento eminentemente administrativo destinado à formação da opinio delicti do parquet, não restando, desse modo, caracterizada uma situação litigiosa pendente de solução jurídica, o magistrado, no curso das investigações, não exerce jurisdição. Portanto, a decisão do juízo que indefere diligência policial não configura error in judicando, mas sim error in procedendo, passível de reparo mediante o uso da correição parcial." (TRF-4. ${ }^{a}$ Região, ACR

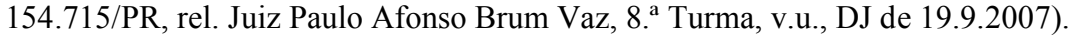

657 Ao utilizarem o termo supervisão, alguns acórdãos de tribunais brasileiros (p. ex., no STF: Rcl 2.349/TO e Rcl 1.258/DF) fazem transparecer a intenção de controle sobre o procedimento investigativo, controle este que, pela Constituição, deve ficar a cargo do Ministério Público.

${ }^{658}$ Conforme registro de Rodrigo Régnier Chemim Guimarães (Controle externo..., cit., p. 49-61), nos trabalhos que antecederam a Carta de 1988, a proposta apresentada pela Comissão Afonso Arinos em 1985 - não adotada pela Constituinte - era de inclusão, no texto que disciplinava o relacionamento do Ministério Público com a Polícia, da função institucional de "exercer a supervisão da investigação criminal". Em 1986, a "Carta de Curitiba", documento que resultou de encontro nacional de 
ordinariamente permitida aos Juízes em geral, nos inquéritos policiais. Não se poderá nele enxergar a abertura para que o órgão judicial pratique os atos específicos do inquérito ${ }^{659}$. No mais, indicar ou requisitar diligências ordinárias (não incluídas na cláusula de reserva de jurisdição), autorizar a concessão de vista do inquérito e a retirada de cópias, tudo isso deve ser feito, em princípio, pela autoridade que está presidindo do inquérito: no nosso ver, como já explicitado, o Delegado de Polícia. Somente em caso de negativa e, pois, de restrição a direitos do investigado, do ofendido ou de terceiros, é que se legitimará a atuação do Juiz natural para restaurá-los ${ }^{660}$.

Em outras palavras, tendo a investigação preliminar natureza administrativopolicial, pensamos não haver congruência alguma em atuar o magistrado Relator como intermediário obrigatório (ou simples referendário) de todos os pedidos de diligência que partam do Ministério Público ou da Polícia Judiciária, já que não toma, ele próprio, a decisão sobre o rumo a seguir a investigação - e por isso não se confunde com a figura do juiz de instrução de inspiração francesa ${ }^{661}$. Queda absolutamente deslocada de nosso

Procuradores-Gerais de Justiça e presidentes das Associações do Ministério Público, propôs estabelecerse, entre as funções institucionais, "promover a ação penal pública e supervisionar os procedimentos investigatórios, podendo requisitá-los ou avocá-los”. A Subcomissão do Poder Judiciário e do Ministério Público, inicialmente, não adotou os institutos da avocação e a supervisão, incluindo outros, como a correição e a comunicação de todas as ocorrências policiais, mas após nova discussão voltou a adotar a supervisão em conjunto com a correição. Após várias discussões, o Projeto apresentado em 9.11.1987 pela Comissão de Sistematização da Assembléia Nacional Constituinte incluiu a expressão "controle externo sobre a atividade policial", do que resultou a redação definitiva do art. 129, VII, da CF. Com isso, vê-se que a origem do controle externo está atrelada à supervisão da atividade policial, justamente essa "supervisão" que alguns julgados, impropriamente, relatam caber ao Tribunal nas investigações preliminares dos delitos de sua competência originária.

${ }^{659}$ Como ficou decidido em precedente do STJ, "a prerrogativa de função ostentada pelo paciente não obsta a prática de atos de investigação a serem promovidos pela autoridade policial, quando requisitados por membro do Ministério Público com atuação perante o Tribunal competente para processar e julgar eventual ação penal originária, sob pena de inviabilizar a adoção das medidas pré-processuais de persecução penal, no âmbito do procedimento investigatório em curso perante o órgão judiciário competente" (HC 35.996/RJ, rel. Min. Arnaldo Esteves Lima, 5. a Turma, v.u., DJ de 6.12.2004).

${ }^{660}$ Lembra Hugo Nigro Mazzilli que, muito embora tenha o Ministério Público o juízo originário sobre a imputação e, via de conseqüência, o controle da necessidade ou não da diligência por si requerida, tal juízo, guiado que é pelo princípio da razoabilidade, não pode ser arbitrário e não escapa ao controle, quer jurisdicional, quer da própria instituição. No primeiro caso, por exemplo, pode o investigado impetrar habeas corpus para insurgir-se contra a realização de diligências eventualmente desnecessárias, abusivas ou ilegais; no segundo, o sistema prevê meios para que a instituição ministerial exerça o controle de mérito sobre a diligência requerida: sempre que o magistrado discordar da diligência, poderá provocar a decisão do Procurador-Geral, por analogia ao art. 28 do CPP, devendo prevalecer o entendimento da chefia da instituição (Considerações..., cit., p. 66-67). No entanto, como se está a tratar de ação penal originária de tribunais, em que o titular da persecução é o próprio Chefe da instituição, não se cogita de poder o Relator acionar a aplicação analógica do art. 28 do CPP, vislumbrando-se tão-somente a possibilidade de controle jurisdicional provocado pelo próprio investigado.

661 Dessa forma, há de consolidar-se em nosso direito a tendência "no sentido de que as requisições do Ministério Público, à exceção da investigação de magistrados, devem ser feitas à autoridade policial, de 
ordenamento a admissão de um Juiz interposto entre as requisições ministeriais e o cumprimento de diligências policiais, não sendo o Relator destinatário, na fase préprocessual, de todo pedido e de todo resultado de diligências investigativas. E mais: a concentração de poderes junto ao Magistrado no que tange ao impulsionamento da investigação acena contra a estrutura acusatória do processo, que pressupõe afastamento do Poder Judiciário da etapa administrativa da persecução ${ }^{662}$.

Apesar de silenciarem a respeito a lei e os regimentos internos, não poderá o Magistrado (Juiz, Desembargador ou Ministro) avocar à sua esfera a direção do inquérito. Não se poderá admitir, no modelo acusatório de processo, que para a prática de toda e qualquer diligência - mesmo a que importe mero pedido de extração de cópias ou de dilação de prazo -, seja preciso a ele se reportar. Pela trilogia elementar do sistema acusatório, o Poder Judiciário não deve ter para si a condução - direta ou indireta - dos atos investigativos.

De mais a mais, com a concentração, em mãos do Relator, de funções que ele mesmo, na essência, não exerce (apenas ratificando, na prática, pedidos feitos pelo titular da ação penal, apondo o seu "cumpra-se"), queda de certa forma desprestigiada a efetiva tarefa que lhe cabe na investigação - qual seja, funcionar como garantidor dos direitos fundamentais envolvidos - e também quiçá prejudicada a efetividade da investigação preliminar ${ }^{663}$. Quanto mais se lhe estiverem reservadas, exclusivamente, atribuições de cunho efetivamente jurisdicional, com maior afinco e imparcialidade exercerá o seu principal e elevado mister.

É o Ministério Público, pelo órgão atuante perante o Tribunal, que deve tratar diretamente com a Polícia Judiciária no que diz respeito aos atos de investigação,

forma direta, e não ser oferecidas à autoridade judicial" (GOMES, Rodrigo Carneiro. As prerrogativas processuais..., cit., p. 56).

${ }^{662}$ Com precisão, enuncia Geraldo Prado (Sistema acusatório..., cit., p. 175) que "não há razão, dentro do sistema acusatório ou sob a égide do princípio acusatório, que justifique a imersão do juiz nos autos das investigações penais, para avaliar a qualidade do material pesquisado, indicar diligências, dar-se por satisfeito com aquelas já realizadas ou, ainda, interferir na atuação do Ministério Público, em busca da formação da opinio delicti. A imparcialidade do juiz, ao contrário, exige dele justamente que se afaste das atividades preparatórias, para que mantenha seu espírito imune aos preconceitos que a formulação antecipada de uma tese produz, alheia ao mecanismo do contraditório. Assim, por ocasião do exame da acusação formulada, o juiz estará em condições de avaliar imparcialmente se há justa causa para a ação penal, isto é, se a acusação não se apresenta como violação ilegítima da dignidade do acusado".

${ }^{663}$ Não se olvide de que os Tribunais brasileiros abarcam, em sua área de jurisdição, vários territórios, muitas vezes dando-se a investigação em delegacias de polícia bastante longínquas da sede do órgão judicial, por isso sendo mais gravosas as conseqüências da angulação das investigações sobre a eficiência da etapa preliminar, porquanto a remessa dos autos ao Tribunal a cada novo pedido de prazo ou de diligências termina por burocratizar e atrasar ainda mais o desenvolvimento da investigação. 
controlando-a, ritmando-a e zelando para que atinja a sua finalidade. É preciso abandonar a burocratização da investigação preliminar e a angulação na requisição e prática de diligências investigativas ${ }^{664}$. A participação mais direta do Ministério Público na orientação da colheita dos elementos de convicção na fase preliminar impõe-se como defluência da sistemática acusatória ${ }^{665}$, que abre também espaço à Defesa e suas postulações de diligências - não, porém, à atividade investigadora do Magistrado. Ademais, a legislação vigente possibilita ao Ministério Público a requisição direta, às autoridades policiais civis e militares, aos outros órgãos públicos e particulares, de quaisquer informações e diligências, não podendo a autoridade policial negar cumprimento a essas ordens nem cabendo à autoridade judicial examinar-lhes a conveniência. Somente o exame da legalidade dessas medidas é que pode ser trazido à apreciação judicial, pelos meios processuais cabíveis.

Quanto ao investigado, tem o direito de requerer - assim como o ofendido qualquer diligência que entenda necessária e útil à investigação e à sua Defesa, conforme preceitua o art. 14 do Código de Processo Penal. Tais diligências, considerando que se está diante de uma investigação policial, deverão ser postuladas à autoridade dirigente do inquérito, que analisará o seu cabimento, podendo deferi-las ou não. O juízo de imprescindibilidade dessas diligências toca, em primeiro lugar, ao próprio investigado ou ao ofendido. Entretanto, como não se está diante de requisições públicas ministeriais, o pleito dos interessados poderá ser ou não acolhido pela autoridade, somente devendo ser rejeitado, mediante decisão fundamentada, quando se tratar de diligência meramente protelatória ou de nenhum interesse para o esclarecimento dos fatos. Em caso de rejeição, abrir-se-á ao peticionário a possibilidade de requerer ao Juiz natural da investigação que

${ }^{664}$ Eis um claro diagnóstico sobre a sistemática atualmente aplicada no tramitar das investigações prévias, válido tanto nos inquéritos comuns como nos inquéritos envolvendo titular de foro especial: "Formalismo inconcebível amarra o desempenho do Ministério Público, que para formar sua convicção vem necessitando dar voltas inúteis, demoradas e absolutamente ilógicas dentro do sistema processual penal. Resultados negativos: atraso na formação da opinio delicti e, conseqüentemente, no impulso inicial da persecução; perigosa falta de informes que vai refletir-se, afinal, na própria atividade jurisdicional. Morosidade e ineficácia entrelaçam-se quando a investigação prévia envolve questões mais técnicas. Distanciado dos órgãos que compõem a chamada polícia científica, o Ministério Público dialoga com eles sempre por interposta pessoa. As perícias chegam às mãos do Promotor Público desviadas dos pontos fundamentais, incompletas, desconformes com as exigências do Poder Judiciário..." (RODRIGUES, Adilson et al. Reforma judiciária..., cit., p. 677).

${ }^{665}$ No dizer de Rodrigo Carneiro Gomes (As prerrogativas processuais..., cit., p. 49), “jamais se deve conceber que o representante do Ministério Público atue passivamente diante de uma investigação presidida pela autoridade policial. Ao contrário, sua missão fundamental para o equilíbrio dessa delicada tarefa, é fiscalizar a atuação do Estado-investigação, requisitando diligências e acompanhando, caso 
lhe conceda o direito de ver realizá-la, recaindo a análise do Magistrado sobre eventual violação ao direito de defesa na etapa preliminar.

Se a oitiva dos investigados e testemunhas, na fase pré-processual, cabe ao dirigente do inquérito - no caso, a autoridade policial -, é certo, por outro lado, que se devem observar algumas cautelas quando se tratar de ouvir agentes detentores de prerrogativa de função. $\mathrm{O}$ art. 221 do Código de Processo Penal, que está inserido no capítulo "Das Testemunhas", preceitua que os parlamentares, chefes dos Poderes Executivo federal, estadual e municipal, secretários de estado, juízes, promotores e ministros serão inquiridos em local, dia e hora previamente ajustados entre eles e o juiz, o que deve ser cumprido também pela autoridade policial, quando estiver na condução do inquérito policial, observando-se, em todo caso, o limite temporal previsto para o encerramento das diligências investigativas. Outras autoridades, enumeradas taxativamente no art. 221, § 1. ${ }^{\circ}$, do CPP (Presidente e Vice-Presidente da República, presidentes do Senado Federal, da Câmara dos Deputados e do STF), poderão optar por prestar o depoimento por escrito.

No caso, porém, em que tais autoridades figurem como investigadas, não gozarão de igual prerrogativa de ajustar previamente local e data para a sua oitiva ${ }^{666}$, não surgindo tal norma imperativa para a autoridade policial, nada impedindo, entretanto, que se proceda ao ajuste, mas de forma facultativa, até porque, enquanto investigadas, não estão obrigadas a comparecer para interrogatório, devendo sua ausência ser interpretada como exercício da garantia constitucional do direito ao silêncio ${ }^{667}$.

queira, todas as que forem realizadas. Com isso, forma livremente, e com segurança, a sua convicção, colhendo elementos para o oferecimento da denúncia".

666 "De fato, o art. 221 do Código de Processo Penal prevê a necessidade de as autoridades ali arroladas serem contatadas previamente pelo juízo para ajustarem a data, o horário e o local da sua inquirição. Todavia, esse dispositivo refere-se à produção de prova testemunhal, tanto que está disposto no Título VII (Da Prova), Capítulo VI (Das Testemunhas), do Código de Processo Penal. Não é caso dos autos. No caso em análise, o impetrante foi citado para ser interrogado, e não para prestar depoimento na qualidade de testemunha." (STF, MS 27.045/DF, rel. Min. Menezes Direito, decisão monocrática, DJ de 19.12.2007).

667 A esse respeito, o pronunciamento, alhures citado, do STF: "Por outro lado, o Parlamentar pode ser convidado a comparecer para o interrogatório no Inquérito Policial, (podendo ajustar, com a autoridade, dia, local e hora, para tal fim - art. 221 do Código de Processo Penal), mas, se não comparecer, sua atitude é de ser interpretada como preferindo calar-se. Obviamente, nesse caso, não pode ser conduzido coercitivamente por ordem da autoridade policial, o que, na hipótese, até foi reconhecido por esta, 


\subsubsection{A definição do juiz de garantias na investigação preliminar}

Já se assentou que os procedimentos de investigação preliminar nos delitos de competência originária de tribunais reclamam observância à cláusula do devido processo penal e às garantias dela decorrentes, entre elas o juiz natural. Afirmou-se também, no capítulo 1, que a função do juiz natural na fase pré-processual, integrada ao sistema acusatório, deveria ser a de garantidor - restrita, portanto, à solução dos incidentes que demandassem jurisdicionalização, por implicarem ferimento a direitos fundamentais do indivíduo ${ }^{668}$. Assim, no Estado Democrático de Direito, a presença do julgador ou do juiz natural na fase prévia da persecutio criminis deveria revelar-se, simplesmente, no papel de Juiz de garantias, aquele cuja atuação - afinada ao princípio acusatório e à estrutura dialética do processo penal - ficaria restrita, agindo não como investigador ou instrutor, mas tão-somente como controlador da legalidade e garantidor dos direitos fundamentais do sujeito passivo.

A justificativa para definir-se a figura do Juiz de garantias (também chamado de juiz de controle, juiz das liberdades, juiz garante, etc. ${ }^{669}$ ), existente em alguns países, está em que, ao ingerir na investigação criminal exercendo tarefas não propriamente jurisdicionais, pode o magistrado acabar comprometendo-se com a prova (por ele mesmo)

quando, nas informações, expressamente descartou essa possibilidade" (HC 80.592/PR, rel. Min. Sydney Sanches, 1. ${ }^{\text {a }}$ Turma, v.u., DJ de 22.6.2001).

${ }^{668}$ Como bem sintetiza Paula Bajer Fernandes Martins da Costa (Igualdade..., cit., p. 131), "o juiz, especialmente na primeira fase da persecução penal, ordena medidas constritivas. Esse ordenar existe para preservar direitos individuais: o juiz não preside a investigação criminal preliminar".

${ }^{669} \mathrm{Na}$ Alemanha, como mostra Bernd Schünemann (La policía alemana como auxiliar del Ministerio Fiscal: estructura, organización y actividades. Cuadernos de doctrina y jurisprudencia penal, Buenos Aires, v. 7, n. 12, sep. 2001, p. 109-110), existe o chamado "juiz investigador" (Ermittlungsrichter), que exerce a proteção do imputado frente a graves violações no procedimento de investigação, e não pode ser confundido com a tradicional figura do juiz instrutor (Untersuchungsrichter), já abolida. O juiz investigador é, em geral, um juiz jovem, de uma instância inferior - cabe notar que a instrução oral alemã é realizada pelos tribunais penais -, que não dirige a investigação em seu conjunto, mas apenas tem que decidir, caso a caso, sobre requerimentos do Ministério Público de ordenar medidas coercitivas. Também em Portugal, para maximizar o alcance da estrutura acusatória do processo, o CPP luso limita a atuação do juiz na fase de inquérito, que fica circunscrita às medidas dirtamente relacionadas aos direitos e liberdades fundamentais das pessoas, vedada a determinação ou realização de qualquer ato de natureza investigatória. Como traduzem Nicolás Rodríguez García e Fernando Andrade Fernandes (Orientações fundamentais da fase preliminar do processo penal: uma análise comparativa. Revista Portuguesa de Ciência Criminal, Lisboa, v. 5, n. 3-4, jul./dez. 1996, p. 434-435), substituiu-se a figura de um "juiz de instrução" por um "juiz na instrução". 
produzida e assim prejudicar a característica da imparcialidade, rompendo-se a haste de garantias que dá base ao sistema ${ }^{670}$.

Na Itália, modelo por excelência do juiz garantidor, com a abolição do sistema do juiz de instrução e a atribuição ao Ministério Público das investigações, surgiu a necessidade de criar-se um instrumento de controle da etapa investigativa, no que tange à sua adequação, ao fundamento da prova para a abertura do processo e à liberdade pessoal do sujeito passivo. Nasceu, então, o giudice per le indagini preliminari, previsto no art. 328 do CPP italiano, cujo papel é basicamente o de custódia da legalidade dos atos levados a efeito na fase prévia. Age a requerimento dos interessados, que a ele se dirigem quando se trata de resolver questões referentes à liberdade pessoal, às intervenções telefônicas, à antecipação de provas urgentes, ao arquivamento do procedimento. É ele que convalidará ou invalidará as detenções feitas pela Polícia e presidirá o contraditório que se desenvolve nos incidentes probatórios ${ }^{671}$.

O Juiz garantidor, tal como propriamente concebido, não investiga; mantémse afastado da investigação preliminar, limitando-se a exercer o controle formal da prisão em flagrante e a autorizar medidas restritivas de direitos. Esse afastamento ou alheamento, pessoal e institucional, revela-se importante garantia de imparcialidade, pressupondo que o magistrado não oriente a investigação policial tampouco presencie seus atos, mantendo uma postura suprapartes e distante da atividade policial $^{672}$.

Parte-se da premissa de que a genuína razão de interferência do Magistrado na fase prévia da persecução penal reporta-se à cláusula de reserva de jurisdição ${ }^{673}$,

${ }^{670}$ Sobre o tema, calha transcrever também a observação de Antonio Magalhães Gomes Filho (Provas..., cit., p. 260): "De fato, é difícil imaginar que um juiz ativo na fase de investigação possa ser, ao mesmo tempo, um magistrado imparcial no momento da decisão, porque a tarefa de recolher elementos para a ação penal é, por natureza, parcial e, no nosso sistema, realizada unilateralmente pelos órgãos oficiais incumbidos da persecução".

${ }^{671}$ Comparando o guidice per le indagine preliminare com o antigo juiz instrutor italiano, Nicolás M. Guzmán (Algunos aspectos del modelo procesal penal italiano: en particular, la novedosa estruturación de la fase de la investigación preliminar. Nueva Doctrina Penal, Buenos Aires, v. B, 2002, p. 629) diz que o que mais caracteriza o primeiro é a sua imparcialidade (terzietà) ou alheamento a respeito da tarefa investigativa, já que ele não se envolve nas investigações promovidas pelo Ministério Público ou pela Polícia Judiciária. Como contrapartida à posição do juiz garantidor, com as investigações preliminares se desenvolvendo de forma livre, fora do controle judicial para a maioria dos autos, o Ministério Público teria recuperado seu natural papel de parte (acusador).

${ }^{672}$ LOPES JR., Aury. Sistemas..., cit., p. 164. No mesmo raciocínio, Emilio de Llera Suárez-Bárcena (La inidoneidad..., cit., p. 126) esclarece que a intervenção do juiz de garantia se concebe com a finalidade de amparar o titular de um direito ameaçado ou lesionado por outro sujeito distinto, mediante um ato de tutela jurídica a cargo do juiz que lhe é pedida por algum interessado, de modo que a intervenção do juiz em garantia de um direito supõe as garantias próprias do processo ou, pelo menos, de um juízo imparcial.

${ }^{673}$ Therezinha Astolphi Cazerta (Ação penal originária..., cit., p. 19-20) explica que "a participação do juiz nessa fase é limitada, sendo os poderes instrutórios reservados à autoridade policial e ao Ministério 
aplicada em alguns episódios da investigação e pela qual determinadas matérias, envolvendo a violação ou a preservação de direitos fundamentais dos indivíduos, que constituem núcleo essencial do Estado de Direito, devem ser apreciadas tão-somente pelo Poder Judiciário. Essa é a capital função do Magistrado na esfera investigativa, senão que, antes da propositura da ação penal, caber-lhe-ia conhecer apenas, de um lado, medidas implicativas de lesão a direitos, por via de habeas corpus, mandados de segurança, pedidos de restituição de coisas, de busca e apreensão, etc. e, de outro, medidas cerceadoras de liberdade ou privacidade do investigado, como pedidos de prisão provisória, de quebra de sigilo bancário ou das comunicações telefônicas ${ }^{674}$. E muitas são as medidas dessa natureza encontradiças na investigação preliminar, por vezes mais que na fase processual.

No Brasil, não temos a definição do Juiz de garantias na investigação preliminar, com essa nomenclatura, sendo certo que o magistrado chamado a atuar como juiz natural na etapa investigativa exerce, por disposições legais, várias outras atividades, além da garantia dos direitos fundamentais porventura ameaçados ou violados.

É de ver-se, por outro lado, que todas as espécies de investigação preliminar em nosso sistema, policiais ou extrapoliciais, constituem mero procedimento voltado à reunião de elementos mínimos para confirmar ou para elidir a prática de um delito. Dessas atividades, administrativas em sua essência, entendemos deva afastar-se o julgador, em prol do equilíbrio visado pela principiologia acusatória, concentrando-se apenas em suas funções precípuas, aquelas que impliquem efetivamente uma prestação jurisdicional, evitando-se que se acumulem sobre o mesmo órgão as atribuições de decidir sobre a

Público, que deterão a iniciativa da produção de provas. Do juiz são exigidas decisões sobre medidas que dependam essencialmente de autorização judicial, v.g., autorização de interceptações telefônicas, expedição de mandados de busca e apreensão, decreto de prisão temporária ou preventiva, quebra de sigilo bancário, fiscal, etc. Nada que resulte em execução de atividade própria de autoridade policial ou do Ministério Público, e nem mesmo acompanhamento direto de trabalhos de campo, realização de diligências policiais, etc. A atuação do magistrado nessa fase é medida de proteção do investigado, para que sejam respeitados seus direitos fundamentais, funcionando como verdadeiro juiz 'garante' ou 'de garantias', órgão suprapartes". Sobre a reserva de jurisdição, vide o item 1.4.2.

674 Portanto, como assinala Afrânio Silva Jardim (Direito processual penal, cit., p. 330), a par do controle externo sobre a atividade policial, mediante o encaminhamento direto dos inquéritos entre Ministério Público e Polícia Judiciária, há de se ressalvar os episódios em que necessário o exercício de uma atividade jurisdicional cautelar por parte do juiz, quando então o expediente deve ser distribuído ao juízo competente. É o caso da comunicação de prisão em flagrante, distribuída normalmente a fim de que o magistrado fiscalize a sua legalidade, relaxando ou não a prisão, bem como examine o cabimento da norma do art. 310 do CPP; das representações por prisão temporária ou preventiva; de eventuais requerimentos de liberdade provisória formulados pelos investigados, etc. 
necessidade de uma ato de investigação e, posteriormente, valorar a legalidade de sua adoção, numa "condescendente auto-avaliação",675.

Com base em tal percepção, a Comissão de Reforma do Código de Processo Penal criada em 5 de junho de 2008, pelo presidente do Senado Federal, Garibaldi Alves, e coordenada pelo Ministro Hamilton Carvalhido, do Superior Tribunal de Justiça, cogita incluir, no Anteprojeto a ser votado no Senado Federal, o Juiz de garantias em nosso sistema, o qual atuaria apenas na primeira fase da persecução penal (etapa pré-processual), para controlar as ações policiais e decretar atos como prisões preventivas, buscas e apreensões ou quebras de sigilo ${ }^{676}$. Caso seja aprovada tal proposição, além de inserir-se a salutar figura do Juiz garantidor em nosso sistema, ter-se-á também instituída a separação entre juiz natural da investigação (agora sinônimo apenas de juiz garantidor) e juiz do $\operatorname{processo}^{677}$.

A presença do julgador nos autos das investigações penais dar-se-ia, portanto, na figura do Juiz de garantias, não se concebendo atribuir-lhe poderes administrativos de investigação, seja porque tal atividade tende a ferir-lhe a garantia da imparcialidade ${ }^{678}$, seja porque vai de encontro a uma realidade facilmente detectável: o juiz não tem pendor nem treinamento para investigar ou orientar investigações. A função que lhe cabe, dentro da estrutura do Estado, é a judicante, não fazendo sentido investi-lo também da função administrativa de investigação dos delitos ${ }^{679}$. Equivaleria, na prática, à mesma disfunção ocorrida nos países que deixam ao membro do Ministério Público, que é parte acusadora no processo penal, o poder de decretar prisões, nítida função jurisdicional $^{680}$.

${ }^{675}$ Dito de outra forma, a atividade investigadora se mostra incompatível com a imparcialidade que caracteriza a estrutura dos órgãos jurisdicionais (SUÁREZ-BÁRCENA, Emilio de Llera. La inidoneidad..., cit., p. 121 e 153 ).

${ }^{676}$ Disponível em: <http://www.conjur.com.br/static/text/73165,1>. Acesso em: 6 jan. 2009.

677 A separação entre juiz da investigação e juiz do processo é diretriz que constará também de sugestão adiante, no item 3.3.6.

${ }^{678}$ A respeito, igualmente se pronuncia Paula Bajer Fernandes Martins da Costa (Igualdade..., cit., p. 130): "O juiz que colhe a prova e assume a iniciativa da pesquisa da verdade aproxima-se das partes e corre o risco de preferir um interesse ao outro. A suspeição do juiz estará evidente quando a preferência a um dos interesses em conflito interferir nas medidas que adotar. Nesse caso, a suspeição substitui a imparcialidade necessária ao ofício jurisdicional".

${ }^{679}$ Afinal, a se entender que o magistrado Relator pudesse ou devesse efetuar atos de investigação, como ouvir investigados e testemunhas - fato comum em algumas investigações tribunalícias noticiadas na mídia -, exerceria assim a própria atividade que cabe à Polícia, escapando ao seu papel institucional.

${ }^{680}$ Nesse sentido, Arthur Pinto de Lemos Júnior (A investigação judicial..., cit., p. 186) lembra que, pelo princípio acusatório, nosso sistema "impede que o Ministério Público determine medidas processuais penais que atinjam a liberdade ou intimidade do cidadão acusado, reservando tal mister ao juiz - de Garantias - de Direito. Ao mesmo tempo, tirou das mãos do magistrado o poder de dar início à ação penal 
Assim, uma vez que seja incorporada a figura do Juiz de garantias em nosso sistema, propõe-se que se extraia, no Tribunal competente para a ação penal, o Juiz que atuará simplesmente como garantidor na investigação preliminar, cuja participação na etapa prévia já se anotou ser meramente contingente (porque a investigação pode iniciar-se, desenvolve-se e concluir-se sem a sua intervenção), embora de suma importância por representar a instância de controle judicial, quando a excepcionalidade do ato exigir autorização ou controle jurisdicional ou ainda para salvaguarda dos direitos e garantias individuais daqueles envolvidos na investigação, sempre que ameaçadas ou vulneradas. A ele caberá conhecer dos mecanismos de impugnação dos atos da Polícia e do Ministério Público, além dos pedidos que visem afetar ou limitar os direitos dos indivíduos.

$\mathrm{Na}$ investigação preliminar, enfim, a (única) função que deveria caber ao magistrado consiste na apreciação de medidas que digam com a afetação (restrição ou resguardo) de direitos fundamentais, seja do investigado, do ofendido ou de terceiros ${ }^{681}$, premissa igualmente válida para as investigações envolvendo titulares de prerrogativa de foro, em que tais pleitos se dirigem ao magistrado Relator, sendo apreciados, ordinariamente, em ato monocrático, independente de submissão ao Colegiado, podendo suas decisões ser contestadas perante o Tribunal. Paralelamente, são essas mesmas funções que deveriam caber ao juiz de primeiro grau no curso do inquérito policial comum.

Com a definição do papel do Juiz de garantias, o controle do andamento da etapa pré-processual caberá ao Ministério Público em atuação perante o Tribunal competente para o processamento da causa. Nem mesmo a pretexto de coibir o uso de influências que possam alterar indevidamente o rumo dessa atividade - por constituírem os investigados, em sua maioria, altas autoridades públicas -, justificar-se-á qualquer participação do Magistrado em atos investigatórios (os quais serão requisitados pelo Ministério Público e concretizados pela Polícia Judiciária) ou em despachos meramente burocráticos da investigação, incompatíveis mesmo com sua função garantidora de direitos fundamentais.

e, por conseguinte, de avaliar o conjunto probatório das peças de informações ou do inquérito policial (...). Essa aferição fica reservada, tão-somente, ao instante processual de recebimento da denúncia".

${ }^{681}$ Sobre o papel do Juiz penal no decorrer das investigações preliminares e sua distinção das atividades de polícia judiciária, esclarecedoras são as palavras de Alexandre Bizzotto e Andreia de Brito Rodrigues (Processo penal garantista. Goiânia: AB, 1998, p. 45): “Ao judiciário incumbe a preservação das garantias constitucionais latejantes, não tendo ligações com a finalidade de tutelar a segurança pública. A função garantista é absolutamente incompatível com a da segurança pública e às vezes até mesmo contraditória a ela, porquanto em diversos momentos, a busca da segurança pública esbarra nas garantias fundamentais". 
Exceção se fará, tão-somente, ao procedimento de investigação interna corporis de magistrados, no qual ainda persiste em nosso sistema a investigação de natureza judicial, com isso o magistrado Relator sendo a autoridade condutora do procedimento. Mesmo nesse caso, todavia, aconselhável é que o papel de juiz garantidor seja deixado a outro magistrado do mesmo Tribunal, evitando com isso a paradoxal situação de o Relator determinar as medidas investigativas e valorar, ele mesmo, a sua juridicidade.

Assim, define-se a divisão do trabalho na investigação preliminar dos delitos submetidos a foro especial, entre os diversos agentes estatais do sistema de justiça, construindo-se um procedimento afinado aos reclamos do processo penal acusatório, que permita à Polícia a discricionariedade regrada na realização dos atos investigatórios e ao Ministério Público, o controle externo dessa atividade, ficando ao Juiz de garantias apenas as matérias que impliquem reserva de jurisdição.

\subsubsection{Separação entre juiz da investigação e juiz do processo}

Outro problema crucial a ser enfrentado nas investigações preliminares dos delitos de competência originária de tribunais (embora não específico dessas investigações) é o de ser o próprio magistrado atuante na fase prévia o Relator também da ação penal a ser intentada.

Como característica da persecução extrajudicial dos delitos de competência originária de tribunais, tal qual hoje posta no direito positivo brasileiro, existe a previsão, nos regimentos internos das Cortes judiciais ${ }^{682}$, seguindo a Lei 8.038/1990 (e esta, por sua vez, o art. 83 do $\mathrm{CPP}^{683}$ ), de que o próprio órgão julgador (no caso, ao Relator) detenha a atribuição de funcionar na fase investigativa e, ao mesmo tempo, a incumbência de relatar a futura ação penal acaso instaurada em decorrência dessa investigação.

${ }^{682}$ Por exemplo: "Art. 69. O conhecimento do mandado de segurança, do habeas corpus e do recurso civil ou criminal torna preventa a competência do Relator, para todos os recursos posteriores, tanto na ação quanto na execução, referentes ao mesmo processo.” (RISTF); “Art. 71. A distribuição do mandado de segurança, do habeas corpus e do recurso torna preventa a competência do relator para todos os recursos posteriores, tanto na ação quanto na execução referentes ao mesmo processo; e a distribuição do inquérito e da sindicância, bem como a realizada para efeito da concessão de fiança ou de decretação de prisão preventiva ou de qualquer diligência anterior à denúncia ou queixa, prevenirá a da ação penal.” (RISTJ).

683 “Art. 83. Verificar-se-á a competência por prevenção toda vez que, concorrendo dois ou mais juízes igualmente competentes ou com jurisdição cumulativa, um deles tiver antecedido aos outros na prática de 
Pela dicção do art. 2. ${ }^{\circ}$ Lei 8.038/1990, “[o] relator, escolhido na forma regimental, será o juiz da instrução" ${ }^{684}$, a qual se realizará na forma prevista no Código de Processo Penal e no Regimento Interno do Tribunal. Desse preceito não se pode inferir, todavia, que nos processos de competência originária de tribunais exista uma instrução preliminar judicial. A instrução a que se refere o art. 2. ${ }^{\circ}$ é a instrução processual, definitiva.

Mas é bem de ver, por outro lado, que o "juiz da instrução" a que se refere a lei é o mesmo relator que funcionou na presidência do inquérito, o que se extrai da leitura conjunta dos arts. $1 .^{\circ}$ e $2 .^{\circ}$ desse diploma. Segundo o art. 1. ${ }^{\circ}$, "o Ministério Público terá o prazo de 15 (quinze) dias para oferecer denúncia ou pedir arquivamento do inquérito ou das peças informativas", sendo que, conforme o $\S 1 .^{\circ}$, "[d]iligências complementares poderão ser deferidas pelo relator" ${ }^{685}$, com interrupção daquele prazo. Não fez a lei qualquer distinção entre as relatorias nas fases investigativa e processual; ao revés, tratouas da mesma forma, concentrando-as na palavra "relator", sem qualquer adjetivação, donde se conclui, pela topologia dos preceitos, que o relator a que se referiu o legislador é somente um para toda a persecução criminal ${ }^{686}$.

Nesse passo, os regimentos atribuem ao magistrado que atuou em algum incidente do inquérito policial - quer autorizando medidas cautelares sujeitas a reserva de jurisdição ou controlando a legalidade dos atos da investigação em geral - a relatoria, por prevenção, também da ação penal ${ }^{687}$. O mesmo magistrado que foi provocado, na fase

algum ato do processo ou de medida a este relativa, ainda que anterior ao oferecimento da denúncia ou da queixa (arts. 70, § 3. $.^{\circ}, 71,72, \S 2 .^{\circ}$, e 78, II, c)."

684 Note-se que o dispositivo se refere ao "juiz $d a$ instrução", e não "juiz de instrução", distinção importante que permite atrelar ao primeiro aquelas funções ordinariamente previstas para o magistrado que conduz a instrução processual ou instrução definitiva, afastando-o da figura do juiz investigador ou do juiz de instrução, tipicamente afeto aos regimes de investigação preliminar judicial. Não existe aqui, insista-se, uma instrução preliminar judicial (LOPES JR., Aury. Sistemas..., cit., p. 164). Nesse sentido, mais clara era a redação do art. 557 do Código de Processo Penal ("O relator será o juiz da instrução do processo, com as atribuições que o Código confere aos juízes singulares.”), revogada pela Lei 8.658/1993, e também constante, de forma similar, no Regimento Interno do extinto Tribunal Federal de Recursos, ao tratar da Ação Penal Originária, no art. 215: "O Relator será o juiz da instrução do processo, com as atribuições que a lei processual confere aos juízes singulares".

${ }^{685}$ Sobre a atribuição de poderes ao relator para deferir ou não diligências de impulsionamento da investigação, cf. o item 3.3.4.

${ }^{686}$ O Superior Tribunal de Justiça firmou o entendimento de que o Ministro Relator, ainda que vencido na fase de recebimento de denúncia, não perde a relatoria do feito (APn 125/DF, rel. Min. Milton Luiz Pereira, rel. p/ acórdão Min. Cesar Asfor Rocha, Corte Especial, por maioria, DJ de 14.4.2003; Inq 282/RJ, rel. Min. Cesar Asfor Rocha, Corte Especial, por maioria, DJ de 12.11.2001).

${ }^{687}$ Como exceção, o Regimento Interno do Tribunal Regional Federal da 4. ${ }^{\text {a }}$ Região estabelece o impedimento do juiz presidente do inquérito (refere-se, portanto, apenas às investigações envolvendo magistrados, que, por natureza, são judiciais, como já se anotou) para a relatoria da ação penal. O art. 200 do Regimento dispõe: “O Desembargador Federal que conduzir a investigação não poderá ser o Relator da ação penal". Embora dirigido tal preceito, especificamente, ao procedimento investigatório relativo a 
preliminar, a autorizar buscas e apreensões, decretar prisões preventivas, homologar prisões em flagrante etc. tem sua competência firmada, por prevenção, para uma futura ação penal. Assim, além de participar diretamente da fase pré-processual, será o relator do caso na etapa processual, cabendo-lhe analisar a viabilidade da acusação e, se for o caso, iniciar a ação penal e presidir a instrução processual, proferindo sempre o primeiro voto no órgão colegiado.

A prevenção fixa a competência, satisfazendo-se com o fato de algum juiz, dentre vários a princípio competentes, haver praticado qualquer ato ou medida relativa à infração que se investiga, ou a uma das infrações (quando for o caso de conexão ou continência). Inspira-se na premissa de que melhor julga quem já teve um contato prévio com a causa, a situação e os atos praticados ${ }^{688}$, não suplantando, porém, o peso dos seus inconvenientes.

A regra - seguida não apenas nos tribunais, mas encontrando equivalente, como antes referido, na persecução criminal em primeiro grau - não se compreende que guarde adequação à Constituição, mercê de colidir frontalmente com o modelo acusatório, máxime por comprometer a principal garantia das partes no processo penal: o direito a um juiz imparcial $^{689}$. Ao se concederem poderes instrutórios ou de gestão ao juiz na fase préprocessual, seja pela atividade de reunir o material, seja por simplesmente estar em contato com as fontes de investigação, ou por autorizar a adoção de prisões cautelares, busca e apreensão, quebra de sigilo, interceptação telefônica, etc., realiza ele diversos pré-

delito praticado por magistrado, em que a identificação das figuras do investigador com o juiz da instrução processual tem reflexos ainda mais gravosos (podendo-se mesmo invocar, por analogia, o art. 252, I, do CPP, que torna impedido para a jurisdição no processo o magistrado que houver funcionado como autoridade policial), estamos em que tal impedimento deveria vigorar em toda e qualquer investigação preliminar, inclusive naquela de natureza policial, porquanto, inevitavelmente, o juiz atuante na investigação toma contato com a prova que ele mesmo autoriza realizar (caso, por exemplo, das medidas restritivas de direitos), tornando-se discutível a posterior isenção na valoração desses elementos.

${ }^{688}$ Essa a justificativa, por exemplo, mutatis mutandis, para o veto presidencial ao $\S 4 .^{\circ}$ do art. 157 do CPP, na redação da Lei 11.690/2008, que visava tornar impedido o juiz que conhecesse o conteúdo da prova declarada inadmissível. Segundo o veto, tal dispositivo iria de encontro aos objetivos de celeridade e simplicidade propagados pela reforma processual penal, podendo causar "transtornos razoáveis ao andamento processual, ao obrigar que o juiz que fez toda a instrução processual deva ser, eventualmente, substituído por outro que bem sequer conhece o caso".

${ }^{689}$ Como se manifesta Juan Luís Gómez Colomer (La investigación criminal..., cit., p. 211), o princípio acusatório garante, essencialmente, a imparcialidade do julgador, o que se atinge mediante a distinção entre as funções de instrução (ou investigação) e julgamento, que necessariamente hão de recair em órgãos distintos, pois o órgão decisório perderia sua imparcialidade se entrasse em contato com as fontes dos materiais do juízo sobre os quais versa o debate contraditório. Em verdade, não só o sujeito que investiga (entre nós, a autoridade policial) entra em contato com essas fontes materiais, mas também o magistrado que é chamado a atuar na investigação, homologando uma prisão em flagrante, decretando a 
julgamentos no curso da fase preliminar, inclusive efetuando subsunções provisórias de fatos a normas penais. E esse mesmo juiz, imbuído naturalmente de idéias pré-concebidas, frutos até de sua perspicácia, formará pré-juízos sobre condutas e pessoas, não sendo conveniente prossiga na condução do processo penal com tal comprometimento subjetivo justo a incompatibilidade psicológica que levou ao descrédito do modelo inquisitório.

Ao tratar do "princípio do juiz não prevenido", também conhecido como "o juiz que instrui não deve julgar", Andrés de Oliva Santos explica que não se trata de um princípio essencial, sem o qual não se possa, em nenhum caso, alcançar-se resultados justos, mas apenas uma garantia básica ou fundamental. Relata o autor que, na Espanha, a Exposição de Motivos da Ley de Enjuiciamiento Criminal de 1882 relacionava problemas que continuam bem atuais, mencionando entre os "vícios capitais" do processo penal o de o juiz que instrui (o sumário) ser o mesmo que pronuncia a sentença, com todas as preocupações e pré-julgamentos que a instrução fez nascer em seu ânimo. Inaugurava-se, então, um processo penal de instância única, dividido em duas fases cometidas a órgãos distintos, sendo que na primeira o juiz instrutor apenas preparava o juízo, este que só começaria com a abertura dos debates perante o Tribunal, estranho à instrução, para que julgasse com imparcialidade. Mas a Lei 3/1967 rompeu esse sistema e atribuiu a instrução e julgamento ao mesmo órgão, sob o simples argumento da rapidez na tramitação e decisão das causas, fomentando profunda crítica por destruir a imparcialidade do julgador ${ }^{690}$. Posteriormente a situação foi revertida, com a Lei Orgânica 10/1980, pela qual a investigação prévia procurou salvaguardar o princípio do juiz não prevenido.

Em benefício da garantia do juiz natural no processo penal e ao contrário do que prevê a regra do art. 83 do Código de Processo Penal, a prevenção deveria ser tida antes como uma causa de exclusão que de fixação da competência para o processo, de modo que o órgão jurisdicional competente para processar e julgar seja distinto daquele que haja participado da investigação. Essa, inclusive, a orientação já consolidada no Tribunal Europeu de Direitos Humanos, segundo a qual a atuação do juiz instrutor no tribunal sentenciador supõe uma violação do direito ao juiz imparcial consagrado no art.

prisão temporária ou preventiva no curso do inquérito, etc., em todo caso exercendo juízos de valor que carregará para a fase processual.

690 Jueces imparciales..., cit., p. 13-19. A adoção do "juiz prevenido", explica o autor, dera-se por razões inerentes ao utilitarismo judicial, em virtude do qual as reformas processuais se regem primordialmente pelo que se pensa ser conveniente e útil aos órgãos jurisdicionais, tendo em conta suas necessidades, possibilidades, limitações e conveniências. No entanto, logo se demonstraram os desacertos do legislador, 
6.1 do Convênio para a Proteção dos Direitos Humanos e das Liberdades Fundamentais, de 1950, porque as atividades de investigação e de verificação e valoração dos fatos constituem atitudes mentais distintas e incompatíveis ${ }^{691}$.

Impõe-se não perder de vista, ademais, a diretriz fundamental encartada nas Recomendações de Toledo ${ }^{692}$ :

Recomendação 4. Na fase do julgamento, deve decorrer da presunção de inocência a exigência de imparcialidade do julgador. Esta pressupõe que a fase de investigação deva ser levada a cabo por uma entidade distinta daquela a quem cabe a fase do julgamento. Assim, o juiz do julgamento não deve participar em actos das fases anteriores. É ainda altamente recomendável, que o juiz do julgamento seja distinto daquele que decide sobre o recebimento da acusação.

Anote-se que o Código de Processo Penal da Itália, procurando adequar-se à normativa européia ditada pelo TEDH, prevê, no art. 34, os casos de incompatibilidade do juiz que emitir o provimento conclusivo da audiência preliminar para funcionar no processo e sentenciar o caso. A Corte Constitucional italiana declarou, por diversas vezes, a inconstitucionalidade por omissão desse preceito legal, por não haver consignado outros casos de incompatibilidade com relação à anterior atuação do juiz na indagine preliminare. Consagrou, assim, o princípio de que o juiz que atua na investigação preliminar está prevento e não pode presidir o processo, por ter comprometida a sua imparcialidade ${ }^{693}$.

Tal princípio, enfim, consiste na exigência de que as decisões na investigação sejam tomadas e as fontes de prova sejam aportadas por órgãos distintos do julgador, pois, com ou sem referência ao princípio acusatório, a separação entre instrutor e julgador é uma exigência de desejável imparcialidade ${ }^{694}$. E no sistema do juiz instrutor, o

pois não se conseguiu diminuir sensivelmente a duração dos processos por delitos menos graves nem tardou a constatar-se uma sobrecarga de trabalho dos órgãos judiciais (Idem, p. 20-21).

691 Trata-se de orientação adotada pela maior parte dos países europeus, que considera haver presunção absoluta de parcialidade do juiz instrutor, a impedir-lhe de julgar o processo que tenha instruído. Nos casos principais, o Piersack, de 1.10.1982, e o de Cubber, de 26.10.1984, o TEDH asseverou que o juiz contaminado, seja por falta de imparcialidade subjetiva ou objetiva, desperta a desconfiança e a incerteza na comunidade e nas suas instituições. Mais além, na Sentença 145, proferida em 28.10.1998, o Tribunal declarou violado o direito a um juiz imparcial pelo só fato de dois magistrados que não atuaram como juiz de instrução (ou seja, não praticaram a investigação direta), mas participaram do julgamento de recurso contra decisão interlocutória tomada no curso da investigação, também haverem participado do julgamento (LOPES JR., Aury. Sistemas..., cit., p. 167-168).

692 RECOMENDAÇÕES de Toledo para um processo penal justo, cit., p. 438.

693 LOPES JR., Aury. Sistemas..., cit., p. 245-246.

${ }^{694}$ SANTOS, Andrés de Oliva. Jueces imparciales..., cit., p. 16-18. Rememore-se o exemplo da Espanha, em que, tanto na época em que vigeu o antejuicio para a persecução criminal de magistrados, quanto no vigente sistema de distribuição de competências pela Lei Orgânica 6/1985, do Poder Judicial, o tribunal competente designa um juiz instrutor especial para proceder ao sumário (instrução preliminar) ou à 
princípio do "juiz que instrui não julga" vige não tanto porque ele instruiu, mas porque decidiu sobre os incidentes da instrução $\operatorname{preliminar}^{695}$.

De anotar-se, porém, que aos olhos do mesmo TEDH não perde a imparcialidade o magistrado que, na fase preliminar, se comportou como juiz, resolvendo um conflito entre partes ao qual era alheio, como nos casos em que adotou decisões de decretação de prisão preventiva, ou praticou "atos inócuos" como receber declarações testemunhais sem emitir qualquer valoração sobre eles (Sentença de 24.5.1989, no Caso Hauschildt), ou mesmo decidiu sobre a viabilidade da acusação (Sentença de 22.4.1994, no Caso Saraiva de Carvalho) $)^{696}$. Nada obstante, conforme exposto neste trabalho, pensamos que tal juiz também se torna incompatível, do ponto de vista institucional (ou externo, ou objetivo), para julgar a causa.

Ainda que nosso sistema não seja o do juizado de instrução, é irrefutável que o magistrado que atua na investigação preliminar conhece dos fatos e os valora previamente, ao tempo em que profere inúmeras decisões importantes nos incidentes da etapa preliminar, entrando em contato com o material colhido e formando - quer involuntária, quer propositalmente - convicções sobre as provas que se vão reunindo ${ }^{697}$. Por isso, aqui, o princípio do juiz não prevenido torna-se igualmente exigível, para o resguardo da imparcialidade daquele que irá julgar a causa.

O nosso modelo, contudo, não apresenta solução adequada para o problema. Não prevê a legislação um juiz exclusivo para figurar na investigação, apartando-o da função de julgar o processo, de modo a melhor adaptar-se à estrutura acusatória do

investigação prévia ao sumário, o qual fica impedido de intervir na fase do juízo oral (arts. 57.2, 61.2 e 73.4 da LOPJ).

${ }^{695}$ LOPES JR., Aury. Sistemas..., cit., p. 271.

${ }^{696}$ Cf., a propósito, SUÁREZ-BÁRCENA, Emilio de Llera. La inidoneidad..., cit., p. 140-143.

${ }^{697}$ Ao tratar da influência das atuações investigativas na produção e valoração judicial da prova na fase do processo alemão (que já não contempla, na etapa preliminar, o juiz de instrução, sendo as investigações praticadas em grande parte pela polícia), Bernd Schünemann (La policía..., cit., p. 116-117) descreve que as atas da investigação, em que constam as declarações tomadas pela polícia, têm papel dominante, pois seu conteúdo exerce enorme influência sobre a formação do critério para ditar a sentença. Diz ele ter podido comprovar, em numerosos experimentos com juízes, que o só conhecimento do expediente já conduz a uma formação de pré-juízos por parte do juiz, de tal modo que informações novas e divergentes são desvaloradas. Em conseqüência, continua, a fase processual tende a uma mera repetição cerimonial e confirmação das atas policiais em que constam as declarações, sendo a explicação dada por duas teorias sócio-psicológicas: pela teoria da dissonância cognitiva, o indivíduo, na aspiração básica de estabelecer relações não-contraditórias entre seu conhecimento e suas opiniões, sobrevalora sistematicamente informações que confirmem uma hipótese anteriormente considerada correta, enquanto as informações opostas e divergentes são subestimadas; e segundo a teoria dos processos sociais de comparação, os seres humanos tendem a orientar-se conforme suas apreciações anteriores diante de situações pouco claras, mediante pessoas de referência tidas por ele como competentes (o juiz adotaria como pessoa de referência o promotor, e não o defensor). 
processo penal $^{698}$. Faz-se necessária, no diagnóstico de Fauzi Hassan Choukr, uma reforma estrutural para cindir o juiz responsável pelo acompanhamento das investigações, com a função garantidora, daquele que efetuará o juízo de admissibilidade da peça acusatória e, por fim, do que realmente instruirá a ação penal ${ }^{699}$. Já segundo Aury Lopes Jr., o sistema dito "ideal" será aquele em que o próprio juiz de garantias, na fase intermediária ${ }^{700} \mathrm{e}$ necessariamente contraditória, fará o juízo de pré-admissibilidade da acusação, a qual, uma vez admitida, dará início ao processo penal, sendo distribuída a outro magistrado, competente para presidir o processo e ao final julgar ${ }^{701}$. Com isso, em lugar da tripartição, bastaria a bipartição dos órgãos judiciais responsáveis pelo acompanhamento das principais fases da persecução penal (investigativa e processual) com vistas à maior asseguração da

${ }^{698}$ Esse modelo é vivenciado, no Brasil, apenas pontualmente, nas unidades federativas que procuram implantar a separação de juízos atuantes na fase preliminar e na fase processual, adotando juízo específico para o inquérito, como é o caso do Juízo da Vara de Central de Inquéritos em Curitiba, Estado do Paraná, e do Juízo de Direito do Departamento de Inquéritos Policiais e Polícia Judiciária, em São Paulo. Atuando no Município de São Paulo, o DIPO - Departamento de Investigações Policiais conta com alguns juízes que têm competência para funcionar unicamente na fase pré-processual, apreciando a regularidade de prisões em flagrante, pedidos de liberdade provisória, etc. (DIPO: justiça auxiliando o trabalho policial. Programa da Justiça, v. 3, n. 13, ago./set. 1998, p. 19). As exceções, contudo, não modificam, antes reafirmam a regra, que continua, no direito positivo nacional, sendo a da prevenção (art. 83 do CPP).

${ }^{699}$ Garantias..., cit., 2006, p. 93.

700 A existência de uma fase intermediária entre a etapa preliminar e o processo propriamente dito funciona como meio de controle judicial da opção feita pelo Ministério Público ao final da investigação preliminar: acusar ou abster-se da acusação. Não se situa mais na investigação propriamente dita. Nela, analisa-se, mediante prévia oitiva do sujeito passivo e uma sumária produção de provas, se existe base suficiente para a imputação e o início do processo. Em alguns sistemas, como no alemão, expressa-se mediante uma audiência judicial a que comparece o denunciado, podendo trazer provas e formular objeções, opondo sua resistência e com isso visando convencer o juízo e impedir o processo (cf. AMBOS, Kai. El proceso penal alemán y la reforma em América Latina. Santa Fe de Bogotá: Gustavo Ibañez, 1998, p. 32-33). No direito português, essa fase intermediária, que não é obrigatória (mas depende de requerimento do acusado ou do assistente de acusação), chama-se instrução (art. 286 do CPP português). Consiste numa garantia do imputado, porquanto propicia o debate contraditório dos interessados, com ou sem produção de prova, antes da decisão do juiz. O resultado desse debate perante o juiz pode neutralizar a acusação (cf. MOURA, José Souto de. Inquérito e instrução. In: Jornadas de Direito Processual Penal: o novo Código de Processo Penal. Coimbra: Almedina, 1998 p. 126-127). Na Itália, a fase intermediária é denominada de udienza preliminare (art. 416 do CPP italiano), celebrada em pleno contraditório: o Ministério Público expõe o resultado das investigações e fontes de prova em que se fundam o seu pedido, depois se manifestam os defensores do acusado, do responsável civil, da pessoa civilmente obrigada pela pena pecuniária e o próprio acusado. $\mathrm{O}$ juiz decide, por sentença, se arquiva o caso ou o envia a julgamento. $\mathrm{O}$ Ministério Público está obrigado a submeter o seu intento à audiência preliminar, mas o acusado pode renunciar à sua realização, solicitando a celebração do juízo imediato, embora tal situação seja escassa na prática (GARCÍA, Nicolás Rodríguez; FERNANDES, Fernando Andrade. Orientações..., cit., p. 438439). Em nosso país, nos delitos de competência originária dos tribunais, tal fase se concretiza pela oportunidade do sujeito passivo de ser ouvido e trazer provas antes mesmo do juízo de admissibilidade da acusação, resumindo-se, via de regra, a atos escritos da defesa (art. 4. ${ }^{\circ}$, Lei 8.038/1990), seguidos de uma decisão judicial que admite ou rejeita a acusação.

701 Sistemas..., cit., p. 271. 
imparcialidade objetiva, implicativa da ausência de ligação do juiz com o objeto do litígio, como elemento essencial para diferenciá-lo das partes ${ }^{702}$.

Seguindo-se tal premissa, no direito brasileiro, em especial na persecução de delitos de competência originária de tribunais, ainda que o juiz prevento não atue como juiz instrutor (pois a investigação preliminar, tirante a que envolve membros do Ministério Público e da própria Magistratura, é policial, e não judicial - conquanto visível a tendência prática dos tribunais em exercer um maior controle sobre ela), dever-se-ia proceder a uma mudança legislativa do critério da prevenção (que vem encampado no CPP e na Lei 8.038/1990), excluindo-se-se, também por disposições regimentais, a possibilidade de o juiz que funcionou na investigação criminal atuar como Relator da fase processual ou mesmo compor o órgão de julgamento, abandonando-se, portanto, a regra da prevenção como determinante da competência no processo ${ }^{703}$.

Esse papel de juiz atuante nas investigações poderá ser deixado, mediante critério regimental, a quaisquer dos membros do Tribunal, por distribuição, ou, nas Cortes menos numerosas, a apenas um de seus membros - como o Corregedor ou o VicePresidente, os quais não acumulam funções jurisdicionais ordinárias e que ficariam, durante seu mandato, sem receber a distribuição de ações penais originárias, levando ainda consigo o impedimento para a relatoria ou julgamento de futuras causas em que houverem atuado na investigação, quando já expirados os seus mandatos. A esse juiz caberá, como visto, apenas a posição de garantidor dos direitos fundamentais na etapa prévia, não exercendo qualquer função que o aproxime do próprio objeto da investigação, menos ainda

702 O TEDH, ao decidir o Caso Langborger, em 22.6.1989, declarou que "Em matéria de imparcialidade, deve-se distinguir entre um aspecto subjetivo, que visaria determinar a convicção pessoal do juiz na situação de que se trata, e outro objetivo, dirigido a assegurar que se ofereçam garantias suficientes para excluir qualquer dúvida legítima a respeito". Inicialmente, a imparcialidade somente foi estudada do ponto de vista subjetivo, como ausência de pré-julgamentos e interesses pessoais e de pressupostos de recusa do magistrado, esquecendo-se do aspecto institucional (ou objetivo, na terminologia do TEDH), pelo qual se indaga se o ordenamento jurídico interno estabelece regras bastantes para garantir a imparcialidade do juiz. Daí a preocupação com que o direito interno, mediante normas de competência (no que se inclui a regra da prevenção), defina o aspecto objetivo do aludido princípio, mediante a previsão comportamentos institucionais desejáveis por parte do magistrado (SUÁREZ-BÁRCENA, Emilio de Llera. La inidoneidad..., cit., p. 143-145).

703 Tanto nas hipóteses em que o foro por prerrogativa de função atrai para o mesmo órgão julgador (ou para um de seus membros) a função de coordenar a instrução preliminar (caso das investigações envolvendo magistrados), como naquelas em que não atrai (caso dos demais agentes com prerrogativa de foro), é preciso evitar que os intensos pré-julgamentos formados na etapa prévia abalem a garantia da imparcialidade. O remédio para tanto, a depender de uma reforma legislativa abrangente, está na exigência de que o órgão julgador seja composto por magistrados que não tenham atuado na investigação preliminar (cf. SANTOS, Andrés de Oliva. Jueces imparciales..., cit., p. 43-44). 
qualquer função assemelhada à de investigador, nem sendo adequado presidir a fase processual ou integrar, como vogal, o órgão colegiado julgador ${ }^{704}$.

Calha noticiar que o Supremo Tribunal Federal decidiu, recentemente, pela nulidade de processo penal, desde o recebimento da denúncia, por entender que o juiz sentenciante teria atuado como se autoridade policial fosse, em virtude de, no procedimento preliminar de investigação de paternidade, em que apurados os fatos, ter ouvido testemunhas antes de encaminhar os autos ao Ministério Público para a propositura de ação penal ${ }^{705}$. Mutatis mutandis, poder-se-ia aplicar os mesmos fundamentos da incompatibilidade do julgador para as hipóteses em que se está diante de investigação preliminar criminal, seja quando o magistrado ouve pessoalmente o investigado ou

${ }^{704}$ Sobre as desvantagens da adoção da prevenção como critério definidor de competência, confira-se decisão da Ministra Eliana Calmon, do Superior Tribunal de Justiça, que, após acompanhar a investigação de agentes com foro especial e emitir seu voto na sessão de apreciação da denúncia, assim se manifestou sobre exceção de suspeição que lhe foi oposta: "De referência à exceção de suspeição argüida pela defesa de S.T.C. (fls. 3021/3024), entendo inexistir razão para a excepcionalidade, na medida em que este Tribunal, pela Corte Especial, entendeu que cabe ao relator originário, quando parcialmente vencido, continuar na relatoria do feito, com a só mudança de relator para o acórdão. No momento da decisão da Corte, ao final da sessão, questionei, com base no regimento interno, sobre a não continuidade da minha relatoria. Estava exausta e confusa com o resultado final da votação, a qual, entretanto, chancelou na maior parte o meu voto, mantendo as denúncias contra os principais envolvidos, J.C.O., S.O.C. e E.S.S. Como reforço de argumentação à tese da mudança de relatoria, disse, na oportunidade, não mais acreditar no processo, o que não me torna mais ou menos imparcial, na medida em que cabe ao julgador conduzir o processo independentemente de sua crença quanto ao resultado do mesmo, especialmente quando está a ação penal tendo início, com o recebimento da denúncia. Lembro que na oportunidade o Sr. Ministro Presidente, à vista da minha afirmação, chegou a dizer que a mudança de relator para efeito de lavratura do acórdão era para não constranger o relator originário, cujo voto não foi recebido por inteiro." (APn 460/RO, DJ de 29.9.2006).

${ }^{705}$ Em acréscimo a esses fundamentos, o Min. Cezar Peluso, em voto-vista, concluiu que, na espécie, pelo conteúdo da decisão do juiz, restara evidenciado que ele teria sido influenciado pelos elementos coligidos no procedimento preliminar de investigação de paternidade, previsto no art. 2. ${ }^{\circ}$ da Lei 8.560/1992. Dessa forma, considerou que teria ocorrido a ruptura da denominada imparcialidade objetiva do magistrado, cuja falta o incapacita, de todo, para conhecer e decidir causa que lhe tenha sido submetida. Esclareceu que a imparcialidade denomina-se objetiva, uma vez que não provém de ausência de vínculos juridicamente importantes entre o juiz e qualquer dos interessados jurídicos na causa, sejam partes ou não (imparcialidade dita subjetiva), mas porque corresponde à condição de originalidade da cognição que irá o juiz desenvolver na causa, no sentido de que não haja ainda, de modo consciente ou inconsciente, formado nenhuma convicção ou juízo prévio, no mesmo ou em outro processo, sobre os fatos por apurar ou sobre a sorte jurídica da lide por decidir. Assim, sua perda significa falta da isenção inerente ao exercício legítimo da função jurisdicional. Observou o Ministro, por último, que, mediante interpretação lata do art. 252, III, do CPP (“Art. 252. O juiz não poderá exercer jurisdição no processo em que:... III tiver funcionado como juiz de outra instância, pronunciando-se, de fato ou de direito, sobre a questão;"), mas conforme com o princípio do justo processo da lei (CF, art. 5. $\left.^{\circ}, \mathrm{LIV}\right)$, não pode, sob pena de perda de imparcialidade objetiva e conseqüente impedimento, exercer jurisdição em causa penal o juiz que, em procedimento preliminar e oficioso de investigação de paternidade, se tenha pronunciado, de fato ou de direito, sobre a questão. Ficou vencida a Min. Ellen Gracie, relatora, que, no ponto, não conhecia do writ ao fundamento de supressão de instância e o indeferia em relação às demais questões suscitadas (HC 94.641/BA, rel. Min. Ellen Gracie, rel. p/ acórdão Min. Joaquim Barbosa, 2. ${ }^{\text {a }}$ Turma, por maioria, j. 11.11.2008, Informativo de Jurisprudência, Brasília, 528, 2008). 
testemunhas, seja pelo fato de exercer diversos juízos valorativos sobre o material que lhe é submetido quando do requerimento de medidas cautelares.

Imperioso, assim, além de desincumbir o juiz da prática de atos de investigação ou de controle meramente burocrático do andamento da investigação preliminar, como antes já se expôs ${ }^{706}$, apartá-lo da competência para relatar a ação penal porventura intentada; entregar-se, com isso, ao membro do Tribunal que funcione na investigação, a ser definido conforme os Regimentos Internos, a competência para atuar nos incidentes jurisdicionalizados na fase investigativa dos delitos de competência originária da Casa, o qual estaria de antemão excluído da relatoria e da composição do órgão julgador da ação penal porventura adiante ajuizada.

O juiz natural na investigação preliminar dos delitos de competência originária tribunalícia deve ser visto como o juiz exclusivo para os episódios de jurisdicionalização que se apresentem nessa etapa, órgão previamente determinado em norma constitucional, com atribuição esmiuçada em norma interna do tribunal e com pleno resguardo de sua imparcialidade, para tanto se propondo reforma legislativa no sentido de superar-se a regra de prevenção do art. 83 do CPP e torná-lo impedido de integrar, como relator ou vogal, o órgão julgador da ação penal porventura desencadeada a partir daquela investigação.

\subsubsection{Publicidade ou sigilo na investigação preliminar}

Um dos pontos mais sensíveis da investigação preliminar diz respeito à

publicidade ou o sigilo de seus atos. É preciso estabelecer, dentre eles, qual o regime mais adequado à investigação praticada nos delitos de competência originária de tribunais, em que o tema assume particular relevo diante da maior exposição pública dos agentes investigados nessas espécies de procedimento (juízes, promotores, deputados, senadores, prefeitos, etc.).

Na legislação especial, apenas as Leis Orgânicas da Magistratura (LC 35/1973, art. 54) e do Ministério Público da União (LC 75/1993, art. 247) mencionam regras sobre o sigilo investigativo, estabelecendo que o processamento das reclamações e

${ }^{706}$ Cf. item 3.3.4. Relembre-se que mesmo na revogada Lei de Falências, que abrigava uma espécie de inquérito judicial, o juiz que investigava (juiz cível da vara de falências) não era o mesmo que processava a ação (juiz criminal). 
representações administrativas contra magistrados, como dos inquéritos administrativos contra membros do Ministério Público, serão automaticamente sigilosos ${ }^{707}$. Não há, porém, referência à investigação criminal propriamente dita, tampouco regulando o assunto a Lei 8.038/1990. Merece a matéria ser tratada à luz dos preceitos da Constituição e do Código de Processo Penal.

A depender da modalidade investigativa, a questão do sigilo tem sido enfrentada a partir de diferentes premissas. Se por um lado se propala, como regra (ainda que em equívoco), o sigilo das diligências praticadas no inquérito policial, o mesmo não se tem no inquérito parlamentar, cujos atos - como os do Parlamento em geral - são a princípio públicos, podendo haver sessões secretas se assim deliberar a comissão ${ }^{708}$.

A adoção da publicidade ou do sigilo dos atos e diligências praticados no curso da investigação originária passa por definir se o sigilo integra a essência da investigação preliminar - questão ainda bastante tormentosa, sobretudo nos inquéritos policiais, a demandar em alguns casos interferência do Poder Judiciário - e se, na apuração de infrações envolvendo autoridades sujeitas a foro por prerrogativa de função, mereceria um olhar diferenciado, justificado pelo cargo ocupado pela pessoa investigada.

Nas investigações preliminares no direito alienígena (Alemanha, Itália, França, Espanha ${ }^{709}$ ), vigora o segredo na etapa investigativa, havendo diferença apenas quanto à possibilidade e amplitude da participação do investigado e da defesa nessa fase. A despeito da opção político-legislativa de tantos países que consagram, como regra, o segredo investigativo, não é o sigilo algo imanente, essencial à investigação criminal ${ }^{710}$.

707 De Fernanda Dias Menezes de Almeida (O sigilo..., cit., p. 235) vem o lúcido questionamento: "Se o julgamento das mais altas autoridades da República, nos crimes de responsabilidade, é conduzido publicamente, por que correr em segredo de justiça processo que envolve membros da judicatura, por mais dignas e relevantes que sejam - e são - as suas funções? Por certo será razoável a reserva quanto a certos aspectos das investigações, se a sua divulgação puder prejudicar o andamento dos trabalhos ou violar eventualmente a intimidade dos investigados ou terceiros. Mas, afora as hipóteses do gênero, não se justifica o tratamento diferenciado que a lei deu aos magistrados".

708 A respeito da publicidade versus secretismo das inquirições parlamentares, cf. FERREIRA, Jorge. Regime jurídico..., cit., p. 29-30 e 55-56.

$709 \mathrm{Na}$ Espanha, o art. 321 da LECrim prevê que os juízes de instrução presidirão o sumário auxliados por secretários e, em casos extraordinários, com a ajuda de notários ou de homens maiores de idade que jurem fidelidade e segredo. Na França, a instrução preliminar, como regra na enquête e na instruction, é secreta (art. 11 do CPP francês), sendo crime a violação deste segredo. Na Itália, é o art. 329 do CPP que estabelece, como regra geral, o segredo das investigações realizadas pelo Ministério Público e pela Polícia, que não deve durar para além do encerramento da investigação. Na Alemanha, o Código de Processo Penal, no $\S 147$, institui o segredo externo como regra até a fase processual, e mesmo o investigado e seu defensor só têm direito a assistir a determinadas diligências, examinar algumas atas e objetos de prova sob custódia oficial.

710 Basta citar o já referido exemplo das CPIs, que, ao exercerem atividade investigativa, guiam-se em regra pela publicidade de seus atos, assentada embora em motivos peculiares: necessidade de transparência dos 
A instituição do sigilo, de modo geral, obedece a determinadas razões, as quais se podem agrupar em quatro ordens: a) realizar uma investigação isenta e independente, alheia à intromissão de terceiros e a especulações que perturbem a serenidade dos agentes envolvidos; b) impedir que o suspeito ou investigado, conhecendo antecipadamente fatos e provas, tumultuem a investigação, dificultando a reunião de indícios, quando a tanto se mostrarem, de forma objetiva, propensos; c) evitar que, pela divulgação de fatos que podem não vir a ser provados, crie-se um juízo negativo sobre o investigado; d) obstar que outros sujeitos da investigação criminal, como os presumíveis ofendidos $^{711}$, tenham revelados fatos prejudiciais à sua honra e reputação social.

As duas primeiras categorias podem ser identificadas como razões voltadas à finalidade da eficiência (êxito da investigação), ao passo que as duas últimas ligam-se a fins garantísticos (integridade moral do investigado, do ofendido e dos demais partícipes da investigação: testemunhas, policiais, magistrados, membros do Ministério Público). Em nosso ordenamento, é o que se extrai do art. 5. ${ }^{\circ}, \mathrm{LX}$, da Constituição, no sentido de que apenas as exigências de defesa do interesse público ou da intimidade podem motivar a restrição da garantia da publicidade.

Em primeiro lugar, portanto, o sigilo no inquérito atenderia ao interesse da investigação (logo, do Estado, enquanto condutor dessa atividade preliminar). Nele residiria, segundo Francesca Molinari, o segredo interno, calcado na exigência de salvaguardar o correto e eficaz desenvolvimento das investigações de intervenções, sobretudo do investigado, voltadas a destruir ou ocultar as fontes de prova, comprometendo a eficiência da justiça. Por outro lado, a razão do segredo externo, antes estribada na tutela do convencimento do juiz, nos últimos tempos se justificaria porque a crescente atuação da imprensa, em alguns casos, tende a orientar em sentido diverso a opinião pública, criando um convencimento errôneo, prematuro ou excessivo acerca da culpabilidade - ainda não definida - do sujeito envolvido ${ }^{712}$.

atos sindicados (que, modo geral, têm reflexo direto na vida pública) e de controle da sociedade sobre o empenho dos parlamentares, detentores de mandatos políticos.

711 Se, por um lado, a participação da vítima é essencial, em muitos casos, para o sucesso da investigação, por outro, é comum não haver, das autoridades policiais, o cuidado de resguardar-se a sua identidade e individualidade. Os meios de comunicação expõem-na à curiosidade pública, impondo-lhe novo sofrimento, dificultando o retorno a sua vida particular e, por outro lado, incrementando-lhe o risco de sofrer intimidações e vingança do ofensor, em tudo perdendo a eficácia da investigação. Acerca do tema, v. FERNANDES, Antonio Scarance. O papel da vítima no processo criminal. São Paulo: Malheiros, 1995, p. 59-83.

712 MOLINARI, Francesca Maria. Il segreto investigativo, cit., p. 245-252. Sob o aspecto subjetivo, o segredo interno pode ser parcial (abranger o sujeito passivo da investigação apenas) ou total (opor-se 
A abertura do segredo externo, assim, pode, em alguns casos, trazer prejuízo quer ao eficaz desenvolvimento das investigações (logo, à administração da justiça, ao que Aury Lopes Jr. denomina de utilitarismo judicial ${ }^{713}$ ), quer à honra (respeito à integridade moral do preso - art. 5..$^{\circ}$, XLIX, da CF) e à intimidade do investigado e dos demais agentes envolvidos na investigação ${ }^{714}$.

Cabe perquirir, agora, que opção teria guiado o legislador brasileiro e que postura interpretativa encontraria lugar no nosso atual sistema constitucional-processual.

No que tange ao inquérito policial, desde sua criação, em 1871, vem mantendo suas notas originais, entre as quais se destaca o sigilo dos atos investigativos, extraído da leitura do art. 20 do $\mathrm{CPP}^{715,716}$. Tal ilação não se faz, porém, à mercê de críticas ou de polêmicas.

A problemática do sigilo ou da publicidade dos atos investigatórios encontra adeptos em um ou em outro sentido. Os defensores da total clausura do inquérito, arrimados quase sempre em razões de "ordem pública" e de "bem comum", no interesse do Estado pela "busca da verdade real" na fase pré-processual, rejeitam a participação do advogado nos atos do inquérito ao qual foi decretado segredo de justiça, admitindo, quando

também ao seu advogado). O segredo interno, uma vez decretado, pressupõe, por lógico, também o externo, que é oposto a terceiros.

713 Propõe ainda o autor classificar a publicidade, a partir da divulgação (ou não) dos atos de investigação, em parcial, quando a acessibilidade é concedida só aos sujeitos da investigação, ou plena, quando também às demais pessoas. Sob tal ótica, a publicidade parcial significa a ausência de segredo interno e existência de segredo externo, ao passo que a publicidade plena representaria a ausência de segredo externo - e, portanto, também de segredo interno (LOPES JR., Aury. Sistemas..., cit., p. 118-120).

714 Os princípios, doutrina Robert Alexy, albergam diretrizes sobre deveres, direitos fundamentais, pretensões, interesses. Quando entram em conflito numa situação de fato, a solução consiste não em eliminar um deles do sistema, ou declarar a sua invalidez, ou introduzir-lhe exceções. Soluciona-se tal colisão estabelecendo, entre os princípios, uma relação de precedência condicionada, de modo que, em cada caso, indicam-se as condições sob as quais um princípio precede ao outro, por ter maior peso naquele caso concreto (Teoría de los derechos fundamentales, cit., p. 91-92). Logo, o direito à informação e o direito à intimidade do indivíduo, ambos de matriz constitucional, devem ser contrabalançados, donde se extrai que a intimidade há de prevalecer sobre interesses que, no caso concreto, apresentem-se meramente expositivos de sua imagem, para fins predominantemente comerciais.

715 “Art. 20. A autoridade assegurará no inquérito o sigilo necessário à elucidação do fato ou exigido pelo interesse da sociedade."

716 Nesse sentido, representando vetusta corrente doutrinária atualmente objeto de forte crítica, Edgard Magalhães Noronha (Curso..., cit., p. 21) afirma: "Quanto ao sigilo da investigação, é ele da essência do inquérito. Não guardá-lo é muita vez fornecer armas e recursos ao delinqüente, para frustrar a atuação da autoridade, na apuração do crime e da autoria”. Mais recente, mas no mesmo sentido, o pensamento de Manoel Messias Barbosa (Inquérito policial: doutrina, prática, jurisprudência. 5. ed. atual. e ampl. São Paulo: Método, 2006, p. 47): “O indiciado, enquanto objeto de ação investigatória, deve ser protegido, para que não ocorra o seu aniquilamento moral ou material pelo sistema repressivo. $\mathrm{O}$ sigilo dos atos investigatórios precisa ser mantido, quando necessário, pois, se não o for, interferências estranhas podem impedir ou dificultar a busca da verdade, ficando a sociedade desprotegida em decorrência de um falso conceito de liberdade. De nada valerá a conclusão de que a polícia pode ser discricionária, se estiver assegurada ao suspeito a sua interferência nos autos do inquérito policial”. 
muito, a consulta dos autos, mas por mera liberalidade da autoridade policial ${ }^{717}$. Curioso notar que se valem (assim como a lei, no citado art. 20) de expressões vagas e ambíguas, sem preocupar-se com a situação concreta, na qual, aí sim, deve ser aferida a imprescindibilidade ou não da decretação do sigilo, bem como sua limitação no tempo.

Em outro vértice, agrupam-se os partidários da publicidade do inquérito, os quais não descuram da necessidade de compreender-se a investigação criminal principalmente sob o aspecto de garantia de liberdades, de sua aptidão a propiciar ao imputado lançar mão dos meios de defesa, esboçando reação à imputação que contra ele se vai formando, contribuindo, enfim, para a credibilidade das conclusões da atividade policial $^{718}$.

A segunda postura, a nosso ver, emerge como a mais consentânea aos anseios democráticos de nossa Constituição, distanciando-se de conotações típicas de regimes autoritários, nos quais o investigado é tomado como objeto da ação repressiva do Estado, mantido alheio às providências preliminares ao exercício da ação penal.

Não custa rememorar o preceito geral da publicidade dos atos do Poder Judiciário, constante do art. 93, IX, da $\mathrm{CF}^{719}$, que deve pautar todos os julgamentos e decisões judiciais, podendo-se excepcioná-lo apenas por exigência do direito à intimidade. Demais, no âmbito administrativo, a atividade policial está imersa na Administração Pública - os funcionários da Polícia Judiciária são servidores públicos - e sujeita, inafastavelmente, aos princípios norteadores encartados no art. 37, caput, da Constituição, entre eles os da publicidade e da eficiência.

717 Assim, Sérgio Demoro Hamilton, para quem o sigilo é da essência daquela peça investigativa, de sorte que ao advogado não seria permitido o acompanhamento e o acesso aos autos da investigação ao inquérito policial, sob pena do insucesso deste (Réquiem para o sigilo no inquérito policial. Revista da EMERJ, Rio de Janeiro, v. 7, n. 25, 2004, p. 112-122), e Marcelo Batlouni Mendroni, para quem o equilíbrio entre acusação e defesa, ou a igualdade de armas no inquérito, implicaria manter-se o total sigilo, já que a defesa jamais revelaria às autoridades as evidências incriminadoras da pessoa investigada ( $\mathrm{O}$ sigilo da fase pré-processual. Justitia, v. 62, n. 189/192, jan./dez. 2000, p. 107). Essa "paridade de armas às avessas", contudo, divisamos incompatível com os princípios e garantias constitucionais aplicados à investigação criminal.

718 Postam-se, cada qual a seu modo, contra o sigilo no inquérito policial, Jacinto Nelson de Miranda Coutinho (O sigilo no inquérito policial..., cit., p. 128-129), ao enunciar que as infinitas discussões sobre o sigilo, no inquérito policial, são, em grande medida, estéreis e vinculadas à ideologia política, e Paula Bajer Fernandes Martins da Costa, para quem "o segredo da investigação implica a inexistência de procedimento e de registro e, portanto, a ilicitude na procura do crime e de sua autoria. O que deveria ser oficial torna-se oficioso e, portanto, para nada serve" (Publicidade na investigação criminal. Boletim IBCCrim, São Paulo, v. 7, n. 84, nov. 1999, p. 13).

719 “Art. 93 (...) IX - todos os julgamentos dos órgãos do Poder Judiciário serão públicos, e fundamentadas todas as decisões, sob pena de nulidade, podendo a lei limitar a presença, em determinados atos, às próprias partes e a seus advogados, ou somente a estes, em casos nos quais a preservação do direito à intimidade do interessado no sigilo não prejudique o interesse público à informação." 
Não há de causar espécie a afirmação. Observe-se, por exemplo, a previsão do art. 204 do CPP argentino, a consagrar a publicidade do sumário, que poderá ser examinado "pelas partes e seus defensores" após o interrogatório do imputado (feito pelo juiz de instrução, existente naquele sistema). Isso não exclui o direito do defensor nomeado de manusear os autos antes de aceitar o encargo (art. 106 do CPP). Ressalva-se a hipótese de segredo, que é exceção e deve ser decretado pelo juiz "sempre que a publicidade ponha em perigo o descobrimento da verdade", não podendo atingir os atos definitivos e irreproduzíveis e perdurando por no máximo dez dias, a menos que a gravidade do fato ou a dificuldade da investigação exijam seu prolongamento. A publicidade aqui referida, vale frisar, é a interna, guardando-se sempre, por força ainda do art. 204 do CPP, o segredo para estranhos à investigação ${ }^{720}$.

Nesse prisma, e ressalvadas as diferenças entre os ordenamentos brasileiro e argentino, a leitura que se propõe ao art. 20 do CPP pátrio importa considerar a premissa (implícita no sistema) de que a investigação criminal, embora em seu nascedouro contenha uma etapa cognitiva inicial de segredo ${ }^{721}$, é pública e assim caminha ${ }^{722}$, cumprindo à autoridade policial assegurar o sigilo quando, em certo momento, para poder avançar nessa tarefa reconstrutiva ${ }^{723}$, tal se tornar necessário à elucidação do fato ou exigido pelo interesse da sociedade ${ }^{724}$, e por um lapso temporal determinado.

${ }^{720}$ DÍAZ, Carlos Alberto Chiara; MEANA, José María. Código procesal penal de la Nación concordado con el de la província de Buenos Aires anotados jurisprudencialmente. Buenos Aires: Rubinzal-Culzoni, 2001, p. 60-61 e 116 .

${ }^{721}$ Sobre esse momento inicial, Luigi Carli explica que, por permanecer o delito, durante algum tempo, escondido e desconhecido seu autor, parte-se de uma situação de "desvantagem cognoscitiva" do investigador (Estado), donde o recurso ao segredo das investigações, um óbice ao conhecimento das informações por terceiros, que ocorre ao menos no início das investigações, tanto no plano interno como no externo, impedindo-se a divulgação do que possa revelar a direção da atividade investigativa (Indagini preliminari e segreto investigativo. Rivista Italiana di Diritto e Procedura Penale, Milano, v. 37, n. 3, lug./set. 1994, p. 763).

722 Destaca-se a seguinte regra, contida na Resolução 13, de 2.10.2006, editada pelo Conselho Nacional do Ministério Público no fito de regulamentar a investigação ministerial: "Art. 13. Os atos e peças do procedimento investigatório criminal são públicos, nos termos desta Resolução, salvo disposição legal em contrário ou por razões de interesse público ou conveniência da investigação" (Disponível em: $<$ http://www.cnmp.gov.br/documentos-e-publicacoes/resolucoes/resolucoes-index $>$. Acesso em: 12 out. 2007).

${ }^{723}$ É bem de ver que a tarefa investigativa (e a instrutória em geral) consiste em uma reconstrução de fatos já ocorridos no passado. Essa reconstituição, pelas naturais limitações humanas e tecnológicas, nunca corresponderá com exatidão à realidade, sendo dela mera aproximação, a qual deve traduzir não uma verdade inatingível, mas o maior grau possível de certeza sobre aquilo que se investiga.

724 As expressões legais "elucidação do fato" e "interesse da sociedade", embora de conteúdo aberto, guardam sentidos, senão idênticos, bastante aproximados, parecendo, a nosso ver, que ambas se relacionam à finalidade de eficiência da investigação, sendo que, no primeiro caso, à eficiência buscada pelo Estado no cumprimento do seu dever investigativo e, no segundo, à eficiência esperada pela sociedade, que tem interesse no esclarecimento de eventual ilicitude das condutas praticadas por seus 
$\mathrm{O}$ fato de caber à autoridade policial guardar o sigilo nas excepcionais hipóteses em que se fizer necessário não significa possa partir dela (autoridade administrativa) a decretação. Por ser exceção constitucional, e por repercutir sobre garantias individuais (entre as quais o direito de defesa, o acesso à informação e o direito à obtenção de certidões ${ }^{725}$ ), somente a autoridade judicial, a quem o ordenamento confere a elevada função de protetora dessas garantias, pode restringir a publicidade interna, delimitando, em decisão fundamentada, os atos a que se estenderá ${ }^{726}$. E o sigilo, uma vez decretado, recobre o ato determinado na decisão (sem que isso contagie, necessariamente, os demais atos de investigação), clamando observância não apenas da autoridade condutora do procedimento, mas vinculando todos os demais atores da investigação, protagonistas ou não (membro do Ministério Público, juiz, advogado, investigado, vítima, testemunhas, peritos, veículos de comunicação, etc.). No mais, todos os partícipes da etapa investigativa são igualmente legitimados a provocar o decisório de restrição, quando se sentirem vulnerados em sua intimidade.

Como exceção em nosso sistema, o sigilo investigativo encontra algumas limitações. Em primeiro lugar, deve vir fulcrado em um daqueles motivos já enunciados como razões para a sua instituição: a proteção da intimidade dos envolvidos na investigação (sigilo externo) e/ou a eficiência da persecução (sigilo interno). E deve ter uma duração limitada, somente subsistindo enquanto perdurar a causa justificativa da exceção $^{727}$.

membros. Não se preocupou, portanto, o legislador, em um primeiro momento e de forma específica, com o sigilo necessário à proteção da intimidade dos envolvidos na investigação, o que não significa não deva ser ele, à luz do desenho constitucional (art. 5. ${ }^{\circ}, \mathrm{LX}$, da CF), considerado quando da apreciação do cabimento do segredo investigativo.

${ }^{725}$ Assegurados, respectivamente, no art. 5. ${ }^{\circ}, \mathrm{LV}$, XIV e XXXIV, $b$, da Constituição da República.

${ }^{726}$ Ressalte-se que, para a prática de atos de investigação, cujo momento e maneira de realização quedam sob a órbita de discricionariedade da autoridade policial, não é necessário decretar o sigilo. A polícia simplesmente age, sendo o segredo inerente ao ato. O sigilo cuja decretação pode fazer-se necessária, e por ordem judicial, é o que paira sobre os atos de instrução (vide item 2.6), os quais vão materializar o inquérito policial.

${ }^{727}$ A temporariedade das medidas restritivas de direitos fundamentais, como é o caso do sigilo, é uma derivação do princípio da proporcionalidade, no subprincípio da necessidade, sob o aspecto quantitativo. Por tal princípio, ensina Suzana de Toledo Barros, deve ser utilizado, quando em jogo a precedência de um bem ou interesse sobre o outro, o meio mais idôneo e de menor afetação ao interesse restringido, o que supõe deva o sigilo ser adotado apenas quando não se puder, com igual grau de eficácia da investigação ou de efetividade das garantias procedimentais, prosseguir na investigação de forma pública. E, para que uma exceção não se torne regra, cumpriria ao legislador "fixar quantitativamente o tempo máximo de duração de uma medida excepcional de restrição a direito fundamental" ( $O$ princípio $d a$ proporcionalidade e o controle de constitucionalidade das leis restritivas de direitos fundamentais. 3. ed. Brasília: Brasília Jurídica, 2003, p. 81-84). 
Isso quer dizer que, se a eficácia da investigação depender, por exemplo, do cumprimento de uma medida de interceptação telefônica deferida judicialmente, a publicidade dessa medida, enquanto estiver em curso a interceptação, pode comprometer a coleta de informações presumivelmente enriquecedoras para o esclarecimento do fato investigado, e então se justifica o sigilo. Aqui se estará no âmbito dos atos de investigação.

Cite-se ainda o esclarecedor exemplo do cumprimento de medidas de busca e apreensão. Desde o requerimento de tal ordem até o seu deferimento judicial, passando pelo estudo do melhor momento a ser cumprida e o início de sua execução, justifica-se o sigilo $^{728}$, inclusive (e principalmente) para as pessoas que detêm os objetos da busca e seus advogados, porquanto, se cientificados de antemão, poderão ter o ímpeto de destruir ou ocultar os indícios da conduta investigada, tornando inócua a medida. Entretanto, uma vez deflagrada a operação de busca, nada impede que o interessado ou seu advogado, fazendose presentes ao local, acompanhem a diligência. Passado o momento de coleta dos elementos, quando não mais pairar o risco de se desnaturarem, já se passará ao âmbito dos atos de instrução: não haverá base para sustentar-se o sigilo quanto ao produto da interceptação, sobretudo o sigilo interno, aquele normalmente oposto ao investigado.

Não é comum nos depararmos com decisões que levantam o sigilo dantes decretado. Uma vez ordenado o sigilo de determinado ato ou diligência, mesmo após a realização desta, o segredo acaba por (indevidamente) acometer todo o procedimento, desde a fase pré-processual até à sentença, como se a tarja de "segredo de justiça" marcasse aqueles autos de forma indelével. Ora, uma investigação que se processe, toda ela, sob o manto do segredo, é uma investigação oficiosa, clandestina até, algo que o nosso sistema constitucional repudia ${ }^{729}$. Se o sigilo vem para resguardar a prática de certos atos (ainda que estes sirvam, como de fato servem, à investigação como um todo), somente tais atos devem tramitar sob o regime excepcional, que por excepcional deve perdurar tão-somente enquanto subsistam os motivos de sua decretação. Uma estratégia recomendada para a incomunicabilidade entre $\mathrm{o}$ ato, a diligência ou o documento sigiloso e o caderno investigativo público é a formação de apensos aos quais se dedicam os cuidados do sigilo, sem prejuízo da acessibilidade imediata do volume principal.

\footnotetext{
${ }^{728}$ Nesse caso, como se viu, o sigilo é próprio do ato de investigação, não dizendo com o ato de produção da prova em si, contido no inquérito, por isso que dispensável a decretação judicial para a sua adoção.

729 "Sobretudo porque dentro de um Estado democrático não há sentido em se falar de 'investigações secretas', até porque, na construção do quadro garantidor e na nova ordem processual acusatória, deve o
} 
Entrementes, ainda é corriqueira a negativa de acesso aos autos do inquérito, na polícia ou em juízo, a advogados de imputados e mesmo às vítimas ${ }^{730}$, que podem ter importantes subsídios ao esclarecimento dos fatos, dando-se tal prática com arrimo no singelo dispositivo do art. 20 do CPP, cuja leitura, adrede proposta, não há por certo conduzir a uma tal ditadura do sigilo. Além disso, cumpre referir que o Estatuto da Advocacia e Ordem dos Advogados do Brasil (Lei 8.906/1994), diploma nascido já sob a égide da nova ordem constitucional, no art. 7. ${ }^{\circ}$ XIV, estatui ser direito do advogado “examinar em qualquer repartição policial, mesmo sem procuração, autos de flagrante e de inquérito, findos ou em andamento, ainda que conclusos à autoridade, podendo copiar peças e tomar apontamentos"

A medida excepcional e temporária do sigilo, portanto, quando decretada, não deve, em princípio, prevalecer para o defensor, o que tem levado inúmeros doutrinadores a proclamar como única conciliação possível entre o art. 20 do CPP e o art. 7. ${ }^{\circ}, \mathrm{XIV}$, do Estatuto da Ordem a de que "o decreto do segredo no inquérito policial ou em qualquer outro procedimento não alcançará, jamais, o advogado" ${ }^{, 732}$. O sigilo será admitido

investigado ser alertado sobre o procedimento instaurado" (CHOUKR, Fauzi Hassan. Garantias..., cit., 1995, p. 92).

${ }^{730}$ Prática comum, sobretudo, nas investigações perpetradas pelo Poder Judiciário em relação a seus próprios membros, não só no âmbito penal, mas também na seara disciplinar. Nesse ponto, Fernanda Dias Menezes de Almeida (O sigilo..., cit., p. 235) noticia que a Ordem dos Advogados do Brasil, seccional de São Paulo, por sua Comissão de Prerrogativas, vem questionando a prática da Corregedoria do Tribunal de Justiça de São Paulo de, com espeque na Loman, impedir a parte que formula representação contra juiz de ter acesso aos autos e à defesa apresentada pelo magistrado. Sobre o tema, assim se pronunciou o STJ: "O processo censório do magistrado está sujeito ao manto do segredo de Justiça (arts. 27, parágs. 2. ${ }^{\circ}, 6 .^{\circ} \mathrm{e}$ 7. ; 40, 43 a 45; 54 e 55, todos da Loman), para afiançar-se a dignidade e independência deste. Desta forma, do mesmo modo que a inamovibilidade, a vitaliciedade e a irredutibilidade de vencimentos são garantias constitucionais dos membros do Poder Judiciário, o direito à integridade do juiz em relação a terceiros deve ser sempre invocado, preservando-se com isso sua imparcialidade e da própria Instituição. No caso sub judice, movida representação por causídico contra juíza estadual, por suposta negligência na prestação dos deveres do cargo, sendo esta por ele protocolada, não há como desconhecer seu conteúdo, sendo impertinente sua reprodução ou certidão acerca dos fatos ali descritos. No mesmo sentido, improcede fornecer-se certidão acerca de eventuais atos praticados pela Corregedoria-Geral, pois a atividade correicional obedece a ritos próprios, observadas, sempre, a integridade e a independência do juiz. Configura-se em etapas administrativas do processo censório, no qual cabe ao interessado, apenas, o conhecimento do resultado. Este último é que se sujeita aos comandos da motivação e da publicidade dos atos administrativos. Logo, ilegal se torna, somente, o indeferimento da expedição de certidão acerca do inteiro teor da decisão que determinou o arquivamento desta, bem como de sua autoria. Inteligência do art. 40, da Loman c/c art. 5. ${ }^{\circ}$, XXXIV, 'b', da Carta Magna.” (RMS 11.255/SP, rel. Min. Jorge

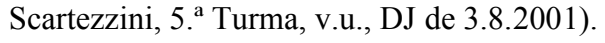

${ }^{731} \mathrm{Na}$ observação de Heleno Cláudio Fragoso (Jurisprudência criminal, cit., p. 18), tal direito "não sofre limitações, pois a defesa constitui interesse público, sendo a sua plenitude garantia constitucional”.

732 COSTA, Paula Bajer Fernandes Martins (Publicidade..., cit., p. 13); PEREIRA, Flávia Rahal Bresser ( $A$ publicidade..., cit., p. 193); BARANDIER, Antonio Carlos da Gama et al. (Inquérito policial: segredo de Justiça; determinação de quebra de sigilo bancário; inadmissibilidade de impedir os advogados de 
no momento da coleta de alguns elementos de convicção, e mesmo antes, para não a frustrar $^{733}$, mas não ao cabo de sua produção.

É bom lembrar que o Supremo Tribunal Federal, diante de situações tais, vem reafirmando o direito fundamental do investigado de fazer-se assistir por defensor técnico no curso do inquérito, vindo daí a inoponibilidade ao advogado do direito de vista dos autos do inquérito policial e o acesso às informações nele já introduzidas, pois "[a] oponibilidade ao defensor constituído esvaziaria uma garantia constitucional do indiciado (CF, art. 5. ${ }^{\circ}$, LXIII), que lhe assegura (...) a assistência técnica do advogado, que este não lhe poderá prestar se lhe é sonegado o acesso aos autos do inquérito sobre o objeto do qual haja o investigado de prestar declarações. (...) dispõe, em conseqüência a autoridade policial de meios legítimos para obviar inconvenientes que o conhecimento pelo indiciado e seu defensor dos autos do inquérito policial possa acarretar à eficácia do procedimento investigatório"

Claro que, em se tratando de investigação ainda acobertada pelo segredo de justiça, a responsabilidade por eventual quebra de sigilo - do advogado que tem acesso aos autos ou dos funcionários que trabalham na investigação - há de ser apurada, incidindo a punição nos termos da legislação em vigor ${ }^{735}$.

exercerem direitos fundamentais para a efetiva defesa (parecer). Revista Brasileira de Ciências Criminais, São Paulo, v. 9, n. 35, jul./ago. 2001, p. 209).

733 "1. A constitucional publicidade dos atos processuais e o direito de acesso indispensável ao exercício da advocacia encontram limites na proteção social, nas hipóteses legais e quando a descoberta da diligência pudesse frustrar seus objetivos. Precedentes. 2. O que não se pode admitir, porém, é que medidas restritivas a direitos dos cidadãos (prisão, seqüestro de bens, invasão de domicílio para busca e apreensão, violação dos sigilos constitucional ou legalmente protegidos...) sejam baseadas em investigações cujo segredo se mantenha. 3. Não é admissível em Estado minimamente de Direito a violação de direito fundamental do cidadão sem que se permita a este conhecer os fatos e as provas existentes e utilizadas como fundamento da decisão restritora. 4. Não existindo na espécie quaisquer atos de restrição individual e ainda menos fundamentados em provas sigilosas, legítima é a imposição do segredo imprescindível à diligência." (TRF-4. ${ }^{a}$ Região, MS 107.951/SC, rel. Juiz Néfi Cordeiro, 7. ' Turma, v.u., DJ de 22.6.2005).

${ }^{734}$ HC 82.354/PR, Rel. Min. Sepúlveda Pertence, 1. ${ }^{a}$ Turma, v.u., DJ de 24.9.2004. Após esse julgado, que se tornou paradigma na Excelsa Corte, vários outros se exararam na mesma direção. É o caso, por exemplo, do julgamento plenário no qual se assentou que "[o] sigilo emprestado a autos de inquérito não obstaculiza o acesso por profissional da advocacia credenciado por um dos envolvidos, no que atua a partir de visão pública, a partir da fé do grau detido" (HC 88.520/AP, rel. Min. Cármen Lúcia, rel. p/ acórdão Min. Marco Aurélio, por maioria, DJ de 19.12.2007). Também o Superior Tribunal de Justiça: HC 47.704/SP, rel. Min. Nilson Naves, 6. ${ }^{\text {a } T u r m a, ~ p o r ~ m a i o r i a, ~ D J ~ d e ~ 1.9 .2008 ; ~ H C ~ 55.356 / R J, ~ r e l . ~ M i n . ~}$ Felix Fisher, 5. ${ }^{\text {a }}$ Turma, v.u., DJ de 26.2.2007; HC 88.104/RS, rel. Min. Maria Thereza de Assis Moura, 6. ${ }^{a}$ Turma, v.u., DJ de 6.12.2007; HC 95.979/SP, rel. Min. Napoleão Nunes Maia Filho, 5. a Turma, v.u., DJ de 18.8.2008.

735 Constituem crimes a quebra de segredo de justiça, nos termos da Lei 9.296/1996 (no caso das interceptações telefônicas), a violação de segredo profissional e a violação de sigilo funcional (arts. $154 \mathrm{e}$ 325 do Código Penal). 
A publicidade ampla, por sua vez, deve ser tida como regra a guiar também a investigação preliminar nos delitos de competência de tribunais, envolvendo autoridades públicas $^{736}$, mesmo porque a autoridade que exerce função pública está sujeita, invariavelmente, à opinião e ao controle popular, donde se pressupor, em conseguinte, a regra da publicidade, também externa - aqui, vale lembrar, no que tange aos atos de instrução, não os de investigação, como já diferenciado.

Se a ocorrência de um delito é um acontecimento público, sua apuração interessa à coletividade. Ademais, o Poder Judiciário, como os órgãos públicos da Polícia Judiciária e do Ministério Público, hão de nortear-se pela transparência de seus atos, sujeitos que estão ao princípio da publicidade e ao escrutínio público.

Outro problema, todavia, costuma surgir com a publicidade dos feitos criminais, tendo em vista as características atuais dos meios de comunicação, como antes anunciado. A publicidade, que foi instituída para beneficiar o sujeito passivo da persecução criminal, possibilitando a realização de um julgamento justo, é muitas vezes utilizada em seu prejuízo, violando a proteção à intimidade que é garantida na Constituição.

Em um Estado democrático, a imprensa desempenha o papel social de esclarecer os cidadãos, informar-lhes a verdade de forma neutra e desinteressada, não devendo sofrer cerceamento e ingerência estatal. As liberdades de expressão e de informação, expressas nos arts. $5^{\circ}$, IX, e $220, \S \S 1 .^{\circ}$ e $2 .^{\circ}$, da Constituição, são direitos fundamentais de grande relevância para a preservação do regime democrático e o respeito aos direitos civis, porém há casos em que a publicidade externa (imposta a terceiros) precisa sofrer limitações para que sejam salvaguardadas as garantias do justo processo.

Faz-se necessário, como alerta Simone Schreiber, superar alguns mitos que envolvem a atividade jornalística, mediante a distinção entre a cobertura lícita de uma investigação, processo ou julgamento criminal, e a campanha midiática prejudicial ao direito a um julgamento justo e imparcial, assim entendido aquele a que se chegou após o devido processo legal, livre de pressões e de preconceitos ${ }^{737}$.

\footnotetext{
${ }^{736}$ Não há razão para cobrir de segredo de justiça os autos investigativos pelo só fato de nele estar figurando uma autoridade pública, sobretudo após a entrada em vigor da Emenda Constitucional 45/2004, que deu nova redação ao art. 93, IX, da Lei Maior, atrás transcrito. Essa, inclusive, a opinião de Fernanda Dias Menezes de Almeida (O sigilo..., cit., p. 235): "Não nos parecem sustentáveis tais exceções à regra da publicidade no exercício das funções públicas. O que está em pauta nas referidas hipóteses legais de sigilo é o julgamento de agentes públicos, cujo comportamento questiona-se exatamente no exercício de suas funções. Trata-se, pois, de matéria que à sociedade interessa acompanhar de perto e abertamente".

737 A publicidade opressiva dos julgamentos criminais: reflexões sobre a colisão da liberdade de expressão e o direito a um julgamento justo, sob a perspectiva da Constituição Federal de 1988. In: PRADO, Geraldo;
} 
Há o constante risco de as coberturas jornalísticas influenciarem indevidamente o desfecho de processos criminais, quando são instauradas verdadeiras campanhas contra determinado investigado ou acusado, um processo paralelo conduzido sem respeito a garantias ${ }^{738}$, com grave violação da presunção de inocência, apresentando-se o investigado ou acusado como pessoa responsável pela infração penal. Com efeito, as manifestações da mídia decorrem não de escolhas técnicas, mas de decisões políticas, moduladas pelas leis de mercado, refletindo apenas versões simplificadas de fatos, sem o costume de confrontação de fatos e argumentos sobre as questões noticiadas ${ }^{739}$. Chega-se a construir uma outra realidade, diferente da real. Ademais, o tempo do jornal (no qual o valor velocidade se impõe ao valor verdade, inviabilizando-se a análise mais cuidadosa dos fatos) é diferente do tempo da justiça (em que o decurso do tempo, com o diálogo e a contraposição das teses e provas trazidas pelas partes, é crucial à formação da convicção do juiz e da verdade processual, construída sob o devido processo legal). Daí decorrem diferenças nos métodos de construção da verdade, com tensões entre as expectativas geradas pela imprensa e as respostas que podem ser dadas pelo Poder Judiciário.

MALAN, Diogo. Processo penal e democracia: estudos em homenagem aos 20 anos da Constituição da República de 1988. Rio de Janeiro: Lumen Juris, 2009, p. 541-542. A autora constata ainda a tendência de a mídia se substituir às instituições públicas responsáveis pela apuração e julgamento de crimes (verdadeira "usurpação da função judicial pela imprensa"), ora para coadjuvar a polícia na atividade investigativa, ora para fazer a justiça funcionar como deveria, de modo que os juízes sejam permeáveis ao clamor público, procurando punir "rápida e exemplarmente" crimes que tenham merecido maior atenção da mídia (Idem, p. 537 e 541).

738 "A exploração das causas penais como casos jornalísticos, com intensa cobertura por todos os meios, leva à constatação de que, ao contrário do processo penal tradicional, no qual o réu e a Defesa poderão dispor de recursos para tentar resistir à pretensão de acusação em igualdade de posições e paridade de armas com o acusador formal, o processo paralelo difundido na mídia é superficial, emocional e muito raramente oferece a todos os envolvidos igualdade de oportunidade para expor seus pontos de vista." (PRADO, Geraldo. Sistema acusatório..., cit., p. 162-163).

${ }^{739}$ Relembre-se o caso do promotor de justiça paulista Thales Ferri Schoedl, acusado de homicídio contra dois jovens em 30 de dezembro de 2004 e absolvido, por unanimidade, pelo Órgão Especial do Tribunal de Justiça de São Paulo em 26 de novembro de 2008, reconhecendo-se a tese da legítima defesa. A trajetória do caso compõe-se de inúmeras reportagens prejudiciais ao acusado, que o davam como culpado, sem maiores confrontações com as provas dos autos. Durante a manifestação oral de seus votos, alguns desembargadores fizeram críticas ao tratamento dado pela imprensa ao episódio, dizendo que, ao acompanhar o caso pelos jornais, tiveram a nítida impressão de que o réu era culpado, mas, ao examinar os autos, a conclusão era outra, como se estivessem tratando de casos distintos (Disponível em: $<$ http://www.estado.com.br/editorias/2008/11/27/cid-1.93.3.20081127.26.1.xml>. Acesso em: $12 \mathrm{dez}$. 2008). Em face do ambiente desfavorável propagado pela mídia, receava a defesa ser o promotor submetido a júri popular, tanto que somente foi julgado pelo Tribunal de Justiça após uma liminar do Supremo Tribunal Federal que o reconduziu ao cargo, suspendendo a decisão de não-vitaliciamento exarada pelo Conselho Nacional do Ministério Público. Deveras, como explica Simone Schreiber (A publicidade..., cit., p. 551), os jurados são mais permeáveis que os juízes togados ao trial by media, tendo em vista o contato superficial deles com a prova dos autos, a não-obrigação de motivar suas decisões e a ausência de prerrogativas que assegurariam, em tese, atuação independente e imparcial em um ambiente adverso. 
Assim, põe-se em questão não apenas a honra e a imagem do suspeito ou do acusado, mas a própria correção da distribuição da justiça, considerando a influência que os modernos meios de comunicação podem provocar na serenidade do juiz ${ }^{740}$. Em tais situações, fica configurado o trial by media $^{741}$, ensejador da colisão entre direitos fundamentais constitucionais, reclamando eventual restrição tópica e fundamentada de um deles, pois não se trata de direitos absolutos ${ }^{742}$.

Para resolução do dilema, deve-se valorizar o princípio que maior proteção dedicar à dignidade humana ${ }^{743}$. Quando se postarem em colisão esses dois direitos fundamentais de igual estatura constitucional, deve a preferência recair, prima facie, sobre o direito do acusado a um julgamento justo, e não sobre a liberdade de expressão ${ }^{744}$, ainda que estiverem envolvidos os direitos à honra, privacidade e imagem de pessoas ou agentes públicos e quando os fatos se classificarem como de interesse público, porquanto

${ }^{740}$ Alberto Zacarias Toron (Notas sobre a mídia nos crimes de colarinho branco e o Judiciário: os novos padrões. Revista Brasileira de Ciências Criminais, São Paulo, v. 9, n. 36, out./dez. 2001, p. 270), diante dessas constatações, entende que a incidência de leis restritivas é uma necessidade, não apenas para se preservar a honra e a imagem alheias, mas para se evitar a montagem do caso pela mídia (manipulações que importem no alijamento da verdade para satisfazer índices de audiência), de modo a se impedir que, posteriormente, uma absolvição ou arquivamento sejam identificados pela desqualificadora expressão tudo acabou em pizza. Lamenta ainda o autor serem comuns os casos em que a televisão tem maior acompanhamento do inquérito ou do processo que o próprio advogado.

${ }^{741}$ No trial by media, segundo observa Alberto Zacharias Toron (Notas..., cit., p. 268), a paridade de armas é inexistente, pois se vocalizam fortemente as versões acusatórias, que na ótica da imprensa são sempre mais interessantes de divulgar ao grande público, além de se criarem situações para ensejar o "fato jornalístico", que estampa o clamor popular construído por pessoas arrebanhadas para o protesto contra o criminoso, com isso possibilitando a prisão preventiva ou pressionando pela acusação.

${ }^{742}$ Como lembra Flávia Rahal Bresser Pereira (Publicidade no processo penal..., cit., p. 274-283), a liberdade de imprensa é valor constitucional que deve ser respeitado e ao qual não se pode impor qualquer censura prévia. No entanto, não é absoluta e, por vezes, opõe-se a outros valores de igual importância. A excessiva exploração do processo pela mídia é ferramenta que interfere na intimidade das pessoas e se contrapõe à realização da justiça, não se podendo admitir que, sob o pretexto de que a publicidade é boa para todos, "se prossiga na desenfreada e descabida superexposição de pessoas e fatos do processo, transformando julgamentos numa espécie de reality show da tragédia". Colhe-se ainda das Recomendações de Toledo para um processo penal justo (cit., p. 439) a seguinte regra: "A publicidade do processo [ao que acrescemos, também, a investigação] através dos meios de comunicação deve ser restringida ou proibida, quando visivelmente dela decorra a condenação prévia do arguido e o processo se transforme num "processo espetáculo"”.

743 Para identificar situações em que se está diante de uma campanha de mídia instaurada contra determinado imputado e capaz de influenciar o resultado do julgamento, Simone Schreiber (A publicidade..., cit., p. 542-548) enumera os seguintes elementos: (i) manifestações expressivas sucessivas prejudiciais ao acusado; (ii) com potencialidade para interferir na imparcialidade dos juízes e influenciar indevidamente o resultado do julgamento, risco este que é presumido pelo ambiente adverso que cerca o julgamento, e (iii) ocorridas na pendência das investigações ou processos criminais, até sentença definitiva.

744 É que, como explica Ana Paula de Barcellos (Ponderação..., cit., p. 161-164), a utilização da técnica da ponderação para a solução de complexos conflitos envolvendo valores ou opções políticas em tensão deve guiar-se por parâmetros preferenciais, segundo os quais: a) regras (constitucionais ou infraconstitucionais) devem ter preferências sobre princípios; e b) as normas que atribuem ou promovem diretamente direitos fundamentais e a dignidade humana devem preferir àquelas que apenas indiretamente contribuem para esse resultado. 
impassível de qualquer restrição ou renúncia o direito a um julgamento justo. Nesse mesmo sentido, as bem-lançadas palavras de Simone Schreiber ${ }^{745}$ :

Pode-se dizer que o crime imputado a um agente público relacionado com o exercício de sua função pública despertará maior interesse da coletividade. Contudo, isso não reduz a esfera de proteção conferida a tal acusado de ser julgado sob as garantias do devido processo legal. O interesse do público na condução do processo pode ser atendido por cobertura jornalística que não se consubstancie em trial by media. O próprio fato de se tratar de um agente público pode ensejar disputas políticas em torno do caso e propiciar campanhas promovidas por eventuais opositores contra o acusado, competindo ao judiciário tomar as medidas necessárias para garantir que o julgamento se faça em ambiente adequado, sereno, por um juiz imparcial.

Não obstante o que se acabou de sustentar, nada obsta que o juiz leve em consideração o fato de se tratar de crime imputado a agente público, no exercício de suas funções, ao buscar a forma mais adequada de resolver a colisão. Pode adotar, dentre as medidas possíveis, aquela que não sacrifique o direito do público em geral de ser informado do andamento do processo judicial. Assim, para harmonizar os valores constitucionais em jogo, a imposição de sanção apenas contra determinados veículos que estejam promovendo a campanha de mídia contra o réu prefere a adoção de medidas de maior alcance, como, por exemplo, a decretação de segredo de justiça que impeça qualquer pessoa de saber como está sendo conduzido o processo ${ }^{746}$.

Portanto, não constituindo o sigilo nota imanente à persecução preliminar, seja de que espécie for, deve subsistir apenas nos casos e pelo tempo necessários, reclamando sempre (salvo naquelas situações contingentes e excepcionais nas quais, pela própria natureza da diligência, o conhecimento pela defesa deva ser ulterior, sob pena de frustrar-se a finalidade do ato) adequada motivação, calcada em razões de eficiência (a melhor elucidação dos fatos investigados) ou em fins garantísticos (preservação da integridade moral dos partícipes da investigação e das garantias do justo processo). Nesses casos, o acesso dos autos a terceiros, que não as autoridades encarregadas da investigação e o imputado, será analisado, caso a caso, pelo Juiz, que pode reforçar a nota do sigilo (designando, por exemplo, funcionário específico para os cuidados dos autos), ou

745 A publicidade..., cit., p. 551.

${ }^{746}$ Na mesma linha, Geraldo Prado (Sistema acusatório..., cit., p. 164-165) cita como alternativas possíveis para o controle das situações de conflito, em que há intensa exploração pela mídia: proibir a imprensa de fazer uso de informações obtidas criminosamente, como é o caso das gravações clandestinas, assim como a proibição de que as partes do processo lancem mão das provas obtidas dessa maneira; o recurso aos mecanismos tradicionais de responsabilidade reparatória; o desaforamento temporal, suspendendo o curso do procedimento enquanto durar o estado de excitação social; por fim, seguir e ampliar o exemplo do direito espanhol, em que se autoriza ao Ministério Público emitir comunicados escritos à imprensa, a fim de evitar informações errôneas, o que se poderia estender a qualquer das partes que se sentir prejudicada. 
flexibilizá-la, permitindo mesmo que terceiros, mediante autorização expressa, a eles

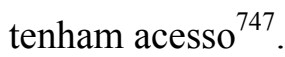

Em suma, na fase investigativa, como na processual ${ }^{748}$, o sigilo externo é exceção, comportando interpretação e aplicação restrita, justificando-se desde que vise ao resguardo do direito à intimidade e do devido processo legal, sempre mediante avaliação do caso concreto e decisão fundamentada, decretando-se-o nos momentos em que se fizer ele premente. Já a publicidade externa, consistente na possibilidade de conhecimento e divulgação ampla dos fatos a terceiros estranhos à investigação criminal, embora consista na regra, poderá ser restringida ${ }^{749}$, para prevenir lesões ao direito fundamental ao julgamento justo, balizado pelas garantias do devido processo legal. Tal postura emerge como a mais congruente aos anseios democráticos de nossa Constituição.

\subsection{Encerramento da etapa investigativa}

Terminadas as investigações preliminares, com as medidas pré-processuais de persecução penal adotadas no âmbito de procedimento investigatório instaurado pela Polícia Judiciária, serão os autos remetidos ao Tribunal, e o Relator ao qual distribuído, nos casos de ação penal de iniciativa pública, abrirá vista ao Procurador-Geral da República ou Procurador-Geral de Justiça, para que ofereça denúncia - em 15 (quinze) dias, ou em 5 (cinco), se o investigado estiver preso -, ou determinará, no caso de ação penal de

${ }^{747}$ No julgamento de questão de ordem no Inq 249/AM (rel. Min. Sálvio de Figueiredo Teixeira, Corte Especial, v.u., DJ de 28.5.2001), envolvendo Desembargador do Tribunal de Justiça do Amazonas, o STJ indeferiu o pedido do advogado de converter a sessão em secreta por ter o processo dados sigilosos tais como informações bancárias e fiscais. Fez-se a observação de que, caso fosse necessário, a sessão seria convertida em secreta. No STF, por ocasião do Inquérito 2.245/MG ("Mensalão"), chegou o Relator inclusive a deferir pedido formulado pelos diretores de grandes veículos de comunicação escrita para consulta dos autos por seus jornalistas, embora ressalvando o acesso pelos advogados dos denunciados, reconhecidamente prioritário.

748 Nessa esteira, a disposição legal do art. 12, II, in fine, da Lei 8.038/1990 (“...podendo o Presidente do Tribunal limitar a presença no recinto às partes e seus advogados, ou somente a estes, se o interesse público exigir") compatibiliza-se ao que prevêem os arts. 5., LX, e 93, IX, da CF, tratando do sigilo como exceção, justificada pelo interesse público. No entanto, sob a mesma ótica, o art. $234, \S 2 .^{\circ}$, do RISTF ("Encerrados os debates, o Tribunal passará a deliberar em sessão secreta, sem a presença das partes e do Procurador-Geral, e proclamará o resultado do julgamento em sessão pública") fere as aludidas disposições constitucionais.

${ }^{749}$ Como escreve Maria Lúcia Karam (O direito a um julgamento justo e as liberdades de expressão e de informação. Boletim IBCCrim, São Paulo, v. 9, n. 107, edição especial, out. 2001, p. 4), as liberdades de expressão e de informação não são "direitos absolutos, superiores a qualquer outro, como parecem querer fazer crer os poderosos meios massivos de informação", podendo encontrar limites "legislativamente estabelecidos e concretamente aplicados através da atividade jurisdicional, quando indispensáveis para salvaguardar outros direitos fundamentais constitucionalmente protegidos, como é o caso do direito a um julgamento justo e imparcial". 
iniciativa privada, o aguardo da iniciativa do ofendido ou de quem por lei lhe faça as vezes. Nesse mesmo prazo, poderá o Ministério Público requerer o arquivamento dos autos, como dispõe o art. 1. ${ }^{\circ}$, caput, da Lei 8.038/1990 750 , ou postular diligências complementares.

Prevê a Lei 8.038 que as diligências complementares interromperão o prazo para oferecimento da denúncia, caso se trate de investigado solto (art. 1. $.^{\circ}, \S 1 .^{\circ}$ ); no entanto, havendo preso, as diligências complementares não geram a interrupção do prazo, salvo se o Relator determinar o relaxamento da prisão (art. $1 .^{\circ}, \S 2 .^{\circ}, b$ ). Pelo Regimento Interno do STF, se tais diligências forem indispensáveis ao oferecimento da denúncia, "o Relator determinará o relaxamento da prisão do indiciado; se não o forem, mandará, depois de oferecida a denúncia, que se realizem em separado, sem prejuízo da prisão e do processo" (art. 231, § 3. ${ }^{\circ}$ ).

Há de ressaltar que o momento da formação da opinio delicti não é prédeterminado. Existem casos, embora raros, em que, do só recebimento de representação contendo peças de informação com indícios de prática delituosa por agente com foro especial, o titular da ação penal desde logo maneja a inicial acusatória, abreviando a etapa investigativa, ou já pede o seu arquivamento, por considerar manifestamente atípica a conduta ou por estar ela prescrita. Em outras oportunidades, são necessárias inúmeras diligências complementares para que possa formar alguma conclusão sobre os fatos apurados.

De modo geral, são duas as formas de encerramento da investigação preliminar, também na persecução de delitos com prerrogativa de foro.

Uma vez se convencendo o Ministério Público da presença da materialidade de conduta típica e de indícios suficientes de autoria delitiva a recair sobre alguma das autoridades com o foro por prerrogativa de função, oferecerá a denúncia, dando ensejo à fase intermediária integrada pela defesa preliminar. Modo inverso, não divisando a ocorrência de justa causa para lastrear a acusação, ou visualizando a prescrição ou a atipicidade da conduta, promoverá o arquivamento do inquérito ou das peças informativas, fundamentadamente, remetendo os autos ao Judiciário para apreciação.

${ }^{750}$ Cuja redação é a seguinte: “Art. 1. ${ }^{\circ}$ Nos crimes de ação penal pública, o Ministério Público terá o prazo de 15 (quinze) dias para oferecer denúncia ou pedir arquivamento do inquérito ou das peças informativas”. Semelhantes preceptivos encontram-se no RISTF (art. 231) e no RISTJ (art. 217). 


\subsubsection{O arquivamento dos autos da investigação}

A etapa do arquivamento do inquérito e de seus sucedâneos (petições, representações, notícias-crime, etc.), nas investigações aforadas nos Tribunais, apresenta matizes próprios se comparada à investigação policial comum.

No processo penal, o arquivamento, em sentido amplo, pode ser conseqüência de uma determinação legal (por exemplo, no art. 522 do CPP, que determina o arquivamento da queixa caso as partes se reconciliem ${ }^{751}$ ), ou resultar de uma decisão judicial initio litis, ao se rejeitar a denúncia ou a queixa. Mas em sentido estrito é a solução dada em juízo, nos termos do art. 28 do CPP, a inquérito policial, representação ou outras peças de informação, em decorrência de resolução motivada do Ministério Público de não promover a ação penal, retirando-se os autos de movimentação para sua manutenção em arquivo, importando definição (provisória ou definitiva, conforme o caso) do procedimento criminal $^{752}$

O Código de Processo Penal não enumera os casos de arquivamento, apenas prevendo, no art. $28^{753}$, que o Ministério Público poderá deixar de denunciar, requerendo, fundamentadamente, aquela medida ao juiz, e sempre depois de esgotados todos os recursos para o esclarecimento do fato, inclusive podendo devolver os autos à polícia, requisitar diligências, documentos e informações (art. 13, I e II, do CPP). No entanto, considerando-se que a instauração do processo demanda o preenchimento de requisitos para o regular exercício do direito de ação e de suporte probatório mínimo, será caso de arquivamento se o fato noticiado no inquérito ou nas peças de informação não constituir crime; se a prova colhida não autorizar a acusação, por não demonstrar a materialidade do

${ }^{751}$ Observe-se, todavia, que nos crimes contra a honra cuja ação penal se processa originariamente perante tribunais não tem lugar a designação, antes do recebimento da denúncia ou da queixa, da audiência para reconciliação prevista no art. 520 do CPP, mercê da incidência do procedimento especial da Lei 8.038/1990, na qual não previsto tal ato. Nesse sentido: STF, HC 77.962/SP, rel. Min. Sepúlveda Pertence, 1. ${ }^{a}$ Turma, v.u., DJ de 19.3.1999; STJ, APn 165/DF, rel. Min. Eduardo Ribeiro, Corte Especial, por maioria, DJ de 29.11.2000.

752 SOUZA, José Barcelos de. Do arquivamento. Belo Horizonte: Imprensa Oficial do Estado de Minas Gerais, 1969, p. 7-8. Vale ressaltar que, pelo já revogado art. 559 do Código de Processo Penal, nos processos de competência originária dos tribunais, o Relator poderia propor ao Tribunal o arquivamento do processo, quando convencido da improcedência da acusação pela defesa prévia do acusado.

753 “Art. 28. Se o órgão do Ministério Público, ao invés de apresentar denúncia, requerer o arquivamento do inquérito policial, ou de quaisquer peças de informação, o juiz, no caso de considerar improcedentes as razões invocadas, fará remessa do inquérito ou peças de informação ao procurador-geral, e este oferecerá a denúncia, designará outro órgão do Ministério Público para oferecê-la, ou insistirá no pedido de arquivamento, ao qual só então estará o juiz obrigado a atender." 
fato delituoso ou por não haver indícios de sua autoria; se estiver extinta a punibilidade ou faltar condição exigida em lei para o exercício da ação penal.

O arquivamento é descrito por Rogério Lauria Tucci como "ato de natureza processual subjetivamente complexo, isto é, complementado necessariamente por órgão jurisdicional - juiz ou tribunal" ${ }^{, 754}$. De fato, no ordenamento em vigor, cabe a promoção de arquivamento, com exclusividade, ao Ministério Público (tanto que o art. 17 do CPP expressamente proíbe que a autoridade policial mande arquivar inquéritos) e se consolida com o subseqüente ato decisório do juiz competente, quando constitui ratificação da opinião negativa sobre o delito manifestada pelo titular da ação penal. Da decisão que ordena o arquivamento de peças de informação, a pedido de agente ministerial, não cabe recurso.

É certo que o Código de Processo Penal (e mais, a Constituição) separou acusação e jurisdição, cabendo ao Ministério Público a resolução de denunciar ou não. Desse modo, não é permitido ao Magistrado, de ofício, encerrar as investigações necessárias à formação da opinio delicti, pois se estaria substituindo ao órgão ministerial no exercício de seu múnus constitucional ${ }^{755}$, postura a ser proscrita em um sistema proclamado acusatório. Em alguns casos, todavia, pode o sujeito passivo da investigação provocar o Poder Judiciário para ver arquivado o inquérito, quando avultarem nos autos determinadas causas impeditivas do desenvolvimento da persecução penal, como nas hipóteses em que se evidencia causa de extinção da punibilidade ou ausência manifesta de tipicidade, fatores objetivos passíveis de maior sindicabilidade judicial.

Em outra via, é possível que o magistrado discorde da promoção de arquivamento formulada pelo Ministério Público. O Estado, assumindo o monopólio do jus puniendi, submete o poder punitivo às normas processuais (nulla poena sine judicio), donde a afirmação do princípio da obrigatoriedade, pelo qual a ação penal passa a ter

${ }^{754}$ Pedido de arquivamento em inquérito policial e preclusão consumativa. Revista dos Tribunais, São Paulo, v. 94, n. 831, jan. 2005, p. 511. Afrânio Silva Jardim (Arquivamento e desarquivamento do inquérito policial. Revista de Direito Penal e Criminologia, Rio de Janeiro, n. 35, jan./jun. 1983, p. 77) aponta-o como uma decisão material e subjetivamente administrativa, de natureza complexa, quando o arquivamento é ratificado (em suas palavras, decidido) pelo procurador-geral. Modo inverso, se acolhidas as razões em primeiro grau, seria uma decisão judicial pura e simples.

755 Já firmou o STJ o entendimento de que "[s]e não há requerimento expresso do Ministério Público, a Corte não pode determinar o arquivamento do Inquérito sob o argumento de delonga para o seu encerramento, pena de coarctar a atuação do titular da ação penal, mormente quando, como no caso dos autos, a apuração das provas é por demais complexa e específica. Ademais, inexiste previsão regimental para este fim” (AgRg no Inq 140/DF, rel. Min. Luiz Vicente Cernicchiaro, rel. p/ acórdão Min. Waldemar Zveiter, Corte Especial, por maioria, DJ de 24.5.1999). 
caráter de função necessária e obrigatória para o órgão público titular do direito de ação, que não pode fazer tábula rasa da lei, afastando a aplicação da norma penal ao seu mero alvedrio, por critérios de conveniência e oportunidade ${ }^{756}$.

Por isso, ao tratar do inquérito policial, o art. 28 do Código de Processo Penal prevê um mecanismo de controle externo do princípio da obrigatoriedade da ação penal pública ${ }^{757}$, consistente na possibilidade de o juiz de primeiro grau, em considerando insubsistentes as razões invocadas pelo Ministério Público, remeter os autos ao ProcuradorGeral, que dará a palavra soberana sobre a ação penal, iniciando-a, designando outro órgão para oferecê-la ou insistindo no arquivamento, caso em que só restará ao magistrado atender ao requerimento do parquet, agora vinculante ${ }^{758}$. Em outras palavras, o juiz de primeira instância contribui para a fiscalização da obrigatoriedade da denúncia, mas a resolução sobre o arquivamento ou não do inquérito, ao fim, não sai da esfera da instituição do Ministério Público ${ }^{759}$, eis que o Poder Judiciário pode vedar a instauração da ação penal, mas não pode determiná-la. Calha referir, ainda, o controle da obrigatoriedade passível de exercer o ofendido, com a previsão da ação penal privada subsidiária, nos arts.

756 CHUT, Marcos André. O controle do princípio da obrigatoriedade nos casos de competência originária dos tribunais. Revista dos Tribunais, São Paulo, v. 87, n. 756, out. 1998, p. 472. Como ensina Joaquim Canuto Mendes de Almeida (Princípios..., cit., p. 86-87), o princípio da indisponibilidade ou obrigatoriedade decorre de que "[o]s interesses tutelados pelas normas penais são, sempre, eminentemente públicos, sociais; sua atuação impõe-se ao Estado não como uma simples faculdade de consecução de um escopo não essencial, mas como obrigação funcional de realizar um dos fins essenciais de sua própria constituição, que é a manutenção e a reintegração da ordem jurídica”.

757 "Diz-se que o legislador optou pelo arquivamento judicial a fim de que, com a independência de que goza o Poder Judiciário, haja um rigoroso controle sobre o não-exercício da ação pública. Com este escopo, introduziu-se o Juiz na fase pré-processual, outorgando-lhe esta função anômala de caráter persecutório." (JARDIM, Afrânio Silva. Arquivamento..., cit., p. 85). Contra a forma judicial de fiscalização do princípio da obrigatoriedade da ação penal pública, Francisco Dias Teixeira (A titularidade..., cit., p. 179) defende que decisão de tal magnitude (não processar um indivíduo tido por agressor de um valor socialmente relevante) deve ser objeto de controle, mas feito internamente, dada a independência funcional do Ministério Público, e não pelo Judiciário. Igualmente, José Barcelos de Souza (Do arquivamento, cit., p. 81) é pela adoção de uma fiscalização interna, do órgão superior do Ministério Público, em todos os casos, para evitar arquivamentos indevidos. É a sistemática já adotada no inquérito civil público e foi a proposta contida na versão inicial do PL 4.209/2001, sobre investigação criminal, a qual, no entanto, não restou acolhida no Substitutivo aprovado na Câmara dos Deputados em 11 de dezembro 2008 e enviado ao Senado Federal.

758 Nessa hipótese, há quem destaque, como Sergio Demoro Hamilton (Alguns pespontos ao artigo 28 do Código de Processo Penal. Revista Síntese de Direito Penal e Processual Penal, Porto Alegre, v. 4, n. 21, ago./set. 2003, p. 25), não se tratar de "pedido" de arquivamento por parte do procurador-geral, porque este, na realidade, mediante decisão administrativa, determina o arquivamento do inquérito ou das peças de informação. Não seria pedido, porque não pode ser desatendido, e a redação do art. 28 do CPP seria defeituosa, ao mencionar que o procurador "insistirá no pedido", pois na realidade ele determinaria o arquivamento, voltando os autos para serem arquivados no juízo de origem.

${ }^{759}$ Segundo explica José Barcelos de Souza (Do arquivamento, cit., p. 68), "é ao próprio titular da ação que compete controlar a recusa de um de seus representantes (ainda que sob os auspícios do juiz) e, o que é 
5. ${ }^{\circ}$, LIX, da CF e 29 do CPP - sempre, porém, sob a condição de não haver sido arquivado o inquérito, porque o pedido de arquivamento não se confunde com inércia do titular da ação penal (condição para a legitimação extraordinária e sucessiva do ofendido).

Nos procedimentos investigatórios atrelados aos tribunais, não estabeleceu a Lei 8.038/1990 qualquer forma de controle da resolução de não denunciar. Referiu-se apenas à atribuição do Relator, a quem cabe "determinar o arquivamento do inquérito ou das peças informativas, quando o requerer o Ministério Público, ou submeter o requerimento à decisão competente do Tribunal" (art. 3. $\left.{ }^{\circ}, \mathrm{I}\right)$. Assim, deveriam prevalecer, no que aplicáveis, as regras gerais do Código de Processo Penal. Ocorre que, nesses casos, o titular da ação penal de iniciativa pública é o Chefe do Ministério Público, não havendo a quem, na hierarquia funcional, ficar sujeito o controle de suas resoluções. Logo, se o próprio Procurador-Geral, pessoalmente ou por mandatário legitimado mediante delegação, propõe o arquivamento do inquérito ou das peças de informação, não existirá órgão superior a que se reportar o magistrado (Relator) para rever o posicionamento originário ${ }^{760}$, caso dele dissinta, donde inaplicável a regra do art. 28 do $\mathrm{CPP}^{761}$.

Por outras palavras, uma vez formulado pelo Chefe do Ministério Público pedido de arquivamento do inquérito ou das peças de informação, outro caminho não

mais, de maneira a respeitar sua convicção pessoal”, tendo esse critério a virtude de não desrespeitar o nemo judex sine auctore, nem direta nem indiretamente.

760 João Cláudio Couceiro (Prerrogativas..., cit., p. 61) propõe como melhor solução a possibilidade de revisão da decisão do procurador-geral no próprio Ministério Público, pelo órgão colegiado que compõe sua instância superior. No entanto, já se cristalizou no STF a orientação pela qual não compete ao Tribunal discutir a procedência ou não da conclusão do Chefe do Ministério Público Federal, quanto à inexistência de elementos nos autos para a propositura da ação penal contra a autoridade sujeita à sua jurisdição, sendo ainda irrecorrível a decisão que a acata (Inq-QO 1.030/DF, rel. Min. Néri da Silveira, v.u., DJ de 13.12.1996; Pet-AgR 2.820/RN, rel. Min. Celso de Mello, Plenário, por maioria, DJ de 7.5.2004; Pet-AgR 2.509/MG, rel. Min. Celso de Mello, Plenário, por maioria, DJ de 25.6.2004).

761 No sentido da irrecusabilidade do pedido de arquivamento formulado por Subprocurador-Geral agindo por delegação, é esclarecedor o seguinte precedente: “Ação Penal de Competência originária do Superior Tribunal de Justiça. Pedido de arquivamento formulado pelo Subprocurador Geral da República e deferido pelo Relator (L. 8.038/90, art. 3. ${ }^{\circ}$ ). Agravo Regimental. Conhecimento. No mérito, negado provimento. O Subprocurador Geral da República, que atua, no Superior Tribunal de Justiça, nos casos de que trata o art. 48, da Lei Complementar n. ${ }^{\circ}$ 75, de 20 de maio de 1993, o faz por delegação do Chefe da Instituição Ministerial e constituiria um bis in idem, submeter ao seu reexame a promoção do órgão delegado. A delegação do Procurador Geral a Subprocurador Geral, juridicamente, equivale à atuação do primeiro. Na espécie, a distinção física é irrelevante. $\mathrm{O}$ art. 28, do CPP, apenas incidirá quando o membro do Ministério Público Federal exerce atribuição própria, sem a qualificação de delegabilidade com a qual não concordou o magistrado.” (AgRg na NC 86/SP, rel. p/ acórdão Min. José Arnaldo da Fonseca, Corte Especial, por maioria, DJ de 11.6.2001). Cf., ainda, AgRg na Sd 32/PB, rel. Min. Cesar Asfor Rocha, Corte Especial, v.u., DJ de 5.9.2005. E, também, no STF: Pet-AgR 4.131/MG, rel. Min. Cármen Lúcia, Plenário, v.u., DJ de 28.8.2008. 
restará ao Tribunal, senão acolher o pleito $^{762}$. Caber-lhe-á, puramente, enviar os autos ao arquivo, numa atividade administrativa burocrática, com mera aparência judicial, porque, além de a competência jurisdicional do Tribunal pressupor a formulação prévia de acusação ou de medida cautelar, em verdade, a conclusão pelo arquivamento emanou mesmo da instituição ministerial. Ressalte-se, porém, que o Procurador-Geral não pode arquivar ou determinar o arquivamento de representação ou notícia-crime sem decisão do Tribunal competente a respeito. É preciso que remeta os autos ao Judiciário para apreciação, a fim de que não reste caracterizada a sua inércia administrativa, ensejadora da ação penal privada subsidiária pelo ofendido ${ }^{763}$.

Em Questão de Ordem no Inquérito $2.341 / \mathrm{MT}^{764}$, o Supremo Tribunal Federal reafirmou antiga e uníssona jurisprudência afirmativa da intangibilidade do pedido de arquivamento formulado pelo Chefe do Ministério Público quando este forma "juízo negativo acerca da necessidade de apuração da prática delitiva”. Restará, então, ao Tribunal acolher a promoção, não havendo margem para questionar o mérito da opinião deduzida pelo titular da ação penal ${ }^{765}$. Deveras, se o exercício da ação penal pública é função

${ }^{762}$ Essa a conclusão de Tourinho Filho (Processo penal, cit., v. 2, p. 149): “Onde, na lei, a atribuição do Poder Judiciário de exercer esse controle da atividade inicial do Ministério Público? Não há. Não se infira da leitura do art. 599 do CPP (...). A palavra 'arquivamento', aí, está mal empregada. (...) O arquivamento aí tem o sentido de julgamento da improcedência da ação, porquanto só se efetiva após o oferecimento da denúncia ou queixa, como se constata pelos arquivos 558 e 559". Também Marcellus Polastri Lima (Ministério Público..., cit., p. 277) anota: "sendo sempre a última palavra em matéria de arquivamento do chefe do parquet, evidente que no caso de atribuição originária, promovido o arquivamento, nada há mais que se cogitar, não podendo o Tribunal discordar da 'decisão', só podendo determinar a remessa ao arquivo". E ainda Célio Silva Castro Sobrinho (Foro especial..., cit., p. 203): "Não vetante possa essa situação vir a causar perplexidade, não há melhor solução para a hipótese, já que o sistema acusatório adotado pela Carta Constitucional de 1988, obsta ao Poder Judiciário a assunção do status de acusador, de sorte que a última palavra é do Ministério Público, titular exclusivo da opinio delicti”.

763 Cf. COUCEIRO, João Cláudio. Prerrogativas..., cit., p. 60; SOUZA, José Barcelos de. Do arquivamento, cit., p. 102.

764 STF, Inq-QO 2.341/MT, rel. Min. Gilmar Mendes, Plenário, v.u., DJ de 17.8.2007.

765 Fortalecendo a intangibilidade do pedido de arquivamento formulado pelo Chefe do Ministério Público, nas ações penais originárias de tribunais, há precedente em que se esclareceu a prioridade do pedido de arquivamento, mesmo que ainda não homologado, sobre posterior denúncia formalizada por sucessor do Procurador-Geral, tornando-se aquele ato, portanto, irretratável para o titular da ação penal. Confira-se: "À luz de copiosa jurisprudência do Supremo Tribunal Federal, no caso de inquérito para apuração de conduta típica em que a competência originária seja da Corte, o pedido de arquivamento pelo procuradorgeral da República não pode ser recusado. Na hipótese dos autos, o procurador-geral da República requerera, inicialmente, o arquivamento dos autos, tendo seu sucessor oferecido a respectiva denúncia sem que houvessem surgido novas provas. Na organização do Ministério Público, vicissitudes e desavenças internas, manifestadas por divergências entre os sucessivos ocupantes de sua chefia, não podem afetar a unicidade da instituição. A promoção primeira de arquivamento pelo Parquet deve ser acolhida, por força do entendimento jurisprudencial pacificado pelo Supremo Tribunal Federal, e não há possibilidade de retratação, seja tácita ou expressa, com o oferecimento da denúncia, em especial por ausência de provas novas. Inquérito arquivado, em relação ao senador da República, e determinada a remessa dos autos ao 
institucional exclusiva do Ministério Público, qual previsto na Constituição, segue-se incontrastável o pleito originado do Chefe do Ministério Público no sentido de pôr termo à persecução do delito, sequer iniciada judicialmente ${ }^{766}$. A rejeição ao pedido de arquivamento formulado pelo titular da ação implicaria o exercício substitutivo do juízo de viabilidade da ação penal.

Precedentes de há muito sedimentam tal postura, ressalvando-se, todavia, as hipóteses em que a determinação judicial do arquivamento possa gerar coisa julgada com autoridade absoluta, quais sejam, a extinção da punibilidade (como a ensejada pela prescrição da pretensão punitiva) e a atipicidade da conduta ${ }^{767}$. Em situações tais, abre-se a porta para o dissenso, podendo acontecer de o Tribunal negar o pedido de arquivamento ${ }^{768}$.

Juízo de origem, quanto aos demais denunciados.” (STF, Inq 2.028/BA, rel. Min. Ellen Gracie, rel. p/ acórdão Min. Joaquim Barbosa, Plenário, por maioria, DJ de 16.12.2005).

766 Ainda na lição de José Barcelos de Souza (Do arquivamento, cit., p. 100): "Não cabendo, pois, ser admissível, qualquer controle judicial, mas tão-somente, e quando possível, a ação penal privada subsidiária, ou - nada o impede - pedido de reconsideração do ofendido ou interessado ao procurador, não seria de cogitar-se, em último recurso, de nomeação de procurador ad hoc, para forçar o cumprimento de uma incabível e impertinente decisão do tribunal".

767 Sobre a distinção entre os atos judiciais praticados nessas operações: "Inquérito policial: arquivamento requerido pelo Chefe do Ministério Público por falta de base empírica para a denúncia: irrecusabilidade. 1. No processo penal brasileiro, o motivo do pedido de arquivamento do inquérito policial condiciona o poder decisório do juiz, a quem couber determiná-lo, e a eficácia do provimento que exarar. 2. Se o pedido do Ministério Público se funda na extinção da punibilidade, há de o juiz proferir decisão a respeito, para declará-la ou para denegá-la, caso em que o julgado vinculará a acusação: há, então, julgamento definitivo. 3. Do mesmo modo, se o pedido de arquivamento - conforme a arguta distinção de Bento de Faria, acolhida por Frederico Marques -, traduz, na verdade, recusa de promover a ação penal, por entender que o fato, embora apurado, não constitui crime, há de o Juiz decidir a respeito e, se acolhe o fundamento do pedido, a decisão tem a mesma eficácia de coisa julgada da rejeição da denúncia por motivo idêntico (C.Pr.Pen., art. 43, I), impedindo denúncia posterior com base na imputação que se reputou não criminosa. 4. Diversamente ocorre se o arquivamento é requerido por falta de base empírica, no estado do inquérito, para o oferecimento da denúncia, de cuja suficiência é o Ministério Público o árbitro exclusivo. 5. Nessa hipótese, se o arquivamento é requerido por outro órgão do Ministério Público, o juiz, conforme o art. 28 C.Pr.Pen., pode submeter o caso ao chefe da instituição, o Procurador-Geral, que, no entanto, se insistir nele, fará o arquivamento irrecusável. 6. Por isso, se é o Procurador-Geral mesmo que requer o arquivamento - como é atribuição sua nas hipóteses de competência originária do Supremo Tribunal - a esse não restará alternativa que não o seu deferimento, por decisão de efeitos rebus sic stantibus, que apenas impede, sem provas novas, o oferecimento da denúncia (C.Pr.Pen., art. 18; Súmula 524).” (STF, Inq-QO 1.604/AL, rel. Min. Sepúlveda Pertence, Plenário, v.u., DJ de 13.12.2002).

768 O Superior Tribunal de Justiça, em situações excepcionais, já indeferiu pedido de arquivamento fundado na atipicidade do fato (afirmando que, no caso, tratava-se de dúvida quanto à tipicidade do fato) e aplicou o art. 28 do CPP, remetendo os autos ao Procurador-Geral da República, com base em orientação antiga do STF (HC 70.029/CE, rel. Min. Marco Aurélio, Plenário, por maioria, DJ de 13/8/1993), hoje superada, eis que, como já explicado, o Subprocurador-Geral da República atua, no STJ, por delegação do Procurador-Geral (Inq 181/DF, rel. Min. Luiz Vicente Cernicchiaro, Corte Especial, por maioria, DJ de 18.11.1996). Em outro julgamento, aquela Corte negou o pedido de arquivamento de investigação interna corporis, quando, após designação de Subprocurador-geral para investigar determinada notícia-crime, sequer houvera uma tentativa de investigação, nem mesmo se ouvindo os imputados. Com isso, a ausência de investigação teria violado o art. 18, parágrafo único, da LC 75/1993. Determinou-se, ao fim, a intimação do Procurador-Geral da República sobre a omissão (NC 358/DF, rel. Min. Ari Pargendler, Corte Especial, por maioria, DJ de 7.8.2006). 
Há necessidade, nessas hipóteses, de decisão jurisdicional a respeito ${ }^{769}$, a qual se revestirá - embora não se trate de sentença - da autoridade da coisa julgada, inviabilizando, em conseqüência, o posterior ajuizamento (ou prosseguimento) de ação penal contra aquele já beneficiado por tal decisão, ainda que o Ministério Público, por intermédio de novo representante e mediante reinterpretação e nova qualificação dos mesmos fatos, chegue a conclusão diversa daquela que motivou o seu anterior pleito de extinção da punibilidade ${ }^{770}$. A distinção, portanto, entre ambas as situações é basicamente quanto à possibilidade de revolvimento ulterior dos autos da investigação.

O problema com que se pode deparar refer-se ao eventual indeferimento do pedido de arquivamento promovido pelo próprio chefe da instituição do Ministério Público, sem que haja órgão superior ao qual submeter os autos nos termos do art. 28 do $\mathrm{CPP}^{771}$. Pois a rejeição ao pedido de arquivamento pelo Tribunal não pode implicar o exercício substitutivo do juízo de viabilidade da acusação, nem compelir o ProcuradorGeral a ofertar denúncia, sob pena de vulnerar-se o art. 129, I, da Constituição. Nesses casos, fica difícil antever os desdobramentos de eventual negativa ao arquivamento, quando mais não se tendo notícia, até o presente, de algum precedente do Supremo Tribunal Federal envolvendo tal situação.

${ }^{769}$ Contra, Afrânio Silva Jardim (Direito processual penal, cit., p. 185) entende que não é possível haver um julgamento sem processo, nem sentença em procedimento administrativo, quando não existe ainda imputação formal nem se individualiza uma infração penal, e que se no curso do inquérito ocorrer algum fato extintivo da punibilidade o Ministério Público deverá requerer o arquivamento dos autos, funcionando a extinção da punibilidade apenas como razão de decidir. Já Sérgio Marcos de Moraes Pitombo (Inquérito policial..., cit., p. 23-25) defende ser o ato de arquivamento uma decisão judicial que encerra um juízo de suficiência sobre a questão penal, alicerçado em preliminar formação da culpa. E mais: tal decisão judicial, no seu entender, "pondo termo à primeira fase da persecução penal, pode só possuir a natureza de sentença. Sentença, diga-se, favorável ao indiciado, que estanca o inquérito, posto qual se acha; ou que decide, liminarmente, sobre não ser caso de ação penal”.

${ }^{770}$ Cf. STF, HC 84.253/RO, rel. Min. Celso de Mello, 2. ${ }^{a}$ Turma v.u., DJ de 17.12.2004.

771 Ressalte-se que, no âmbito do Ministério Público da União, a LC 75/1993 atribui às Câmaras de Coordenação e Revisão, colegiados superiores da instituição, "manifestar-se sobre o arquivamento de inquérito policial, inquérito parlamentar ou peças de informação, exceto nos casos de competência originária do Procurador-Geral" (art. 62, IV), donde se sustentar que tal órgão atua como revisor do pedido de arquivamento requerido por Procurador Regional da República, junto aos Tribunais Regionais Federais e Eleitorais. Apregoa-se que estaria derrogado o art. 28 do CPP na parte em que atribui ao Procurador-Geral da República a revisão do destino do inquérito (cf. FONTELES, Cláudio Lemos. Ainda sobre a questão do artigo 28 do Código de Processo Penal. Boletim dos Procuradores da República, São Paulo, v. 3, n. 27, p. 4-7, jul. 2000). Já nos Estados, o art. 12, XI, da Lei 8.625/1993 estabelece caber ao Colégio de Procuradores de Justiça "rever, mediante requerimento de legítimo interessado, nos termos da Lei Orgânica, decisão de arquivamento de inquérito policial ou peças de informações determinada pelo Procurador-Geral de Justiça, nos casos de sua atribuição originária”. Assim, ao próprio Ministério Público se permite rever a decisão de arquivamento tomada pelo Chefe da instituição. 
Não obstante a Lei 8.038/1990 estabeleça que compete ao Relator decretar a extinção da punibilidade, nos casos previstos em lei (art. 3.․, II), é possível que, nas hipóteses mais complexas, submeta o pedido ao órgão colegiado ${ }^{772}$.

Uma vez arquivados os autos da investigação, descabe revolvê-los, a menos que o arquivamento se tenha motivado por carência de base empírica para a denúncia e (i) esteja-se diante de novos elementos de convicção, além de (ii) não se encontrar extinta, por qualquer causa legal, a punibilidade, nos termos do art. 18 do Código de Processo Penal e da súmula 524 do Supremo Tribunal Federal ${ }^{773}$. É hoje assente o entendimento de que não se admite a propositura de ação penal após o arquivamento do inquérito por decisão da autoridade judicial, sem que haja notícia de novas provas, a partir das quais podendo desencadear-se novas investigações, e não mera repetição das anteriormente já integradas ao inquérito ${ }^{774}$.

\subsubsection{O juízo de admissibilidade da peça inicial acusatória}

Encerrado o procedimento investigativo, caso se convença o titular da ação penal da existência de crime praticado por autoridade detentora de foro especial e de indícios suficientes de sua autoria, ofertará, perante o órgão competente segundo o critério funcional, a acusação, em petição escrita.

772 Proclamou o Supremo Tribunal Federal: "Inquérito policial. Arquivamento. Requerimento do ProcuradorGeral da República. Pedido fundado na alegação de atipicidade dos fatos. Formação de coisa julgada material. Não atendimento compulsório. Necessidade de apreciação e decisão pelo órgão jurisdicional competente. Inquérito arquivado. Precedentes. O pedido de arquivamento de inquérito policial, quando não se baseie em falta de elementos suficientes para oferecimento de denúncia, mas na alegação de atipicidade do fato, ou de extinção da punibilidade, não é de atendimento compulsório, senão que deve ser objeto de decisão do órgão judicial competente, dada a possibilidade de formação de coisa julgada material." (Pet 3.297/MG, rel. Min. Cezar Peluso, Plenário, v.u., DJ de 17.2.2006).

773 Súmula 524 do STF: “Arquivado o inquérito policial, por despacho do juiz, a requerimento do Promotor de Justiça, não pode a ação penal ser iniciada, sem novas provas”. Note-se, com Afrânio Silva Jardim (Arquivamento..., cit., p. 84), que o art. 18 do CPP exige apenas, para o desarquivamento dos autos da investigação, que haja a "notícia" de novas provas, o que já legitima o prosseguimento das investigações encerradas; já a súmula 524 trata do momento de apresentação da demanda após o inquérito policial haver sido arquivado: a propositura da ação penal dependerá do sucesso dessas novas investigações, ou seja, da efetiva produção desse novo elemento de convicção.

774 E sobre o que se constitui em "novas provas", já decidiu o Excelso Pretório, em antigo e preclaro julgado, que: "Novas provas, capazes de autorizar inicio da ação penal, segundo a súmula 524, serão somente aquelas que produzem alteração no panorama probatório dentro do qual fora concebido e acolhido o pedido de arquivamento. A nova prova há de ser substancialmente inovadora e não apenas formalmente

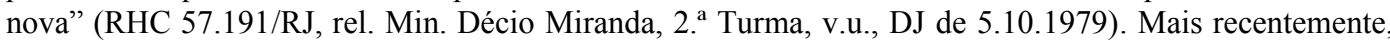
acompanhando a já consolidada orientação: "Se o procedimento administrativo encaminhado à Procuradoria vem a ser arquivado, essa decisão administrativa não pode ser substituída por nova 
Apresentada ${ }^{775}$ a denúncia ou queixa-crime, o Relator determinará a notificação do denunciado ou querelado para oferecer resposta no prazo de 15 (quinze) dias (art. 4. ${ }^{\circ}$, caput, da Lei 8.038/1990), ingressando-se assim em etapa intermediária entre a fase investigativa e a fase processual propriamente dita.

Antes da notificação, porém, se o delito imputado pelo titular da ação penal for definido como de menor potencial ofensivo - assim entendida aquela infração cuja pena máxima em abstrato não seja superior a dois anos, ex vi do art. 61 da lei 9.099/1995 c/c art. 2. ${ }^{\circ}$, parágrafo único, da Lei 10.259/2001 -, é aplicável o instituto da transação penal (art. 76 da Lei 9.099), que cumpre ser de logo proposta pelo Ministério Público, desde que presentes os demais requisitos autorizadores. Nesse caso, o Relator deve adotar as medidas pertinentes, ao receber o inquérito ou as peças informativas, designando audiência para realização da proposta de transação penal. Aplicáveis são, de resto, aos delitos perseguidos originariamente em tribunais, as demais medidas previstas na Lei 9.099/1995, como a composição civil dos danos (art. 74) e a suspensão condicional do processo (art. 89) ${ }^{776}$.

A notificação prévia ao exame de admissibilidade da acusação consiste em peculiaridade benfazeja das investigações originárias de tribunais (e recentemente estendida aos procedimentos ordinário e sumário ${ }^{777}$ ), na medida em que permite, ao menos ao seu findar, e caso haja a dedução formal da acusação, a chamada resposta ou defesa preliminar, oportunidade em que o denunciado ou querelado é notificado para expor as suas razões defensivas ante os termos da peça acusatória, podendo, assim, elidir a formalização do processo, frustrando-o em seu átrio. É formalidade - verdadeira

denúncia, apresentada pelo novo Procurador-Geral, sem a existência de provas novas.” (Inq 2.054/DF, rel. Min. Ellen Gracie, Plenário, por maioria, DJ 6.10.2006).

775 A redação do art. 4. ${ }^{\circ}$ da Lei 8.038 é mais precisa e menos equívoca que a outrora vigente, do art. 558, caput, do CPP, segundo a qual, "recebida a queixa ou a denúncia, notificar-se-á o acusado para que, no prazo de quinze dias, ofereça resposta escrita". Discutia-se se o uso da palavra "recebida" era feito no sentido técnico-jurídico ou na aplicação coloquial, significando apenas "apresentada" ou "oferecida", predominando, na doutrina, a primeira vertente. Cf., sobre a celeuma: LESSA, Paulo Inácio Dias. Do 'recebimento' da queixa ou da denúncia nas ações penais da competência originária dos Tribunais de Justiça (TJMT). Revista Trimestral de Jurisprudência dos Estados, São Paulo, v. 17, n. 116, p. 9-12, set. 1993.

776 Essa diretriz é antiga e pacífica no Supremo Tribunal Federal: Inq-QO 1.055/AM, rel. Min. Celso de Mello, Plenário, v.u., DJ de 24.5.1996; HC 77.303/PB, rel. Min. Carlos Velloso, 2. ${ }^{\text {a } T u r m a, ~ v . u ., ~ D J ~ d e ~}$ 30.10.1998; Inq 2.170/DF, rel. Min. Carlos Britto, Plenário, v.u., DJ de 30.6.2005. Cf., ainda: JORGE, Mário Helton. Crimes de menor potencial ofensivo: ações penais de competência originária dos tribunais: aplicabilidade dos benefícios despenalizadores da composição civil dos danos e da transação penal. Revista dos Tribunais, São Paulo, v. 93, n. 830, p. 451-457, dez. 2004.

777 Vide nota 203. 
prerrogativa concedida ao acusado - que consta da Lei 8.038/1990 e de todos os regimentos internos das Cortes, ao cuidarem das ações penais originárias ${ }^{778}$.

A notificação deve seguir com cópia da denúncia ou da queixa, do despacho do Relator e dos principais documentos, por ele indicados ${ }^{779}$. Nada impede sejam produzidas provas nessa fase preliminar. Se com a resposta forem juntados documentos novos, será intimada a parte contrária para sobre eles se manifestar, em 5 (cinco) dias, em obediência ao contraditório ${ }^{780}$.

Trata-se de etapa necessária e que consome tempo considerável nas ações com numerosos denunciados, tanto assim que, no Inquérito 2.245/MG (uma vez mais, o “caso Mensalão"), o Ministro Relator determinou fossem concedidos os pedidos de vista formulados por cada advogado, porém sem a retirada dos autos, sob pena de tornar-se impraticável a carga dos autos por todos que o pedissem, além de ser necessária a permanência dos autos na secretaria para a realização das notificações e cumprimento do prazo por todos os denunciados. Medida salutar seria, nesses casos, a digitalização de documentos, para não privar os imputados e seus advogados do acesso integral aos atos e diligências praticados, por tempo razoável para prepararem sua defesa, o que prestigiaria a celeridade do feito, sem menoscabar o direito do advogado de inteiro acesso aos autos.

Por se tratar de oportunidade de defesa que antecede ao processo, recebe o adjetivo de preliminar, não se podendo entretanto olvidar, como já destacado, a inserção da defesa do investigado também no próprio curso da investigação.

Após a apresentação da defesa preliminar do denunciado, os autos devem ser conclusos ao Relator com vistas à apreciação da admissibilidade da ação penal. Como reza o art. $6^{\circ}$, caput, da Lei 8.038/1990, “o relator pedirá dia para que o Tribunal delibere sobre o recebimento, a rejeição da denúncia ou da queixa [art. 395 do CPP], ou a improcedência da acusação, se a decisão não depender de outras provas”.

O juízo de prelibação sobre a acusação apresentada não cabe, portanto, ao Relator, mas sim ao Tribunal, seja pelo Plenário ou pelo órgão fracionário competente, nos termos do seu regimento interno. Assim, além do voto do Relator pelo recebimento ou não da peça acusatória, externado em sessão específica à qual comparecem as partes e seus advogados, não raro com teses oralmente sustentadas, é preciso colher o pronunciamento

\footnotetext{
778 Art. $4 .^{\circ}$ da Lei 8.038/1990; art. 233 do RISTF e art. Art. 220 do RISTJ.

779 Art. 4. ${ }^{\circ}, \S 1 .^{\circ}$, da Lei 8.038/1990.

780 Art. 5. ${ }^{\circ}$, caput, da Lei 8.038/1990.
} 
dos demais integrantes do órgão julgador, a fim de que, sob concerto ao menos da maioria, seja decidido o destino daquela imputação.

Consoante recente precedente da Corte Especial do Superior Tribunal de Justiça, em havendo vários co-réus com diferentes advogados, em observância ao princípio do contraditório e da ampla defesa, deve-se observar o prazo de 15 (quinze) minutos de sustentação oral para cada um dos causídicos, ressalvada a hipótese de defenderem o mesmo réu ${ }^{781}$.

É de observar-se que, nas acusações oferecidas no Supremo Tribunal Federal contra o Presidente ou o Vice-Presidente da República ou Ministros de Estado, ou no Superior Tribunal de Justiça contra Governador de Estado ou do Distrito Federal, não sendo o caso de inépcia da denúncia ou a queixa (caso em que a inicial pode ser rejeitada de plano), o processo paralisa, sendo solicitada, pelo Relator, autorização à Casa Legislativa respectiva ${ }^{782}$ para o seu processamento, solicitação esta que já implica suspensão do prazo prescricional ${ }^{783}$. Não cabe nem mesmo ser feita a notificação prevista no art. $4 .^{\circ}$ da Lei 8.038/1990 enquanto não concedida a autorização assemblear ${ }^{784}$, a qual representa uma condição para o exercício da ação penal ${ }^{785}$. A autorização, licença ou admissão prévia da acusação pela Assembléia não vincula o Tribunal, que pode ainda rejeitar a inicial, ou mesmo julgar o mérito logo no início do processo, permitida que é a

781 A Corte Especial do STJ, dando interpretação mais ampla aos dispositivos regimentais (arts. 160, $\S 7 .^{\circ}$, e $222, \S 1 .^{\circ}$, do RISTJ) que estabelecem o prazo em dobro de sustentação oral para o caso de litisconsórcio, decidiu que o prazo de quinze minutos, quando houver vários indiciados com diferentes advogados, será individual para cada causídico, ressalvando que, se defenderem o mesmo acusado, o prazo será dividido entre os advogados (Inq-QO 323/PE, rel. Min. Cesar Asfor Rocha, por maioria, DJ de 30.6.2003). Igual posicionamento foi tomado na APn-QO 425/ES (rel. Min. José Arnaldo da Fonseca, por maioria, DJ 15.5.2006), esclarecendo-se ainda que, nesses casos, o prazo para sustentação oral do autor será de trinta minutos. Vale registrar que na sessão de julgamento do mérito da ação penal originária, o prazo para sustentação oral será de uma hora para cada parte, conforme o art. 12, I, da Lei 8.038/1990.

782 Segundo o art. 51, I, da CF, compete à Câmara dos Deputados autorizar, por dois terços de seus membros, a instauração de processo contra o Presidente e o Vice-Presidente da República e os Ministros de Estado; e, por simetria (art. $25 \mathrm{da} \mathrm{CF}$ ), às Assembléias Legislativas cabe autorizar o processamento criminal dos Governadores de Estado, previsão esta constante das Constituições Estaduais. Em sentido oposto, entendendo que a Constituição Federal não condicionou o recebimento de denúncia contra Governador a qualquer manifestação do Legislativo Estadual, sendo tal matéria de competência legislativa exclusiva da União (art. 22, I, da CF) e não se podendo deixar a cada Estado criar, aleatoriamente, tal condição, sob pena de discriminação injusta, João Cláudio Couceiro (Prerrogativas..., cit., p. 103).

783 Cf.: STJ, Pet 377/DF, rel. Min. Antônio de Pádua Ribeiro, Corte Especial, por maioria, DJ de 8.9.1997.

${ }^{784}$ Nesse sentido: STJ, AgRg no Inq 185/AC, rel. Min. Anselmo Santiago, rel. p/ acórdão Min. William Patterson, Corte Especial, por maioria, DJ de 25.5.1998. Por outro lado, "a circunstância de a Assembléia Legislativa manifestar-se contrariamente à instauração de processo penal contra governador não traduz óbice definitivo à propositura da ação ou ao prosseguimento do processo já iniciado. Deixando ele o cargo, desaparece o obstáculo.” (STJ, APn 27/BA, rel. Min. Eduardo Ribeiro, Corte Especial, por maioria, DJ de 20.2.1995). 
decisão pela improcedência liminar da acusação, se a decisão não depender de outras provas (art. 6. ${ }^{\circ}$, caput, da Lei 8.038/1990) ${ }^{786}$.

Recebida a denúncia, pode ser determinada medida cautelar restritiva de liberdade (decisão esta que não necessariamente tocará ao órgão colegiado, podendo ser exarada pelo Relator, a teor do art. 2. ${ }^{\circ}$, parágrafo único, da Lei 8.038/1990) ou ainda a medida cautelar de afastamento do cargo. $\mathrm{O}$ afastamento do acusado do cargo, sempre por decisão colegiada, não emerge de forma automática ${ }^{787}$, reclamando adequada motivação ${ }^{788}$. Os dispositivos que os prevêem (art. 86, $\S 11^{\circ}, \mathrm{I}$, da CF, para o Presidente da República, e art. 29 da Lei Complementar 35/1979, para os magistrados) precisam ser lidos de forma harmônica com o ordenamento jurídico, não se dispensando a verificação da necessidade da decretação da medida cautelar, pela aplicação do princípio da proporcionalidade. Já os membros do Congresso Nacional não podem ser afastados cautelarmente de suas funções ${ }^{789}$.

Lembre-se que os Deputados Federais e Senadores, desde a expedição do diploma, serão submetidos a julgamento pelo Supremo Tribunal Federal (art. 53, $\S 1 .^{\circ}$, da $\mathrm{CF}$ ), tendo havido, como já declinado, importante alteração no seu estatuto com a Emenda

${ }^{785}$ Ou mais uma condição legal para o exercício do direito à jurisdição penal, cuja falta obstaculiza a regular formação do processo (TUCCI, Rogério Lauria. Teoria..., cit., p. 98).

786 O julgamento liminar pela improcedência equivale à absolvição do acusado na ocasião da admissibilidade da denúncia. No procedimento comum do CPP, a Lei 11.719/2008 instituiu a possibilidade de absolvição sumária do acusado, quando provadas determinadas situações (art. 397), casos em que o juiz também decide antecipadamente o mérito da imputação. No STF, julgou-se liminarmente improcedente a acusação no Inq 933/MG, por atipicidade penal do fato (rel. Min. Sepúlveda Pertence, Plenário, v.u., DJ de 28.6.2002). Entendendo que a improcedência liminar prevista no art. $6^{\circ}{ }^{\circ}$, caput, da Lei 8.038 viola o art. $5 .^{\circ}$, caput, primeira parte, o inciso LIV e o $\S 2 .^{\circ}$, da CF, por ofender os princípios da igualdade, do devido processo legal, da proporcionalidade, da verdade real e do contraditório: SARAIVA, Wellington Cabral. Absolvição liminar de réus com foro por prerrogativa de função: inconstitucionalidade. Revista dos Tribunais, São Paulo, v. 84, n. 716, p. 548-559, jun. 1995.

${ }^{787}$ Como fazem parecer algumas Constituições, p. ex., a do Estado de Pernambuco, ao prever: "Art. 39. Admitida a acusação contra o Governador, por dois terços da Assembléia Legislativa, será ele submetido a julgamento perante o Superior Tribunal de Justiça, nas infrações penais comuns, ou perante o Tribunal Especial, nos crimes de responsabilidade. $\S 1 .^{\circ}$ O Governador ficara suspenso de suas funções: I - nas infrações penais comuns, se recebida a denúncia ou queixa-crime pelo Superior Tribunal de Justiça; II nos crimes de responsabilidade, após a instauração do processo pelo Tribunal Especial.”.

${ }^{788} \mathrm{Na}$ APn 401/RO, único caso, até o presente, em que houve autorização assemblear para processamento criminal de Governador de Estado - envolvendo o governador de Rondônia, Ivo Cassol -, resolveu-se pela competência do STJ para deliberar sobre o afastamento do governador. Para se declarar competente, a Corte Especial confrontou o art. 86 da Constituição Federal com o art. 67, § 1. ${ }^{\circ}$, da Constituição do Estado de Rondônia. Recebida a denúncia por unanimidade, a maioria da Corte Especial decidiu pelo nãoafastamento do acusado (STJ, rel. Min. Carlos Alberto Menezes Direito, DJ de 21.8.2006).

789 É de lembrar que a Emenda Constitucional 1/1969 previa, no art. 32, § 5..$^{\circ}$ " Nos crimes contra a Segurança Nacional, poderá o Procurador-Geral da República, recebida a denúncia e considerada a gravidade do delito, requerer a suspensão do exercício do mandato parlamentar, até a decisão final de sua representação pelo Supremo Tribunal Federal”. 
Constitucional 35/2001. Somente após o recebimento de denúncia contra parlamentar, por crime ocorrido após a diplomação, o Tribunal cientificará a Casa a que ele pertence, a qual poderá, pelo voto da maioria de seus membros, sustar o andamento da ação, já iniciado (art. 53, § 3. ${ }^{\circ}$, da CF). Em deliberando a Casa pela sustação, ficam suspensos assim o processo como a prescrição, enquanto durar o mandato (art. 53, $\S 5^{\circ}$, da $\mathrm{CF}$ ). A norma contém indiscutível avanço se comparada à redação primitiva do art. $53, \S 10^{\circ}$ - pela qual o parlamentar não podia sequer ser processado criminalmente sem a licença de sua câmara (condição ainda persistente, conforme visto, para os chefes do Poder Executivo Federal e Estadual), na maioria das vezes negada ou, simplesmente, não apreciada -, já que, agora, o processo principia e prossegue e o curso da prescrição é retomado, cabendo à Casa deliberar por sua sustação ${ }^{790}$.

A inclusão do feito em pauta para apreciação do órgão jurisdicional legitimado (seja ele plenário, especial ou fracionário) há de ser publicada na imprensa oficial, para que com isso se pratique a necessária comunicação aos interessados, indispensável ao pleno exercício dos seus direitos e faculdades ${ }^{791}$. Além disso, a comunicação dos atos ao membro do Ministério Público, titular da ação penal pública no tribunal, deve dar-se pessoalmente, conforme prerrogativa institucional. Somente com a publicidade conferida à designação de data para a sessão pode ser exercida, por exemplo, a faculdade dos denunciados, querelantes ou querelados, de sustentação oral, prevista no art. $6^{\circ}, \S 1 .^{\circ}$, da Lei 8.038/1990 por 15 (quinze) minutos. Nessa oportunidade, a defesa poderá suscitar, entre outras, questões de ordem que impeçam o julgamento naquela sessão.

Como bem anota Ada Pellegrini Grinover, o contraditório se efetiva pela contraposição dialética entre acusação e defesa, fortalecendo a imparcialidade do juiz, no momento da síntese, "pela apreciação do resultado de atividades justapostas e paritárias desenvolvidas no curso do procedimento". Surge indiscutível a relação entre os meios de

790 "Prescrição Criminal. Prazo. Pretensão punitiva. Denúncia contra deputado federal. Oferecimento durante a vigência da redação original do art. 53 da Constituição da República. Solicitação de licença à Câmara dos Deputados e sobrestamento do feito. Despacho do Ministro Relator. Suspensão do curso da prescrição. Demora na apreciação do pedido por falta de cópias do inquérito. Irrelevância. Licença indeferida. Impedimento jurídico ao curso do processo penal. Suficiência. Superveniência da Emenda Constitucional n. 35/2001. Retomada do fluxo do prazo. Prescrição não consumada da ação penal. Preliminar repelida. Até o advento da Emenda Constitucional n. 35/2001, reputava-se suspenso o curso da prescrição da pretensão punitiva desde a data do despacho do Ministro Relator que solicitava licença para instauração de ação penal contra membro do Congresso Nacional.” (STF, Inq 1.326/RO, rel. Min. Cezar Peluso, Plenário, v.u., DJ de 3.2.2006). 
comunicação processual e a participação dos interessados nos atos preparatórios do provimento, "pois sem a informação não há contraditório possível". Dessa forma, o acompanhamento dos atos judiciais pelas partes, especialmente quando se trata de julgamentos por órgãos colegiados de tribunais, "constitui expressão da publicidade interna, que, por sua vez, é uma garantia instrumental em relação à própria defesa, na medida em que assegura o conhecimento imediato das decisões e das razões de decidir, para o que o interessado possa valer desde logo os seus direitos" ${ }^{\text {,792. }}$.

Considerando que nem todos os tribunais possuem órgão especial, muitas acusações são apreciadas pelo Plenário (casos, por exemplo, do STF e, entre os Tribunais Regionais Federais, apenas o da 5. ${ }^{a}$ Região), nos dias previamente designados para suas reuniões ordinárias, cuja pauta comporta feitos os mais diversificados, inclusive cíveis.

À luz dessa moldura, é possível prever uma sessão longa, na qual nem sempre se obtém a apreciação de só uma acusação penal, pois, corriqueiramente, até pela freqüente complexidade dos fatos que baseiam as acusações, são formulados pedidos de vista pelos demais componentes do órgão para detida análise da questão levada pelo Relator. O encerramento da admissibilidade da acusação, portanto, que em primeiro grau consuma-se com a decisão do juiz singular, nos tribunais pode postergar-se por mais de uma sessão, senão quando cada um dos membros componentes do órgão julgador poderá formular seu pedido de vista.

Ocorre que em nenhuma passagem a Constituição se refere à necessidade de que seja o Plenário ou a Corte Especial o órgão competente ratione personae. Daí que o cometimento dessa atribuição, mediante norma regimental, às turmas ou câmaras do tribunal poderia resultar em melhor experiência, sobretudo do ponto de vista da garantia da razoável duração da investigação ${ }^{793}$, eis que, quanto maior o órgão colegiado, mais demorado poderá ser o processo de decisão coletiva, admissíveis que são sucessivos pedidos de vista, retardando, em muito, a decisão sobre o início da ação penal.

A solenidade do ato de admissão ou rejeição da peça acusatória vem estampada, de outro lado, pelo relevo substancial que a ele se confere. O rigorismo

791 Já decidiu o STJ que é prescindível a intimação via postal da inclusão da ação penal (ou do inquérito) na pauta de julgamentos (Inq-QO 282/RJ, rel. Min. Cesar Asfor Rocha, Corte Especial, v.u., DJ de 12.11.2001).

792 O juiz natural..., cit., p. 422-424.

793 Elementar à garantia da razoável duração do processo (art. 5. ${ }^{\circ}$, LXXVIII, a CF). Assim, por exemplo, o Regimento Interno do Tribunal de Justiça do Rio Grande do Sul, no art. 24, parágrafo único, atribui competência à 4. ${ }^{\mathrm{a}}$ Câmara Criminal para o processo e julgamento dos Prefeitos Municipais. 
imprimido pelos tribunais sobre a visualização dos requisitos mínimos a demonstrar a justa causa para a ação penal aproximam, equivocadamente, o juízo de prelibação do juízo sobre o mérito da acusação, como se se tratasse de condenar ou absolver o denunciado, prática que não se compadece com a garantia da presunção de inocência aplicada aos imputados durante toda a persecução criminal e cria o risco de se anteciparem, indevidamente, juízos de mérito que somente ao cabo do exercício do direito à prova e da ampla defesa se poderão, legitimamente, afirmar. O ideal seria submeter o juízo de admissibilidade da acusação a um órgão colegiado, porém menos numeroso, como uma turma ou câmara do Tribunal, ficando ao órgão especial ou plenário o julgamento final, com isso mantida a garantia da prerrogativa de função.

No mais, não é previsto recurso das decisões de órgãos plenários, o que vai de encontro à garantia de duplo grau de jurisdição prevista para todo acusado em processo criminal, no esteio dos tratados a que o Brasil aderiu ${ }^{794}$. Quando as decisões são tomadas individualmente, pelo Relator, ou por um colegiado fracionário do Tribunal, poderiam os Regimentos prever recursos como o agravo regimental para o Órgão Especial ou para o Plenário, permitindo-se o reexame da matéria de fato, atendendo assim à mencionada garantia. Poder-se-á, em todo caso, valer-se do habeas corpus e dos recursos especial ou extraordinário, com os âmbitos de cognição que lhes são permitidos.

Sob o aspecto da classificação do feito perante o Tribunal, quanto ao momento em que passa ele de "Inquérito" a "Ação Penal", insta sublinhar uma divergência de posturas notada ao menos entre as Cortes superiores. Ao passo que, no STJ, o só oferecimento da denúncia ou queixa já atrai a classificação de "Ação Penal”, no STF o momento para a conversão dá-se apenas quando recebida a peça acusatória pelo órgão Plenário (antes disso, se não vier lastreada em inquérito, a inicial é simplesmente autuada como "Denúncia"795, na ação pública, ou como "Inquérito", no caso de ação privada), essa que, a nosso ver, caracteriza-se como a mais adequada opção, pois somente a partir do recebimento da vestibular é possível conceber instaurada a ação penal, com todas as conseqüências daí decorrentes, inclusive quanto ao status do sujeito passivo.

Caso recebida a denúncia ou a queixa, ingressa-se na fase processual propriamente dita. É citado o acusado e designado o seu interrogatório, abrindo-se o prazo

\footnotetext{
${ }^{794}$ Vide art. 14.5 do Pacto Internacional de Direitos Civis e Políticos e art. 8.2, $h$, da Convenção Americana sobre Direitos Humanos, ambos ratificados pelo Brasil.

795 Não existindo, em paralelo, a classe "Queixa”, sendo as peças correlatas autuadas como "Inquérito".
} 
de 5 (cinco) dias para apresentação de defesa prévia (arts. 7..$^{\circ}$ e 8. ${ }^{\circ}$ da Lei 8.038/1990). A partir daí, segue-se a instrução criminal, aplicando-se as normas dos arts. $7 .^{\circ}$ e seguintes da Lei 8.038/1990, com a inquirição de testemunhas, requerimento de diligências e apresentação, por escrito, de alegações finais (arts. 10 e 11 da Lei 8.038/1990). 


\section{CONCLUSÕES}

A investigação preliminar é assunto crucial ao estudo do processo penal, na medida em que permite a reunião de elementos que justifiquem a instauração ou não da persecução judicial, além de impedir a formulação de acusações açodadas, exercendo assim relevantes funções preventiva e preparatória do processo. Além disso, na etapa prévia, de natureza administrativa e procedimental, muitos direitos individuais são postos em jogo e, por vezes, amesquinhados ou simplesmente ignorados, o que torna imperiosa a compreensão do estatuto dos direitos e garantias fundamentais, expressos na Constituição Federal e em tratados aos quais o Brasil aderiu, extensivos à etapa prévia da persecução. Entre eles, o juiz natural, a presunção de inocência, o direito de defesa, a publicidade e a motivação das decisões, todos derivados de uma mesma fonte - o devido processo legal - e interdependentes, de modo que o procedimento preliminar de investigação com fins penais, de qualquer espécie que seja (policial, judicial, parlamentar, ministerial), somente obedece ao devido processo legal quando os observa em seu conjunto.

Pela dignidade de suas funções, a investigação preliminar tem relevante papel a cumprir no Estado de Direito - cujos contornos hão de abrigar a tutela de liberdades -, não sendo, porém, difícil constatar que, na prática, seus objetivos muitas vezes malogram, por fatores freqüentemente atrelados à burocratização excessiva desse procedimento (que deveria ser o mais simples possível) e à repetição inútil de atos, postergando-se em demasia a sua tramitação e chegando-se mesmo ao termo da prescrição, verdadeira sanção ao ente público por sua ineficácia na tarefa investigativa.

As dificuldades são potencializadas se direcionarmos nosso foco às investigações preliminares nos delitos de competência originária de tribunais, cuja importância é sobressalente no sistema criminal, por representarem a persecução do Estado contra seus próprios agentes, aqueles que ditam muitas vezes o rumo da política, da segurança e da economia do país, com reflexo direto em toda a sociedade. É que, para esses agentes, a Constituição Federal e Constituições Estaduais atribuem a prerrogativa de foro especial, fazendo com que o seu juiz natural em matéria penal seja não o juiz de primeiro grau, e sim um Tribunal, indicado conforme o cargo ou a função exercida pelo dignitário.

Diante da anomia existente na matéria, a investigação preliminar dos delitos de competência originária de tribunais - uma realidade que nos é cada vez mais presente - 
requer estudo cauteloso e tratamento legal adequado, pois, ao representar o início de uma atividade estatal que pode implicar a supressão da liberdade do indivíduo, deve ser pautada em regras claras, que traduzam segurança jurídica e respeito ao devido processo legal.

Não se apresentando suficientes, para sistematização desses procedimentos investigatórios, as escassas diretrizes cunhadas pela Lei 8.038/1990 e as instáveis normas regimentais de cada Tribunal, surge necessário um exaustivo trabalho no plano legislativo para que eles venham ser formalmente regulados, harmonizando-se ao Texto Constitucional de 1988 e, sobretudo, aos reclamos do processo penal acusatório, que visa propiciar, ao mesmo tempo, a efetiva implementação das garantias individuais talhadas na Constituição e uma releitura dos papéis dos agentes estatais da persecução criminal, em especial do julgador.

Necessária, ainda, uma revisão da postura atualmente adotada nos tribunais pátrios, eles mesmos discrepantes entre si, eliminando-se as principais incoerências com o modelo de processo penal anunciado na Constituição. Diante da notória divergência entre a praxe atualmente verificada nos pretórios brasileiros e aquele modelo tido por "ideal", proposições legislativas claras contemplando todos os principais aspectos das investigações tribunalícias seriam muito bem-vindas, mas não sem a indispensável absorção cultural, pelo Poder Judiciário, de sua real posição dentro do sistema acusatório de processo penal.

Com o intuito de servir de parâmetros para essa nova postura interpretativa, passamos a sintetizar as propostas traçadas, algumas de lege ferenda, ao longo do trabalho, para a regulação desses procedimentos de cunho penal, posto se reconheça a polêmica e sensibilidade inerentes ao tema, não havendo, portanto, a pretensão de esgotá-lo.

1. O fato de ser o Tribunal o órgão competente para o processo e o julgamento do agente público não implica admitir-se a sua titularidade também para a condução da investigação preliminar. A prerrogativa de foro é critério pertinente, de modo exclusivo, à determinação da competência jurisdicional originária do Tribunal respectivo, agindo seja no momento do oferecimento da acusação ou, eventualmente, antes dela, apenas se necessária alguma medida cautelar sujeita à prévia autorização judicial.

A primeira questão controversa a resolver, portanto, diz com a própria natureza dessas investigações preliminares, que muitos ainda afirmam tratar-se de procedimentos judiciais e não policiais. Nesse ponto, é preciso distinguir claramente a existência de dois tipos de investigação preliminar envolvendo agentes com prerrogativa de foro criminal: aquelas que se realizam pela própria instituição a que pertencem os 
investigados (investigações interna corporis, que englobam os membros da Magistratura e do Ministério Público) e as demais, que envolvem sobretudo os agentes políticos, mandatários eletivos, e não refogem, por qualquer regra constitucional ou infraconstitucional, à atribuição da Polícia Judiciária, investigador-padrão dos indivíduos em nosso ordenamento.

Assim, afora as investigações interna corporis, sobre as quais incidem normas próprias (Leis Orgânicas da Magistratura e do Ministério Público), os demais procedimentos de investigação preliminar têm natureza administrativo-policial. Desnecessária proposição legal nesse sentido, visto ser o inquérito policial o instrumento típico de investigação em nosso sistema, além de não haver expressa derrogação de sua pertinência nessas espécies de delitos ou de investigados.

2. Propõe-se, todavia, a unificação desses procedimentos sob uma mesma nomenclatura, para facilitar-se o trabalho da Polícia Judiciária no que tange à observância de regras específicas a eles aplicadas, tratando-se assim de um inquérito policial especial, compatível com a definição do foro penal especial, relacionado à competência jurisdicional hierárquica. A expressão inquérito penal originário, recorrente na prática forense, carece de sentido jurídico, eis que o inquérito, nesses casos, não se origina nem tramita nos tribunais. Outra medida, no mesmo intuito de racionalização do trabalho da Polícia Judiciária, que nesses inquéritos lida com membros do Ministério Público e Magistrados de instâncias superiores, é constituir-se, paulatinamente, nas Delegacias de Polícia (Civil e Federal), órgãos ou equipes específicas com conhecimento especializado nos aludidos inquéritos.

3. A instauração do inquérito policial especial deve ficar a cargo, como regra geral, da autoridade policial com atribuição para o caso, não dependendo de qualquer autorização, seja judicial, legislativa ou do Ministério Público, visto não lhe ser oposto, no ordenamento brasileiro, qualquer condicionamento dessa natureza. Ademais, reforma legislativa deve afastar definitivamente a possibilidade de o membro do Poder Judiciário requisitar a instauração de inquéritos policiais, hoje ainda prevista no art. . $^{\circ}$, II, do CPP.

4. No que tange à condução da investigação preliminar, em consonância com a sua natureza, os atos ordinários de investigação devem ser praticados pela autoridade policial. No entanto, da maneira como se desenvolvem hoje as investigações em alguns Tribunais, o Relator vem desempenhando atribuições próximas à de investigador (ora atuando diretamente, ora efetuando a delegação ou requisição de atos, hipóteses que 
fazem presumir uma suposta legitimidade originária para a investigação), seja nos apuratórios aforados no Supremo Tribunal Federal ou nas demais Cortes de julgamento do país, estas quase sempre reproduzindo, em seus regimentos internos, as disposições constantes do Regimento Interno do STF. Há que se buscar a compatibilidade desses modelos de investigação penal com nosso sistema processual, que não abriga a (já banida de muitos ordenamentos que a adotavam) figura do juiz de instrução, donde a posição do magistrado não deve ser jamais a de investigar ou de dirigir os caminhos da investigação, mas apenas a de instruir e julgar processos criminais.

5. Cumpre afastar a chamada "supervisão judicial" ampla sobre inquéritos policiais, eis que a participação do Poder Judiciário na etapa pré-processual da persecução penal somente se justifica quando chamado a resolver os incidentes que impliquem a afetação de direitos fundamentais dos envolvidos na investigação. É garantia própria da investigação criminal a intervenção de um juiz imparcial nos incidentes que demandem judicialização, e para o resguardo de tal imparcialidade o juiz (seja ele de primeiro grau ou membro de tribunal) deve afastar-se dos atos próprios do inquérito. A sua intervenção não pode significar a atuação de ofício na indicação de diligências investigatórias, a filtração das diligências ordinárias requisitadas pelo Ministério Público ou a homologação de cada ato investigatório praticado pela Polícia. Nesse toar, propõe-se a instituição, por lei, da figura do Juiz de garantias da investigação.

6. A aquisição ou perda superveniente da prerrogativa do foro por qualquer dos investigados deverá implicar apenas a mudança do juiz competente para a decisão acerca das medidas cautelares na investigação, sempre se observando a regra da atualidade do cargo ou função do investigado, observando-se a validade dos atos praticados pelo então juiz natural, à luz da regra tempus regit actum. Por sua vez, a regra do aproveitamento dos atos não-decisórios praticados por juízo incompetente (art. 567 do CPP) somente servirá aos casos de incompetência com fonte infraconstitucional, não aos casos de foro especial.

Para amenizar os efeitos negativos do nomadismo da investigação preliminar nos delitos de competência originária de tribunais sobre a sua eficiência, propõe-se adotar a tramitação direta dos inquéritos entre a Polícia Judiciária, além da pronta ciência do investigado sobre o aforamento do inquérito em cada instância a que deslocado.

7. Os critérios de conexão e continência de fatos sob investigação devem ser de observância cogente, integrando a garantia do juiz natural, do qual não se pode subtrair 
o investigado. Ressalvam-se as situações legais de separação obrigatória e de separação facultativa, sendo que esta última, regulada pelo art. 80 do CPP e informada por motivos de simples conveniência da investigação ou do processo, implicará mera cisão de autos, com distribuição dos desmembrados por dependência ao primeiro, não dizendo com a revogação da modificação da competência ou a quebra da hierarquia determinante da atração dos fatos sob o mesmo juízo, sob pena de ferimento à garantia do juiz natural.

8. O controle externo da investigação preliminar nos delitos de competência originária de tribunais é atribuição constitucional do Ministério Público (art. 129, VII, da Constituição), o que abrange o exercício da fiscalização do trâmite da atividade investigatória criminal, do cumprimento das diligências requisitadas e a observância de prazos para sua conclusão. Logo, não se compadece com a ordem constitucional o art. $1 .^{\circ}$, $\S 1 .^{\circ}$, da Lei 8.038/1990, quando atribui ao Relator o deferimento ou não das diligências ordinárias do inquérito, cumprindo ser abolidos os institutos e práticas que outorgam referido controle ao Magistrado - cuja função de garantidor deve ganhar relevo, em salvaguarda dos direitos fundamentais ameaçados ou violados na investigação. Um dos instrumentos essenciais para o efetivo desempenho desse mister é a tramitação direta dos inquéritos policiais, sejam comuns ou especiais, que se propõe adote o legislador expressamente na Lei 8.038 e no Código de Processo Penal, disciplinando os casos em que o inquérito deve necessariamente passar pelo Poder Judiciário, evitando, assim, que toda diligência, para ser praticada, deva seguir, necessariamente, o itinerário Polícia-RelatorMinistério Público-Relator-Polícia.

9. Por exigência da garantia da imparcialidade objetiva do órgão julgador, é imperioso tornar impedido o juiz que atuou na investigação (aquele ora projetado como Juiz de garantias, de atuação restrita aos episódios que implicam reserva de jurisdição, como são as medidas de restrição de direitos, para as quais a intervenção judicial é de rigor) de funcionar como Relator na fase processual, abandonando-se, por reforma legislativa, a regra da prevenção descrita no art. 83 do CPP e no art. 2 . $^{\circ}$ da Lei 8.038/1990.

Dever-se-ia adotar, tanto na persecução criminal em primeiro grau como naquela afeta aos Tribunais, diretiva similar à da incisiva jurisprudência Tribunal Europeu de Direitos Humanos, no sentido de que tal prática oblitera o modelo acusatório e não traz qualquer vantagem em termos de garantias processuais. $\mathrm{O}$ modelo brasileiro, a par da definição legal do papel do Juiz de garantias, ainda carece da separação entre juiz da investigação e juiz do processo, no fito de evitar que o julgador (aquele que vai, 
efetivamente, apreciar o pedido condenatório) mantenha contato prévio com os elementos informativos que não poderão sequer validar uma sentença, como são muitas das peças do acervo coletado na investigação. Daí se alcançaria maior isenção do juiz, garantindo-se a sua imparcialidade.

Propõe-se, assim, na investigação de delitos de competência originária de tribunais (seja naquelas realizadas interna corporis ou nas demais), reservar-se um juiz exclusivo para exercer a função de garante da investigação - distinto do Relator da fase processual e excluído da composição do órgão de julgamento -, papel que se sugere fique a cargo do Corregedor ou do Vice-Presidente de cada Corte, estabelecido regimentalmente.

10. O procedimento deve seguir as linhas básicas do inquérito policial comum, conduzindo-se, como toda investigação preliminar com fins penais, sob a égide da publicidade, interna e externa, apenas se justificando o sigilo externo em hipóteses excepcionais e devidamente fundamentadas, em que necessária a proteção de valores como honra, privacidade, imagem dos envolvidos e a preservação do postulado da inocência. Não se compatibilizam com o regime democrático constitucional dispositivos legais que acobertam de sigilo, automaticamente, o processamento de reclamações e inquéritos contra membros do Poder Judiciário e do Ministério Público.

Já o sigilo interno não poderá ser decretado, alijando-se o próprio sujeito passivo do conhecimento dos autos da investigação, somente subsistindo durante a prática de diligências cuja prévia divulgação possa interferir nos resultados de sua execução. A atividade da defesa, desde a fase pré-processual, não poderá ser cerceada, pois a investigação revela-se apta a impingir nódoa ao status libertatis do investigado. Em caráter mais imediato, surge-lhe o direito de atuar no sentido de afastar a suspeita que se lhe recai, possibilitando assim obviar eventuais medidas cautelares contra sua pessoa e seus bens. Melhor seria, portanto, que o legislador infraconstitucional aclarasse, no CPP, a regra da publicidade das investigações, surgindo o sigilo como exceção, diferentemente da redação atual do art. 20 do Código, que dá margem a interpretações equivocadas.

As reflexões sobre o tema da investigação preliminar nos tribunais procuraram, enfim, trazer subsídios para moldar-se um procedimento em que se respeite o devido processo penal na sua vertente instrumental e também no seu aspecto substancial, visto ser a investigação prévia, nos dias atuais, uma garantia que se presta a proteger o indivíduo de acusações temerárias, devendo o Estado prever meios para que essa etapa possa cumprir a sua missão. 


\section{BIBLIOGRAFIA}

\section{Livros e periódicos}

ABADE, Denise Neves. Garantias do processo penal acusatório: o novo papel do Ministério Público no processo penal de partes. Rio de Janeiro: Renovar, 2005.

ALEXY, Robert. Teoría de los derechos fundamentales. Trad. Ernesto Garzón Valdés. Madrid: Centro de estudios políticos y constitucionales, 2001.

ALMEIDA, Fernanda Dias Menezes de. O sigilo no sistema democrático. In: YARSHELL, Flávio Luiz; MORAES, Maurício Zanoide de (Org.). Estudos em homenagem à professora Ada Pellegrini Grinover. São Paulo: DPJ, 2005. p. 217-240.

ALMEIDA JUNIOR, João Mendes de. O processo criminal brasileiro. 4. ed. Rio de Janeiro: Freitas Bastos, 1959. v. 1 e 2.

AMBOS, Kai. El proceso penal alemán y la reforma en América Latina. Santa Fe de Bogotá: Gustavo Ibañez, 1998.

; CHOUKR, Fauzi Hassan. A reforma do processo penal no Brasil e na América Latina. São Paulo: Método, 2001.

AMICO, Carla Campos. A nova redação dos artigos 155 e 156 do Código de processo penal e a produção antecipada da prova testemunhal na fase do inquérito policial. Boletim IBCCrim, São Paulo, v. 16, n. 192, p. 7-8, nov. 2008.

AMODIO, Ennio et al. Il nuovo processo penale: dalle indagini preliminari al dibattimento. Milano: Giuffrè, 1989.

ANDRADE, Mauro Fonseca. Ministério Público e sua investigação criminal. 2. ed. rev. e atual. Curitiba: Juruá, 2008.

. O inquérito judicial frente à imparcialidade do julgador. Revista do Ministério Público do Rio Grande do Sul, Porto Alegre, n. 43, p. 121-160, jul./out. 2000.

ARONNE, Ricardo. O princípio do livre convencimento do juiz. Porto Alegre: Sergio Antonio Fabris, 1996.

AZEVEDO, David Teixeira de. A CPI: Estado de Direito ou direito sem fronteiras do Estado? In: Atualidades no direito e processo penal. São Paulo: Método, 2001.

BADARÓ, Gustavo Henrique Righi Ivahy. Correlação entre acusação e sentença. São Paulo: Revista dos Tribunais, 2000. 
Limites aos poderes das comissões parlamentares de inquérito. Boletim IBCCrim, São Paulo, v. 7, n. 83 (esp.), p. 11-12, out. 1999.

BALDAN, Édson Luís. Investigação defensiva: o direito de defender-se provando. Revista Brasileira de Ciências Criminais, São Paulo, v. 15, n. 64, p. 253-273, jan./fev. 2007.

BANDEIRA DE MELLO, Celso Antônio. Curso de direito administrativo. 15. ed. São Paulo: Malheiros, 2003.

BAPTISTA, Francisco das Neves. O mito da verdade real na dogmática do processo penal. Rio de Janeiro: Renovar, 2001.

BARACHO, José Alfredo de Oliveira. Processo e Constituição: o devido processo legal. Revista de Direito Público, São Paulo, v. 16, n. 68, p. 55-79, out./dez. 1983.

. Teoria geral dos procedimentos de exercício da cidadania perante a Administração Pública. Revista dos Tribunais, São Paulo, v. 86, n. 743, p. 26-63, set. 1997.

BARANDIER, Antonio Carlos da Gama et al. (Inquérito policial: segredo de Justiça; determinação de quebra de sigilo bancário; inadmissibilidade de impedir os advogados de exercerem direitos fundamentais para a efetiva defesa (parecer). Revista Brasileira de Ciências Criminais, São Paulo, v. 9, n. 35, p. 203-210, jul./ago. 2001.

BARBOSA, Manoel Messias. Inquérito policial: doutrina, prática, jurisprudência. 5. ed. atual. e ampl. São Paulo: Método, 2006.

BARCELlOS, Ana Paula de. Ponderação, racionalidade e atividade jurisdicional. Rio de Janeiro: Renovar, 2005.

BARRETTO, Lauro. Investigação judicial eleitoral e ação de impugnação de mandato eletivo. 2. ed. rev. e ampl. Bauru: Edipro, 1999.

BARROS, Antonio Milton de. Processo penal segundo o sistema acusatório: os limites da atividade instrutória judicial. Leme: LED, 2002.

BARROS, Marco Antonio de. A busca da verdade no processo penal. São Paulo: Revista dos Tribunais, 2002.

BARROS, Romeu Pires de Campos. O procedimento nos crimes da competência originária dos tribunais. Revista dos Tribunais, São Paulo, v. 8, n. 30, p. 168-192, abr./jun. 1983.

BARROS, Suzana de Toledo. O princípio da proporcionalidade e o controle de constitucionalidade das leis restritivas de direito fundamentais. 3. ed. Brasília: Brasília Jurídica, 2003. 
BARROSO, Luís Roberto. Interpretação e aplicação da Constituição. 5. ed. rev. atual. e ampl. São Paulo: Saraiva, 2003.

BARTOLOMÉ, Plácido Fernández-Viagas. El juez imparcial. Granada: Comares, 1997.

BECHARA, Fábio Ramazzini. Crime organizado e o sigilo na investigação. Revista Síntese de Direito Penal e Processual Penal, Porto Alegre, v. 6, n. 32, p. 32-60, jun./jul. 2005 , . Inquérito policial: procedimento contraditório ou inquisitivo? Revista Síntese de Direito Penal e Processual Penal, Porto Alegre, v. 4, n. 23, p. 11-12, dez./jan. 2004.

BELLOCCHI, Roberto Antônio Vallim; BISCAIA, Antônio Carlos; CAZERTA, Therezinha. Investigações preliminares: ação penal de competência dos tribunais. In: Propostas para um novo modelo de persecução criminal: combate à impunidade. Brasília: CJF, Centro de Estudos Judiciários, 2005. p. 151-173.

BELLOQUE, Juliana Garcia. Sigilo bancário: análise crítica da LC 105/2001. São Paulo: Revista dos Tribunais, 2003.

BERTOLINO, Pedro J. El debido proceso penal. La Plata: Platense, 1986.

BILÓ, Luiz Roberto. Da competência no processo penal. Dissertação (Mestrado em Direito) - Pontifícia Universidade Católica de São Paulo, São Paulo, 2000.

BINDER, Alberto M. Introducción al derecho procesal penal. 2. ed. actual. y ampl. Buenos Aires: Ad-Hoc, 2002.

BIZZOTTO, Alexandre; RODRIGUES, Andréia de Brito. Processo penal garantista: visão constitucional e novas tendências. Goiânia: AB, 1998.

BONAVIDES, Paulo. Curso de direito constitucional. 21. ed. atual. São Paulo: Malheiros, 2007.

BOVINO, Alberto; PINTO, Federico. La prueba preconstituida por particulares: su incorporación y valoración en el procedimiento penal. In: PLAZAS, Florencia G.; HAZAN, Luciano A. (Comp.). Garantías constitucionales en la investigación penal: um estudio crítico de la jurisprudencia. Buenos Aires: Editores del Puerto, 2006. p. 279-301.

BRITTO, Carlos Ayres. "Direitos subjetivos" e "prerrogativas" constitucionais. Revista de Direito Público, São Paulo, v. 22, n. 90, p. 70-78, abr./jun. 1989.

BUONO, Carlos Eduardo de Athayde; BENTIVOGLIO, Antônio Tomás. A reforma processual penal italiana: reflexos no Brasil. São Paulo: Revista dos Tribunais, 1991. 
CANOTILHO, José Joaquim Gomes. Direito constitucional e teoria da Constituição. 7. ed. Coimbra: Almedina, 2003. . Estudos sobre direitos fundamentais. São Paulo: Revista dos Tribunais, 2008. ; MOREIRA, Vital. Constituição da República portuguesa anotada. 1. ed. brasileira. 4. ed. portuguesa. São Paulo: Revista dos Tribunais; Coimbra: Coimbra, 2007. v. 1.

CARLI, Luigi. Indagini preliminari e segreto investigativo. Rivista Italiana di Diritto e Procedura Penale, Milano, v. 37, n. 3, p. 762-792, lug./set. 1994.

CARNEIRO LEÃO, Nilzardo. Princípios do processo penal. Recife: Imprensa Universitária, 1960.

CARNELUTTI, Francesco. Como se faz um processo. Trad. Ricardo Rodrigues Gama. Campinas: Russell, 2008.

CARRIÓ, Alejandro D. Garantías constitucionales en el proceso penal. 4. ed. Buenos Aires: Hammurabi, 2004.

CARVALHO, Luis Gustavo Grandinetti Castanho de. O processo penal em face da Constituição: princípios constitucionais do processo penal. 2. ed. ampl. Rio de Janeiro: Forense, 1998.

CASTRO, Carlos Roberto Siqueira. O devido processo legal e os princípios da razoabilidade e da proporcionalidade. 3. ed. Rio de Janeiro: Forense, 2005.

CASTRO SOBRINHO, Célio Silva. Foro especial por prerrogativa de função e a garantia do juiz natural. Dissertação (Mestrado em Direito) - Pontifícia Universidade Católica de São Paulo, São Paulo, 2004.

CAZERTA, Therezinha Astolphi. Ação penal originária: apontamentos: reflexões. Revista TRF 3. ${ }^{a}$ Região, São Paulo, v. 80, p. 9-79, nov./dez. 2006.

CHOUKR, Fauzi Hassan. Garantias constitucionais na investigação criminal. São Paulo: Revista dos Tribunais, 1995.

. Garantias constitucionais na investigação criminal. 3. ed. rev., ampl. e atual. Rio de Janeiro: Lumen Juris, 2006.

. Processo penal à luz da Constituição. Bauru: Edipro, 1999.

CHUT, Marcos André. O controle do princípio da obrigatoriedade nos casos de competência originária dos tribunais. Revista dos Tribunais, São Paulo, v. 87, n. 756, p. 471-478, out. 1998 . 
CINTRA, Antônio Carlos de Araújo; GRINOVER, Ada Pellegrini; DINAMARCO, Cândido Rangel. Teoria geral do processo. 17. ed. rev. e atual. São Paulo: Malheiros, 2001.

CLÈVE, Clèmerson Merlin. Investigação criminal e Ministério Público. Boletim Científico da Escola Superior do Ministério Público da União, Brasília, v. 4, n. 16, p. 157-189, jul./set. 2005.

COMOGLIO, Luigi Paolo. Giurisdizione e processo nel quadro delle garanzie costituzionali. Rivista rimestrale di Diritto e Procedura Civile, Milano, v. 48, n. 4, p. 1063-1111, dic. 1994.

COSTA, Paula Bajer Fernandes Martins da. Igualdade no direito processual penal brasileiro. São Paulo: Revista dos Tribunais, 2001.

. Inquérito policial e a investigação dos fatos que antecede a ação penal no ordenamento jurídico instaurado pela Constituição de 1988. Revista Brasileira de Ciências Criminais, São Paulo, v. 5, n. 19, p. 171-178, jul./set. 1997.

. Publicidade na investigação criminal. Boletim IBCCrim, São Paulo, v. 7, n. 84, p. 13, nov. 1999.

COUCEIRO, João Cláudio. Prerrogativas de agentes políticos no processo penal. Tese (Doutorado em Direito) - Faculdade de Direito, Universidade de São Paulo, São Paulo, 2006.

COUSELO, Gonzalo Jar. Modelos comparados de policía. Madrid: Dykinson, 2000.

COUTINHO, Jacinto Nelson de Miranda. $\mathrm{O}$ ato administrativo de instauração do inquérito policial. In: BARRA, Rubens Prestes; ANDREUCCI, Ricardo Antunes. Estudos em homenagem a Manoel Pedro Pimentel. São Paulo: Revista dos Tribunais, 1992.

. O sigilo no inquérito policial e os advogados. Revista Brasileira de Ciências Criminais, São Paulo, v. 5, n. 18, p. 123-134, abr./jun. 1997.

D’ANGELO, Andréa Cristina; DEZEM, Guilherme Madeira. Acesso aos autos do inquérito policial pelo não formalmente indiciado. Boletim IBCCrim, São Paulo, v. 14, n. 162 , p. 13-14, maio 2006.

DALLARI, Dalmo de Abreu. A polícia civil no Estado brasileiro. In: MORAES, Bismael Batista de (Coord.). A polícia à luz do direito. São Paulo: Revista dos Tribunais, 1991. p. $58-74$.

DAURA, Anderson Souza. Inquérito policial: competência e nulidades de atos de polícia judiciária. 2. ed. rev. e atual. Curitiba: Juruá, 2008. 
DEL CASTILlO, Manuel M. Gómez; González, José I. Ugalde. Procesos penales ordinarios y especiales. 2. ed. Madrid: Tecnos, 1991.

DELMAS-MARTY, Mireille. Procédures pénales d'Europe. Paris: Presses Universitaires de France, 1995.

DEMO, Roberto Luis Luchi. Competência penal originária: uma perspectiva jurisprudencial crítica. São Paulo: Malheiros, 2005.

DEU, Teresa Armenta. Principio acusatorio y derecho penal. Saragoza: Bosch, 1995.

DI PIETRO, Maria Sylvia Zanella. Direito administrativo. 12. ed. São Paulo: Atlas, 2000.

DIAS, Jorge de Figueiredo. Direito processual penal. Coimbra: Coimbra, 1974. v. 1.

DÍAZ, Carlos Alberto Chiara; MEANA, José María. Código procesal penal de la Nación concordado con el de la província de Buenos Aires anotados jurisprudencialmente. Buenos Aires: Rubinzal-Culzoni, 2001.

DINAMARCO, Cândido Rangel. A instrumentalidade do processo. 9. ed. rev. e atual. São Paulo: Malheiros, 2001.

DIPO: justiça auxiliando o trabalho policial. Panorama da Justiça, São Paulo, v. 3, n. 13, p. 19, ago./set. 1998 .

DÓRIA, Hélio Ivo Angrisani. Ação e jurisdição no Código do Processo Penal: notas sôbre duas inconstitucionalidades. Estudos de direito processual in memoriam do Ministro Costa Manso. São Paulo: Revista dos Tribunais, 1965. p. 19-58.

DOTTI, René Ariel. O desafio da investigação criminal. Boletim IBCCrim, São Paulo, v. 12, n. 138, p. 8, mai. 2004.

ESTADOS UNIDOS DA AMÉRICA. ORDEM DOS ADVOGADOS. ABA Standards for Criminal Justice: Prosecution and Defense Function. 3. ed. Washington DC: American Bar Association, 1993. Disponível em: $<$ http://www.abanet.org/crimjust/standards/dfunc_toc.html $>$. Acesso em 8.10.2008.

FALCONE, Roberto Atilio. El principio acusatorio: el procedimiento oral en la Província de Buenos Aires y em la Nación. Buenos Aires: Ad-Hoc, 2005.

FARANDA, Cláudio. La “par condicio” nel processo penale. Milano: Giuffrè, 1968.

FAZZALARI, Elio. Instituições de direito processual. Trad. Elaine Nassif. Campinas: Bookseller, 2006.

FELDENS, Luciano. Tutela penal dos interesses difusos e crimes do colarinho branco: por uma relegitimação da atuação do Ministério Público: uma investigação à luz dos valores constitucionais. Porto Alegre: Livraria do Advogado, 2002. 
; SCHMIDT, Andrei Zenkner. Investigação criminal e ação penal. 2. ed. rev., atual. e ampl. Porto Alegre: Livraria do Advogado, 2007.

FELICIONI, Paola. Le ispezioni e le perquisizioni. Milano: Giuffrè, 2004.

FENECH, Miguel. El proceso penal. 4. ed. Madrid: Agesa, 1982.

FERNANDES, Antonio Scarance. A reação defensiva à imputação. São Paulo: Revista dos Tribunais, 2002.

. O equilíbrio na investigação criminal. In: YARSHELL, Flávio Luiz; MORAES, Maurício Zanoide (Org.). Estudos em homenagem à professora Ada Pellegrini Grinover. São Paulo: DPJ, p. 319-330, 2005. . O papel da vítima no processo criminal. São Paulo: Malheiros, 1995.

. Processo penal constitucional. 3. ed. rev., atual. e ampl. São Paulo: Revista dos Tribunais, 2002.

. Reflexões sobre as noções de eficiência e de garantismo no processo penal. In: FERNANDES, Antonio Scarance; MORAES, Maurício Zanoide de; ALMEIDA, José Raul Gavião de (Coord.). Sigilo no processo penal: eficiência e garantismo. São Paulo: Revista dos Tribunais, 2008. p. 9-28.

. Rumos da investigação criminal no direito brasileiro. Boletim do Instituto Manoel Pedro Pimentel, São Paulo, v. 5, n. 21, p. 12-13, jul./set. 2001.

. Teoria geral do procedimento e o procedimento no processo penal. São Paulo: Revista dos Tribunais, 2005.

FERRAJOLI, Luigi. Diritto e ragione: teoria del garantismo penale. 8. ed. Roma: Laterza, 2004.

FERRARI, Eduardo Reale. Código de Processo Penal: comentários aos projetos de reforma legislativa. Campinas: Millennium, 2003.

FERREIRA, Jorge. Regime jurídico dos inquéritos parlamentares. Coimbra: Almedina, 1999.

FERREIRA FILHO, Manoel Gonçalves; GRINOVER, Ada Pellegrini; FERRAZ, Anna Cândida da Cunha. Liberdades públicas: parte geral. São Paulo: Saraiva, 1978.

FONSECA, José Arnaldo da. Juizado de Instrução Criminal. In: Propostas da Comissão de Altos Estudos da Justiça Federal. Brasília: CJF, Centro de Estudos Judiciários, 2002. v. 1. p. 31-43. 
FONTELES, Claudio Lemos. A legitimação para propositura da ação penal pública originária no Superior Tribunal de Justiça. Universitas/Jus, Brasília, n. 2, p. 23-27, jul./dez. 1998.

Ainda sobre a questão do artigo 28 do código de processo penal. Boletim dos Procuradores da República, São Paulo, v. 3, n. 27, p. 4-7, jul. 2000.

FONTES, Paulo Gustavo Guedes. Investigação criminal pelo Ministério Público: discussão dos principais argumentos em contrário. Boletim dos Procuradores da República, São Paulo, v. 7, n. 69, p. 10-14, jan. 2006.

FRAGOSO, Heleno Cláudio. Jurisprudência criminal. 4. ed. Rio de Janeiro: Forense, 1982. v. 1.

FRANÇA, Vladimir da Rocha. Contraditório e invalidação administrativa no âmbito da Administração Pública federal. In: FIGUEIREDO, Lucia Valle (Coord.). Devido processo legal da Administração Pública. São Paulo: Max Limonad, 2001. p. 187-226.

FRANCO, Alberto Silva; MORAES, Maurício Zanoide. Dos princípios e garantias constitucionais do devido processo legal. In: FRANCO, Alberto Silva; STOCCO, Rui (Coord.). Código de Processo Penal e sua interpretação jurisprudencial. v. 1, 2. ed. São Paulo: Revista dos Tribunais, 2004. p. 239-1062.

FRANCO, Fernão Borba. Processo administrativo. São Paulo: Atlas, 2008.

FREITAS, Ricardo de Brito A. P. As razões do positivismo penal no Brasil. Rio de Janeiro: Lumen Juris, 2002.

FREITAS, Vladimir Passos de. Julgando os juízes. Boletim IBCCrim, São Paulo, v. 13, n. 154, p. 19, set. 2005 .

FREYESLEBEN, Márcio Luis Chila. O ministério público e a polícia judiciária: controle externo da atividade policial. Belo Horizonte: Del Rey, 1993.

GANDINI, Jean-Jacques. Les droits de l'homme. Paris: Librio, 2003.

GARCÍA, Nicolás Rodríguez; FERNANDES, Fernando Andrade. Orientações fundamentais da fase preliminar do processo penal: uma análise comparativa. Revista Portuguesa de Ciência Criminal, Coimbra, v. 5, n. 3-4, p. 419-444, jul./dez. 1996.

GOMES, Luiz Flávio. Sobre o conteúdo processual tridimensional do princípio da presunção de inocência. In: Estudos de direito processual penal. 1. ed., 2. tir. São Paulo: Revista dos Tribunais, 1999. p. 101-117. 
; CERVINI, Raúl. Crime organizado: enfoques criminológico, jurídico (Lei 9.034/95) e político-criminal. 2. ed. rev., atual. e ampl. São Paulo: Revista dos Tribunais, 1997.

GOMES, Rodrigo Carneiro. As prerrogativas processuais na investigação criminal. Revista CEJ, Brasília, v. 12, n. 41, p. 47-58, abr./jun. 2008.

GOMES, Suzana de Camargo. A Justiça Eleitoral e sua competência. São Paulo: Revista dos Tribunais, 1998.

GOMES FILHO, Antonio Magalhães. A motivação das decisões penais. São Paulo: Revista dos Tribunais, 2001.

. Direito à prova no processo penal. São Paulo: Revista dos Tribunais, 1997. . O princípio da presunção de inocência na Constituição de 1988 e na Convenção Americana sobre Direitos Humanos (Pacto de São José da Costa Rica). Revista do Advogado, São Paulo, v. 42, p. 30-34, abr. 1994. . Presunção de inocência e prisão cautelar. São Paulo: Saraiva, 1991. . Provas: Lei 11.690, de 09.06.2008. In: MOURA, Maria Thereza Rocha de Assis (Coord.). As reformas no processo penal: as novas Leis de 2008 e os projetos de reforma. São Paulo: Revista dos Tribunais, 2008. p. 246-297.

GÓMEZ COLOMER, Juan Luis. La investigación criminal: problemas actuales y perspectivas de unificación internacional. Revista del Poder Judicial, Madrid, n. 64, p. 205-245, 2001.

GRECO FILHO, Vicente. Manual de processo penal. 6. ed. São Paulo: Saraiva, 1999.

GRINOVER, Ada Pellegrini. A iniciativa instrutória do juiz no processo penal acusatório. Revista Forense Comemorativa - 100 anos, Rio de Janeiro, t. 7, p. 795-806, 2006. . As garantias constitucionais do direito de ação. São Paulo: Revista dos Tribunais, 1973.

. Do direito de defesa em inquérito administrativo. In: O processo em evolução. Rio de Janeiro: Forense Universitária, 1996. p. 81-88. . Influência do Código-Modelo de Processo Penal para Ibero-América na legislação latino-americana: convergências e dissonâncias com os sistemas italiano e brasileiro. In: O processo em evolução. Rio de Janeiro: Forense Universitária, 1996. . Liberdades públicas e processo penal: as interceptações telefônicas. 2. ed. atual. São Paulo: Revista dos Tribunais, 1982. 
. O juiz natural como órgão constitucionalmente competente. Delegação da competência para a prática de atos instrutórios: limites. A modificação da competência por conexão e continência. Contraditório e necessidade de informação. Capacidade postulatória dos membros do Ministério Público. Impedimento do desembargador que figure como vítima. (parecer). In: A marcha do processo. Rio de Janeiro: Forense Universitária, 2000. p. 412-429.

; FERNANDES, Antonio Scarance; GOMES FILHO, Antonio Magalhães. As nulidades no processo penal. 10. ed. rev., ampl. e atual. São Paulo: Revista dos Tribunais, 2007.

GUIMARÃES, Rodrigo Régnier Chemim. Controle externo da atividade policial pelo Ministério Público. Curitiba: Juruá, 2002.

GUZMÁN, Nicolás M. Algunos aspectos del modelo procesal penal italiano: en particular, la novedosa estruturación de la fase de la investigación preliminar. Nueva Doctrina Penal, Buenos Aires, v. B, p. 619-643, 2002.

HABIB, Sérgio. Brasil: quinhentos anos de corrupção: enfoque sócio-histórico-jurídicopenal. Porto Alegre: Sergio Antonio Fabris, 2004.

HAMILTON, Sergio Demoro. A ortodoxia do sistema acusatório no processo penal brasileiro: uma falácia. Revista de Direito da Defensoria Pública, Rio de Janeiro, v. 13, n. 17, p. 191-214, 2001.

. Alguns pespontos ao artigo 28 do Código de Processo Penal. Revista Síntese de Direito Penal e Processual Penal, Porto Alegre, v. 4, n. 21, p. 19-25, ago./set. 2003. . Réquiem para o sigilo no inquérito policial. Revista da EMERJ, Rio de Janeiro, v. 7, n. 25, p. 112-122, 2004.

HARGER, Marcelo. Princípios constitucionais do processo administrativo. 2. ed. rev. e atual. Rio de Janeiro: Forense, 2008.

HERBEL, Gustavo Adrián. La investigación penal preparatoria del fiscal como forma de otorgar eficacia y garantías al sistema punitivo: nuevo código procesal penal bonaerense. Cuadernos de Doctrina y Jurisprudencia Penal, Buenos Aires, v. 4, n. 8B, p. 687-716, dic. 1998.

JARDIM, Afrânio Silva. Arquivamento e desarquivamento do inquérito policial. Revista de Direito Penal e Criminologia, Rio de Janeiro, n. 35, p. 76-89, jan./jun. 1983. . Direito processual penal. 10. ed. rev. e atual. Rio de Janeiro: Forense, 2001. 
JESUS, Damásio Evangelista de. Inquérito policial contra promotor de justiça e juiz de direito. Justitia, São Paulo, v. 47, n. 129, p. 102-103, abr./jun. 1985.

JORGE, Mário Helton. Crimes de menor potencial ofensivo: ações penais de competência originária dos tribunais: aplicabilidade dos benefícios despenalizadores da composição civil dos danos e da transação penal. Revista dos Tribunais, São Paulo, v. 93, n. 830, p. 451-457, dez. 2004.

KARAM, Maria Lúcia. Competência no processo penal. 4. ed. rev., atual. e ampl. São Paulo: Revista dos Tribunais, 2005.

. O direito a um julgamento justo e as liberdades de expressão e de informação. Boletim IBCCrim, São Paulo, v. 9, n. 107, edição especial, p. 3-4, out. 2001.

KOERNER, Andrei; MELHEM, Célia Soibelman; SCHILlING, Flávia. A garantia dos direitos fundamentais no processo penal: a implementação do controle do inquérito policial pelo Ministério Público no Estado de São Paulo. Revista Brasileira de Ciências Criminais, São Paulo, v. 7, n. 28, p. 265-271, out./dez. 1999.

LACAVA, Thaís Aroca Datcho. O sigilo nas Comissões Parlamentares de Inquérito e as garantias individuais. In: FERNANDES, Antonio Scarance; MORAES, Maurício Zanoide de; ALMEIDA, José Raul Gavião de (Coord.). Sigilo no processo penal: eficiência e garantismo. São Paulo: Revista dos Tribunais, 2008. p. 115-137.

LEMOS JÚNIOR, Arthur Pinto de. A investigação judicial no âmbito da Corregedoria da Polícia Judiciária e a titularidade da ação penal do Ministério Público. Revista da Escola Paulista da Magistratura, São Paulo, v. 5, n. 2, p. 179-194, jul./dez. 2004.

LEONE, Giovanni. Manuale di diritto processuale penale. 10. ed. Napoli: Jovene, 1978.

LESSA, Paulo Inácio Dias. Do 'recebimento' da queixa ou da denúncia nas ações penais da competência originária dos Tribunais de Justiça (TJMT). Revista Trimestral de Jurisprudência dos Estados, São Paulo, v. 17, n. 116, p. 9-12, set. 1993.

LIMA, Marcellus Polastri. Ministério Público e persecução criminal. 3. ed. rev. e atual. Rio de Janeiro: Lumen Juris, 2002.

LIMA, Walberto Fernandes de. Considerações sobre a criação do $\S 2 .^{\circ}$ do art. 82 do Código de Processo Penal Militar e seus reflexos na Justiça penal comum (Lei n. ${ }^{\circ}$ 9.299/96). Revista Brasileira de Ciências Criminais, São Paulo, v. 5, n. 20, p. 153-166, out./dez. 1997. 
LOPES JR., Aury. Introdução crítica ao processo penal: fundamentos da instrumentalidade constitucional. 4. ed. rev., atual. e ampl. Rio de Janeiro: Lumen Juris, 2006.

. Sistemas de investigação preliminar no processo penal. 3. ed. rev., ampl. e atual. Rio de Janeiro: Lumen Juris, 2005.

LUHMANN, Niklas. Legitimação pelo procedimento. Trad. Maria Luiza de Carvalho. Rio de Janeiro: Revan, 1999.

MAGALDI PATERNOSTRO, María José. Procedimientos especiales y actuación de oficio del juez: análisis del procedimiento especial para el enjuiciamiento de diputados y senadores. In: Cuadernos y Estudios de Derecho Judicial, San Sebastián: Consejo General del Poder Judicial, 1995. 1 CD-ROM.

MAGALHÃES, Roberto Barcellos de. Prática do processo falencial. 3. ed. rev., atual. e aum. Rio de Janeiro: Freitas Bastos, 1977. v. 1.

MAIER, Julio B. J. Derecho procesal penal argentino. Buenos Aires: Hammurabi, 1989. t. 1, v. b.

. La investigación penal preparatoria del Ministerio Público. Buenos Aires: Córdoba, 1975.

MALAN, Diogo. Investigação defensiva nos Estados Unidos da América e reflexos no processo penal brasileiro. Palestra proferida nas VII Jornadas Brasileiras de Direito Processual Civil e Penal do Instituto Brasileiro de Direito Processual (IBDP). Florianópolis, 2008.

MARCON, Adelino. O princípio do juiz natural no processo penal. Curitiba: Juruá, 2004.

MARQUES, José Frederico. A investigação policial. O inquérito policial e a instrução criminal contraditória: interpretação do art. 141, § 25, da Constituição Federal. Revista dos Tribunais, São Paulo, v. 47, n. 271, p. 20-30, maio 1958.

. Anteprojeto de Código de Processo Penal: publicado no DOU, suplemento, de 29.6.1970. São Paulo: Sugestões Literárias, [s.d.]. . Estudos de direito processual penal. Rio de Janeiro: Forense, 1960. . Tratado de direito processual penal. São Paulo: Saraiva, 1980. v. 1.

. Da competência em matéria penal. 1. ed. atual. por José Renato Nalini e Ricardo Dip. Campinas: Millennium, 2000. 
MARTINS JÚNIOR, Wallace Paiva. A exclusividade do 'jus postulandi' do Ministério Público na ação penal pública e no inquérito policial. Justitia, São Paulo, v. 53, n. 156, p. 15-18, out./dez. 1991.

MAZZILLI, Hugo Nigro. Considerações sobre a aplicação analógica do art. 28 do Código de Processo Penal. Justitia, São Paulo, v. 63, n. 193, p. 58-68, jan./mar. 2001.

. Foro por prerrogativa de função: crime praticado por promotor de justiça em Estado da Federação diverso daquele onde exerce suas atribuições. Justitia, São Paulo, v. 48, n. 136, p. 39-41, out./dez. 1986. . O foro por prerrogativa de função e a Lei n. ${ }^{\circ}$ 10.628/02. Revista Síntese de Direito Penal e Processual Penal, Porto Alegre, v. 3, n. 18, p. 33-37, fev./mar. 2003. - Regime jurídico do Ministério Público: análise da Lei Orgânica do Ministério Público, aprovada pela Lei n. 8.625, de 12 de fevereiro de 1993. 3. ed. rev. ampl. e atual. São Paulo: Saraiva, 1996.

MEDAUAR, Odete. A processualidade no direito administrativo. 2. ed. rev., atual. e ampl. São Paulo: Revista dos Tribunais, 2008.

MEDEIROS, Flávio Meirelles. Princípios de direito processual penal. Revista Forense Comemorativa - 100 anos, Rio de Janeiro, t. 7, p. 497-547, 2006.

MEIRELLES, Hely Lopes. Direito administrativo brasileiro. 24. ed. atual. São Paulo: Malheiros, 1999.

MELLO, João de Deus Cardoso de. O inquérito policial em face do Anteprojeto. Revista Brasileira de Criminologia e Direito Penal, Rio de Janeiro, v. 3, n. 9, p. 47-64, abr./jun. 1965.

MELlO FILHO, José Celso de. A tutela judicial da liberdade. Revista dos Tribunais, São Paulo, v. 68, n. 526, p. 291-302, ago. 1979. . Investigação parlamentar estadual: as comissões especiais de inquérito. Justitia, São Paulo, v. 45, n. 121, p. 155-160, abr./jun. 1983.

MENDES, Gilmar Ferreira; COELHO, Inocêncio Mártires; BRANCO, Paulo Gustavo Gonet. Curso de direito constitucional. São Paulo: Saraiva, 2007.

MENDES DE ALMEIDA, Joaquim Canuto. Princípios fundamentais do processo penal. São Paulo: Revista dos Tribunais, 1973. . O direito de defesa no inquérito policial. Revista Forense Comemorativa - 100 anos. Rio de Janeiro: Forense: 2006. t. 7, p. 315-342. 
MENDRONI, Marcelo Batlouni. O sigilo da fase pré-processual. Justitia, São Paulo, v. 62, n. 189/192, p. 103-108, jan./dez. 2000.

MIAILLE, Michel. Uma introdução crítica ao direito. Trad. Ana Prata. 3. ed. Lisboa: Estampa, 2005.

MIRABETE, Julio Fabbrini. Processo penal. 8. ed. São Paulo: Atlas, 1998.

MOLINARI, Francesca Maria. Il segreto investigativo. Milano: Giuffrè, 2003.

MONREAL, Eduardo Novoa. O direito como obstáculo à transformação social. Trad. Gérson Pereira dos Santos. Porto Alegre: Sergio Antonio Fabris, 1988.

MORAES, Alexandre de. Direito constitucional. 7. ed. atual. São Paulo: Atlas, 2000.

MORAES, Bismael Batista de. O inquérito policial é o vilão no direito brasileiro? Revista Brasileira de Ciências Criminais, São Paulo, v. 7, n. 28, p. 255-264, out./dez. 1999. . Polícia, segurança pública, governo e sociedade. In: MORAES, Bismael Batista de (Coord.). A polícia à luz do direito. São Paulo: Revista dos Tribunais, 1991. p. 119 141.

MORAES, Maurício Zanoide. Esgrimando com o Professor Sérgio Marcos de Moraes Pitombo: os inexistentes poderes investigatórios criminais do Ministério Público. Revista do Advogado, São Paulo, v. 24, n. 78, p. 67-74, set. 2004.

MOREIRA, José Carlos Barbosa. O processo penal norte-americano e sua influência. Revista de Processo, São Paulo, v. 26, n. 103, p. 95-107, jul./set. 2001.

MOSSIN, Heráclito Antônio. Aspectos relevantes no projeto de reforma do código de processo penal em tema de investigação. Revista Cejap, Campinas, v. 3, n. 5, p. 3-9, nov. 2002.

MOURA, José Souto de. Inquérito e instrução. In: Jornadas de Direito Processual Penal: o novo Código de Processo Penal. Coimbra: Almedina, p. 83-145, 1998.

MOURA, Maria Thereza Rocha de Assis. A prova por indícios no processo penal. São Paulo: Saraiva, 1994.

. Competência por prerrogativa de função. In: FRANCO, Alberto Silva; STOCCO, Rui (Coord.). Código de Processo Penal e sua interpretação jurisprudencial. v. 2, 2. ed. São Paulo: Revista dos Tribunais, 2004. p. 1074-1175. . Justa causa para a ação penal: doutrina e jurisprudência. São Paulo: Revista dos Tribunais, 2001.

; BASTOS, Cleunice A. Valentim. Defesa penal: direito ou garantia. Revista Brasileira de Ciências Criminais, São Paulo, v. 1, n. 4, p. p. 110-125, out./dez.1993. 
NERY JUNIOR, Nelson. Princípios do processo civil na Constituição Federal. 5. ed. rev. e ampl. São Paulo: Revista dos Tribunais, 1999.

NORONHA, Edgard de Magalhães. Curso de direito processual penal. 6. ed. São Paulo: Saraiva, 1973.

OLIVEIRA, Francisco da Costa. A defesa e a investigação do crime: guia prático para a análise da investigação judiciária e para a investigação pelos recursos próprios da investigação criminal. Coimbra: Almedina, 2004.

OSÓRIO, Fábio Medina. Direito administrativo sancionador. 2. ed. rev., atual. e ampl. São Paulo: Revista dos Tribunais, 2006.

PAÇO, André Medeiros do. Foro por prerrogativa de função: prefeitos municipais. Belo Horizonte: Del Rey, 2000.

PASSOS, Paulo Roberto da Silva; OLIVEIRA, Thales Cezar de. Princípios constitucionais no inquérito e no processo penal. São Paulo: Themis, 2001.

PASTRANA, Ángel Tinoco. Fundamentos del sistema judicial penal en el common law. Sevilla: Universidad de Sevilla, 2001.

PAULA PESSOA, Vicente Alves de. Código do processo criminal de primeira instância do Império do Brasil. Rio de Janeiro: Cruz Coutinho, 1882.

PELLEGRINO, Laércio. Substituição do inquérito pelo juizado de instrução. Revista dos Tribunais, São Paulo, v. 68, n. 527, p. 462-466, set. 1979.

PEREIRA, Flávia Rahal Bresser. A publicidade no processo penal brasileiro: confronto com o direito à intimidade. Dissertação (Mestrado em Direito) - Universidade de São Paulo, São Paulo, 2000.

- Publicidade no processo penal: a mídia e o processo. Revista Brasileira de Ciências Criminais, São Paulo, v. 12, n. 47, p. 270-283, mar./abr. 2004.

PEREIRA, Milton Luiz. Foro privilegiado: contravenções penais. Revista Síntese de Direito Penal e Processual Penal, Porto Alegre, v. 2, n.7, p. 18-20, abr./maio 2001.

PIERANGELLI, José Henrique. Processo penal: evolução histórica e fontes legislativas. Bauru: Jalovi, 1983.

PIMENTA, José Carlos. Processo eleitoral e controle jurisdicional. Belo Horizonte: Mandamentos, 2002.

PIMENTA BUENO, José Antônio. Apontamentos sôbre o processo criminal brasileiro. Atual. e compl. por José Frederico Marques. São Paulo: Revista dos Tribunais, 1959. 
PINTO, Adilson José Vieira. O inquérito policial à luz dos direitos e garantias individuais da Constituição Federal de 1988. Revista Brasileira de Ciências Criminais, São Paulo, v. 7, n. 27, p. 251-264, jul./set. 1999.

PITOMBO, Sérgio Marcos de Moraes. Breves notas sobre o Anteprojeto de Lei, que objetiva modificar o Código de Processo Penal, no atinente à investigação policial. Revista Cejap, Campinas, v. 1, n. 2, p. 3-19, set. 2000.

. Do art. 40, do Código de Processo Penal. Revista do Instituto dos Advogados de São Paulo, São Paulo, v. 3, n. 2, p. 65-72, 1977. . Inquérito policial: novas tendências. Belém: Cejup, 1987. . Inquérito policial: exercício do direito de defesa. Boletim IBCCrim, São Paulo, v. 7, n. 83, edição especial, p. 14, out. 1999.

PIZA, M. de Toledo. O inquérito no processo penal brasileiro. Niterói: [s.n.], 1953.

PIOVESAN, Flávia. Reforma do Judiciário e direitos humanos. In: TAVARES, André Ramos; LENZA, Pedro; ALARCÓN, Pietro de Jesús Lora. Reforma do Judiciário: analisada e comentada. São Paulo: Método, 2005. p. 67-81.

PORTUGAL. Código de Processo Penal e outra legislação processual penal. Introdução de Jorge de Figueiredo Dias. [Lisboa]: Aequitas, 1992.

POZZER, Benedito Roberto Garcia. Uma, dentre muitas, lição do professor Pitombo. Boletim IBCCrim, São Paulo, v. 11, n. 125, p. 3, abr. 2003.

PRADEL, Jean. La phase préparatoire du procès pénal en droit comparé. Revue de Science Criminelle et de Droit Pénal Comparé, Paris, n. 4, p. 623-639, oct./déc. 1983.

PRADO, Geraldo. Sistema acusatório: a conformidade constitucional das leis processuais penais. 4. ed. Rio de Janeiro: Lumen Juris, 2006.

RANGEL, Paulo Castro. Reserva de jurisdição: sentido dogmático e sentido jurisprudencial. Porto: Universidade Católica Portuguesa, 1997.

RECOMENDAÇÕES de Toledo para um processo penal justo. Revista Portuguesa de Ciência Criminal, Coimbra, v. 4, n. 3, p. 437-441, jul./set. 1994.

RIVERO, Jean; MOUTOUH, Hugues. Liberdades públicas. Trad. Maria Ermantina de Almeida Prado Galvão. São Paulo: Martins Fontes, 2006.

RODRIGUES, Adilson et al. Reforma judiciária e persecução penal: papel do Ministério Público. Justitia, São Paulo, v. 60, n. esp., p. 672-687, 1999.

RODRIGUES, José Narciso da Cunha. Sobre o princípio da igualdade de armas. Revista Portuguesa de Ciência Criminal, Coimbra, v. 1, n. 1, p. 77-103, jan./mar. 1991. 
ROLIM, Luciano. Limitações constitucionais intangíveis ao foro privilegiado. Boletim Científico da Escola Superior do Ministério Público da União, Brasília, v. 4, n. 14, p. 111-146, jan./mar. 2005.

ROOF, Judith. Investigating the Special: the symbolic function of the Independent Counsel. Indiana Law Journal, v. 77, p. 277-293, 2002.

RUÍZ VADILLO, Enrique. Valor de las diligencias practicadas por la polícia judicial en el proceso penal. Eguzkilore: Cuaderno del Instituto Vasco de Criminología, San Sebastián, n. 13 ext., p. 291-303, mar. 1999.

SAAD, Marta. O direito de defesa no inquérito policial. São Paulo: Revista dos Tribunais, 2004.

SALDANHA, Nelson. Estado de direito, liberdade e garantias: estudos de direito público e teoria política. São Paulo: Sugestões Literárias, 1980.

SAMPAIO, Nelson de Souza. Do inquérito parlamentar. Rio de Janeiro: Fundação Getulio Vargas, 1964.

SANTOS, Andrés de la Oliva. Jueces imparciales, fiscales “investigadores", y nueva reforma para la vieja crisis de la justicia penal. Barcelona: PPU, 1998.

SANTOS, Bonni dos. Sistemas processuais e interpretação da lei penal na persecução criminal: uma contribuição ao debate. Revista da EMERJ, Rio de Janeiro, v.6, n.21, p. 191-204, 2003

SARAIVA, Alexandre José de Barros Leal. Inquérito policial e auto de prisão em flagrante nos crimes militares. São Paulo: Atlas, 1999.

SARAIVA, Wellington Cabral. Absolvição liminar de réus com foro por prerrogativa de função: inconstitucionalidade. Revista dos Tribunais, São Paulo, v. 84, n. 716, p. 548559, jun. 1995.

SCHREIBER, Simone. A publicidade opressiva dos julgamentos criminais: reflexões sobre a colisão da liberdade de expressão e o direito a um julgamento justo, sob a perspectiva da Constituição Federal de 1988. In: PRADO, Geraldo; MALAN, Diogo. Processo penal e democracia: estudos em homenagem aos 20 anos da Constituição da República de 1988. Rio de Janeiro: Lumen Juris, 2009, p. 535-566.

SCHÜNEMANN, Bernd. La policía alemana como auxiliar del Ministerio Fiscal: estructura, organización y actividades. Cuadernos de doctrina y jurisprudencia penal, Buenos Aires, v. 7, n. 12, p. 95-126, sep. 2001. 
SILVA, Danielle Souza de Andrade e. A atuação do juiz no processo penal acusatório: incongruências do sistema brasileiro em decorrência do modelo constitucional de 1988. Porto Alegre: Sergio Antonio Fabris, 2005.

SILVA, Edimar Carmo da. Princípio acusatório e a repercussão no processo penal brasileiro: a legitimidade para restrição de direito fundamental. Monografia (Pósgraduação em Sistema de Justiça Criminal) - Universidade Federal de Santa Catarina, Florianópolis, 2006.

SILVA, Eduardo Pereira da. Prerrogativa de foro no inquérito policial. Revista CEJ, Brasília, n. 36, p. 6-13, jan./mar. 2007.

SILVA, José Geraldo da. O inquérito policial e a polícia judiciária. 4. ed. Campinas: Millenium, 2002.

SILVEIRA, Paulo Fernando. Devido processo legal. 3.ed. rev., atual. e ampl. Belo Horizonte: Del Rey, 2001.

SIQUEIRA, Francisco J. de. O Papel do Banco Central no processo de intervenção e liquidação extrajudicial. In: SADDI, Jairo (Org.). Intervenção e liquidação extrajudicial no Sistema Financeiro Nacional: 25 anos da Lei 6.024/74. São Paulo: Textonovo, 1999. p. 239-256.

SIQUEIRA, Galdino. Curso de processo criminal. 2. ed. rev. e aum. São Paulo: Magalhães, 1924.

SIRACUSANO, Delfino et al. Diritto processuale penale. 3. ed. Milano: Giuffrè, 2001. v. 1.

SIRINO, Sérgio Inácio; TAGGESELL, Hildegard. Inquérito policial federal. Curitiba: Juruá, 2006.

SOUZA, Carlos Laet de. Da investigação policial e da instrução criminal provisória. Revista Brasileira de Ciências Criminais, São Paulo, v. 6, n. 21, p. 159-162, jan./mar. 1998.

SOUZA, José Barcelos de. A defesa na polícia e em juízo: teoria e prática do processo penal. Belo Horizonte: Bernardo Álvares, 1963.

. Do arquivamento. Belo Horizonte: Imprensa Oficial do Estado de Minas Gerais, 1969.

SOUZA, Luiz Roberto Salles de. Da atuação do Ministério Público brasileiro na fase préprocessual: uma análise crítica. Dissertação (Mestrado em Direito) - Universidade de São Paulo, São Paulo, 2002. 
SUANNES, Adauto. Os fundamentos éticos do devido processo penal. São Paulo: Revista dos Tribunais, 1999.

SUÁREZ-BÁRCENA, Emilio de Llera. La inidoneidad constitucional de jueces y fiscales para asumir la investigación oficial. In: El modelo constitucional de investigación penal. Valencia: Tirant lo Blanch, 2001. p. 119-163.

SUNDFELD, Carlos Ari. Fundamentos de direito público. 3. ed. São Paulo: Malheiros, 1998.

TÁCITO, Caio. Comissão Parlamentar de Inquérito - requisição de informações - sigilo bancário. (parecer). Revista de Direito Administrativo, Rio de Janeiro, v. 208, p. 399403, abr./jun. 1997.

TEIXEIRA, Francisco Dias. A titularidade da ação penal e o arquivamento do inquérito. Revista Brasileira de Ciências Criminais, São Paulo, v. 4, n. 14, p. 174-182, abr./jun. 1996.

TEIXEIRA, Marcelo Chiara. Procedimentos administrativos interna corporis de investigação criminal e o devido processo legal. Tese de Láurea (Graduação em Direito) - Universidade de São Paulo, São Paulo, 2005.

TORNAGHI, Hélio. Compêndio de processo penal. Rio de Janeiro: José Konfino, 1967. t. I e II.

TORON, Alberto Zacharias. Notas sobre a mídia nos crimes de colarinho branco e o Judiciário: os novos padrões. Revista Brasileira de Ciências Criminais, São Paulo, v. 9, n. 36, p. 257-272, out./dez. 2001.

TOURINHO FILHO, Fernando da Costa. Processo penal. 19. ed. rev. e atual. São Paulo: Saraiva, 1997. v. 1 e 2.

. Da competência pela prerrogativa de função. Revista Síntese de Direito Penal e Processual Penal, Porto Alegre, v. 5, n. 28, p. 5-26, out./nov. 2004.

TOVO, Paulo Cláudio. O inquérito policial em sua verdadeira dimensão. In: TOVO, Paulo Cláudio (Org.). Estudos de direito processual penal. Porto Alegre: Livraria do Advogado, 1995. p. 147-151.

TREANOR, William Michael. Independent counsel and vigorous investigation and prosecution. Law and contemporary problems, v. 61, n. 1, p. 149-164, 1998.

TUCCI, Rogério Lauria. Direitos e garantias individuais no processo penal brasileiro. 2. ed. rev. e atual.São Paulo: Revista dos Tribunais, 2004. . Lineamentos do processo penal romano. São Paulo: Bushatsky, 1976. 
. Ministério Público e investigação criminal. São Paulo: Revista dos Tribunais, 2004.

. Pedido de arquivamento em inquérito policial e preclusão consumativa. Revista dos Tribunais, São Paulo, v. 94, n. 831, p. 507-516, jan. 2005.

. Persecução penal, prisão e liberdade. São Paulo: Saraiva, 1980.

. Teoria do direito processual penal: jurisdição, ação e processo penal (estudo sistemático). São Paulo: Revista dos Tribunais, 2002.

VALENTE, Manuel Monteiro Guedes. Regime jurídico da investigação criminal. 3. ed. rev. e aum. Coimbra: Almedina, 2006.

VALLE, Diógenes Pereira do. Dos processos policiaes: crimes de alçada. São Paulo: Graphica Rossetti, 1928.

VIEIRA, Ana Lúcia Menezes. Processo penal e mídia. São Paulo: Revista dos Tribunais, 2003.

XAVIER DE ALBUQUERQUE, Francisco Manoel. Aspectos da conexão. Manaus: Sergio Cardoso, 1956.

ZACARIOTTO, José Pedro. Portaria DGP 18/98 e polícia judiciária democrática. Revista dos Tribunais, São Paulo, v. 88, n. 769, p. 461-479, nov. 1999.

ZAGREBELSKY, Vladimiro. Modello accusatorio e deontologia dei comportamenti processuali nella prospettiva comparatistica. Rivista Italiana di Diritto e Procedura Penale, Milano, n. 36, p. 435-492, apr./giugno 1993.

ZARZALEJOS NIETO, Jesus. El proceso penal contra jueces y magistrados: la especialidad del antejuicio. Madrid: Arias Montano, 1992.

ZILLI, Marcos Alexandre Coelho. A iniciativa instrutória do juiz no processo penal. São Paulo: Revista dos Tribunais, 2003.

\section{Documentos eletrônicos}

GOMES, Luiz Flávio. Nova lei de falência: procedimento penal. Disponível em: $<$ http://www.faceb.edu.br/faceb/RevistaJuridica/m196-018.htm>. Acesso em: 9 out. 2008.

GOMES, Rodrigo Carneiro. O inquérito policial na investigação de parlamentar. Disponível em: <http://www.ibccrim.org.br>, Seção Artigos. Acesso em: 15 abr. 2007. 
NAVES defende criação de juizado de instrução criminal para crimes de maior potencial ofensivo. Notícias do Superior Tribunal de Justiça. Disponível em: <www.stj.gov.br/webstj>. Acesso em: 2 maio 2006.

\section{Dicionários}

DICIONÁRIO eletrônico Houaiss da língua portuguesa, versão 1.0.7. Rio de Janeiro: Objetiva, set. 2004. 1 CD-ROM.

SILVA. De Plácido e. Vocabulário jurídico. 27. ed. Rio de Janeiro: Forense, 2008. 